\title{
Psihijatrijski diskurs u hrvatskom društvu na prijelazu iz devetnaestoga u dvadeseto stoljeće
}

Drača, Vinko

Doctoral thesis / Disertacija

2021

Degree Grantor / Ustanova koja je dodijelila akademski / stručni stupanj: University of Zagreb, Faculty of Humanities and Social Sciences / Sveučilište u Zagrebu, Filozofski fakultet

https://doi.org/10.17234/diss.2021.8789

Permanent link / Trajna poveznica: https://urn.nsk.hr/urn:nbn:hr:131:304963

Rights / Prava: In copyright/Zaštićeno autorskim pravom.

Download date / Datum preuzimanja: 2023-04-26

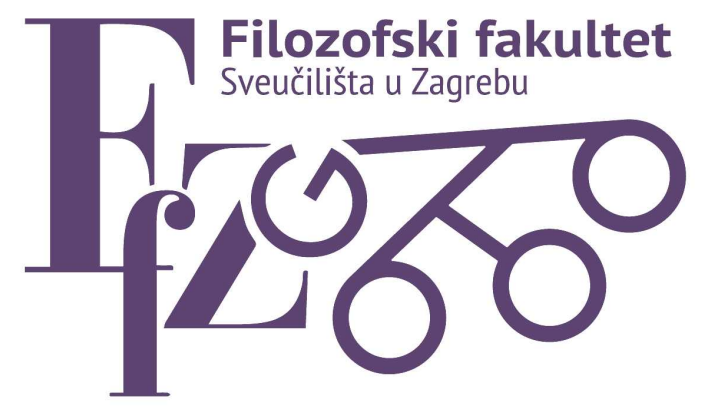

Repository / Repozitorij:

ODRAZ - open repository of the University of Zagreb Faculty of Humanities and Social Sciences
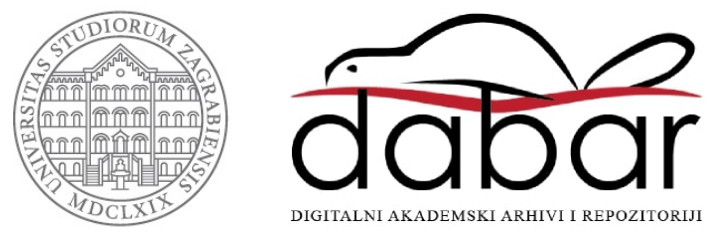


\title{
SVEUČILIŠTE U ZAGREBU
}

FILOZOFSKI FAKULTET

Vinko Drača

\section{Psihijatrijski diskurs u hrvatskom društvu na prijelazu iz devetnaestoga u dvadeseto stoljeće}

\author{
DOKTORSKI RAD
}

Mentorice:

dr.sc. Ida Ograjšek Gorenjak, doc.

dr. sc. Željka Matijašević, redovita profesorica

Zagreb, 2020. 
University of Zagreb
Faculty of Humanities and Social Sciences

Vinko Drača

\section{Psychiatric Discourse in Croatian Society at the turn of the 19th and 20th century}

Doctoral Dissertation

Supervisors:

dr.sc. Ida Ograjšek Gorenjak, doc.

dr. sc. Željka Matijašević,

Zagreb, 2020. 



\section{Zahvale}

Pri pisanju ove disertacije otisnuo sam se prema teritoriju koji mi je dotad bio nepoznat i snalaženje na tom puto bilo bi mnogo teže bez pomoći brojnih divnih ljudi . Prvo trebam spomenuti svoje strpljive mentorice, profesorice Idu Ograjšek Gorenjak i Željku Matijašević. One su strpljivo iščitavale moj tekst, imale strpljenja za moje uporne pravopisne pogreške, ispravljale francuska i njemačka imena koja bih uporno pogrešno pisao, pronalazile mi članke i knjige koje su mi uvelike pomogle pri istraživanju, te mi pomogle da dobijem pristup arhivu bez kojeg bi ovaj rad bio nemoguć. Na marljivom angažmanu i podršci zahvaljujem i ostalim profesorima s Poslijediplomskog studija moderne i suvremene hrvatske povijesti u europskom i svjetskom kontekstu: brojni od Vas su mi dali savjet, otvorili vrata, ili me upoznali s nekom informacijom koja mi je koristila u radu. Posebne zahvale upućujem ljudima iz Klinike za psihijatriju Vrapče: pokojnom ravnatelju Vladi Jukiću koji nažalost nije dočekao obranu ovog rada i arhivaru Zlatku Stanišaku koji mi je pravio društvu u arhivu Klinike tijekom dugih i usamljenih jutara. Pri istraživanju ovog rada veliku pomoć i podršku pružili su znanstvenice i znanstvenice koji se bave sličnom tematikom i koji su uvijek bili spremni dati savjet na okruglim stolovima i konferencijama. Veliko hvala Luci Malatestiju, Heike Karge, Ani Antić, Filipu Čeču, Vanniju D'Alessiu, Franku Doti i Jeleni Seferović. Naš zajednički rad na projektu proučavanja povijesti psihijatrije u Srednjoj i Jugoistočnoj Europi obogatio je moj metodološki pristup i natjerao me da si postavim uzbudljiva pitanja koja si inače ne bih postavio. Zahvaljujem i članovima i članicama komisije za obranu teme doktorskog rada. Oni su postavili pitanja koja su me usmjerila i učinila ovaj rad potpunijim. Ekipa iz Centra za ženske studije, na čijim sam skupovima gostovao iz godine u godinu, pokazala je izniman interes za temu ove disertacije i pomogla brojnim sugestijama i savjetima. U samoj završnici pisanja rada, na ljetnoj školi u Dubrovniku, upoznao sam brojne mlade znanstvenike i znanstvenice koji su mi otvorili nove perspektive u razmatranju mog vlastitog polja, iako su se bavili drugačijim temama. Topao i srdačan pozdrav Nataliji Lago, mojoj „borboleti“ koja je dala osoban pečat zadnjim poglavljima ove disertacije, i ostalima iz Global Humanities Institutea koje neću navoditi poimence jer bi lista bila odviše duga- svi ste učinili moje istraživačke dane zabavnijima i bogatijima. Zahvaljujem svima koji su dali savjet ma kako minoran bio, mojim prijateljima Žutom koji je slušao o mojoj disertaciji za mnogih dugih večeri, Snowy koja je pronašla najbolji soundtrack za pisanje doktorata i fantastičnoj Vlatki Košir 
koja mi je prije gotovo deset godina posudila knjigu Thomasa Szassa i zainteresirala me za propitivanje pojma duševne bolesti. Naravno, ništa ne bi bilo moguće bez moje obitelji koja je uvijek bila tu da pruži emotivnu i financijsku podršku. 


\section{Sažetak}

Rad analizira povijest psihijatrijskog diskursa u hrvatskom društvu na prijelazu iz devetnaestog u dvadeseto stoljeće. Razdoblje obuhvaćeno radom počinje 1879. godine, osnutkom Kraljevskog i zemaljskog zavoda za umobolne u Stenjevcu, kao prve psihijatrijske institucije u hrvatskom dijelu Austro-Ugarske Monarhije, a završava 1918. godine. Teorijski i metodološki pristup bazira se na konstruktivističkoj školi povijesti psihijatrije, koja smatra da je medicinski pogled na um i duševno zdravlje bio uvelike obilježen povijesnim kontekstom, institucionalnim praksama psihijatrije i dominantnim emotivnim režimima društva. Pri analizi izvora koristi se metodološki aparat povijesti emocija i kulturne povijesti psihijatrije. Psihijatrijski diskurs bio je neodvojiv od psihijatrijske prakse i razvijao se u stalnoj komunikaciji između psihijatara i štićenika psihijatrijskih zavoda, te psihijatara i ostalih društvenih institucija i pojedinaca: pravosudnih organa, organa lokalne administrativne vlasti, obitelji štićenika i drugih liječnika. Izvori za opis i analizu ove mreže odnosa su psihijatrijski članci i knjige, te povijesti bolesti štićenika sačuvane u arhivu Klinike za psihijatriju Vrapče. Na temelju navedenih izvora analizira se razvoj i nastanak hrvatske psihijatrije u kontekstu europskih intelektualnih kretanja druge polovice devetnaestog stoljeća, naročito s obzirom na u to vrijeme prevladavajuće evolucionističke i somaticističke teorije te narative o degeneraciji i primitivizmu, usko povezane sa znanstvenim rasizmom. Opisuju se uvjeti života štićenika i terapeutske metode primjenjivane u zavodu. Osobita pažnja posvećuje se mjestu roda, seksualnosti, straha i sukoba u psihijatrijskom diskursu. Diskursi oko tih pojmova čine bitan dio narativa o duševnoj bolesti u devetnaestom stoljeću, a psihijatrijski pristup tim konceptima analizira se gustim opisom niza povijesti bolesti. Pri analizi istaknuto se mjesto nastoji dati upravo glasovima štićenika i štićenica. Proučavanje njihovih iskaza bilo je ključno za formiranje psihijatrijskog znanja, iako se onodobna psihijatrija prema njihovom govoru ponašala ambivalentno. $\mathrm{S}$ jedne strane, isti je bio pomno zapisivan, s druge strane kao „govor luđaka“ bio je delegitimiran, te je štićenicima i štićenicama oduzeto bilo kakvo pravo objašnjavanja i tumačenja vlastitih simptoma. 


\section{Summary}

Thesis analyzes history of psychiatric discourse in Croatian society at the turn of the nineteenth and twentieth century. The time period covered by this research starts in 1879, the year Royal and Land Asylum for the Insane in Stenjevec was opened as the first psychiatric institution in Croatian part of Austria-Hungary and it ends in 1918. Theoretical and methodological approach is based upon the constructivist school of history of psychiatry which assumes that medical perspectives of mind and mental health were necessarily informed by specific historical context, institutional practices of psychiatry and dominant emotional regimes present in society.

In the analysis of sources methodological apparatus of the history of emotions and the cultural history of psychiatry was used. Psychiatric discourse was inseparable from psychiatric practice and developed in constant communication between psychiatrists and inmates of psychiatric institutions, and psychiatrists and other social institutions and individuals: judicial authorities, local administrative authorities, families of inmates and other physicians. Sources for the description and analysis of this network of relationships are psychiatric articles and books, as well as the patient histories kept in the archives of the Vrapče Psychiatric Clinic. Based on these sources, the development and emergence of Croatian psychiatry in the context of European intellectual movements of the second half of the nineteenth century is analyzed, especially given the prevailing evolutionary and somaticist theories and narratives of degeneration and primitivism, closely related to scientific racism. The living conditions of the asylum inmates and the therapeutic methods applied in the institution are described. Particular attention is paid to the place of gender, sexuality, fear, and conflict in psychiatric discourse. Discourses around these concepts form an essential part of the narrative of mental illness in the nineteenth century, and the psychiatric approach to these concepts is analyzed by a dense description of a series of medical histories. In the analysis, a prominent place is given to voices of the inmates. The medical study of their statements was crucial for the formation of psychiatric knowledge, although psychiatry at the time treated their speech ambivalently. On the one hand, it was carefully written down, on the other hand, it was delegitimized as "madman's speech", and the inmates were deprived of any right to explain and interpret their own symptoms. 
1.Uvod

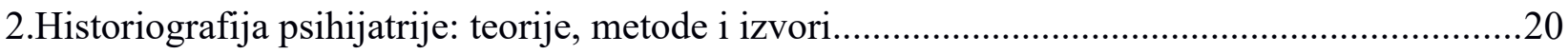

2.1. Povijest psihijatrije između ,vigovske” povijesti i društvenog konstruktivizma.....................20

2.2.Povijesti bolesti i glas psihijatrijskih pacijenata: metodologija istraživanja psihijatrije..........26

3. Europska psihijatrija u devetnaestom stoljeću..........................................................................34

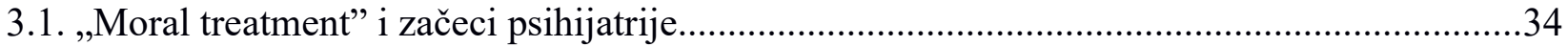

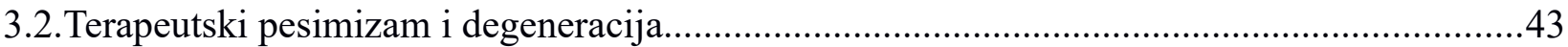

3.3. Od Griesingera do Kräpelina: njemačka neuropsihijatrija na prijelazu stoljeća.......................50

4. Kraljevski i zemaljski zavod za umobolne u Stenjevcu............................................................58

4.1.Osnutak i izgradnja zavoda za umobolne u Stenjevcu..........................................................58

4.2. Liječnici Kraljevskog i zemaljskog zavoda za umobolne u Stenjevcu.....................................62

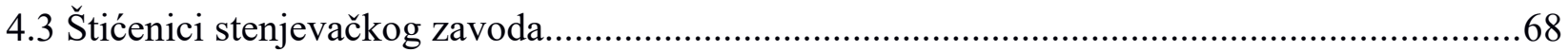

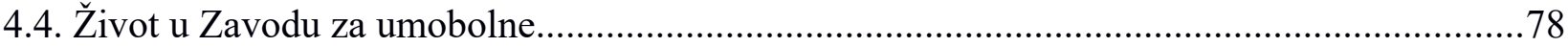

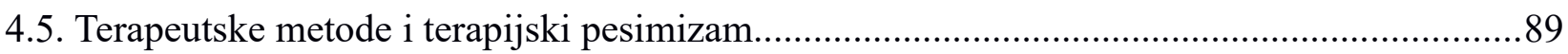

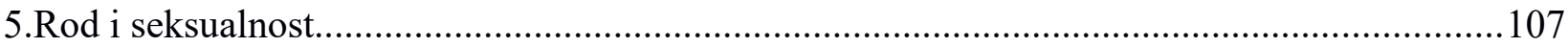

5.1.Rodne uloge i seksualnost u emotivnom režimu građanstva kasnog devetnaestog stoljeća. .107

5.2. Spektakl histerije u Stenjevcu..............................................................................................114

5.3. Tijelo van kontrole: „Rittermeisterov satni mehanizam” i „viloviti” notar iz Veliševca“.....133

5.4. Nevidljivost sifilisa: progresivna paraliza u Stenjevcu........................................................ 138

5.5. Seksualna nastranost, primitivizam i „,moral insanity”: Seksualnost, moral i ludilo na

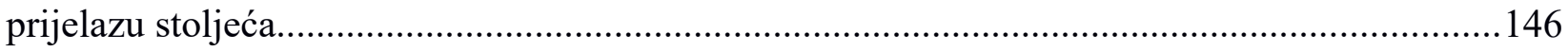

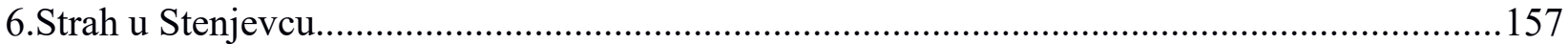

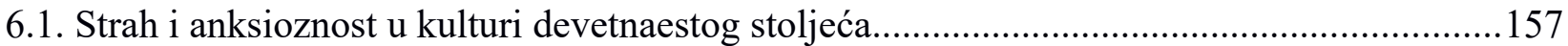

6.2.Strah i anksioznost u psihijatriji devetnaestog stoljeća..........................................................167

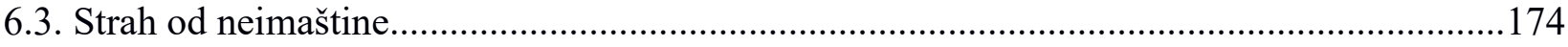

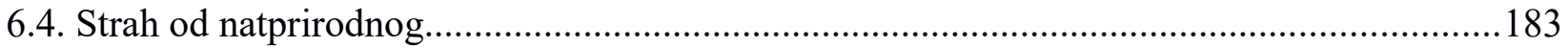

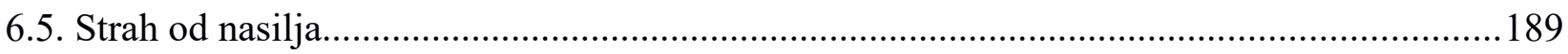

6.6.Paranoidne mreže i strah od moći države............................................................................200

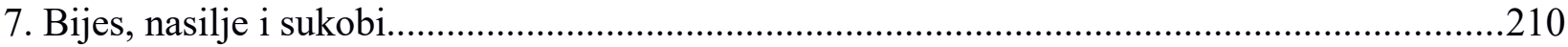


7.1. Bijes, nasilje i sukobi u psihijatriji devetnaestog stoljeća............................................210

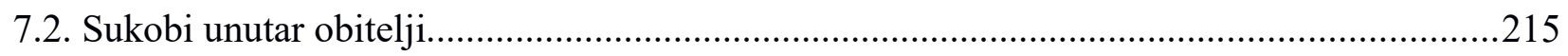

7.3.Dječaci s revolverima: nasilničko ponašanje adolescenata..........................................2230

7.4. Epileptičari i gorući štagljevi: sukobi unutar ruralnih zajednica....................................249

7.5. Anarhisti i atentatori: politički sukobi u psihijatriji 19. stoljeća......................................263

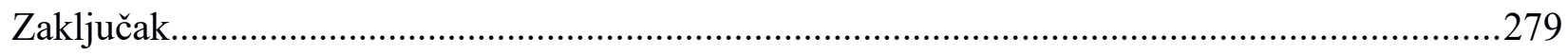

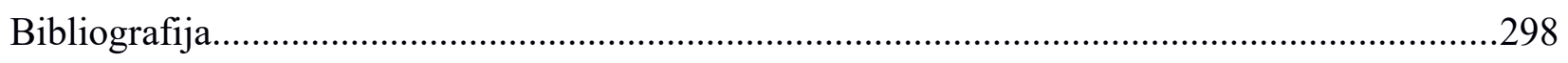

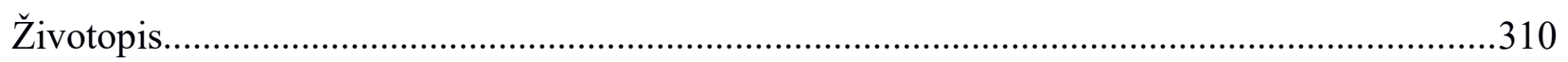


Za Tenu jer svaki je pogled odraz u krhotinama vječnosti. Volim te, djevojko! 


\section{Uvod}

Klinika za psihijatriju Vrapče danas se proteže kroz ogroman kompleks zgrada i obuhvaća raznovrsne medicinske i pomoćne zgrade: od centralnog neoklasicističkog zdanja čiji „dvokrilni” plan još odaje tragove devetnaestoljetnog Kirkbrideovog dizajna, do moderne bijele zgrade $u$ kojoj je smješten arhiv bolnice. Dok sam provodio istraživanje za ovu disertaciju često sam bio iznenađen uklopljenošću kompleksa u okoliš i odsutnošću bilo kakvog osjećaja izolacije kakav ljudi obično povezuju s psihijatrijskim institucijama - u prostor bolnice se ulazilo nesmetano (postojala je čak i ,,prečica” koja je vodila do rupe u ogradi koju sam koristio da bih brže došao do najbliže trgovine), pacijenti su zajedno s osobljem, učenicima i učenicima obližnje škole za medicinske sestre i slučajnim posjetiteljima šetali prostranim perivojima. Bolnica je s obje strane ograde bila okružena kućama tipičnima za predgrađe poput Vrapča i jedino što bi nekom neupućenom moglo odati dojam da se radi o psihijatrijskoj bolnici, bile su rešetke na prozorima ponekih zgrada.

U periodu obuhvaćenom ovom disertacijom, bolnica je pružala daleko drugačiju sliku. Tada se zvala Kraljevski i zemaljski zavod za umobolne u Stenjevcu. Njezin dugogodišnji ravnatelj, Ivo Žirovčić jednom je napisao da je naziv osobito nepogodan jer asocira na stenjanje, a bio je neprikladan jer sama bolnica nije zapravo bila u naselju Stenjevec nego je dobila to ime zbog blizine željezničke stanice koja je nosila to ime. Nalazila se u izoliranom ruralnom kraju, okružena poljima i vinogradima. Tlo je bilo močvarno, nije bilo učinkovitog načina odvođenja kanalizacijskih voda, a zadah koji se tijekom ljeta širio oko prostora bolnica je bio neizdrživ. Izolacija mjesta je bila tolika da su ravnatelj, kućni liječnici i osoblje bili prisiljeni živjeti u samom krugu bolnice, a umrli kojih je zbog generalne onemoćalosti štićenika, kao i epidemija, bio nemali broj, sahranjivani su na obližnjem bolničkom groblju. Radilo se o mjestu koje je bilo daleko zatvorenije i izoliranije nego što su to današnje psihijatrijske klinike: perspektiva ljudi koji su u njemu završili bila je mračna: ako i nisu umrli, na njima je ostajala stigma duševnog bolesnika. Nisu se mogli nadati izlječenju, niti tretmanu koji bi učinio njihovu bolest lakšom. Liječnici su imali težak zadatak skrbi za stotine i tisuće onih koje je društvo odbacilo; bili su to 
ljudi koji su odabrali granu medicine koja na raspolaganju još nije imala učinkovite metode liječenja. Njihov rad se uglavnom svodio na kontroliranje nemirnih štićenika, nekad pomoću vlastitog autoriteta i lijekova za smirenje nekad poprilično brutalnim metodama poput vezivanja ili umatanja u plahte i na produženje života onih koji su patili od kroničnih ili infektivnih bolesti.

Kao prva i najveća psihijatrijska institucija Stenjevec je bio mjesto na kojem se formirala hrvatska psihijatrija. Iako su liječnici u godinama kojima se ovaj rad bavi bili obrazovani na sveučilištima u današnjoj Češkoj, Austriji i Njemačkoj, njihovi pogledi na duševnu bolest bili su formirani kliničkim iskustvom stenjevačkog zavoda. Njihovi pacijenti bili su ljudi tragičnih sudbina čiji život je često bio obilježen neimaštinom, odbacivanjem, sukobima s okolinom i marginalnim položajem u zajednici. Povijesti bolesti sačuvane u Arhivu Klinike za psihijatriju Vrapče u velikom broju slučajeva su jedini zapisi koji govore o njihovim životnim iskustvima. U njima štićenici neposredno ili posredno progovaraju o iskustvu osoba čiji je život bio obilježen dijagnozom „umobolje” ili „ludila” u Hrvatskoj na prijelazu stoljeća. Njihov govor i govor liječnika koji su u kontaktu s medicinskom zajednicom i javnošću razvijali psihijatrijsku disciplinu, njeno znanje i diskurs i etablirali svoj pogled na pojedinca i društvo u cjelini čine osnovu ove disertacije.

Od šezdesetih godina dvadesetog stoljeća psihijatrija je predmet historiografskog istraživanja. Unutar povijesti psihijatrije javile su se različite struje i pristupi. No, psihijatrija se također gotovo isključivo istraživala iz pozicije liječnika. Glas psihijatrijskih pacijenata predstavlja rijetko korišten, vrijedan ali i metodološki problematičan izvor.

Za glavne hipoteze ovog rada ključno je upravo mjesto glasa štićenika u formiranju psihijatrijskog diskursa. Hipoteze koje ću istraživati u ovom radu su:

1. Psihijatrijski diskurs u Hrvatskoj formirao se pod utjecajem europske (osobito njemačke i austrijske) biološke psihijatrije, te na temelju spoznaja formiranih u interakciji psihijatara Kraljevskog i zemaljskog zavoda za umobolne u Stenjevcu i njihovih štićenika. 
2. Stavovi hrvatskih psihijatara o rodu i seksualnosti odražavaju patrijarhalnu i seksualno konzervativnu kulturu građanstva.

3. Mjesto straha i strepnje u psihijatrijskom diskursu devetnaestog stoljeća je izuzetno problematično: strah i strepnja zauzimaju bitno mjesto u emotivnom režimu onog doba, no biološki fokus psihijatrije rezultira potcjenjivanjem njihovog utjecaja u etiologiji duševnih bolesti.

4. Psihijatrija se u devetnaestom stoljeću predstavlja kao grana medicine koja nastoji izliječiti duševne bolesti znanstvenim i humanim pristupom. No, postoji i druga percepcija psihijatrije- kao sredstva biopolitičkog nadzora koje ima bitnu ulogu u suzbijanju društvene devijacije. Suprotstavljenost tih dvaju poimanja izražava se na osobito vidljiv način u odnosu psihijatrije prema različitim oblicima nasilnih konflikata: od sukoba unutar obitelji i adolescentskog nasilja, do političkih sukoba.

Prvu od pretpostavki istražit ću kroz proučavanje odnosa između intelektualnih utjecaja europske psihijatrije na teoretska razmatranja i kliničku praksu stenjevačkih psihijatara i njihovih refleksija o životu i ponašanju štićenika zavoda. Dualitet tih utjecaja vidljiv je u primjeni koncepata proizišlih iz europske psihijatrije poput borderlandsa i degeneracije na procese dijagnosticiranja i liječenja zavodskih pacijenata i ponekad na kontekst hrvatskog društva prijelaza stoljeća u cjelini. S druge strane, interakcija liječnika i štićenika, često obilježena izrazitom asimetrijom moći i epistemičkim nasiljem, sama je rezultirala proširenjem psihijatrijskih znanja. Govor štićenika, njihova tijela i njihove životne prilike bile su podvrgnute kliničkom zoru i poslužile su kao elementi konstrukcije diskursa o ludilu koji je objedinjavao postojeće društvene kontradikcije $\mathrm{s}$ eugeničkim i moralističkim nazorima društvenih elita.

Druga teza temelji se na pretpostavci da su psihijatri kao profesionalci koji su pripadali građanskom sloju i predstavljali stavove intelektualnih i društvenih elita, imali izrazito konzervativno poimanje seksualnosti i roda, oblikovano patrijarhalnom građanskom kulturom devetnaestog stoljeća i biološkim i medicinskim teorijama koje su prikazivale ženska tijela na način koji je u fokus stavljao njihovu reproduktivnu funkciju. Pri tome će u psihijatriji izražena biti dihotomija između „feminine“ histerije i maskuline „progresivne paralize“. Tim bolestima 
pridavani su orođeni uzroci: histerija je imala uzrok u „,inferiornom“ živčanom sustavu žena, dok se progresivna paraliza nije dovodila u vezu sa spolno prenosivim sifilisom, već se njen uzrok tražio u ,iscrpljenosti“ produktivne građanske klase.

Treća hipoteza vezana je uz mjesto straha i strepnje (anksioznosti) unutar psihijatrijskog diskursa. Iako sami pacijenti često spominju strah i strepnju, zbog naglaska koji psiijatrija prijelaza stoljeća stavlja na biologiju, hereditet i degeneraciju dovela do činjenice te se emocije rijetko smatraju važnima u etiologiji duševnih bolesti. S druge strane, diskurs psihijatrije će biti informiran strahovima i strepnjama društvenih elita vezanim uz društvene promjene koje je donio modernitet, što će biti vidljivo u nekim od ključnih medicinskih tekstova nastalih u drugoj polovici devetnaestog stoljeća.

Praksa psihijatrije, često će biti vezana i uz strah od duševno bolesnih pojedinaca kao osoba koje remete javni mir i društveni poredak. S tom percpecijom je povezana posljednja hipoteza u kojoj se nastoji ispitati odnos između dvije različite društvene uloge psihijatrije. Psihijatrija se u devetnaestom stoljeću nastojala predstaviti kao nova grana medicine koja je nudila inovativan znanstveno utemeljen terapeutski pristup liječenju duševnih oboljenja. No s druge strane, postoji percepcija psihijatrije kao sredstva društvene kontrole, institucije koja bi trebala biopolitičkim metodama i izolacijom suzbiti društvenu devijaciju. Kompleksan odnos psihijatrije prema društvenim sukobima zasniva se na stalnoj napetosti između tih društvenih uloga. Naravno, te uloge nisu uvijek bile suprotstavljene, no u periodu kojim se ovaj rad bavi, posvemašnji terapeutski pesimizam dovest će do percepcije stenjevačkog zavoda kao institucije kojoj je primarna svrha izolacija društveno devijantnih pojedinaca, usprkos činjenici da se i sami psihijatri često opiru takvim pogledima na vlastitu struku.

U prvom poglavlju nastojati pozabaviti različitim pristupima povijesnog istraživanja psihijatrije i metodološkim problemima medicinskih izvora. Budući da je psihijatrija u Hrvatskoj uvijek nastojala ići u korak s europskim razvojem discipline, u drugom poglavlju će biti sažeto prikazan razvoj europske psihijatrije u dugom devetnaestom stoljeću. U prikazu bit će navedene glavne postavke moral treatmenta, opisat će se terapeutski pesimizam i kriza psihijatrije koja se javlja od sredine devetnaestog stoljeća, a posebna pažnja bit će posvećena njemačkoj neuropsihijatriji kao 
intelektualnoj tradiciji koja je bila u najintenzivnijem dodiru s hrvatskom psihijatrijom. $\mathrm{Na}$ početku trećeg poglavlja govorim o izgradnji Kraljevskog i zemaljskog zavoda za umobolne u Stenjevcu, te dajem kratak životopis liječnika koji su bili ravnateljima zavoda između 1879. i 1918.. godine. Nakon poglavlja o liječnicima slijedi duži prikaz socijalne strukture štićenika zavoda. Osim boravka u zavodu i njihovog društvenog položaja, za stanje i govor štićenika bitna su i njihova individualna iskustva prije dolaska u zavod, koja također nastojim opisati. U poglavlju ću ocrtati i teške uvjete života u zavodu. Budući da je Kraljevski i zemaljski zavod za umobolne u Stenjevcu osnovan u trenutku kad je moral treatment ustupao mjesto pesimizmu prijelaza stoljeća, jedna od teza koju ću istražiti u prva dva poglavlja bit će da je hrvatska psihijatrija od samih početaka obilježena ispreplitanjem humane misije zavoda kao mjesta skrbi za duševno bolesne i sve veće percepcije duševnih bolesti kao znaka nepovratne degeneracije. Zavod je praktički od svog osnutka bio mjestom čija je terapeutska uloga dovedena u pitanje u samom psihijatrijskom diskursu, a visoka smrtnost i niska stopa izlječenja doprinijeli su tome da je zavod sve češće bio mjestom na koje su upućivani pojedinci u čije se šanse izlječenja nije vjerovalo. Četvrti dio disertacije govori o rodu i seksualnosti. Rod i seksualnost su, kako je devetnaesto stoljeće odmicalo, dobivali sve izraženiju ulogu u medicinskim i psihijatrijskim diskursima. Slijedeći četiri diskursa o seksualnosti koja je u prvom dijelu svoje Povijesti seksualnosti istaknuo Michael Foucault (diskurs o „histerizaciji” ženskih tijela, maltuzijanskoj kontroli populacije, seksualnoj nastranosti i masturbaciji) i pridodavši im diskurs o „primitivizmu” i „moralnoj izopačenosti” ruralne populacije, narativ „tijela izvan kontrole” koji se pojavljivao kod pojedinih štićenica i diskurs o „nevidljivosti sifilisa” u poglavlju opisujem kakvu su ulogu patrijarhalno poimanje roda i konzervativno poimanje seksualnosti imali u psihijatriji Banske Hrvatske. U petom poglavlju, prelazim na strah i anksioznost. Te emocije bile su bitan dio emotivnih režima u zapadnoj kulturi, a o istima već postoje brojne historiografske studije. Psihijatrijski pogled na strah promatra se kroz proučavanje takozvanih „društvenih strahova" vezanih uz degeneraciju i strepnju pred propašću europske kulture i načinu na koji su se isti reflektirali u medicini i psihijatriji. Zatim se prelazi na strahove samih štićenika i kroz brojne studije slučaja analiziraju se strah od neimaštine, strah od natprirodnog, strah od nasilja i strah od moći državnog sustava represije nad pojedincima. Analizom tih strahova nastoji se 
ustanoviti kakva je bila uloga straha i strepnje u emotivnim režimima devetnaestog stoljeća. Posljednje poglavlje problematizira nasilje, agresiju i sukobe. Na početku tog poglavlja promatram sukobe i nasilje unutar obitelji i ulogu koju je psihijatrija imala u posredovanju i medijaciji tih sukoba te objašnjavanju uzroka i posljedica tog nasilja. Zatim govorim o sve izraženijem problemu adolescentske delinkvencije. Prepoznavanje i konstruiranje adolescenta kao osobe u specifičnom životnom razdoblju i formiranje „mladenačkog identiteta” postavilo je nove izazove pred društvene institucije koje su dolazile u doticaj s mladima. Psihijatrija je specifično reagirala na te izazove: prvo se javilo prepoznavanje i zasebno tretiranje psihičkih poremećaja u djetinjstvu i adolescenciji, zatim konstrukcija hebefrenije i dementiae praecox kao „mladenačkog ludila” koje se dovodilo u usku vezu s adolescencijom kad se ličnost pojedinca integrira i na posljetku pokušajem šire društvene kampanje koja je objedinjavala zahtjev za psihijatrijskim obrazovanjem liječnika koji rade s djecom i eugeniku. Osim problematike obitelji i adolescenata (kroz koju se istovremeno propituje i kompleksan međuodnos privatne sfere, psihijatrije i društva) prelazim na analizu sukoba i nasilja u ruralnim zajednicama. U toj se analizi osvrćem na postupnu medikalizaciju nasilnih sukoba koji su prije bili promatrani kroz kulturno ili društveno očište. Na posljetku, analizirat ću pojedine slučajeve politički motiviranog nasilja. Politički motivirano nasilje je u devetnaestom stoljeću zahtijevalo izuzetno kompleksan angažman psihijatara jer je istovremeno postojala potreba da se ovaj ekstreman oblik društvene devijacije prikaže i kao medicinski problem i kao moralnu i zakonsku transgresiju. U okviru pravnog sustava, te su dvije kategorije u devetnaestom stoljeću bile isključive, a psihijatri su ih često nastojali premostiti. 


\section{Historiografija psihijatrije: teorije, metode i izvori}

\subsection{Povijest psihijatrije između ,vigovske” povijesti i društvenog konstruktivizma}

Prve zapisane povijesti znanstvenih i medicinskih disciplina imale su praktičnu ulogu pregleda dosadašnjih spoznaja ostvarenih unutar nekog znanstvenog polja. Zato nije neobično da su prve zapisane povijesti psihijatrije pisali upravo sami psihijatri kako bi pomogli doprinijeti daljnjem napretku psihijatrijskog znanja. Prve ,povijesti psihijatrije” bile su objavljene kao povijest pojedinih psihijatrijskih institucija ili biografije zaslužnih liječnika. Fokusirale su se uglavnom na usku institucionalnu i intelektualnu historiju, a povijest psihijatrije predstavljale su kao povijest linearnog napretka i poboljšanja skrbi za duševno oboljele. Osim već spomenute uloge psihijatrijskih povijesti kao kataloga dosadašnjih postignuća te povijesne studije imale su i drugu svrhu, sličnu onoj koju se pridaje povijesti znanstvenih disciplina uopće. Stvaranjem kontinuiteta između „velikih umova” iz prošlosti discipline i suvremenih radnika ostvaruje se inicijacija mlađih učenjaka u disciplinu. ${ }^{1}$ Za povjesničare psihijatrije, položaj ,velikih umova” najčešće su zauzimali pioniri suvremene medicinske psihijatrije poput Phillipea Pinela i Jean-Étiennea Dominiquea Esquirola, te učenjaci za koje se smatralo da su unaprijedili disciplinu poput Emila Kräpelina i Henryja Maudsleyja. Hrvatski povjesničari psihijatrije će za svog „velikana” uzimati doktora Ivana Žirovčića, u svoje vrijeme poprilično kontroverznog ravnatelja Kraljevskog i zemaljskog zavoda za umobolne u Stenjevcu. U slučaju psihijatrije kao relativno nove i u svojim počecima često marginalizirane i osporavane medicinske discipline te su povijesti također imale svrhu uspostavljanja epistemološkog integriteta pokazujući napredak psihijatrijske misli kao evolucijski put prema sve ,znanstvenijim” i učinkovitijim dijagnostičkim, i terapeutskim metodama, čime sama disciplina u očima intelektualne javnosti dobiva znanstveni kredibilitet. ${ }^{2}$

Put psihijatrije u tim povijestima uvijek se bio prikazan na sličan način: od praznovjernog straha pred ludilom, preko sve učinkovitijih i humanijih tretmana duševno oboljelih. Samim time, slijedio je uvriježeni prosvjetiteljski narativ o pobjedi znanosti nad praznovjerjem, medicine nad

1 Micale i Porter, 1994: 4-5.

2 Ibid: 5 . 
bolestima i razuma nad strahom i predrasudama. Fokus istraživanja bio je na intelektualnoj povijesti, često ignorirajući utjecaj društvenih, političkih i ekonomskih faktora na razvoj psihijatrije. Takav pristup kasnije je prozvan vigovskom historijom psihijatrije. Naziv „,vigovska historija" (whig history) preuzet je iz knjige britanskog povjesničara Herberta Butterfielda The Whig Interpretation of History iz 1931. godine. Butterfield je u svojoj knjizi kritizirao tendenciju onodobnih britanskih povjesničara da trenutno stanje vide kao neku vrstu „vrhunca razvitka” ili „ideala”. Za Butterfielda, vigovska historija ima sljedeće karakteristike: promatra prošlost referirajući se na sadašnjost, često svrstava povijesne aktere i ideje u kampove ,pokretača progresa” i ,nazadnih”, u prošlim događajima vidi uzroke ili anticipaciju sadašnje situacije i prosuđuje prošle događaje na temelju njihovih percipiranih konačnih posljedica. ${ }^{3}$

„Vigovske” povijesti psihijatrije doživjele su svoj vrhunac u tridesetim, četrdesetim i pedesetim godinama dvadesetog stoljeća. Jedna od najistaknutijih takvih studija bila je djelo psihoanalitičara i ruskog emigranta Gregoryja Zilboorga A History of Medical Psychology (Povijest medicinske psihologije). ${ }^{4}$ Zilborgova studija predstavlja freudovsku psihoanalizu kao vrhunac psihijatrijskog i psihološkog znanja i poistovjećuje napredak psihijatrije s napretkom humanizma. ${ }^{5} \mathrm{U}$ tim godinama, svjetlo dana ugledale su brojne slične studije uglavnom fokusirane na razvoj nacionalnih psihijatrija i povijest pojedinih institucija, a uglavnom su nastajale $u$ zemljama engleskog govornog područja. Navedena struja unutar povijesti psihijatrije bila je otporna na promjene paradigmi i pristupa unutar historijske znanosti. To se vidi i na primjeru knjige Edwarda Shortera A history of psychiatry: from the era of the asylum to the age of Prozac iz 1996. godine. U toj opsežnoj intelektualnoj historiji europske i američke psihijatrije, Shorter podređuje cjelopkupnu intelektualnu misao psihijatrije suvremenim dosezima farmakološke psihijatrije. Shorter će isticati upravo somaticističku struju, od Maudsleyja, preko Kräpelina i Alzheimera do pojave prvih antipsihotika kao kontinuiran niz intelektualnog razvoja medicinske discipline koji je rezultirao uspješnim i humanim tretmanom duševnih bolesti kakav postoji danas. Tradicije koje pretpostavljaju drugačiju etiologiju i terapeutske metode poput psihoanalize,

3 Butterfield, 1965:12-13.

4 Micale i Porter, 1994: 6.

5 Ibid: 7. 
„moral treatmenta” i reformskog pokreta psihijatara poput Lainga i Basaglie, Shorter će smatrati svojevrsnim epistemološkim ,slijepim ulicama” koje u najboljem slučaju nisu doprinijele razvoju psihijatrije, a u najgorem su ga unazadile. Shorter time slijedi i teleološki pristup i tendencioznost ranijih ,vigovskih” povjesničara, eksplicitno odbacivši konstruktivističku struju i ne osvrćući se na rodne i post-kolonijalne studije psihijatrije. U Hrvatskoj, primjer „vigovskog” historiografskog djela je doktorska disertacija liječnika Lavoslava Glesingera Povijest psihijatrije u Hrvatskoj objavljena 1959. godine u kojoj Glesinger ustanovljuje godinu osnivanja „Kraljevskog i zemaljskog zavoda za umobolne u Stenjevcu” kao početak psihijatrije u Hrvatskoj. Sličan pristup nalazi se i u brojnim spomenicama Klinike za psihijatriju Vrapče, koje daju kronološki pregled razvoja bolnice od njezinih teškoćama ispunjenih početaka do trenutnog stanja. Takve spomenice objavljivali su brojni ravnatelji bolnice od Rudolfa Hercega koji je svoju spomenicu povodom pet desetljeća rada objavio 1933. godine do Vlade Jukića koji je povijesti Klinike za psihijatriju Vrapče posvetio priličan broj publikacija.

U šezdesetim godinama prošlog stoljeća brojne su društvene i humanističke znanosti doživjele teorijsku i metodološku transformaciju pod utjecajem epistemoloških spoznaja strukturalizma, poststrukturalizma i postmodernističke filozofije. Spoznaje društvenih i prirodnih znanosti, do tada promatrane kao dio nepromjenjive istine otkrivane sve savršenijim metodološkim aparatom neprekidno napredujućih znanstvenih disciplina počinju se gledati kao produkt određenih konstelacija moći u društvu. Medicina i psihijatrija se također počinju promatrati kao discipline na čiji su razvoj utjecale specifične društvene i političke okolnosti, a u slučaju psihijatrije, izrazita se pažnja počela posvećivati modernizacijskim procesima, naročito onima povezanima uz jačanje državne moći. Aspekti državne moći povezani s kontrolom populacije i borbom protiv javnog nemorala, zločina i epidemija objedinjavali su policijski represivni aparat i politike javnog zdravlja. Smjer povijesti psihijatrije koji se formirao tih godina najčešće se naziva „socijalnim revizionizmom” ili „socijalnim konstruktivizmom”. „Velika revizija” koja se u povijesti psihijatrije dogodila šezdesetih godina najčešće se povezuje s četirima djelima koja su dovela u pitanje shvaćanje duševne bolesti kao neupitne medicinske činjenice. Navedene knjige su Azili Ervinga Goffmana, Mit o duševnoj bolesti Thomasa Szassa, Povijest ludila u doba klasicizma 
Michela Foucaulta i „Podjeljeno Ja” Ronalda D. Lainga. ${ }^{6}$ U Azilima Goffman je opisao proces „institucionalizacije” duševno oboljelih u psihijatrijskim ustanovama. Proces institucionalizacije za Goffmana znači usvajanje određenih obrazaca ponašanja uslijed prilagodbe na depersonalizaciju koja je posljedica života u totalnoj instituciji poput psihijatrijskog zavoda. Ti obrasci ponašanja su isti obrasci ponašanja prepoznati kao simptomi kroničnih duševnih bolesti. U skladu s time, Goffman je zaključio da sam sustav zatočenja i izolacije duševno oboljelih proizvodi elemente stanja percipiranog kao ludilo ili duševna bolest. Thomas Szasz pak dovodi u pitanje samu duševnu bolest kao medicinsku činjenicu: budući da je bolest identična s patološkom promjenom na tijelu, a promjene na ličnosti je nemoguće kontinuirano opažati, duševna bolest je zabluda proizvedena kako bi se određeni oblici ponašanja koji prkose društvenim normama mogli regulirati, nadzirati i suzbijati. Povijest psihijatrije je, za Szasza, povijest legitimiranja zablude koja je formirana kao sredstvo opresije nad osobama koje je društvo izoliralo kao „drugačije” ili „opasne”. Robert David Laing bio je škotski psihijatar koji je napao epistemološke temelje psihijatrije tvrdnjom da se biološka patologija ne može uvjerljivo dijagnosticirati na temelju ponašanja, a Michel Foucault je u Povijesti ludila potpuno obrnuo „vigovski” narativ napretka postavivši tezu o „Velikom zatočenju”. Za Foucaulta, pojava moderne medicinske psihijatrije početkom devetnaestog stoljeća predstavlja kulminaciju uspostave sve rafiniranijih metoda kontrole nad tijelima pojedinaca: bilo da se radilo o duševno bolesnima, kriminalcima, alkoholičarima, oboljelima od zaraznih bolesti ili siromašnima i prosjacima. „Veliko zatočenje” povijesni je proces koji koincidira s početkom postupnog uvođenja sve učinkovitijih mjera državnog nadzora nad teritorijem i populacijom krajem sedamnaestog i početkom osamnaestog stoljeća, a sastoji se u osnivanju posebnih institucija za izolaciju i zatočenje pojedinaca koji su zbog svog ponašanja bili shvaćeni kao prijetnja postojećem poretku.

Prvi socijalni revizionisti nisu bili povjesničari (Laing i Szasz su bili liječnici, Foucault je bio filozof, a Goffman sociolog) i njihova su ključna djela bila temeljena na uskom fondu prilično površno interpretiranih izvora. No njihov rad inspirirao je niz povijesnih analiza od kasnih

6 Ibid. 
šezdesetih godina do danas. Prve metodološki sustavnije historijske studije revizionističkog smjera objavili su Ida Macalpine i Richard Hunter, majka i sin koji su kao trenirani psihoanalitičari pristupili historijskoj analizi duševnih oboljenja povijesnih ličnosti poput „ludog” engleskog kralja Georgea III. i Daniela Schrebera, suca koji je objavio memoarski zapis vlastite duševne bolesti i boravka u psihijatrijskoj instituciji, a u povijesnoj studiji zavoda za siromašne u Colney Hatchu, istražili su utjecaj ekonomskih faktora i socijalnih politika na razvoj psihijatrije. Ubrzo su uslijedili drugi važni tekstovi: njemački povjesničar i psihijatar Klaus Doerner objavio je 1969. studiju Luđaci i građanstvo u kojoj analizira vezu između uspona građanske klase u kasnom sedamnaestom stoljeću i razvoja psihijatrije, a britanski sociolog Andrew Scull je od sedamdesetih godina prošlog stoljeća nadalje objavio niz dobro potkrijepljenih studija koje predstavljaju ključan doprinos za socijalnu povijest angloameričke psihijatrije. Najveći doprinos historiografiji psihijatrije dao je britanski povjesničar znanosti i medicine Roy Porter. U svojim knjigama Anatomy of Madness, A Social History of Madness: Stories of the Insane (1987), MindForg'd Manacles: A History of Madness in England from the Restoration to the Regency (1987), Madness: A Brief History (2002) i posthumno objavljenom Madmen: A Social History of Madhouses, Mad-Doctors and Lunatics (2006) Porter čini svojevrstan odmak kako od „vigovske” historije tako i od „socijalnih revizionista” priznajući važnost i jednih i drugih, ali i jednima i drugima zamjerajući suviše suženu perspektivu usmjerenu više na tendenciozno potkrepljivanje vlastitih stavova o mjestu psihijatrije u društvu nego na sustavnu historiografsku analizu. $^{7}$

Osim pristupa povijesti psihijatrije koji su nužno „vigovski” ili „revizionistički” od kasnih šezdesetih do danas pojavio se niz studija povijesti psihijatrije u kojima autori i autorice analiziraju ulogu psihijatrije u različitim povijesnim procesima: od kolonijalizma, rasizma i dekolonizacije, borbe žena za rodnu ravnopravnost, te uloge psihijatrije u društvima koja prolaze ubrzane procese modernizacije. Za povijest psihijatrije iz rodne perspektive naročito je bitan rad britanske povjesničarke književnosti i znanstvenice na polju kulturnih studija Elaine Showalter, koja je u knjizi The female malady: women, madness, and English culture, 1830-1980 (1985)

7 Ibid: 12. 
istaknula ulogu koju su psihijatrijske dijagnoze poput histerije, ,shellshocka”(granatnog šoka) i shizofrenije imale pri perpetuiranju postojećih rodnih stereotipa i patrijarhalnih odnosa moći u društvu. Na sličan se način poviješću histerije u antičkoj medicini bavila antička povjesničarka Helen King. Karipski psihijatar Frantz Fanon koji će kasnije biti prepoznat kao jedan od utemeljitelja postkolonijalne misli, svoja je istraživanja pedesetih godina temeljio na svojoj psihijatrijskoj praksi, te se bavio specifičnom psihopatologijom kolonijalizma. Nakon Fanona javio se niz istraživača kolonijalne psihijatrije. Od bitnih studija na polju kolonijalne psihijatrije valja istaknuti rad američkog povjesničara Jonathana Sadowskog koji je u svojoj knjizi Imperial Bedlam Institutions of Madness in Colonial Southwest Nigeria (1999) problematizirao odnos psihijatrije i kolonijalne politike u britanskom imperijalnom kontekstu devetnaestog stoljeća.

Za povijest psihijatrije na području Hrvatske, izrazito je bitan rad povjesničara koji proučavaju razvoj psihijatrije u društvima koja prolaze modernizacijsku transformaciju iz pretežno ruralnih društava u industrijalizirana društva obilježena kapitalističkim odnosima proizvodnje. Američka povjesničarka Ann Goldberg 1999. godine objavila je studiju pod nazivom Sex, Religion, and the Making of Modern Madness: the Eberbach Asylum and German Society, 1815-1849 u kojoj analizira način na koji su psihijatrijske dijagnoze poput religiozne manije i nimfomanije u ranoj njemačkoj psihijatriji konstruirane putem „kliničkog zora” u promatranju ruralnih praksi vezanih uz religioznost i seksualnost. Golberg pokazuje kako su kulturno i ideološki informirane percepcije ponašanja štićenika i štićenica ruralnog porijekla od strane obrazovanih liječnika koji su pripadali građanskoj klasi ili aristokraciji i percipirali se kao nositelji prosvjetiteljstva i modernizacije, bili ključni za nastajanje dijagnostičkih kategorija moderne psihijatrije. ${ }^{8}$ Povjesničarka Manuella Meyer u svojim studijama istražuje ulogu psihijatara kao aktera političkih procesa modernizacije u Brazilu u devetnaestom stoljeću i prvoj polovici dvadesetog stoljeća, naročito njihovu ulogu u formiranju Brazila kao moderne nacije-države. ${ }^{9}$ Tamniju ulogu modernizacijskih procesa u Brazilu istražila je novinarka i aktivistica za ljudska prava Daniela Arbex. U svojoj knjizi Holocausto Brasileiro opisala je tragičnu sudbinu štićenika psihijatrijske kolonije Barbacena u kojoj je od prijelaza stoljeća do 1980. uslijed neljudskih uvjeta života i 
zlostavljanja preminulo 60000 ljudi. Više od osamdeset posto štićenika nije imalo medicinsku dijagnozu duševne bolesti, već su pripadali širokoj kategoriji „nepoželjnih” i društveno devijantnih osoba. ${ }^{10}$

Pristupi koji promatraju psihijatriju u širem kontekstu modernizacijskih procesa u središtu su istraživačkih pristupa povjesničara i povjesničarki koji su proučavali povijest psihijatrije na području bivše Jugoslavije. Jedna od najrelevantnijih studija na tom polju je knjiga Therapeutic Fascism. Experiencing the violence of Nazi New Order in Yugoslavia,(2017) srpske povjesničarke Ane Antić, koja živi i radi u Velikoj Britaniji. Antić je na temelju povijesti bolesti i stručne psihijatrijske literature istražila ulogu koju su psihijatri imali u turbulentom političkom razdoblju neposredno prije, za vrijeme i neposredno nakon Drugog svjetskog rata. Njemačka povjesničarka Heike Karge je u svojim radovima istraživala ulogu psihijatrije u konstrukciji socijalnih kategorija u Srednjoj i Jugoistočnoj Europi. Od hrvatskih istraživača treba spomenuti rad Marina Kuhara i Stele Fatović-Ferenčić koji su u nizu članaka objavljenih u domaćim i međunarodnim publikacijama analizirali formiranje distinktivnih kategorija duševne bolesti kroz mrežu interakcija psihijatrije i pravosuđa u Banskoj Hrvatskoj.

U ovom radu nastojim slijediti pristupe koji smještaju psihijatrijski diskurs u širi društveni kontekst i promatrati odnos psihijatrije prema različitim aspektima društva fin de sieclea poput rodnih uloga i seksualnosti, odnosa privatne i javne sfere, strahova koji su često postajali elementom političkog života i nasilja. Moj rad, kao i brojni od radova koje sam upravo naveo oslanja se na povijest bolesti kao specifičan izvor za povijest psihijatrijskog diskursa i psihijatrijske prakse. Iz tog razloga, potrebno je detaljno problematizirati povijest bolesti kao nesvakidašnji tip arhivskog izvora u historijskim istraživanjima.

\subsection{Povijesti bolesti i glas psihijatrijskih pacijenata: metodologija istraživanja psihijatrije}

Prilikom proučavanja psihijatrijskog diskursa u Hrvatskoj i istraživanja kako se isti formirao pod utjecajem terapijskih i izolacijskih praksi stenjevačkog zavoda (te kako je diskurs pomogao formirati proučavane prakse) bilo je potrebno detaljno opisati polje medicine i psihijatrije $u$ Europi i hrvatskom dijelu Austro-Ugarske monarhije. Za opisivanje intelektualnog horizonta

10 Arbex, 2013: 23. 
hrvatskih psihijatara i ostalih liječnika koji su na više ili manje neposredan način sudjelovali u radu zavoda za umobolne, primarno su poslužili članci i izvještaji objavljeni u Liječničkom vjesniku, glasilu Hrvatskog liječničkog zbora koje je počelo izlaziti 1877. godine i nastavilo do danas izlaziti na mjesečnoj bazi. Pri iščitavanju Liječničkog vjesnika nastojao sam što je moguće vjernije opisati razvoj određenih medicinskih ideja i diskurzivnih koncepata unutar liječničke struke. Budući da su priloge Liječničkog vjesnika pisali i čitali liječnici, isti daju vjernu sliku formiranja i širenja medicinskog znanja unutar same struke. Pritom valja naglasiti da razvoj medicinskog znanja u stručnom miljeu ne treba doživljavati u smislu jednosmjernog progresa već kao niz rasprava unutar liječničke zajednice koje su oblikovane kako obrazovanjem koje su liječnici stekli na inozemnim sveučilištima, tako i njihovom svakodnevnom praksom i susretima s pacijentima, te njihovim osobnim uvjerenjima. Način formiranja tih znanja može se pobliže objasniti pojmovima polja, habitusa i doktrine, koje je uveo francuski sociolog Pierre Bourdieu. U bourdieuvskom smislu, polje u kojem su locirani liječnici kao akteri koji razvijaju psihijatrijske koncepte i prakse odgovara prostorima javnog djelovanja medicinske profesije. Njihov habitus čine njihove prakse i dispozicije koje oni kao agenti društvenog djelovanja zauzimaju. Te prakse istovremeno su pomogle strukturirati društveni kontekst medicine i psihijatrije u Hrvatskoj na prijelazu stoljeća, ali $\mathrm{i}$ formirale određenu (auto)percepciju mjesta psihijatrije $u$ društvu. ${ }^{11}$ Intelektualni položaj samih psihijatara bit će na prijelazu stoljeća obilježen njihovom stalnom borbom za socijalni kapital unutar medicinske profesije i društva u cjelini, a društveni položaj psihijatara kao pripadnika obrazovane društvene elite koja je pripadala plemstvu ili građanskom sloju, a koji ipak djeluje na dvostrukim marginama: Austro-Ugarskog Carstva i marginama medicinske profesije oblikovao je njihova uvjerenja i vrijednosti. Te vrijednosti koje Bourdieau naziva „doxa” ili doktrina utjecale su na njihovo intelektualno i institucionalno djelovanje i u velikoj mjeri formirale sam psihijatrijski diskurs. S tim na umu, nastojao sam članke objavljene u Liječničkom vjesniku čitati kao primjer javnog djelovanja psihijatara na polju medicine s ciljem legitimacije hrvatske psihijatrije kao moderne medicinske discipline koja nastoji izboriti svoje mjesto unutar polja hrvatske medicine koje se na prijelazu stoljeća još uvijek tek počinje formirati. Istinsko formiranje i etabliranje moderne medicine na ovim prostorima

11 Bourdieu, 1996: 171. 
dogodit će se tek nakon Prvog svjetskog rata osnivanjem Medicinskog fakulteta i kasnijim formiranjem Škole narodnog zdravlja putem koje su hrvatski liječnici počeli aktivnije sudjelovati u formiranju zdravstvenih politika. Od posebnog su značaja bila i zdravstvena izvješća Kraljevskog i zemaljskog zavoda za umobolne u Stenjevcu koja su u prvim desetljećima rada psihijatri objavljivali u Liječničkom vjesniku, a koja su osigurala podatke brojnosti, socijalnoj strukturi i smrtnosti štićenika, a koje sam nastojao prikazati i grafički.

Pored članaka objavljenih u Liječničkom vjesniku kao izvor za poučavanje psihijatrije služit će i stručni tekstovi europskih i američkih psihijatara. Radi se o radovima objavljenim u stručnim publikacijama i medicinskim priručnicima. Proučavanje tekstova inozemnih (uglavnom austrijskih, njemačkih, francuskih i britanskih) psihijatara daje detaljan pregled razvoja i transfera pojedinih termina i koncepata u psihijatrijskoj znanosti. To se naročito odnosi na dijagnostičke kategorije, etiologiju duševnih bolesti i terapeutske pristupe. Svaki od koncepata opisanih u tekstovima hrvatskih psihijatara i primijenjenih u praksi zavoda, legitimiran je pozivanjem na određene psihijatrijske autoritete što pokazuje kako je hrvatska psihijatrija bile uvelike formirana pod utjecajem spoznaja europskih psihijatara i neurologa. Istraživanje psihijatrijskih priručnika napisanih na stranom jeziku (u vremenu obuhvaćenom ovim istraživanjem ne postoje takvi priručnici na hrvatskom jeziku) omogućava smještanje psihijatrije u širi europski kontekst i odaje transformaciju i primjenu koncepata europske psihijatrije u diskursu i praksi hrvatskih psihijatara. Osim komunikacije psihijatara sa psihijatrijskom zajednicom izvan Hrvatske i s drugim liječnicima, bitno je pratiti i emotivni režim obrazovanih društvenih elita pripadali. Osim sekundarne literature o kulturnoj povijesti emocija u kasnom devetnaestom i ranom dvadesetom stoljeća, poslužio sam se književnim djelima koja su nastajala ili bila čitana u Hrvatskoj za vrijeme ili neposredno nakon i prije proučavanog razdoblja. Smatram kako je književnost, kao jedan od bitnih medija kroz koji su obrazovani slojevi formirali svoj stav o emotivnosti i međuljudskim odnosima značajan izvor za objašnjavanje emotivnog režima razdoblja u kojem je pisana riječ još uvijek dominantni oblik društvene komunikacije. 
Medicinski i književno-umjetnički tekstovi formiraju vanjski pogled na emocije, psihu i duševnu bolest no psihijatrijski diskurs se primarno formira unutar heterotopije zavoda i bolnica za duševne bolesti. Sama klinička praksa obilježena je aktivnom interakcijom liječnika i pacijenta. I dok stručna medicinska literatura raspravlja i opisuje medicinske koncepte, praksa podvrgavanja tijela pacijenta ,medicinskom zoru” koji strukturira, grupira i klasificira osobine uočene na tijelima pacijenata u definitivne označitelje ,zdravog” i ,patološkog” događa se u izoliranom prostoru klinike koji je prilagođen isključivo toj vrsti proizvodnje znanja. Prostor psihijatrijskog zavoda i prostor stručnog medicinskog teksta odgovaraju dvama prostorima čije je postojanje Foucault pretpostavio činu kliničke opservacije: prostoru bolnice i prostoru podučavanja ${ }^{12}$. Mjesto zavoda mjesto je gdje kategorije psihijatrijskog znanja bivaju strukturirane i opisane kroz procese izmjene kliničkog govora i kliničkog zora, uspostavom korelacije između njih i konačno, opisom patologije koju zor otkriva na tijelima i u riječima psihijatrijskih štićenika. ${ }^{13}$

Povijest bolesti je jedan od konačnih artefakata znanja koji nastaje tim procesom, mjesto gdje se tijela štićenika transformiraju u objekte psihijatrijskog znanja ključnog za formiranje svakog diskursa. U Klinici za Psihijatriju Vrapče, svaka povijest bolesti organizirana je kao jedinstvo liječničkih kliničkih opservacija i govora štićenika. Kliničke opservacije počinju od prve stranice na kojoj su doneseni osnovni podaci o svakom štićeniku - ime i prezime, dob, vjerska pripadnost, zanimanje, mjesto stanovanja, datum dolaska u zavod (eventualni raniji boravak u zavodu se također bilježi), dijagnoza, pretpostavljeni uzrok bolesti, dodatne bilješke, te datum i okolnosti izlaska iz zavoda. U slučaju smrti naveden je i uzrok smrti štićenika. Nakon osnovnih podataka opisanih na prvoj stranici, prelazi se na nekoliko stranica gusto ispisanih kliničkih bilješki o ponašanju i zdravstvenom stanju štićenika. Te bilješke počinju biti pisane od prvog dana dolaska u zavod kad se štićenika podvrgava detaljnom tjelesnom pregledu i intervjuu s liječnikom. Time se sustav konstantnog kliničkog nadzora uspostavlja kao dominantni okvir unutar kojeg nastaje dokument o štićenikovom boravku u zavodu. ${ }^{14}$ Iako je sam proces promatranja u stručnim tekstovima prezentiran kao objektivan i informiran postojećim

12 Foucault, 2003: 135.

13 Ibid: 140.

14 Lunbeck, 1995: 133-134. 
medicinskim i znanstvenim kategorijama, povijesti bolesti odaju njegovu subjektivnu prirodu. Kao što je u svom ranijem istraživanju prepoznala Ana Antić, kategorije na osnovu kojih se dijagnosticira duševno zdravlje štićenika bile su u velikoj mjeri kulturno i društveno uvjetovane. ${ }^{15}$ Od štićenika se tako očekivalo da poznaju trenutnu političku situaciju, rješavaju matematičke zadatke, odgovaraju na pitanja o vlastitim vjerskim i moralnim načelima (idu li u crkvu, znaju li molitve, daju svoj stav o pitanjima poput: je li u redu krasti i treba li supruga slušati svog muža) ${ }^{16}$. Brojni opisi ponašanja i izgleda štićenika i štićenica su izrazito subjektivni i daleko od egzaktnih znanstvenih i medicinskih kategorija. Tako se u povijestima bolesti nalaze opisi poput: „Izraz lica inteligentan, pogled erotičan”, ${ }^{17}$,„nesnošljiva ženska”, ${ }^{18}$ „,Smiješi se kao seoska guska.”, ${ }^{19}$ „,Jedna od najužasavajućih katatoničnih prikaza." ${ }^{20}$ Pored bilješki povijest bolesti sadrži i obaveznu liječničku svjedodžbu na temelju koje je štićenik primljen u zavod, a koja sadrži opservacije mjesnog ili kotarskog liječnika ili liječnika zaposlenih u nekoj od općih bolnica. Bilješke kotarskih liječnika uglavnom sadrže iste podatke kao i naslovne stranice povijesti bolesti, no često daju detaljniji pregled anamneze štićenika - prethodne bolesti kao i informaciju o eventualnim bolestima članova obitelji. Uz liječničku svjedodžbu pojedine povijesti bolesti sadrže i pisma samih štićenika, njihovih članova obitelji, prijatelja i poznanika, poslodavaca te ponekad predstavnika lokalne vlasti.

Za razumijevanje povijesti bolesti nužno je, osim liječničkih i bolničarskih primjedbi prepoznati i govor samih štićenika kao konstitutivni element izvora. Glasovi štićenika javlja se u tri oblika: posredovan glas, djelomično posredovan glas i neposredan glas. Potpuno posredovan glas javlja se kada se govor štićenika prenosi u trećem licu od strane psihijatara i bolničara. U primjerima takvog posredovanja rijetko dobivamo riječi koje je štićenik direktno koristio, a iskazi štićenika uglavnom su reducirani na informacije koje je osoba koja je zapisivala govor smatrala bitnima. U nekim slučajevima, navedene su pojedine riječi štićenika unutar prepričanog iskaza, uglavnom kako bi ih se osobito istaknulo na primjer, u slučaju sluškinje Tereze G:

15 Antić, 2016: 31.

16 Arhiv Klinike za psihijatriju Vrapče, povijesti bolesti. U daljnjem tekstu koristim kraticu KPV.

$17 \mathrm{KPV}, 1895: 2630$.

$18 \mathrm{KPV}, 1895: 1737$.

$19 \mathrm{KPV}, 1914: 6787$.

$20 \mathrm{KPV}, 1914: 9053$. 
„Kasnije služila u Mariboru, Zagrebu i Grazu. Nije nigdje dugo zadržala (sic!), jer je žestoke ćudi i lako se svadila a sve je to kriv rittmajstor, mladi Perger u Gracu. On ju progoni, sluša, zna njezine misli, ona mora govoriti ono, što on misli, može njezino tijelo micati kako hoće i to sve pomoću nekakvog hoeraparata. On joj napravio „Schuttelfrost” poslije kog je morala mnogo urinirati. ${ }^{21}$

Iako je cijeli Terezin govor zapisan u neupravnom govoru, s opisom njezinih deluzija u trećem licu, osoba koja je zapisivala njezin iskaz istaknula je njemačku riječ „Schuttelfrost” (nazeb) kao frazu koju uglavnom germanofona Tereza koristi. Slično je i u povijesti bolesti seljakinje Jane L.: „Tužila se zatim, da joj hoće neko oči izvaditi, da joj ispanu svaki čas „gadne riječi, tako da je i sad izbacila dvije gadne riječi." ${ }^{22}$. Nakon prepričavanja Janinih strahova i pritužbi, fraza „gadne riječi” odijeljena je navodnicima i označena kao izvorni navod štićenice, te ju se zatim nastavilo koristiti kroz povijest bolesti. Upotreba navodnika, kao što je navela i Ana Antić, osim odjeljivanja izvornog i prepričanog govora štićenika odaje i eksplicitnu asimetriju moći između štićenika i liječnika. Pozivajući se na Bahtinov koncept lingvističkih zona, Antić je primijetila da govor pacijenata često zauzima prostor medicinskog dokumenta i pokušava nametnuti štićenikovu perspektivu njegovog vlastitog mentalnog stanja i okolnosti u kojima se našao. ${ }^{23}$ Navodnici, kao direktna intervencija označuju liječnikovo distanciranje od štićenikovih riječi i ekspliciraju ih kao simptom. Govor štićenika postaje iskaz podvrgnut kliničkom nadzora koji ima ulogu potvrđivanja štićenikove duševne bolesti. Navodnicima su često istaknute upravo neuobičajene fraze ili krivo upotrijebljeni iskazi kao vid dodatnog naglašavanja da ih koristi upravo sam štićenik.

Djelomično posredovan glas štićenika također je zapisan od strane bolničara ili liječnika, ali su iskazi preneseni u prvom licu, često i na dijalektu štićenika, ponegdje odijeljeni navodnicima, a ponegdje ne. Taj je govor najčešće uokviren izjavom koja jasno obilježava iskaz kao štićenikov poput „kaže da” ili „govori: ”. Često je djelomično posredovan glas dodatno ilustriran izjavom o emotivnom stanju štićenika na primjer: 
„Kod vizite se vrlo plaši, boji se kad mu bolničar stoji iza glave, svi moraju stajati pred njim, do nogu kreveta; iznenada zaplače i vikne: Nemojte mi stavljati prisilne maske na lice."24

U povijestima bolesti štićenici neposredno progovaraju kroz pisma koja su pisali liječnicima, obitelji ili predstavnicima vlasti. Takva pisma su brojna i napisana su rukom štićenika. Iako tu glas štićenika dolazi cjelovito uobličen od strane štićenika, treba imati na umu da je i tu prisutna selekcija od strane liječnika. Radi se isključivo o pismima koja nisu odaslana na adrese na koje su ih štićenici namjeravali odaslati i sačuvana su kao dio povijesti bolesti upravo jer su ih liječnici smatrali artefaktom patologije štićenika. Pisma priložena povijestima bolesti nisu izmijenjena, ali su kontekstualizirana unutar narativa kroz koji su štićenici zavoda konstruirani kao osobe „abnormalnog” i „poremećenog” uma. Glas štićenika, je čak i kad progovara neposredno unutar zavoda uvijek podložan intervenciji kliničkog zora, koji se u konkretnom primjeru sačuvanih pisama javlja u formi moći selekcije: liječnik odlučuje koji će od iskaza biti zabilježeni, a koji ignorirani, koje izjave postaju dijelom štićenikove povijesti, a koje su predane zaboravu. Komunikacija unutar zavoda isključivo je jednodimenzionalna i locirana je isključivo između medicinskih koncepata normalnog i patološkog. Iskazi koji su zabilježeni, zabilježeni su upravo kao elementi kliničke slike, bez osvrta na sve druge dimenzije tih iskaza, a naročito one koje bi mogle predstaviti autentičan pogled štićenika na njihovo vlastito duševno stanje. Povijest bolesti je izvor u kojem je glas štićenika neprekidno podvrgnut epistemičkom nasilju liječnika i u potpunosti stavljen u subalternu i marginalnu poziciju iz koje može progovarati jedino unutar kategorija propisanih samom svrhom zavoda kao mjesta pripisivanja ili potvrđivanja stigme ludila.

U ovom radu nastojim povijesti bolesti, stručne medicinske tekstove i književne tekstove podvrgnuti geertzovskom gustom opisu i prikazati poglede tek nastajuće hrvatske psihijatrije na seksualnost, strah i nasilje. Rad se trudi zahvatiti sve razine manifestacije psihijatrijskog diskursa: od najširih intelektualnih debata unutar europske i američke psihijatrije, preko postupnog razvoja

$24 \mathrm{KPV}, 1909: 7130$. 
psihijatrijske misli u kontekstu hrvatske medicine, do bliskih susreta liječnika i štićenika, te naposljetku, interakcije medicine i društva kroz način na koji je psihijatrija prenosila kategorije formirane unutar zavoda na društvo u cjelini. Pritom ću pokušati neprestano imati na umu da govoreći o hrvatskim psihijatrima i štićenicima za koje su se, nekad manje a nekad više uspješno skrbili, prenosim priču s trostrukih margina u kojoj stručnjaci stasali u polju marginalne grane medicinske profesije, svakodnevno komuniciraju s marginaliziranim članovima društva koje se nalazilo na marginama Austro-Ugarskog Carstva. 


\section{Europska psihijatrija u devetnaestom stoljeću}

\section{1. „Moral treatment” i začeci psihijatrije}

Usprkos smjeloj tvrdnji Michaela Foucaulta o osamnaestom i devetnaestom stoljeću kao vremenu u kojem dolazi do „Velikog utamničenja” duševno bolesnih ${ }^{25}$, pomnije proučavanje tog vremena otkriva stalnu diskurzivnu borbu između raznih intelektualnih disciplina koje su htjele imati autoritet nad tumačenjem pojava povezanih sa unutarnjim životom čovjeka. U toj borbi, psihijatri i ravnatelji zavoda u kojima se ,zatočivalo” ljude s psihičkim tegobama nisu uvijek imali glavnu riječ: vjerski autoriteti, pučka medicina, privatne i državne inicijative, te brojne intelektualne struje unutar medicine, psihologije i filozofske antropologije sebi su pridržavali pravo objašnjavanja ljudske psihe te nudili različite oblike tretmana onoga što su u različitim epohama nazivali „ludilom”, „umoboljom” psychozom” ili „psihopatologijom”. Činjenica da je dugo devetnaesto stoljeće u povijesti psihijatrije na simboličan način prikazano poznatom slikom na kojoj francuski „otac psihijatrije” Philippea Pinela koji u pariškoj klinici Salpetriere skida okove sa štićenika zapravo više odražava suženu sliku koju su o tom vremenu imali i povijesničari institucija poput Gruba i Shortera i socijalni konstruktivisti poput Foucaulta i Goffmana. Devetnaesto stoljeće obiluje raznolikim i konfliktnim odgovorima na problem uzroka ludila. No ipak, do kraja stoljeća, psihijatrija se, najprije u građanskim krugovima, a potom i šire postepeno nametala kao jedina disciplina koja može pružiti odgovore na pitanje uzroka duševnih bolesti i tretmana duševno oboljelih.

„Moral Treatment”je pojam koji je skovao Phillipe Pinel i koji bi na hrvatski bilo najumjesnije prevesti kao „psihološki tretman” budući da riječ „,moral” ovdje konotira misli, strasti, emocije, sentimente $\mathrm{i}$ afekte pacijenata, ukratko njihovu psihu ${ }^{26}$. Pod tim imenom najčešce se podrazumjeva niz ,predmedicinskih"27 terapeutskih metoda liječenja duševnih bolesti poput terapeutske arhitekture, terapije radom i izolacijom te principa „,non-restrainta”, to jest ukidanja starih mehaničkih načina sputavanja štićenika. Iako je definicija pojma ,moral treatment” pomalo

25 Foucault, 2002: 10.

26 De Young,2015: 447.

27 Ibid. 
nejasna i neodređena, na temelju preskriptivnih opisa psihijatrijskih institucija koji često bili pisani i objavljivani od kraja osamnaestog do sredine devetnaestog stoljeća možemo odrediti četiri osnovna trenda „moral treatmenta” kao razdoblja u povijesti psihijatrije:

1. Odustajanje od različitih fizioloških terapija poput klistira, purgativa, abrazivnih terapija i puštanja krvi,

2. Etiologija duševnih bolesti se temelji na emocionalnim uzrocima. Prema tome i terapije imaju za svoj cilj discipliniranje pacijentovih emocija nasuprot discipliniranju fizičkog tijela.

3. Svrha institucija za duševno oboljele je primarno terapeutska te se smatra se da arhitektura institucija ima blagotvorni utjecaj na zdravlje oboljele osobe.

4. Postoji trend ukidanja dosadašnjih metoda sputavanja duševno oboljelih (tzv. „non-restraint” princip). Taj trend ne rezultira potpunim prestankom same prakse sputavanja nemirnih bolesnika već uglavnom uvođenjem „humanijih” mehanizama sputavanja poput „luđačkih košulja” ili stezulja i soba za izolaciju s mekim zidovima. Te metode su humanije utoliko što je deklarativna ideja iza njihove implementacije sprečavanje namjernog ili slučajnog samoozljeđivanja, a ne isključivo ograničenje slobode kretanja štićenika.

Razvoj institucionalne brige za duševno oboljele zapravo ne počinje s Pinelom i s praksom „moral treatmenta”. No, načini na koje je ludilo kao društvena pojava bilo percipirano tretirano prije nastanka institucionalne psihijatrije bili su temom brojnih debata među povjesničarima psihijatrije. S jedne strane stoji slabo potkrijepljena teza Michaela Foucaulta o vremenu kad je život duševno bolesnim bio obilježen lutanjem ${ }^{28}$. S druge strane, psihijatri devetneatog stoljeća često ističu primjere ranijeg okrutnog postupanja s duševno oboljelima, te navode da su se opsjednutost demonima, natprirodno djelovanje vještica i vukodlaka i uroci smatrali uzrokom ludila. ${ }^{29}$ Čini se da su se iskustva duševno bolesnih u ranom novom vijeku, uvelike razlikovala kao što su se razlikovale i paradigme ludila- medicinske metode stajale su uz bok religijskim i magijskim pogledima na ludilo i terapeutskim riznicama pučke medicine. Stoga „moral

28 Foucault, 2002: 9.

29 Glesinger, 2012: 20. 
treatment" ipak predstavlja prvi pokušaj standardizacije psihijatrijske skrbi u širem europskom kontekstu.

U protopsihijatrijskim metodama koje favoriziraju liječnici prije „,moral treatmenta” mogu se još uvijek naći kontinuiteti humoralne medicine, koja svoje intelektualne korijene vuče iz antike. Humoralna medicina, temelji se na uvjerenju da četiri tjelesne tekućine: krv, sluz te crna i žuta žuč upravljaju ritmovima razvoja i promjenama koje se odvijaju unutar ljudskog tijela. ${ }^{30}$ Promjene $u$ ravnoteži između tih tjelesnih sokova također nalaze odraz u karakternim crtama čovjeka, te mogu izazvati napade ludila. Na primjer, prevelike količine krvi i žute žuči mogu dovesti do manije, dok prevelike količine crne žuči dovode do melankolije i depresije. ${ }^{31}$ Takvo viđenje duševnih bolesti dovelo je do česte primjene terapija baziranih na izlučivanju određenih tjelesnih tekućina poput puštanja krvi, sredstava za čišćenje poput klistira i emetika u tretiranju duševnih bolesti. Sa pojavom ,moral treatmenta” na kraju osamnaestog i početku devetnaestog stoljeća, ta se sredstva se rijeđe upotrebljavaju u zavodima- zamijenjuju ih režimi prehrane, psihološke metode liječenja poput liječenja strahom i hidroterapija koja sve više dobija na popularnosti kako se ugled kupališne medicine širi međi višim slojevima. Metode liječenja koje Philippe Pinel ističe u svom slavnom psihijatrijskom udžbeniku Traité médico-philosophique sur l'aliénation mentale; ou la manie (Medicinsko-filozofski traktat o duševnom otuđenju ili maniji) ponajviše proizlaze iz karaktera same institucije u kojoj se liječenje odvija. Pinel je preuzeo zavod u Bicetreu pokraj Pariza 1795. godine, nakon iskustva rada u brojnim privatnim liječilištima u Francuskoj. Potaknut humanističkim načelima prosvjetiteljstva i užasnut kaosom Francuske revolucije i terorom i nasiljem koji su uslijedili nakon nje, Pinel se trudio istaknuti važnost nadzora i reda u instituciji za liječenje duševnih oboljenja. Pinel tako kaže da su najvažnije karakteristike ravnatelja ,velika pronicljivost, neumorna predanost, trajna i neumorna pozornost koja se pridaje svakom pojedinačnom slučaju". ${ }^{32}$ Sam unutarnji ustroj institucije i uloga ravnatelja kao figure autoriteta koja nadzire svaki aspekt života u instituciji i uspostavlja nepobitan, gotovo očinski autoritet nad pacijentima i pomoćnim osobljem bivaju istaknuti kao

30 Porter, 2002:37.

31 Ibid:41.

32 Pinel, 1806:99. 
ključni u Pinelovom udžbeniku dok se bogatstvo ranonovovjekovne farmakopeje i kirurških metoda ne spominju. U isto vrijeme kao Pinel, liječnici poput britanskog kvekera Williama Tukea i firentinskog upravitelja bolnice Svetog Bonifacija Vincenza Chiarugija počinju posvećivati sve više pažnje ustroju same institucije i autoritetu liječnika, napuštajući dotadašnje neučinkovite metode liječenja zasnovane na humoralnoj medicini.

Primjena novih terapeutskih metoda neodvojiva je od promjene paradigme vezane uz etiologiju duševnih bolesti. Krajem osamnaestog i devetnaestog stoljeća vode se brojne rasprave o tome je li duševna bolest posljedica patoloških promjena na mozgu ili se radi o primarno afektivnom poremećaju čiji su uzroci psihološke prirode. U pozadini tih prijepora, nalaze se zapravo filozofsko-antropološka rasprave o samom ustroju čovjekova uma i njegove ličnosti, koje svoje korijene vuku iz filozofije klasičnog njemačkog idealizma i njezinog suprotstavljanja mehanicizmu prosvjetiteljstva. Naime sredinom devetnaestog stoljeća, dolazi do sukoba oko definiranje odnosa tijela i uma između ,somaticističke škole” kojoj su pribadali brojni liječnici i platonističke škole koju su uglavnom predstavljali filozofski antropolozi. Somaticisti, inspirarirani Descartesom su smatrali da um i tijelo jasno odvojeni pojmovi, pri čemu um sam ne može oboljeti. Samim time, duševne bolesti moraju biti samo simptomi tjelesnih oboljenja koja sprečavaju da um obavlja svoje više funkcije. Druga škola, inspirirana platonističkim koncepcijama, prema kojima je duša predstavlja istinskog čovjeka dok je tijelo samo njezina sjena. ${ }^{33}$ Samim time, duševne bolesti su uistinu bolesti duše, koje nastaju zbog grešnog života ili jake emotivne patnje. Većina pobornika „moral treatmenta” među europskim psihijatrima odabrala je upravo afekt kao uzrok psihičkih poremećaja i time se svrstala uz „platonističku”, monističku struju. O tome detaljno govori Pinelovo čitanje povijesti bolesti pacijenata bolnice Bicetreu i njegovo objašnjenje uzroka ludila.

Pinel uzrok ludila vidi u velikim duševnim potresima: na primjer, jedan od Pinelovih pacijenata je svećenik za kojeg Pinel navodi da je poludio zbog progona katolicizma nakon Francuske

33 Verwey, 1985: 21. 
Revolucije. ${ }^{34}$ Slične poglede na uzrok duševnih bolesti imaju i ostali pobornici „moral treatmenta" u ranom devetnaestom stoljeću- talijanski liječnik i reformator skrbi za duševno oboljele, Vincenzio Chiarugi, smatrao je da za ispravan tretman duševnih bolesti nužno objediniti neurološku perspektivu sa dušom, duhom i umom jer se ljudski život, za Chiarugija sastoji u reciprocitetu između spiritualnog i materijalnog ${ }^{35}$. Kod najizrazitijeg britanskog predstavnika rane zavodske psihijatrije Williama Tukea također se naglašava simpatička i recipročna veza između tijela i uma, te se napuštaju agresivni fiziološki tretmani poput puštanja krvi. ${ }^{36}$ Umjesto njih, Tuke u svojoj instituciji „The Retreat” u Yorku, kombinira blagotvoran utjecaj rustikalne arhitekture, rutiniranog života, ispravne prehrane, rada i tjelovježbe. ${ }^{37}$ Općenito gledano pri etiologiji duševnih poremećaja i praktičnom pristupu liječenju istih na psihu i tijelo se gledalo kao jednu neodvojivu cijelinu. Samim time, psihijatrija se etablira kao distinktivna intelektualna disciplina koja se uzima „ludilo” za svoje područje proučavanja, dok ju teoretska pretpostavka međuovisnosti psihe i tijela spojena s primarno terapeutskim ciljem konačno približavaju medicini i udaljuju od alternativnih filozofsko antropoloških izvorišta, kojima će se ponovno vratiti tek početkom dvadesetog stoljeća u okviru psihoanalize.

Treće bitno obilježje „moral treatmenta” vezuje psihijatriju za terapeutsku ustanovu zavoda. Psihijatrijski zavod, na engleskom govornom području često nazvan ,asylum” će se tek kasnije preobraziti u psihijatrijsku bolnicu ili psihijatrijsku kliniku. To ispreplitanje psihijatrijske prakse i institucijskog konteksta najvidljivije je u terapeutskoj arhitekturi i velikoj pažnji posvećenoj unutarnjem institucionalnom ustroju zavoda. Neki od ključnih elemenata terapeutske arhitekture izolacija od društva, dnevna rutina i uklanjanje mehaničkih sredstava sputavanja vuku porijeklo iz malih privatnih klinika u kojima su se, prije uspostave prvih velikih zavoda, liječili imućniji pripadnici plemstva i građanstva. ${ }^{38}$ Te privatne klinike, usko su se vezivale uz kupališnu kulturu ranog devetnaestog stoljeća iuz blagotvorno djelovanje izolacije, nudile su obilje fizioloških lijekova za probleme ,napetih živaca” i ,poremećene ravnoteže tjelesnih sokova”. Omasovljenje 34 Pinel, 1806: 61.

35 Gerrard, 1977, 383.

36 Kibria i Metcalfe, 2014: 3.

37 Ibid: 2-3.

38 Yanni, 2007: 29-30. 
institucionalizacije osoba s duševnim poteškoćama stvara potrebu za inovativnim arhitektonskim rješenjima koja će objediniti potrebu za efikasnim nadzorom, disciplinu i blagotvorno djelovanje krajolika. Prvo takvo rješenje je takozvani linearni ili Kirkbrideov plan (nazvan tako po američkom reformatoru brige za mentalno zdravlje i ravnatelju psihijatrijske institucije u Pennsylvaniji). Linearni plan zamišlja psihijatrijsku instituciju kao zgradu u obliku širokog slova U ili W sa odvojenim krilima za mirne i nemirne štićenike, prostranim hodnicima i sobama smještenim s jedne strane kako bi se olakšao nadzor. ${ }^{39}$ Osim soba za štićenike, večina planova predviđa i stanove u kojima, u sklopu zavoda žive ravnatelj, glavni liječnik i ostali bitni zaposlenici. Time se osigurava kontinuiran nadzor ravnatelja i njemu podređenog osoblja nad čitavim zavodom, a i riješava se problem koji bi predstavljalo putovanje liječnika iz grada u često izolirani zavod. Najviše psihijatrijskih institucija izgrađenih u devetnaestom stoljeću, izgrađeno je po Kirkbridgeovom planu .

U drugoj polovici devetanestog stoljeća, razvijen je i alternativni paviljonski plan kojeg su prvenstveno osmislili američki liječnici inspirirani primjerom belgijskog grada Ghaela u kojem je svećenstvo vodilo skrb za duševno oboljele još od 13. stoljeća. ${ }^{40}$ Separatni, paviljonski ili „cottage” plan se zasniva na organizaciji prostora institucije oko niza odvojenih paviljona u kojima bi štićenici imali relativni mir i slobodu kretanja, a koji bi bili razmješteni oko središnje zgrade u kojoj se nalaze stanovi ravnatelja i liječnika. Taj je model do neke mjere korišten i u Stenjevcu, ali se javio u vrijeme kad je paradigma „terapeutske arhitekture” već polako bivala napuštana u ozračju terapeutskog pesimizma fin de sieclea.

Model terapeutske arhitekture je nerazdvojno vezan uz uvjerenje da fizička izolacija i smještaj u pastoralnom okruženju blagotvorno djeluju na duševno zdravlje. Opis idealne lokacije za smještaj zavoda dao je otac francuske forenzičke medicine François-Emmanuel Fodéré u svom šestotomnom djelu Traité de médecine légale et d'hygiène publique ou de police de santé iz 1813. godine:,Htio bih da se takvi domovi grade u svetim šumama, na nepristupačnim i izoliranim mjestima. U svetim gajevima usred velike divljine..." ${ }^{41}$ Važnost izolacije i pastoralnog karaktera mjesta na kojem bi se zavodi trebali graditi je ovdje pojačana i sakralizirana opetovanim 
dodavanjem pridjeva „sveti”. Imena zavoda poput Tukeovog „Retreata” (utočočište, odmorište, mjesto na koje se osoba povlači) su također ostavljala dojam zavoda kao izdvojenog prostora, heterotopije isključivo posvećene liječenju, na koju ne bi trebao djelovati širi društveni kontekst. Istovremeno, opetovano se ističe kako je liječenje nemoguće izvan tog izdvojenog svijeta te da je za oporavak nužna dobro regulirana instuticija zatvorenog zavodskog tipa, čiji ravnatelj može uspostaviti potpunu kontrolu nad režimom štićenikovog oporavka. ${ }^{42}$

Ovaj režim autoritarne kontrole ravnatelja nad cjelokupnim životom unutar institucije, drugi je bitan element „moral treatmenta”. Ustroj psihijatrijatrijske institucije takav je da daje apsolutni „očinski” autoritet upravitelju ludnice. Arhitektonski planovi poput Kirkbrideovog su pružali mogućnost da se stari sustav „mehaničkog sputavanja” često kritiziran kao okrutan ili primitivan zamijeni struktuiranim sustavom nadzora štićenikovog okoliša. ${ }^{43}$ Pored toga, bilo je bitno da psihijatrijske institucije odaju dojam „domaćinstva” a ne institucije posvećene nadzoru, tako da su rešetke na prozorima i pojačana vrata zamijenjeni inovacijama poput dvostrukih staklenih okana i običnim vratima koja su se mogla otvarati samo s vanjske strane. ${ }^{44}$ Arhitektura je, samim time zapravo služila kao panoptikonski instrument disciplinarne moći koja je, zaodjevena u diskurs „moralnog autoriteta” liječnika koji blagim, ali nepokolebljivim značajem vraća razum štićenicima, zapravo učinjena terapeutskom osnovom „moral treatmenta”.

S liječničkim autoretitom i principom humanog postupanja povezano je i napuštanje mehaničkih instrumenata sputavanja poput metalnih okova i lanaca u zavodima koji su uveli moral treatment kao terapeutski princip. William Tuke je tako naglašavao da se mehanički načini kontrole trebaju izbjegavati kad god je to mogući i zamijenjivati kombinacijom blagog postupanja i izazivanja straha od autoriteta kod štićenika. ${ }^{45}$ Pinel u svom traktatu ističe da se za smirivanje nemirnih štićenika trebaju koristiti jedino „stezulje, fizička nadmoć i izolacija na ograničeno vrijeme” dok bolničarima ne smije nipošto biti dopušteno da udaraju štićenike. ${ }^{46}$ Za Pinela je, kao i za Tukea, najbitnije bilo održavanje i upravljanje strahom kod njegovih štićenika, koji za njega mora biti

42 Pinel, 1806: 59-60.

43 Showalter, 1985: 35.

44 Ibid.

45 Kibria i Metcalfe, 2014: 4.

46 Pinel, 1806: 68. 
povezan s osjećajem poštovanja kako bi bio potpuno učinkovit. ${ }^{47}$ Može se zapravo reći da „,moral treatment" kao psihološki i emotivni tretman predstavlja obrat s kontrole tijela putem mehaničkih sprava za vezanje prema kontroli emocija. Međutim, kontrola emocija nije mogla biti odvojena od nametanja režima „terapeutske arhitekture” i nadzornikovog suverenog vladanja izdvojenim prostorom institucije na sama tijela štićenika. Čini se da se radi o foucaultovskom principu zaodjevanja direktne sile u diskurs autoriteta koji rezultira kapilarnim širenjem ultimativne disciplinarne moći kroz cjelokupnu instituciju.

Kraj dominacije „moral treatmenta” kao paradigme u tretmanu duševnih oboljenja povezan je s činjenicom da je utopiju izoliranih, pastoralnih utočišta za oboljele bilo nemoguće provesti u društvu koje je zahtijevalo sve veći opseg institucionalizacije društveno devijantnih osoba. Jedan od uzroka tog fenomena je velika epidemija progresivne paralize ili kasnog cerebralnog stadija sifilisa koji je postajao sve rašireniji među muškarcima srednje klase, a kako su modernizacijski procesi uzimali maha širio se i na radničke i zemljoradničke slojeve. ${ }^{48}$ Drugi dominantni uzrok bila je sve veća promjena koncepta obitelji, kao primarno afektivne intimne zajednice. ${ }^{49}$ Formiranje takve zajednice zahtijevalo je novi, specifični emotivni režim koji je imao manje tolerancije za devijacije duševno bolesnih. Taj je režim rezultirao izolacijom svih onih koji su prezentirali oblike ponašanja koji u njemu nisu imali mjesto ili us bili smatrani odviše disruptivnima za takvu, građansku sliku obitelji. Treći uzrok bio je donekle iatrogenetski. Naime, osnivanje sve većeg broja zavoda koji su izolirali osobe s psihičkim poteškoćama, potiče državu i lokalne zajednice da koriste te zavode za uklanjanja sve većeg broja devijantnih pojedinaca iz društva. Osobe sklone konfliktima, agresivne osobe, pojedinci skloni skitnji, epileptičari, osobe s poteškoćama u razvoju, ljudi mentalno onemoćali zbog starosti i alkoholičari postaju predmetom psihijatrijske skrbi i bivaju sve češće upućivani u psihijatrijske institucije, često unatoč otporu samih ravnatelja tih institucija. Prenapučenost i povećanje broja neizlječivih štićenika dovest će do svojevrsnog terapeutskog pesimizma koji će, već pred kraj devetnaestog stoljeća rezultirati ponovnom okretanju somaticističkoj psihijatriji, naročito u kontekstu njemačke i austro-ugarske sveučilišne i zavodske psihijatrije. Pridržavanje određenih temeljnih principa moral treatmenta

47 Ibid: 67.

48 Shorter, 1996: 56-57.

49 Ibid: 50. 
poput ideje o apsolutnoj nužnosti institucije i nepobitnog autoriteta njenog ravnatelja će se usprkos tome, zadržati u psihijatriji sve do pokreta za reformu psihijatrije koji se počinje polako pojavljivati od šezdesetih godina dvadesetog stoljeća. 


\subsection{Terapeutski pesimizam i degeneracija}

Sredinu devetnaestog stoljeća obilježava nagli uspon psihijatrijskog zavoda kao institucije u Europi i Sjedinjenim Američkim Državama. Broj psihijatrijskih institucija je u stalnom porastu, i dok su u Sjedinjenim Državama i Engleskoj one uglavnom vezane uz privatnu inicijativu, ili inicijativu lokalnih vlasti, u Francuskoj, Rusiji i Srednjoj Europi inicijative za njihovim osnivanjem je uglavnom državna. Kao što je spomenuto u prethodnom poglavlju, legitimacija institucije kao terapeutskog sredstva, u nekim je slučajeva imala iatrogenički efekt na samu praksu- sve veći broj ljudi koji nisu nalazili svoje mjesto u modernizirajućim društvima devetnaestog stoljeća bivalo predano na skrb u psihijatrijske institucije i broj štićenika je rastao iz godine u godinu. Istovremeno, financijsko stanje institucija i njihova infrastruktura nisu mogle pratiti taj brzi rast i zavodi diljem Europe su se sve češće odavali sliku zapuštenosti, prenapučenosti i užasnih higijenskih uvjeta, te su bili u izrazito lošem stanju. Otvaranje Conley Hatcha, velikog zavoda za siromašne štićenike u engleskom Middlesexu pratila je atmosfera viktorijanskog progresa i optimizma- zavod je 1851 u godine velike izložbe otvorio Princ Albert, kraljevski suprug kraljice Victorije ${ }^{50}$. Već šest godina kasnije, grandiozno historicističko zdanje se raspadalo: cijeli dijelovi zida i stropa su se urušavali, broj štićenika je neprekidno rastao a država nije mogla osiguravati sredstva za njegovo održavanje ${ }^{51}$. Broj „recidivista”- štićenika koji su se nakon navodnog izlječenja vraćali u nabujali sustav psihijatrijske skrbi je istovremeno sve više rastao, što je narušilo kredibilitet početnih tvrdnji psihijatrijskih upravitelja koji su se hvalili velikim brojem uspješno izliječenih štićenika. U isto vrijeme, sami zavodi su došli na loš glas kao „muzeji ludila”. Poznati pisac Charles Dickens, obišao je britanske zavode za psihijatrijsko oboljele i svojim uobičajeno slikovitim stilom pisao o letargičnoj i beznadnoj atmosferi kojom su odisali tadašnji zavodi. ${ }^{52} \mathrm{Na}$ sličan se način mijenja i percepcija stenjevačkog zavoda. Iako je zavod na početku hvaljen kao „hram čovječnosti” ${ }^{33}$ Matoš ga 1910 u jednom putopisu iz zbirke Naši ljudi $i$ krajevi ocrtava u slikama koje referiraju na najstrašnije prizore iz klasične književnosti:

50 https://historicengland.org.uk/research/inclusive-heritage/disability-history/1832-1914/daily-life-in-the-asylum/. 51 Showalter, 1985: 101.

52 Scull, 2014: 54-54.

53 Izraz „hram Čovječnosti” stoji na ploči koja je postavljena na ulazu u današnju Kliniku za Psihijatriju Vrapče. Njegov je autor navodno ban Ivan Mažuranić. 
„Tamne, užasne spirale Danteova pakla tri koraka od Zagreba! U nasmijanom zatišju Zagrebačke gore, pri blagoj idili ubave savske ravnice, na podnožju vinorodnih brežuljaka i župnih selamračno poglavlje iz najmračnijeg Dostojevskoga, zelene mrtve oči iz zakutka Poeove vinske fantazije, oči mutne i nijeme iz haotičnih raskrša gdje se križa sedam putova razuma, gdje duva zagonetni vjetar iz čudnog, iz onoga svijeta, nagomilavajući u žutoj kući, u ludnici, svoje jesenje lišće mrtvih, usahnulih, obezdušenih života" ${ }^{\$ 4}$

Znakovito je da Matoš mračne i potresne slike stenjevačkog zavoda stavlja u kontrast $\mathrm{s}$ pastoralnom pitomošću okolnog krajolika. Krajolik i okoliš gube svoju terapeutsku ulogu i prisutni su tek kako bi stilski naglasili patnju i pesimizam koja vlada unutar skučenog i beznadnog prostora ,žute kuće”.

Osim široke kampanje pisaca i novinara i sami pacijenti su počeli opisivati svoja stravična iskustva u psihijatrijskim institucijama. Žanr protestne literature pacijenata koji su pisale ugledne autorice i aktivistkinje poput Elizabeth Packard u Sjedinjenim Američkim Državama i Louise Lowe u Ujedinjenom Kraljevstvu govorio je o lakoći s kojom su liječnici i predstavnici lokalne vlasti upućivali pacijenta, (a pogotovo pacijentice) u psihijatrijske institucije. ${ }^{55}$ Porast pesimizma je u Europi koincidirao s rastućom popularnosti Darwinove teorije evolucije i prirodne selekcije u znanstvenim i medicinskim krugovima. Charles Darwin je svoju knjigu Porijeklo vrsta objavio 1859. godine. Budući da su i ranije psihijatri poput Pinela, Esquirola i Morela isticali važnost herediteta kao jednog od faktora koji mogu pridonijeti duševnoj bolesti, ideje o prirodnoj selekciji brzo su se u europskoj psihijatriji aktualizirale u vidu zabrinutosti zbog hereditarnog tereta psihičke nestabilnosti, histerije i napetih živaca koji pritišće cijele generacije Europljana. Ubrzo su se kroz psihijatrijsku literaturu počele širiti turobne i pesimistične teorije o degeneraciji koje su gotovo preko noći zamijenile pastoralno-prosvjetiteljski optimizam ranih pobornika. Začetnik teorija o degeneraciji bio je francuski psihijatar Benedict Morel, veliki dijagnostički inovator koji je, između ostalih i prije Kräpelina prepoznao konceptualizirao „dementiu praecox” kao zasebni poremećaj. Morel je bio ravnatelj zavoda za duševno oboljele u komuni Saint Yon na

54 Matoš, 1990: 215.

55 Scull, 2014: 55. 
sjeveru Francuske. Kao intelektualac, Morel je stasao u za francusko društvo turbulentnim tridesetim i četrdesetim godinama devetnaestog stoljeća i pokazivao je velik interes za društvene probleme poput siromaštva, kriminala i alkoholizma, kao i za religijsku antropologiju. U svom djelu Traité des dégénérescences physiques, intellectuelles et morales (Traktat o fizičkoj, intelektualnoj i moralnoj degeneraciji) objavljenom u Parizu 1857.godine Morel je prikazao dvanaest portreta svojih pacijenata i pacijentica na kojima su navodno uočljivi dokazi trajne i nepromjenjive fizičke, mentalne i moralne degeneracije. ${ }^{56} \mathrm{U}$ svojoj sljedećoj knjizi iz 1860. godine Traité des maladies mentales (Traktat o mentalnoj bolesti) Morel je jasnije elaborirao samu degeneraciju kao proces ,patološke devijacije od idealnog tipa ljudskog bića kakvo je stvorio Bog, proces koji je počeo s Adamom i Evom. Dok je dio čovječanstva bio zdrav i prilagodljiv, dio je bio sve više nesposoban za društvenu djelotnast i prenosio je te svoje karakteristike na potomstvo". ${ }^{57}$ Degeneracija se, po Morelu manifestirala kao duševna bolest i kao prisustvo vidljivih tjelesnih „stigmi” poput urođenih deformacija i „nepravilnog” oblika lubanje. Na stvaranje navedenih hereditarnih osobina utjecale su uglavnom životne navike poput nemorala i alkoholizma, kao i određene tjelesne bolesti, a proces se pogoršavao iz generacije u generaciju te ga je bilo moguće usporiti ili zaustaviti jedino eugeničkim mjerama. ${ }^{58}$ Morel je u nastavku studije dao novu klasifikaciju duševnih bolesti koja je bila uže vezana uz njihovu etiologiju (za Pinela i ranije psihijatre od etiologije je bila bitnija kvaliteta simptoma, što je vidljivo i u nazivima kategorija poput „manije”, „melankolije”, „monomanije” i „manije bez delirija"). Morel duševne bolesti dijeli na:

1. „Ludila radi intoksikacije” („Folies par intoxication”) kao mentalne bolesti u kojima su fizičke, intelektualne i moralne funkcije pojedinca trajno narušene često konzumacijom alkohola ili drugog opojnog sredstva.

2. „Histerična, hipohondrična i epileptička ludila” koja imaju uzrok u nervnoj konstituciji pojedinca.

3. „Bolesti bez vidljivog uzroka”

56 Morel, 1857: 6.

57 Morel, 1860: II.

58 Ibid: III-IV. 
Za Morela ipak hereditet leži u korijenu svih duševnih bolesti bez obzira na to što se smatralo njihovim direktnim povodom. ${ }^{59} \mathrm{U}$ nastavku knjige Morel će, za razliku od ranijih autora koji su većinu prostora posvećivali liječenju najveći dio knjige posvetiti spekulaciji o različitim uzrocima ludila- od obrazovanja i načina života, bolesti mozga i krvožilnog sustava, menstruacije, trudnoće i dojenja do religijskih i političkih uzroka, ali će se pri opisivanju svakog od njih ponovno vraćati na hereditarne dispozicije $i$ isticati važnost eugeničkih mjera.

Eugenika i hereditet su naročito veliku podršku dobili među britanskim psihijatrima, među kojima je prednjačio ambiciozni Henry Maudsley, urednik časopisa Journal for Medical Science i jedan od prvih psihijatara koji je uspio steći značajan imetak od svog psihijatrijskog poziva. ${ }^{60}$ Maudsley je, prije svega bio izrazito plodan i dobar pisac koji je pisao o psihijatrijskim tegobama stilom pristupačnim velikom dijelu građanske klase. Postavka koja je u korijenu njegovog pogleda na psihu čovjeka je hijerarhijski ustroj mentalnih, intelektualnih i emocionalnih karakteristika od instinkta divljaka do rafinirane perceptivnosti civiliziranih elita ${ }^{61}$ Prema Maudsleyu, postoji jasna linija napretka „od senzacije, preko strasti, emocije i razuma do najviše faze, dobro oblikovane volje". ${ }^{62} \mathrm{Za}$ psihijatre koji su, poput Maudsleya prigrlili darvinističke principe, ludilo je atavizam ili regresija na niže stupnje inelektualnog ili duševnog razvoja i zato ju Maudsley, poput Morela često dovodi u vezu s određenim tjelesnim karakteristikama ili osobinama ličnosti. U drugom izdanju svoje knjige „Responsibility in Mental disease” koje je objavljeno 1870. godine Maudsley ističe: „Ne bi bilo pretjerano reći da malobrojni polude bez da pokažu, više ili manje očito po svom hodu, manirama, gestama, načinima mišljenja osjećanja ili ponašanja da imaju neku vrst predispozicija prema ludilu". ${ }^{63} \mathrm{U}$ ranijoj knjizi Body and Mind Maudsley preciznije opisuje znakove koji upućuju na predispoziciju za duševne bolesti „nepravilan i asimetričan oblik glave, nedostatak harmonije i pravilnosti u tjelesnim obilježjima, deformacija ušnih školjki, tikovi, govorne mane, neobičnosti u očima ili sklonost igrama riječima". ${ }^{64}$

59 Ibid V-VI.

60 Showalter, 1985: 113.

61 Ibid: 103.

62 Maudsley, 1870: 116.

63 Maudsley, 1874: 276.

64 Maudsley, 1870: 55-56. 
Uvođenje evolucionističke hijerarhije mentalnih osobina i sve veće pretvaranje mentalnog zdravlja u pitanje javne rasprave (čemu su široko citirani pisci poput Maudsleya uvelike doprinijeli) dovelo je do prodora dva nova i povezana pojma u diskursu o psihijatriji. Prvi od tih pojmova je pojam, „borderlandsa” a drugi je degeneracija. Degeneracija u smislu u kojem ju je shvaćao i opisao Morel postat će jedan od dominantnih strahova europske i američke srednje klase. On će biti ponovno aktualiziran u eugeničkom pokretu i u jednoj značajnoj mjeri biologiziranoj slici društva u autoritarnim fašističkim režimima prve polovice dvadesetog stoljeća.

Za razliku od pogleda na duševnu bolest kao na prolazno stanje uzrokovano afektima, psihijatri darvinističke psihijatrije vidjeli su psihičke poremećaje kao na neku vrstu urođenog hereditarnog tereta kojem je podvrgnut velik broj ljudi. Prostor duševne slabosti, histeričnog karaktera i ekscentričnosti počeo se smatrati graničnim prostorom između mentalnog zdravlja, predstavljenog Muadsleyevim, tipično viktorijanskim poimanjem čvrste i dobro formirane volje i ludila. Pojam „borderlandsa” u psihijatriju je uveo britanski liječnik Andew Wynter koji je u svom domu u Chadwicku primao imućne pacijente i liječio ih od duševnih bolesti. Kao načitan provincijski intelektualac redovno je pisao priloge za mnoge časopise i bavio se širokim rasponom tema, a za života je postao poznat po tome što je često uspoređivao ljudsko društvo s društvom pčela. Wynterova knjiga The Borderlands of Insanity and other Allied Papers objavljena je 1875. godine i izvršila je velik utjecaj na psihijatriju, pa i na kulturu fin de sieclea. Prvi esej u Wynterovoj knjizi „The Borderlands of Insanity” govori o duševnoj bolesti kao o pojavi koja je u većem dijelu populacije latentna. Na takvu percepciju duševne bolesti utjecala je već ranije spomenuta epidemija progresivne paralize, odnesno neurosifilisa. Karakter progresivne paralize kao oboljenja koje se manifestira iznenada, pogađa uglavnom muškarce građanske klase starije od 35 godina i ima za posljedicu naglo i progresivno propadanje psihičkih i tjelesnih funkcija, bio je velik šok i neobjašnjiva zagonetka za liječnike kasnog devetnaestog stoljeća koji su se i sami najčešće nalazili u navedenoj društvenoj skupini. Wynter navodi primjere pacijenata kod kojih su simptomi bolesti dugo bili neprimjetni da bi se onda pojavili sasvim iznenada u trenucima kad je pacijent bio na vrhuncu života. Dapače, Wynter ističe da je duševno propadanje 
već počelo u trenutku kad se pacijent još kreće u društvu i brine o svojim poslovima i nitko osim liječnika ne primjećuje da je ,propao kroz rupu na mostu i da se nikad više neće kretati u zaposlenim prebivalištima ljudi". ${ }^{65}$ Wynter je manje jasan kad govori o uzrocima progresivne paralize. Tako će progresivnu paralizu dovesti u vezu s „omekšanjem mozga” (vjerojatno bolest koju će mnogi drugi autori nazivati neurastenijom), navodeći užurban i napet tempo života koji od „mladića zahtijeva da za zvanje službenika prođe ispit rigorozniji od onog koji se nekad zahtijevao za sveučilišno zvanje", ${ }^{66}$ ozlijede glave u djetinjstvu, poremećaje krvotoka i neizostavni hereditet kao moguće uzroke. „Latentna iscrpljenost mozga” za Wyntera postaje problem epidemijskih proporcija, pa tako Wynter govori o ,generaciji koja je sistematski prenapregnula svoje mozgove." $\mathrm{U}$ sk skladu s već formiranim pretpostavkama darvinističke psihijatrije, hereditet je presudan faktor u slabljenju mentalne snage generacije. Djeca duševno bolesnih često prelaze u granično područje ludila iako sama nemaju nikakvu uočljivu duševnu bolest. Kod njih se uglavnom mogu uočiti „stigme” o kojima su još ranije govorili Morel i Maudsley: „neuralgije, epilepsije ili koreje” ili pak u moralnom pogledu „ekstremna sklonost strastima, sklonost okrutnostima, krađa, laganje i ostali poroci u kojima je volja nadvladana impulsom. " 68

Matoš je prilikom svog posjeta Stenjevcu također koristio odrazio mišljenje o postojanju graničnog prostora između duševnog zdravlja i duševne bolesti:

„Pritajena ludost, abnormalnost, sakrivena pod nervozama i neuropatijama svakog modernog čovjeka, budi se kod tog kontakta kolektivne ludosti: srodnost s tim nesretnicima biva sve očiglednija i imperativnija i strah, neopisiv strah vas uhvati da tkogod ludu, prikrivenog luđaka u vama ne primjeti..." 69

Matoš, kao i Wynter i Maudsley vidi ludilo skriveno ispred naoko banalnih duševnih procesa karakterističnih za njegove suvremenike. I sam susret s duševno oboljelima dovoljan je da „izvuče” iz čovjeka latentno ludilo.

65 Wynter, 1877: 25 (kao izvor koristim drugo, nadopunjeno izdanje Wynterove knjige kojoj je doprinio Joseph Mortimer Granville.

66 Ibid: 6.

67 Ibid: 36.

68 Ibid: 42.

69 Ibid: 215. 
Ideja povezana s predodžbom da se čitave generacije mogu nalaziti na samoj granici ludila je sve češća percepcija čitavog društva kao bolesnog organizma opterećenog teretom užurbanog života čija volja postupno slabi i koji postepeno degenerira. U takvim idejama ne moguće je ne vidjeti rastuću zbunjenost i anksioznost koju su muškarci viših slojeva osjećali pri susretu sa svijetom koji se mijenja i unutar kojeg su se pastoralne i ladanjske utopije toliko česte u književnosti i slikarstvu ranog predviktorijanskog i viktorijanskog doba sve više pokazivale kao nezreli eskapizam elita koja su odbijale prihvatiti stvarnost sve ubrzanijih modernizacijskih procesa. Povezanost diskursa o degeneraciji s moralističkim i konzervativnim viđenjem čovjeka bilo je prisutno još i u Morelovoj apokalitpičnoj viziji konstantnog pada iz blagodati Rajskog vrta u današnji svijet u kojem su ludilo, siromaštvo i kriminal sve rašireniji.Uistinu, kako je stoljeće odmicalo, sve se veći dio modernih pojava, poput emancipacije žena i novih modernističkih smjerova u kulturi opisivao upravo diskursom degeneracije, a takav narativ služio je kao alternativa onim narativima koji su u problemima vidjeli primarno društvene uzroke. No, činjenice nisu bile tako jednostrane. Eugenički pokret je supostojao s brojnim socijalno angažiranim pokretima upravo jer je darvinistički diskurs dao snažan znanstveni legitimitet teoriji o hereditarnim uzrocima društvenih problema. Bilo je pretjerano očekivati da onodobni europski intelektualci prihvate bilo koji svjetonazor koji nije pristupao emocijama i duševnim procesima strogo hijerarhijski, stavivši čvrstu volju kao (auto)percipiranu karakteristiku obrazovanog bijelog muškarca na sam vrh piramide mentalne evolucije. Degeneracija postaje jedan od najbitnijih dijelova slagalice koje čine sliku intelektualnog horizonta građanske klase na prijelazu stoljeća. Virginia Woolf u svojim dnevnicima iz 1915 daje sljedeći opis londonskih invalida ili siromaha:

„Na obali smo sreli i prošli kraj dugog reda imbecila. Prvi je bio visok mladić, dovoljno neobičan da bi ga se pogledalo dvaput, ali ne više od tog; drugi se meškoljio i gledao u stranu; tada se moglo primjetiti da je svaki od ljudi u tom dugom redu, bijedno, nesposobno teturajuće idiotsko stvorenje, bez čela i brade s cerekom imbecila ili divljim sumnjičavim pogledom. Bilo je užasno. Sigurno bi ih trebalo pobiti."’70

70 Woolf, Virginia prema Blom, 2008: 341. 
Do početka dvadesetog stoljeća, degeneracija će uglavnom biti identificirana kao uzrok društvenih problema, a eugeničke mjere preporučane kao poželjno, efikasno i humano riješenje istih. Prvi Međunarodni Eugenički Kongres održan 1912. godine u Londonu na kojem se okupila znanstvena i politička krema kasnog devetnaestog stoljeća (od Alexandera Grahama Bella do mladog Winstona Churchilla) ${ }^{71}$ bio je dokaz široke prihvaćenosti socijalnog darvinizma kao društvenog svjetonazora. Bez previše pretjerivanja moglo se reći da je viktorijanski zavod za duševno oboljele, u vremenu svoje intelektualne i terapeutske krize, uistinu postao ključni argument u prilog tvrdnji da moderno društvo postaje sve bolesnije i sve brže posrće pod teretom raširenog poroka i ludila. Rastući broj štićenika u tim „muzejima ludila” opetovano je služio kao statistički uvjerljiv i emotivno snažan dokaz teorija o „borderlandsu” i degeneraciji, a neizlječivost većine štićenika i visoka smrtnost dovela do sve beznandnije i očajnije perspektive za europsku psihijatriju.

\subsection{Od Griesingera do Kräpelina: njemačka neuropsihijatrija na prijelazu stoljeća}

Teraupetski pesimizam zavodske psihijatrije uspio je poljuljati vjeru liječnika u moral treatment i blagotvorno djelovanje zavodske arhitekture i ,non restraint” principa, ali nipošto nije umanjio interes za proučavanje ljudske psihe. Paradigme darvinističkih psihijatara poputa Maudsleya skrenule su pažnju liječnika prema biološkim uzrocima ludila. Da bi se došlo do bioloških uzroka bolesti poput progresivne paralize i epilepsije, seciralo se mozgove preminulih zavodskih pacijenata i mikroskopski ispitivalo uzorke cerebrospinalnog likvora, a da bi se otkrilo „stigme” koje bi mogle ukazivati na hereditarne predispozicije provodila su se antropometrijska mjerenja i bilježilo se svako odstupanje. Psihijatrija prijelaza stoljeća nije više samo bila psihijatrija zavoda, već i psihijatrija laboratorija. Kultura sveučilišne laboratorijske psihijatrija najbolje se razvila u Njemačkoj i Austro-Ugarskoj, zemljama koje su posjedovala jak državni sustav zdravstvene skrbi (brojne su ga Njemačke države imale od prve polovice devetnaestog stoljeća, a u AustroUgarskoj je nastajao u dva ,apsolutistička” vala, za vrijeme prosvjećenog apsolutizma Josipa Drugog i neoapsolutizma Franje Josipa I.). U Njemačkoj je razvoj psihijatrije bio povezan sa sustavom cijenjenih sveučilišta od kojih su neka, poput badenskog i wurtemberškog imala i

71 Blom, 2008: 334. 
međunarodnu reputaciju. ${ }^{72}$ Decentraliziran sustav sveučilišta $u$ malim njemačkim državicama povezan s činjenicom da su sva ta sveučilišta pripadala istom jezičnom području rezultirao je u isto vrijeme i natjecanjem za prestiž i intenzivnom razmijenom ideja između raznih intelektualnih škola i krugova. Čini se da je takav ustroj osobito pogodovao razvoju psihologije i psihijatrije. Već i samo neurološko i psihijatrijatrijsko nazivlje od Nisslove mrlje do Kräpelinove dihotomije govori o ogromnom doprinosu kojeg su austrijski i njemački liječnici dali psihijatrijskoj dijagnostici i metodologiji, a većina tih spoznaja razvila se u devetnaestom stoljeću. Između 1850. i 1914. austrijski su i njemački sveučilišni i zavodski liječnici i psiholozi razvili niz novih teorija o psihi i duševnim bolestima i otkrili mnogobrojne procese vezane uz način rada i patologiju ljudskog mozga. Wilhelm Griesinger je 1845. godine objavio jedan od najšire korištenih psihijatrijskih udžbenika (još veću primjenu doživjelo je prošireno drugo izdanje iz 1861.). Austrijski liječnik Theodor Hermann Meynert je otkrio karminsko bojilo koje je omogućilo efektnije mikroskopiranje moždanih stanica. ${ }^{73}$ Wilhelm Wundt je 1879. u Leipzigu osnovao prvi psihološki laboratorij, Sigmund Freud je na prijelazu stoljeća utemeljio psihoanalizu, a Alois Alzheimer je 1911. otkrio da je teška degenerativna bolest mozga koja danas nosi njegovo ime uzrokovana specifičnim lezijama mozgovnog tkiva. ${ }^{74}$ Druga polovica devetnaestog stoljeća bila je razdoblje kad se intelektualna središta proučavanja mozga i psihe sele iz rustikalnih psihijatrijskih ustanova Francuske i Velike Britanije u njemačka sveučilišta i austrijske laboratorije.

Na samom početku devetnaestog stoljeća, duševne su bolesti u Njemačkoj filozofskoj zajednici tema intenzivne rasprave između psihicističke i somaticističke škole. Psihicisti su svog najuglednijih saveznika našli u leipziškom teologu i liječniku Johannu Christianu Augustu Heinrothu koji je u svom djelu Störungen des Seelenlebens (Poremećaji duševnog života) iznio vlastitu teoriju etiologije dušenih bolesti. Po Heinrothu, duševne bolesti imaju uzrok $u$ „zamračenju duše koja dolazi u dodir sa zlom izvana” ${ }^{75}$. Heinroth dakle, daje primat duševnom

72 Shorter, 1996: 35 .

73 Shorter, 1996: 77.

74 Draaisma, 2009: 217.

75 Verwey, 1985: 19. 
nad tjelesnom, te čak ide toliko daleko da je odbacio izraz ,duševne bolesti” tvrdeći da duša ne može biti bolesna i u svojim djelima koristio izraz „duševni poremećaj."

Poziciju suprotnu Heinrothu veoma je rano počeo isticati Carl Wigand Maximilian Jacobi, upravitelj zavoda za duševno oboljele u Salzburgu i Siegburgu, koji se kratko vrijeme obrazovao u inozemstvu i uveo ideje Tukea i Pinela u srednjoeuropsku psihijatriju. Jacobi je u prvoj polovici devetnaestog stoljeća bio poznat po ekstremnom somaticizmu, tvrdeći da je duševna bolest zapravo samo simptom somatskog poremećaja koji može nastati bilo gdje u tijelu: u mozgu, probavnim organima, koži ili bilo kojem drugom organu. ${ }^{77}$ Jacobi otpočekta odbacuje spiritualističko objašnjenje, polazeći od kartezijanskog principa odvojenosti tijela i duše, poput Heinrotha tvrdeći da duša kao savršena spiritualna esencija čovjeka ne može biti bolesna. ${ }^{78}$ Jacobijev ugled i činjenica da su u njegovim dvama zavodima radili brojni njemački i austrijski liječnici koji su kasnije stekli značajan utjecaj učvrstili su somaticističku školu u Njemačkoj i Austro-Ugarskoj psihijatriji. Bernhard von Gudden, Jacobijev asistent i kasniji profesor psihijatrije na Munchenskom sveučilištu u svoje je učenike ubrajao Augustea Henrija Forela i Emila Kräpelina, a skončao je u jezeru Starnberg na dno kojeg ga je 1886. povukao njegov posljednji i najslavniji pacijent, bavarski kralj Ludwig II.

Jacobi je vjerovao u organske uzroke duševnih bolesti i optimistično držao da se liječenjem izvornog tjelesnog oboljenja može izliječiti i psihički poremećaj. Kako je medicina otkrivala nove i bolje dijagnostičke instrumente, ljudski je mozak postao sve češćim predmetom proučavanja na njemačkim sveučilištima. Jedan od liječnika koji će dati najveći doprinos proučavanju neuroloških uzroka duševnih bolesti bio je Wilhelm Griesinger, psihijatar i internist koji je tijekom bogate i burne karijere bio upraviteljem brojnih psihijatrijskih zavoda. Osim već spomenutog udžbenika, Griesinger je već kao mladi liječnik postao poznat po svojim nastojanjima da približi psihijatriju granama somatske medicine. Bolnicu Charite u Berlinu, gdje je 1865. godine imenovan za ravnatelja podjelio je u dva dijela: onaj na kojem su bili smješteni 
pacijenti s običnim živčanim poteškoćama i onaj na kojem su bili pacijenti sa živčanim poteškoćama koji su pokazivali primarno psihijatrijske simptome. ${ }^{79}$ Pored toga, Griesinger je redovito držao predavanja i demonstracije simptoma duševnih oboljenja studentima, te obrazovao psihijatrijske pripravnike na način da su usvajali znanje ostalih medicinskih disciplina, tražeći od njih da, na primjer, obavljaju komplicirane porode. ${ }^{80}$ Te metode služile su približavanju psihijatrije, koja se u Griesingerovo vrijeme još uvijek nalazila između antropološko-filozofske i medicinske discipline medicini i stvaranju reputacije psihijatra kao liječnika, a ne pukog ravnatelja institucije koja služi izolaciji društveno neprilagođenih pojedinaca. Drugo izdanje Griesningerovog udžbenika Pathologie und Therapie der psychischen Krankheiten (Patologija $i$ terapija duševnih bolesti) bit će najraširenije primjenjivana stručna knjiga iz područja psihijatrije sve do objavljivanja knjige Lehrbuch der Psychiatrie koju je 1893. objavio njemački psihijatar Emil Kräpelin, osoba koja je uz Freuda najviše obilježila razvoj psihijatrije u dvadesetom stoljeću.

Kräpelin je rođen na sjeveru Njemačke ali je već 1878. došao u München, gdje je sedamdesetih godina psihijatrija doživljavala procvat. U Münchenu amo je boravio i radio poznati predstavnik biološke psihijatrije Bernhard von Gudden i njegov kolega Frank Nissl. Obojica su razvili inovativne metode seciranja i bojenja mozga. Von Gudden je izumio mikrotom, cilindričnu spravu za pripravljanje mikroskopskih preparata od mozgovnog tkiva, dok je Nissl usavršio Meynertovu metodu bojenja, koristeći plavu boju umjesto karmina, što je tehnika koja je danas poznata kao Nisslova mrlja. ${ }^{81}$ Kräpelin ipak nije mogao sudjelovati u mikroskopskom proučavanju mozga radi vlastitih problema $\mathrm{s}$ vidom, te se zbog toga posvetio proučavanju ponašanja pacijenata $^{82}$ (kasnije će, za provođenje mikroskopskih analiza angažirati Aloisa Alzheimera, koji će na svoju ruku otkriti patološke promjene koje dovode do Alzheimerove bolesti). Smatrao je da mu proučavanje eksperimentalne psihologije može pomoći pri dijagnosticiranju duševnih bolesti; stoga 1882. napušta Munchen i odlazi u Leipzig raditi u psihološkom laboratoriju Wilhelma Wundta. ${ }^{83}$

79 Shorter, 1996: 75.

80 Ibid.

81 Draaisma, 2009: 204.

82 Shorter, 1996: 101.

83 Ibid. 
Nakon usavršavanja u leipziškom psihologijskom laboratoriju i kratkog angažmana na sveučilištu u estonskom gradu Dorpatu, Kräpelin 1890. postaje ravnateljem sveučilišne klinike u Heidelbergu, gdje dovodi Nissla i Alzheimera. Zahvaljujući ovom medicinskom timu koji je pokrivao različite discipline unutar neuropsihijatrijske struke (Nissl je bio stručnjak za anatomiju, Alzheimer vrstan neurolog, a Kräpelin je imao nova znanja iz područja eksperimentalne psihologije), sveučilište u Heidelbergu postalo je centrom proučavanja duševnih oboljenja, a rezultat tih proučavanja bio je Kräpelinov Udžbenik psihijatrije (Lehrbuch der Psychiatrie) iz 1893. godine. Kräpelinov udžbenik je sjajan dijagnostički i klinički priručnik koji će biti pretečom kasnijih dijagnostičkih priručnika poput Dijagnostičko-statističkog priručnika. Udžbenik daje detaljan opis i pregled psihijatrijskih simptoma, a zatim klasificira duševne bolesti s obzirom na njihov uzrok i na karakteristične pravilnosti u simptomima koji se pojavljuju tijekom dužeg vremena. To predstavlja odmak u odnosu na dosadašnju psihijatrijsku praksu koja je bolesti klasificirala s obzirom na jedan dominantan simptom koji se unutar bolesti javlja. Novost je i Kräpelinovo razgraničenje između manično-depresivnog ludila i dementie praecox (Kräpelin navodno nije znao da je Morel upotrijebio isti naziv za tu bolest) ${ }^{84}$. Time je okončana unitarna teorija duševne bolesti koja je ranije bila na snazi, a koja je pretpostavljala da su sve duševne bolesti zapravo samo različite manifestacije jednog oboljenja nazivanog „manijom” ili „ludilom”. Uz taj bitan doprinos, „dementia praecox” je dobila vlastiti dijagnostički naziv i set dijagnostičkih kriterija. Može se, donekle reći da su ranije klasifikacije bile prilagođene specifičnim potrebama ravnatelja psihijatrijskih institucija- kategorije poput „manie”, „melancholie” i ,dementie” omogućavale su ravnateljima da predvide hoće li štićenici biti mirni ili nemirni, te ima li nade za njihovo izlječenje i eventualno otpuštanje iz zavoda. Kräpelin je, s druge strane esencijalizirao pojedina psihijatrijska oboljenja na temelju simptomskih uzoraka i samim time stvorio jasne i neodvojive kategorije ,abnormalnog uma”. Manično-depresivno ludilo će biti primarno afektivno oboljenje, dok će se na „dementiu praecox” gledati kao na postupno slabljenje intelekta koje počinje u mladoj životnoj dobi. ${ }^{85}$ Čini se da je Kräpelinu bilo stalo do toga da jasno razdvoji afektivnu i intelektualnu sferu čovjekovog mentalnog života i da svakoj od njih pripiše zasebnu kategoriju poremećaja. Također, naziv „dementia” koji je Kräpelin

84 Ibid: 105.

85 Greenfeld, 2013: 118. 
dao toj novoj bolesti implicira degeneraciju intelekta, što upućuje na to da je bolest degenerativne prirode i neizlječiva (slično kao što je Alzheimerova bolest na početku bila nazivana Alzheimerovom demencijom, dok se za progresivnu paralizu koristio naziv „dementia paralytica"). Švicarski psihijatar Eugen Bleuer, blizak psihoanalitičarima nije dijelio to mišljenje $\mathrm{i}$ istu je bolest nazvao shizofrenijom što upućuje na njen disocijativni, a ne degenerativni karakter. $^{86}$

Što se tiče etiologije, Kräpelin je dementiu praecox smatro oboljenjem koje je u tri četvrtine slučajeva uzrokovano defektivnim hereditetom dok je ostatak slučajeva uzrokovan tifusnom groznicom i ozlijedama glave. Bolesnici često još u djetinjstvu pokazuju poneke predispozicije poput sklonosti samoći i prekomjernom uživanju alkohola te pretjeranoj pobožnosti. ${ }^{87}$,Dementia praecox" se za Kräpelina manifestira slabljenem gotovo svih mentalnih funkcija od opažanja koje je ometano halucinacijama ${ }^{88}$ do propadanja moralnih i emocionalnih karakteristika. ${ }^{89}$ Kräpelin naglašava emocionalno propadanje oboljelih od „dementie praecox” ističući da oboljeli u kasnoj fazi bolesti ,žive prazan život, bez briga i strepnji i bez razmišljanja o budućnosti”. ${ }^{90}$ Uzroke manično- depresivnog ludila Kräpelin također vidi $\mathrm{u}$ hereditetu, ali smatra rod bitnom predispozicijom- ističe da bolest pretežno pogađa žene, a često počinje za vrijeme trudnoće. ${ }^{91}$ Druga ključna razlika je tok bolesti. Manično-depresivno ludilo ne rezultira trajnom degeneracijom psihičkih funkcija, već obično dolazi do poboljšanja u roku od nekoliko dana do nekoliko tjedana za manični oblik poremećaja ${ }^{92}$ i nekoliko mjeseci za depresivni oblik. ${ }^{93}$ Naravno Kräpelin ističe da se napadi manije i depresije najčešće ponavljaju kroz čitav život pacijenta, naročito kod žena za vrijeme klimakterija, ${ }^{94}$ ali nema progresivnog pogoršanja stanja, niti propadanja intelektualnih ili emocionalnih sposobnosti.

86 Ibid: 119.

87 Kräpelin, 1902: 170.

88 Ibid: 155.

89 Ibid: 158-159.

90 Ibid: 167.

91 Ibid: 283.

92 Ibid: 298.

93 Ibid: 303.

94 Ibid: 311. 
Iako su Kräpelinova znanstvena metodologija bila više psihologijska nego tradicionalno somaticistička, Kräpelin se i dalje pridržava načela socijalnog darvinizma koja su bila ukorijenjena $u$ onodobnoj psihijatriji. Premda je manje pažnje posvetio traženju somatskih znakova, a više opisivanju psihološke simptomatologije, Kräpelin će nebrojeno puta u svojoj knjizi istaknuti važnost herediteta, tvrdeći da je hereditarna degeneriranost osobito važan faktor kod javljanja pojedinih kompulzivnih misli. ${ }^{95}$ Također, Kräpelin je bio ogrezao u beznandni terapeutski pesimizam i nije pristupao svojim pacijentima kao ljudima koje se uopće isplati pokušavati liječiti. Veliki pomor štićenika psihijatrijskih institucija u Njemačkoj za vrijeme i nakon Prvog svjetskog rata, uzrokovan glađu i epidemijom španjolske gripe Kräpelin je nazvao olakšavanjem ekonomskog tereta koji su za zdravstveni sustav predstavljali neizlječivi pacijenti. ${ }^{96}$ Uopće, čini se da je njemačka psihijatrija bila osobito sklona teoriji degeneracije i obilježavanju određenih kategorija ljudi kao duševno manje vrijednih. U osvit rastuće borbe za ravnopravnost spolova, neki od stavova njemačkih psihijatara poprimali su osobito reakcionaran karakter. Studija leipziškog psihijatra Paula Juliusa Mobiusa objavljena 1900. godine pod naslovom Fiziološka mentalna zaostalost žena odiše diskursom koji za ono doba možemo smatrati izrazito mizoginim. Konzervativna klima u društvu i sveopći antropološki i terapeutski pesimizam doveli su do sve intenzivnijeg zagovaranja eugeničkih mjera. Posljedice takve klime u njemačkoj i austrijskoj psihijatrijskog zajednici rezultirale su dvama događajima u dvadesetom stoljeću Prvi je rođenje psihoanalize kao svojevrsnog novog pravca koji je obećavao određene uspjehe $u$ tretmanu neuroza. Drugi, daleko tragičniji bio je manjak otpora nacističkom programu masovne eutanazije duševno bolesnih osoba i invalida među psihijatrima. Tek šačica liječnika, najpoznatijih od kojih je bio bavarski neurolog Hans Gerhard Creutzfeldt odlučila je pokušati spasiti svoje štićenike. ${ }^{97}$ Naravno, može se reći da je strah od kazne bio bitan faktor, ali ostaju činjenice da su i prije dolaska nacista na vlast među psihijatrima postojali brojni zagovornici mjera poput akcije T4, te da nijedan od malobrojnih psihijatara koji su se usprotivili eutanazijskim mjerama nije bio ozbiljno kažnjen. ${ }^{98}$ Njemački psihijatar Alfred Hoche u brošuri

95 Ibid: 25.

96 Ibid: 260.

97 Lifton, 1986: 80.

98 Beddies i Mueller, 2006: 101. 
Uništenje života koji nije vrijedan življenja objavljenoj još 1920. godine dao je i konkretnu teoretsku podlogu za tu zločinačku akciju. ${ }^{99}$

Premda će svi ravnatelji Zavoda za umobolne u Stenjevcu u devetnaestom stoljeću studirali na austrijskim i njemačkim sveučilištima, čini se da eugeničke ideje ovdje nisu uzele tolikog maha kao u Njemačkoj i Austriji. Teorije o degenaraciji su u Hrvatskoj bile marginalne i u potpunosti su potisnute $u$ drugi plan za vrijeme međuratnog pokreta socijalne medicine, a psihijatrija je os svojih početaka u devetnaestom stoljeću imala određenu humanu i socijalnu komponentu koja u Austriji i Njemačkoj nije bila zastupljena u značajnijoj mjeri.

99 Ibid: 94-95. 


\section{Kraljevski i zemaljski zavod za umobolne u Stenjevcu}

\subsection{Osnutak i izgradnja zavoda za umobolne u Stenjevcu}

Psihijatrija u Hrvatskoj je u devetnaestom stoljeću još uvijek bila u povojima. Nisu postojale institucije gdje bi se empirijskim metodama mogli proučavati razvoj i etiologija psihičkih poremećaja što je rezultiralo činjenicom da su se psihijatri morali obučavati u inozemstvu. Također, medicinska bibliografija vezana uz psihijatrijske poremećaje bila je oskudna i nije bila dostupna većini liječnika. Sam Ugarski dio Monarhije zaostajao je za austrijskim dijelom u izgradnji zavodskih institucija - zavod Lipótmező u Budimpešti osnovan je tek 1868. godine. Hrvatski Sabor je 1840. godine zaključio da se iz županijske zaklade izgradi „luđački dom”, no došlo je samo do osnutka odjela za umobolne u zagrebačkoj Bolnici Milosrdne braće. ${ }^{100}$ Pitanje osnutka zavoda za Hrvatsku i Slavoniju ponovno je pokrenuto pedesetih godina 19. stoljeća. Tadašnje carsko i kraljevstvo ministarstvo unutrašnjih poslova priznalo je 1853. godine potrebu podizanja takvog zavoda ${ }^{101}$. Međutim, kaotična unutarnjepolitička i vanjskopolitička situacija u kojoj se tadašnja Habsburška Monarhija nalazila u prednagodbenim godinama doveli su do toga da je to pitanje ponovno pokrenuto tek sredinom 1860-ih godina.

Glavni zagovornik osnutka novog zavoda postao je protomedicus Josip Kalazancije Schlosser koji je u to vrijeme bio na funkciji zemaljskog praliječnika i namjesničkog savjetnika ${ }^{102}$. Schlosser, koji je bio jedan od uglednijih liječnika sredine devetnaestog stoljeća, rođen je u Moravskoj, a obrazovao se u Beču i Italiji. Dugi niz godina radio je kao kupališni liječnik u Varaždinskim Toplicama, a 1867. proglašen je vitezom i dobio je plemićki predikat „Klekovski”. ${ }^{103}$ Godine 1865. podnio je namjesničkom vijeću „Osnovu o podignuću i ustrojstvu zemaljske ludnice" 104 . Schlosser u svojem izvješću ističe kako „Takozvana ludnica kod milosrdne braće u Zagrebu nije nikakvo liječilište ili vidalište, već samo prosto čuvalište kao i prehranilište za takve

100 Ulčnik, 1957.: 302.

101 Glesinger, Lavoslav prema Fatović- Ferenčić i Pećina, 2012. :80.

102 Barle, 1904.: 370.

103 Ibid.

104 Glesinger, 2012: 80. 
bolesnike, koji se smatraju da bi po naravi svoje bolesti ili sami sebi ili pako drugima opasni bili" ${ }^{\prime 105}$. Schlosser ističe ključne uvjete koje novi zavod treba ispunjavati kako bi poslužio terapeutskoj svrsi koja mu je u okviru tada dominantne „moral treatment” paradigme. Schlosserovi uvjeti su bili u skladu s naglaskom koji je psihijatrija kasnog devetnaestog stoljeća stavljala na arhitektonske i higijenske karakteristike zavodskih građevina, kao i na njihovu opskrbu. Opskrba se temeljila na korištenju terapijskog rada štićenika u svrhu što veće samoodrživosti zavoda u pogledu hrane. Po Schlosseru, zavod nije smio biti dijelom opće bolnice, već treba biti samostalan. Također, zavod treba imati i vrt i gospodarstvo zbog „pribavljanje hrane i uposlenja bolesnika”. Po mogućnosti trebalo je iskoristiti postojeću zgradu koja ne bi bila previše daleko od grada jer niti jedan liječnik ne bi htio ići stanovati tamo. Zavod ne treba služiti pukom zatvaranju luđaka već i liječenju, treba biti dovoljno prostran da odgovara broju duševnih bolesnika u trojednoj kraljevini. Neizliječeni bolesnici bi se mogli ostaviti u Bolnici milosrdne braće dok bi se izlječivi trebali odijeliti po bolesti i po spolu. Schlosser je procijenio ukupni broj bolesnika u trojednoj kraljevini na 100 duševnih bolesnika, među kojima je 20 „nečišćenaka, pozlobica i goropadnika” koji moraju biti smješteni u posebne ćelijice udaljene od ostalih bolesnika. U tim ćelijama vrata moraju biti bez kvake a namještaj treba biti pričvršćen za pod. Zahodi u ćelijama se moraju prazniti izvana, a mirni bolesnici bi trebali biti smješteni u manjim ili većim grupama. Dimenzije prostorija, koje moraju biti svijetle i zračne su točno navedene. Zavod bi se sastojao od 87 prostorija, dok gospodarstvo treba obuhvaćati 14 do 16 jutara. ${ }^{106}$

Namjesničko je vijeće izradilo troškove i nacrt, te odlučilo da će troškove gradnje snositi zemaljska konkureciona zaklada. Troškovi su trebali iznositi 132539 forinti i 55 novčića, čemu je dodano 6000 forinti za nabavu zemljišta te 42920 forinti za unutrašnje uređenje. ${ }^{107}$ Nakon rasprave u državnom ministarstvu u Beču i sugestija koje je dao, ravnatelj bečkog zavoda i liječnik meksičke carice Carlote Josef Gottfried Riedel prijedlog je vraćen Hrvatskom Saboru.

105 Ibid:73.

106 Ibid: $80-81$.

107 Ibid. 
Sabor je u sljedeća dva zasjedanja raspravljao o uključenju vojnog erara u financiranje izgradnje zavoda, budući da je isti trebao pokrivati potrebe Vojne Krajine ${ }^{108}$. Rasprave o izgradnji zavoda su trenutno odgođene 1870. zbog teške financijske situacije i razvojačenja bjelovarske vojne krajine $^{109}$ da bi bila nastavljena 17. 8. 1872. od strane Dr. Franje Kviringa.

Franjo Kviring bio je zastupnik Strossmayerove Narodne stranke iz virovitičkog kotara. ${ }^{110}$ On je naveden kao potpisnik „Osnove zakona o ustrojenju javne ludnice za obseg kraljevina Hrvatske i Slavonije od 23. 12. 1873". Konačni tekst tog nacrta imao je samo 4 stavka: prvi je odredio „javnu ludnicu” kao zemaljski zavod i istaknuo da se ista treba podići u Zagrebu. Drugi je govorio da će trošak snositi građanska i vojna Hrvatska i Slavonija po razmjeru broja pučanstva. Treći govori da će građanska Hrvatska i Slavonija namirivati svoj prinosak iz bolničkih zaklada, a četvrti imenuje bana kao izvršitelja zakona. ${ }^{111}$ Nakon donošenja zakonskog prijedloga ustanovljeno je da će kao prototip za gradnju zavoda poslužiti zavod „Feldhof” u Grazu (danas „Državna klinika za živčane poteškoće „Sigmund Freud”"112). Komisija sačinjena od doktora Schlossera, tajnika zdravstvenog odsjeka zemaljske vlade Antuna Schwarza i vojnog liječnika Stjepana Mađareviča koji je zastupao vojni erar upućena je u ljeti 1874. godine u Graz kako bi proučila ustroj Feldhofa. ${ }^{113}$

Antun Schwarz bio je još jedan liječnik obrazovan u Beču koji je služio kao željeznički liječnik u Požunu i rudarski liječnik u Banatu, te županijski liječnik u Križevcima i Varaždinu, pokrenuo je Liječnički vjesnik te je radio na osmišljavanju hrvatske liječničke terminologije. ${ }^{114}$ Od 1875 objavljivao je u Liječničkom vjesniku detaljne zdravstvene izvještaje u kojima je davao podatke i o broju duševnih bolesnika. ${ }^{115}$ Usprkos svojoj mladosti, uživao je znatan ugled u hrvatskim liječničkim krugovima. Treći član delegacije Madjarević, imao je u tom trenutku već dvadeset

108 Ulčnik, 1957: 302.

109 Glesinger, 2012: 82.

110 Horvat, 1936: 39.

111 Glesinger, 2012: 83.

112 U originalu: "Landesnervenklinik Sigmund Freud".

113 Ibid.

114 Liječnički vjesnik, (u daljnjim bilješkama, LV.) 1880:32.

115 Glesinger, 2012: 68. 
godina iskustva kao vojni liječnik. Upravo će se Antun Schwarz u kasnijim godinama najviše zauzimati za izgrađu zagrebačkog zavoda. Zemaljska vlada je 1877. nakon prvotnog pokušaja da se zavod izgradi na zemljištu koje je donirao veleposjednik Pongrac kupila od zagrebačkog kaptola jeftino močvarno zemljište pod imenom Jačkovina. ${ }^{116}$ Izbor zemljišta biti će izvorom brojnih problema za zavod: močvarno tlo će pogodovati širenju raznih bolesti i redovno zračenje prostorija će biti otežano zbog toga što je zavod bio smješten u udolini. Gradnja je povjerena mladom arhitektu Kuni Weidmannu koji je uzore, osim u gradačkom tražio i u bečkom i budimpeštanskom zavodu. Glavna zgrada bila je izgrađena u neorenesansnom stilu s dvokatnim središnjim dijelom i nešto nižim, jednokatnim krilima. Pisarnica, liječnikov stan i stan glavne sestre su bili smješteni u središnjem dijelu, dok su se bolesničke sobe bile smještene na sjevernoj strani hodnika (slika 1). Smještanje soba samo s jedne strane hodnika omogućavalo je liječniku ili bolničarima da promatraju bolesnike bez da im ikad budu okrenuti leđima. Kao što sam naveo u prethodnom poglavlju takav se,plan izgradnje zavoda $\mathrm{u}$ devetnaestom se stoljeću nazivao linearnim ili Kirkbridgeovim planom po prvom ravnatelju Pennsylvania Hospital for the Insane Thomas Story Kirkbridgeu koji je 1854. godine napisao studiju On the Construction, Organization, and General Arrangements of Hospitals for the Insane with Some Remarks on Insanity and Its Treatment ${ }^{117}$. Iako se pri izradi nacrta glavne zgrade Kuno Waidmann držao linearnog plana, sam je zavod osim glavne zgrade imao još osam manjih paviljona ili, kako ih je članak u Liječničkom vjesniku nazvao „nuszgrada" "118 čime se približio drugoj vrsti plana zvanoj paviljonski ili separatni plan. Paviljonski plan gradnje zavoda postaje sve češći u drugoj polovici devetnaestog stoljeća i njegovo glavno obilježje je niz odvojenih paviljona, u Velikoj Britaniji i SAD-u često zamišljenih kao rustikalne kućice, u kojima bi bolesnici trebali živjeti jednostavnim životom uz bavljenje poljoprivredom ${ }^{119}$. Sam Waidmann je na svom predavanju pred skupštinom zbora liječnika hvalio paviljonski stil ${ }^{120}$, a dograđivanja koja su vršena kasnije, naročito za vrijeme dok je zavodom upravljao dr. Ivo Žirovčić kojem je bilo izuzetno važno biti u toku sa svjetskim medicinskim trendovima išla su u daljnjem smjeru pretvaranja Zavoda za umobolne u

116 Ibid: 84 .

117 Yanni, 2007: 38.

118 LV 5, 1879: 80.

119 Yanni, 2007:84.

120 LV, br. 3, 1894: 44-45. 
Stenjevcu u ustanovu paviljonskog tipa. Stenjevački paviljoni bili su povezani natkrivenim hodnicima koji su olakšavali premještanje bolesnika s odjela na odjel. No glavni problem zavoda bio je u tome što se već od početka pokazao premalenim za potrebe kojima je trebao služiti. Izgradnja je trajala gotovo dvije godine i već nakon svečanog otvorenja 16. studenog 1879. prevezeni su bolesnici iz Bolnice milosrdne braće fijakerima u novu bolnicu ${ }^{121}$. Usprkos naputcima koji su davani prilikom originalnih rasprava o svrsi zavoda, među bolesnicima je bilo mnogo već umirućih i neizlječivih, oboljelih od poteškoća u razvoju, staračke demencije ili progresivne paralize. U uvjetima prenapučenosti, epidemije su počele harati i zavod je nažalost ubrzo postao mjestom umiranja.

\subsection{Liječnici Kraljevskog i zemaljskog zavoda za umobolne u Stenjevcu}

U razdoblju kojim se ovaj rad bavi zavod je promijenio tri ravnatelja i velik broj kućnih i pomoćnih liječnika. Budući da u hrvatskom dijelu Austro-Ugarske nije bilo medicinskog fakulteta na kojem bi ti liječnici mogli dobiti potrebno obrazovanje većina se školovala $u$ inozemstvu, te su sa stranih sveučilišta donosili nove spoznaje o psihi i duševnim oboljenjima. Te spoznaje bile su uglavnom primjenjivane u Stenjevcu samo u onoj mjeri koliko je to kontekst Stenjevca kao nove i financijski slabo stojeće institucije dopuštao. Njihov praktični rad u Stenjevcu mijenjao je i proširivao neke isključivo akademske medicinske spoznaje i rezultirao formiranjem praktične zavodske psihijatrije koja je trebala odgovarati specifičnim potrebama društva Banske Hrvatske.

Prvi ravnatelj Zavoda bio je Ivan (Jan) Rohaček (1843.-1898.). Rohaček je prije imenovanja za ravnatelja zavoda bio sekundarni liječnik na ludničkom odjelu u Kosmonosyju u Češkoj, no 1877. preselio se u kaznionicu u Lepoglavi, gdje djeluje kao privremeni kućni liječnik. ${ }^{122}$ Moguće je da ga je za ravnatelja predložio Dr. Ante Schwarz koji se zanimao za izgradnju zemaljskog zavoda $\mathrm{i}$ bio upoznat $\mathrm{s}$ medicinskom službom u Lepoglavskoj kaznionici- pisao je o zdravstvenom stanju u Lepoglavi iste godine kad je Rohaček ondje zaposlen. Rohačeka su, zbog njegovog ranijeg iskustva smatrali velikim stručnjakom za psihijatriju, a da je uživao nesumnjiv

121 Glesinger, 2012: 85.

122 LV, 1877: 199. 
ugled kao psihijatar dokazuje i činjenica da mu je nuđenu prestižno mjesto kućnog liječnika u Pragu koje je iz nepoznatih razloga odbio. ${ }^{123}$ Nema puno podataka o njegovom obrazovanju prije zaposlenja u Kosmonosyju, no po njegovim izvješćima i ustroju Stenjevca u njegovo vrijeme, čini se da je imao određeni oblik psihijatrijskog obrazovanja. Kao kaznionički liječnik, mnogo je polagao na forenzičku psihijatriju i psihijatrijska vještačenja optuženik u Stenjevcu se počinju provoditi od samog osnivanja institucije. Rohaček je također uveo većinu terapeutskih i dijagnostičkih praksi koje su se primjenjivale u Stenjevcu. Njegova stručnost bila je predmetom kontroverze u dvadesetom stoljeću, kad su psihijatri Herceg i Bazala tvrdili da je Rohaček bio samo kaznionički liječnik bez specijalističke naobrazbe i da je njegovo imenovanje dokaz marginalnog mjesta psihijatrije u medicini devetnaestog stoljeća, dok je Zvonimir Sučić tvrdio da je Rohaček imao potrebne kvalifikacije za taj položaj. ${ }^{124}$

Rohaček je umirovljen 1894. nakon čega se vratio u Češku kako bi se tamo posvetio privatnoj praksi. Između 1894. i 1896. Zavodom je privremeno upravljao Ivo Žirovčić, koji će kasnije postati najdugovječnijim i najzaslužnijim ravnateljem Stenjevca. Nakon tog kratkog interregnuma, za ravnatelja je imenovan još jedan liječnik iz Češke Ivan (Jan) Šimsa (1865.1945.). Ivan Šimsa je doveden od strane tadašnjeg bana Dragutina Khuena Hedervaryja i ban ga je direktno imenovao izvanrednim članom zemaljskog zdravstvenog vijeća ${ }^{125}$. Šimsa preuzima zavod u pomalo kaotičnom stanju- zbog financijske neodrživosti zavod je 1894. prešao u zakup samostana reda časnih sestara svetog Vinka Paulskog, a odmah po dolasku Šimsa iz nekog razloga mijenja cjelokupno osoblje zavoda. ${ }^{126}$ Šimsa je prije zaposlenja u Stenjevcu bio liječnik u zavodu za umobolne u Dobžany u Češkoj, a bio je na glasu kao neurolog i stručnjak za mikroskopsku analizu tkiva. Njegov interes ostavio je traga i u Stenjevačkom zavodu gdje je naručio skupu opremu za mikroskopske i bakteriološke testove. ${ }^{127}$ Osim toga, Šimsa je počeo mikroskopski testirati vodu koja je štićenicima služila za piće kako bi spriječio eventualne epidemije, a naročit interes pokazao je za detaljne obdukcije umrlih štićenika. ${ }^{128}$ Nalazi obdukcija

$123 \mathrm{LV}, 1878: 130$.

124 LV, 1954: 709.

$125 \mathrm{LV}, 1896: 175$.

$126 \mathrm{LV}, 1897: 432$.

127 Ibid.

128 Dujić, 2012: 142.

60 
prilagani su povijestima bolesti jedino u vrijeme Šimsinog kratkotrajnog, ali plodnog upravljanja zavodom. Šimsa je bio uvjereni zagovornik apstinencije od alkoholnih pića, a zahvaljujući detaljnom mikroskopskom proučavanju mozga preminulih štićenika počeo je naslućivati ezu između progresivne paralize i tercijarnog sifilisa. Odbacivao je teorije po kojima do progresivne paralize dovodi prenapregnutost živaca, već je kao presudne faktore koji dovodi do razvitka progresivne paralize nakon prvotne infekcije sifilisom navodio hereditet i alkoholizam. ${ }^{129}$ Iako se teorija o povezanosti sifilisa i progresivne paralize javila već sredinom devetnaestog stoljeća, nepobitno ju je dokazao tek Hideyo Noguchi 1913. godine. Kraft- Ebbing, jedan od glavnih autoriteta među psihijatrima u Austro-Ugarskoj smatrao je da je sifilis uzrokom progresivne paralize u manjem broju slučajeva dok je primarni uzrok progresivne paralize nalazio $u$ duševnom naporu koji je iscrpljivao živčani sustav muškaraca građanskog sloja. Šimsa se nije slagao s Kraft-Ebbingom i tražio je uzroke epidemije progresivne paralize u alkoholizmu i prostituciji kao socijalnim faktorima koji se mogu ispraviti društveno angažiranima djelovanjem liječnika. Šimsa je naročito osuđivao zaradu koju od alkohola ostvaruju "države i obćine" dok epidemija alkoholizma ima dugoročne i dalekosežne posljedice po čitavo društvo. ${ }^{130}$

Šimsa je otišao u mirovinu početkom 1901. godine ,a nakon umirovljenja otvorio je privatni sanatorij za liječenje živčanih i duševnih bolesti u Krču u Češkoj. ${ }^{131}$ Nakon umirovljenja nastavio je pisati brojne članke i knjige u kojima je isticao štetnosti alkoholizma i zalagao se za potpunu apstinenciju od alkoholnih pića, a postao je poznat po istraživanju glasina o duhovima i pisanju o spiritizmu. ${ }^{132}$

Ivan Žirovčić (1855.-1940.) bio je drugi i četvrti ravnatelj Stenjevca i ostao je zapamćen kao jedan od najuspješnijih i najcjenjenijih ravnatelja Zavoda, a često ga se spominje i kao „oca hrvatske psihijatrije”. Rođen u Križancu, u Hrvatskom Zagorju u plemićkoj obitelji, nakon studija medicine u Beču svoju je karijeru počeo kao kupališni liječnik u Lipiku, zatim podžupanijski liječnik u Pisarovini i Severinu i okružni liječnik u Ogulinu. Nakon odlaska Ivana Rohačeka, Dr.

129 Šimsa, 1898: 2.

130 Ibid.

$131 \mathrm{LV}, 1901: 363$.

132 Wanger, 2011.

61 
Viktor Struppi je zamolio Žirovčića da preuzme zavod, na što Žirovčić nakon kraćeg nagovaranja i specijalizacije u gradačkom zavodu Feldhof pristaje. ${ }^{133}$

Za vrijeme studija u Beču, Žirovčić upoznao s Theodorom Meynertom, koji je u mladom liječniku probudio interes za psihijatriju. U vrijeme kad je Žirovčić studirao u Beču, kod Meynerta su studirali i Sigmund Freud i Josef Breuer. Ta cijela generacija psihijatara će, uz Richarda von Krafta- Ebbinga koji je kasnije radio kao liječnik u Feldhofu pretvoriti AustroUgarsku monarhiju u jedan od najproduktivnijih centara psihijatrijske i psihoanalitičke misli. Žirovčić preuzima Stenjevec 1894. kao prvi specijalizirani psihijatar ne njegovom čelu i odmah biva razočaran zatečenim stanjem. Zavod je prešao u zakup milosrdnih sestara, bio je slabo financiran, infrastruktura nije bila zadovoljavajuća a adinistrativnom i liječničkom osoblju je nedostajalo stručnosti i iskustva. Iz tih razloga Žirovčić dolazi u sukob s Hedervarijevom zemaljskom vladom i biva prijevremeno umirovljen 1896. godine. ${ }^{134}$

U vrijeme svog prvog mandata Žirovčić nije stigao provesti reformu zavoda željenom opsegu, no utvrdio je vlastitu klasifikaciju duševnih bolesti koja se oslanjala na Meynertovu. Prije Žirovčića nije bilo usustavljene klasifikacije duševnih oboljenja u Stenjevcu, što je otežavalo upravljanje Zavodom. Žirovčić je klasifikaciju temeljio na tada modernim načelima austrijske biološke psihijatrije te uvodi i „neurasthenične ili konstitucionalne psihoze”. ${ }^{135}$ Radi se o duševnim slabostima koje su uvjetovane hereditarnim slabljenjem duševne konstitucije, a ljudi koje pate od istih predstavljaju "graničnu skupinu” (u skladu s Maudsleyevim pojmom „borderlandsa”) herditarno opterećenih pojedinaca koje ,riedko vidjamo u ludnicah, jer imaju dosta inteligencije, da se mogu održati usried čovječanskoga družtva" ali slabost njihovog živčanog ustroja ih navodi na impulzivno djelovanje koje ih „,dovadjaju... ...često pred kriminalni forum." ${ }^{136}$

Žirovčića je, nakon prvog neuspješnog mandata naslijedio Jan Šimsa, koji ubrzo dolazi u istu vrstu sukoba sa zemaljskom vladom. Žirovčić se 1901., nakon Šimsine ostavke vraća iz prijevremene mirovine kako bi nastavio upravljati zavodom. Njegov odnos sa zemaljskom

133 Lopašić, 1925: 230.

134 Ibid.

135 Žirovčić, 1895a: 67.

136 Ibid: 66-67.

62 
vladom bio je uvijek pomalo napet, posebno iz razloga što je Žirovčić intenzivirao svoje javno djelovanje. Članci koje je pisao u Liječničkom vjesniku i ostali javni istupi, imali su intenciju podizanja ugleda psihijatrije kao struke i samim time, vjerojatno, poticanja večeg izdvajanja za psihijatrijske zavode. Također, Žirovčić posreduje između medicine i pravosudnog sustava kao psihijatrijski vještak. Iako su se psihijatrijska vještačenja u Stenjevcu provodila od samog osnutka Zavoda, Žirovčić ih prvi nastoji publicirati. Kroz njihovu publikaciju, Žirovčić često debatira s uvriježenim pravosudnim i medicinskim pojmovima poput „ubrojivosti” ili „moral insanity”. Najveća kontroverza vezana uz Žirovčićev rad dogodila se 1912. kad je pozvan da provede psihijatrijsko vještačenje nad Lukom Jukićem, atentatorom na kraljevskog povjerenika Slavka Cuvaja. Žirovčić je bio pod iznimnim pritiskom javnosti i svojih kolega da proglasi Jukića neuračunjivim. ${ }^{137}$ No, Žirovčićevo vještačenje proglasilo je Jukića ubrojivim što je omogućilo da isti bude osuđen na smrt. Osim Jukićevog, Žirovčić vodi vještačenje u nizu politički nabijenih sudskih slučajeva, poput slučaja I.M. studenta koji je 1909. uništio portret bana Khuena Hedervaryja i Josipa Vugrina koji je 1907. izvršio atentat na brdovečkog župnika, koji je bio politički motiviran. U zaključku tog vještačenja, Žirovčić se ne libi izricanja vlastitih političkih sudova, pa premda osuđuje čin umorstva i atmosferu nasilja koju raspiruje stranački tisak, također ističe da „ljute rane našeg naroda, koje su Josipa Vugrina potaknule na čin osvete, žalibože nisu tlapnja"138 Predan forenzičkoj antropologiji i željan dati psihijatriji znanstveni i pozitivistički pečat Žirovčić nije bježao od ovakvih, kontroverznih slučajeva. U mirovinu je morao otići 1919. nakon što ga je nemirni štićenik prilikom vizite oslijepio udarcem u glavu ${ }^{139}$. Nakon umirovljenja, ostatak života provodi u okolini Stenjevca, često sudjelujući u raspravama psihijatrijskog društva i s mnogo interesa prateći nova medicinska otkrića na polju psihijatrije.

Mnogi stenjevački psihijatri, poput Dragutina Forenbachera, Armanda Vinskog i Milana Lončareka istakli su se kao poznati psihijatri iako nikad nisu bili ravnateljima zavoda. Zanimanje zavodskog liječnika u devetnaestom stoljeću nije bilo prestižno niti omiljeno, zbog čega mnogi od njih, usprkos nedvojbenoj stručnosti nisu birali ostali u Stenjevcu. Teški uvjeti života u

137 Lopašić, 1925: 231.

138 Žirovčić, 1907: 33.

139 Lopašić, 1925: 231.

63 
zavodu, sveprožimajući pesimizam i bezizglednost i velika smrtnost pacijenata odbijali su liječnike od psihijatrije uopće, a naročito od stenjevačkog zavoda, koji je imao reputaciju loše izgrađene, provincijske bolnice u koju se nedovoljno ulaže. 


\section{3 Štićenici stenjevačkog zavoda}

\subsubsection{Socijalna struktura štićenika zavoda za umobolne u Stenjevcu}

Budući da je većina stanovnika Hrvatske krajem devetnaestog stoljeća živjela na selu, najveći dio štićenika zavoda također je došao iz ruralnih sredina. Uz to, imućniji građani i plemići bili su u boljoj prilici osigurati kućnu njegu ili skrb u nekom od inozemnih zavoda, dok su siromašniji štićenici bili sprovođeni u Stenjevac, gdje su samo bolesnici prvog razreda plaćali vlastitu obskrninu, dok su oni drugog i trećeg razreda, djelomično ili u cijelosti bili smješteni u Stenjevac na teret grada.

U izvješću koje pokriva godine od 1879. do 1882. kao zanimanje većine štićenika navedeno je „poljodjelci” (166 odnosno 48.25 \%) zatim ,zanatnici” odnosno obrtnici (36 odnosno 10.46\%) dok težaci i sluge zajedno čine 61 štićenika odnosno 14. 8 \%. Mali je broj štićenika iz građanskih zanimanja. U zavodu je tek troje učitelja, po jedan liječnik i ljekarnik, dok je supruga činovnika među štićenicama bilo deset a samih činovnika sedam ${ }^{140}$. Osim zanimanja, indikativan je i omjer broja štićenika koji je dolazio iz gradova naspram broju koji je dolazio sa sela. Isto rano izvješće navodi da je iz gradova ukupno došao četrdeset i jedan štićenik, iz podžupanija Hrvatske i Slavonije 232, iz nekadašnje Vojne Krajine 57 a ostalih (iz drugih zemalja AU, iz Bosne i iz Italije) trinaest. ${ }^{141}$

Takav trend se nastavlja sve do 1918. godine. Većina štićenika ostaju poljodjelci iz ruralnih sredina, sluge služavke i težaci, što oslikava populaciju Stenjevca kao siromašnu, uglavnom slabije obrazovanu i naviklu na težak fizički rad. Također, brojnost seoskog stanovništva u zavodima za umobolne, nije bila isključivo hrvatski fenomen. Britanski statističari sredine

$140 \mathrm{LV}, 1883: 86-87$.

141 Ibid.

65 
devetnaestog stoljeća su također zaključili da većina duševno bolesnih dolazi za sela, ${ }^{142}$ što je navelo i Maudsleyja da zaključi da je „ludila najviše tamo gdje ima najmanje ideja, gdje su osjećaji najjednostavniji i žudnje i način života najprostiji." ${ }^{143}$ Kontinuirano je malo prosjaka i lutalica, što bi moglo ići u prilog Shorterovoj tezi o institucionalizaciji kao posljedici promjena u poimanju obiteljskog života i porodične svakodnevice krajem 19. stoljeća. ${ }^{144}$

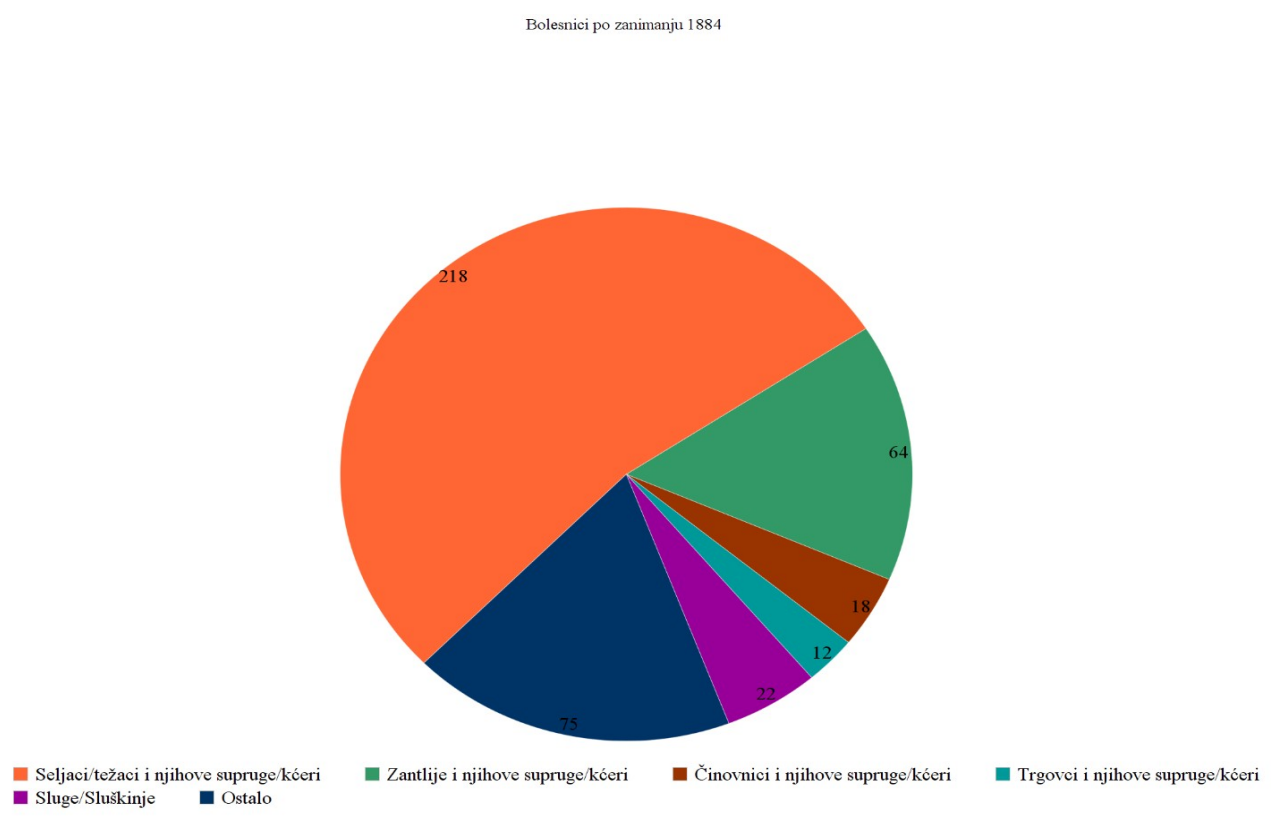

Graf 1: Bolesnici po zanimanju 1884. godine ${ }^{145}$

U ranim su godinama muškarci znatno brojniji od žena- u prvih pet godina (od 1879. do 1884.) oni uvijek čine više od polovice štićenika zavoda. ${ }^{146}$ Te brojke se na prvi pogled čine suprotstsavljene podacima koje navodi E. Showalter, prema kojima žene prevladavaju među štićenicama zavoda za umobolne u devetnaestom stoljeću ${ }^{147}$. No, nakon 1883. godine omjeri između pacijenata i pacijentica postaju takvi da se može zaključiti kako je ludilo i u Stenjevcu

142 Showalter, 2001: 108.

143 Maudsley, 1895: 30.

144 Shorter, 1997: 51.

145 Rohaček, 1885:50.

146 Ibid.

147 Showalter, 2001: 52.

66 
bilo ,ženskom boljkom”. Napokon, 1885. godine je prvi put u Stenjevački zavod primljeno više Žena nego muškaraca. ${ }^{148}$ Ubrzo nakon, toga 1887. u zavodu opet ima znatno više muškaraca nego žena, no budući da su muškarci odlazili iz zavoda i umirali u većoj mjeri nego žene, krajem godine broj štićenika i štićenica je po prvi put bio izjednačen 146 muškaraca i 146 žena. ${ }^{149}$

Izvori ukazuju na još nekoliko aspekata onodobnog poimanja ludila kod kojih je rod štićenika igrao veliku ulogu i koji objašnjavaju kako trend postepenog izjednačavanja broja muškaraca i žena u zavodu za umobolne, tako i percepciju Elaine Showalter o vezi između ženske seksualnosti i ponašanja koje je prkosilo društveno uvriježenim normama i broja institucionaliziranih žena. Najočitiji primjer toga su dijagnoze i uzroci bolesti. U prvim izvješćima muškarci brojem prevladavaju u gotovo svim dijagnozama, samo je kod slučajeva „melancholie” i ,epilepsie” broj žena i muškaraca podjednak. ${ }^{150} \mathrm{~S}$ vremenom, raste broj žena s dijagnozama „manie”, „melancholie” i ,anoie”, a u 1885. žene su brojnije u svim dijagnostičkim kategorijama osim „vesanie”, „paralysys” i „epilepsie”. ${ }^{151}$ Ove brojke govore da je veći broj muškaraca, nego žena smještenih u Stenjevcu bolovao od ,progresivne paralize” odnosno terminalnog krajnjeg stadija sifilisa koji je u drugoj polovici devetnaestog stoljeća u Europi poprimao epidemijske razmjere. ${ }^{152}$ Druga pojava koja je u devetnaestom stoljeću poprimala epidemijske razmjere bio je alkoholizam, koji uzrokuje niz psihičkih poremećaja i koji je uglavnom pogađao muškarce, budući da je socijalno opijanje bilo muška aktivnost. Bolji standardi života i nove destilacijske tehnologije omogućili su veliku dostupnost jeftinog alkohola što je povećalo potrošnju alkoholnih pića diljem Europe. ${ }^{153}$ Može se pretpostaviti i da jedan dio muškaraca koji je u zavodu bio s dijagnozom druge bolesti također možda bolovao od progresivne paralize u početnoj fazi koja je karakterizirana tek rastresenošću, omaglicama i povremenim promjenama raspoloženja ${ }^{154}$. Obzirom na to da je progresivna paraliza najčešće

148 Ibid.

149 Rohaček, 1888.: 68.

150 LV, br. 6. 1883. str. 86 .

151 Rohaček, 1886:66.

152 Shorter,1997:54.

153 Ibid: 59.

154 Forenbacher, 1892: 2-3.

67 
završavala smrću, podatak koji govori da se nakon „otpada” broj muškaraca i žena izjednačava može ukazivati na činjenicu da veći broj muškaraca u Stenjevcu znači veći broj onih koji su u Stenjevec došli zbog neuroloških tegoba prouzročenih terminalnim sifilisom. Kada se dakle, od ukupnog broja štićenika odbiju oni s degenerativnim procesima na mozgu poput sifilitičara i epileptičara, ostaje nam zbilja veči broj žena koje su u Stenjevac primane bez vidljive neurološke patologije. One su uglavnom bile tu zbog poremećaja vezanih za emocije i izražavanje istih (melacholiu i maniju). Od toga broja zasigurno je velik broj onih čiji je način ponašanja i nošenja s emocijama bio predmetom diskurzivnih modela patologizacije, selektivne diskurzivne prakse koja je na temelju kriterija društvene prihvatljivosti određene načine ponašanja označavala stigmom patologije, što ide u prilog tezama Elaine Showalter.

Dijagnoze (muškarci) u 1884 godini

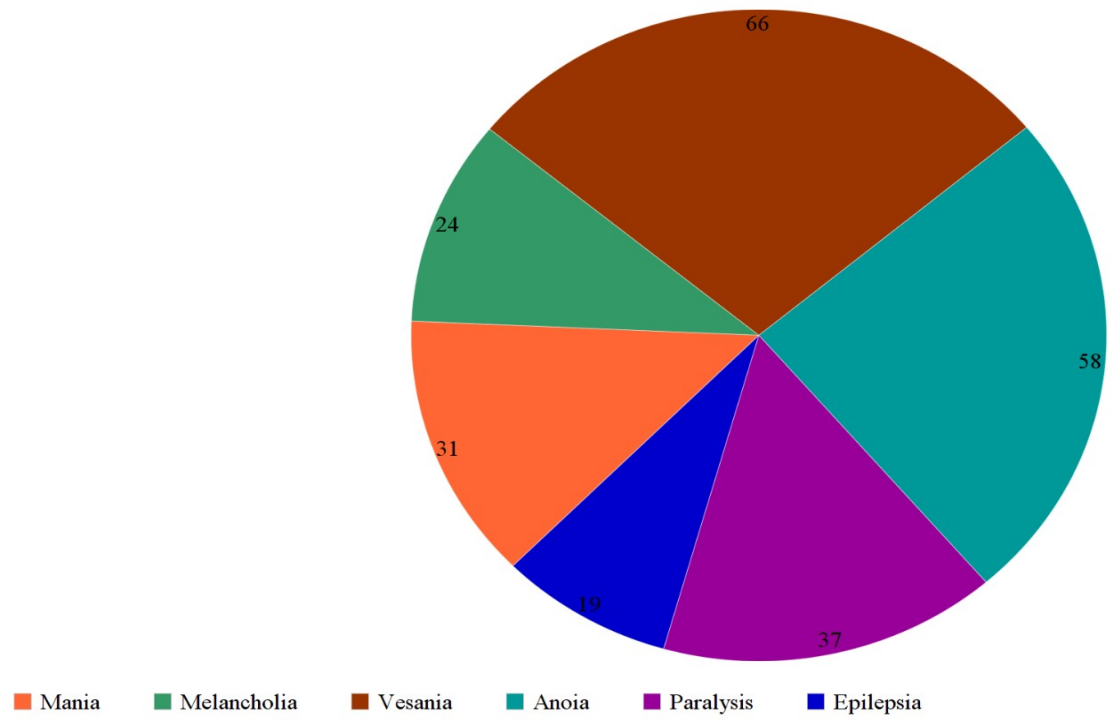

Graf 2 : Dijagnoze (muškarci) u 1884. godini $^{155}$

155 Rohaček, 1885:50. 
Ovisnost stigme patologije o rodu vidi se iz pretpostavljenih uzroka bolesti. U prvih deset godina zavoda, izvješća navode brojne uzroke bolesti koji su specifični za žene. „Spirituosas” (pijanstvo) je u tim ranim izvješćima gotovo isključivo „muški” uzrok duševnog poremećaja. Kod žena prevladava „affectus” ili, kako je Rohaček to preveo na hrvatski „silno ganuće srdca”" ${ }^{156}$. Kod muškaraca su tri vodeća uzroka oboljenja pijanstvo, affectus i nasljedni elementi (hereditas), dok su kod žena to affectus, nasljedni elementi i ponekad glavobolja a ponegdje porod. Valja istaknuti da Rohaček zapravo za većinu štićenika ne zna navesti uzrok oboljenja no uvijek pretpostavi da

Dijagnoze (žene) u 1884. godini

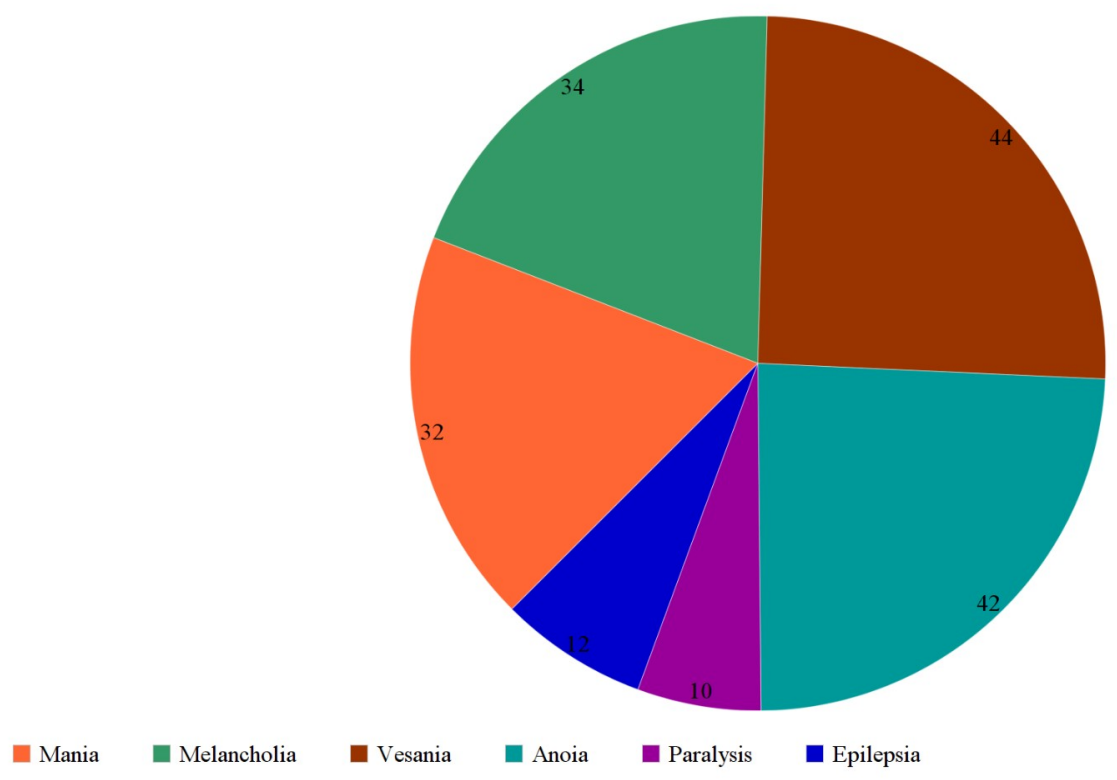

Graf 3: Dijagnoze (žene) u 1884. godini ${ }^{157}$

156 Rohaček, 1889:149.

157 Ibid. 
je kod muškaraca riječ o oskudici, a kod žena o oskudici i s njom povezanom slabokrvnosti ${ }^{158}$

Neki uzroci ludila pak govore o ranjivom položaju žena i o patrijarhalnim predrasudama vezanim za ustroj ženskog uma. Tako se među uzrocima ludila kod žena navode: „razmažen odgoj” „mensess cessantes”, „excessus in Venere”, „duševni napor" i „,citanje romana” ${ }^{160}$. To ide u prilog dominantnoj paradigmi koja gleda na žene kao na bića čije su djelovanje i zdravlje upravljane njihovim reproduktivnim funkcijama i kod kojih težak intelektualni napor može prouzročiti duševno oboljenje. Tako je Maudsley u svojoj raspravi „Sex and Education” istakao kako „žene koje prolaze istu vrstu obrazovanja kao muškarci to čine pod cijenu velikih poteškoća i patnje koja ih na kraju čini nesposobnima za obavljanje prirodnih funkcija njihovog spola" ${ }^{161}$ Drugi podatak kojeg se može izvući iz uzroka bolesti je činjenica da su liječnici vidjeli oskudicu kao dominantan uzrok bolesti. Čini se da su štićenici i štićenice u Stenjevac dolazili iz života koji je bio obilježen teškim egzistencijalnim uvjetima, neimaštinom i nedovoljnom prehranom. Budući da Rohaček nekoliko godina za redom pretpostavlja da je neimaština uzrok bolesti kod većine štićenika kod kojih se ne može naći drugačiji, jasan povod njihovog ludila, razumno je zaključiti da je siromaštvo bilo najuočljivija i najodredljivija karakteristika stenjevačkog pacijenta. Rana percepcija veze između siromaštva i ludila dat će zapisima stenjevačkih psihijatara distinktivan socijalno angažirani ton.

Traženje uzroka ludilu u teškim životnim uvjetima i neimaštini je bila jedinstvena pojava za europsku psihijatriju prijelaza stoljeća, koja je bila previše opterećena seksualnošću i hereditetom. Tako je uvid u tešku svakodnevicu socijalno depriviranog stanovništva utjecao na formiranje socijalne struje u hrvatskoj psihijatriji. No pod pritiscima terapeutskog pesimizma i forenzičko-eugeničkog fokusa mainstream psihijatrije, ta će se struja uspjeti u potpunosti aktualizirati tek nakon Drugog svjetskog rata.

158 Ibid.

159 Ibid.

160 Rohaček, 1887: 69.

161 Maudsley, 1884: 17. 


\subsubsection{Iskustva štićenika prije dolaska u Stenjevac}

Teško je sa sigurnošću reći kakva su bila iskustva štićenika prije dolaska u Stenjevac. Zapisi psihijatara i povijesti bolesti govore o životu koji je bio ispunjen zlostavljanjem, praznovjernim predmedicinskim praksama liječenja duševne bolesti i nasiljem. Psihijatar Rudolf Herceg u jednom od svojih zapisa govori ovako o položaju duševnih bolesnika:

„U našim krajevima bila je teška sudbina tih jadnika još koncem prošlog stoljeća kad se duševne bolesne viđalo po cestama,gdje se izlažu ruglu djece i neozbiljnih ljudi, a samo opasni ili akutno oboljeli sklanjali su se u bolnicu Reda milosrdne braće na Jelačićevom trgu u Zagrebu. Odjel broj 13 u dvorištu te bolnice bio je dugi niz godina onaj zloglasni broj, koji je u toj bolnici značio naročitu nevolju i nesreću."

Članci liječnika i povijesti bolesti često govore o okrutnom postupanju rodbine, seoskih vlasti, pa čak i liječnika i bolničara zaposlenih u bolnici Milosrdne braće koji su nerijetko neprimjereno liječili, zatvarali i tukli bolesnike. Članak Ive Žirovčiča, dugogodišnjeg i veoma uspješnog ravnatelja Zavoda za umobolne u Stenjevcu, objavljen u Liječničkom vjesniku iz 1904. govori u slučaju mlade seljakinje Minke P. koja je osumnjičena zbog umorstva suprugova brata gluhonijemog Franje P. jer je nekoliko dana prije Franjine pogibije (koja je kasnije Žirovčićevim tumačenjem objašnjena kao bizarna nesreća) bila u stanju koje bi suvremena psihijatrija označila kao psihotičnu epizodu, odnosno akutnu psihozu. U članku se kroz iskaze brojnih svjedoka (redarstvenika i suseljana) govori o postupku suprugove obitelji prema Minki. Liječnici koji su pregledali Minku su tako našli „tragove vezivanja i na leđima dugoljaste ogrebotine.” 163 Žirovčić, književno obrazovan i vjerojatno svjestan da psihijatrijska vještačenja privlače pažnju javnosti i čine, inače zapostavljenu, zavodsku psihijatriju vidljivijom prepričava ovaj slučaj u maniri gothic romana i ističe još jedan prilično bizaran detalj. Naime, svjedoci govore kako je suprugova obitelj Minku golu zavezala lancem za stup od žrvnja, ističući pritom da je zavezana lancem jer je „dretu” kojom su je prvotno razvezali bila razgrizla. ${ }^{164}$

162 Herceg, 1933: 6.

163 Žirovčić, 1904: 309.

164 Žirovčić. 1904: 312-313. 
Pomalo makabričan opis postupanja seljaka s bolesnom Minkom, koji zauzima ključno mjesto u članku čiji je predmet psihijatrijsko vještačenje. Njegova uloga je povezivanje senzacionalističke privlačnosti slike mlade žene privezane nage za stup sa željenom predodžbom o psihijatriji kao čovječnoj disciplini koja uistinu liječi one prema kojima se iz straha i praznovjerja neljudski postupa. Možda upravo zbog toga zapisi o zlostavljanju duševnih bolesnika uvijek zauzimaju prominentno mjesto u stenjevačkim povijestima bolesti. Dapače, često se upravo u tim zapisima makabrizam psihijatrijskog diskursa, koji je često bio usmjeravan prema štićenicima okreće prema van i postaje kritičan prema nekim štetnim i nehumanim praksama.

Među praksama koje bivaju kritizirane u tim zapisima na udaru se nalaze mnoge metode liječenja koje spadaju u narodnu medicinu, a koje liječnici smatraju pogubnima za tjelesno i duševno zdravlje. Povijest bolesti stanovite Jele S. lončareve supruge koja je u zavod primljena 1881. kazuje da je povod bolesti: „neumjestan odgoj, obćenje s babami koje joj glavu napunjavahu raznimi praznovjernim pričami..." 165 Bolesnica je za vrijeme boravka pokazivala izražen strah od čarolija i imala noćne more. Liječnik koji je pisao izvješće na temelju koga je bolesnica primljena u bolnicu pravi jasnu razliku između postupanja s bolesnicom u zavodu i ,pučkih lijekova” kojima su pribjegavali njeni ukućani:

„Lječenje u bolnici od 14. veljače se sastojalo samo u tome što se je nastojalo mirnim pristupom, otklonjenjem svakog razdraživanja umobolnu umiriti, a ljekarie dobiala je kad kada prema potrebi... Kod kuće postupaše s njom protivno zdravom umu, iztjerivaše iz nje vraga, držaše molitve nad njom, kadiše ju meni nepoznatim tvorinami. Taj postupak ju je do najvećeg stepena razdraženosti doveo." $" 166$

Osim egzorcizama i sličnih postupaka koji su rezultat folklornih vjerovanja o duševnoj bolesti kao „opsjednutosti” ili posljedici crne magije brojni su primjeri koji govore o tome kako se bolesnike otvoreno zlostavljalo prije dolaska u zavod. Tako je Obrada S. mladića iz Sošana sklonog lutanju bio zlostavljao njegov otac: „Dosele u ogradi čvrstoj u štali pod kućom, iz koje

$165 \mathrm{KPV}, 1881: 312$.

166 Ibid. 
nije nikud mogao. Isprva ga je otac tukao, a kad je vidio da je bolestnik zbilja lud i pogibeljan, zatvorio ga u štalu i nikad ga više nije pustio slobodna, inače je s njim dobro postupao"167

Ovdje je zanimljiv izbor riječi. Usprkos tome što ga je otac tukao i zatvarao u štalu ispod kuće, povijest bolesti svejedno navodi da je ,inače s njim (sic!) dobro postupao” što implicira da su stenjevački liječnici i bolničari u svojoj praksi susretali slučajeve mnogo goreg zlostavljanja od ovog. Osim rodbine, kao zlostavljači se navode i bolničari sa već kritiziranog odjela 13 bolnice Reda milosrdne braće. Bolesnica Marta V., seljanka iz Dubrave kod Ogulina koja je u bolnicu Milosrdne braće primljena u trudnoći tako svjedoči da je žalosna jer su ju „kod braće vezali i zlostavljali"168. Djevojka seljačkog porijekla iz Plaškog koja je odvedena kod milosrdne braće jer se s roditeljima sukobila zbog nedozvoljene ljubavne veze govori kako je u bolnici bila zlostavljanja i dobivala injekcije, a njen nalaz prilikom pregleda govori kako je ,(njena) koža udarana na više mjesta ogrebena i modričava." ${ }^{169}$ Činjenica da je bolesnica otpuštena kao zdrava tek mjesec dana nakon primitka u zavod također baca zanimljivo svjetlo na ovaj slučaj.

Jedno od najdramatičnijih svjedočanstava o zlostavljanju u bolnici Reda Milosrdne braće dolazi iz bolničkog kartona Ane V. sluškinje iz Mihovljana koja je jedno vrijeme radila u zagrebačkoj bolnici kao sluškinja. Nakon što je optužila jednog liječnika za zlostavljanje, poglavarstvo ju je predalo u istu bolnicu radi motrenja. Nakon što je upućena u Stenjevac, jedna od povijesti bolesti donosi njen glas:

„,...uvek se tuži da su joj u zagrebačkoj bolnici liječnici najprije s rukami njezino djevičanstvo uzeli, a kašnje kad su ju postavili za bolničarku napastovali su ju fratri te su ju svi hteli silovati, a jednomu je i zbilja pošlo za rukom. Od to doba jerbo se je prestrašila i zasramila nema mira niti pokoja..."170

Iako bi ponašanje Ane V. u Zavodu današnji psihijatri vjerojatno tumačili kao posljedicu neke vrste traume uzrokovane seksualnim zlostavljanjem, stenjevački su liječnici bili odlučni u zaključku da ona nije bila silovana. Usprkos njihovoj nesklonosti da povjeruju takvim tvrdnjama svojih štićenika, psihijatri su temeljito bilježili sve što je moglo ukazivati na neku vrst okrutnog postupanja prema duševno oboljelima. Jednoj povijesti bolesti je tako priloženo pismo Ivana B.

$167 \mathrm{KPV}, 1895: 2537$.

168 KPV, 1911: 8104.

169 KPV, 1911: 8138.

170 KPV, 1895: 1066. 
pravnika iz Vrblja kod Nove Gradiške koji je 1915. četiri godine nakon što je bio institucionaliziran, optužio liječnika Kostu Mladenovića da ga je poslao u Stenjevec zbog političkih sukoba. U pismu, (koje vjerojatno zbog ratnih okolnosti u kojima je napisano obiluje antisrpskim sentimentom) Ivan B. govori kako se :

„...čuvajući livadu od susjeda koji su pasli i štetu činili te se po noći tvorno grozili, fićukali itd. nahladio i pao u groznicu. Isti su nešto od neukosti svoje nasilno izveli puštanje krvi po Mikolcu iz Gunjavaca, pravoslavne vjere (srpske) uz crkvenu molitvu sa zamotanom rukom po nekoj crnoj postavi. Na to me rođaci dovezoše u bolnicu u Novu Gradišku. Službujući liječnik, dr. Kosta Mladenović, grko-istočne vjere dao me po sluzi Jovanu pravoslavne vjere (srpske) zatvarati u samici rujna 1911 u mrežu. Taj je i drugi vikom kroz zid (da se ne opaze), grožnjom, pogrdama, provociranim neosnovanim pitanjima prema svojim intencijama nastojali provocirati nekakvi hrvatski proces radi nemira smjerajući onamo da stave vjernost prema hrv. kralju u dvojbu i ocrne te naškode, i nepoštujući kat. Vjeru i hrv. junake. To je sve dojavljeno g. dr. K. Mladenoviću, koji je i sam sugestijama i sl. bolest da se poveća htio te sve u (srpstva) političku korist izrabio. Kad sam prinužden otvorio nekoliko puta mrežu iznutra bacili me u smradnu sobu pred bolnicom, koja se nije zračila, niti se prozor otvarao - a niti sam vode dobio za umivanje." 171

Iako su od samog slučaja prošle četiri godine, ravnatelj Ivo Žirovčić, kojem je pismo bilo upućeno ga je sačuvao u kartonu nekadašnjeg štićenika, što govori o tome da se ovakvim slučajevima pridavala velika važnost.

Članak dr. Rudolfa Hercega, objavljen u monografiji „Stenjevec - državna bolnica za duševne bolesti 1879.-1933” koji nosi naslov „Prijava bolesnika u bolnicu”, iako datiran mnogo kasnije od navedenog razdoblja obiluje sličnim primjerima nasilnog i često brutalnog odvođenja ljudi u bolnicu, kao i primjerima liječničke aljkavosti pri izdavanju uputnica. Herceg navodi da su se slučajevi nasilnog postupanja prema bolesnicima i u 1930-ima događali svakodnevno. ${ }^{172}$ Herceg iznosi primjere seljaka koji su svezali bolesnika za kola „debelim konopom, a voze se već šest

$171 \mathrm{KPV}, 1911: 8232$.

172 Herceg, 1933: 159. 
sati” i općinskog pandura koji štapom tjera bolesnika svezanog u stezulju. ${ }^{173}$ Nasilno postupanje s psihički oboljelima od strane općinskih vlasti, obitelji i susjeda je dakle i u 19. i u 20. stoljeću bila svakodnevica pred kojom liječnici nisu pokazivali veliko zgražanje i čuđenje, iako su takve postupke naravno osuđivali svakom prilikom.

\section{4. Život u Zavodu za umobolne}

\subsubsection{Dolazak u zavod}

Prvo iskustvo štićenika nakon prijema u bolnicu bio je prvi pregled koje je ostalo zabilježeno u povijestima bolesti bio je pregled u pisarnici tijekom kojeg bi liječnik pisao takozvani „status praesens”. „Status praesens” je bio zapis o trenutnom tjelesnom i duševnom stanju bolesnika prilikom prijema u bolnicu. Taj pregled i izvještaj su bili ključni za postavljanje dijagnoze, te su pomogli odrediti na koji će od odjela bolesnik biti smješten. Pregled bi se događao na dan prijema, ili najkasnije dan ili dva nakon prijema u zavod, što je vjerojatno ovisilo o tome je li liječnik bio dostupan u trenutku kad bi štićenika doveli. Pacijent bi bio doveden u jednu od pisarnica gdje bi ga jedan od kućnih liječnika ili ravnatelj pregledali.Sve pisarnice nalazile su se u prizemlju glavne zgrade. ${ }^{174}$ Pri tom pregledu, velika se pažnja posvećivala određenim tjelesnim karakteristikama za koje se smatralo stigmama hereditarne degeneracije. Takvi detalji bili su deformacije usta, ušiju, lica i zubala ${ }^{175}$ a stenjevački ravnatelji Ivan Rohaček i Ivo Žirovčić su kao specijalisti za forenzičku psihijatriju ${ }^{176}$ pokazivali izniman interes za socio-darvinističke teorije autora poput Maudsleyja i Mobiusa i kriminalnu antropologiju Cesarea Lombrosa. Zapisi s prvih pregleda redovito daju opis zubala, ušiju, oblika lubanje (nekad s točnim mjerama, nekad bez), prisutnost određenih neuroloških znakova koji bi mogli upućivati na progresivnu paralizu poput stanja zjenica i provjere refleksa. Pregledani bi bili i otkucaji srca i disanje, a kod žena bi se posebna pažnja posvetila obliku grudi i spolnih organa. Pregled već spomenute Minke obiluje hereditarnim znakovima: ,...žena sitna, srednje ugojena. Lubanja nepravilnog oblika objam 510 duljina 175 širina $140 \mathrm{~mm}$...Ušesa vrlo malena, izobličena, nejednaka, lievo veće, desno

173 Ibid.

174 Jukić, 2015: 11.

175 Showalter, 2001: 106-107.

176 Prvi je bio kaznionički liječnik, prije nego što je postao ravnateljem Stenjevca, drugi je pokazivao veliki interes za sudska vještačenja i o tome redovito objavljivao članke u Liječničkom vjesniku. 
manje... Nos malen, tubast, sedlast u korenu nizak i širok. Desni ustni kut niži. Zubi zdravi, sitni, rašljasti. “177.

Poneki opisi obiluju nekim motivima u kojima se razaznaju natruhe devetnaestoljetnog znanstvenog rasizma. Povijest bolesti Katarine F., žene krčmara iz Apatina posebnu je pažnju posvetilo njezinom židovskom porijeklu, a opis tjelesnih karakteristika je, neuobičajeno krenuo u smjeru navođenja određenih tjelesnih osobina koja su bile opisivane kao atavističke. Također, neke od njenih tjelesnih karakteristika opisivane su jezikom rasnih atavizama, na primjer oblik usta koja su opisana kao „laloke na van svedene davajuć licu izraz majmuna" ${ }^{\text {"178 }}$.

Nakon tjelesnog pregleda uslijedio je intervju u kojem je liječnik utvrđivao duševno stanje štićenika. Taj intervju imao je neka opća mjesta: štićenika se pitalo zašto je ovdje, pokušalo se od njega saznati podatke iz obiteljske povijesti, naročito uzroke smrti drugih članova obitelji i je li itko drugi iz obitelji bio duševno bolestan. Također, pribjegavalo se testovima pismenosti i provjeravalo razlikuju li štićenici pojedine novčanice, znaju li molitve, imena mjeseci i dane u tjednu, te rješavati jednostavnije matematičke zadatke. Iz zapisa je, doduše, nejasno u kojoj su mjeri liječnici pogreške u zbrajanju i neznanje specifičnih molitvi pripisivali duševnoj bolesti ili neobrazovanosti štićenika. S obzirom na dobro poznatu Maudsleyevu paradigmu o ludilu kao posljedici „siromaštva ideja” moguće je da su izvodili eventualnu vezu između duševne bolesti i nedostatka obrazovanja. Primjer takve provjere znanja možemo vidjeti u objavljenom vještačenju Gjure Gjankovića. Gjuro Gjanković bio je 22. veljače predan u Zavod za umobolne u Stenjevcu radi psihijatrijskog vještačenja, jer je iz osvete zapalio štalu svog očuha. Prilikom razgovora u liječničkoj pisarni morao je riješiti sljedeći zadatak: „Ako imaš 20 krajcara, pa kupiš za 3 krajcara pakl duhana, koliko ti još ostane novaca ? Ne odgovara-veli, da on kupuje pakl po 4 krajcara. Dakle 4, pa koliko ti onda ostane od 20 krajcara? Nakon dugog razmišljanja veli: ostane 10 krajcara. Kako to? Ja kupim još šibica i papirića. ${ }^{179}$

177 Žirovčić, 1904: 56.

$178 \mathrm{KPV}, 1879.246$.

179 Žirovčić, 1906: 221. 
U slučajevima citiranima u Liječničkom vjesniku navedeno je obilje ovakvih zadataka.neuspjeh pri rješavanju ovakvih zadataka najčešće se smatrao simptomom duševne zaostalosti ili oboljenja. Pritom se nije uzimala u obzir činjenica da su takvi zadaci prikladniji i razumljiviji obrazovanim ljudima, dapače, iz gornjeg primjera vidimo da Gjuro uopće ne razumije očekivanja koja liječnik postavlja pred njega ovim matematičkim problemom: on uporno govori iz vlastitog iskustva jer je dosadašnji razgovor bio o njegovim iskustvima. Dapače on ne pokazuje nemoć da riješi matematički račun, već ga kontekstualizira u vlastito konkretno iskustvo. Žirovčić na temelju njegove nemogućnosti, zaključuje da je Gjuro „mladić vrlo ograničenih umnih sposobnosti”180

Osim provjere herediteta, životnih navika i duševnih sposobnosti, liječnici nekad pokazuju detaljan interes za poneke simptome duševnih bolesti, naročito za sadržaj halucinacija i deluzija. Pritom s osobitom pažnjom bilježe sve što, prema onodobnim konvencijama može upućivati na abnormalnu seksualnost, te na onaj oblik deluzija koje bi današnja psihijatrija nazvala bizarnim deluzijama. Tako u slučaju kranjskog sluge Antona P. koji je 30. listopada 1910. doveden u Stenjevec s dijagnozom „manije” Žirovčić pokazuje izražen interes za njegovo vjerovanje u „mure” (vjerojatno dijalektalni oblik „more” čestog čudovišta u narodnim predajama). U povijesti bolesti nalazimo sljedeći zapis:

„Pripovieda da se kod kuće napio rakije i onda smeo. On se je htio liečiti jer ga je njeka „mura sisala”. Najprije je htio muru oterati tako da na molitveniku spava, pa je uzeo molitvenik pod jastuk, što je i pomoglo, nu onda je oćutio boli u želudcu, uzeo je paprike, a nato se i dobro napio rakije. Onako zmotan otišao je u trafiku da kupi duhana i to onoga za 4 novčića „,crveni neki iz Srbije u Mađarskoj i koji je određen za županiju zagrebačku.” To se je ljudima činilo smešno, pa su ga prijavili...Šta je to „muria?” To ni ja neznam, ali ima više ljudi koje murija (sic) sisa nu oni se toga ne mogu otresti, ali ja sam ipak došal na to kak se more oterati,”... ,Što je dakle sa murom?” „Neće ništa da otom danas razgovara već onako opet smeteno peć gledati”... „Obećao da će sve napisati o onoj muri” ...,Predao pismo gdje opisuje svoju bolest o „muri”" 181

180 Ibid.

$181 \mathrm{KPV}, 1911: 7947$. 
Nakon početnog pregleda u pisarni štićenik biva upućen na jedan od zavodskih odjela. Sama politika odjela u zavodu je izrazito bitna jer se pomoću njih razvrstavalo štićenike u strogo definirane kategorije. Svaka kategorija imala je određeno mjesto u arhitektonskom rasporedu zavoda, vlastiti set pravila, te vlastite uvjete života. Te kategorije određivale su vrstu i blizinu kontrole te način primjene psihijatrijske moći na tijela pacijenata raspoređena u prostor zavoda: možemo čak reći da su tijela štićenika kao objekti disciplinskog nadzora bila ukalupljivana u arhitekturu zavoda koja je u velikoj mjeri služila uspostavljanju i perpetuiranju kontrole nad tijelima.

\subsubsection{Sustav odjela u Zavodu za umobolne u Stenjevcu i uvjeti života}

Kao što je spomenuto u poglavlju o izgradnji zavoda, Zavod za umobolne u Stenjevcu u svom je nacrtu zamišljen kao prijelazni tip između Kirkbrideovog linearnog i paviljonskog plana. Oba plana odražavala su tipičnu onodobnu paradigmu o povoljnom terapeutskom utjecaju pažljivo strukturiranog prostora zavoda. U Kirkbrideovom planu „terapeutske arhitekture” odjeli su imali ključno mjesto: pacijenti koji su povoljno reagirali na režim institucije bili bi premještani na odjele na kojima su uvjeti života bili bolji, a najbolji su bili rezervirani za one koji su se ponašali u skladu s pravilima. Tako su u zavodima široko shvaćene dijagnoze (u slučaju Stenjevca „mirni”, „siloviti”, „nečisti” itd.) uzurpirale identitet štićenika, a uniformnost kategorija je apsorbirala individualnost ${ }^{182}$ i medicinsku praksu brige o pacijentima kao pojedinačnim slučajevima. Primjer odjela najbolje pokazuje kako su devetnaestoljetni zavodi za umobolne služili kao svojevrsne heterotopije biomoći. Biomoć se ovdje uzima u smislu kako ju je definirao Michel Foucault, kao kategorija upravljanja koja dijeli populaciju na uniformne kategorije čijim se tijelima upravlja preko specifičnih disciplinarnih aparatusa. ${ }^{183} \mathrm{~S}$ obzirom na česte epidemije koje su pogađale Stenjevec, svrstavanje na određeni odjel moglo je doslovno značiti razliku između života i smrti.

U povijestima bolesti, odjeli su designirani brojem, i ponekad popratnim slovom prema čemu se može zaključiti da ih je bilo dvanaest. Iako nigdje nije točno navedeno koji od odjela je čemu služio, zna se da su muškarci bili smješteni na zapadnoj strani bolnice, a žene na istočnoj. U 182 De Young, 2015: 485-486.

183 Foucault, 2003: 242. 
glavnoj zgradi, u istočnom su krilu bile „mirne“ i ,polumirne“ žene, a u zapadnom „mirni“ i „polumirni“ muškarci ${ }^{184}$. U udaljenijim paviljonima smještenim sjeverno od glavne zgrade, nalazile su se „nečiste” (inkontinentne) i „,silovite” žene i „nečisti” i „siloviti” muškarci ${ }^{185}$, a istočno od glavne zgrade izgrađena je 1895 „nemoćnica” za one bolesnike koji su bili teško bolesni ili invalidni ${ }^{186}$. Kasnijim nadogradnjama, sjeverno od glavne zgrade su bila izrađena još dva „radnička” paviljona u kojima su bili smješteni bolesnici koji su radom doprinosili gospodarstvu bolnice. ${ }^{187}$ Budući da su stanovi ravnatelja, liječnika i glavne sestre, bili smješteni u glavnoj zgradi, kao i većina prostora namijenjenih slobodnom vremenu bolesnika, bolesnici koji su bili klasificirani kao „mirni“ su imali bolji pristup liječničkoj skrbi i priliku za druženje s drugim bolesnicima, dok su ,siloviti” i ,nečisti” smješteni u najdaljem dijelu bolnice, udaljeni od ceste, glavne zgrade bili osuđeni na svojevrsnu izolaciju. Osim poštivanja zavodskih pravila i higijene, čini se da je i socijalni status štićenika imao utjecaj na raspored odjela. Plan glavne zgrade tako predviđa zasebne sobe za bolesnike „klasiste“ koji sami snose troškove liječenja ${ }^{188}$, a ravnatelj dr. Ivo Žirovčić je u jednom članku nazvao odjel IVa, odjelom ,za mirne bolestnike naobraženijih slojeva." ${ }^{189}$ U izvorima postoje brojni primjeri korištenja premještanja s odjela na odjel radi discipliniranja štićenika. Štićenica Lena Glueck, je tako „Sbog ogovaranja, laganja i zadirkivanja, nesloge premještena s V na I razdjel" ${ }^{190}$. Također, nekad izvor implicira da je premještanje na bolji odjel rezultiralo promjenom stanja štićenika na bolje, a ne obrnuto. Povijest bolesti švelje Marice P. navodi da je ista premještena s odjela III na odjel II, nakon čega se počela ponašati ,čisto i pametno"

Sami štićenici često traže da ih se premjesti na odjele na kojima su uvjeti života bolji. Razdjeli za „nečiste” i „silovite” često su bili prenapučeni jer su zgrade u kojima su se nalazili bile manje, miris je bio neugodan, vjerojatno su bili slabije grijani i štićenici su bili izloženi napadima bolesnika koji su bili u uznemirenom stanju ili su se iz drugih razloga ponašali agresivno.

184 KPV, "Izgradnja i razvoj bolnice", 2014: 28-29.

185 Ibid: 34.

186 Ibid: 32.

187 Ibid: 36.

188 Ibid: 29.

189 Žirovčić, 1905:122.

$190 \mathrm{KPV}, 1881: 265$.

$191 \mathrm{KPV}, 1880: 206$. 
Štićenik Jakob F. je, prema dijagnozi postavljenoj u Stenjevcu, bolovao od progresivne paralize, bolesti koja je često rezultirala nasilnim ispadima. Smješten na odjel za „silovite“, uspio je u dva dana dvaput ozlijediti istog štićenika, prvi put ga udarivši vrčem po glavi i „razbivši mu glavu na četiri strane“. ${ }^{192}$ Dva dana kasnije ga je „udario peharom,” te mu zadao „tri velike rane na glavi." ${ }^{193}$ Bolesnica Filomena B., smještena na prvi odjel, žalila se i tražila premještaj „,na drugi razdjel, da joj se dade bolje jelo. Tuži se da ju čapaju, da će joj sve vlasi potrgati." ${ }^{194}$

Zahvaljujući prenapučenosti odjela za „silovite” i „nečiste” kvaliteta života bila je niska, a smrtnost na tim odjelima je bila neuobičajeno visoka. Na odjel za „nečiste” su često smještani štićenici koji su bolovali od dizenterije ili tuberkoloze. Zaraze su širile brzo i bile su primarni uzrok pomora bolesnika. Zavod je bio sagrađen na močvarnom tlu i „,...po svojem položaju niže od nadolazećeg potoka Vrapčaka, gušio (se) u nečisti i smradu jer otoka iz zavoda nije bilo" ${ }^{195}$. Ogroman broj oboljelih od zaraznih bolesti, osobito tuberkoloze, naveo je 1910. poznatog liječnika Frana Oriovčanina Gundruma da kritizira ravnateljstvo zavoda i u članku upita koliko se umrlih od tuberkuloze zarazilo u samom zavodu ${ }^{196}$.

Problemi kanalizacije i opskrbe pitkom vodom bili su prisutni od same izgradnje zavoda. Zahodske su jame bile izgrađene od opeke i propuštale su, a odvodni kanali vodili su u otvorenu, jamu ispred zavoda koja je bila obrasla raslinjem i užasno je zaudarala. Svi apeli ravnatelja zavoda da se taj ogromni higijenski problem riješi, bili su ignorirani. Situacija je, donekle poboljšana 1900 godine kada je iskopan kanal. koji je trebao odvoditi kanalizaciju u Savu. No budući da je jama bila smještena niže od korita Save, za napajanje kanala bila je potrebna pumpa koja se često kvarila. Usto, kanal je bio otvoren i prolazio je kroz cijeli zavod, šireći smrad i zaraze što je 1901 godine uzrokovalo veliku epidemiju tifusa i dizenterije tijekom koje je umrlo

192 KPV, 1880: 32.

193 Ibid.

194 KPV, 1895: 2657.

195 Herceg, 1933: 11.

196 Gundrum, 1910: 152.

80 
230 štićenika. ${ }^{197}$ Velike i smrtonosne epidemije tifusa i crnih boginja pogodile su zavod i 1916. godine, i bile su znatno pogoršane neadekvatnom prehranom štićenika uslijed ratnih uvjeta. ${ }^{198}$

Opskrba vodom vršena je pomoću deset metara dubokog bunara iskopanog u blizini glavne zgrade. Voda se iz njega, pomoću pumpi, izvlačila u spremnik koji se nalazio na tavanu glavne zgrade, odakle je vodovodnim cijevima raspoređivan po zavodu. S obzirom na činjenicu da je kanalizacija bila otvorena, a bunar plitak, voda je često bila onečišćena, a ljeti je bunar znao i presušiti, ostavljajući zavod bez pitke vode. ${ }^{199}$ Dovođenje vode u odjele udaljene od glavne zgrade otvorenim vodovodnim cijevima moglo je postati opasno za štićenike. Zabilježena su barem dva slučaja u kojima su štićenici umrli od ozbiljnih opeklina prilikom kupelji jer se dovod hladne vode zimi zaledio što prezaposleno bolničko osoblje nije primijetilo. Žirovčić spominje slučaj štićenika oboljelog od progresivne paralize koje, je vruća voda oparila kožu i koji je nekoliko sati nakon toga umro ${ }^{200}$, a identičan incident dogodio se i Katarini K., podvornikovoj supruzi koja je 1914. umrla u zavodu od posljedica opeklina: „Jutros ju je bolničarka metnula u kupelji otvoriv obje pipe, kao obično, od vrućeg i mrzlog vodovoda, a nije opazila da mrzla voda neteče (ona se je od velike studeni vani smrzla) i opržila joj obje noge.)"201

Osim vodovoda i kanalizacije, problematični su bili i ventilacija i zagrijavanje zavoda. Po jednom od ranih izvještaja za zagrijavanje i ventilaciju bila je zadužena bečka tvrtka Holdorrf i Bruckner. Po nalazu prve inspekcije prostorije u glavnoj zgradi i zgradama za „silovite“ i „nečiste“ su bile ugrijane na 17-18 stupnjeva po Reaumurovoj skali (oko 25 stupnjeva celzijevih) ${ }^{202}$, a zrak se mijenjao jedan i pol puta po satu. Prema istom izvješću, zrak se u prostorijama za „nečiste” i „silovite" mijenjao do sedam puta u satu. Uz to navedeno je da se glavna zgrada grijala „kaloriferima osebujne konštrukcije.” a ostale zgrade „pećima nasipnjačama”. ${ }^{203}$ Iako ovaj

197 Herceg, 1933: 11.

198 Ibid: $12-13$.

199 Ibid: $11-12$.

200 Žirovčič, 1896b: 282.

$201 \mathrm{KPV}, 1914: 8505$.

202 Činjenica da zavod još krajem devetnaestog stoljeća koristi zastarjelu Reaumurovu skalu vjerojatno upućuje na stare mjerne instrumente.

203 LV, 1880: 29-30.

81 
izvještaj zaključuje da je stanje grijanja i ventilacije u zavodu zadovoljavajuće, povijesti bolesti bilježe brojne pritužbe štićenika. Jana B. seljakinja iz Sušinovca, koja je 1879. dovezena u Stenjevec s ludničkog odjela bolnice Milosrdne braće opetovano je tražila da ju vrate u „Zagreb u špital” jer ovdje ne zrače ${ }^{204}$. Osobito je zanimljiv slučaj težaka Miška M. koji je u zimi 1880. odlučio provaliti u zavodsku mrtvačnicu kako bi skinuo odjeću s trupla jednog od štićenika jer mu je bilo suviše hladno. ${ }^{205}$ Problem ventilacije i grijanja u zavodu vjerojatno dijelom vuče porijeklo iz osebujne arhitekture, sa sobama raspoređenim samo duž jedne strane hodnika kako bi se bolničarima i liječnicima olakšao nadzor štićenika i otežao eventualan bijeg. Iz tih razloga je i broj vrata i prozora u zavodima za umobolne bio daleko manji od onog u ostalim bolnicama. ${ }^{206}$ Teškoćama s ventilacijom pridonio je i izbor zemljišta.Iako je praksa devetnaestog stoljeća nalagala da se bolnice grade na ugodnim lokacijama koje osiguravaju cirkulaciju svježeg zraka i daleko su od zagađenih gradova ${ }^{207}$, stenjevački je zavod bio izgrađen na niskom, isušenom močvarnom tlu (prije izgradnje zavoda tamo je bio ribnjak u kojem su se lovile divlje patke) ${ }^{208}$, bez mogućnosti učinkovitog odvoda otpadnih voda. Uz to, tlo je vjerojatno bilo vlažno što je zavod činilo izrazito energetski neučinkovitim.

Visoka smrtnost pacijenata u Stenjevcu ostala je zabrinjavajuća kroz cijelo devetnaesto stoljeće, rijetko padajući ispod 10\% a dosežući preko 25\% u godinama Prvog svjetskog rata (vidi grafove 4 i 5). U brojnim povijestima bolesti navodi se kako je rodbina štićenika priložila novac za brzojave koje je ravnatelj trebao odaslati u slučaju njegove ili njezine smrti. ${ }^{209}$ Takva praksa postaje sve učestalija kako vrijeme odmiče i svjedoči o činjenici da se Zavod za umobolne u Stenjevcu sve više počelo smatrati institucijom iz koje se bolesnici rijetko vraćaju živi. Visoka smrtnost je vjerojatno utjecala na sve veći terapeutski pesimizam stenjevačkih psihijatara koji se kako vrijeme odmiče sve više suočavaju s neuspjesima „moral treatmenta”. Već 1892. u jednom

204 KPV, 1879: 48.

$205 \mathrm{KPV}, 1880: 219$.

206 Yanni,2007: 32.

207 Ibid: 31.

208 Herceg, 1933:7.

209 KPV,1914: 8715.

82 
predavanju dugogodišnjeg zavodskog kućnog liječnika Dragutina Forenbachera odjekuje pesimizam europskih psihijatara koji sve češće govore o degeneraciji zapadne civilizacije:

„Tisućljetni hrast koji je prkosio stoljetnim vjetrovom i olujam počinje klonuti... ...Dok je svijet bio u muževnoj dobi, nije se svačega bojao, jer mu ustroj bijaše čvršći i žilaviji. Sad smo marasmični, odtud i snaga i jakost svakog upliva na nas." ${ }^{210}$

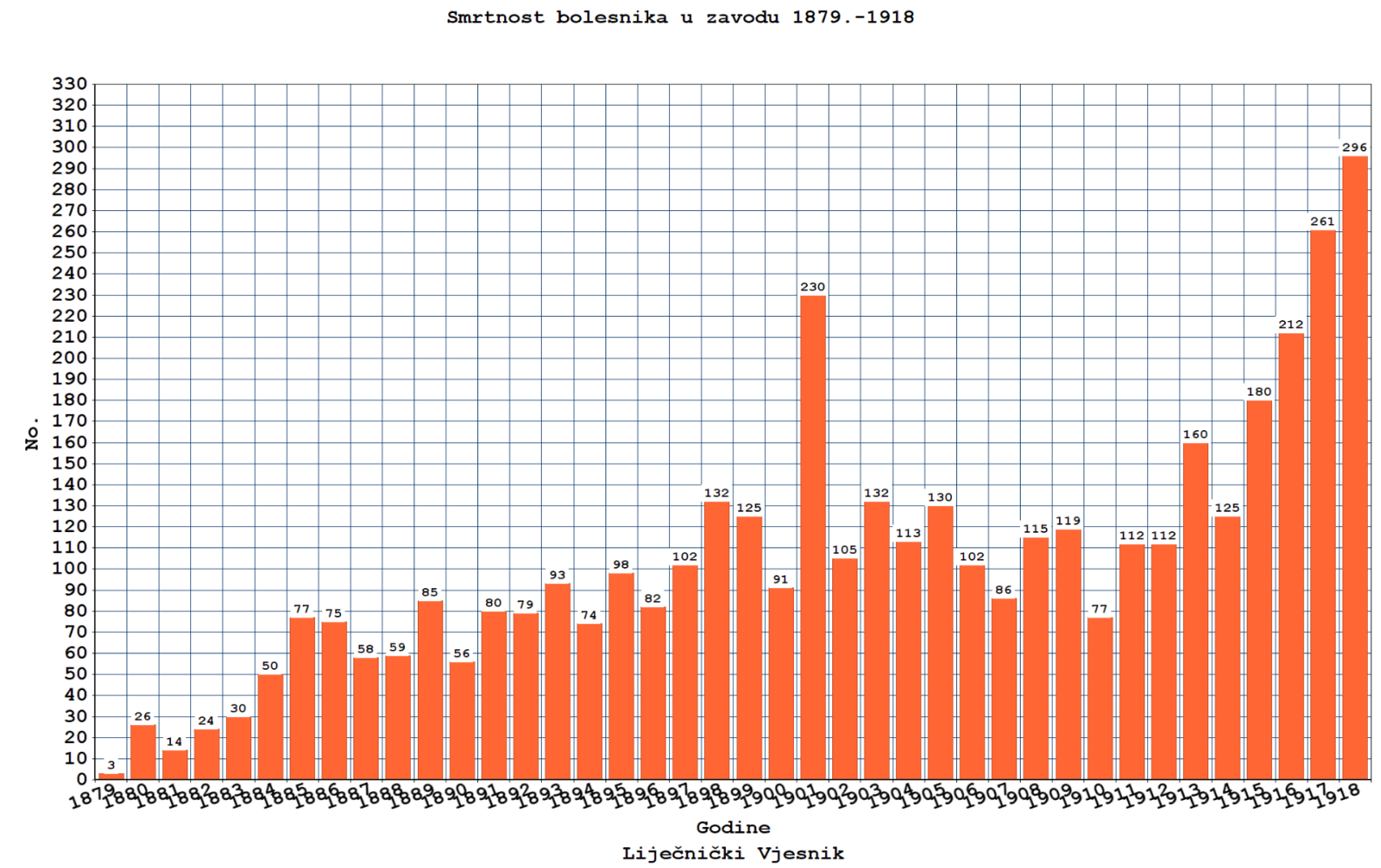

Graf 4 (smrtnost bolesnika u zavodu 1879.-1918.) 211

210 Forenbacher, 1892: 6.

211 Kuljženko, 1931: 675. 


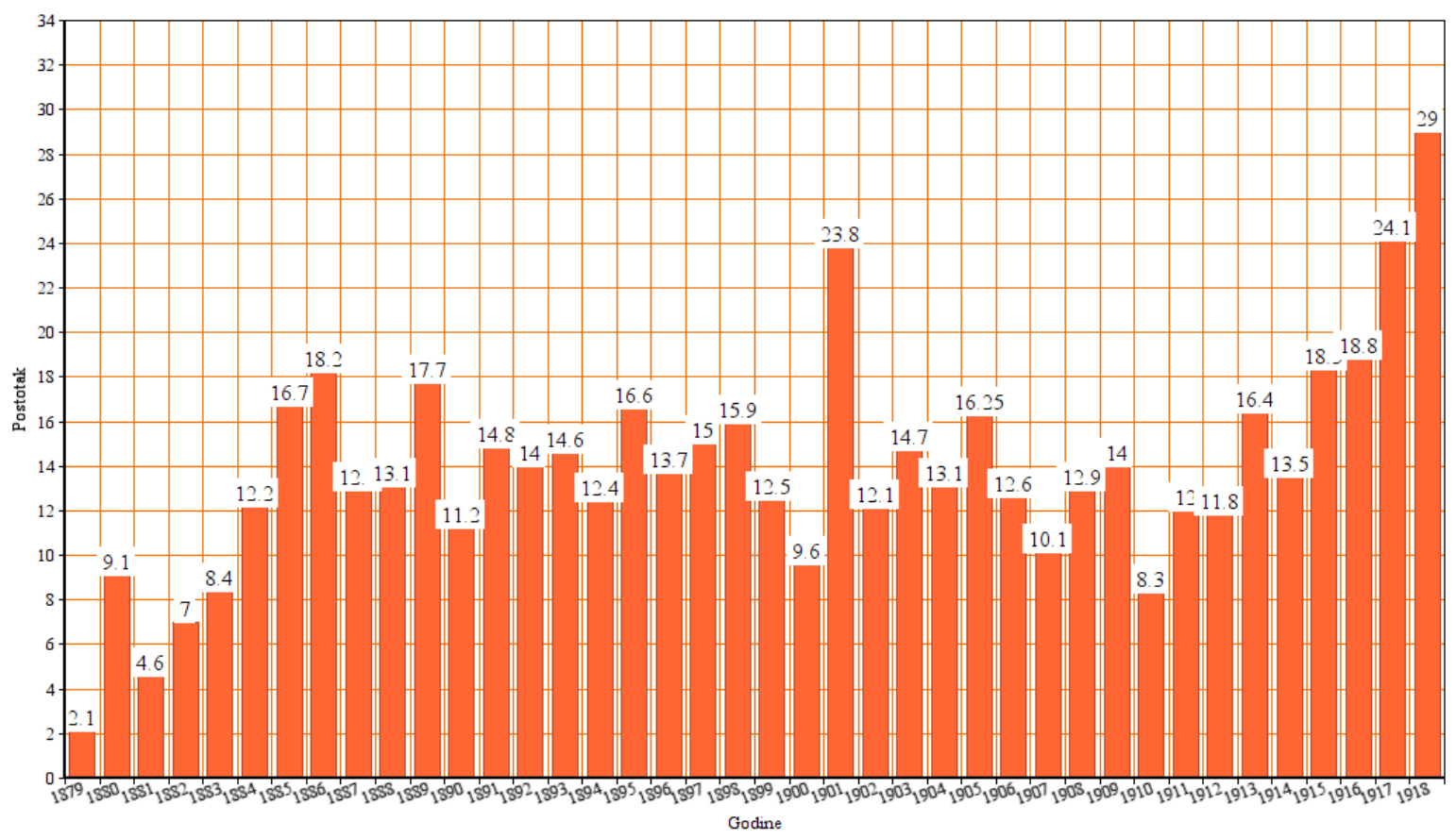

Graf 5 : Smrtnost bolesnika izražena u postocima ${ }^{212}$

212 Ibid. 
Broj bolesnika u zavodu 1879.-1918

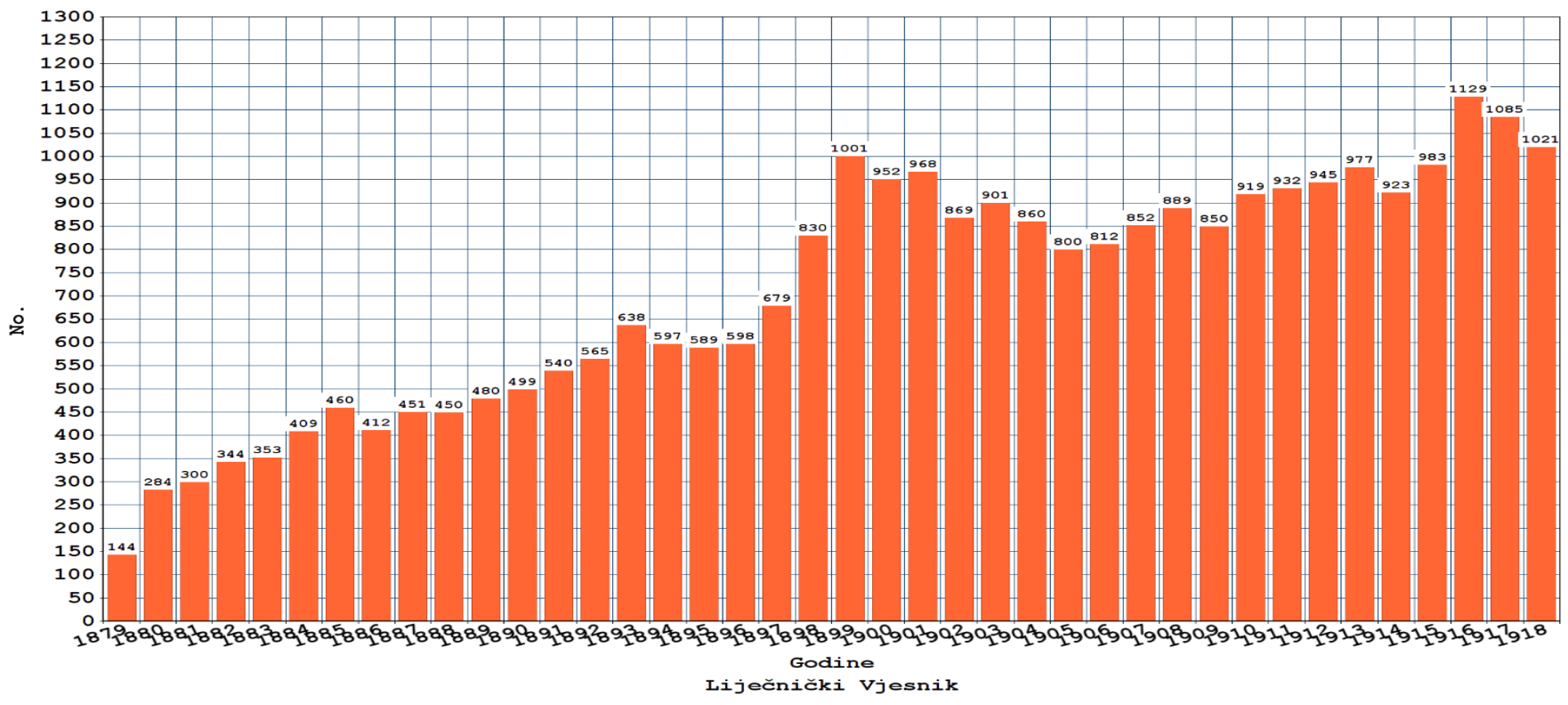

Graf: 6 Broj bolesnika u zavodu 1879.-1918. ${ }^{213}$

213 Ibid. 


\subsection{Terapeutske metode i terapijski pesimizam}

Nakon uspona „moral treatmenta” sredinom devetnaestog stoljeća, druga polovica stoljeća rezultirala je svojevremenim terapeutskim pesimizmom u liječenju duševnih bolesti. Teze o postepenoj degeneraciji rase koje su iznijeli Morel i kasnije Maudsley, bile su rezultat rasta broja duševnih bolesnika u zavodima diljem Europe. Taj rast je bio uvjetovan brojnim faktorima, ali ono što je bilo presudno za gubitak vjere u izlječivost duševnih oboljenja bio je velik broj recidivista- ljudi koji su jednom bili otpušteni iz zavoda kao izliječeni, da bi se opet vratili u zavod nekoliko godina kasnije. Ipak, ravnatelji stenjevačkog zavoda u proučavanom razdoblju inzistiraju na terapeutskoj ulozi zavoda. Žirovčić u svom članku pod naslovom: „O postupku s duševno bolestnimi” koji je izašao u Liječničkom vjesniku 1897.u dva dijela vrlo decidirano ističe:,,Govoreći o liečenju duševno bolestnik, moramo si ponajprije staviti načelno pitanje: može li se u obće duševni bolestnik izliečiti, ili još bolje, može li duševno oboljeli čovjek ozdraviti?Na takvo pitanje možemo odlučno odgovoriti: da."214

U Stenjevcu su se uistinu koristile brojne terapijske metode, neke od njih iz razloga što su tadašnji psihijatri zbilja vjerovali u njihovu učinkovitost, a neke su bile korištene isključivo kako bi disciplinirale i olakšale nadzor bolesnika. Iz onodobnih izvora možemo izlučiti sljedeće metode liječenja:
a) odmor u krevetu
b) radna terapija
c) „fiksiranje” i ostali oblici autoritarnog podvrgavanja volji liječnika
d) sredstva za sputavanje i osamljivanje
e) rana psihofarmakološka terapija
f) hipnotizam
g) prehrana
h) hidroterapija

214 Žirovčić, 1897: 320. 


\subsubsection{Odmor u krevetu}

Terapiju krevetom u europsku su psihijatriju uveli njemački psihijatri. Sredinom devetnaestog stoljeća izrazitim zagovornikom ove terapije bio je Wilhelm Griesinger, ${ }^{215}$ njemački liječnik i sveučilišni profesor, kojeg su stenjevački psihijatri često citirali. S obzirom na činjenicu da su stenjevački psihijatri bili obrazovani u austrijskim i njemačkim zavodima i na Griesingerov utjecaj, odmor u krevetu je bio jedno od glavnih terapeutskih sredstava koje se primjenjivalo u Stenjevcu. Držanje bolesnika u krevetima je u zavodima devetnaestog stoljeća imalo trostruku svrhu. Prva svrha bila je povezana s poznatom psihijatrijskom paradigmom o ,prenapregnutosti živčanog sustava" kao uzroku duševne bolesti. Prema tome bilo je važno izolirati štićenika od vanjskih podražaja kako bi mu se um odmorio. ${ }^{216}$ Slično rezonira i Žirovčić koji tvrdi da i sama ludnica, zapravo, kod duševno oboljelih igra onu ulogu koju kod tjelesno oboljelih igra bolesnička postelja. ${ }^{217}$ Također, Žirovčić je smatrao da je ležanje u krevetu za duševno oboljele velika blagodat i da melankolični, histerični i neurastenični bolesnici vole ležati u krevetu dok manične i nemirne treba na to privoliti silom, te je propisivao da je korisno da i nemiran bolesnik leži u krevetu makar ga tamo trebalo i fizički zadržati. ${ }^{218}$ Drugi razlog zbog kojeg se pribjegavalo smještanju bolesnika u krevet bilo je olakšavanje nadzora. Liječnik je mogao pratiti ponašanje, tjelesnu temperaturu i puls ${ }^{219}$, a štićeniku je u geografiji zavoda bilo fiksirano lako pamtljivo mjesto na kojem je provodio većinu vremena, što je olakšavalo ograničavanje kretanja i sprječavalo mogućnost bijega. Pored toga, svrha propisivanja ostanka u krevetu bila je i u tome da se što vjernije pokuša replicirati kontekst bolnice i odnosi koji su vladali u istoj. Ako je štićeniku propisano mirovanje u krevetu, onda postaje očito da je on uistinu bolestan, što ga navodi da lakše prihvati liječnikov autoritet. ${ }^{220}$

U Stenjevcu, štićenike bi se smještalo u krevete odmah po dolasku na određeni odjel. Često bi u krevetu odležali po nekoliko dana ${ }^{221}$ prije nego što bi ih se pustilo u šetnju ili na rad. Odbijanje

215 De Young, 2015: 19.

216 Ibid, 20.

217 Žirovčić, 1897: 322.

218 Ibid, 355.

219 De Young, 2015: 19.

220 Ibid.

$221 \mathrm{KPV}, 1911: 6295$.

87 
ležanja u krevetu shvaćalo se kao znak agitacije i kao simptom bolesti pa su se natuknice poput „,izlazi više puta iz kreveta"222 u povijestima bolesti pojavljivale kako bi potkrijepile dijagnozu duševne bolesti. No jednako tako se kao simptom navodi odbijanje ustajanja iz kreveta, što je u skladu s vjerovanjem da bi pretjerivanje u upotrebi „krevetne terapije” moglo rezultirati razvijanjem takozvanog „poriva za ležanjem” tj. bolesnikovog odbijanja da ikad napusti krevet $^{223}$. Prisilno smještanje u krevet se koristilo jedino kod bolesnika koji su bili agitirani, dok se dugotrajno ostajanje deprimiranih bolesnika u krevetu nastojali obeshrabriti.

\subsubsection{Radna terapija}

Stenjevački zavod je otpočetka predviđao korištenje bolesnika za rad, ponajviše za rad u poljoprivredi. Prilikom gradnje dvanaest i pol jutara zavodskog zemljišta je odvojeno za potrebe zavodskog poljodjelstva. ${ }^{224}$ Radni kapaciteti zavoda uvelike su prošireni za vrijeme uprave ravnatelja Ive Žirovčića kad je zavodskom gospodarstvu pridodano deset krava, četiri konja i pedeset svinja, a osnovane su krojačka, postolarska, stolarska i tapetarska radionica. U svim tim radionicama su rad bolesnika nadzirali od zavoda plaćeni strukovni namještenici. ${ }^{225}$

U psihijatrijskoj literaturi devetnaestog stoljeća, naročito u zapisima sljedbenika „moral treatment" terapije ima puno primjera u kojima se ističe povoljan utjecaj fizičkog rada na psihu, no takav je rad imao i svoje veoma opipljivo ekonomsko opravdanje. Rad štićenika činio je zavod djelomično samoodrživim i manje ovisnim o državnim donacijama. Takav sentiment odražava i Žirovčić kad kaže da je primarna svrha rada „da se bolesnici čine donekle korisnima i da doprinose smanjenju troškova zavoda” te da „,ne padaju na teret obitelji niti državi." 226 Jedan od kriterija potrebnih da bi se štićenika smatralo izliječenim bila je spremnost istoga da radi na poljoprivrednom imanju ili u jednoj od radionica. Muškarci su naravno češće bili zaduženi za

poljoprivredni rad, dok su žene uglavnom radile u krojačkoj radionici. Osim tih terapijskih poslova, štićenici su također pomagali nositi ugljen za loženje u podrum zavoda, a za jednu od

222 KPV, 1911: 8067.

223 De Young, 2015: 21.

224 Herceg, 1933: 12.

225 Ibid.

226 Žirovčić, 1897: 359.

88 
štićenica je navedeno kako je barem tri godine radila kao sluškinja u stanu ravnatelja Šimse, usprkos nekom sukobu kojeg je imala s ravnateljevom suprugom. ${ }^{227}$

Sami štićenici nisu uvijek shvaćali prirodu rada u zavodu. Neki od njih su tražili da budu što prije pušteni na rad kako bi se osjećali korisnima. No mnogi od njih pokazuju otvoren otpor radu. Mara G. seljakinja iz Hercegovca je tako bolničarima rekla da ne želi ovdje raditi već „da je se pusti kući pa će onda kući raditi”"228.

Postolarski pomoćnik Tomo G. koji je u Stenjevac doveden 1907. s dijagnozom „Paranoia confusa" također nije shvaćao terapijski karakter rada. Čim je prispio u zavod tražio je da ga se pusti kako bi izvan zavoda mogao „sebi zanatom steći kruh.” ${ }^{229}$ Nakon što je počeo raditi u zavodskoj postolarskoj radionici počeo se tužiti kako „ne zna računa i nema svoje knjige”230. Nakon toga često pokušava pobjeći i napada bolničare tražeći da mu se plati za rad koji je obavio u zavodu ili da ga se pusti da nastavi pošteno zarađivati kao postolarski pomoćnik.

Radna terapija je u zavodu korištena dvadesetom stoljeća, a primjenjuje se i danas. Zanimljivo je da je o korištenu rada u terapijske svrhe malo napisano u literaturi koja se bavi poviješću psihijatrije, dok je isti imao bitnu ulogu u svakodnevici zavoda te je činio jednu od osnovnih terapijskih praksi „moral treatmenta”. Povezanost duševnog zdravlja sa spremnošću za rad zapravo odražava ulogu koji je građanski moral imao u diskursu devetnaestoljetne psihijatrije. U svjetonazoru građanske klase visoko su vrednovani rad i produktivnost. Zavodi za umobolne nam mogu, sa svojim radionicama, poljoprivrednim gospodarstvima i detaljno vođenim financijskim knjigama, poslužiti kao sjajan primjer povezanosti psihijatrijske skrbi i razvijajućeg kapitalizma te načina na koji je radna etika građanstva utjecala na medicinsko poimanje mentalnog zdravlja $\mathrm{i}$ prirode psihičkih poremećaja.

227 KPV, 1911: 3401.

$228 \mathrm{KPV}, 1895: 2216$.

229 KPV, 1911: 6905.

230 Ibid. 


\subsection{3. „Fiksiranje” $i$ ostali oblici autoritarnog podvrgavanja volji liječnika}

Ako slijedimo Foucaultovu paradigmu koja odnos moći gleda kao na mehanizam koji smješta tijela $u$ prostor, oblikuje ih $\mathrm{i}$ definira onda u mreži odnosa moći koji čine psihijatriju najistaknutiju ulogu ima tijelo liječnika. Upravo je liječnik onaj nadzornik na vrhu Benthamova panoptikona koji može kapilarno proširiti svoju moć čitavim zavodom i kao produžetak čije moći zapravo zavod funkcionira. Posluživši se tekstom francuskom ,moral treatment” psihijatra Jean Ettienea Dominiquea Esquirola iz 1818 Foucault je ovako opisao pojavu liječnika:

„Uopće, jedan od prvih uvjeta uspjeha u našoj profesiji je odlična, to jest muževna i plemenita pojava- ista je neophodna kako bi se impresioniralo luđake. Tamna kosa, ili kosa osijedila od godina, žive oči, udovi i prsa koji odaju snagu i zdravlja, istaknute crte lice i jak i izražajan glas su prizori koji u pravilu imaju jak efekt na pojedince koji misle da su superiorni svima ostalima“. 231 "

Liječnik prvenstveno funkcionira kao impozantno tijelo koje je odraz autoriteta i moći. Naravno, ako za trenutak stavimo Foucaultov „body politics” sa strane vidjet ćemo da je moć liječnika (a osobito ravnatelja zavoda) prisutna i na mnoge druge načine. Upravo ravnatelj vodi brigu o administraciji zavoda, zapošljava i otpušta osoblje, odjeli s pacijentima koji pokazuju najviše poštovanja za zavodske propise su mu fizički najbliži te kao autoritet za teme duševnog zdravlja i ludila zapravo oblikuje društveni diskurs o psihi. No u direktnom odnosu s pacijentom, zbog razlike u obrazovanju i miljeu mora premostiti određen kulturni jaz. Taj jaz proizlazi i iz emotivnog stanja pacijenta i njegovog stanja svijesti. Liječnik mora funkcionirati kao simbol autoriteta, slika koja će bez mnogo riječi i argumentacije pokazati kako je upravo u njoj izvor psihijatrijske moći. Takav pristup se smatrao nužnim jer su u svojoj nemoći i nedostatku razumijevanja duševni bolesnici bili dugo smatrani „nepotpunim ljudima”, ili kako ih je Ivo Žirovčić to jednom opisao ,individualnostima manje vrijednosti” ${ }^{232}$ te je prema njima trebalo postupati kao s djecom. I Eleaine Showalter je također, u analogiji koja povezuje viktorijansku ludnicu s obiteljskim domom ravnatelju ludnice dala ulogu supruga i oca, a štićenicima ulogu djece koju strog, ali pravedan otac odgaja i vraća na pravi put. U opisima zavoda iz

231 Foucault, 2006: 4.

232 Žirovčić, 1905a: 280.

90 
viktorijanskog perioda isti se često opisuju kao škole ili obdaništa ${ }^{233}$ Iz toga možemo zaključiti da je uspješnost psihijatrijskog liječenja ovisila o stalnom potvrđivanju liječnikova autoriteta nad pacijentima. Jedan od najdirektnijih i „najtjelesnijih” načina reaktualizacije tog specifičnog odnosa moći bilo je takozvano „fiksiranje”.

Fiksiranje je zapravo čin kojim liječnik „hvata” štićenikov pogled i dugotrajnim i autoritativnim gledanjem utvrđuje svoju moć nad pacijentom. Upravo je fiksiranje ključni instrument Foucaltovog „kliničkog zora” koji razdvaja pacijentovo tijelo od njegove individualnosti i pretvara pacijenta u objekt medicinske dijagnoze. ${ }^{234} \mathrm{Za}$ potpunu aktualizaciju psihijatrovog autoriteta bitno je pacijentovo pokoravanje kliničkom zoru - pacijent mora prihvatiti objektifikaciju i činjenicu da će njegovo tijelo za liječnike postati tek skup simptoma, svojevrsni tekst bolesti preko, kojeg će se narativ njegovih kretnji, riječi i izraza lica prevoditi u medicinski diskurs o duševnoj bolesti. Fiksiranje je prema tome, primjena kliničkog pogleda kojim se primarno fiksira pacijentov položaj u odnosu liječnik-pacijent. Pacijent postaje onaj kojeg se promatra, kojeg se ima pravo promatrati i sve što se sa štićenikom dogodi od dolaska u zavod do njegovog izlaska iz zavoda bit će obilježeno tim promatranjem. Liječnik postaje onaj kojem pacijent mora predati pravo na tumačenje njegovih postupaka. Pacijentova perspektiva postaje bitna za daljnji razvoj njegove bolesti jedino ako ju liječnikov autoritet odobri, a tada jedino kao simptom ludila. Duševna bolest tako postaje ne samo stanje pacijenta već i njegov identitet.

Fiksiranje se u člancima stenjevačkih liječnika spominje zajedno s pojmom sugestije. Pojam sugestije za psihijatre predstavlja nametanje vlastite moći pacijentu. To je epistemička moć je da se tumači stvarnost: pacijent je bolestan ne zbog eventualne nelagode koju sam osjeća već upravo zato što liječnik vidi bolest u njegovom tijelu. Prihvaćanje te sugestije bolesti, prihvaćanje vlastitih stavova i osjećaja kao morbidnih prvi je korak prema ozdravljenju. Pritom valja „sugestiju” razlikovati od suvremenog pojma „talking cure” prisutnog u psihoterapiji jer su psihijatri devetnaestog stoljeća sami veoma rezolutni u odbacivanju ideje bilo kakvog govora s psihički oboljelima kao s razumnim bićima. Žirovčić tako piše da ,nastojiš li ludu čovjeku iz 
glave izbiti njegove tlapnje i lude misli, na krivom si putu, nikad nećeš uspjeti”, ${ }^{235}$ Žirovčić kao glavno sredstvo psihijatrijskog liječenja, u humanističkoj maniri, navodi „duševni postupak” pribjegavši sljedećoj analogiji kako bi istakao „,roditeljsku” ulogu psihijatra u zavodu:,,...kao što odgojitelj duševnim utjecajem djeluje na razvijajuću se dušu dojenčeta, tako će i psychiater djelovati na bolestnu dušu luđaka."236

Pri fiksiranju pacijenta izrazito se važnom smatrala uspostava očnog kontakta. O važnosti pogleda kao instrumenta uspostavljanja dominacije govori i osnivač moderne psihijatrije Pinel koji je opisao Willisa, liječnika kralja Georgea II kao čovjeka čiji je pogled dopirao u samo srce pacijenta i koji je uz pomoć tog pogleda samog mogao uspostaviti autoritet nad pacijentom. ${ }^{237}$ Spremnost štićenika da uspostavi kontakt pogledom i tako bude ,fiksiran” u svoju ulogu tijela izloženog kliničkom zoru ima važnu ulogu u povijestima bolesti. Pogled štićenika opisuje se na različite načine- bolničarima i liječnicima je tako važno kamo gledaju (,Zagledala se u neku točku"238 „gleda obično okolo" "239) i kako gledaju (,gleda plaho"240, „gleda ljutito"241) i izbjegavaju li očni kontakt (,„neće ni da pogleda u lice”242, „,ne može je se fiksirati”"243).

Pored bolničara i liječnika, štićenici također često naslućuju važnost „kliničkog zora” i razvijaju taktike otpora prema istom. Foucault je histeriju objasnio kao otpor vrsti autoriteta koja se temelji na pretvaranju tijela u predstavu simptoma koji zbunjuju klinički pogled liječnika svojom nekonzistentnošću, naglim pojavljivanjem i nestajanjem i neuhvatljivom etiologijom. ${ }^{244}$ Povijesti bolesti bilježe brojne suptilne i manje suptilne načine opiranja liječnikovom pogledu. Štićenice, naročito često skrivaju lice rukama ili u jastuk ${ }^{245}$ ili direktno prigovaraju liječnicima zbog toga što ih intenzivno gledaju (,„što me gledate kao da me hoćete pojesti”) ${ }^{246}$. Možda je i čin razodijevanja

235 Žirovčić, 1897: 232.

236 Ibid, 356.

237 De Young, 2015: 258.

238 KPV, 1911: 7946.

239 KPV, 1895: 2621.

240 KPV, 1911: 7789.

$241 \mathrm{KPV}, 1914: 5731$.

242 KPV, 1911: 7281.

243 KPV, 1895: 2589.

244 Foucault, 2006: 305.

245 KPV, 1914: 5731.

246 KPV, 1910: 7579. 
kojem su brojni štićenici i štićenice pribjegavali imao ulogu tjeranja liječnika da odvrate pogled od pacijenata. U svakom slučaju, fiksiranje je često primjenjivano, ali je rijetko o njemu pisano. Štićenici su ga svejedno, prepoznavali kao instrument kontrole i svjesno ili podsvjesno mu se opirali.

\subsubsection{Sredstva za sputavanje i osamljivanje}

Terapijski princip „,moral treatmenta” u anglo-saksonskoj je literaturi poznat i kao „non-restraint princip" jer je uklanjanje mehaničkih mehanizama sputavanja pacijenata navodio kao svojevrsni civilizacijski doseg. Usprkos tome, mehanička sredstva obuzdavanja štićenika još se uvijek koriste u stenjevačkom i u drugim zavodima i njihovo korištenje se ne taji, već se prema istome odnosi kao prema nužnom zlu koje je potrebno kako bi se osigurala sigurnost pacijenata. Među sredstva mehaničkog obuzdavanja u Stenjevcu se koristi stavljanje pacijenta u izolaciju s ograničenom mogućnošću kretanja („osamljivanje”) i razne vrste sprava za vezanje štićenika (stezulje, užad, mrežasti krevet).

Izolacija kao terapeutsko sredstvo je nešto što stoji iza same ideje zavoda kao institucije. Osamljena lokacija zavoda u pretežno ruralnom području ${ }^{247}$ i izdvajanje duševno bolenih osoba kako od njihovih obitelji, tako od drugih već izoliranih grupa (poput zatvorenika ili kronično oboljelih od tjelesnih bolesti $)^{248}$ su prakse koje devetnaestoljetna psihijatrija neprestano ponavlja kao presudne za izlječenje duševnih bolesti. Unutar zavoda, izolacija se provodi tako da se štićenika smjesti u posebnu prostoriju (u Stenjvcu su ju zvali „samica” ili „soba za osamljivanje”) čime se onemogućio kontakt štićenika sa ostalim štićenicima. Izolacijska soba u Stenjevcu je bila dobro prozračivana i grijana ${ }^{249} \mathrm{~s}$ ležajem od konjske dlake, trave ili drvenih vlakana u koju su štićenici stavljani goli ${ }^{250}$ koji je osiguravao osamljenu osobu od slučajnih ozljeda. Štićenike se u nju smještalo ako bi bili nemirni ili ulazili u fizičke sukobe s drugim štićenicima.

247 De Young, 2015: 357.

248 Žirovčić, 1897: 323.

249 LV, 1880: 30.

250 Žirovčić, 1897: 356.

93 
Od sredstava mehaničkog obuzdavanja najčešće su korištene stezulje i mrežasti kreveti. Stezulja je korištena veoma često, kad bi štićenik bio agitiran i kad bi ga trebalo prisilno hraniti jer je odbijao hranu (kao u slučaju pjesnika Vladimira Vidrića, koji je prisilno hranjen u stezulji jer je vjerovao da je hrana otrovana ${ }^{251}$ ). Iako se „moral treatment” pokret hvalio svojim non-restraint principom, proponenti istog su primjenjivali i preporučivali sredstva sa mehaničko sputavanje duševno bolesnih, pa je čak i Pinel bio pobornik korištenja stezulje. ${ }^{252}$ Žirovčić opravdava korištenje stezulje tvrdeći da „ona teoritično nije dozvoljena, dok se u praksi ne može vazda izbjeći” ${ }^{253}$ i da bi ju se puno rjeđe koristilo kad bi bolničko osoblje bilo obučenije. No, korištenje stezulje nije mnogo doprinosilo smirivanju bolesnika- povijest bolesti nekih od njih pokazuje da su bili puno nemirniji u stezulji, dok bi im se ponašanje popravilo čim bi liječnici ili bolničari uklonili stezulju. ${ }^{254}$ Zanimljivo je da Žirovčić u člancima ne spominje korištenje mrežastih kreveta, koji su krajem devetnaestog stoljeća bili često kritizirani kao nehumani, ${ }^{255}$ dok povijesti bolesti pokazuju da su se koristili prilično učestalo ${ }^{256}$. Prešućivanje pojedinih disciplinskih mjera, ukazuje na činjenicu da se Žirovčić ipak nije htio previše izložiti osudi javnosti. Uzrok tome može biti činjenica da su zavodi za umobolne u Njemačkoj bili izloženi žestokim kritikama zbog sudske afere koju je potaknuo jedan gostioničar i antipsihijatrijski aktivist koji je razotkrio brojne slučajeve okrutnog postupanja prema bolesnicima u jednom zavodu kraj Mariaberga. ${ }^{257}$ Osim stezulja i mrežastih kreveta, povijesti bolesti upućuju na barem jedan slučaj u kojem se štićenica, tužila da ju „,vežu na križ”258. Opis tog postupka možda upućuje na primjenu takozvanog „križnog položaja”. Tu praksu vezanja razvio je početkom devetnaestog stoljeća berlinski psihijatar Ernst Horn. Osobu se uz pomoć užeta veže u stojeći položaj dok su joj ruke sapete rukavima stezulje i privezane za zid iznad njezine glave ${ }^{259}$. Sama praksa je bila česta u njemačkim zavodima u devetnaestom stoljeću, ali ponovno, jedini spomen nečeg što može indicirati na primjenu te vrste

251 Župić, 1937: 343.

252 De Young, 2015: 451.

253 Žirovčić, 1897: 356.

$254 \mathrm{KPV}, 1880: 208$.

255 De Young, 2015: 423.

$256 \mathrm{KPV}, 1914: 9095$.

257 Goldberg, 2002: 7-8.

$258 \mathrm{KPV}, 1890: 1355$.

259 De Young, 2015: 412. 
sputavanja u Stenjevcu je govor jedne od pacijentica, koja se možda nije ni referirala na nešto što se dogodilo u stenjevačkom zavodu.

\subsubsection{Rana psihofarmakološka terapija}

Budući da su gotovo svi lijekovi koji se u na prijelazu stoljeća koriste u Stenjevcu hipnotici, ranu psihofarmakološku terapiju je teško gledati odvojeno od terapije smještanjem u krevet. Širokoj primjeni hipnotika doprinijelo je $\mathrm{i}$ to što je u ondašnjoj medicini san imao izrazito istaknutu ulogu, te se smatralo da je dobar san i uredan režim spavanja ključ zdravog života. Terapeutsko djelovanje sna spominju još antički liječnici i u povijesti medicine se povoljno djelovanje istog na organizam drugo podrazumijevalo. Ipak, unutar psihijatrijskih zavoda su prenapučenost, loši životni uvjeti, velika buka i smrad i agitirani štićenici kojih je bio velik broj doveli do ponovnog opetovanog isticanja važnosti sna za psihičko i fizičko zdravlje. ${ }^{260}$ Vrtoglav rast broja štićenika u zavodima se dogodio u isto vrijeme kad i otkriće ranih sedativa i narkotika koji su ubrzo našli široku primjenu pri uspavljivanju agitiranih štićenika i pomaganju onima koji su mučili od nesanice ili anksioznosti. Iako Žirovčić nije smatrao hipnotike idealnim rješenjem, u svom se članku složio da je san izazvan hipnoticima bolji od nikakvog sna, iako se njegova blagotvornost ne da usporediti s potonjim. ${ }^{261}$ Od specifičnih lijekova u Stenjevcu se ranih godina često rabi kloral-hidrat, sedativ sintetiziran 1869, kojeg stenjevački liječnici navode pod imenom „chloral”262, a koji se tamo rabio za uspavljivanje onih štićenika koji zbog uzbuđenosti nisu mogli spavati. ${ }^{263}$ Osim „,chlorala”, u Stenjevcu se kao hipnotici koriste i trional i sulfonal, koji ubrzo potiskuju kloral-hidrat. Također, barbiturat Veronal se u povijestima bolesti počinje spominjati ubrzo nakon što ga se 1904. počelo distribuirati.

Drugi lijek koji je još od početka osamdesetih godina devetnaestog stoljeća uživao široku primjenu u hrvatskoj psihijatriji bio je kalijev bromid, kojeg hrvatski liječnici zovu bromkalij. Otkad je prvi put primijenjen 1857. godine za uspješno suzbijanje epileptičnih napadaja ${ }^{264}$, bromkalij se smatralo jednim od najuspješnijih psihofarmakoloških preparata. Činjenica da

260 Ibid, 83.

261 Žirovčić, 1897: 355.

$262 \mathrm{KPV}, 1881$ : bez broja.

263 Žirovčić, 1897: 355.

264 Goodman, 1970: 121-122. 
kalijev bromid ima i jaka sedativna svojstva i da ga je relativno lako dozirati i dati štićenicama učinila je kalijev bromid najpopularnijim psihofarmakom kasnog devetnaestog stoljeća. U Stenjevcu se primjenjuje od samih početaka rada zavoda i propisuje ga se u velikom boju dijagnoza- osim kod epileptičara daje ga se štićenicima kojima je dijagnosticirana melankolija (zabilježeno je da je jedna od melankoličnih štićenica nakon terapije bromkalijem postala veselija $^{265}$ i onima koji haluciniraju ${ }^{266}$, A Žirovčić ga hvali kao naročito učinkovit lijek pri liječenju „hysteričnih, epileptičnih, neurastheničnih bolestnika, kao i sexualno-hypochondrične senzacije." ${ }^{267}$ Ako izuzmemo epileptičare, kalijev bromid je također disproporcionalno propisivan štićenicama zbog uvjerenja da djeluje smirujuće na ženske reproduktivne žlijezde.

Za smirivanje nemirnih bolesnika i onih koji su imale bolove, široko se koristi morfij što nije nimalo iznenađujuće, budući da su morfij i ostali derivati opijuma temeljni anelgetici ondašnje medicine koji i izvan zavoda imaju široku farmakološku primjenu. Iako ga Žirovčić tek ovlaš spominje (možda upravo i zbog sveprisutnosti morfija) povijesti bolesti bilježe da se pojedine pacijente tretiralo ,velikim injekcijama morfija”. ${ }^{268}$ Čini se, ipak da je korištenje morfija s vremenom postajalo sve rijeđe. $U$ anelgetskoj i sedativnoj upotrebi ga je u velikom broju slučajeva zamijenio hioscin, alkaloid dobiven iz bunike kojeg je 1880 sintetizirao njemački znanstvenik Albert Ladenburg. Žirovčić hioscin, zajedno s njegovom podvrstom, duboisinom, uglavnom preporuča za smirivanje nemirnih štićenika i onih koji su u delirantnom stanju. ${ }^{269}$ Većina lijekova koja se koristi u Stenjevcu, sintetizirana je u Njemačkoj i najveću je primjenu doživjela upravo tamo. Također, zavod je relativno brzo dobivao nove psihofarmake i počinjao ih redovito koristiti. Svrha većine lijekova (s mogućim izuzetkom kalijeva bromida) nije bila izliječenje duševne bolesti, pa čak niti ublažavanje simptoma (ako izuzmemo neispavanost) koji su mučili štićenike već smirivanje nemirnih štićenika.

$265 \mathrm{KPV}, 1880: 257$.

266 KPV: 1911: 6295.

267 Žirovčić, 1897: 355.

$268 \mathrm{KPV}, 1881$ : bez broja.

269 Žirovčić, 1897:355. 


\subsubsection{Hipnotizam}

Slika psihijatra kao hipnotizera koji liječi psihičke tegobe uz pomoć smirujućeg glasa, sugestije i buđenja potisnutih sjećanja mnogo je starija od Sigmunda Freuda. Prvo povezivanje psihijatrije i hipnoze ima svoje korijenjene u mesmerizmu ili ,animalnom magnetizmu” pseudomedicinskoj metodi koja je u 18. stoljeću postala izrazito raširena u mondenim krugovima plemstva i imućnijeg građanstva. Mesmerizam je dobio ime po Franzu Antonu Mesmeru (1734-1815), bečkom liječniku koji je tvrdio da je otkrio ,životinjski magnetizam”- novu fluidnu silu koja protječe kroz ljudska tijela. ${ }^{270}$ Mesmer je tvrdio kako se na tu silu može utjecati, bilo pomoću magnetiziranih štapova, bilo pomoću vještine mesmerista. ${ }^{271}$ Naravno, ideja nevidljive sile je bila u skladu s tadašnjim svjetonazorom elita u kojem su se misticizam i znanost često prožimali i nadopunjavali. Mesmerove će ideje u devetnaestom stoljeću preuzeti i propagirati škotski liječnik James Braid, koji će ih povezati sa činjenicom da dug i fokusiran pogled u jednu točku ,paralizira živčane centre u osjetilima i izbacuje živčani sustav iz ravnoteže, time uzrokujući sugestibilno stanje koje je nazvao hipnozom". ${ }^{272}$ Braid je odbacio dosadašnje pretpostavke da se kod hipnoze radi o bilokakvom, „životinjskom magnetizmu” i istakao da se radi o stanju koje je slično snu i koje izaziva prenapregnutost živčanog sustava usred usredotočivanja. Braid je time poznanstvenio hipnozu i iako njegova terapeutska metoda nikad nije doživjela širu legitimaciju unutar medicine, ona ipak postaje praksom koju se sada primarno vezuje uz profesionalne liječnike i to uz specifičnu vrstu liječnika, takozvanog ,liječnika za živce”. Liječnici za živce su uglavnom radili u privatnoj praksi, te liječili bogatije klijente koji su zbog velike stigme koju je duševna bolest nosila izbjegavali obraćanje psihijatrima. Također, smatralo se da hipnoza može biti koristim sredstvom anestezije pri kirurškim zahvatima, no otkriće kemijskih sredstava za narkozu je učinilo takvu primjenu hipnoze nepotrebnom. Veliki terapeutski autoritet hipnozi je dao Charcot koji ju je koristio prilikom svojih javnih demonstracija slučajeva histerije. ${ }^{273}$ Charcotovi eksperimenti krajem 1870-ih i početkom 1880-ih postaju široko poznati u europskoj medicinskoj zajednici i tada raste interes za hipnozu među hrvatskim liječnicima. Psihijatri nisu jedini koji prednjače u tome- liječnik Niko Selak, koji je radio kao općinski liječnik u Jelsi je

270 Scull, 2015: 181.

271 Ibid, 182.

272 Braid, 1853: 16.

273 Scull, 2015: 278. 
napisao jednu od najsustavnijih rasprava o hipnozi. U raspravi objavljenoj u Liječničkom vjesniku 1890. i 1891. Niko Selak se poziva na Charcota kad tvrdi da je hipnoza zapravo „na umjetni način stvorena neurosa"274 i naširoko govori o njenim terapeutskim primjenama u anesteziji i pri liječenju epileptičkih grčeva ${ }^{275}$. Prije Selaka o hipnotizmu je pisao i stenjevački kućni liječnik Dragutin Forenbacher koji govori o uspješnom liječenju „hystero-epileptične žene” kombinacijom hipnoze i terapije kalijevim bromidom ${ }^{276}$ I Forenbacher i Selak nalaze potrebnim iznijeti argumente za znanstveno utemeljenje hipnoze, što pokazuje da je ista kao terapeutska metoda bila osporavana u medicinskim krugovima. Također, liječnici koji pišu o hipnozi nastoje ju odvojiti od teorija o ,animalnom magnetizmu” i tako prisvojiti medicini pravo na znanstveno tumačenje hipnotičkih fenomena. S obzirom na prisustvo spiritizma u građanskim krugovima kasnog devetnaestog stoljeća, medicinska struka se vjerojatno morala stalno boriti protiv uvriježenih okultističkih predodžbi o hipnozi.

Hipnoza se u Stenjevcu primjenjivala najviše tijekom vala interesa za hipnozu kojeg su među psihijatrima izazvali Charcotovi eksperimenti i to ponajviše na štićenicima kojima su dijagnosticirane histerija i epilepsija Sobarica Kornelija H. Primljena je u Zavod 1889 s dijagnozom „hystero-epilepsije” čiji su glavni simptomi čini se bili „razvratan i raskalašen život”, „strah od muškaraca” i „glavobolje i omaglice”. Po dolasku nije htjela odgovarati na pitanja liječnika, no nakon što je hipnotizirana, počela je surađivati, a uz pomoć hipnoze su joj se „odsugerirale” glavobolja i omaglica, te osjećaj tjeskobe. ${ }^{277}$ Osim histeričnih pacijentica, hipnoza je primjenjivana i kod epileptičara, gdje liječnici i bolničari često navode njenu uspješnost. ${ }^{278}$ Početkom dvadesetog stoljeća čini se da se u terapeutski učinak hipnoze prestaje vjerovati te se ista prestaje primjenjivati u stenjevačkom zavodu.

274 Selak, 1891: 9.

275 Ibid, 10-11.

276 Forenbacher, 1886: 160.

277 KPV, 1895: 1435.

278 KPV, 1890: 2337. 


\subsubsection{Prehrana}

Već je rečeno kako je u ranim danima stenjevačkog zavoda kao najčešći uzrok duševne bolesti bila navođena „bijeda” ili „slabokrvnost zbog bijede"279. Nalaženje uzroka bolesti u materijalnoj bijedi i važnost koju su uravnoteženoj i obilnoj prehrani pripisivali ravnatelji zavoda u kojima se razvio „moral treatment” su rezultirale u činjenici da se u Stenjevcu posebna pažnja posvećivala prehrani štićenika. Važnost zdrave, redovite i obilne prehrane bazirane na obilju ugljikohidrata i bjelančevina je često isticana kako u inozemnoj, tako i u hrvatskoj psihijatrijskoj literaturi. Naravno, opskrba hranom je često bila otežana, a za vrijeme Prvog Svjetskog Rata, stenjevačkim je zavodom zavladala glad. ${ }^{280}$

Važnost prehrane u Stenjevcu nazire se u kako u godišnjim izvješćima, tako i u člancima liječnika. Ivo Žirovčić u svom članku o postupanju s duševno oboljelima govori kako hrana u psihijatrijskim zavodima mora biti obilna zdrava i raznolika. ${ }^{281} \mathrm{U}$ godišnjim izvješćima često se detaljno navode troškovi hrane i, ,poboljšica” u prehrani štićenika. Izvješće za 1882. godinu tako javlja da su se ,bolestnikom tielesno propalim pružale u okviru jestvenika sve moguće poboljšice: u jutro ili mlieko ili kava u 10 satih ili goveđa ili vinska juha, na obied ili pečenka ili tiestenina.. a za južinu dobivalo je samo nekoliko bolestnikah kavu sa žemljom"282 Prema izvješću za 1887. i 1888. na hranu bolesnika trošilo se dnevno 25.77 novčića, a za bolesnike koji rade još se dodatno trošilo na duhan, vino i kavu te za ,poboljšice” u vidu grožđa i voća. ${ }^{283}$

Iako se alkoholizam smatrao čestim uzrokom duševnih oboljenja, mnogi onodobni psihijatri smatrali su da u umjerenim količinama može djelovati blagotvorno. To je gledište u psihijatriji zastupao i poznati britanski liječnik Joseph Mason Cox, koji je smatrao da umjerene količine alkohola pomažu kod liječenja melankolije. ${ }^{284}$ Slično misli i Žirovčić koji tvrdi da manje količine

279 Rohaček, 1889:149.

280 Herceg, 1933: 12.

281 Žirovčić, 1897: 353.

$282 \mathrm{LV}, 1883: 101$.

283 Rohaček, 1889: 150.

284 De Young, 2015: 147. 
alkohola ne mogu štetiti bolesniku iako nisu nužne za njegov oporavak. ${ }^{285}$ Drugačiji je bio stav njegovog prethodnika na mjestu ravnatelja zavoda, Ivana Šimse koji je bio žestoki protivnik alkoholizma i pobornik potpune zabrane alkoholnih pića. Nakon Šimsina odlaska iz Stenjevca u zavodu su se alkoholna pića mogla slobodno konzumirati. Vladimir Vidrić je, već anegdotalno, prije smrti nazdravljao šampanjcem ${ }^{286}$ a zidarski pomoćnik Filip P. je tijekom 1910. godine redovito dobivao alkoholna pića kao nagradu za zidarske poslove koje je obavljao u Zavodu, iako je u Stenjevac primljen s dijagnozom alkoholizma. ${ }^{287}$

Budući da su mnogi od zavodskih štićenika prije dolaska u zavod živjeli u stanju egzistencijalne oskudice koja je nedvojbeno mnogima utjecala na psihičko stanje, nije isključeno da je redovita prehrana jedan od faktora koji je najvidljivije utjecao na poboljšanje stanje štićenika. Samim time, razumljiva je terapeutska važnost koju su zavodski liječnici davali zdravoj i obilnoj prehrani. Važnost prehrane postala je još izraženija kad se uzme u obzir da je prenapučeni Zavod stalno bio na rubu oskudice i gladi. Većina planova o postepenoj sammodrživosti zavoda padala je u vodu jer velik broj štićenika nije bio sposoban ni motiviran za radnu terapiju. Uz to vođenje poljoprivrednog gospodarstva zahtijevalo je osobit tip znanja i iskustva kakvo ravnatelji zavoda, obrazovani kao liječnici, nisu imali. Samim time, može se reći da je prehranjivanje štićenika, i posljedično, prehrana općenito, postala neka vrsta opsesije zavodskih liječnika, zbog čega je učestalo figurirala u njihovim studijama o skrbi za duševno oboljele.

\subsubsection{Hidroterapija}

Primjena vode kao sredstva liječenja duševnih tegoba starija je od pojave zavodske psihijatrije i svoja izvorišta vjerojatno ima u tradiciji toplica i ljekovitih kupki. Ljekovita svojstva vode poznata su još od antike, a krajem osamnaestog i početkom devetnaestog stoljeća, takozvana „kupališna medicina” postaje neka vrst trenda među plemstvom i građanskim elitama. Prve terapije vodom u psihijatrijskim zavodima zapravo su služile plašenju štićenika. Naime, vjerovalo

285 Žirovčić, 1897:353.

286 Župić, 1937: 344.

287 KPV, 1911: 6807. 
se da jak i intenzivan strah može prenuti duševno oboljelu osobu i uzrokovati njeno ozdravljenje što se nazivalo „salutornim strahom”. ${ }^{288}$ Prvi tip hidroterapije u modernoj medicini popularizirao je Vincent Priessnitz početkom devetnaestog stoljeća. Priessnitz nije bio obrazovani liječnik, već nadriliječnik ruralnog porijekla. Ipak njegova terapija vodom je postala izrazito popularna nakon što je otvorio vlastitu kliniku za hidroterapiju i tvrdi da je uz pomoć vode zacijelio vlastite prijelome rebara nakon nesreće s kolima. ${ }^{289}$ Među njegovim pacijentima bili su brojni pripadnici društvenih elita, koji su u hidroterapeutskim metodama poput kupki tražili lijek za brojne živčane teškoće. Njegov uspjeh pri primjeni hidroterapije ohrabrio je i brojne ravnatelje zavoda za umobolne da, s većim ili manjim uspjehom, počnu primjenjivati hidroterapijske metode. Ravnatelji Stenjevca bili su uvjereni u ljekovita svojstva vode. Hidroterapija se u Stenjevcu primjenjivala na dva načina: zamatanjem pacijenata u plahte i kupkama. Ravnatelj Žirovčić bio je protiv nekih intenzivnijih tehnika koje su se primjenjivale u europskim umobolnicama, smatrajući da one samo dodatno agitiraju pacijente. ${ }^{290}$

Primjena plahti na nemirnim pacijentima bila je jedna od tehnika koju je u praksu uveo Priessnitz u svome liječilištu. Sredinom 19. stoljeća ju je u psihijatrijske institucije donio C. Lockheart Robinson, ravnatelj umobolnice u Sussexu, koji je dao detaljan opis postupka:

„Plahta od vodootpornog platna se položi preko madraca, a preko nje se stavi pokrivač. Obična plahta se tada natopi vodom i rasprostre preko pokrivača. Pacijent se položi na plahtu koja se brzo omota oko njega tako da mu i ruke budu umotane. Plahta je učvršćena oko tijela i preko nje su položena još tri ili četiri pokrivača. Ispočetka pacijent malo drhti, no to ubrzo prolazi kako se plahta zagrijava i kako krv dolazi na površinu tijela." ${ }^{291}$

U članku u kojem opisuje tretman, Robertson ističe sedativna svojstva hladne vode ${ }^{292}$, a Žirovčić postupak umatanja štićenika u plahte direktno uspoređuje s navlačenjem stezulje nemirnom pacijentu. ${ }^{293}$ Čini se da su Priessnitzove hidroterapijske metode zadobile disciplinirajući značaj kad ih se počelo primjenjivati unutar zavoda. U psihijatrijskim

288 De Young, 2015: 307.

289 Ibid, 2015: 250.

290 Žirovčić, 1897: 356.

291 Lockheart Robertson, 1861: 267.

292 Ibid: 266.

293 Žirovčić, 1897: 356. 
tekstovima ima malo pozivanja na blagotvorno djelovanje vode na liječenje duševnih oboljenja već se primjena iste svodi na smirivanje nemirnih štićenika, što pokazuje velik odmak od značaja koju je hidroterapija imala u folklornoj i kupališnoj medicini. Priessnitzova vjera u čudotvorno djelovanje vode je pokleknula pred terapeutskim pesimizmom institucionalne prakse; ono što je ostalo bila je primjena vode za sputavanje i umirivanje štićenika.

Povijesti bolesti često svjedoče o disciplinskoj primjeni zamatanja u plahte i povremenoj upotrebi kupelji. Gjuri Ž. su tako 1909. plahte određene kroz tri dana, nakon što je skupini pacijenata koji su kartali oteo i bacio karte tvrdeći da slike na kartama prikazuju njegove rođake. ${ }^{294}$. Činjenica da su mu plahte određene „kroz sljedeća tri dana” upućuje na to da takav tretman nije bio viđen kao medicinski postupak terapije već kao disciplinski postupak kažnjavanja- zbog nemirnog ponašanja štićenik će „dobivati plahte” bez obzira na eventualno poboljšanje njegovog duševnog stanja.

Marija S. koju je u Stenjevec smjestio suprug nakon što ga je odlučila napustiti također je bivala zamatana u plahte, a u povijesti bolesti je navedeno da od plahti ima ,silni rešpekt”295. Plahte su na njoj primjenjivane u trajanju od dva sata svaki put kad bi bila nemirna i suprotstavljala se bolničarima. Kasnije se navodi da je i prijetnja umatanjem u hladne plahte bila dovoljna da se štićenica smiri. ${ }^{296}$

Osim navedenih terapijskih metoda jedno rano izvješće spominje primjenu elektroterapije, iako ne pojašnjava u kojem se obliku ona tada primjenjivala. ${ }^{297}$ Nekim štićenicima davale su se i tinkture željeza, vjerojatno kao dodatak prehrani, budući da se anemija usred neimaštine smatrala jednim od glavnih uzroka duševne bolesti u zavodu ${ }^{298}$. U skladu s ,moral treatmentom” velika se pažnja pridavala slobodnom vremenu štićenika: zavod za umobolne je već nekoliko godina nakon svog utemeljenja imao malu knjižnicu koja je prikupljena donacijama, kuglana te gusle, biljar i

294 KPV, 1911: 7367.

295 KPV, 1914: 8715.

296 Ibid.

297 Rohaček, 1885: 60.

298 LV, 1883: 100-101. 
glasovir za „uglednije bolestnike" te tamburice za one iz „seljačkog stališa"299. Štićenici su dobivali novine $\mathrm{i}$ časopise ${ }^{300}$, a vrijeme su kratili i kartanjem. ${ }^{301}$

Povijesti bolesti govore o određenom terapeutskom pesimizmu koji je vladao u Stenjevcu. Nema pokušaja sustavne terapije niti dugotrajnog liječnikovog bavljenja pojedinačnim pacijentima. Pokušaji dijagnosticiranja konkretnih patoloških promjena na mozgu putem autopsija prestaju, a sva gore navedena terapijska sredstva zapravo postaju disciplinska sredstva koja su trebala omogućiti dobro vladanje štićenika. Postupak prema štićenicima kako vrijeme odmiče, a broj istih raste sve manje dobiva obilježje trajnog izlječenja, a sve više određenog oblika palijativne skrbi povezane sa strogom disciplinom. Nejasno je je li svrha te discipline imala ulogu podvrgavanja štićenika neospornog liječničkom autoritetu ili se jednostavno radilo o posljedici prenapučenosti i nedostatka materijalnih i ljudskih resursa u Zavodu, što je dovelo do fokusa na discipliniranje kako bi se jednostavno Zavod učinilo funkcionalnim unjegovoj ulozi mjesta na kojem su se čuvali oni pojedinci koje je njihova okolina okarakterizirala opasnima za sebe i druge.

299 Rohaček, 1885: 62. 


\section{Rod i seksualnost}

\subsection{Rodne uloge i seksualnost u emotivnom režimu građanstva kasnog devetnaestog stoljeća}

Pogledi psihijatara i štićenika na rod i seksualnost često su se razlikovali zbog toga što su psihijatri bili pripadnici obrazovanih građanskih slojeva dok su štićenici Zavoda u Stenjevcu najčešće bili osobe bez formalnog obrazovanja koje su dolazile iz ruralnih područja. Na kraju devetnaestog stoljeća etički i filozofski nazori građanskih slojeva o seksualnosti, romantičnoj ljubavi i rodnim ulogama bili su naturalizirani u načinu života, umjetnosti i znanosti. Odstupanja od istih često su se gledala kroz prizmu moralnih devijacija ili duševne bolesti. Prije nego što se objasni kako se unutar psihijatrije formirao diskurs o ljudskoj seksualnosti i rodu, potrebno je promotriti koje su mjesto seksualnost, rod, tjelesnost i ljubav zauzimali unutar emotivnog režima građanske klase, kojoj su psihijatri pripadali.

Pojam emotivnog režima shvaćam u smislu u kojem ga je opisao William Reddy kao „skup normativnih emocija i praksi, rituala i emotiva koji ih izražavaju i preko kojih se isti uče“302. Emotiv je Reddy definirao kao komunikacijski iskaz o emocijama, koji ima i deskriptivnu i performativnu komponentu, budući da $\mathrm{u}$ isto vrijeme opisuje emocije i kroz aktivan iskaz nam omogućuje da reflektiramo o istima ${ }^{303}$ Po Reddyju, emotivni režim je u temelju svakog uspješnog političkog režima. ${ }^{304}$ Pristup institucijama u okviru kojih su formirani diskurzivni elementi emocionalnog režima koji su se odnosili na tretman roda i seksualnosti bio je područje djelovanja obrazovanih muškaraca iz građanskih ili aristokratskih slojeva. Same te institucije nastajale su u okviru modernizacijskih procesa karakterističnih za devetnaestoljetna europska društva.

Odnos seksualnosti i psihijatrije zrcali predodžbe o odnosu između tijela i duše, odnosno tijela i uma koje se intenzivno razvijaju od 17. stoljeća nadalje pod utjecajem razvoja svijesti o „individualnom sebstvu”. Pod utjecajem reformacije i izmijenjenog odnosa prema religioznosti, te pojave tiska i brže komunikacije ideja, razni filozofski, teološki i pučko-kulturni oblici odnosa

302 Reddy, 2002: 145.

303 Ibid, 120-121.

304 Ibid, 145. 
između duše i tijela kojima se opisivao čovjekov identitet se sve više formiraju kao modeli dihotomije uma i tijela među kojima postoje različite vrste međuodnosa. Kartezijanska premisa koja je definirala um kao izvor sebstva („self”) imala je dvije važne posljedice za poimanje identiteta i poimanje roda. Prva je zamišljala sebstvo kao univerzaliziranu misleću strukturu, povezanu s tijelom, ali ipak pojmovno odijeljenu od istog ${ }^{305}$. Druga bitna odrednica je da su se rodne razlike počele uglavnom shvaćati kao tjelesne razlike - rod tako prestaje biti shvaćen aristotelovski kao razlika između muškog djelatnog uzroka i ženskog materijalnog principa i njegova se osnova počinje tražiti u biološkim razlikama muškaraca $i$ žena ${ }^{306}$. Unutar međuovisnosti uma i tijela, tijelo je još uvijek donekle shvaćano sekundarnim ili animalnim dok je um, u svojim različitim koncepcijama od „racia” do ,volje” smatran onime što razlikuje čovjeka od životinje i stavlja ga na hijerarhijski povlašteno mjesto u prirodnom poretku. Unutar tog poretka emocije su doživjele različit tretman - neke od njih poput melankolične tuge (u književnom i intelektualnom diskursu devetnaestog stoljeća nazivana „spleen”) su pozitivno predstavljane kao izraz duševne i intelektualne rafiniranosti ${ }^{307}$ dok su druge, poput bijesa, straha $\mathrm{i}$ seksualne žudnje bile odrazom niže ,životinjske” strane čovjeka. Ljubav je od početka bila kognitizirana kroz antitetičke pojmove: tjelesna ljubav (,eros” ili „cupidas”) bila je suprotstavljena duhovnoj ljubavi (,agape” ili „,caritas”) ${ }^{308}$. Ista je distinkcija od samih svojih početaka bila prožeta patrijarhalnim diskursom. U ranom novom vijeku tijelo je tradicionalno predstavljano kroz lik senzualne Eve, a duša i kasnije razum identificirani su s Adamom. ${ }^{309}$ Ukorijenjena slika čovjeka u obrazovanoj građanskoj kulturi tako je podrazumijevala uniju ili „brak” ženske, putene tjelesnosti i maskulinog razuma i ta se arhetipska slika preslikavala na kulturne i intelektualne koncepcije roda i seksualnosti. Također se dvojna „eros-agape” ljubav u okviru građanske kulture kasnog osamnaestog i ranog devetnaestog stoljeća objedinjuje u pojmu romantične ljubavi.

Glavni aspekti romantične ljubavi kako se ona shvaća u zapadnom modernitetu su želja da se djeluje u skladu s dobrobiti voljene osobe, želja da se provode vrijeme u neposrednoj blizini

305 Laqueur, 1990: 55.

306 Ibid, 152.

307 Scull, 2009: 49.

308 Porter, 2003: 45.

309 Ibid. 
voljene osobe i želja za fizičkim kontaktom i seksualnim odnosom s voljenom osobom. ${ }^{310} \mathrm{U}$ tim aspektima ujedinjeni su fizički i duhovni/intelektualni aspekti ljubavi, a rituali poput udvaranja, sastanaka, darivanja, zaruka, pisanja ljubavne poezije i ljubavnih pisama (pisma su najčešće posredovana) i vjenčanja vezali su romantičnu ljubav uz ideju obitelji kao afektivne zajednice.

Podjela između javne i privatne sfere koja je karakterizirala građansko društvu je još jedan važan aspekt u shvaćanju emocija i seksualnosti u devetnaestom stoljeću. Nastanak i razvoj javne sfere kao prostora vidljivog društvenog djelovanja vezan je uz konstrukciju i elaboraciju posebnog područja proizvodne i komercijalne djelatnosti. Koncepti privređivanja kako bi se preživjelo i ideja „profesije“ kao aspekta osobnog identiteta u velikoj su mjeri proizvodi devetnaestog stoljeća. ${ }^{311}$ Leonore Davidoff pokazuje kako je $\mathrm{u}$ devetnaestom stoljeću ideja maskulinog idenititeta bila usko povezana s posjedovanjem vlastitog rada kojim se ulazi u javni svijet kapitalističke proizvodnje. Takvo poimanje proširilo se i na niže slojeve manualnih radnika koji ju prihvaćaju kako bi kompenzirali za unižen položaj koji je manualni rad zauzimao. Odnos prema radu i otuđenje istog u velikoj je mjeri utjecao na proširenje javne sfere i vezanost iste za svijet profesionalaca. Žene su u tradicionalnim obiteljima bile podređene muškarcima i takav im je odnos prema radu bio zapriječen. ${ }^{312} \mathrm{U}$ devetnaestom stoljeću javna sfera obuhvaća čitav niz formi i funkcija: znanstvenu, religijsku, kulturnu, političku i ekonomsku. “313 $\mathrm{S}$ druge strane, područje obiteljskog doma postaje povezivano s atmosferom intimnosti, afektivne obiteljske zajednice i privatnosti. Budući da su žene u području javne sfere tradicionalno zauzimale marginalno mjesto (s mogućom iznimkom žena iz radničkih slojeva koje su bile djelomično prisutne u javnoj sferi proizvodnje dobara) muškarci su dominirali javnom sferom dok je ženama bila prepuštena skrb o kućanstvu. Pored toga, muškarci su imali privilegiranu poziciju i mogli su premošćivati javnu i privatnu sferu. Izvan obiteljskog doma bila su im dostupna brojna mjesta poput klubova, kavana i bordela gdje su mogli uživati u više ili manje privatnim aktivnostima. Također, kao gospodar doma o čijem radu za plaću ovisi financijska obstojnost kućanstva, muškarac je imao realnu moć nad domom kao prostorom artikulacije privatnog. S druge strane, žene srednjih i viših društvenih slojeva bile su okružene mrežom neformalnih zabrana i 
psiholoških barijere koje su ih sprečavale da djeluju izvan prostora vlastitog doma, pa čak i da ga napuštaju bez pratnje. ${ }^{314}$ Takva demarkacija društvenog prostora utjecala je i na poimanje emotivnosti i seksualnosti i učinila patrijarhat dominantnim aspektom emotivnog režima građanske klase, dok je sam emotivni režim dodatno učvršćivao patrijarhalne društvene odnose. Pripisivanje kvaliteta senzualnosti i emotivnosti ženama, također je smjestila seksualnost i emotivnost $\mathrm{u}$ područje privatne sfere i tako dodatno učvrstili semantičke asocijacije vezane uz pojam ženstvenosti.

Prema tome, možemo zaključiti da shvaćanje roda i seksualnosti unutar emotivnog režima građanskih slojeva ima sljedećih elemente:

1. Ljubav između muškaraca i žena konceptualizira se kroz emotive i rituale romantične ljubavi

2. Odnos razuma i tijela je hijerarhiziran, pri čemu se razum identificira s muškarcima a tijelo sa ženama.

3. Postoji jasna podjela između javne i privatne sfere u kojoj javna sfera kao prostor političkog i društvenog djelovanja pripada muškarcima. Seksualnost i tjelesnost pripadaju privatnoj sferi gdje ih se regulira pomoću patrijarhalnih moralnih normi.

4. Postoje određene heterotopije seksualnosti, mjesta unutar kojih se seksualne prakse mogu prakticirati na način suprotstavljen uobičajenim moralnim normama. Okviri društvene prihvatljivosti ispoljavanja seksualnosti su mnogo manje rigidni za muškarce, gdje je seksualna transgresija društveno institucionalizirana kroz kulturu bordela. Ženska seksualnost ostaje svedena na žensku reproduktivnu ulogu i posve potisnuta iz javne sfere, a emocije vezane uz istu bivaju ili moralno osuđivane ili patologizirane kao znak duševnih bolesti ili mentalne devijacije.

Primjeri ovakvog emotivnog režima u životu građanske klase u Hrvatskoj devetnaestog stoljeća su brojni, a nalazimo ih u intelektualnim i književnim publikacijama i u svakodnevici građanskog društva. Udvaranje i odnosi između mladića i djevojaka bili su u građanskom društvu strogo ritualizirani. Iskra Iveljić navodi brojne primjere iz bontona pisanih krajem devetnaestog $\mathrm{i}$ početkom dvadesetog stoljeća. Pravila pristojnog ponašanja su tako nalagala suzdržavanje od bilo kakvih tjelesnih kontakata čak i između zaručnika:,Zaručnici su morali izbjegavati da budu sami,

314 Ibid, 19. 
morali su voditi pristojnu konverzaciju, što je značilo da nisu mogli razgovarati o svojim osjećajima, a tjelesni su dodiri morali biti vrlo čedni." 315

Nekad se i iz samih proskribiranih ponašanja mogu nazrijeti prakse u koje su se zaljubljeni upuštali. Djevojkama je tako bilo zabranjeno pisati ljubavna pisma, a ako su ih primile morale su ih odmah predati roditeljima ${ }^{316}$ no to nije sprječavalo intenzivnu razmjenu ljubavnih pisama koja obiluju izrazima karakterističnim za koncept romantične ljubavi. Pismo Vladimira Deželića njegovoj zaručnici Tonki tako obiluje izrazima poput „,angjeo...ideal...nada...ljubav” i reminiscencijama na njihova druženja uz glasovir gdje mu je Tonka šaptala „Tvoja...samo tvoja" ${ }^{317}$. Roman Mala Revolucionarka Marije Jurić Zagorke, čija je radnja smještena u vrijeme banovanja Khuena Hedervaryja, obiluje opisima ritualiziranog udvaranja. Djevojkama Nadi i Zlati obožavatelji tajno upućuju pisma preko posluge ${ }^{318}$ ili ih bacaju na prozor pretvarajući se da šeću ulicom pored njihove kuće. Takav ritual njihova starija rođakinja Elza naziva „Fenster promenadom“. 319

Identifikacija razuma s muškošću, a tjelesnosti s femininošću je česta u kulturi devetnaestog stoljeća te je prisutna u svim intelektualnim krugovima. Čak i rane feministkinja poput Mary Wollstonecraft kao problem ističu opsesiju djevojaka vlastitim tijelom što ih čini putenima $\mathrm{i}$ taštima, „životinjama jedino prikladnim za seraglio”. Mary Wollstonecraft smatra taj trend posljedicom lošeg odgoja koji naglašava brigu o fizičkom izgledu nauštrb duhovnog razvoja ${ }^{320}$. Povezivanje žena s putenošću i seksualnošću vidljivo je i u opsesivnoj kontroli kojima je društvo nastojalo podvrgnuti njihova tijela - od restriktivnih korzeta do strogog pravila kojima se propisivalo prihvatljivo tjelesno držanje i hod. Djevojkama je tako bilo zabranjeno „zibati se, obijesno poskakivati i oholo se previjati." ${ }^{321}$ Ukratko, bilo kakvo privlačenje pažnje na tijelo žene bilo je osuđivano, osim u onim primjerima kad je ono bilo pod strogom kontrolom i u službi muškog pogleda kao u primjerima bordela ili u medicinskom spektaklu histerije o kojem će kasnije biti riječi. Proces histerizacije ženskih tijela, koji je od početka prisutan u psihijatriji devetnaestog stoljeća (a intenzivirat će se šezdesetih i sedamdesetih godina devetnaestog stoljeća

315 Iveljić, 2007: 321.

316 Ibid.

317 Ibid.

318 Zagorka, 1988: 18.

319 Zagorka, 1988: 21-22.

320 Porter, 2003: 216-217.

321 Iveljić, 2007: 320. 
u Charcotovom spektaklu histerije) ima u korijenu upravo semantičko povezivanja žene $\mathrm{s}$ tjelesnim, a tjelesnog sa seksualnim. Histerizacija ženskih tijela koja je, prema Foucaultu, trodijelni proces kojim su ženska tijela analizirana kao „sustavi iskonski zasićeni seksualnošću” bio je integriran u sferu medicinskih praksi, te na kraju stavljen u organsku komunikaciju $s$ društvenim tijelom, obiteljskim prostorom i brigom o potomstvu. ${ }^{322}$ Histerizaciju možemo shvatiti i kao pokušaj legitimiranja antičkog aristotelovskog shvaćanja žene kao materijalnog principa u diskursu medicine. Ako je, naime, suvremena znanstvena i politička paradigma iziskivala biološku uvjetovanost razlika između spolova, patrijarhalna je ideologija morala naći legitimiranje rodne nejednakosti u tijelima. Bujanje javne sfere krajem osamnaestog i početkom devetnaestog stoljeća neprestano je dovodilo pitanje rodne ravnopravnosti na dnevni red, a modernizacija društva činila je stare transcendentalne izvore razlikovanja među rodovima sve manje uvjerljivima ${ }^{323}$. Zbog toga su rodne razlike morale iznaći svoju legitimaciju u biologiji i medicini, a histeričnost ženskog tijela je „otkrivena” kao strukturni temelj konstruirane biološke nejednakosti i „manje duševne vrijednosti” žena. Iako se ideja formirala na znanstvenom polju neuropsihijatrijske znanosti, već na prijelazu stoljeća hiperseksualizirana histerična junakinja napustila je medicinsku sferu i postala dijelom uvriježenog društvenog imaginarija kojim se prikazivalo žene. To dokazuju brojni primjeri iz književnosti; Ksaver Šandor Gjalski tako u svom romanu Đurđica Agićeva objavljenom 1889. opisuje ushit zbog pedagoškog zvanja svoje junakinje istaknuto somatizirajući njezine misli i emocije:„Nešto snažno, mlado i jedro sijevnulo bi joj u taki tren dušom, a nježno nad poslom prignuto tijelo čisto bi uvis poraslo."’324

Ne samo da u trenutku ushita Đurđica reagira svojim čitavim „nježnim” tijelom nego su i njezini dojmovi opisani epitetima kakvima se najčešće opisuju tijela (snažno, mlado, jedro). Ante Kovačić je svoju fatalnu Lauru definirao događajima iz prošlosti koji su svi redom seksualne prirode: začeta je silovanjem ${ }^{325}$, upušta se u incestnu vezu s ocem, sama je žrtva silovanja, a svoju motivaciju crpi iz libidne strasti za muškarcima. Na kraju do svoje osvete dolazi seksualnim sakaćenjem Ivičine supruge Anice. ${ }^{326}$ Ljudmila Borković iz Propalih dvora Janka Leskovara je pak književni lik junakinja na čije je emotivno stanje pod stalnim utjecajem muškaraca iz njezine

322 Foucault, 1998: 104.

323 Laqueur, 1990: 152.

324 Gjalski, 1964: 28-29.

325 Kovačić.2015: 66.

326 Ibid, 235. 
neposredne okoline, a njezine svakodnevne kretnje poput popravljanja ukosnice opisane su kao da odišu senzualnošću. ${ }^{327}$ Naravno, muški likovi u hrvatskoj prozi prijelaza stoljeća će najčešće u svojim akcijama biti vođeni razumom, ili barem čuvstvima i uvjerenjima koja pokazuju njihove mentalne snage ili slabosti, dok je kod junakinja aspekt tjelesnog opetovano naglašavan.

Postupno uklanjanje tjelesnog iz javne sfere proces je koji je kao dio „civilizacijskog procesa” opisao sociolog Norbert Elias. On na temelju izvora iz ranog novog vijeka bilježi sve veće sužavanje emotivne granice srama i sve više restrikcija vezanih uz odnos prema tijelu i seksualnosti. Tako od šesnaestog stoljeća nadalje golotinja u javnosti postaje sve manje prihvatljiva i raste razina društvenih inhibicija vezanih uz javno prikazivanje seksualnosti. ${ }^{328}$ Naravno, kao što je Foucault istaknuo, devetnaesto stoljeće ne odlikuje isključivo potiskivanje seksualnosti iz javne u privatnu sferu već i proizvodnja raznih hijerarhiziranih diskursa o seksualnosti. ${ }^{329} \mathrm{Na}$ prijelazu stoljeća se javlja proliferacija znanstvenih i medicinskih djela koja tematiziraju seksualnost od Krafft-Ebingove Psychopatia sexualis (1886) do Freudovih Tri eseja o teoriji seksualnosti (1905). Pored proliferacije znanstvenih diskursa, u određenim kontekstima seksualna transgresija poprima obilježja javnog spektakla: suđenje transvestitima iz visokog društva Ernestu Stelli Boultonu i Fredericku Fanny Parku probudilo je širok interes londonskog tiska i zainteresirane javnosti koja je iz tjedna u tjedan popunjavala sudnicu. ${ }^{330}$ Sličan interes pobudilo je i suđenje piscu Oscaru Wildeu. Seksualnost je tako u javnoj sferi postala prisutna ili kao znanstveni diskurs ili kao karnevalski spektakl transgresije. Uz marginalizaciju seksualnosti javila se i marginalizacija žena koje bivaju isključene iz rastuće sfere političke javnosti. Dok muškarci i adolescenti vrijeme provode u kavanama diskutirajući o politici, ${ }^{331}$ pisci bontona preporučuju da se takve teme izbjegavaju pred ženama jer bi to moglo „povrijediti njihovu tankoćutnost". ${ }^{332}$ Iako žene u devetnaestom stoljeću sve više javno i politički djeluju, njihovo javno djelovanje, kad nije ograničeno na prostor dobrotvornog rada ${ }^{333}$ smatra se transgresijom koju se ponekad ismijava i moralno osuđuje, a ponekad se smatra znakom duševne bolesti.

327 Leskovar, 1993:207.

328 Elias, 2000: 138-139.

329 Foucault, 1998: 30.

330 Kaplan, 2005: 89.

331 Iveljić, 2007: 321.

332 Ibid, 320.

333 Ibid, 290. 
Također, prostor bordela postaje prostor nesmetanog prakticiranja muške seksualnosti. Zagrebačke gradske vlasti u devetnaestom su stoljeću tako blagonaklono gledale na svijet bordela i krčmi koji se pružao današnjom Tkalčićevom ulicom i Kožarskom ulicom. ${ }^{334}$ Rad „bludilišta” bio je reguliran posebnim gradskim propisima, ali ona nisu bila na udaru formalnih zabrana. Nalazila su se na mjestu doticaja privatne i javne sfere i tvorila su određenu vrstu heterotopije za slobodno iskazivanje seksualnosti. Polujavni karakter bordela i razvratnih krčmi jedan je od primjera koji najbolje ilustriraju asimetrične poglede građanskog društva na seksualnost. Iako relegirana na privatnu sferu, o istoj se sve više govori kao o rubnom prostoru javne sfere, prostoru koji se nastoji iskoristiti za afirmaciju i legitimaciju patrijarhalnog poretka. Taj pogled prenijet će se i na psihijatriju: seksualno će u psihijatriji biti isključivo prisutno kao ilustracija tjelesnog i ,seksualne” prirode ženskog spola ili kao spektakl „devijantne” seksualnosti kojem je cilj potvrditi teorije o moralnoj i duševnoj degeneraciji društva.

\subsection{Spektakl histerije u Stenjevcu}

Pariški psihijatrijski zavod Salpêtrière postao je u drugoj polovici devetnaestog stoljeća prostorom seksualiziranog spektakla histerije. Neuropsihijatar Jean-Martin Charcot povezao je vlastiti znanstveni interes za traženje tjelesnog uzroka histerije s talentom za javne nastupe i organizirao medicinske demonstracije na kojima je javnost mogla uživati u prizorima seksualno nesputanog i erotiziranog ponašanja Charcotovih štićenica. Neke od njih, poput Louise Augustine Gleizes i „kraljice histerika” Marie Blanche Wittman postale su slavne zbog svojih izvedbi a sam Charcot uživao je u pariškom tisku komičnu i grandioznu titulu „Napoleona neuroza”. 335

Charcot je svoju praksu temeljio na bogatoj medicinskoj tradicija ,liječnika za živce” sedamnaestog i osamnaestog stoljeća. Ti liječnici su uglavnom bili praktičari koji su tretirali bogate slojeve plemstva i građanstva. Njihov novi uvid u histeriju ogledao se u tome da se uzrok iste prestao vezivati uz maternicu, te ga se počelo tražiti u „slabosti nervne konstitucije.” ${ }^{336}$ Dijagnostički i etiološki temelji histerije prvi su put detaljno opisani u sedamnaestom i osamnaestom stoljeću (sam termin vuče porijeklo iz antičke medicine). U devetnaestom stoljeću histerija postaje sveprisutna u medicinskom govoru i javnom diskursu - zavodi za umobolne ju bilježe kao dijagnozu, simptom ili uzrok oboljenja. Sanatoriji, toplice i lječilišta u medicinskim se

334 Ibid, 319.

335 Borossa, 2003: 19.

336 Scull, 2009: 82. 
časopisima reklamiraju kao mjesta koja nude obilje raznih tretmana za histerične poteškoće. ${ }^{337}$ Charcot dolazi na vrhuncu tog vala medicinskog i laičkog interesa za histeriju i pokreće trend intenzivnog istraživanja i eksperimentalnog tretiranja histerije koje će na kraju kulminirati u psihoanalitičkom obratu koji je stavio histeriju u središte novog psihodinamskog modela ličnosti.

Charcota je bitno spomenuti i zbog njegove uloge u konstruiranju histerije kao poremećaja. Njegovo tendenciozno čitanje ranijih medicinskih tekstova $i$,histeriziranje” povijesnih fenomena poput vjerskih ekstaza i zaposjednutosti demonima pomoglo je u prepoznavanju histerije kao poremećaja koji je bio oduvijek prisutan. Uz stvaranje kontinuiteta između nejasnih dijagnoza poput Galenovog „gušenja maternice” i histerije kakvu su opisali liječnici osamnaestog stoljeća, Charcot je uveo standardiziran set simptoma koji za tu dotad prilično različito opisivanu protejsku bolest.

Time Charcotov spektakl histerije dobiva novo značenje- nije se samo radilo o demonstraciji histeričnih simptoma pred auditorijem pariške javnosti već su Charcot, njegovi asistenti i njegove štićenice kroz te nastupe zajedno konstruirali novi diskurs o histeriji koji je istovremeno bio zagrnut aurom erotike i medicinskim autoritetom. Time je histerizacija ženskih tijela o kojoj govori Foucault zapravo konačno institucionalizirana u psihijatrijskom diskursu. Charcot je, doduše, prepoznavao histeriju kod muškaraca i to najčešće kod manualnih radnika nižeg socioekonomskog statusa, ${ }^{338}$ no to ne znači da sama histerija u Charcotovim demonstracijama nije imala rodni karakter. Kao prvo, Charcot je smatrao da histerija kod muškaraca ima drugačiji uzrok nego histerija kod žena. Kod žena, histerija je bila uzrokovana njihovom krhkom emocionalnom prirodom i nemogućnošću žena da kontroliraju svoje emocije, dok je uzroke muške histerije Charcot tražio u fizičkoj traumi živčanog sustava zadobivenoj radom, alkoholizmom ili seksualnim ekscesima. Prema tome, kako Elaine Showalter tvrdi: „histerične žene su patile od ekscesa vezanih uz feminina ponašanja, a histerični muškarci od ekscesa vezanih uz maskulina ponašanja." 339 Također, nizak socio-ekonomski status Charcotovih muškaraca implicirao je njihovu drugotnost, a traženje uzroka u alkoholu i seksualnom razvratu projiciralo je građanske moralističke predrasude o načinu života radničkih slojeva. Može se

337 Porter, 1993: 228.

338 Showalter, 1993: 335.

339 Ibid, 336. 
također reći da Charcotov tretman muških pacijenata nije imao obilježje seksualiziranog spektakla, kao što je to slučaj s njegovim „kraljicama histerije”.

Po Charcotu, histerija ima četiri prepoznatljiva stadija koja se uvijek javljaju u pravilnom slijedu jedan za drugim. Prvi je bio takozvani epileptoidni period u kojem bi pacijentica pretrpjela konvulzivni napadaj sličan epileptičnom. Njega je slijedio „period previjanja i grandioznih pokreta" u kojima bi pacijentica činila dramatične poze, od kojih je najpoznatija bila poza nazvana „arc de cercle” u kojoj bi se pacijentica savila unatrag tako da su joj samo vrh glave i pete doticale $\operatorname{pod}^{340}$. Charcot je tvrdio da može izazvati taj stadij pritiskom u predjelu jajnika, na mjestu koje je nazivao „histeriogenom zonom"341 i nazivao je te poze „klaunizmima” $\left(\right.$ clownisme $^{342}$. Treća faza sastojala se u usvajanju takozvanih „attitudes passionelles” u kojima bi pacijentice prikazivale poze nalik „razapinjanju” ili „,erotskoj ekstazi”. Nakon te faze slijedila bi faza karakterizirana halucinacijama i sumanutim mislima, nakon koje bi napadaj prošao. ${ }^{343}$

Hrvatski su se liječnici pri svojim opisima histerije često oslanjali na Charcota, a najraniji izvještaji o histeriji opisani u Liječničkom vjesniku datiraju iz osamdesetih godina devetnaestog stoljeća. Budući da je to vrijeme Charcotove najveće aktivnosti, one svjedoče o činjenici da su Charcotove demonstracije bile poznate liječnicima diljem Europe. Izvješće iz zavoda u Stenjevcu koje potpisuje doktor Rohaček a koje datira iz 1885. i koje pokriva prvih šest godina rada zavoda ne spominje histeriju kao mogući uzrok bolesti ili dijagnozu No već iduće godine u Liječničkom vjesniku kućni liječnik u Stenjevcu dr. Dragutin Forenbacher „objavljuje svoje predavanje o liječenju hystero-epileptične žene bromkalijem i hipnozom". ${ }^{344}$ Radilo se o njegovoj privatnoj pacijentici dvadesetogodišnjoj Ružici K. koja nije bila štićenica zavoda. Sam članak opisuje jedino prvu od četiriju Charcotovih faza histeričnog napadaja, a fokusira se više na hipnozu kao metodu liječenja nego na samu histeriju, iz čega se može zaključiti da je histerija sama po sebi bila dobro poznata hrvatskim liječnicima. Čini se da Forenbacher, u skladu s organicističkom tradicijom, nalazi hereditet uzrokom histerije, opisujući Ružičinu majku kao „veoma neurastheničnu bolujuć od histerije". ${ }^{345}$ Forenbacher će kasnije i demonstrirati jedan slučaj

340 Scull, 2009:124.

341 Showalter, 1993: 334 .

342 Scull, 2009: 124.

343 Ibid.

344 Forenbacher, 1886: 158.

345 Ibid. 
„hystero-epilepsije” na javnom predavanju. ${ }^{346}$ Općinki liječnik iz Jaske Niko Selak pak sljedeće godine daje detaljan opis slučaja histerične rodilje koju je također liječio hypnozom: „Arc de cercle bio je na dlaku spodoban onome što se vidi na slikah iz Saltpêtrière, pak i za takozvani Clownismus nikad boljeg primjera nisam vidio." ${ }^{3^{347}}$

Izbor termina i direktna referenca na Charcotove javne pokuse, kao i izbor hipnoze kao metode liječenjan govore o tome kako se predodžba o histeriji u hrvatskoj medicini formirala pod utjecajem Charcota. Ona će biti opisivana sličnim terminima i biti tretirana pod utjecajem devetnaestostoljetnih nazora o rodu, te na identičan i podjednako spektakularan način. Dapače, Selak na kraju izlaganja kaže da se nada da će moći predstaviti svoju pacijenticu drugim liječnicima i na njoj „na umjetan način izazvati iste grčeve upiranjem ili trenjem po kojoj histeriogenoj zoni” ${ }^{348}$. Također, Selak kao provincijski liječnik svjedoči da je „za vrijeme službovanja kod dra Mullera vidio više od 50 histeričnih žena“, što ponovno dokazuje dobro poznavanje charcotovske histerije u hrvatskoj medicinskoj zajednici. ${ }^{349}$ Selak će i u ostalim svojim člancima pokazivati izniman interes za histeriju, a napisat će i poduži tekst o hipnozi kao metodi liječenja. ${ }^{350}$ Zanimljivo je da se na stranicama Liječničkog vjesnika javljaju brojni oglasi koji reklamiraju ljekovite vode i kupališta kao sredstvo za liječenje histerije. ${ }^{351}$ Osobit stav o histeriji izražava Ivan Žirovčić. Žirovčić se upušta u definiranje histerije na kraju svoje studije slučaja Ane Schier koja će biti prikazana u nastavku ovog poglavlja. I premda je histerija zabilježena i kod muškaraca, Žirovčić ju ovdje opisuje kao poglavito žensku bolest koja upravo zbog toga vuče ime od riječi za maternicu. ${ }^{352}$ Žirovčić, u svom povezivanju histerije s rodom odlazi još korak dalje od Charcota i europskih psihijatara i navodi kako je histerija „zbirka ženskih slabosti u pojačanom i iskrivljenom obliku: nestalnost, hirovitost, razdražljivost, samoljublje, taština, lažljivost, okrutnost, podlost, ujedljivost, himbenost, nepromišljenost, lakovjernost, uporna tvrdoglavost, kićenost, raznježenost i boležljivost." ${ }^{353}$ Također, umjesto Charcotovog preciznog opisa četiriju distinktivnih faza histerije i niza diferencijalnih simptoma

$346 \mathrm{LV}, 1892: 8$.

347 Selak, 1887: 114.

348 Ibid: 116.

349 Ibid.

350 Selak, 1890: 170.

351 Na primjer oglas iz LV, 1888. str. 48 ili Stojanović, 1888: 140.

352 Žirovčić, 1905a: 275.

353 Ibid, 275-276. 
(poput „globusa hystericusa”, osjećaja gušenja u grlu koji je svojstven ranim fazama histeričnog napadaja $)^{354}$, Žirovčić u maniri starije medicinske tradicije ponovno opisuje histeriju kao protejsku bolest koju je moguće prepoznati na temelju bilo kojeg seta simptoma, pa tako kaže da „ne ima bolestnoga pojava koji se ne bi mogao u obliku hysteričnom prikazati." ${ }^{355}$ Čini se da je, nasuprot Charchotu i nekim drugim hrvatskim liječnicima Žirovčić bio uvjeren da od histerije oboljevaju jedino žene. Čak i kad govori o epidemijama masovne histerije, on isključivo govori o ženama kao akterima takvih pojava:

„Hysterične osobe vrlo su podatne društvenom uplivisanju, one su sugestibilne. Jedna hysterična osoba može množinu ženskih svojim vladanjem zaraziti, na oponašanje potaknuti; tako nastaju čitave hysterične epidemije" ${ }^{\text {356 }}$

Žirovčić se također osvrće na izgled i ponašanje histeričnih žena. One se odlikuju ,ako ne baš ljepotom, to nekim osobito zamamljivim čarom svoga bića kojim umiju okolinu za sebe pridobiti" ${ }^{357}$. Nadalje, one su sklone spletkarenju i fantazijama i raznašanju najnejerojatnijih laži koje prenose „polusvjesno” brkajući ono što su čule čitale ili sanjale sa stvarnim događajima. Kao takve one često pobuđuje sažaljenje i zanimanje ljudi i senzaciju. ${ }^{358}$

Za Žirovčića ključno je obilježje histerije prenaglašenost pojedinih crta ličnosti koje on smatra obilježjima ženskog karaktera. Dapače, u skladu s tada poznatim nazorima o „graničkom području" u kojem egzistiraju hereditarne klice duševnih bolesti, Žirovčić pretpostavlja mnogo različitih stupnjeva histerije: ,...počam od obične ženske ćutljivosti, strašljivosti, plačljivosti...pa sve do teškog hysteričnog izopačenja i do hysteričnih psihoza"359. Ako je histerija prisutna u nekim običnim, tradicionalno „ženskim” duševnim osobinama koje su kod žena histeričnog karaktera jednostavno prenaglašene, onda Žirovčić zapravo podrazumijeva da svaka žena u sebi nosi klicu histerije. Sam histerija kao duševno oboljenje je zapravo samo prenaglašenost femininih crta karaktera. Takvo gledanje na rod poistovjećuje femininost s duševnom patologijom podrazumijevajući maskulini um kao idealnu sliku duševnog zdravlja.

354 Scull, 2009: 14.

355 Žirovčić, 1905a: 276.

356 Ibid.

357 Ibid.

358 Ibid.

359 Ibid. 
Primjeri iz Stenjevca pokazuju kako je takvo poimanje histerije prenošeno i na tijela štićenica kojima nije bila postavljena dijagnoza histerije. U stenjevačkom zavodu postojale su brojne dijagnoze povezane s histerijom. U povijestima bolesti se, uz histeriju, tako nalaze „hysterička smetenost”, „hystero-epilepsija”, „hysterica”, „paranoia hysterica”, „exaltatio hysterica”, „psychosis hysterica” i ,mania hysterica”. Histerija je prepoznata isključivo kod štićenica zavoda i ne navode se slučajevi Charcotove „muške histerije”. Ipak postoji jedan slučaj histerije kod muškarca nastale uslijed fiziološke traume naveden u Liječničkom vjesniku koji nije tretiran u zavodu. ${ }^{360}$ Jednom osamnaestogodišnjem štićeniku iz Odre, dijagnoza „hysterije” izmijenjena je u epilepsiju $^{361}$. Liječnici su u teoriji i u praksi dopuštali postojanje histerije kod muškaraca, ali jedino bi žene sa sličnim dijagnozama bile institucionalizirane. . Ana B., neudana švelja iz Mitrovice primljena je s dijagnozom „exaltatio hysterice” u ožujku 1895. Dijagnoza, dana u liječničkoj svjedodžbi je ubrzo izmijenjena u „amentiu”. Za štićenicu je rečeno kako je pri prijemu „dočekala liječnike afektirano obučena, ista takova u kretnjama i govoru, odmah se predstavi i poče pripovijedati da je ona zapravo iz plemićke madjarske obitelji, ona je rodjena grof. Bačani ${ }^{362}$, ona da je nezakonito dijete madjarskog grofa Bačanija i sudbina dovela ju u kuću učitelja B....izraz lica inteligentan, pogled erotičan. Kod istraživanja postaje vrlo erotična." ${ }^{363}$. Liječnici su iz liječničke svjedodžbe dobili informaciju o štićenici kao „histeričnoj”. Nakon toga opis u „statusu preasensu” započinje neuobičajeno slikovitim izrazom: štićenica je liječnike „dočekala" čime se implicira njena podređenost i određena vrst žudnje za maskulinom figurom liječnika. Odmah zatim opisuje se njena odjeća (kao da se specifično, ,afektirano” odjenula za liječnike) i njene kretnje i govor, koji narira njezino imaginarno porijeklo kao „grofice Bačani”. Također, liječnik se ne uspjeva dugo zadržati na opisu Aninog lica bez da naglasi „erotičnost” njezinog pogleda. Opisi stanja štićenika i štićenica pri prijemu u zavod bili su, kako smo ranije vidjeli, zaodjeveni u diskurs kojim se nastojala postići objektivnost i znanstveni karakter. U slučaju „histerizirane” Ane B. on se posve fokusira na njezin „,afektiran” i „erotičan” izgled. Kao što se može vidjeti, opisi histeričnih štićenica štićenica bili su izrazito seksualizirani

Klinički zor liječnika ovdje ne traži hereditarne, tjelesne stigme i ne zamara se navođenjem točnih mjera obujma glave, već traži stigme izražene ženske seksualnosti. Sličan tretman

360 Selak, 1888: 169.

$361 \mathrm{KPV}, 1894: 1995$.

362 Pravo prezime štićenice, koje izostavljam iz etičkih razloga nije Bačani.

$363 \mathrm{KPV}, 1895: 2630$. 
erotizacije ženskih tijela nalazimo i u drugim povijestima bolesti štićenica. Seljakinja Mara, s dijagnozom „hysterične smetenosti” će tako u svojoj liječničkoj svjedodžbi biti opisana samo jednom riječju „erotična” a stenjevačka povijest bolesti će istaknuti kako joj je „uvijek spolno druženje na pameti.” Bilješka nakon te će reći da smatra „izvanjski svijet neprijateljskim, navlastito u pogledu spolnih napada." ${ }^{" 364}$ Bilješka u opisu Kornelije, sobarice iz Petrinje, navodit će kako je štićenica ,pomalo slaboumna, a k tome nagnuće imala na razkošni i bludni život. Bijaše i služavka i sobarica samo da po volji može ljubakati se." ${ }^{365}$ Kristinea H., pučka učiteljica iz Siska, u Stenjevcu je proboravila punih četrnaest godina, od 1897. do svoje smrti u 1911. Prvotna dijagnoza bila je „hysteria”, no kasnije joj je dijagnoza promijenjena u „Dementiu secundariu" što je naziv koji se koristio za neizlječive duševne bolesti koje nastaju kao posljedice neizlječene ranije duševne bolesti. Kao uzrok bolesti navodio se njezin „naporan školski rad” zbog kojeg je oboljela na živce. ${ }^{366}$ Uspostavivši vezu između intelektualnog zanimanja štićenice i njene bolesti, liječnik ju je upitao ,je li možda imala kakav ljubavni odnošaj" ${ }^{367}$ te zabilježio njezinu reakciju koja se sastojala od pokrivanja lica rukama i crvenjenja. Tijekom dugogodišnjeg boravka u bolnici mnogo je pažnje posvećeno Kristininim histeričnim napadajima u kojima je nasilna i trga odjeću sa sebe. ${ }^{368}$ No, na pojedinim mjestima se opet nalaze seksualizirani opisi dani u kratkim rečenicama: „Namiguje liečnikom. Počinje drhtati. Kaže da više nije djevica.”

Jedan od najbolje dokumentiranih slučajeva histerije bio je slučaj Terezije H. „udovice trgovca i ubogarke" koja je u Stenjevcu boravila dvaput: prvi put od 8. rujna 1908. do 4.srpnja 1910. i drugi put od 2. kolovoza 1910. do 3. kolovoza 1911. Oba puta, majka ju je odvela kući nakon poboljšanja u stanju. U toj opsežnoj povijesti bolesti nalazimo priču žene iznimno zainteresirane za aktualna burna politička zbivanja, a povijest bolesti sadrži i njezin autentični neposredovani glas u pismima koja je slala članu zagrebačkog poglavarstva Zlatku Hotkiću, Slavku Cuvaju i gradonačelniku Milanu Amrušu. Također, povijest bolesti sadrži sve najistaknutije primjere psihijatrijskog diskursa o histeriji: žensku seksualnost koja se probija u „mušku” sferu političkog, te uvriježenu predodžbu histerične pacijentice kao žene koja se iscrpljuje intelektualnim radom, emocionalno je nestabilna, ali ju odaje buntovnost i silovitost karaktera ${ }^{369}$

$364 \mathrm{KPV}, 1895: 2216$.

365 KPV, 1895: 1435.

$366 \mathrm{KPV}, 1897: 3071$.

367 Ibid.

368 Ibid.

369 Showalter, 1993: 329. 
Terezija je u Stenjevac dovedena na preporuku liječnika iz Virja gdje je boravila kod majke, nakon suprugove smrti. Čini se da je tridesetogodišnja Tereza bila iz skromne, ruralne sredine i da je njezin brak sa zagrebačkim trgovcem predstavljao znatan uspon na društvenoj ljestvici, dok je njegova smrt i povratak u sredinu u kojoj je odrasla shvaćen traumatično. Kotarski liječnik je, poštujući propisanu proceduru za pisanje liječničkih uputnica opisao njeno Terezijino ponašanje prije primanja u zavod, naročito se osvrnuvši na njezino obrazovanje:

„Ona potiče od seljačkog stališa, svršila samo 4 razreda pučke škole, a odkad se udala počela se je po gradjanski nositi, novine i svakojačke knjige čitati. Ona je bila od djetinjstva uvjek zdrava, menstruirala je u 14 godini, a udala se u 17 godini za jednoga trgovca. Ona je bila već onda eksaltirana, utvarala si da ona nije za seljaka, već za gospodina. Nakon smrti supruga htjela se je više gospode udati, koji nisu na nju ni izdaleka mislili, a ona je komu god pisala ljubavne listove, makar nije dobila nikad odgovora. Već godinu dana pripovjeda ona okolo da će ju najprvi čovjek Bosne i Hercegovine dr. Ivica Elegović ženiti. Osim toga piše ona već dulje vremena našem obć. načelniku g. Andriji Ljubiću ljubavne listove da se hoće za njega udati, a potpiše jedanput Tereziju Elegović. Drugi put Tereziju Ljubić. Susjedi kažu da se ona u sobi gola svuče zove dečke, da ju gledaju, drugiput pak obuče se u bijelo odijelo, a bježi okolo po ulicama ili pako ide u crkvu, istupi gore $\mathrm{k}$ oltaru i pogleda u narod, kao da je ona svećenik." ${ }^{370}$

Charcot je histeriju proučavao u kliničkom kontekstu. Često je podvrgavao svoje štićenice hipnozi i sugestiji kako bi pred publikom demonstrirale teatralno i seksualizirano ponašanje. Njegov znanstveni rad bio je obilježen nastojanjem da svede gomilu raznolikih simptoma i duševnih stanja (od ponašanja svojih štićenica, do povijesnih primjera vjerske ekstaze na renesansnim slikama) na univerzalno prepoznatljiv sindrom hystero-epilepsije. ${ }^{371}$ Nasuprot tome, Terezijino je ponašanje bilo promatrano u kontekstu njezine svakodnevice, i ona nije mogla producirati jasno razlučiv niz simptoma. Kako bi uklopio duševno stanje svoje pacijentice u predodžbu histerične osobe kotarski liječnik poseže za selektivnim opisom njenog ponašanja kako su mu ga prenijeli njezini susjedi i obitelj. Terezija je tako opisana kao žena koja se želi (ponovno) udajom izdići iznad svog statusa što je bilo u skladu s opisom histerije kao bolesti koja naročito pogađa pretjerano ambiciozne žene. Također vidljive su deluzije, koje je Charcot opisao

$370 \mathrm{KPV}, 1911: 7845$.

371 Scull, 2009: 124-125.

118 
kao jednu od faza histerije. Liječnik pridaje pažnju i bijelom odijelu i ,istupanju naprijed” u crkvi, što je možda čitano kao simptom histerične ekstaze. Znakovito je kako su glasine o Terezijinom ekshibicionističkom ponašanju stavljene odmah pokraj njezinog istupa u crkvi, što navodi na zaključak da je liječnik možda htio tvoriti vezu između simptoma vjerske i erotske ekstaze.

Osim opisa ponašanja, kotarski liječnik prenosi i Terezijine riječi:

„Kod pregledbe ponaša se ona preko mjere exaltirano. Brblja mnogo, brzo i nesavjestno, traži od načelnika oružanu silu, detektive i vojsku da tjeraju njezinu djecu u školu, jer njezin sin neće da ide u školu, a ima pameti kao dr. Kršnjavi, a postat će inšpektor leptira i žaba. Ako se njezinom zahtjevu udovoljiti neće obratiti će se na brata dra Amruša koji hoće već u našoj obćini red obnašati. Obćina će se razpustiti kako i ruska duma, a nastat če revolucija. Dr. Ivica Frank je prvi i najljepši čovjek u Hrvatskoj a tko nije za njega taj će glavom nastradati." ${ }^{372}$.

Prije navođenja njezinog govora, liječnik ih na retoričkoj razini diskvalificira kao ,...brzo i nesavjesno brbljanje” naglasivši pritom „exaltiranost” njezina ponašanja. Time su njezine riječi određene kao emotivne čime ih se, unutar emotivnog režima obilježenog pozitivnom normativizacijom racionalnosti diskvalificira, a samo emotivno raspoloženje štićenice određeno je kao „prekomjerno”. Osim toga, diskvalificirajući Terezijin govor kao „brbljanje”, liječnik daje jasan subjektivan komentar izrečenog i oduzima njezinim riječima ikakvu istinsku važnost. No, navođenje tog govora nije sasvim nevažno, inače bi on bio izostavljen. Terezijine riječi su upisane u klinički odnos moći i prisvojene od strane liječnika kao demonstracija bizarnosti njezinih kognitivnih procesa. Opisan kao besmisleno brbljanje njezin iskaz nije više samo niz slikovitih pritužbi na ponašanje vlastitog djeteta ili hiperboličan izraz frustracije političkom situacijom. On zadobiva klinički značaj, kao simptom patološkog duševnog stanja i retoričko sredstvo za dodatnu legitimaciju asimetrija moći upisanih u odnos Terezije i liječnika. Ana Antić je u svojoj analizi međuratne i ratne psihijatrije u Jugoslaviji pokazala kako su slične diskurzivne prakse diskvalifikacije govora štićenika služile kako bi potvrdili organicističke i determinističke modele duševne bolesti, te naglašavale razliku između obrazovanih i racionalnih psihijatara i njihovih ,primitivnih” i „degeneriranih” štićenika i štićenica ${ }^{373}$

$372 \mathrm{KPV}, 1911: 7845$.

373 Antić, 2017: 69. 
Po dolasku u Stenjevac, Terezija je pregledana gdje je njen način govora opisan sličnim izrazima: „Po prijemu mirna, prilikom pregleda živahna Nije nikad čula da je tko u familiji bio lud, ali joj je mati grozna baba, grđa nego ruska revolucija. Ona ima sa majkom proces radi grunta.Sve to ona pripovjeda vrlo brzo, oštro, afektirano, preokreće očima, drži se zanosno. U svom pripovjedanju prepliće ideje progonstva i veličine. Ljudi su joj neprijatelji, načelnik u Virju ju je proglasio umobolnom, a on je hoće ženiti. Već njezin pokojni suprug joj je rekao, samo ti čitaj romane i odgajaj djecu na taj način onda ćeš doći u sanatorij gdje će te 4 liečnika izpitivati." ${ }^{374}$

Stenjevačka povijest bolesti prepoznaje zanosno držanje kao simptom bolesti, a znakovito je da se navodi prenošenje riječi Terezijinog pokojnog supruga, gdje Terezija sama misli kako je u zavod (ona ga naziva sanatorijem, koristeći riječ koja je u 19. stoljeću obično označavala elitniju, privatnu ustanovu) dospjela radi svojih neuobičajenih životnih navika. U Stenjevcu se puno pažnje posvećivalo Terezijnom čitanju političke literature. Tri dana nakon prijema navodi se kako Terezija želi čitati „Hrvatsko pravo, Napried i Nastićevu brošuru” koja je poslužila kao dokaz na veleizdajničkom procesu. Čini se da će Terezijin interes za politiku i njezina ljubavna opsesija Josipom Frankom postati središtem psihijatrijskog narativa o njezinoj bolesti. Također, često će se isticati njezina želja da se ponaša na način nesvojstven njezinom društvenom položaju. $\mathrm{Na}$ primjer, u jednoj se bilješci navodi kako upotrebljava brojne tehničke izraze ,iskrivljene i na krivom mjestu." ${ }^{375}$

Prolaskom vremena, tako njezine maštarije o moći postaju elaboriranije, dok opisi liječnika naglašavaju njihovu teatralnost i seksualiziranost. Čini se da je Terezija opsjednuta brojnim moćnim muškarcima iz političkog života:

„Ne radi ništa - već šeće kao paunica po razdjelu ili vrtu- čita samo novine, traži ih svaki dan i ljuti se, da će umrijeti ili poluditi, ako neće svaki dan dobiti novina. Jer ona mora čuti, što radi njezin premoćni Rauch i veleučeni dr. Josip Frank. Frank, Ivica Elegović i ban su je posjetili i ona je određena za hrvatsku kraljicu. Ona je njihova žrtva i samo je ovdje u zatočju- ali tad će

$374 \mathrm{KPV}, 1911: 7845$.

375 Ibid. 
još slavnije izaći iz tog zatvora kao kraljica- biti će okrunjena zlatnom krunom, stanovat će u zlatnom dvoru s kraljem Rauchom- a uz nju će biti uvijek Ivica Frank i Elegović."376

Njezino ponašanje prema liječnicima se često opisuje kao „erotično”. Terezija često traži od liječnika bolju hranu te se ,mazi i vješa po liječnicima”. Opisi njezinog fizičkog izgleda su također česti i u njima ju se opisuje kao „liepu žensku koja se osebujno i gizdavo oblači”. ${ }^{377} \mathrm{Ne}$ dobije li što želi, niže uvrede koje imaju distinktivno politički karakter i odražavaju opsege političke polarizacije hrvatskog društva na prijelazu stoljeća:

„Ako joj se želje ne ispune, uzruja se žestoko, stane vikati, a znade biti i veoma prosta. Tad psuje veoma frivolno kralja, veli on nije kralj, jer nezna niti hrvatski- već će biti Rauch uz Franka svemoćni kralj ujedinjene Hrvatske. Psuje Pokretaše, Slavoljube na najgrublji način, jer će oni prodati Hrvatsku. Ona bi ih još više povješala-nego će ih biti povješano. Piše uzastopce listove čas milom Rauchu - prevažnom Franku - Elegoviću ili Ivici Franku itd. - sadržaj tih listova je obično zahtjev da se odavde oslobodi ili nada u budući ljepši život kao kraljica. Katkad je čudi, što se njezini spasitelji za nju tako slabo brinu. Tad svali svoj gniev i na njih." 378

Čini se da liječnici udovoljavaju Terezijinoj želji za novinama. Bilješka nakon njezinog izljeva bijesa govori o Terezijinom živahnom interesu za veleizdajnički proces. Također, čini se da liječnici, barem na razini opisa pristaju na njezinu igru - u kasnijim zabilješkama prestaju se na nju referirati kao na „bolesnicu” i nazivaju ju „kraljicom”. Ta ironična kvalifikacija narušava dosadašnji prividno objektivni ton povijesti bolesti i dodatno literarizira već ionako romantizirani opis njezinog ponašanja. Kao da svrha povijesti bolesti više nije u kliničkom opisu simptoma već u senzacionalističkom praćenju Terezinih ekscentričnosti. Kako se radilo o internom dokumentu kojeg su koristili jedino bolničari i liječnici, tituliranje dobiva obilježje svojevrsne interne šale. Moglo bi se čak reći da je tom promjenom Tereza uistinu pretvorena u „kraljicu” Stenjevca, te se odlučuje povlađivati njezinoj fantaziji. No nedugo nakon te promjene u odnosu Terezija čini i politički zaokret:

„Kad je saznala da je Rauch pao - bila je isprva neutješiva-plakala... Sad će se Hrvatska sva povlašiti- prokleti pokretaši će domovinu izdati itd. Za čas ali okrenula list - neće više čitati Hrvatskog Prava već traži Pokret- jer su to pravi ljudi. Rauch, Frank su je i onako zaboravili, 
ma da je ona njihova žrtva. Želi im da propadnu. „Kraljica” se gubi vječno u politici, svojom osobom se bavi i traži slobodu. Ne radi ništa već se samo cifra." ${ }^{\text {"379 }}$

U povijesti bolesti se ne navodi čime je ovaj preokret motiviran, no čini se da ga je sama štićenica argumentirala činjenicom da joj aktualni politički moćnici nisu pružili pomoć koju je od njih očekivala i na koju je apelirala u pismima. Ubrzo nakon Terezijinog odricanja lojalnosti Josipu Franku i njegovoj Čistoj Stranci Prava, nastupa poboljšanje njezinog duševnog stanja. Često se raspitkuje za političku situaciju, navodeći da nije čitala novine zadnjih mjesec dana, a u jednom trenutku pita liječnika ,kad će je već jednoć tatica velmožni pustiti kući. Ne može već živiti medju ovima jopcima". Zanimljiv je izbor riječi koji Terezija koristi obraćajući se liječniku kao „velmožnom tatici”. Čini se da je, pred kraj svog boravka prestala maštati o zaštiti moćnih političara i prihvatila zavodskog ravnatelja kao „velmožnog” oca potčinivši se njegovoj simboličkoj patrijarhalnoj moći Puštena je kući kao poboljšana, a u zavod se htjela vratiti već nakon mjesec dana. Čini se da je razlog povratku bio osjećaj odbačenosti od okoline. Terezija se pojavila u „svojoj svijetloj visokoj opravi” i „,veličanstvenom držanju”. ${ }^{380}$ Njen drugi boravak uglavnom dokumentira njezinu nemogućnost nošenja sa stigmom koju je iskusila zbog svog boravka u zavodu i nekadašnjeg ponašanja. Terezija, ovaj put prilično suosjećajnog liječnika naziva „taticom” i govori kako „tko je jednom bio u ludnici za njeg nije da ide van među ovaj zlobni svijet." ${ }^{\text {"21 }}$ Iako se stidi svog ponašanja čini se da, kad je sama nastavlja živjeti fantaziju o političkoj moći:

„Kad je liečnik nagovorio odgovarala je uvijek vrlo promišljeno, birano a kad bi joj čovjek spomenuo njezinu ljepotu, gizdavost ili nazvao ju "kraljicom" tada je obično uvrijeđeno odbila, no kad je bila sama a mislila da je se ne motri tad se vidilo kako sama sobom govori, kako se smješka, klanja, prima deputacije i kako dostojanstveno prolazi mahnuvši kadšto blagohotno rukom nekoj umišljenoj valjda osobi." ${ }^{, 32}$

Godinu dana nakon povratka u zavod, Terezija H. je otpuštena kao poboljšana. Povijest bolesti sadrži i tri njena nikad odaslana pisma napisana tijekom 1908. i 1909. godine kad su njene fantazije o Rauchu i Josipu Franku bile najintenzivnije, Prvo je naslovljeno na Zlatka Hotkića, senatora kod zagrebačkog poglavarstva. U navedenom pismu Terezija moli novac za opravu i svoju zamolbu ilustrira pomalo bizarnim obećanjem koji se tiče njezinog angažmana:

379 Ibid.

380 Ibid.

381 Ibid.

382 Ibid. 
„Stoga molim da mi naručite kod Božičevića 1 opravu crnu, finu i crne cipele kod (nečitjivo) tvornice i bledi šešir kod Bratiček ili Klompfa i biti će dosta za te stvari 100 forinti.Dajem vam na znanje da se u buduće neću baviti politikom i zaljubljivanjem nego pragmatikom i uredbami ustavnih reformih koje su u Hrvatskoj na žalosti jako zamršene. Budem se posvetila žurnalistici i programu Programu Spasitelja Monarhije Privatnomu i Putovanju na automobili i mislim da će ovo biti najbolje i uvjeravam samu sebe da će mi svirati Sirena na Margiti. Ovaj Sanatorium skrivio mi je Frankov doktor više nemam nikakve političke mozgovne opne samo mladu grešku na srcu političkomu.",383

Čini se da je tijekom boravka u zavodu Tereza sama počela procjenjivati svoj interes za politiku kao simptom bolesti. Njezino drugo pismo adresirano je na tadašnjeg podbana Slavka Cuvaja i gradonačelnika Milana Amruša. Ono se uglavnom sastoji od Terezijinih zahtjeva, pa tako traži da podban Cuvaj prenese Rauchu da Terezija potrebuje opravu, šešir, nakit cipele i donje rublje. Također, Terezija u tom pismu naglašava kako smatra svoje zatočenje u Stenjevcu oblikom političkog progona i uspoređuje se sa Zrinskim i Frankopanom:,Ja sam ovdje za velike i ozbiljne stvari za domovinu, nisam za insulte nego za mučenike Zrinjski i Frankopane i moga tatu Pavicu Raucha." 384

U drugom, kraćem pismu upućenom Pavlu Rauchu, Terezija moli bana da ju izvede iz Stenjevca i traži „ekipažu, adjutanta i banska kola da ju isprate u Zagreb." ${ }^{385}$

Povijest bolesti Terezije H. Govori o ženi koja je zahvaljujući svom braku s trgovcem doživjela određeni uspon na društvenoj ljestvici. Nakon udaje živjela je u Zagrebu i tako mogla biti neposrednim svjedokom političkih previranja s prijelaza stoljeća. Povratkom u Virje izgubila je financijsku sigurnost i vezu s političkim životom, te se vratila u okolinu s kojom je bila u sukobu. Njezina pisma i izjave koje su liječnici zapisali pokazuju da je Terezija žudjela za zaštitom moćnog muškarca, vjerojatno misleći da bi time povratila ekonomsku sigurnost. Sve njezine fantazije vrte se oko političke moći, pa se čak i njezino „erotično ponašanje prema liječnicima” može gledati kao ponašanje motivirano istim željama. Dok je Terezija maštala o životu u kojem se upravo ona nalazi u središtu pažnje poznatih političkih ličnosti, slučaj Ane Schier, koja se u Stenjevcu našla zbog sudskog vještačenja, našao je odjek u javnosti.

383 Ibid.

384 Ibid.

385 Ibid. 
Slučaj je objavljen kao studija u sedmom broju Liječničkog vjesnika iz 1905. godine pod naslovom Hysterična žena pred sudom radi klevetanja. Njegova zanimljivost leži upravo u činjenici da u njemu vodeći hrvatski psihijatar kraja devetnaestog stoljeća, doktor Ivan Žirovčić, iznosi svoje poglede na histeriju. Također, dok je sukob između Terezije i njezine okoline tek površno ocrtan u liječničkoj svjedodžbi, Žirovčić detaljno dokumentira sudski slučaj koji se vodio protiv Ane Schier.

Priča o Ani Schier, rođenoj Škert počela je nakon smrti njezinog oca Josipa Škerta. Josip Škert je bio umirovljeni šumar koji je u Donjem Miholjcu živio skromno. Prije umirovljenja, radio je na kao revirni šumar na posjedu plemićke obitelji von Prandau u Poganovcima ${ }^{386}$. Imao je više odrasle djece koja su se odselila od njega, tako da mu je kućanstvo vodila Otilija Magnani uz pomoć svoje kćeri Marije. Ana Schier, u to vrijeme stara trideset i sedam godina je živjela u Budimpešti kao krojačica, netom razvedena od svog supruga, trgovca Karola Schiera ${ }^{387}$. Njegova najstarija kći, Terezija udala se 1884. za književnika (tada učitelja na posjedu baruna Prandau) Janka Leskovara kojemu je Ana Schier kasnije pisala iz Stenjevca moleći ga da se zauzme za nju $\mathrm{u}^{388}$. Škert je umro 27. lipnja 1901. od srčanog udara u sedamdesetoj godini. Ubrzo nakon toga, Ana Schier je optužila Otiliju i Mariju Magnani da su otele njezinom ocu štedioničku knjižicu nakon što su ga otrovale arsenom koji su nabavile od poštanskog činovnika Ljudevita Wuchse, Marijinog zaručnika. ${ }^{389}$ Nakon početka istrage, Ana Schier iznosi jednu za drugom sve senzacionalnije optužbe, pa tako između ostalog optužuje kotarskog suca da je uništio oporuku J. Škerta, krivotvorio isprave i zatajio zakonite nasljednike i općinskog liječnika Božidara Katušića da je „dao prije vremena zakopati mrtvo tijelo Josipa Škerta da se time prikrije otrovanje." 390 Ubrzo je tijelo Josipa Škerta ekshumirano, no novine su pisale kako je ,ekshumacija Škertovog trupla bila samo komedija” i da je ,podmetnuta druga lješina." ${ }^{391}$ Istraga protiv Otilije i Marije Magnani je ubrzo obustavljena, ali su njih dvije i Wuchsa počele dobivati anonimna prijeteća

386 Milošević, 2016: 42.

387 Budapest Főváros Levéltára.1906. Civil law cases: HU BFL - VII.2.c - 1906 - V.0530: 1- 7.

388 Žirovčić, 1905a: 274.

389 Ibid, 271.

390 Ibid.

391 Ibid. 
pisma, a zbog glasina koje su u dalje objavljivane u novinama, Wuchsi je prijetilo otpuštanje $\mathrm{s}$ mjesta poštanskog činovnika. ${ }^{392}$

Svi koje je Ana Schier optuživala, podigli su protiv nje tužbu zbog „zločinstva potvore”393 i Schier je odvedena u istražni zatvor u Osijeku. Od tamo je 12. rujna 1904. upućena na psihijatrijsko vještačenje u Kraljevski i zemaljski zavod za umobolne u Stenjevcu. ${ }^{394}$ Kao glavni razlog provođenja psihijatrijskog vještačenja nad Anom Schier navedena je tvrdnja da njezine optužbe „ne stoje”. To je prilično čudno, budući da su druga forenzička vještačenja koja su se vršila u Stenjevcu uglavnom bila potaknuta bizarnim karakterom zločina ili čudnim ponašanjem optuženog prije ili nakon zločina. Žirovčić pak, kao kriterij navodi samu neistinitost optužbi koje je Ana Schier iznijela. Prilikom prijema u Stenjevec, Schier je bila u sedmom mjesecu trudnoće. Pri utvrđivanju statusa preasensa liječnici su detaljno opisivali njezinu trudnoću, ali i tražili karakteristične hereditarne stigme koje bi ukazivale na duševnu bolest. Tako se, u skladu s uvjerenjima psihijatara somaticističke škole poput Maudsleyja osobita pažnja ukazuje obliku ušiju i nosa Ane Schier. Za uši se kaže da su „malene, nejednake i deformirane”395, a za nos da je

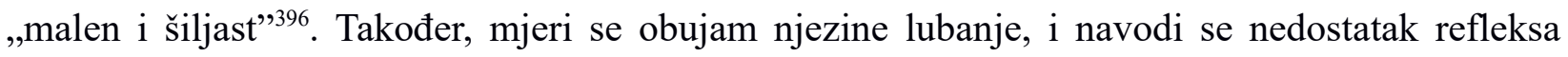
mekog nepca. U bolnici se Ana Schier ponaša mirno, svaljujući svoje tegobe na političke prilike u Hrvatskoj i prepričavajući svoj slučaj ostalim bolesnicama. Posjećuje ju budimpeštanski novinar Paul Engelman. Engelmanov odnos s Anom Schier je podosta nejasan - pred liječnicima Engelman tako tvrdi da je Schier „umobolna pravdašica” dok u pismu koje piše nekoliko dana poslije pokazuje simpatiju za nju i njezin slučaj. Engelman joj piše da ne odustaje od krojačkog zanata u kojem je umjetnica i da se i njemu dogodio sličan politički progon kad su ga uhapsili kao socijaldemokrata. ${ }^{397}$ Prvog listopada Žirovčić u zavodskoj pisarnici provodi razgovor s Anom Schier u kojem ona govori o svojim teškim obiteljskim prilikama. Ana je imala elementarno obrazovanje: išla je 4 godine u školu u Josipovcu, a nakon toga ju je otac podučavao kod kuće. Otac je navodno bio grub čovjek koji je zlostavljao svoju suprugu i varao ju s nekom seljakinjom Simeonom Lazić koju Ana Schier slikovito opisuje kao „mužaču” ${ }^{398}$ zbog čega ga je majka Ane

392 Ibid.

393 Ibid, 272.

394 Ibid.

395 Ibid.

396 Ibid.

397 Ibid, 273.

398 Ibid, 274. 
Schier napustila i otišla živjeti u Osijek kao nadničarka. Ana je vodila kućanstvo i upravo ona je 1884. dovela u kuću Otiliju Magnani koja je tada bila, prema Aninim riječima 24 godine stara neznatna, nelijepa, lijena i neuredna osoba sklona skitnji. ${ }^{399}$ Ana opisuje kako se njezin otac ubrzo upustio u vezu s Otilijom Magnani, govori kako je otac imao štednu knjižicu, te kako se Otilia Magnani nije slagala s njezinim mlađim sestrama. Sukobi u kućanstvu su jednom gotovo završili nasilno- navodno su mlađe sestre Julija i Aurelija ,htjele ubiti Otiliju revolverom koji su uzeli s očeva stola, a Ana im je revolver otela" ${ }^{400}$. Osim života u krugu obitelji, Ani Schier je i kasniji bračni život bio obilježen teškoćama i sukobima. Za svog supruga govori da je najveći „zlotvor i lopov" te da je odlučio pomagati Otiliju Magnani.

Nakon opisivanja svojih bračnih prilika i obiteljske povijesti, Ana Schier opisuje sam trenutak očeve smrti i opetuje optužbe o trovanju. Prema njenom objašnjenju, otac joj je iznenada dobio „herzkrampf” i postao žut i crn. Liječnici i ljekarnici kojima se obratila, učvrstili su ju u uvjerenju da je njen otac otrovan arsenom. Uz mišljenje liječnika, Schier tvrdi da ju je na zaključak o trovanju navelo i vlastito iskustvo. Naime, Schier je u Budimpešti učila retušerski zanat kod fotografa Strelitzkog i tamo svjedočila slučajnom otrovanju skupine djevojaka arsenom. Ana Schier je tvrdila da su djevojke pokazale iste simptome. ${ }^{401}$ Ana Schier također ponavlja i elaborira optužbe protiv suca i liječnika: govori kako je i dalje uvjerena da je umjesto njezinog oca ekshumiran drugi leš. Čini se da je Ana Schier bila prisutna u trenutku ekshumacije i da je u jednom trenutku prišla samom lešu i gurnula mu ruku u usta kako bi mu prebrojila zube. Prebrojavši zube lešu, ustanovila je da ih je tijelo na ekshumaciji imalo samo četiri, dok ih je njezin otac imao više. Ovdje se prvi put u članku detaljno oslikava pomalo makabričan i neuobičajen prizor: Ana Schier gura lešu prste u usta, ne pokazajući nikakav osjećaj straha, gađenja ili bilo kakve druge averzije koju bi devetnaestoljetno društvo očekivalo od žene. Taj trenutak predstavlja jednu prilično jasnu transgresiju u okviru emotivnog režima devetnaestog stoljeća. Iako taj postupak nije naveden kao razlog predavanja Ane Schier na vještačenje u Stenjevec, kasnije će biti apostrofiran kao važan za dijagnozu histerije koju je Žirovčić postavio u svom vještačkom mišljenju. Uz broj zubi, Ana Schier navodi kako je ime njezinog oca na lijesu izgledalo „friško priljepljeno" ${ }^{402}$. Nakon prepričavanja ekshumacije, Ana iznosi optužbe na račun 
kotarskog suca i okružnog liječnika. Za suca tako kaže da je „opak čovjek, pijanica, kartaš i ženskar" te implicira da bi zbog tih svojih navika lako mogao primiti mito. Doktora Katušića optužila je da je ,pijanica i da javno tuče svoju ženu”. ${ }^{403}$

U konkretnom slučaju Ane Schier, Žirovčić je odlučio posve zanemariti njezin iskaz. Umjesto toga, u njegovom mišljenju je ključna važnost dana iskazu njezina supruga koji je u ono vrijeme živio s Anom Schier. Prema njegovom iskazu Ana Schier je „divlja, hladnokrvna, lažljiva, gruba, lijena, pravdalica, razkošna, razuzdana" ${ }^{404}$. Žirovčić suprugove riječi potvrđuje nekritički konstatiravši da „taj opis odgovara vladanju Ane Schier, koja se upornom tvrdoglavošću pravda za lažnu stvar, koja bezobzirnim bijesom ujeda poštenje svakoga, koji joj pravdanjem na put dodje te hladnokrvno čeprka prstom po ekshumiranoj lješini svog oca." ${ }^{\text {405 }}$

U svojoj dijagnozi Žirovčić se, kao i liječnik koji je preporučio smještanje Terezije H. u Stenjevec oslanja na iskaz supruga, posve zanemarivši govor štićenice. Iako je Ana Schier napustila supruga, živjela u lošim odnosima s istim i zatrudnjela s drugim muškarcem, suprugovo se mišljenje uzima kao nepristran sud o njezinom karakteru. Kroz očište te prosudbe se gledaju kasniji javni istupi Ane Schier i postavlja medicinska dijagnoza. Zanimljivo je, da u svom opisu histeričnog karaktera i Aninog ponašanja Žirovčić često imenuje brojne emocije i time ih zapravo vrijednosno smješta unutar psihijatrijskog diskursa o rodu. Tako su ,ženska ćutljivost, strašljivost i plačljivost” zapravo najmanje intenzivna obilježja histerije dok se „bezobziran bijes” i „hladnokrvnost” kasnije navode kao dokazi da je upravo Ana Schier histerična. Svraćanje pažnje na emocije, davanje rodnog karaktera istima i prepoznavanje ,abnormalnosti” određenih emocija na temelju unaprijed stvorenih pretpostavki o ženskoj psihi zapravo čini histeriju poremećajem koji služi kao kod za žensku izvedbu emocija. To naročito vrijedi za slučajeve poput onog Ane Schier gdje su emocije poput bijesa zbog nepravde postale prisutne u javnom prostoru, te čak pobudile suosjećajnu reakciju pojedinih dijelova javnosti. Na kraju krajeva, angažman budimpeštanskog socijaldemokratskog tiska i politizacija slučaja su vjerojatno potakli kod Žirovčića reakciju koja je kroz medikalizaciju emotivnog stanja Ane Schier, trebala delegitimirati

403 Ibid.

404 Ibid.

405 Ibid. 
javni odjek njezinih riječi. Zbog toga se vjerojatno upustio u objašnjavanje fenomena masovne histerije i pridao histeričnim ženama neku sugestivnu i zavodljivu moć nad drugim ljudima.

U svom zaključku Žirovčić je još jednom pojasnio rezultate svog forenzičkog vještačenja. Tako ističe da je „um Ane Schier oslabljen uslijed hysteričnog živčanog rastrojenja”406. Zanimljivo je i da su njezine ranije pritužbe na fiziološke teškoće, čak i one koje su mogle biti pripisane trudnoći poput nadutosti i bolova u nogama i leđima pripisane histeričnom živčanom ustroju, kao i „nećutljivost ždrijelne i nepčane sluznice” i „labilitet krvnocijevnog aparata, po čem ona lako blijedne i rumeni”. Naravno, kao ključni znak njezinog „histeričnog ustroja” navedene su njezine karakterne crte: sklonost „laganju, spletkarenju, tužakanju, pravdanju i pogrđivanju tuđeg poštenja. ${ }^{~} 407 \mathrm{Uz}$ to, Žirovčić je smatrao da Ana Schier pati od histerije višeg stupnja jer se histerija kod nje manifestirala i „izopačenjem karaktera." ${ }^{408}$ Usprkos činjenici da ju je okarakterizirao kao teško duševno bolesnu ženu, Žirovčić ju ipak ne proglašava neubrojivom. Argumentaciju za svoj zaključak on nalazi u pravnoj definiciji neubrojivosti prema kojoj se kaznene odgovornosti za zločin oslobađa ona osoba koja je u trenutku počinjenja bila: „,a) sasvim bez porabe razuma“, ili b) u stanju ludovanja“ ili „u ćutilnoj smetnji.“409

Budući da je Ana Schier više puta ponovila svoje optužbe i ustrajala u njima, bila dovoljno prisebna da nastupa pred sudom i javno djeluje i budući da njezine optužba nisu bile posljedica halucinacija i sumanutih misli, Žirovčić ju nije mogao proglasiti neubrojivom. Ipak zaključio je kako je Ana Schier, „kao ženska hysterična, afektivna, umno ograničena, individualnost manje vrijednosti." ${ }^{410}$

Iz slučajeva Ane Schier i Terezije H. možemo vidjeti kakva je bila percepcija histerije unutar Stenjevca i u kojoj mjeri se ona razlikovala od Charcotovog spektakla. S jedne strane, štićenice kojima je dijagnosticirana histerija su uistinu histerizirane i erotizirane u kliničkom kontekstu u smislu da su njihove duševne tegobe somatizirane i vezane uz njihov rod i njihovu seksualnost. Tako su i afektivnost Ane Schier i njezine fizičke tegobe i njezina javna eksponiranost i upornost

406 Ibid, 278.

407 Ibid.

408 Ibid.

409 Ibid, 279-280.

410 Ibid, 280. 
u suprotstavljanju moćnim muškim figurama poput liječnika i suca za Žirovčića dokaz njezinog histeričnog karaktera. Isto se može reći i za ponašanje Terezije $H$. U njoj stenjevački liječnici ne vide ženu koja se, shrvana i traumatizirana nakon smrti supruga i povratka majci u sredinu s kojom je bila u sukobu, predaje maštarijama o zaštiti moćnih ljudi i sudjelovanju u političkom životu, nego ju isključivo gledaju kroz prizmu njezinog erotičnog ponašanja, ponegdje ju čak pretvarajući u romantizirani objekt vlastite žudnje. Također, stenjevački liječnici su imali velike teškoće u repliciranju spektakularnih Charcotovih simptoma u kliničkom kontekstu. Zbog toga, histerija ponovno postaje ekskluzivno ženskom protejskom bolešću. Njezin uzrok se, pod utjecajem predstavnika njemačke somatičke medicine sad usko vezuje uz nižu duševnu vrijednost žena. Simptomi histerije se uglavnom traže u javnom pokazivanju određenih emocija, i u ustrajnosti u suprotstavljanju autoritetima. Znakovito je kako u slučaju Ane Schier, doktor Žirovčić snažnim riječima spominje Aninu spremnost da pogrdi tuđe poštenje i koliko spremno u obranu uzima općinskog liječnika, kotarskog suca i poštanskog činovnika Wuchsu. Čini se da mu se sama ideja žene niskog obrazovanja i po ondašnjim moralnim normama upitnog seksualnog morala koja iznosi optužbe za korupciju protiv muškaraca građanske klase činila izrazito izopačenom i nepojmljivom.

Duševne bolesti kod žena su se u psihijatrijskoj literaturi često povezivale $\mathrm{s}$ intelektualnim naporom: Maudsley je tako često isticao da obrazovanje uništava reproduktivne organe i mozgove žena ${ }^{411}$. Bolest Ane B. će kao uzrok navesti: „tjelesno prenaprezanje napornim radom uz slabu konstituciju; a duševno čitanjem zamršenih i za nju nerazumljivih stvari” ${ }^{412}$. Podatke o njezinim čitalačkim navikama liječnici su dobili iz njenih izjava i pisama u kojima je spominjala čitanje Schopenhauera, Goethea, Darwina i Shakespearea. ${ }^{413}$ Iako njezina pisma pokazuju zavidnu razinu obrazovanja s obzirom na njezin socioekonomski status i zanimanje, liječnici ipak tvrde da su knjige koje je čitala za nju bile nerazumljive. Sličan stav nalazimo kod supruga stenjevačke štićenice Terezije H. koja je strastveno pratila političke prilike i čitala dnevni tisak.

Iskazi Terezije H. i Ane Schier se također odbacuju od strane liječnika. Terezijin će biti opisan kao „brbljanje” dok će Žirovčić ismijavati izjavu Ane Schier da je prepoznala simptome trovanja

411 Showalter, 1995: 124-125.

$412 \mathrm{KPV}, 1895: 2630$.

413 Ibid. 
arsenom, iako je ona, za jednog laika dobro opisala karakteristične znakove otrovanja, uključujući i diskoloraciju lica, ${ }^{414}$ te se u zaključku neće niti jednom referirati na njezin iskaz. Daleko veći značaj bit će dan izjavi njezinog supruga, čiju prosudbu karaktera Ane Schier, Žirovčić bez propitkivanja prihvaća kao objektivnu. Možemo reći da su „histerične” štićenice u Stenjevcu bile tretirane kao osobe čija je transgresija emotivnog režima i rodnih normi promatrana kao dokaz njihove ,niže duševne vrijednosti” koja je proistjecala iz njihovih karakteristično ženskih karakternih crta. Kao takvima, u pravilo im je oduzeto pravo na vlastiti glas, a čak i u slučajevima poput onog Ane Schier kad bi javno istupale i dobile podršku javnosti, sama ta podrška bila je pripisivana njihovoj „histeričnoj zavodljivosti”. Promjenjiv karakter histerije, njezina uska povezanost s rodom i njezin spektakularan i erotiziran karakter rezultirali su potpunom objektifikacijom štićenica s tom dijagnozom u kojoj je njihovo duševno oboljenje posve dominiralo slikom o njima. Sve što bi izrekle ili učinile, dojam koji bi ostavile na druge, njihove tjelesne karakteristike i emocije koje bi iskazale, moglo se gledati kroz prizmu histerije koja je ujedno predstavljala i hiperseksualiziranu i reduciranu sliku ženskosti.

\subsection{Tijelo van kontrole: „Rittermeisterov satni mehanizam” $i$,viloviti” notar iz Veliševca“6}

Brojni su slučajevi u kojima se štićenice žale da su izgubile kontrolu nad vlastitim tijelom. Takvi se slučajevi mogu povezati s rodnom nejednakošću i supresijom seksualnosti. Kao što smo već ranije spomenuli u dijelu rada o životu štićenika i štićenica prije dolaska u zavod, seksualno i drugo zlostavljanje od strane muškaraca, nevolje u braku i podređen položaj u društvu obilježili su iskustvo brojnih štićenica. Budući da je ženska seksualnost u devetnaestom stoljeću bila strogo regulirana društvenim normama, brojni simptomi o kojima štićenice Stenjevca govore tokom svog boravka i koji su ostali zabilježeni u povijestima bolesti vezani su uz seksualnost i kontrolu. U deluziji Tereze D., četrdeset i četverogodišnje sluškinje iz Bjelovara, ženska seksualnost postaje dio kompliciranog tehnološkog mehanizma kontrole u kojem se susreću Terezina subalterna i marginalna pozicija sluškinje, fantazije o"strojevima kontrole" i anksioznosti modernog doba.

Tereza D. primljena je u Stenjevac 1903. iz klinike u Grazu. U zavodu je boravila do svoje smrti od upale žučnog mjehura 1911. godine. Dijagnoza koja joj je postavljena glasila je ,paranoia” 414 Drača, 2017: 47. 
dok je kao uzrok naveden „klimakterij” ${ }^{415}$ Tereza je, prema status preasensu, bila služavka u Zagrebu, Mariboru i Grazu no nigdje se nije dugo zadržala zbog vlastite svadljivosti. Za svoju svadljivost okrivljavala je muškarca za čiju obitelj je radila nekog mladog Pergera iz Graza kojeg je nazivala „rittmeisterom”, naziv koji označava časnički čin u austrijskoj konjici. Terezina povijest bolesti bilježi različite sumanute misli i halucinacije vezane uz Pergera. Naime, Tereza je bila uvjerena da ju mladi Perger kontrolira preko nekog uređaja koji je nazivala „hoeraparatom” što je njemačka riječ za satni mehanizam. Pomoću navedenog hoeraparata, Perger je mogao na daljinu pomicati njezino tijelo i komunicirati sa njim telepatski bez da ju itko drugi čuje, što je Tereza, koja u komunikaciji s liječnicima redovito govori njemački, nazivala „Das ist ein Sprachen in Gedanken” („To je govorenje u mislima”). Tereza vjeruje da joj je „rittermeister” pomoću svog satnog mehanizma prouzrokovao „Schuttelfrost” (nazeb) nakon kojeg je morala učestalo mokriti ${ }^{416}$ Pergerov utjecaj na Terezu imao je i snažne seksualne elemente. Tereza optužuje Pergera da joj je „napravio da je morala rukom na spolovilo" ${ }^{117}$. S vremenom, utjecaj „rittmeistera” postaje sve veći i Tereza se često žali kako on gospodari njezinim mislima i kako joj nalaže što treba govoriti ili učiniti. Učestalo tvrdi kako „rittermeister” plaća njezino uzdržavanje u zavodu i kako također plaća boravak i „koštu” ostalim štićenicama, što ju čini ljubomornom. U jednom od kasnijih napada bijesa, Tereza će reći da „rittermeister” uzdržava cijeli zavod i da živi u vili u blizini zavoda. ${ }^{418}$

Halucinacija o tehnološki naprednom stroju koji kontrolira tijelo i misli jedna je od češćih pojava u povijesti. Tako je James Matthews, trgovac čajem i štićenik londonske klinike Bedlam, 1798. tvrdio da ga francuski agenti kontroliraju pomoću pneumatskih strojeva za proizvodnju misli i osjećaja. Matthews je svom liječniku dao čak i precizne skice tih strojeva koji su „tkali” emocije iz zraka, nalik tada novim parnim tkalačkim strojevima ${ }^{419}$ Bečki psihoanalitičar Viktor Tausk nazvat će tu vrstu deluzije „strojem za kontrolu” (eng. „influencing machine“) i opisao pet različitih efekta koje pacijenta pripisuju tim strojevima: projiciranje slika, proizvodnja ili „otimanje” misli”, upravljanje motornim funkcijama tijela, proizvodnja senzacija u tijelu i proizvodnja patoloških procesa u tijelu. ${ }^{420}$ Kod Tereze vidimo da stroj ima četiri od pet tih 415 KPV, 1911: 5604.

416 Ibid.

417 Ibid.

418 Ibid.

419 Haslan, 1810.

420 Tausk, 1992: 186. 
funkcija. Psihijatri Hirjak i Fuchs su našli uzroke prevalentnosti takvih deluzija u nekim karakteristikama modernih tehnologija poput činjenice da moderne tehnologije imaju skrivene efekte, da čine prostorne i vremenske granice propusnijima, mogu stvoriti dojam drugačijih realnosti te reificiraju tijela. ${ }^{421}$ Premda se ne može poreći da je Terezina fantazija o „hoeraparatu” mogla imati izvore u strepnjama vezanim uz tehnologiju, moguće je da ona odražava i neke od strepnji vezanih za njezin položaj kao služavke. Prvo što saznajemo o „rittermeisteru” Pergeru je da se radi o članu gradačke porodice za koju je Tereza radila. Sluškinje su zbog teške financijske situacije često bile prisiljene osiguravati sredstva za svoju materijalnu egzistenciju radom $u$ drugim gradovima, daleko od svojih obitelji. Pritom su kao stranac koji je svjedočio obiteljskoj intimi bile u izrazito nepovoljnom položaju. Njihova individualnost često je bila negirana do te mjere da su prilikom dolaska u službu morale usvojiti druga imena, a njihova privatnost, prostor za život, intima i seksualnost su često bile pod kontrolom njihovih poslodavaca. ${ }^{422}$ Kontrola nad tijelom, mislima i seksualnošću povezana s idejama o financijskoj ovisnosti cijelog zavoda o „rittermeisteru” na gotovo jezovit način odražava financijsku ovisnost sluškinja i reifikaciju njihovih tijela i individualnosti u okviru patrijarhalnih kućanstava.

Dok su primjeri tehnološke kontrole podosta rijetki, jer mnogi štićenici dolaze iz ruralnih krajeva, gdje moderna tehnologija još nije dio svakodnevnog iskustva, štićenice često artikuliraju predodžbe o gubitku kontrole nad vlastitim mislima i tijelom kroz iskustvo opsjednutosti. Opsjednutost od strane nekih nadnaravnih entiteta dio je folklornih vjerovanja u brojnim zajednicama, a u devetnaestom stoljeću za isti fenomen postaju zainteresirani i psihijatri. Jedan od najpoznatijih primjera kolektivne opsjednutosti dogodio se u zajednici migrantskih radnika u mjestu Morzine koje je tada bilo dio okruga Chablai u Francuskoj, pedesetih i šezdesetih godina devetnaestog stoljeća. Opsjednutost je bila povezana s ukazanjima Djevice Marije, koja je ubrzo počela i zaposjedati lokalne žene i djevojke. Slučaj je privukao izrazitu pažnju javnosti i psihijatrijske struke, a masovna opsjednutost je navodno poprimila takve razmjere da je morala intervenirati i vojska. ${ }^{423}$ Za slučaj je indikativna činjenica da su zaposjednute bile samo žene koje su govorile u nekoj vrsti transa i preuzimale identitet muškaraca, najčešće lovaca i ostalih ljudi koji nisu pripadali njihovoj zajednici, već su tek povremeno dolazili u kontakt sa selom. ${ }^{424}$ Ann

421 Fuchs i Hirjak, 2010: 100-101.

422 Fugier i Perrot, 1990: 235-236.

423 Harris, 1997: 452.

424 Ibid, 463. 
Goldberg je u svojoj studiji „Sex, Religion, and the Making of Modern Madness: The Eberbach Asylum and German Society, 1815-1849." povezala slučajeve zaposjedanja sa sukobom između predmodernih koncepcija sebstva koje postoji u stalnoj interakciji sa zajednicom i natprirodnim svijetom i moderne koncepcije integriranog sebstva kojim upravlja razum. ${ }^{425}$ Iako stenjevačke povijesti bolesti ne govore o slučajevima grupne opsjednutosti, neke od njih prenose slučajeve žena koje su tvrdile da su zaposjednute i u tom se stanju često ponašale sablažnjivo. Ono što je naročito značajno u tim slučajevima je jezik kojim su štićenice govorile o vlastitom stanju zaposjednutosti- kao da je neka nadnaravna sila, opisana gotovo isključivo u muškom rodu, uspostavila kontrolu nad njihovim tijelima protiv njihove volje.

Seljakinja iz Čazme, Jaga Š., koja je bila u Stenjevcu između 1891. i 1895.godine, kad je otpuštena kao poboljšana predstavlja još jedan primjer zaposjedanja. Njena dijagnoza glasila je „hysteria”. Prilikom boravka u zavodu tvrdila je da ima „vraga u želucu”" ${ }^{26}$. U trenucima kad bi ju vrag preuzeo, govorila bi o sebi u muškom rodu, i otvoreno pokazivala bijes vikanjem, udaranjem rukama i nogama, lupanjem glavom u zid i bacanjem po podu. Liječnik je u povijesti bolesti identificirao mirna (,melankolična”) i „manijakalna” stanja. U skladu sa Charcotovim eksperimentima, manijakalno bi stanje kod Jage nastupilo nakon pritiska na histerogenu točku. Zanimljivo je da taj podatak iznosi sama štićenica: „,pokazuje na maternicu, veleć kad je tamo prime da joj leti jezik i govor, tako da se nije kadra da izdrži, a da neviče i nepjeva"427

Usprkos ovako izraženom bogohulnom ponašanju u stanjima kad "iz nje nije govorio vrag" Jaga se ponašala mirno i pobožno:

„Govori u muškom spolu, kao da tobože to vrag govori:smrdi crkva, kvragu neka ide krunica, ja mrzim boga, ja vrag okrećem k crkvi rit, ja mrzim majku božju itd. Kad se je već naderala i nabacala te nadrečila tad lupi sobom u zemlju i leže kao mrtva. U svojem ludovanju, oponaša i lavež psa, tvrdeć da to vrag u njoj laje."

Jaga je u svojim ,melankoličnim” stanjima bila svjesna činjenice da ponekad ne može kontrolirati vlastito tijelo i izjavila je kako se osjeća prisiljenom da se ponaša bogohulno. Govorila je da se mora valjati i bacati po zemlji kad god vrag u njoj zaviče, a u povijesti bolesti

425 Goldberg, 1999: 81

426 KPV, 1895: 1882.

427 Ibid.

428 Ibid. 
se naglašavao kontrast između njezinih dvaju duševnih stanja i njezin osjećaj gubitka kontrole nad vlastitim tijelom:,Čudnovato je to da u stadiju manijakalnom veli da ima vraga u sebi, da je sama vrag, te pljuje na križ i otčenaše i kune. U melankoličnom stanju moli boga, ljubi križeve i otčenaše i pripovjeda da se nemože u manijakalnom stanju uzdržati da ne pljuje na križ." ${ }^{429}$ Bizarniji oblik gubitka kontrole nad vlastitim tijelom iskusila je Dora G., seljakinja iz Pokupskog kraj Turopolja, koja je 1895. godine bila u Stenjevcu nešto više od mjesec dana prije nego što ju je neizlječenu odveo suprug. Dora je u Stenjevec primljena 27. srpnja, no njezine su poteškoće počele mnogo ranije, još od zime, ili kako je sama Dora izjavila „od božićne nedjelje”. ${ }^{430}$ Iako je Dora kratko boravila u Stenjevcu, tamošnji liječnici su detaljno zabilježili njezino svjedočanstvo. Dora je ispričala kako su u njoj:

„,...slike pokupskog bilježnika i jedne vile iz Veliševca koje iz nje govore. Boji i plaši se po noći, malo spava. Pokupska obćina izgubila jednu šumu krivnjom bilježnika i ona je putila ljude da idu u Zagreb fiškalu radi te šume... misli da je zato bolestna, što je ljude putila proti bilježniku, koji da je vilovit”\$31

Dora je iskustvo gubitka kontrole nad vlastitim tijelom gledala kroz prizmu sukoba s bilježnikom, kojem je pak pridavala natprirodne moći. U liječničkoj svjedodžbi Dora kotarskom liječniku govori kako ju ,slike” veliševačkog bilježnika i njegove supruge vile sve više obuzimaju:

„U njoj su vilovske slike...Ona ništa ne govori nego ta slika govori....Traži medicinu da bi se ovu sliku moglo iz nje protjerati, ona nema ni uma ni razuma, sve joj je oteto, srdce i jezik...Raste joj novi nos. Slika promjenjuje obraze njezine. Govori o sebi u trećoj osobi...

Slika sve pojeda, G. jede a on u njoj sve pojede. Sve je njezino, oko, ruka, noga, glava, lice. Jezik je njezin ali su se slike naturile na njega" ${ }^{432}$

Čini se da je Dora svoj gubitak kontrole gledala kroz prizmu folklornih vjerovanja o vilama. O tome svjedoči pomalo morbidna slika u kojoj joj vile mijenjaju lice. Naime, jedan skup vjerovanja u vile, zabilježen u Srednjoj i Jugoistočnoj Europi, govori o vilama koje zaposjedaju tijelo osoba koje im se zamjere te im ,restruktuiraju” tijelo i um. Pritom vile često mijenjaju dijelove lice zaposjednute osobe ili joj oduzimaju udove ili dijelove lica. ${ }^{433}$

429 Ibid.

$430 \mathrm{KPV}, 1895: 2702$.

431 Ibid.

432 Ibid.

433 Pocs, 2018: 260. 
Iskustvo strane kontrole nad mislima i tijelom o kojem često pričaju štićenice zavoda za umobolne u Stenjevcu može se dakako, isključivo gledati kao psihotični ili disocijativni simptom, no u svjedočanstvima o kontroli nazire se nekoliko razina rodne opresije. Iza različito artikuliranih osjećaja gubitka vlasti nad osobnim mislima i tijelima često stoje ljudske sudbine koje govore o vlastitoj depersonalizaciji, gubitku identiteta ili sukobu s autoritetom koji je, kao u slučaju „rittermeistera” ili bilježnika, posjedovao stvarnu ekonomsku ili administrativnu moć nad štićenicama. Također, narativ o kontroli ženskih tijela se proteže i na svakodnevicu života u zavodu: dok su štićenice umišljale da njihova tijela kontroliraju natprirodnim moćima ili naprednom tehnologijom, liječnici i bolničari su, uz pomoć njihove rodbine i administrativnih vlasti ostvarivali stvarnu tehnološku moć nad njihovim tijelima. Njihova tijela su tako bila smještena u sustav odjela arhitektonski osmišljen s ciljem učinkovitije kontrole, vezana u stezulje ili omatana u plahte i podvrgnuta terapijskom radu ili umirujućim psihoaktivnim sredstvima. Strogi emotivni režimi i nadzor seksualnosti podvrgavali su njihovu tjelesnost i njihov unutarnji život sofisticiranim oblicima društvenog nadzora. Samim time može se reći da je žensko iskustvo na prijelazu stoljeća, a naročito iskustvo „histeriziranih” štićenica zavoda za umobolne bilo u mnogome iskustvo prisilne kontrole nad njihovima tijelima i osjećajima.

\subsection{Nevidljivost sifilisa: progresivna paraliza u Stenjevcu}

Uska isprepletenost morala i seksualnosti bila je naglašeno prisutna u psihijatriji druge polovine devetnaestog stoljeća. Maudsley je tako, oslanjajući se na Darwina, svojevremeno proglasio seksualni nagon izvorom društvenog poretka ${ }^{434}$. Richard von Krafft-Ebing, kojeg mnogi smatraju začetnikom moderne seksologije je nadovezujući se na Maudsleyja istom neraskidivom vrpcom povezao seksualnost, religiju, etiku i estetiku ustvrdivši da je ,seksualni osjećaj korijen svake etike i bez sumnje, esteticizma i religije". ${ }^{435}$ Seksualnost u devetnaestom stoljeću postaje sve vidljivija u javnom prostoru, a njezina prisutnost kao dio medicinskih, društveno-reformskih ili moralističkih rasprava ju čini političkim pitanjem. Eugenički pokret, koji je nastao sredinom devetnaestog stoljeća i jačao sve do kraja Drugog svjetskog rata, pretvara seksualnost u bojno polje na kojem se vodi ključna bitka za opstanak ,zapadne civilizacije” ili čak, ljudske vrste. Povećana vidljivost seksualnosti, koju Foucault naziva „multiplikacijom diskursa o

434 Maudsley, 1873. prema Krafft- Ebing, 2011: 24.

435 Krafft- Ebing, 2011: 24. 
seksualnosti” ${ }^{436}$ nije zaobišla ni psihijatriju. Unutar psihijatrije nastao je diskurs o seksualnosti usko vezan uz moralistički koncept degeneracije. Taj je diskurs pretendirao na znanstvenost i nastojao se legitimirati somatičkom neurologijom, a njegova je primarna svrha bila naturalizacija uvriježenih rodnih predodžbi i koncepcija o seksualnosti. U hrvatskoj psihijatriji se diskurs o seksualnosti uglavnom razvijao oko triju točaka: progresivne paralize, „seksualne perverzije” i „moral insanityja”. Dok je progresivna paraliza bila posljedicom zaraze seksualno prenosivim sifilisom, „moral insanity” je bila dijagnoza kojom su se opisivali različiti oblici ponašanja koje se smatralo devijantnim, uključujući i određene seksualne prakse. Seksualne perverzije nisu pripisivane nijednoj pojedinoj bolesti, ali su često spominjane u člancima ili povijestima bolesti. Njihovo spominjanje u kontekstu duševnih oboljenja, često je davalo tim dokumentima koji su pretendirali na vlastitu znanstvenost izraženu moralističku notu. Uopće, sve tri točke psihijatrijskog diskurse povlačile su za sobom jake moralističke konotacije i predstavljaju jedinstven primjer dodirivanja $\mathrm{i}$ ispreplitanja predznanstvenog pojma grijeha $\mathrm{s}$ medicinskim pojmom patologije.

Progresivna paraliza bila je neizlječiva i terminalna bolest koja je prema Shorteru, bila jedan od uzroka naglog porasta broja štićenika u psihijatrijskim zavodima ${ }^{437}$. Iako je pogađala i muškarce i žene, bila je češća među muškarcima. Bolest je bila posljedicom tercijarnog stadija infekcije sifilisnom spirohetom (Treponema Pallidum), uzročnikom sifilisa. Prema najuvjerljivijoj teoriji , sifilis se u Europu proširio s Hispanole, odakle su ga donijeli mornari ekspedicije Kristofora Kolumba. ${ }^{438}$ Među prvim narativima o sifilisu bili su iskazi koji su odisali rasističkim osjećajem moralne superiornosti europskih kolonijalnih osvajača. Madridski plemić Ferdinand de Oviedo tvrdi da je zaraza nastala zbog općenja s nemoralnim ženama Hispanole koje su ,poznate po nečistoći, indolenciji, često jedu crve, pauke, zmije i šišmiše i vrste guštera koje su otrovne za sve osim za urođenike. ${ }^{, 439}$ Kroz cijeli rani novi vijek, povezan sa smrtnim grijehom bludnosti, sifilis je među kršćanima bio smatran kaznom za moralno posrnuće. U devetnaestom stoljeću, sifilis i progresivna paraliza navođeni su kao jedan od dokaza u prilog eugeničkih teorija hereditarne degeneracije kojima su europski psihijatri bili osobito skloni. Između kršćanskog morala i upozorenja o propasti društva zbog ,naslijeđenog grijeha” sifilis i progresivna paraliza

436 Foucault, 1998: 53.

437 Shorter, 1997:56.

438 Hayden, 2003: 25.

439 Spongberg, 1997: 18. 
bili su usko vezani uz moralistički i konzervativni pogled na seksualnost. Britanska povjesničarka umjetnosti Monika Pietrzak-Franger pokazala je da su pogledi na sifilis u znanosti i kulturi devetnaestog stoljeća bili obilježeni stalnom napetošću između njegove vidljivosti i nevidljivosti. ${ }^{440}$ Ta napetost odlikuje i poglede psihijatrije na sifilis i progresivnu paralizu: iako se sifilis relativno često javlja kao uzrok duševnih bolesti i premda povijesti bolesti redovito bilježe slučajeve ranije infekcije sifilisom, psihijatri još uvijek ne prave eksplicitnu vezu između sifilisa i progresivne paralize. To poricanje eksplicitnih veza između tih dvaju čestih oboljenja postaje još paradoksalnije kad se uzme u obzir da je Alfred Fournier još 1879. dokazao vezu između tih dvaju bolesti. ${ }^{441}$ Europski psihijatri su odbacivali takvu ideju zbog uvjerenja da bacil sifilisa ne može proći krvno-moždanu barijeru. ${ }^{442}$ Drugi uzrok neprihvaćanja Fournierovog otkrića bio je u činjenici da je između zaraze sifilisom i pojave progresivne paralize slijedio period latencije za vrijeme kojeg su se simptomi zaraze pojavljivali sporadično i često bivali otpisani kao znakovi lošeg zdravlja, hipohondrije ili neurasteničnog oboljenja. Treći razlog odbijanja veze između sifilisa i progresivne paralize bio je u činjenici da su psihijatri često bili neskloni iznalaženju jasne etiologije duševnih bolesti. Ranije smo pokazali da je upravo postojanje mutnog graničnog prostora između duševnog zdravlja i ludila bilo jedno od općih mjesta psihijatrije druge polovice devetnaestog stoljeća. Upravo zbog takve percepcije duševnog oboljenja, psihijatri su bili skloni progresivnu paralizu pripisivati brojnim labavo definiranim uzrocima koji su uključivali „naprezanje mozga2, alkoholizam i nemoralan život. Uz to, predmoderna dihotomija ludila i razuma bila je još uvijek dominantan način gledanja na duševne bolesti. Umjesto jasne povezanosti konkretnih uzroka i definitivne dijagnoze, na pojedina se duševna oboljenja više gledalo kao na različite manifestacije iste bolesti-ludila dok su svi različiti uzroci mogli u većoj ili manjoj mjeri biti svedeni pod krovni pojam degeneracije.

Sifilis je napadao različite organe i tjelesne sustave, izazivajući jako širok spektar simptoma, što je navelo britanskog kirurga i venerologa Jonathana Hutchinsona da ga nazove „Velikim Imitatorom" ${ }^{443}$. Percepcija sifilisa kao bolesti ,imitatora” činila ga je u neku ruku muškim ekvivalentom protejskoj histeriji. Naravno, paralele između sifilisa i histerije tu ne prestaju. Javni diskurs o sifilisu bio je bremenit moralističkim poimanjem seksualnosti, kao i diskurs o histeriji.

440 Pietrzak- Franger, 2017: 1.

441 Hayden, 2003: 39.

442 Ibid, 40.

443 Pietrzak- Franger, 2017: 5. 
Dok je histerija predstavljala erotizirani spektakl ženske nezapriječene seksualnosti, sifilis je predstavljao gotički spektakl strave i užasa i služio kao opomena usmjerena protiv preslobodnog seksualnog ponašanja, predstavljajući svojevrsni „tamni odraz” histerije. Dok je histerija bila medicinski konstrukt koji je novim, znanstvenim rječnikom artikulirao i naturalizirao konzervativnu podjelu rodnih uloga, sifilis je bio stvarna bolest sakrivena iza slojeva ideoloških i moralističkih narativa o degeneraciji. Histerija je bila prikazivana i promatrana, dok je sifilis bio potiskivan.

Odnos sifilisa, moralnih nazora i degeneracije bio je mnogostruk i kompleksan. Dijete zaraženo kongenitalnim sifilisom (naslijeđenim od zaraženih roditelja) postalo je u devetnaestom stoljeću jednom od najsnažnijih ideologema kojim su se podjednako služili zagovornici eugeničkih teorija, feminističke autorice i umjetnici pesimističnog pogleda na svijet. $\mathrm{Na}$ slici Naslijeđe Edwarda Muncha iz 1903. godine referira se kršćanski motiv „Madone s djetetom”, no majka na Munchovoj slici drži dijete prekriveno sifiličnim lezijama. ${ }^{444}$ Prizor predstavlja sumorno upozorenje o budućim generacijama koje nose bolest kao teret naslijeđa modernizacije. Dok je na Munchovoj slici muškarac odsutan, u zapisima feminističkih autorica upravo on snosi glavnu krivnju za rasnu degeneraciju i slabljenje budućih naraštaja. „Nove žene” i feministkinje poput Emmeline Pankhurst naglašavale su prijetnju hereditarnog sifilisa kako bi legitimirale vlastiti pristup medicinskom znanju, koje su u devetnaestom stoljeću isključivo posjedovali muškarci. ${ }^{445}$ Hrvatska feministička književnica i prevoditeljica Vilma Vukelić također navodi spolne bolesti kao posljedicu rodne nejednakosti i dogovorenih brakova pri čemu naročito ističe žene kao žrtve. Spominje svoju sestričnu koju je nametnuti suprug već u prvoj bračnoj noći zarazio spolnom bolešću od koje je patila cijeli život. ${ }^{446}$ Sam sifilis je bio bolest od čijeg se spomena u građanskim krugovima najčešće zaziralo. Van Gogh, Nietzsche i Maupassant su pokazivali simptome progresivne paralize, a posljednja dvojica su i umrla od posljedica iste.Vincent Van Gogh i njegov brat Theo će tako u svojim pismima izbjegavati direktno spomenuti zarazu, služeći se umjesto toga brojnim eufemizmima. ${ }^{447}$ Također Elizabeth Förster-Nietzsche, sestra filozofa Friedricha Nietzschea dugo se trudila da ospori dijagnozu sifilisa koju su brojni liječnici i biografi postavili

444 Ibid, 233-234.

445 Ibid, 282.

446 Vukelić, 2003: 365.

447 Hayden, 2003: 138. 
njezinom bratu. ${ }^{448}$ No neki su smatrali šutnju o sifilisu znakom licemjerja građanske kulture. Buntovni francuski književnik Guy de Maupassant prilično euforičnim tonom izražava prezir prema tajenju sifilisa u pismu prijatelju gdje slikovito opisuje trenutak u kojem je doznao da je zaražen sifilisom:

„Imam lues! Napokon! Prava stvar! Ne prezira vrijedni triper, ne crkvenjačku podagru, ne buržujsku klamidiju, niti grahoraste izrasline - ne, ne, veliki lues od kojeg je umro Francois I. Veličanstveni lues, jednostavno; elegantni sifilis...Imam lues i ponosim se time, grom i pakao i dovraga s buržujima. Aleluja, imam lues i ne trebam se više brinuti da ću se zaraziti pa ševim uličarke i kurve i kažem im: Imam lues. Njih je strah, a ja se smijem!"449

Od iste bolesti su umrle ili barem patile brojne poznate ličnosti iz kulturnog i političkog života Hrvatske u devetnaestom stoljeću, poput bana Josipa Jelačića Bužimskog, Augustina Harambašića, Vladimira Vidrića i Frane Supila. Progresivna paraliza bila je jedna od prevladavajućih dijagnoza među stenjevačkim štićenicima - tu je dijagnozu 1909. imalo 60 od 262 štićenike, što ju je činilo drugom dijagnozom iza široko definirane ,amentie” ${ }^{450}$. Izuzetna raširenost i velika smrtnost te socijalni značaj bolesti koja je najčešće pogađala muškarce srednjeg i višeg sloja u dobi od 30 do 50 godina rano je probudila interes zavodskih liječnika za uzroke i tretman progresivne paralize.

U Hrvatskoj medicinskoj publicistici je jedan od prvih članaka o progresivnoj paralizi bio članak stenjevačkog kućnog liječnika Dragutina Forenbachera „O progresivnoj paralizi““ objavljen u prvom i drugom broju Liječničkog vjesnika iz 1892. godine. Forenbacher nikad nije postao ravnateljem Zavoda u Stenjevcu, ali je u ranim godinama postojanja zavoda upravo on najviše pisao o duševnim bolestima. Njegov članak o progresivnoj paralizi zanimljiv je upravo iz razloga što je dvije godine ranije u Liječničkom vjesniku objavio opsežan članak o paološkim promjenama na mozgu nastalim uslijed sifilisa Syphilis u moždjanih (Lues cerebri). Indikativno je da Forenbacher navodi sličan set simptoma za progresivnu paralizu i za bolest koju je nazvao cerebralnim luesom. Kao simptome moždanog luesa Forenbacher tako navodi glavobolje, vrtoglavice i kljenuti te niz duševnih simptoma, od naglih promjene raspoloženja, umora i smetnji

448 Ibid, 2003: 152.

449 Bogousslavsky i Boller, 2005: 10.

450 Žirovčić prema Gundrum, 1910: 152. U prijašnjim izvještajima se dijagnoza progresivne paralize naziva drugačije- Rohačekovi izvještaji iz 1883. i 1885 ju nazivaju „Alienatio mentis cum paralysis”. Ta definicija nužno nije identična s onom progresivne paralize, ali njezina učestalost je slična onoj iz 1910 Od nje je 1893. patilo 51 od 344 štićenika a 189547 od 409 štićenika koji su te godine primljeni u Stenjevac. 
mišljenja i pamćenja, promjene ličnosti do konačnog propadanja duševnih funkcija koje je Forenbacher znakovito nazvao "pseudoparalizom" ${ }^{451}$ Kod progresivne paralize Forenbacher navodi isti skup simptoma - omaglice, vrtoglavice, klijenuti promjena raspoloženja i promjena ličnosti. ${ }^{452}$ No dok u članku u „lues cerebri” Forenbacher više govori o histološkim nalazima dobivenih obdukcijom oboljelih i tjelesnim simptomima, kod progresivne paralize su znakovi duševnog propadanja opisani prilično detaljno, a sam članak završava dvama kazuističkim prilozima. ${ }^{453}$ Po tome se vidi da Forenbacher „luesu cerebri” pristupa kao primarno somatičkom oboljenju, dok u progresivnoj paralizi vidi duševnu bolest. Forenbacher također otvoreno osporava sifilis kao uzrok progresivne paralize, smještajući ga radije među faktore koji mogu doprinijeti bržem razvoju bolesti:

„Sve, što moždjane direktno vriedja kao: trauma i insolacija, nadalje intoksikacije alkoholom, a navlastito Syphilis imadu se smatrati važni faktori za causalni momenat paralize. Osobito mi je naglasit to o syphilisu, naravno ne u onom smislu, kao da on nefaljeno i direktno prouzročuje paralizu. Excessus in Venere, ako moždjane i oslabljuje, nemože se sam po sebi uzeti kao veoma težući faktor." ${ }^{\$ 454}$

Sam sifilis je tako naveden kao jedan od mogućih popratnih faktora koji oslabljuju mozak. Nije jasno doprinosi li razvitku paralize sam sifilis ili slobodne seksualne navike koje Forenbacher naziva „excessus in Venere”, a koje su povezane i sa spolnim bolestima i s razvitkom duševnih bolesti (sam pojam „excessus in Venere” često će se sam po sebi javljati kao uzrok duševnih oboljenja). Sukladno svojoj percepciji progresivne paralize kao primarno duševnog oboljenja Forenbacher će i njezin uzrok smjestiti u mutnu sferu interakcije mentalnog i tjelesnog. Za Forenbachera su tako primarni uzroci progresivne paralize ,afekti kao briga, skrb, borba za obstanak duševno preobterećuje” (sic). ${ }^{455}$ Dok je „ženska" histerija bila posljedicom konstitutivne slabosti ženskog mozga i živčanog sustava, uzroci „muške” "dementie paralytice” su radikalno drugačiji. Naime muškarci su „,izvrženiji od žena borbi za opstanak i duševnom naporu”. Kako je stres modernog života sve veći tako i raste broj oboljelih od te bolesti u inteligentnom dijelu pučanstva. Kasnije u članku Forenbacher povlači direktnu paralelu između progresivne paralize i neurastenije, bolesti za koju se u 19. stoljeću smatralo posljedicom brzog i neumoljivog tempa

451 Forenbacher, 1890: 74-75.

452 Forenbacher, 1892: 4-5.

453 Ibid, 21-22.

454 Ibid, 5.

455 Ibid. 
modernog života. ${ }^{456}$ Znakovito je da se Forenbacher u svom članku ne zadržava na pisanju o progresivnoj paralizi, već se upušta u digresiju o modernitetu kao znaku nestajanja „muževne snage" čovječanstva. Forenbacher će čovječanstvo prispodobiti s tisućljetnim hrastom koji počinje klonuti od starosti, a želju za brzim tehnološkim napretkom istaknut će kao još jedan simptom neurastenične slabosti:

„Naš viek baš teži zatim, da si sve prilagodi, izmišlja svašta, da si osladi svoj boravak; čezne za novostmi, žudi za promjenom: već mu neudovoljuje ni željeznica, pa teži zatim, da nebom zaplovi!Nepotiče li baš ta čežnja za promjenami, za izumi iz patoložke razpoloživosti živčane, drugimi riečmi: nije li sve to plod današnje nevrastenije?"457

Ivan Žirovčić će u svojoj podjeli duševnih bolesti nazvati progresivnu paralizu, odnosno „dementiu paralyticu” „bolešću u kojoj se pojavljuju sve moguće duševne abnormalnosti” a njezinim uzrocima smatrat će „alcoholismus, lues, i prekomjerno naprezanje moždjana.” odbacivši hereditet kao faktor. ${ }^{458}$ Žirovčić, za razliku od Forenbachera neće negirati sifilis kao mogući uzrok progresivne paralize već će ga, uz alkoholizam pridodati „prekomjernom naprezanju moždjana".

Čini se da Žirovčić i Forenbacher imaju različite poglede na progresivnu paralizu: Forenbacher je sklon previdjeti vezu između sifilisa i progresivne paralize jer smatra muškarce koji uglavnom obolijevaju od progresivne paralize moralnim stupovima društva. Kao najčešće pacijente Forenbacher navodi „,vojne časnike, činovnike i bersijance”, a pojavu bolesti kod potonjih povezuje s krahovima burze ${ }^{459}$. Zbog toga mu je prirodnije pretpostaviti da oni obolijevaju zbog brige i duševnog napora nego zbog vlastitih nemoralnih navika ili neodgovornog seksualnog ponašanja. Žirovčić je skloniji tražiti različite uzroke progresivne paralize i povezivati ih sa životnim navikama bolesnika. U svom kasnijem članku iz 1898. godine Žirovčić će iznijeti slučaj bankara koji je umro od progresivne paralize i njegovu će bolest pripisati prenaprezanju uslijed napornog rada da se uspostavi bankovni integritet ${ }^{460}$ Kao što sam već ranije naveo, češki psihijatar Jan Šimsa koji je kratko vrijeme bio ravnatelj stenjevačkog zavoda vršio je detaljne obdukcije štićenika oboljelih od progresivne paralize i našao kod mnogih dokaz cerebralnog sifilisa ${ }^{461}$ zbog čega se suprotstavio dominantnom stavu austro-ugarskih psihijatara da je temeljni

456 Ibid, 6 .

457 Ibid, 6-7.

458 Žirovčić, 1895a: 90-91.

459 Forenbacher, 1892: 5.

460 Žirovčić, 1898: 412.

461 Šimsa, 1898: 1. 
uzrok progresivne paralize duševni napor uzrokovan modernim tempom života koji je zastupao Krafft-Ebing. ${ }^{462}$ Čini se da Šimsini nalazi ipak nisu našli širi odjek u stenjevačkoj praksi: povijesti bolesti ne uspostavljaju jasnu vezu između sifilisa i progresivne paralize.

Uzroci progresivne paralize navođeni u povijestima bolesti će biti raznoliki, od „affectusa” i alkoholizma do luesa, „neimaštine” i „raspuštenog života” no ono što će im biti zajedničko je da će isti biti iščitavani iz životnih navika oboljelih. Stjepanu K., umirovljenom činovniku solarskih ureda će tako u povijesti bolesti pisati da je dementia paralytica uzrokovana „spirituosom” 463 (alkoholizmom) dok se Mariji H. ženi mlinarskog radnika iz Garčina u Banatu uzrok bolesti traži u uzrujavanju zbog predstojeće sudske parnice. ${ }^{464}$ Povijesti bolesti često ističu seksualne navike štićenika oboljelih od „dementia paralytica”, no u podjednakoj se mjeri fokusiraju na stres ili na naporan rad.

Čini se da je postojala tendencija da se sifilis, alkoholizam i nemoralan život prije pretpostavljaju kao uzroci oboljenja kod štićenika i štićenica iz nižih društvenih slojeva. Razloge tome možemo naći kako u činjenici da su liječnici, i sami pripadnici građanskog sloja imali predrasude o nižim slojevima kao nemoralnima tako i u činjenici da su građanske obitelji bile sklonije skrivati alkoholizam i sifilis. Tako će kćerku seljanke Roze S. iz Sigetca kod Koprivnice liječnik ispitivati o majčinim seksualnim navikama: „Na pitanje da li je majka i sama sprovadjala nemoralan život, nije dala točnog odgovora; iz nećkanja njezinog opazilo se, da je to bilo moguće, jer je želja

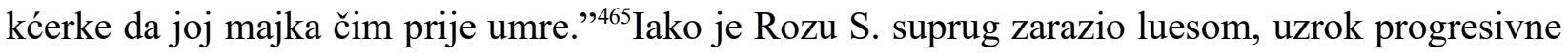
paralize je ipak tražen u njezinim vlastitim tobožnjim seksualnim ekscesima. ${ }^{466}$ Napetost između vidljivosti i nevidljivosti sifilisa koje je definirala ambivalentan odnos devetnaestoljetnog društva prema toj bolesti se tako odražava i u teorijskim i kliničkim osvrtima stenjevačkih psihijatara na „dementia paralytica”. Sifilis se tako uvijek spominje u kontekstu te raširene bolesti ali ga se uporno odbija prepoznati uzrokom iste. Također, iako se eventualni dokazi infekcije sifilisom kod građana zanemaruju, stenjevački opisi dementia paralytica kod štićenika iz nižih društvenih slojeva često vrve referencama na isti. Možemo reći da je progresivna paraliza bila bolest čija se seksualno prenosiva priroda potiskivala zbog predodžbi liječnika o građanstvu kao visoko

462 Ibid, 2.

$463 \mathrm{KPV}, 1895: 2288$.

$464 \mathrm{KPV}, 1911: 7972$.

$465 \mathrm{KPV}, 1911: 8213$.

466 Ibid. 
moralnoj klasi koja se odlikuje napornim radom zbog kojeg često žrtvuje vlastito duševno zdravlje.

\subsection{Seksualna nastranost, primitivizam i ,moral insanity”: Seksualnost, moral i ludilo na prijelazu stoljeća}

Govor o seksualnosti u kontekstu patologizacije određenih seksualnih praksi bit će česta tema stenjevačkih liječnika, a naročito će izraženi biti opisi seksualnih nastranosti u forenzičkopsihijatrijskim člancima u Liječničkom vjesniku. U prvim povijestima bolesti seksualnost štićenika se rijetko spominje, no sedam godina nakon otvaranja zavoda, austrijski psihijatar Richard von Krafft-Ebing objavljuje svoje seminalno djelo Psychopatia sexualis: forenzičkokliničke studije. Hrvatski zavodski liječnici bili su pod izrazitim utjecajem austrijske psihijatrijske škole, a kako se njihov suvremenik Krafft Ebing intenzivno bavio seksualnošću, tako joj se i Stenjevcu počela pridavati izrazita važnost. Može se vidjeti kako nakon objavljivanja „Psychopatie sexualis“ stenjevački liječnici pokazuju sve više interesa za seksualno ponašanje svojih štićenika. O tome da je sam Krafft-Ebing bio jedan od većih intelektualnih autoriteta među stenjevačkim liječnicima govori i činjenica da se u liječničkom izvješću iz 1883. spominje kako se kalijev bromid kao sredstvo za liječenje epilepsije koristio u skladu s uputom dobivenoj od Krafft-Ebinga u Grazu. ${ }^{467}$ Samim time, moguće je da stenjevački liječnici nisu samo čitali KrafftEbingova djela, već i osobno dobivali upute od njega. Pojedine povijesti bolesti govore i o tome da su se u Stenjevcu liječili i neki od Krafft- Ebingovih pacijenata između ostalih i trgovac iz Virovitice, Jakob Konig, kojem je Krafft Ebing postavio dijagnozu „Einfersuchtswahn” („ljubomorno ludilo”), a u Stenjevcu su ga liječili od „,neurasthenije.”468

„Psychopatia sexualis” donosi detaljnu klasifikaciju poremećaja vezanih uz seksualnost, sa sažetim studijama slučaja iz prakse različitih psihijatara, ili iz sudske povijesti. U samoj knjizi nigdje nije objašnjeno zašto su upravo ti slučajevi najrelevantniji, a sami dokazi „devijantnosti” opisanih seksualnih praksi ili sklonosti ukorijenjeni su u Krafft-Ebingovom konzervativnom shvaćanju ljudske seksualnosti. Iako je za Krafft-Ebinga seksualnost izvor religijskih i estetskih osjećaja, njegovo shvaćanje zdrave seksualnosti je izuzetno suženo i odnosi se samo na seksualni nagon koji je usmjeren prema produžetku vrste i čije su funkcije kod ljudi nužno vezane s

467 LV, 1883: 101.

468 KPV, 1895: 2640. 
idejama „morala, sublimnog i ljepote”. ${ }^{469}$ Uska isprepletenost morala i estetike sa seksualnošću je u neku ruku misao vodilja cijele Psychopatia sexualis, a emotivne i seksualne prakse koje KrafftEbing uzima kao osnovu zdrave seksualnosti u potpunosti su informirane konzervativnim moralnim nazorima i emotivnim režimom građanskih slojeva. Krafft- Ebing će tako smatrati seksualnost neodvojivom od koncepta romantične monogamne ljubavi. Ljubav je za KrafftEbinga primani element seksualne naklonosti, ${ }^{470}$ a istinsku ljubav Krafft- Ebing definira kao „prepoznavanje moralnih i mentalnih kvaliteta voljene osobe.” ${ }^{\text {"41 }}$ No Krafft- Ebing ju također odvaja od puke sentimentalnosti i zamišlja ju kao spoj građanske etike i senzualnosti. ${ }^{472}$ Psychopatia sexualis također pretpostavlja tradicionalno patrijarhalno poimanje rodnih uloga. Za Krafft- Ebinga muškarci imaju jači spolni nagon, agresivni su, a njihova ljubav je izraženo senzualna i usmjerena na fizički izgled. No kod muškarca seksualni poriv ne ispunjava čitavo psihu i „nakon što osvoji nagradu njegovu ljubav zasjenjuju drugi životni i društveni interesi.”473 Žena pak, ,ako je mentalno i fizički normalna ima malo senzualne žudnje” i „muškarac koji izbjegava žene i žena koja traži muškarce su anomalije”. Žene moraju ostati seksualno pasivne jer to „od njih zahtjeva njihov seksualni ustroj, a u tome joj pomažu pravila dobrog odgoja". ${ }^{474}$ Konzervativno poimanje seksualnosti i rodnih uloga od početka će obojiti Krafft-Ebingovi klasifikaciju seksualnih poremećaja i njegovu selekciju slučajeva na primjeru kojih je te pokušaje objašnjavao. Po Krafft-Ebingu, seksualni se poremećaji dijele na periferne neuroze, spinalne neuroze i cerebralne neuroze. Periferne neuroze odnose se na neuralgije, gubitak osjeta i preosjetljivost koji su vezani uz patologiju perifernih živaca, sredstava za izlučivanje ili organa za pokretanje. Kao jedini primjer spinalnih neuroza Krafft-Ebing navodi jedino „bolesti centra za erekciju"475 dok je najveći prostor posvećen upravo cerebralnim neurozama koje Krafft-Ebing dijeli na sljedeći način:1. Paradoksija ili pojava seksualnog nagona neusklađene s fiziološkim razvojem seksualnih organa (u studijama slučaja naglasak će biti uglavnom na izraženoj seksualnosti osoba starije životne dobi)2. Anestezija ili psihički uvjetovano odsustvo spolnog

469 Krafft- Ebing, 2011: 24.

$470 \mathrm{Ibid}, 28$.

471 Ibid, 30 .

472 Ibid.

473 Krafft-Ebing, 2011: 31.

474 Ibid.

475 Krafft-Ebing, 2011: 55. 
nagona.3. Hiperestezija ili preintenzivan spolni nagon 4. Parestezija ili uzbuđivanje seksualnog nagona uslijed neadekvatnim podražajima ${ }^{476}$

Poimanja „zdrave” spolnosti ukorijenjena u građanskom moralu bit će ključne za određivanje toga što Krafft-Ebing u Psychopatia sexualis shvaća kao normalan intenzitet seksualnog nagona i adekvatan podražaj za pobuđivanje spolnog nagona. Krafft-Ebing ilustrira hiperesteziju pomoću slučaja preuzetog od francuskog psihijatra Valentina Magnana koji govori o „mladoj ženi, kćeri luđaka, majci troje djece... koja je jednog dana otvoreno rekla svom suprugu da je zaljubljena u jednog mladića”477. Sam Krafft-Ebing navodi kako je sam tretirao još pet slučajeva ,patološke ljubavi udanih žena prema mlađim muškarcima". ${ }^{478}$ Krafft- Ebing je očito smatrao da seksualno i emotivno pasivna uloga žene znači da će duševno i tjelesno zdrava žena pokazivati seksualnu privlačnost jedino prema vlastitom suprugu. Uz to, jedino je spolni nagon koji može rezultirati reprodukcijom smatran zdravim, tako da su svi oblici muške i ženske homoseksualnosti obrađeni u poglavlju o parestezijama.

I muška i ženska tijela su kod Krafft-Ebinga neodvojiva od patrijarhalnih moralnih nazora o ustroju društva. Krajnji produkt takvog diskursa je bio dvojak: s jedne strane seksualnost je moralizirana, s druge strane građanski moral (a samim tim i emotivni režim građanske klase) je naturaliziran time što ga se zaogrnulo u auru medicinskog i znanstvenog autoriteta. Krafft-Ebing je eksplicitan u svojoj eticizaciji tjelesnosti ponegdje direktno nalazeći dokaze svojih nazora o seksualnosti u društvenim institucijama. Kad Krafft-Ebing govori o ženskoj seksualnosti kao u većoj mjeri pasivnoj i spiritualnoj nego senzualnoj, ta je kvalifikacija argumentirana tvrdnjom da bi u suprotnom: „brak i obiteljski život bili prazne riječi”. ${ }^{479}$ Naturalizacija takve slike svijeta dodatno je potkrijepljena eurocentričnim opisom odnosa među spolovima u različitim kulturama. Pojednostavljen i ahistoričan prikaz seksualnosti unutar okvira europske kulture obilježene antičkim nasljeđem i kršćanstvom Krafft-Ebing ističe kao najviši civilizacijski doseg. S druge strane, seksualne prakse i bračni običaji drugih kultura su arogantno otpisani kao „tretiranje žena kao rasplodnih životinja". ${ }^{480}$ Moralistički pogled Krafft-Ebinga na ljudsku seksualnost uklapa

476 Ibid, 57.

477 Ibid, 73.

478 Ibid.

479 Krafft-Ebing, 2011: 31.

$480 \mathrm{Ibid}, 25$. 
psihijatrijsku seksologiju devetnaestog stoljeća u proces izdvajanja seksualnosti kao zasebnog instinkta koji će odmah po svom izdvajanju putem različitih diskurzivnih praksi biti podvrgnut društvenoj kontroli. Pritom su, kako je u svojoj studiji istaknuo Michel Foucault bitni objekti koji služe kao loci kontrole upravo pojedina tijela: tijelo žene koje se histerizira, tijelo masturbirajućeg adolescenta koje se podvrgava pedagoškom nazoru, maltuzijanski par koji je podvrgnut demografskoj biopolitici i perverzna odrasla osoba koju se nastoji kontrolirati putem medicinske seksologije. ${ }^{481}$ Psihijatrija je u određenoj mjeri stvarala svoj diskurs oko navedenih lokusa. Diskurzivna histerizacija ženskih tijela je redovno provođena u psihijatrijskoj zavodskoj praksi. Masturbacija je u nekim slučajevima smatrana simptomom duševne bolesti, nekad u formi masturbatornog ludila kao duševna bolest sama po sebi, a ponegdje kao njezin uzrok, no psihijatri su je općenito često isticali u povijestima bolesti. Maltuzijanski par čije je razmnožavanje podređeno opstanku vrste će postati ključnim objektom psihijatrijske eugenike, a nastrana odrasla osoba bit će utemeljenjem diskursa o moralnoj ludosti.

U okvirima hrvatske psihijatrije navedeni aspekti medicinske biopolitike su imali još jedan važan socijalni element. Naime, stenjevački psihijatri su se uglavnom bavili pacijentima ruralnom porijekla čije se obrazovanje i imovinski status razlikovao od onog samih liječnika. Taj dodir visoke građanske kulture s ruralnim stanovništvom čija je egzistencija često bila obilježena neimaštinom i predmodernim poimanjem vlastite tjelesnosti i seksualnosti proizvest će dodatne diskurzivne forme u okviru kojih će hrvatski psihijatri govoriti o seksualnosti. Njihov govor o seksualnosti neće se isključivo usredotočiti na pesimistične opise patologija modernog neurasteničnog i histeričnog pojedinca (iako će i oni biti prisutni) nego će, pod utjecajem konkretnih iskustava iz kliničke prakse, krenuti u smjeru povezivanja patološke seksualnosti i percipiranog primitivizma štićenika. Samim time stenjevački će liječnici na sebe preuzeti svojevrsnu „civilizirajuću” zadaću u okviru koje će borba protiv duševne bolesti biti neodvojiva od borbe protiv primitivizma.

U tome naravno neće biti usamljeni: jedan od prvih tekstova u Liječničkom vjesniku koji se bavi problemima bračnih običaja u Hrvatskoj doći će iz pera sisačkog liječnika Ante Gučija. Guči je na mjesečnoj skupštini Zbora liječnika 27. listopada 1879. održao izlaganje pod naslovom Kako se može preranoj ženidbi u Posavini na put stati ${ }^{482}$. Izlaganje je objavljeno u prvom i drugom broju Liječničkog vjesnika iz 1880. godine. Iako se radi o izvještaju provincijskog liječnika koji

481 Foucault, 1998: 105.

482 Guči, 1880: 1. 
se bavi problematikom iz svog kraja, u njemu se mogu nazrijeti pogledi medicinara na neke običaje koji su bili prisutni u kulturi hrvatskog sela. Osim toga, predavanje je zanimljivo i kao dokaz ranih početaka angažmana hrvatskih liječnika na polju socijalne reforme. Ta će tendencija doživjeti svoj vrhunac i punu aktualizaciju za vrijeme djelovanja Škole narodnog zdravlja i doktora Andrije Štampara, ali Gučijevo izlaganje pokazuje da su nastojanja u smjeru prosvjećivanja ruralnog stanovništva vukla korijen duboko iz devetnaestog stoljeća. U svom predavanju Guči povezuje ranu ženidbu u posavskom kraju (uglavnom u dobi od petnaest do dvadeset godina) s potrebom siromašnih zadružnih kućanstava za radnom snagom koju im nevjesta pruža. Zaključuje da su uzroci „,rane ženidbe” to što su Posavci „baš od maloće i baš radi preranih ženidaba lijeni, da im se ako dobiju ma kakovu problematičnu radnu silu više neće raditi” zatim to što je narod „veoma malo neobražen” i ,da još nisu dorasli” te u tome da postoje sebični, bezdušni i lakomi ljudi koji narod potiču na ranu ženidbu iz tobožnjih patriotskih razloga ${ }^{483}$.

Predodžbe o bračnim i ljubavnim običajima na selu su se od početka razvijale u paternalističkom tonu. Uzrok nekih nedvojbeno štetnih praksi liječnici devetnaestog stoljeća ne vide u teškim socijalnim prilikama, već u neobrazovanosti nedoraslosti i moralnoj inferiornosti ruralnog stanovništva. Sami razlozi zbog kojih Guči smatra ranu ženidbu štetnom su kombinacija medicinskih, moralističkih i eugeničkih tvrdnji kakva inače karakterizira medicinski govor o seksualnosti na prijelazu stoljeća: rano upuštanje u spolne odnose tako „škodi zdravlju muža i žene i priječi potpuni razvitak njihovih „tjelesnih i duševnih moći”, ${ }^{484}$, djeca iz takvih brakova nisu „tjelesno ni moralno dozrela" ${ }^{\$ 45}$, postoji rizik od neplodnosti, ${ }^{486}$ takva ženidba promiče nećudorednost, pobačaj i u takvim brakovima u pravilu nema ljubavi. ${ }^{487}$ Iako Gučijev angažman iskreno ide u smjeru poboljšavanja kvalitete života na posavskom selu, njegova percepcija seoskog života i seksualnih praksi ide u smjeru moralne osude ruralnog stanovništva. Često nalaženje uzroka problema u moralnim manjkavostima ruralnog stanovništva i njihovim seksualnim praksama stvorit će kod dijela hrvatskih liječnika jasnu dihotomiju između „civilizacije” predstavljene medicinom i građanskim moralom i „primitivizma” i nemorala koji postaje jedna od glavnih karakteristika njihovih pacijenata. Stavovi stenjevačkih psihijatara u

483 Ibid, 19.

484 Ibid, 4.

485 Ibid, 6 .

486 Ibid.

487 Ibid,7-8. 
velikoj su mjeri reflektirali moralističke stavove šire medicinske zajednice. Zbog toga su često povezivali devijantnu seksualnost $\mathrm{s}$ urođenim primitivizmom i moralnom „uniženošću” stenjevačkih štićenika ${ }^{488}$.

Nazori o „primitivizmu” štićenika iz ruralnih krajeva često se javljaju u prikazima Žirovčićevih psihijatrijskih vještačenja. Minku, mladu ženu iz ,jednog od najsiromašnijih krajeva naše zemlje” ${ }^{489}$ koja je bila na psihijatrijskom vještačenju jer je bila optužena da je ugušila brata svog supruga Žirovčić opisuje na način koji prispodobljuje njezin fizički izgled i duševno stanje sa siromašnim podnebljem iz kojeg je potekla: „Minka P. mlada je seljačka žena, kratka i nesumjerna tiela, nepodobne glave, „mongoloidnoga” tipa. Duševni njezin razvitak na nizkom je stepenu, nu odgovara sriedi, u kojoj je odrasla..." 490

Ideje o povezanosti primitivizma i određenih duševnih oboljenja dugo će opstojati u hrvatskoj psihijatriji. U međuratnom razdoblju, a još naglašenije u prvim godinama socijalističke Jugoslavije psihijatri će sebe percipirati kao prosvjetitelje koji imaju bitnu ulogu u oblikovanju umova nacije. No istovremeno gledanje vlastitih štićenike kroz očište „primitivizma” dovelo je do određene epistemološke i terapeutske krize. Opetovano su se nalazili u situaciji da ne razumiju ljude kojima bi trebali pomoći, što je mnoge vodilo u novi pesimizam i dvojbe oko toga postoji li u njihovim pacijentima išta nalik intelektu ${ }^{491}$. To je, naravno doprinijelo pomalo dehumanizirajućem diskursu o duševno oboljelim ljudima- On nikad nije dosegao isti opseg kao u Njemačkoj ili u brojnim kolonijalnim psihijatrijskim kontekstima, ali je svejedno ponekad izbijao na površinu.

Psihijatri će patološki seksualni nagon ponekad dovoditi i u vezu s pojmom „moral insanityja”. Dragutin Forenbacher je 1893. u Liječničkom vjesniku objavio rad O takozvanoj moralnoj ludosti (moral insanity) osobitim obzirom na patološki spolni nagon (s gledišta psychiatrijsko-pravna). Iz Forenbacherovog se članka može iščitati da je na njegove stavove o seksualnosti uvelike utjecao Krafft-Ebing- dapače, oko trećine članka zauzima sažimanje glavnih ideja i primjera

488 Takav stav neće biti vidljiv samo u odnosu prema seksualnosti. Primjerice,, stenjevački psihijatri često ističu raširenost alkoholizma u ruralnim krajevima i povezanost tog problema s duševnim oboljenjima. No jedino će Jan Šimsa proširiti svoju kritiku na društvene probleme koji uzrokuju alkoholizam, dok će za Žirovčića isti biti tek još jedan simptom moralnog posrnuća "primitivnih" nižih slojeva.

489 Žirovčić, 1904: 309.

490 Žirovčić, 1904: 311.

491 Antić, 2017: 241. 
iznesenih u Psychopatiji sexualis. Kao i za Krafft - Ebinga i za Forenbachera je seksualnost izvor estetskih osjećaja, ali je "nered u spolnom nagonu" uzrokom brojnih psihoza i neuroza. ${ }^{492}$ Članak odražava tada veoma aktualne rasprave o prirodi kriminalnog ponašanja koje su često dijelile pravnike i psihijatre. U trenutku kad se psihijatrija krajem osamnaestog stoljeća počela etablirati kao grana medicine, počeli su prijepori o tome jesu li izuzetno nasilni i brutalni zločini zapravo simptom duševne bolesti i pripadaju li počinitelji istih u djelokrug rada kaznenog prava ili psihijatrije. Te rasprave rasplamsale bi se svaki put kad bi neki novi nasilni zločin ili senzacionalni sudski slučaj privukao pažnju javnog mnijenja. Početkom devedesetih godina devetnaestog stoljeća, jedan od povoda buđenju interesa za forenzičku psihijatriju i patološku seksualnost bila su ubojstva prostitutki u londonskoj četvrti Whitechapel počinjena između 1888. i 1891. Umorstva oko kojih je stvoren mit o Jacku Rasparaču isticala su se osobitom brutalnošću, nedostatkom motiva i činjenicom da je ubojica, usprkos angažiranom radu londonske policije ostao neuhvatljiv. Iz th razloga su umorstva, u sjećanju javnosti bila događaj bez presedana ${ }^{493}$, a ulogu u njegovoj ozloglašenosti igralo je i sve "žutije" novinarstvo koje je u nedostatku jasnih informacije širilo glasine i rasplitalo nevjerojatne teorije o umorstvima. Forenbacher se u članku direktno referira na zločine Jacka Rasparača od kojih je posljednji počinjeno manje od dvije godine prije objavljivanja članka ${ }^{494}$. Poremećaje seksualnog nagona Forenbacher smatra podvrstom moralne ludosti. Moralna ludost ili „moral insanity” je kojeg je u psihijatriju uveo Bénédict Morel, a kasnije su ga usavršili Henry Maudsley i Cesare Lombroso. ${ }^{495}$

U hrvatskoj psihijatriji pojam „moral insanity” bio je usko vezan uz devijantnu seksualnost, a koristio se kako bi opisao „oblik degeneracije koji zahvaća onaj dio duše koji zovemo čuvstvom i koji rezultira potpunim gubitkom etičkih i moralnih sudova" ${ }^{\text {496 }}$. Po Forenbacherovom mišljenju, takvi pojedinci su:

„...tupi na sve što je liepo, dobro, plemenito i uzvišeno. Oni ne mogu da shvate ili prosude etičke pojmove. Jer ne poznadu ništa plemenita, ne imađu srdca ni za braću, ni za roditelje, niti znadu, što je to ljubav domovine, što li sućut prema bližnjemu nevoljniku. Oni ne mogu da dublje proniknu u zakon, da mu ođkriju njegovu etičnu i estetičnu stranu, pače sam zakon nije im drugo, već samo zapriekom, da ne čine zlo." 497

492 Forenbacher, 1893: 67-68.

493 Sugden, 2006: 71.

494 Forenbacher, 1893: 68.

495 Čeč et al., 2017: 224-225.

496 Forenbacher, 1893: 50.

497 Ibid, 49-50. 
Žirovčić definira „moral insanity” na sličan način kao i Forenbacher. I za njega postoji čitava skupina ljudi koji su „nemoralni porijeklom”. ${ }^{498}$ Znakovito je da Žirovčić u svojoj eksplikaciji „moral insanity” istu ne shvaća bolešću, već urođenim defektom koji je neizlječiv, pa se prema tome protivi smještanju istih u zavodu. Naime, Žirovčić ipak poima zavod kao lječilište, a „moralni idioti” nisu bolesni i ne mogu se izliječiti a uz to su „trajna neprilika i spačka za druge bolestnike" ${ }^{499}$ Stoga su takvi bolesnici u Stenjevcu izuzetno rijetki.

Dokumentirana je povijest bolesti nekog Petra G. pisara iz Orlovca koji je u Stenjevcu bio u tri navrata između 1883. i 1895. godine, pri čemu je prvi put otpušten kao oporavljen nakon dvije godine boravka, dok je drugi put uspio pobjeći nakon samo mjesec dana. No jedino dijagnoza iz njegovog prvog boravka, 1883 glasi „,moral insanity”. Pri kasnijim prijemima Rohaček i Žirovčić su mu postavili dijagnoze „vesania” i „imbecilitas" ${ }^{500}$. Petar je prvi put primljen u Stenjevac nakon što se pokušao ubiti iz revolvera zbog nesretne ljubavi. ${ }^{501}$ Pisma njegove sestre, zapisi liječnika iz novogradiške bolnice i bolnice milosrdne braće gdje se prije liječio se mogu čitati kao katalog Petrovih seksualnih ekscesa i konflikata s obitelji. Izvješće iz novogradiške bolnice ga opisuje na način kako su se stereotipno prikazivali „,rođeni zločinci”:,,...od rane mladosti naginje piću, gine za ženskim spolom, vodi razvratan život, sanjari o ženidbi, utuvio si je u glavu nečiste misli, godi mu ako ga tko potiče na zlo, tjera u potaji onaniju i ponašanje mu je u opće nevaljalo" 502

U cijeloj povijesti bolesti gotovo uopće se ne spominje njegov posao, niti simptomi koji ne bi bili povezani sa seksualnim ponašanjem. Čak i sam štićenik stavlja vlastite seksualne navike u fokus kad piše svoj životopis koji je priložen povijesti bolesti. Životopis je prilično nečitljiv i nekoherentan, pun opscenih pjesmica i epizoda koje uključuju zabavljanje s prostitutkama. Liječnikov komentar iz dvanaestog siječnja 1884. govori gotovo isključivo o Petrovom gubitku etičkih nazora. Njegove homoseksualne sklonosti pomalo su osebujno opisane kao „gubitak ćudorednosti genitalne sfere."

„Pojmovi u obće čisti, inteligencija nije potamnila, pače vidja se velika oštroumnost, ali samo u zlih poslovih, te njegova umobolja ide samo na način pokvarene ćudorednosti. Ukoren s činih opisanih u anamnezi, nije se niti najmanje pokazao pokaljan, pače se nekom prilikom izrazi da

498 Žirovčić, 1896a: 203.

499 Ibid, 205.

$500 \mathrm{KPV}, 1895: 2678$.

501 Ibid.

502 Ibid. 
bi svog otca za 10 forinti ubio, isto tako nije ga sram ukrasti te pozvat kako je pokrao nekog putnika, odvrati smiešeći se „kad je imao novaca” te dodaje da bi više bio imao bio bu mu sve uzeo. Bolestnik pripovjeda nadalje da je bio kadetom/što je veoma dvojbeno/ te nekom prilikom svojem majoru sabljom /koju inače kadeti ne nose/ uho odsjeko, jer je tobože major njemu bio prije čelo posieko...”Kako je daleko moralno propao dokazuje to činjenica, što veli danas da bi sakupio četu poput Kovačevića /harambaša u Hercegovini/ te mu se ne bi smililo ni živa čovjeka rezati. I čudnorednost genitalne sfere sasvim izgubljena, te nekoliko puta na nekojih bolestnicih pederastiju izveo bez ikakva srama. ${ }^{~}{ }^{503}$

Brojne druge povijesti bolesti redovito spominju seksualne navike štićenika i štićenica. Ranije je spomenuta neodređena „erotičnost” kojom su se opisivale pojedine štićenice. Osim takvih nedefiniranih pojmova, puno se pažnje posvećuje masturbaciji i homoseksualnim odnosima između štićenika. Kod Pavla B. dvadeset i jednogodišnjeg učenika trgovačke škole iz Osijeka koji je u Stenjevcu proboravio skoro tri godine prije nego što je 1911. godine umro od tuberkuloze, isticala se njegova sklonost masturbiranju. Dijagnoza mu je glasila „Dementia juvenilis" što se može čitati kao pomalo neobična varijanta Kräpelinove „Dementiae praecox” Pavao je već ranije bio u privatnom sanatoriju dr. Gluecka u Budimpešti ,radi nervoznosti i što je rado onanirao" ${ }^{\$ 04}$, a opisan je kao „žestoki masturbant" ${ }^{\text {"05. }}$. Zanimljivo je da je Pavao i sam pretpostavljao da su njegove nikad detaljno opisane duševne tegobe uzrokovane masturbiranjem, barem je tako naveo u pismu koje je adresirao na liječnika:

„Ovim hoću da opišem moju bolest radi koje sam ovdje u Zagrebu u bolnici. Prvi početak moje bolesti jeste što sam se naučio onanirati, te se od toga poslije dugog već onaniziranja koje je trajalo tri godine nisam mogao predomisliti da je to za mene vrlo vel. zahtjev da se od toga odučim te da to više ne radim ili barem da to rijetko radim. Ja sam to započeo jedanput raditi te sam se od toga posve odučio i onda sam poslije nekog vremena opet radio te se meni to činilo uvijek težje i sa većim zaprekama spojeno da se od toga odučim. Ja sam poslije to tako radio da nisam znao pošto sam to uvijek prije zaspanja na krevetu obavio kada sam već polak ili sasvim spavao dali se od toga mogu odučiti ili ne. Ja sam od toga imao te poslijedice da sam u opće postao trom da mislim i poslije sam već postao trom da se dignem iz kreveta u jutro i da se obučem poslije sam se već sasvim zanemario u svemu te sam već i teško nastojao iz moje

503 Ibid.

$504 \mathrm{KPV}, 1911: 7281$.

505 Ibid. 
školske knjige učiti. Ja sam poslije već i nesigurno išao, a glavno je od svega da sam se i u karakteru promijenio. Ja se ne ćutim sada ako prizivam istinu u opće bolestan niti je meni sada više teško misliti, ja sam sada uopće u tom bolestan što sam kod kuće bio vrlo uzrujan i što sam ja dijelom kodkuće demoralizirao i radi čega su mene uvijek psovali čemu je bio taj razlog što du dvojica kodkuće mislili da ja sve krivo radim i držali su me da ja tako hoću biti što sam slab na umu. Ja hoću još konačno reći da si nisam mogao ni kod kuće ni u školi pribaviti moj mir kako sam htjeo. Sada sebi da preduzmem da ću se drugačije držati vladati itd. te da ću se mirno vladati kao što se vide ljudi kod kuće na šetanju u društvu, na zabavi i.t.d. Pošto to držim da ću to učiniti." 506

Pavlovo pismo možemo čitati kao svojevrsnu ispovjest liječniku u kojem štićenik konačno priznaje da njegova „nemogućnost da si pribavi mir” potjeće od njegovog seksualnog ponašanja. Pored tromosti i „uzrujanosti” i teškoća u učenju, Pavao kao jedinu tegobu zapravo navodi sukobe s vlastitom obitelji zbog vlastitog ,demoraliziranja”.

Pritisak na obitelji da reguliraju seksualno ponašanje djece $\mathrm{i}$ adolescenata počinje još $u$ osamnaestom stoljeću, a unutar građanskih obitelji vidljiv je sve veći trend usvajanja psihijatrijskog diskursa kojim se masturbacija prije isključivo gledana kao grešna i nemoralna sada počela gledati kao patološka pojava. ${ }^{507}$ Sam Pavao posve usvaja gledište koje su psihijatri zastupali o masturbaciji kao praksi koja dovodi do lijenosti i nepoštovanja prema roditeljima ${ }^{508}$, vjerojatno u nadi kako će njegovo uviđanje vlastite pogreške dovesti do njegova puštanja iz institucije. U povijesti bolesti Petra G. vidljivo je kako je njegovo nemoralno ponašanje dovedeno u vezu s homoseksualnim sklonostima. Seksualnost koja nije odgovarala uvriježenim društvenim normama je stavljena uz bok Petrovoj sklonosti prema krađi i njegovim izjavama o vlastitoj sklonosti nasilju. Seksualni nagon je, u skladu s Krafft-Ebingovim pretpostavkama, za Stenjevačke psihijatre imao veliku važnost. Njegova će ,abnormalnost“ zbog toga služiti kao eksplanatorni model za ostale moralne transgresije štićenika s „,moral insanityjem“.

Seksualnost je u psihijatrijskom diskursu bila mjesto na kojem su predmoderni moralistički nazori upisani u patrijarhalne strukture građanskog društva dobivali svoj znanstveni legitimitet i

506 Ibid.

507 Neumann, 1975: 9-10.

508 Ibid, 11. 
medicinsku potvrdu. Psihijatri Zavoda u Stenjevcu su posvećivali iznimno veliku pažnju seksualnim praksama svojih štićenika: njihova seksualnost je pomno kontrolirana, istraživana $\mathrm{i}$ bilježena i smatrala se bitnim elementom u etiologiji njihovih duševnih poremećaja. Mogla je biti korištena kao simptom poremećaja ili kao dokaz njihove „niže duševne vrijednosti”. Usprkos formalnom somaticizmu psihijatrije na prijelazu stoljeća, samim fiziološkim funkcijama vezanim za seksualnost pridavalo se malo pažnje. Iako su pojmovi poput „histeriogenih zona” i „,slabljenja nervne konstitucije uslijed masturbacije" bili relativno često spominjani, nije bilo pokušaja da se za njih nađe somatsko opravdanje. Oni su prožimali diskurs u kojem je seksualnost bila prezentirana kao pomalo burleskni, a često i makabrični spektakl u kojem su se zrcalile brojne anksioznosti građanske klase kojoj su liječnici pripadali. Degeneracija, užurbani tempo života, modernitet, emancipacija žena, sifilis i „primitivizam” borili su se za mjesto u pomalo konfuznom pokušaju da se artikulira vlastito traumatično iskustvo svijeta suočenog sa svim proturječnostima modernizacije u okviru kojeg supostoje tradicionalne strukture i grčevita želja za promjenom. 


\section{Strah u Stenjevcu}

\subsection{Strah i anksioznost u kulturi devetnaestog stoljeća}

U proljeće 1750. godine diljem Pariza izbile su pobune potaknute policijskim mjerama hapšenja mladih skitnica. Tijekom dvodnevnih pobuna, bijesni građani ubili su gradskog pozornika poznatog po imenu Labbe, razbijali prozore i vrata, kamenovali javne institucije i pljačkali lokalne trgovine. ${ }^{509}$ Pobune su u jednoj mjeri bile motivirane strahom da će policija početi otimati gradsku djecu. Jedna od glasina koja je kružila govorila je o „gubavom princu“ kojem policajci dovode djecu kako bi ih ubijao i kupao se u njihovoj krvi. Princ je navodno vjerovao da takve krvave kupke liječe njegovu bolest. ${ }^{510}$

Slična bizarna manifestacija masovnog straha dogodila se gotovo stoljeće i pol kasnije u selima u okolici Karlovca, prilikom buna 1897. godine. Iako su uzroci buna bili brojni i kompleksni (nezadovoljstvo teškim ekonomskim i društvenim prilikama u kojima su se ta sela našla nakon pripojenja nekadašnje Vojne Krajine Banskoj Hrvatskoj), u njima je važnu ulogu imao strah potaknut raznolikim glasinama. Selima su kružile glasine o tome da će morati plaćati porez na sunce $^{511}$ i da će vladina ,mađaronska“ stranka ukinuti brakove i vjenčanja. ${ }^{512}$ Strah je potaknuo eskalaciju nasilja koja je vrhunac doživjela u selu Sjeničak pokraj Karlovca gdje su brutalno ubijena trojica vladinih službenika.

Povijest je puna ovakvih epidemija nasilja potaknutih strahom od neke realne, preuveličane ili umišljene prijetnje. Ti primjeri svjedoče o bitnoj ulozi koju je strah igrao u životu zajednica i o tome da, kad govorimo o strahu ne govorimo samo o individualnoj emociji ili afektu već o pojavi koja često ima konkretne društvene manifestacije. Feministička teoretičarka Sarah Ahmed u svojoj studiji politike emocija govori o strahu kao emociji koja konfigurira javni i tjelesni prostor. Strah omogućuje određenim tijelima da se sigurno kreću kroz javni prostor istovremeno ograničavajući taj isti prostor drugim tijelima. Tijela kojima strah omogućuje slobodno kretanje kroz javni prostor zamišljena su kao tijela koja valja štititi od onih tijela koja se čitaju kao izvor opasnosti. Efektivno, strah pretvara prostore u teritorije. Psihijatrija je u devetnaestom stoljeću pristupala strahu kao osobnom afektu te nije obraćala puno pažnje na društvene komponente

509 Farge i Revel, 1999:12.

510 Ibid, 124.

511 Petrungaro, 2011: 68.

512 Ibid,49. 
straha, no u okviru suvremene historiografije strah se rijetko promatra kao puka manifestacija kognitivnih procesa odvojena od kulturnog i društvenog okružja.ž

Jedan od terminoloških prijepora u pristupu povijesti straha je njegova povezanost s pojmom anksioznosti. Jedan od najčuvenijih povjesničara straha Jean Delumeau definira strah kao osjećaj zapanjenosti kojem često prethodi iznenađenje izazvano uviđanjem neke opasnosti koja prijeteći nadire i koja ugrožava naš opstanak. ${ }^{513}$ Anksioznost se pak manifestira kao bolno iščekivanje pred nekom opasnošću koja nije jasno identificirana; ona je opći osjećaj nesigurnosti. ${ }^{514}$ Klinički psiholog Stanley Rachman, jedan od vodećih stručnjaka na polju anksioznih poremećaja radi sličnu distinkciju. I strah i anksioznost su mješavina osjećaja napetosti i osjećaja neugodne anticipacije. No strah je, prema Rachmanu, emotivna reakcija na specifičnu percipiranu opasnost, na prijetnju koju je moguće identificirati. Fokusiran je, epizodan i prestaje (ili mu barem intenzitet slabi) kad se ukloni izvor percipirane opasnosti. U tom smislu strah je ovisan o vanjskom percipiranom događaju ili podražaju. ${ }^{515}$

Anksioznost se razlikuje od straha po tome što osoba koja osjeća anksioznost ne može sa sigurnošću identificirati izvor svoje unutarnje napetosti ili prirodu anticipirane katastrofe. U svojem najčišćem obliku, anksioznost je raspršena, nedostaje joj objekt, ona je neugodna i trajna. ${ }^{516}$ Upravo zbog svoje fluidnosti i neodređenosti svog objekta, anksioznost je pobuđivala velik interes psihoanalitičara. Inhibicije $\mathrm{i}$ potiskivanje nagona igraju bitnu ulogu $u$ psihoanalitičkim pogledima na psihu čovjeka. Prema tome, pojava nagonske napetosti i anticipacije kojoj nedostaje jasno definiran objekt ili gdje se objekt percipirane opasnosti ne može racionalno objasniti (npr. fobija spram konja, malog Hansa) bio je bitan za psihoanalitičku koncepciju neuroza. Sigmund Freud se opširno bavio anksioznošću i u toku svoje karijere razvio je dva psihoanalitička modela anksioznosti. U prvim spisima, Freud strepnju promatra kao „posljedicu nagomilane i neispražnjene libidalne napetosti““.517 $\mathrm{U}$ svom kasnijem djelu „Zapreka, simptom i strepnja“ "Freud je znanto proširio svoju prvotnu definiciju strepnje i vezao ju uz pojam „signala strepnje“. Signalom strepnje Freud naziva mehanizam što ga pokreće ego kad je suočen s opasnošću, kako bi se zaštitio pred prejakim dotokom podražaja. ${ }^{518}$

513 Delimo, 2003: 35.

514 Ibid, 38.

515 Rachman, 2004: 3.

516 Ibid.

517 Laplanche i Pontalis, 1992: 30-31.

518 Ibid, 434-435. 
Od psihoanalitičkih teorija strepnje treba još spomenuti i onu koju je iznio francuski psihoanalitičar, Jacques Lacan. Lacanov pogled na aksioznost jedinstven je u tome jer je suprotno uvriježenoj percepciji, Lacan ustvrdio da anksioznost ima objekt. Objekt anksioznosti za Lacana je ,objekt a“. U Lacanovom sustavu, objekt a je onaj objekt kojeg se nikad ne može doseći, jer je on izvorom žudnje, a ne objektom prema kojem žudnja stremi. ${ }^{519}$ Kao takav, objekt a, se ne može simbolički izraziti, to jest nema svoje mjesto u Simboličkom - sustavu lingvističkih i kulturnih označitelja pomoću kojih se strukturiraju odnosi Imaginarnog. ${ }^{520}$

Klinička psihologija i psihoanaliza, kao i Delumeau, imaju tendenciju gledati na strah i anksioznost kao prirodne emocije ili afekte s korijenom u neurobiološkom ili psihodinamskom ustroju ljudi. No, pri proučavanju emocija ne smije se izgubiti iz vida činjenica da su iste često određene kulturnim i povijesnim kontekstom. Delumeau kroz svoj rad primjećuje nekoliko društvenih promjena koje se tiču straha. Tako ističe kako je kroz povijest strah promatran kao emocija koja priliči jedino nižim društvenim slojevima, pritom se pozivajući na niz izvora od Vergilija do Montaignea ${ }^{521}$. Kroz Rani novi vijek, Delumeau čini sličnu distinkciju između straha neobrazovanog i ruralnog stanovništva (ono se češće plaši prirodnih pojava, vojnika i razbojnika, divljih zvijeri, čarolija i hodajućih mrtvaca) i „,sofisticiranijih” strahova obrazovanih. Strahovi obrazovanih ili kako ih Delumeau naziva strahovi „,vladajuće kulture“ su eshatološke prirode i proizlaze iz kršćanske teologije i strepnji povezanih s religijskim i političkim krizama. ${ }^{522}$ Percepcija i izražavanje straha i anksioznosti su u dugom devetnaestom stoljeću također poprimili nekoliko transformacija. $U$ europskom i sjevernoameričkom kontekstu te transformacije su uglavnom bile potaknute modernizacijom i načinom na koje su različiti umjetnički i znanstveni trendovi ulazili u javni diskurs. Kulturne transformacije vezane uz strah i anksioznost u devetnaestom stoljeću možemo podijeliti u tri grupe:

a) Različiti pozitivni i negativni pogledi na strah u umjetnosti i filozofiji koji sežu od prosvjetiteljske glorifikacije razuma i odbacivanja iracionalnog, preko romantičarske estetizacije emocija i straha, do medikalizacije straha i formiranja pojma traume na samom kraju dugog

519 Evans, 1996: 125.

520 Ibid, 11-12.

521 Delimo, 2003: 23.

522 Ibid, 274. 
devetnaestog stoljeća. Ti trendovi često supostoje u društvu i stvaraju pluralizam kulturnih perspektiva straha unutar kompleksnih emotivnih režima devetnaestog stoljeća.

b) Pojava novih objekta strahova poput straha od živog pokopa ili strahova vezanih uz utjecaj razvoja tehnologija poput željeznice.

c) Sve veća prisutnost anksioznosti u političkim, filozofskim i znanstvenim narativima, poput narativa o degeneraciji. U tim narativima, anksioznost nije otvorena iskazana kao emocija, već potisnuta i izražena diskursom koji joj daje auru znanstvene objektivnosti.

U kasnom osamnaestom stoljeću, razum i emocije nisu smatrani suprotstavljenim pojmovima. Sentiment kojeg se moglo odrediti kao „zdravog” i „prirodnog” smatran je izvorom vrline. ${ }^{523}$ Ipak, nasilje Francuske revolucije i kasnijih napoleonskih ratova dovelo je do skepticizma prema strastima. Nazivi pojedinih ključnih događaja koji su prethodili Francuskoj revoluciji ili slijedili neposredno poslije nje (,Veliki strah” ne selima ili „Vladavina Terora” koju su jakobinski vođe zazivali u pozitivnom smislu) doveli su strah u središte govora o politici. Još od ljeta 1789. glasine o zavjerama su kružile među pariškom populacijom, često dopirući i do novih političkih elita. ${ }^{524}$ Strasti i sentimenti su se pokazali politički opasnim konceptima koji imaju potencijala ugroziti javnu sigurnost i politički poredak. Radi toga su se u emotivnom režimu elita, ,prirodni sentimenti” sve više zamjenjivani konceptom vrlina. Vrlina se počinje promatrati kao prirodni izdanak volje koja je vođena razumom i usmjerena prema obuzdavanju strasti. ${ }^{525} \mathrm{U}$ novom emotivnom režimu koji je nastojao podrediti emocije vladavini razuma, strah će biti osobito negativno kogniziran (pitati kako prevesti ,,cognized emotion) jer se važnost počela pridavati osobnim kvalitetama među kojima su principijelnost i hrabrost bile veoma važne zauzimale istaknuto mjesto. ${ }^{526}$

S druge strane emocije su počele zauzimati jedno od središnjih mjesta u poetici romantizma. Gotički romani osamnaestog stoljeća poput Hoffmanovih Đavoljih eliksira i Misterija Udolfa Ann Radcliffe tretiraju emociju straha na znatno drugačiji način od sentimentalizma kasnog osamnaestog stoljeća i kasnije etike vrlina. Unutar estetika gotičkog romana osjećaj strave se invocira preko niza narativnih tropa i umjetničkih postupaka. Izazivanje straha i sličnih intenzivnih emocija usko vezuje estetiku uz emotivnost. Naravno, može se reći da je strah koji

523 Reddy, 2004: 216.

524 Tackett, 2015: 124.

525 Ibid.

526 Reddy, 20014: 217. 
prevladava u romantičarskim književnim djelima predstavljen kao nešto inherentno iracionalno i prema tome predstavlja mračni zrcalni odraz prirodi čovjeka određenoj vrlinom i razumom. U Đavoljim Eliksirima strast, žudnja i strah personificirani su kao mračni dvojnik (doppelgänger) Medardu, talentiranom i staloženom redovniku koji je prije kušanja đavoljih eliksira predstavljen kao primjer kršćanske vrline. U romanu Frankenstein ili novi Prometej Mary Shelley, znanstvena znatiželja Waltona i Frankensteina stoji u kontrastu s ispočetka djetinje nevinom, a kasnije destruktivnom i osvetoljubivom prirodom Frankensteinove odbačene kreacije. Frankensteinovo čudovište postaje objekt straha i svojevrsna „tamna slika“ znanstvenog optimizma prosvjetiteljstva. Trenutak nastanka Frankensteina kako je opisan u autoričinom uvodu iz 1831. godine svjedoči o određenoj fikcionalizaciji same geneze teksta. Frankenstein kao i samo čudovište ${ }^{527}$ nastaje za olujne noći na obalama Ženevskog jezera kao produkt natjecanja između Mary Shelley, Lorda Byrona i Percyja Shelleya u pisanju i pričanju stravičnih priča. ${ }^{528}$ Sama atmosfera nastanka književnog djela morala je biti u skladu s atmosferom jeze kojom je djelo prožeto.

Primjera stravičnih priča imamo i u hrvatskoj književnosti sredine i kraja 19. stoljeća. Poimanje straha kao emocije koja je usko vezana uz nasilno, primalno i iracionalno, ali koja također nosi određenu privlačnost bit će prisutno u umjetnosti kroz čitavo devetnaesto stoljeće. U većini tih djela strah je nužno vezan uz određene likove koji su percipirani kao ontološki i imagološki Drugi. Primjerice, u Jorgovanićevoj kratkoj priči „Stella Raiva” protagonist počinje osjećati jezu pri susretu s naslovnom junakinjom, egzotičnom indijskom opernom pjevačicom. Strah obuzme junaka u trenutku kad mu Stella Raiva” strastveno obeća da će mu se „u ponoć razgaliti”. Jorgovanić opisuje trenutak jeze:

„Stella se sruši natrag na divan i zadubi lice u jastuk. Jeza me prođe po svem tijelu, i misli tol sablastive i grozne zakružiše mojom glavom. Što je toj ženi, je li poludjela? pitah se ja. Zašto mi baš o ponoći hoće razgaliti srce, kad je tomu sada vremena i zgode? Pogledam na sat - bilo je jedanaest sati. Imao sam dakle još jednu uru čekati. Uzmem roman sa ormara i stanem ga čitati, ali čitam deset i više puta jednu te istu izreku a da ne znam štosam čitao. Čujem kako mi srce jako bije, kako mi se kosa na glavi podiže... upravo onako kao da sam slutio da nismo nas dvoje

527 Shelley, 1994: 55.

528 Ibid, 7. 
sami u toj tihanoj sobici, već da je još netko s nama al ne stvor od mesa i krvi, već duh, sablast..." 529

Pokazuje se da je protagonistov osjećaj jeze i neodređene sablasne prisutnosti u prostoriji dolazio od lubanje nekadašnjeg zaručnika koju je Stella Raiva sačuvala kao fetišs ${ }^{530} \mathrm{Ne}$ samo da je sentimentalnost junakinje time prikazana kao groteskna, već je i sam strah egzotiziran - njegov je objekt u dvostrukom onostranom- onom koje je onkraj smrti i onom koje je onkraj dominantnog kulturnog poimanja emocija.

Usprkos prevladavajućem poimanju književnosti kao objektivnog i ponegdje čak znanstvenog prikaza društva u realizmu, mnogi su istaknuti predstavnici realizma poput Honoréa de Balzaca i Guya de Maupassanta također pisali priče strave i užasa. Kulturni fenomeni kasnog devetnaestog stoljeća poput spiritualizma i opsesije znanstvenim proučavanjem paranormalnog predstavljat će svojevrsno proširenje te tendencije na polje znanosti. Književnost prijelaza stoljeća bila je obilježena estetikom moderne. Moderna je često tematizirala psihološka stanja, pritom se nerijetko služeći i tada aktualnim teorijama iz područja medicine i parapsihologije. Zbog toga ne čudi da se strah, kao bitan motiv književnosti često javlja i u djelima modernističkih pisaca poput A. G. Matoša. Osnovni narativni motiv Matoševe modernističke kratke priče „Camao” je zazorni papagaj koji predstavlja projekciju negativnih osjećaja glavnih likova. Budući da je u središtu radnje Camaa ljubavna afera Kamenskog i Fanny, papagaj možda služi kao mjesto projekcije niza tjeskobnih emocija vezanih za seksualnu transgresiju glavnih likova.

Izvan književnosti kraj stoljeća dolazi i sve veću medikalizaciju strahu preko pojma traume. Prve natruhe traumatskog poremećaja vezane su uz pojavu nazvanu „railway spine”. „Railway spine” je bio naziv za niz psiholoških simptoma prisutnih kod ljudi koji su preživjeli nesreće vlakova, a koji nisu pokazivali vidljive ozlijede. Simptomi „railway spinea” su bili raznoliki. Članak u Liječničkom vjesniku iz 1906. godine opisuje devetnaest slučajeva „railway spinea” kod hrvatskih radnika u kamenolomu Illis kod Chicaga koji su preživjeli sudar vlakova. ${ }^{531} \mathrm{U}$ sažeto opisanim slučajevima navedeni su simptomi poput omaglice, šuma u ušima, psihijatrijskih simptoma, afazije i bolova po cijelom tijelu. ${ }^{532}$ Poremećaj je prvi put opisan u engleskom listu „Lancet“ 1862. godine. ${ }^{533}$ Od trenutka kad je opisan, vodile su se debate oko njegove etiologije: dok su

529 Jorgovanić, 2002: 316.

530 Ibid.

531 Blankini, 1906: 79.

532 Ibid, 81-84.

533 Lerner i Micale, 2001: 39-40. 
pojedinci pripisivali simptome mikroskopskim oštećenjima leđne moždine, javila su se i tumačenja koja su pretpostavljala efekt psihičke traume kao uzrok simptoma. Među onima koji naglašavaju moguće psihološke uzroke „railway spinea“ je i stenjevački psihijatar Dragutin Forenbacher. Forenbacher u jednom predavanju o „traumatičnim psychozama i nevrozama“ rekao da navedene psihičke poteškoće često nastaju nakon ozljeda centralnog živčanog sustava. No za njihov nastanak, prema Forenbacheru, nije nužna direktna ozljeda mozga ili leđne moždine već je dovoljan i takozvani „psychički shock“ ${ }^{534}$ Traumatične posljedice straha će biti dodatno medikalizirane u praksi Sigmunda Freuda i Eugena Bleulera, a vrhunac medicinskom bavljenja traumom uslijedit će nakon masovne pojave „shellshocka” u rovovima Prvog svjetskog rata.

Devetnaesto stoljeće svjedoči i pojavi brojnih novih strahova. Već spomenuti ,railway spine“ kao traumatski poremećaj ne može se odvojiti od stravičnih, novih nesreća koje su pratile pojavu brzih vlakova i širenje željeznice kao dominantnog prijevoznog sredstva. Lerner i Micale tako drže ,railway spine“ odrazom šire društvene traume koju je izazvala pojava željeznice kao brzog masovnog načina prijevoza. Iako su ljudi već bili upoznatim s masovnim i tragičnim nesrećama na moru, one su se u pravilu događale daleko od očiju javnosti i u okolišu koji je odavno bio poznat kao opasan i nepredvidiv. Željezničke su se nesreće događale u okolici prostora na kojima su ljudi živjeli i radili, a njihove žrtve nisu bile mornari ili putnici u daleke krajeve, već ljudi koji su željeznicom putovali svakodnevno na posao, tržnicu ili odmor. ${ }^{535}$ Kako su vlakovi postajali brži a broj ljudi koji se služio željezničkim prijevozom veći, povećavao se i broj nesreća i žrtava. ${ }^{536}$ Velikoj smrtnosti sigurno je doprinijela i neusklađenost brzog tehnološkog razvoja željezničkog transporta s donošenjem adekvatnih sigurnosnih propisa na željeznicama. O kolektivnoj traumi koju su za društvo predstavljale nesreće na željeznici svjedoče i brojne folk-pjesme iz devetnaestog stoljeća koje tematiziraju željezničke nesreće poput pjesama „Wreck of Old 97“ i „Casey Jones“. I Blankinijev ranije spomenuti članak o „railway spineu“ kod hrvatskih radnika ne propušta spomenuti loše sigurnosne uvjete na američkim željeznicama. Za vlak na kojem se

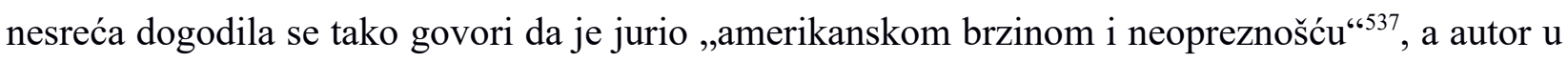
posebnoj bilješci navodi niz podataka o rekordnim brzinama američkih lokomotiva, doveden $\mathrm{u}$

$534 \mathrm{LV}, 1892: 163$.

535 Ibid, 34 .

536 Ibid 33.

537 Blankini 1906: 79. 
vezu s rekordnim brojem poginulih u željezničkim nesrećama. ${ }^{538}$ Pored željezničkih nesreća, još je jedan strah postao izrazito raširen u devetnaestom stoljeću.

Devetnaesto stoljeće je promijenilo odnos prema umiranju i smrti. Smrt osobe u vlastitom domu i u okruženju obitelji sve je više ustupala mjesto smrti u bolnici ili barem u prisutnosti liječnika. Povezanost liječnika uz proces umiranja stvorio je dvije vrste novih strahova vezanih uz smrt. Ti su se strahovi pridružili ranijim strahovima od kazne u zagrobnom životu, a sekularizacijom građanskom društva su ih počeli sve učestalije zauzimati njihovo mjesto kao primarni. Jedna vrsta straha bila je naročito prisutna kod siromašnijih, a radilo se o strahu od posthumne disekcije. Zakon o anatomiji prošao je u Britanskom parlamentu 1832. godine i omogućio je anatomima da iskoriste tijela osoba umrlih u ubožnicama i domovima za siromašne u svrhu akademskog poučavanja anatomije. Usprkos činjenici da je relativno malen broj siromašnih uistinu završio na autopsijskim stolovima, senzacionalistički je tisak bio pun opisa užasa autopsijske dvorane kao mjesta gdje mladi liječnici komadaju leševe bez ikakvog poštovanja za dostojanstvo preminulih. ${ }^{539}$

Medikalizacija smrti dovela je i do straha od mogućnosti živog pokopa. Glasine o ljudima koji su se probudili iz duboke nesvjestice, samo da bi doživjeli pravu, užasnu smrt u lijesu su zahvatile europsku javnost i dovele do izuma „sigurnih ljesova“ opremljenih zvoncem, ili kasnije telefonskom vezom s uredom čuvara groblja. Zastupnici javnih kampanja protiv preuranjenog pokapanja tvrdili su da su skupili stotine svjedočanstava ljudi koji su preživjeli taj postupak. Istraživanje provedeno na 1200 ekshumiranih trupala u New Yorku tijekom 1860-ih i 1870-ih pokazalo je da je tak strah barem djelomično bio ukorijenjen u stvarnosti: šest leševa je navodno pokazivalo znakove preranog pokopa ${ }^{540}$ Ipak, opseg straha i anti-medicinski podtekst narativa o preranom pokopu pokazuje da su izvori te panike vjerojatno u društvenoj nelagodi vezanoj uz depersonalizaciju procesa umiranja i uz nov status liječnika kao znanstvenog autoriteta koji proglašava smrt. Ideja znanstvenog i objektivnog medijatora između života i smrti bila je u suprotnosti s ranijim idealiziranim i sentimentalnim prikazima umiranja kao produhovljenog i intimnog procesa.

538 Ibid.

539 Bourke, 2011.

540 Ibid 
Dok su različite vrste straha i jeze krajem stoljeća posve preseljene u sferu umjetnosti ili medicine, anksioznost je sve više postajala diskursom kroz koji se promatrala, spoznavala i opisivala stvarnost. Različite političke i društvene tenzije koje su obilježile fin de siècle, davale se svakom govoru o društvu pomalo nervoznu i napetu notu.

Pred kraj stoljeća i najkonzervativnijim društvenim slojevima postalo je jasno da se vremena mijenjaju, a imperativ promjene donosio je nesigurnost i strepnju pred neizvjesnom budućnošću. Ta budućnost se često činila mračnom, a svijet se promatrao kao neprekidna borba pojedinaca, država, nacija i rasa za opstanak. Jedan od dominantnih ideoloških narativa bila je teorija degeneracije koja je potekla upravo iz medicinskih krugova. Već sam spomenuo Benedicta Morela i utjecaj koji je njegovo djelo imalo na somaticističku psihijatriju utemeljenu na lamarkističkim teorijama herediteta. Prema kraju stoljeća teorije o degeneraciji postaju sve prisutnije izvan psihijatrijskih krugova i postaju očište kroz koje se promatra društvo u cjelini. Osoba koja je možda najzaslužnija za širenje pojma degeneracije izvan medicine bio je Max Nordau. Nordauova knjiga $O$ degeneraciji, posvećena talijanskom utemeljitelju kriminalne antropologije Cesareu Lombrosu, proširila je medicinski pojam degeneracije na polje čitave kulture prijelaza stoljeća. Nordau je i sam bio liječnik, a kao mađarski Židov koji je živio u Parizu za vrijeme neslavne antisemitizmom obilježene Dreyfussove afere postao je zabrinut za budućnost Zapadne kulture. Nordau je vjerojatno i val antisemitizma smatrao izrazom propasti kulture, a napetosti modernizacije nastojao je iskazati diskursom tada suvremene medicine. ${ }^{541}$

Knjiga je postala europski bestseler i bitno je utjecala na dominantna poimanja moderniteta $u$ kulturi prijelaza stoljeća. Jedna od ideja knjige - Nordauov intelektualni protest protiv antisemitizma i iskaz želje za emancipacijom europskih Židova je pao u drugi plan pred distopijskim vizijama suvremene kultura kojima je knjiga obilovala, a iz kojih izbija strepnja za budućnost građanskih društava Zapadne Europe. Stil Degeneracije Maxa Nordaua varira između duhovitosti i mračnih slutnji. Nordau vidi fin de siècle kao „emancipaciju od tradicionalne discipline, koja teoretski još vlada. Za naviklog na obilje to znači nesputanu putenost, za uvelo srce egoista prezir prema bližnjem...sve u svemu kraj uvriježenog poretka koji je zadovoljavao

541 Blom, 2008: 185. 
logiku, okovao nemoral i u svakoj umjetnosti uzgojio nešto lijepo." $542 \mathrm{Na}$ stranicama Degeneracije pažnju privlače motivi koji odaju anksioznost kao stil kojim se propadanje tradicionalnog i rađanje novog opisuje. Oblaci gore „čudnim prekrasnim sjajem koji se mogao godinama vidjeti nakon erupcije Krakatoe, dok se zemljom provlače turobne duboke sjene, obgrljavajući sve u misterioznu tamu koja uništava svu sigurnost i svaka se mogućnost čini relevantnim. Oblici gube svoje obrise i rastaču se u lebdećoj magli. ${ }^{543}$ Nordau slika stvarnost nakon implicirane katastrofe prispodobive erupciji vulkana, stvarnost koja i sama postaje fluidna poput anksioznosti. Stvarnost je stalno postojanje bez mogućnosti ukotvljenja u sigurnostima tradicionalnog života. Kriza tradicionalnih vrijednosti za Nordaua je vidljiva osobito na polju estetike, koju on čini se usko povezuje s moralom. Koristeći se pojmovima degeneracije i „borderlandsa” kako su opisani kod Maudsleyja, Morela i ostalih psihijatara druge polovice devetnaestog stoljeća, Nordau opisuje kulturne predstavnike moderniteta kao degenerirane histerike i neurastenike. Brojnima od njih Nordau dijagnosticira „moral insanity” u blažem opsegu. Oni ne čine kriminalna djela, ali žele „filozofskim floskulama dokazati da su dobro i zlo, vrlina i porok arbitrarne distinkcije." 544 Naravno, progovarajući o kulturnim fenomenima medicinskim diskursom, Nordau zaogrće moralističku kritiku moderniteta aurom objektivnosti.

Anksioznost neće prožimati samo diskurs o degeneraciji bit će vidljiva i u diplomaciji kraja devetnaestog stoljeća. U Velikoj Britaniji počinje se sumnjati u premoć vojske i mornarice i raste strah od potencijalnih njemačkih špijuna tako da čak i konobari njemačkog porijekla i stranci s čudnim naglaskom bivaju sumnjivi. ${ }^{545} \mathrm{U}$ Francuskoj afera Dreyfuss rezultira antisemitizmom i ksenofobijom kod monarhista i konzervativaca. Na lijevoj strani političkog spektra, anksioznost je vezana uz vojsku koju se promatra kao utočište reakcionarnih snaga i unutarnji neprijatelj političkog poretka. ${ }^{54} \mathrm{U}$ svijetu znanosti, anksioznost izazivaju spoznaje suvremene termodinamike o mogućem „toplinskom kraju svemira” postupnom gubitku sunčeve topline. ${ }^{547}$ Bilo da se radilo o termodinamici, medicini ili rastućim političkim napetostima, anksioznost se na prijelazu stoljeća činila samorazumljivim pogledom na svijet obrazovanih elita. Možda upravo

542 Nordau, 2016: 12.

543 Ibid, 13.

544 Ibid, 24.

545 Blom, 2008: 181.

546 Ibid, 164.

547 Tattersall, 2014: 19. 
zbog normalizacije anksioznosti kroz brojne znanstvene i političke diskurse, tradicionalna psihijatrija je nije prepoznala kao mogući uzrok brojnih psihičkih poteškoća.

\subsection{Strah i anksioznost u psihijatriji devetnaestog stoljeća}

Psihijatrija devetnaestog stoljeća kontinuirano spominje strah u opisima simptoma duševnih bolesti i u dijagnozama. S druge strane anksioznost je odsutna iz njezinog diskursa, a tamo gdje se spominje, ona je opisana kao skup fizioloških simptoma koji prate strah, a ne kao zasebna emocija. Ako odlučimo koristiti podjelu antropologa Roberta Levyja između hiperkogniziranih emocija (emocije koje se u nekom društvu smatraju relevantnima) i hipokogniziranih emocija (one koje nisu društveno relevantne) ${ }^{548}$, možemo reći da je unutar psihijatrije strah hiperkogniziran, a anksioznost hipokognizirana. Takav stav prema anskioznosti djelomice potiče od činjenice što klasična medicina dugo vremena nije pravila vidljivu razliku između straha $\mathrm{i}$ anksioznosti. Hipokrat je opisao anksioznost kod nekoliko individualnih slučajeva melankolije, ali ju nije jasno razlučio od straha. Kod Hipokratovog sljedbenika, Andreasa od Charystosa anksioznost je također opisana kao ,panphobia” ili „strah od svega. ${ }^{549}$

Kasniji pisci medicinskih djela poput Roberta Burtona i Nicholasa Robinsona govore o neutemeljenim strahovima, ponekad opisujući anksioznost kao simptom melankolije, ali ju ne odvajajući od straha. ${ }^{550}$ Phillipe Pinel, jedan od utemeljitelja moral treatment pristupa i suvremene psihijatrije također hiperkognizira strah i često ističe važnost istog kod patoloških psihičkih stanja. Pinel je često vidio uzroke duševnih oboljenja u snažnim i potresnim emotivnim stanjima. Spominjući moguće vrste psihičkih podražaja koji mogu dovesti do duševnog oboljenja, Pinel će tako istaknuti kako „,...u Bicêtreu možemo naći brojne svećenike i redovnike, kao i ljude sa sela, užasnute do tog stanja (duševne bolesti), anticipacijom mučenja u paklu. ${ }^{551}$ Također, $u$ svom opisu melankolije, Pinel ističe kako „svaki uzrok straha i užasa može proizvesti osjetljivost na te emocije i potkopavši duševnu snagu, uzrokovati opasnu slabost i smrt" 552 Pinel se, kao liječnik inspiriran idejama francuskog Prosvjetiteljstva, često referira na specifično religijsku komponentu straha kao mogućeg uzroka duševnog oboljenja. Tako navodi slučaj redovnika koji

548 Plamper, 2012: 96.

549 Horwitz i Wakefield, 2012: 80-81.

550 Ibid, 83.

551 Pinel, 1806: 114.

552 Pinel, 1806: 141. 
je „doveden do stanja ludila religijskim entuzijazmom tvrdio da ga je Bogorodica u snu nagovorila da ubije svog poznanika." ${ }^{553}$

Kasnijim razvojem psihijatrije strah nije izgubio svoju važnu ulogu u razvoju pojedinih poremećaja. Emil Kräpelin će, kao kasni predstavnik njemačke biologijske psihijatrije istaknuti strah kao najperzistentniju emociju u morbidnim stanjima. ${ }^{554}$ No, Kräpelin će obratiti pažnju i na anksioznost. Naime, Kräpelin ističe da je u morbidnim stanjima strah isprva bez objekta i da se pacijent boji bez da nalazi uzrok svom strahu i shvaća da je njegov strah neopravdan. ${ }^{555}$ Kräpelin takav strah neće definirati kao anksioznost $\mathrm{i}$ istaknut će ga kao isključivo morbidnu i patološku pojavu. Uz to, Kräpelin će opisati dva tipa manifestacije straha: anksiozno uzbuđenje i anksioznu napetost. Anksiozno uzbuđenje se manifestira intenzivnom reakcijom i pripremom na obranu ili bijeg. Anksiozna napetost je manje intenzivno stanje straha koje pokazuje remisije, naročito noću. ${ }^{556}$ Prema tome, kod Kräpelina se pojam „anksioznosti” javlja tek kod opisa specifičnih manifestacija straha u morbidnim stanjima, a ono što se danas u psihološkoj, psihijatrijskoj i psihoanalitičkoj literaturi naziva anksioznošću, Kräpelin opisuje jednostavno kao patološki strah bez objekta. Kao pobornik teorija o „borderlandsu” Kräpelin spominje konstantnu bojažljivost i kukavičluk kao neke od najččšcih znakova „konstitutivnog psihopatskog stanja." ${ }^{557}$ Za Kräpelina ti aspekti ličnosti odaju „naslijeđene osebujnosti” koje u konačnici mogu rezultirati kompulzivnim strahovima, odnosno fobijama. Kräpelin će kasnije strah povezati s kompulzivnim radnjama, koja također smatra znakom konstitutivnog psihopatskog stanja ${ }^{558}$ kao jednog od elemenata hereditarne degeneracije.

Osim straha kao uzroka ili simptoma bolesti, psihijatrija devetnaestog stoljeća prepoznaje i terapijski efekt straha. Terapija „ljekovitim strahom” bila je utemeljena u percepciji duševno oboljelih kao ljudi kojima dominira gotovo animalni instinkt kojeg se može suzbiti jedino strogom disciplinom. Načini kako se u povijesti historiografije strah koristio u terapijske svrhe bili su raznoliki. Najčešće su se koristile verbalne prijetnje, ponegdje i fizičko kažnjavanje. Pacijente se također naglo uranjalo u hladnu vodu, što je oblik terapije koji je naročito hvalio 553 Ibid, 142.

554 Kräpelin, 1902: 50.

555 Ibid.

556 Ibid.

557 Ibid, 50-51.

$558 \mathrm{Ibid}, 65$. 
Phillipe Pinel zbog učinkovitosti tog načina pri prekidanju „lanca deliroznih ideja". ${ }^{559}$ Joseph Guislain, belgijski liječnik koji će kasnije postati ravnateljem zavoda za duševno bolesne u Ghentu 1821 godine je u tu svrhu projektirao posebnu napravu koju je nazvao „kineskim hramom”. Kineski hram se sastojao od metalne konstrukcije situirane na mostu položenom preko jezerca. U trenutku kad bi se pacijent našao unutar konstrukcije, sustav kolotura i poluga naglo bi spustio cijeli taj dio mosta $\mathrm{u}$ jezero, zajedno $\mathrm{s}$ pacijentom. ${ }^{560}$ Taj elaborirani mehanizam projektiran je s namjerom (kako je rekao sam Guislainu) da u štićenicima izazove strah od utapanja na siguran način. Guislan ističe da je na umu imao dva cilja: „učiniti liječnika pacijentovim gospodarom i spriječiti slučajno utapljanje pacijenta" ${ }^{561}$ Naglo uranjanje štićenika u vodu s ciljem postizanja straha i kontrole zadržalo se u duševnim bolnicama kroz cijelo devetnaesto stoljeće, o čemu svjedoče zapisnici brojnih istraga u britanskim i američkim zavodima krajem devetnaestog stoljeća. U njima se zaranjanje glave u hladnu vodu navodi kao čest oblik zlostavljanja kojem su štićenici bili izloženi. ${ }^{562} \mathrm{U}$ njemačkim zavodima početka devetnaestog stoljeća strah se ponekad postizao izuzetno maštovitim sredstvima. Poznati njemački liječnik Johann Christian Reil je u knjizi objavljenoj 1803. godine „Rapsodije o korištenju psiholoških terapija za mentalno oboljele" tvrdio da se duševna bolest može izliječiti tako da se kod oboljelog izazovu osjećaji straha, gađenja ili bijesa. Uz manje nekonvencionalne tretmane poput šibanja bolesnika koprivama, škakljanja i žigosanja pacijenata rastopljenim voskom ili užarenim željezom, ${ }^{563}$ Reil je predložio osebujnu napravu koju je nazvao „mačji klavir" (Katzenklavier). Svrha te naprave bila je u ispunjavanju štićenika strahom kako bi se oni mogli bolje fokusirati na svijet oko sebe. „Mačji klavir” se sastojao od naprave unutar koje bi bile sputane mačke:

„,(mačke) bi zatim bile poredane jedna do druge s repovima nategnutima prema van. Ploča s tipkama, na dnu kojih bi bili naoštreni čavli bi se položila preko repova. Mačka bi nakon udarca u tipku proizvela zvuk. Fuga odsvirana na tom instrumentu - kada je bolesna osoba smještena tako da ne može propustiti izraz na licima mačaka niti zvuk tih životinja- morala bi privesti i Lotovu ženu iz njezinog zaluđenog stanju u stanje u kojem je svjesna okoline"

559 Pinel, 1806: 265.

560 De Young, 2015: 323.

561 Guislain, 1826: 166.

562 De Young, 2015: 323-324.

563 Ibid, 326-327.

564 Reil, 1803: 205. 
Nije poznato je li ova metoda ikad primijenjena u njemačkim zavodima, no Reil je još za života slovio kao jedan od najutjecajnijih predstavnika „,moral treatmenta” u njemačkim zemljama i mnoge od njegovih manje ekscentričnih terapija su bile primjenjivane u prvoj polovici devetnaestog stoljeća. ${ }^{565}$ Hrvatski psihijatri, oslanjajući se na tradiciju somaticističke psihijatrije tretiraju strah primarno kao simptom duševnog oboljenja, a tek u rijetkim slučajevima kao njegov uzrok. Bolesti uz koje su se strah i anksioznost naročito povezivale bile su melankolija, paranoja i neurastenija.

Melankolija je još od antike usko povezana s emocijama straha i tjeskobe. U klasifikaciji Ive Žirovčića iz 1895. godine, melankolija se upravo često opisuje kao afektivni poremećaj za kojeg su ključne emocije tuge i strah. Strah je kod melankolika povezan s osjećajem neke umišljenje krivnje. Kod Žirovčića,"Melankolik traži uzrok svojoj boli uviek samo u svojoj vlastitoj krivnji, on sebe obtužuje, sebe potvara, da se je ogriešio, da je počinio zlo djelo, unesrećio svoju obitelj, cielo čovječanstvo; on sebe ponizuje, drži se nevriednim, da se s njim prijazno postupa, da mu se daje jesti, njega bi trebalo uništiti, objesiti, baciti na djubre; on pati od straha i užasa, savjest ga peče svejedno, kao daje sbilja šta zla počinio...."566

„Strah” i „užas” kao emocije od kojih melankolik pati pojavit će se i u kasnijem članku u kojem Žirovčić opisuje neke temeljne simptome duševnih bolesti. Članak Ive Žirovčića iz studenog 1896. navodi bolesti kod kojih se mogu javiti patološke emocije. Strah, tjeskoba, užas i očajnost su opet navedeni kao osjećaji jako izraženi kod melankolika, a u manjem stupnju kod neurastenika. ${ }^{567}$

Neurastenija je bolest karakteristična za ubrzani tempo života koju je prvi opisao američki psihijatar E. H. Van Duesen, a slavnom ju je učinio njujorški neurolog George Beard. Sama neurastenija bila je još jedna od svojevrsnih „,protejskih bolesti” devetnaestoljetne psihijatrije. Od 1869. kad je prvi put opisana do polaganog prestanka korištenja dijagnoze u međuratnom razdoblju prošla je brojne etiološke transformacije i opisivana je kao skup različitih simptoma. U kliničkim opisima neurastenije se često eksplicitno spominjao strah, a implicitno anksioznost. Zbog toga možemo reći da je povijest neurastenije bitna za daljnje razumijevanje straha i anksioznosti u psihijatriji prijelaza stoljeća. E.H. Van Duesen bio je ravnatelj psihijatrijskog zavoda u Kalamazoou u državi Michigan. Van Duesen je neurasteniju uočio kod mladih supruga

565 De Young, 2015: 282.

566 Žirovčić, 1895a: 4.

567 Žirovčić, 1896b: 252. 
siromašnih farmera, a kao njene uzroke vidio je monoton život, intelektualno nepoticajno okružje brige za kućanstvo i razdvojenost od roditeljskog doma. ${ }^{568}$ Rani simptomi te bolesti za Van Duesena su nalikovali simptomima malarije, a sastojali su se od gubitka apetita, pospanosti, čudne boje urina, gubitak snage u mišićima, razdražljivosti i neuralgija. ${ }^{569}$ No, Van Duesen je svojoj bolesti pridodao još brojne somatske i psihičke simptome. Opis između ostalog navodi nepovjerljivost, promjene raspoloženja, paranoidne ideje, glavobolje, prestanak mjesečnice, probavne smetnje, iscrpljenost, poremećaje rada srca. Anksioznost i strah se ne spominju eksplicitno u opisu bolesti, ali primjeri psiholoških simptoma su uvijek povezani s određenom tjeskobom. „Nepovjerenje” neurasteničnih žena je tako povezano sa zebnjom nad različitim aspektima života:

„Ako je bolesnica osoba dubokih religijskih uvjerenja... ...javlja se nepovjerenje u Božja obećanja, morbidni pogledi na osobne odnose s crkvom i društvom-ono što se nepravilno naziva „religiozno melankolijom. Ako je stjecanje imetka i posjedovanje velikog zemljišta njezin životni cilj, muči ju strah od siromaštva.... Ako su bračni odnosi bili bliski i ispunjeni nježnošću, muči je ljubomora." ${ }^{570}$

Van Duesen je neurasteniju prepoznao kod svojih siromašnih ruralnih pacijentica. Promatrao ju je u odnosu prema malariji i ukazivao na distinktivno psihološku prirodu neurastenije. George Beard je svoj prikaz neurastenije dao nekoliko mjeseci kasnije i njegov će opis simptoma i uzroka te bolesti imati daleko veći utjecaj na psihijatre od Van Duesenovog. Beard se u svom predavanju o neurasteniji održanom pred njujorškom udrugom urednika medicinskih časopisa ne poziva na Van Duesena i govori kako u trenutnim medicinskim traktatima trenutno ne postoji poglavlje ili rad o neurasteniji. Čini se da je pojam neurastenije ipak bio korišten u medicinskoj praksi i prije Bearda i Van Duesena jer Beard navodi kako je pojam ,živčane iscrpljenosti” već poznat u dijelu medicinske literature. ${ }^{571}$

Ono u čemu se sastoji najznačajniji Beardov doprinos ideji ,živčane iscrpljenosti” je činjenica da je od iste učinio bolest modernog doba povezavši strahove pacijenata sa stresnim utjecajima užurbanog urbanog života na pojedinca. Primarni uzrok neurastenije za Bearda nije socijalna izolacija na farmama pograničnog i ruralnog Michigana, već moderna civilizacija. Među glavne osobine kojima se moderna civilizacija razlikuje od „drevnih” civilizacija Beard ubraja parni

568 Van Deusen, 1869: 447.

569 Ibid, 448-450.

570 Ibid, 450-451.

571 Beard, 1869: 217. 
stroj, periodični tisak, telegraf, znanost i duševnu aktivnost žena. ${ }^{572}$ Sekundarni i tercijarni faktori uzroci neurastenije su klima, institucije, osobne navike i prekomjerno prepuštanje porivima i strastima. ${ }^{573}$ Užurbani način života i modernizacija za Bearda su odlike američkog života i zbog toga je neurastenija prepoznata kao ,američka bolest”. Živčano oboljenje postalo je svojevrstan odraz nacionalnog identiteta i dokaz razvijenosti Sjedinjenih Američkih Država u odnosu na Europu- naročito u odnosu na Veliku Britaniju koju Beard direktno spominje u knjizi koja je popratila njegovo predavanje, ${ }^{574} \mathrm{U}$ spomenutoj knjizi, prikladno nazvanoj American Nervousness Beard opisuje tjelesni ustroj ljudi koji se značajno razlikuje od Van Duesenovog: oni su profinjenog ustroja, tanke nježne kose i kože, malih kostiju, izduženih udova i slabe muskulature. ${ }^{575}$ Takav tjelesni ustroj Beard prepoznaje kao dominantan u Sjedinjenim Američkim Državama kao opis onog sloja ljudi koji svojim radom „tjera zemlju naprijed”. Pritom Beard pod radom podrazumijeva isključivo intelektualni $\operatorname{rad}^{576}$ koji za sobom donosi slabljenje živčanog sustava i mnogobrojne psihosomatske tegobe, strahove i nervozno raspoloženje.

Hrvatski psihijatri nisu prepoznali mnogo slučajeva neurastenije, ali su opsežno pisali o njoj. Također, može se reći da je u okvirima hrvatske psihijatrije neurastenija dodatno somatizirana i povezana sa hereditetom. Za Žirovčića će neurastenične osobe nužno biti ,hereditarno obterećene individue" 577 . Neurastenija je, uz melankoliju također definirana strahovima i fobijama, te osjećajem strepnje i nelagode koji bismo danas možda prepoznali kao anksioznost:

„Ovamo spadaju nadalje razne fobije: bolestnik se plaši visokih, visećih, gibajućih se predmeta, otvorenoga prostora, samoće, množtva ljudi; žaca sedirnuti kvaku na vratih, pak ako je to morao učiniti, pere si neprestano rake, kao da se je nečim zamrljao...boji se preći preko mosta, jer bi sebe ili koga drugoga morao u vodu baciti; strah ga hvata, neće li se ovo ili ono dogoditi, neće li sviet propasti itd." 578

Osim što je kod Žirovčića neurastenija povezana s hereditetom i što je karakterizirana kao „konstitutivna psihoza” pojedinaca sklonih strepnjama, kompulzijama i fobijama, ona gubi svoju vezu s napornim mentalnim radom, već se počinje vezivati i uz moralna posrtanja. Kod hereditarnih neurastenika se tako pojavljuju razni „duševni defekti” između ostalih i lažljivost i

572 Ibid, vi.

573 Ibid.

574 Beard, 1860 vii.

575 Beard, 1869: 23.

576 Campbell, $2007: 162$.

577 Žirovčić, 1895a: 67.

578 Ibid, 66. 
„protivno spolno osjećanje”. Nadalje, oni su nepostojani i nepouzdani. ${ }^{579}$ Žirovčić uz hereditarnu neurasteniju opisuje i stečenu neurasteniju koja se odlikuje sličnim simptomima kao i hereditarna. „Plahost” i „strašljivost” se pojavljuju i kod jedne i kod druge bolesti. ${ }^{580}$

Melankolija i neurastenija su jedine bolesti u čijem opisu Žirovčić spominje strah. U nekim povijestima bolesti strah se navodi kao mogući uzrok psihičkog poremećaja. Premda je hrvatska psihijatrija bila somaticistička u svom shvaćanju etiologije duševnih bolesti, rana izvješća su navodila „affectus” kao jedan od kontinuirano najčešćih uzroka oboljenja. „Affectus” će prevladavati kao uzrok mentalne bolesti kod žena koje su u devetnaestoljetnoj medicini smatrane podložnije djelovanju snažnih osjećaja jer ih se smatralo osobama krhkijeg „živčanog ustroja”. Liječnička svjedodžba bolesti lončarove supruge Jele S. povezuje početak njezine bolesti sa strahom od „,̌arolija”: „,26 prosinca pr. g. da se je probudila kao preplašena, okol sebe gledala zatim poče pripovjedati o strašnih sanjah i čarolijah pa kad joj ne htjedoše vjerovati razgnjevi se i poče sve oko sebe parati i tući" ${ }^{\prime 51}$

Seljak Pavao T., tvrdio je da se razbolio služeći vojsku kad je ,je jedne noći, dok je bio na svojoj patroli, došao u stražarnicu k njemu čovjek, legao uz njega i opet ustao. Od tada ga lovi strah." 582 . Liječnička svjedodžba također govori kako je uzrok Pavlovog oboljenja bio strah, ali navodi znatno drugačiji kontekst. Prema liječničkom izvješću Pavla je veliki strah uhvatio zbog nekih trgovačkih ugovora koje je nosio svom ocu. ${ }^{583}$ Seljanka Zlata Š. se, prema izjavi koju je liječnicima dao njezin suprug, uplašila i razboljela kad im je susjed s kojim su bili u zavadi otrovao kokoši. ${ }^{584}$

Strah se kao uzrok bolesti najčešće navodi kod štićenica ili muškaraca nižeg socio-ekonomskog statusa, no kao što će analiza slučajeva u ovom poglavlju pokazati, svjedočanstva o strahu kao uzroku bolesti se često ignoriraju jer nisu u skladu sa dominantno somaticističkom etiologijom kojom se psihijatrija vodi. Objekti straha i njihov konkretan odnos s izbijanjem bolesti bili su raznovrsni: osim uzroka bolesti, štićenici osjećaju razne strahove i strepnje vezane uz različite aspekte svoje svakodnevice.

U nastavku nastojat ću opisati četiri temeljne manifestacije straha ili tjeskobe u povijestima bolesti stenjevačkih štićenika. Radi se o strahu od neimaštine, strahu od natprirodnog, strahu od 579 Ibid.

580 Ibid, 67.

$581 \mathrm{KPV}, 1881: 319$.

$582 \mathrm{KPV}, 1895: 2685$.

583 Ibid.

584 KPV, 1910: 7771. 
nasilja, te paranoidnim strahovima vezanim uz politiku i opresivnu moć države. Na temelju navedenih manifestacija, nastojat ću razlučiti kakvu su ulogu strah i strepnja imali u psihijatrijskom diskursu. Od naročite će važnosti biti distinkcija između emotivnih stanja koja su se smatrala normalnima i onih koja su se doživljavala kao patološka, bilo da ih se promatralo kao distinktivni simptom duševnog oboljenja ili ih se dovodilo u vezu s pojavom duševne bolesti. Osim toga, strah i anksioznost štićenika su bili povezani sa njihovim iskustvom, sustavom mišljenja i vjerovanja i svakodnevicom, a nerijetko su se u njima javljali strahovi i strepnje potaknuti širom društvenom i političkom situacijom.

\subsection{Strah od neimaštine}

Liječnici i bolničari stenjevačkog zavoda bili su svjesni da velik broj njihovih štićenika vodi život na rubu oskudice ili se direktno bori za preživljavanje. Prvi ravnatelj zavoda Ivan Rohaček je usprkos dominiranju somaticističkih teorija u jednom od godišnjih izvješća pretpostavio da je kod većine štićenika uzrok oboljenja siromaštvo i s njime povezana slabokrvnost. ${ }^{585}$ Većina liječnika, osobito onih koji su imali iskustvo rada u ruralnim krajevima Hrvatske je svjesna nepovoljnih utjecaja siromaštve i bijede na zdravlje stanovništva. Siromaštvo i bijeda su rašireni, naročito kod pojedinaca koji iz različitih razloga ne mogu računati na materijalnu podršku najbližih. Štićenici u Stenjevcu često opisuju teške uvjete života i osjećaj strepnje koje su isti u njima izazivali. Očekivano, takvi opisu dominiraju u povijestima bolesti seljaka i sitnih obrtnika, te nadničara.

$\mathrm{Na}$ samom početku rada Stenjevca pojedini bolesnici su zavedeni kao „,bosanski bjegunci”. Radilo se, vjerojatno o ruralnoj populaciji Bosne koja je izbjegla nakon intervencije AustroUgarske vojske u Bosni 1878. godine. Intervencija, nakon koje je uslijedila Austro-Ugarska okupacija Bosne, bila je praćena otporom lokalnog stanovništva, a nasilje okupacije je utjecalo i na civile. Točan broj ljudi koji su izbjegli iz Bosne nakon okupacije i pobuna koje su uslijedile nakon iste u razdoblju između 1879. i 1882. godine nije istražen, no dio stenjevačkih povijesti bolesti govori o egzistencijalnoj nesigurnosti i strahu od ekstremne bijede koju su izbjeglice osjećali. Bosanski bjegunac Nikola K. primljen je u zavod 15. studenog 1879. i boravio je u zavodu do 13. lipnja 1880. godine. U zavodu mu nije postavljena nikakva dijagnoza, a opis njegovog psihičkog stanja kaže da je ,prilikom bijega iz Bosne izgubio svoju marvu i od toga vremena počeo bolovati" ${ }^{586}$. U zavodu, Nikola je miran i staložen, vrijedno obavlja sve poslove

585 Rohaček, 1889: 149.

$586 \mathrm{KPV}, 1880: 29$. 
no opetovano je zabilježena njegova strepnja nad vlastitom budućnošću. Čini se da je htio biti primljen u službu kao zavodski sluga ,jer ne zna kako će kod kuće živjeti”. ${ }^{587}$ Nikolin strah za vlastiti život povezan je s gubitkom stoke od koje je ranije preživljavao. Druga "bosanska bjegunica", Sava R. također često govori o gladi i teškim uvjetima života pred kojima je pobjegla, jednom čak plačući jer je „,izbljuvala lijepi ručak koji su joj liječnici dali." 588

Osim bosanskih bjegunaca, strah od siromaštva je gotovo stalno prisutan i kod ruralnih štićenika. Prilično često ga izražavaju štićenici kojima je dijagnosticirana ,melancholia” a koji su bili sa sela. Može se uočiti da je sama „melancholia” (uz „maniu”) češće bila dijagnosticirana štićenicama iz ruralnih krajeva, nego onima iz gradova. Budući da su se u Žirovčićevoj klasifikacija „melancholia” i „mania” smatrale ,afektivnim psihozama”,589 i da su afekti u okviru emotivnog režima građanske klase zauzimali hijerarhijski niži položaj od razuma ili „etičkih i estetičkih čuvstava" to može odražavati percepciju siromašnog seoskog stanovništva kao „primitivnijeg” i sklonijem emocijama.

Udovici iz Grane. Mari Š. Dijagnoza „,melancholie” kasnije je pretvorena u ,anoiu”. Mara je boravila u Stenjevcu 1881. godine, a tamo je i preminula od tuberkuloze krajem iste godine. Kao uzrok Marine bolesti naveden je ,,prestanak mjesečnice”. Bolest se manifestirala time što je Mara „prvo zapuštala posao, zatim se klatarila po noći, vikala psovala i trgala odielo" ${ }^{590}$. U kući je ležala, raskuštrane kose,motreći oštrim pogledom svoju okolinu i pokrivena starim pokrivačem te često pjevala, vikala i psovala. ${ }^{591}$ Prema izjavama koje daje u zavodu, Mara je uglavnom zdvajala oko udaje za nekog „dimnjačara, bogca” pred kojom je strahovala. Mara je nekoliko puta dala do znanja da će se morati udati za „bogca” ili će izgubiti kuću te da će i ona biti „bogec”. U jednoj od izjava koju je dala liječnicima 21. travnja 1881, Mara tumači svoju bolest kao posljedicu straha od ponovne udaje za nekog siromašnog:

„Mora bogca uzeti, a ona ga neće... Bogca se boji od lanjske godine, prem ga vidjela nije: kad ju iznenada strah spopadne tako pa poče bježati po kući. Inače više-manje na pitanja uredno odgovara, no sve misli joj se oko bogca i kuće vrte. Takve bogce čuje ona na sve strane koji joj dovikuju: ,,i ti buš bogec, bogec i ti. ${ }^{592 "}$

587 Ibid.

588 KPV, 1881: 116.

589 Žirovčić, 1895a: 20.

$590 \mathrm{KPV}, 1881: 309$.

591 Ibid.

592 Ibid. 
Kod nekih štićenika bolest se pojavila u trenutku kad su im se dogodile velike ekonomske poteškoće, bilo zbog neke nesreće ili zbog dugova. Seljanka Mara K. razboljela se nakon što su joj kuća i marva izgorjele u požaru. Nakon toga je često palila vatru u kući i u strahu zvala seljane da ju idu gasiti. ${ }^{593}$ Druga seljakinja, po imenu Kata K. primljena je u Stenjevec 20. kolovoza 1880. godine s dijagnozom „melancholie”. Jedini simptom njezine bolesti koji se provlači kroz povijest bolesti je strah od nekog povjerenstva koje će joj prodati kuću zbog duga. ${ }^{594}$ U povijesti bolesti je ostala zabilježena i njezina slikovita izjava da su ju službeni organi, načelnik i panduri „u pakao upisivali”595. Bara D. iz Dražica udala se prema izjavi općinskog liječnika „iz bogate kuće za bogeca” ${ }^{996}$. Suprug ju je doveo liječniku i opisao okolnosti nastanka njezine bolesti:

„Ovog proljeća hranila je ona 2 kom. svinjah što ih je kupila bila kako se čini, istom namjerom da ih dobro uhrani i onda prodade. $\mathrm{Nu}$ na jednom- bez poznatog razloga krepalo je joj oba ona dva svinjčeta. Ovaj gubitak dojmio se nje tako silno da je ona, koja je do sada uvijek nabožna bila- mislila da je to očito kaštiga božja. To se vidi iz njenih rieči polog kojih smo svi mi grešni, te za griehe naše bogu se moliti moramo. , 597

Čini se da je gubitak svinja bio izrazito traumatičan za Baru: nakon ugibanja svinja često je „Čislom u ruci oplakivala svoje krepane svinje, išla bi po selu čislom i Bogu se molila i nabožne pjesme pjevala..."598 U zavodu se Bara ponaša mirno, često izražavajući naklonost prema svom suprugu te ne pokazuje strah zbog financijskog gubitka koje je smrt svinja predstavljala. Zanimljivo je i da Barina povijest bolesti sadrži zanimljivu dijagnozu „Mania religiosa ex amissis suibus" (religiozna manija zbog gubitka svinja". Kosta F. iz Opatovca je pak zapao u beznađe i strepnju jer se bojao da neće moći financijski opstati nakon što mu je sin unovačen. Odlazak odraslog djeteta u vojsku je vjerojatno značio gubitak radne snage na zemlji i neizvjesniju budućnost za čitavu Kostinu obitelj. Kosta je nakon sinovljevog unovačenja bio neutješan:

"...bojao se da će žena i djeca od glada morat poginuti, zadržavao se većinom na dvorištu gor i dol hodeć, psovao domare" ${ }^{599}$. Liječnik koji je preporučio njegovo smještanje u zavod pričao je

$593 \mathrm{KPV}, 1880$ : bez broja.

$594 \mathrm{KPV}, 1880: 257$.

595 Ibid.

$596 \mathrm{KPV}, 1881: 250$.

597 Ibid.

598 Ibid.

599 KPV, 1880: bez broja. 
s njegovim ukućanima i susjedina koji su svjedočili da Kosta ,jede samo suhi kruh i uklanja se vlastima”. ${ }^{600}$ Došavši u Stenjevec, Kosta opetovano očituje svoju zabrinutost za preživljavanje svoje obitelji govoreći kako ,...će svi u kući od gladi poginuti, da niti hleba niti druga sredstva u kući nema, raditi ne može i to je zlo što uslijed toga mora sve propasti. Upitan zašto da ne radi odgovorio je razjaren da on raditi u stanju nije jer ništa nema i jer je sve propalo" ${ }^{601}$

Odnos liječnika zavoda prema traumatičnim posljedicama siromaštva nalazimo artikuliran u dva slučaja koji uključuju štićenice dovedene u Stenjevac na psihijatrijsko vještačenje zbog umorstva vlastite djece. Obje su tvrdile da su počinile umorstva kako bi spasile djecu mučne smrti od gladi. Slučajevi su se dogodili s razmakom od dvadeset i sedam godina, no nalazi vještačenja koje su napisali Drago Forenbacher i Ivan Žirovčić odaju slične poglede na emotivne posljedice siromaštva. Prvi slučaj odnosi se na Baru O. tridesetgodišnju seljanku iz Podgarja kod Virovitice koja je optužena da je ,zaklala kamom troje svoje djece” pa nakon toga pokušala počiniti samoubojstvo. ${ }^{602} \mathrm{O}$ uvjetima njezinog života doznaje se uglavnom od nje same i od rođaka $\mathrm{i}$ susjeda. Bara je navodno bila zlostavljana od strane svog supruga koji ju je ,tukao i proganjao, ${ }^{603}$ a kad je uhapšena priznala je da je ubila djecu jer ,,joj je djece žao bilo da se ne muče i ne trpe glad, pa da je bila voljna i sama s djecom umrieti." ${ }^{604}$ U Stenjevec je dovedena 10. lipnja 1890. godine. Kao što je to često bio običaj u vrijeme upravljanja ravnatelja Rohačeka, njeno psihijatrijsko vještačenje na sebe je preuzeo Dragutin Forenbacher. U Stenjevcu nema puno zapisa o Barinom ponašanju budući da je nakon dva mjeseca preminula od tuberkuloze. Čini se da Bara u nekoliko navrata navodi različite motive za umorstvo svoje djece. Tako prvo odbija reći razloge koji su ju nagnali na zločin i „,.. bezbrižno, skoro smijuć se veli da je i sebe htjela ubiti” ${ }^{605}$ Dva dana kasnije u nastavku razgovora s liječnikom Bara tvrdi da je ubila djecu jer ,,su ljudi sumnjičavi, da neimade djecu sa svojim mnogo starijim mužem nego s drugim," "606 U svom konačnom mišljenju Forenbacher je specifično išao opovrgavati siromaštvo kao mogući motiv zločina. Naime, Forenbacheru se čini da teško ekonomsko stanje ne može biti motiv takvog zločina jer je glad toliko učestala, a umorstva i samoubojstva nisu čest au toj populaciji:,,Da se je

600 Ibid.

601 Ibid.

602 KPV, 1890: 1626.

603 Ibid.

604 Ibid.

605 Ibid.

606 Ibid. 
motrenica zbilja toliko mučila i da je glad trpjela, to nije istina; druge žene bog zna koliko trpe pa ne ubijaju sebe i djecu. Taj čin neima dakle razloge u izvanjskom svietu"607

U svom mišljenju, Forenbacher potpuno ignorira bilo kakav mogući utjecaj emocija (makar i sasvim patoloških) na Barin zločin. Bari je dijagnosticirao „Dementiu” ali ju na više mjesta spominje kao „,melankolika”:,U melancholika nadodju momenti da takav bolesnik gonjen nekom nevoljom silom nadvlada pasivnost te prijeđe u pravo bjesnilo uništavajuć sve što mu ruku dođe." 908

Iako se u većini opisa melankolije spominju tuga i strah/anskioznost kao dominantne emocije, jedina emocija koju Forenbacher indirektno spominje je „bjesnilo” (moguće je, također da se tim pojmom prije opisuje stanje svijesti nego emocija). U stanje ,bjesnila” melankolik dolazi tako da ga na to nagoni „neka nevoljna sila.” Forenbacher tako udaljuje moguće motivacije za nasilan čin od konkretnih životnih uvjeta Bare O., te ih apstrahira na razinu neodređenih „,nevoljnih” sila koje utječu na postupanje melankolika. Dvadeset i osam godina kasnije, u jeku Prvog svjetskog rata, Ivan Žirovčić je u članku objavljenom u Liječničkom vjesniku opisao drugi slučaj umorstva djece motiviranog neimaštinom. Radilo se o psihijatrijskom vještačenju R. D. tridesetogodišnje muslimanke koja je živjela u Misurićima kraj Maglaja, gradića u središnjoj Bosni. Maglajska srednjovjekovna utvrda i šumom obrasle planine oko nje se često pojavljuju na austrijskim orijentalističkim razglednicama prijelaza stoljeća, koje su gradu pridavale auru pastoralne egzotike. No, već u godinama prije okupacije Bosne i Hercegovine, Maglajska je utvrda bila zapuštena i urušavala se, a stanovništvo Maglaja i okolnih mjesta često je bilo na rubu neimaštine. Izbijanjem Prvog svjetskog rata, zavladale su nestašice hrane koje će biti jednim od uzroka tragedije o kojoj Žirovčić piše. R. D. i njezin suprug Salko su bili siromašni, a susjedi su R. opisivali kao marljivu kućanicu i brižnu majku koja je do trenutka tragedije bila duševno zdrava. ${ }^{609}$ Njezin suprug je bio unovačen, a ona i kćeri ostale su same i živjele su u iznimnoj neimaštini. R. i najstarija kćer, jedanaestogodišnja Šaha, morale su privređivati za hranu. U srpnju 1917 R. je utopila dvije mlađe kćeri, sedmogodišnju Ajku i četverogodišnju Nailu u Bosni, negdje uz cestu od Maglaja prema Doboju. ${ }^{610}$ Prvo je utopila Nailu zaronivši joj glavu pod vodu. Ajka je uspjela pobjeći i izići do obale, ali su je prolaznici vratili majci misleći da je upala u vodu slučajno. Nakon toga ju je R. odvela do obližnjeg potoka Jelovca i tamo joj držala glavu

607 Ibid.

608 Ibid.

609 Žirovčić, 1918: 336.

610 Ibid: 333. 
pod malenim vodopadom dok nije izdahnula. Poslije svog čina, pričekala je najstariju kćerku koja se nalazila u gradu i s njom odnijela djecu kući, predstavivši svima njihove smrti kao nesretan slučaj. No, netko je posumnjao u njezinu priču i nakon što su lokalne vlasti povele istragu R. je priznala zločin. ${ }^{611}$

Nakon uhićenja R. je bila podvrgnuta višestrukim psihijatrijskim vještačenjima tijekom kojih je više puta navodila kako je ubila djecu jer je patila i gladovala pa je odlučila ubiti i sebe i djecu. Psihijatrijski vještaci u Tuzli i Sarajevu susreli su se s istim problemom s kojim se ranije susreo Dragutin Forenbacher: može li strah od smrti od gladi nadvladati majčinski instinkt (kojeg psihijatri poput Krafft-Ebinga ističu kao najjači prirodni poriv kod žena) i nagna ženu na umorstvo vlastite djece. U horizontu devetnaestoljetne psihijatrije, potvrdan bi odgovor na to pitanje podrazumijevao određeno duševnu abnormalnost, a s obzirom na prevladavajuću somaticističku paradigmu, ta je abnormalnost morala proizlaziti iz tjelesnog ustroja žene. S druge strane, psihijatre je zbunjivala promišljenost i planiranje čina, koji su opet bili u neskladu s emotivnim stanjem koje us primjećivali kod R.. Prvo forenzičko mišljenje iz 25. kolovoza 1917. koje su dali vještaci suda u Tuzli, odaje njihovu zbunjenost i zdvojnost u slučaju R.D.:

„Nedvojbeno, u slučaju postoji proračunatost i određen logičan odnos prema činjenicama. S druge strane, osoba je manjkavih duševnih kvaliteta, budući da pati od određenog stupnja melankolije. Dvojbeno je, je li čin počinjen u trenutku melankoličnog napada, u neubrojivom stanju budući da glad kao motiv ne može objasniti počinjene djela" ${ }^{{ }^{12}}$

R. je upućena na daljnje vještačenje u zemaljsku bolnicu u Sarajevu, a tamošnji su vještaci dali dva različita nalaza. U prvom koje je datirano 13. 11. 1917. nije nađen konkretno duševno oboljenje pod utjecajem kojeg je R. D. mogla počiniti zločin već se navodi da je ubila djecu ,ppod uplivom velike bijede, koja ju je dovela do zdvojnosti”, ${ }^{613}$. No, kako je istraga napredovali, Sarajevski su vještaci promijenili svoj stav. Čini se da je presudno za njihov sud bilo otkriće neke hrane koje ju je R. imala kod kuće. Njihovo izmijenjeno mišljenje od prvog ožujka 1918. kvalificiralo je R. kao duševno zaostalu:

611 Ibid.

612 Ibid: 333-334 original: »Es liegt demnach auch eine Berechnung und gewisse logische Erwagung der Tatsachen zweifellos vor; anderseits aber ist die Untersuchte nicht von einwandfreier geistiger Qualitat, da zweifellos ein gewisser Grad von Melancholie vorhanden ist. Es ist aber für uns zw eifelhaft, ob diese Tat wirklich im Zeitpunkt eines melancholischen Raptus vollbracht wurde, in einem Zustande, der Zurechnungsfähigkeit ausschliessen würde, da das Motiv Hunger die vollbrach te Tat nicht erklären kann", preveo autor

613 Ibid: 334. 
„,...duševna labilnost i defekti R. D. su patološke naravi, označuju se kao slaboumnost, i kvalificiraju je, kao da je sasvim bez uma: to proizlazi iz opstojnosti na raspravi ustanovljene, da je u nje u kući nadjeno dovoljno hrane za nju i za djecu za više dana, te oskudica ne može dovoljno motivirati njezin čin; njezina prevrtljivost $u$ iskazivanju, nestalnost reprodukcije $i$ defekti rasudjivanja očituju se naročito time, što je potvrdjivala iskaze svjedoka, koji su protuslovili njezinim čas prije navedenim izjavama. U ostalom kažu vještaci, izmedju duševne tuposti i patološke slaboumnosti ne može se povući točna granica...” Njezina je bolest navedena kao „urođena slaboumnost”. ${ }^{614}$

Budući da su i dalje postojale dvojbe oko R-inog psihičkog stanja u trenutku počinjena umorstva upućena je u Kraljevski i zemaljski zavod za umobolne u Stenjevcu. U zavodu je R. letargična i mirna. Pri dolasku zabilježena je njezina iznimna pothranjenost, koja je možda i uzrokovala njezino gotovo katatonično ponašanje. Kad je primljena u zavod R. je težila 49 kilograma na visinu od 167 centimetara $\mathrm{i}$ iz zapisa se vidi da je ustala iz kreveta $\mathrm{i}$ čak počela raditi na zavodskom poljoprivrednom dobru nakon što je dobila na težini. ${ }^{615}$

U iskazu koji je dala doktoru Žirovčiću, R. opisuje tešku oskudicu koja je vladala u Maglaju. Iako je težačkim poslom mogla zaslužiti novac, čini se da u cijelom gradu nije bilo hrane na prodaju. Imućniji koji su imali hrane, nisu je htjeli prodavati jer su „od njih nosili u Carevinu” (vjerojatno rekvirirali hranu za vojne potrebe) pa su se i sami bojali gladi. ${ }^{616} \mathrm{R}$. i kćeri su preživljavale od voća koje bi kupile za zasluženi novac i od „gebira” (sljedovanja) koji su se sastojali od tri četvrt kilograma brašna tjedno i suhih šljiva. Uz to, R. je kuhala bilje koje je raslo kraj puteva. ${ }^{617} \mathrm{Kad}$ govori o svom zločinu, Žirovčić bilježi da se R. kaje i „,gorko i dugo plače” čim ju se pita o djeci ili o umorstvima. ${ }^{618}$ Žirovčić, kao i drugi vještaci primjećuje da se R. ne sjeća točno detalja svog čina, te da o njemu govori šturo i kroz plač. Nakon tromjesečnog vještačenja, Žirovčić donosi zaključak kojim pokušava objediniti utjecaj neimaštine i somaticističke i rodno determinističke pretpostavke psihijatrijske misli. Naime, Žirovčić nalazi da je R. D. histeričnog duševnog ustroja što potkrepljuje smanjenim osjetom za bol i izostankom refleksa u ždrijelu. ${ }^{619}$ Izostanak osjeta na bol, Žirovčić čak dovodi u asocijativnu vezu s nedostatkom majčinskog instinkta u nastojanju da

614 Ibid.

615 Ibid.

616 Žirovčić, 1918: 335.

617 Ibid.

618 Ibid.

619 Žirovčić, 1918: 337. 
prikaže R. kao patološki bešćutnu osobu,usprkos njezinim intenzivnim emotivnim reakcijama na događaj:

„Za ovršenje tako okrutnoga posla mora se pretpostaviti sasvim vanredno duševno raspoloženje, po gotovo, kad to još mati na vlastitom svojem djetetu ovršuje, mora se za taj posao pretpostaviti posvemašnja duševna bešćutnost (anaesthesia psychica), koja ne može biti svojstvena zdravom duševnom stanju matere, prije toga neporočne i koja tupa praznina ćudi odgovara onoj kožnoj bešćutnosti (anaesthesia cutanea), što su je liječnici vremenito našli kod R., ,, ${ }^{620}$

Žirovčić histerijom objašnjava i nekonzistentnost u različitim verzijama događaja koje je R. D. ispričala:

„Mišljenje histerično bolesnih biva često tako maglovito i nejasno i sa činjenicama neskladno, da je teško razabrati hotimičnu lažljivost od one lažne reprodukcije, za koju sam pripovijedač pravo ne zna, što je istina, što nije, To pomućeno duševno stanje histeričnih naziva se sumračnim stanjem (Dammerzustand, intenebratio hysterica), a to može biti raznoga stepena, kao što je sumrak u prelazu iz dnevnog svjetla u noćnu tminu raznog stepena jasnoće: tako može biti za histeričnu osobu u stanju duševnog sumraka doživljeni dogodjaj sasvim nepoznat, ako joj je svijest bila sasvim potamnjena, ali pojedinosti dogadjaja mogu osvanuti u sjećanju, ako duševni sumrak nije bio potpun."621

Vidimo da Žirovčić pomiruje proturječne pozicije vještaka smještajući R. D. na granično područje između svjesnog postupanja i neke vrsti privremene histerične zbunjenosti. Kao ni u slučaju Ane Schier kojeg sam opisao u prethodnom poglavlju, ni ovdje histerija nema ništa zajedničkog sa Charchotovim jasnim opisom neuroloških simptoma. To jest, histerija nema ulogu dijagnoze konkretnog oboljenja, već medicinskog eksplanatornog modela za ponašanje koje transgresira kulturno dominantnu percepciju roda. No ako Žirovčić i smatra da je histerija stvorila preduvjete za abnormalno duševno stanje R. D., on ipak ne ignorira utjecaj gladi i nestašice. Zbog toga će, za razliku od Forenbachera ipak priznati da je neimaština mogla utjecati na umorstvo. Žirovčić će istaknuti kako prisutnost hrane u kući R.D. ne znači da ona prilikom počinjenja zločina, ipak nije bila pothranjena. No, kao somaticistički psihijatar, Žirovčić neće tražiti uzroke u stresu kojim je nestašica mogla utjecati na psihu R. D. Umjesto toga pribjeći će

620 Ibid.

621 Ibid: 338. 
eksplanatornom modelu koju objedinjuje suvremene spoznaje o ljudskom metabolizmu i anakrone pretpostavke humoralne medicine:

„Jedno je lokalni glad, čuvstvo praznine želuca, koje traži, da se želudac napuni; tomu gladu dade se časovito udovoljiti i takvom tvarju, koja ima malo ili ništa hranbenih vrijednosti, kao što je i R. u nuždi kuhala koprive i neko zelje, nemajući brašna. Drugo je opći glad organizma, u kojem svaka stanica ćuti nedostatak materijala za tvarnu izmjenu u svojoj životnoj djelatnosti, to je kronični glad, koji neminovno dovodi do stradanja i propasti organizma. Gladovanje znatno mijenja izlučivanje životnih sokova, koji bitno djeluju na moždjansku djelatnost. Prastara medicina osnovala je na mješavini 'tjelesnih sokova glavna četiri temperamenta: sanguinični (sanguis krv), flegmatični (flegma=sluz), holerični (hole=žuč) i melanholični (crna žuč), Kod stanovitih obolenja poremeti se sekrecija i ekskrecija sokova na štetu organizma, na pr. kad bolesni bubrezi ne izlučuju mokraćevinu, te ona prelazi u krv i djeluje na moždjane tako otrovno, da bolesnik zapane u smrtonosan delir." ${ }^{622}$

Ono što je zajedničko ovim dvama psihijatrijskim vještačenjima je činjenica da je utjecaj siromaštva na psihičko i emotivne stanje pojedinca neprepoznat kod stenjevačkih liječnika: Forenbacher će, zaobišavši emocije govoriti o nekoj sili koja utječe na volju dok će Žirovčić postupke optužene tumačiti kroz biokemijske modele i diskurs histerije. Za stenjevačke liječnike neimaština će ostati vidljiva kroz svoje materijalne manifestacije: anemiju, neuhranjenost, loše higijenske uvjete, ili kroz diskurs o moralnoj i duševnoj inferiornosti siromašnih. Anksioznost i strepnja zbog svakodnevnog egzistiranja na rubu oskudice i očaj zbog dugotrajne nemogućnosti da se pobjegne od gladi nisu imali mjesto u psihijatrijskom diskursu orijentiranom na tijelo. Upravo iz tog razloga, o strahu od siromaštva doznajemo uglavnom iz govora štićenika i njihovih poznanika- čak ni u onim slučajevima duševnog oboljenja gdje je „affectus” naveden kao uzrok duševne bolesti, taj afekt nije doveden u vezu s teškim imovinskim prilikama. Osim fokusa psihijatre na tjelesnu etiologiju duševnih bolesti tima je sigurno i doprinio stav da je siromaštvo pojava na koju su ljudi nižih društvenih slojeva trebali naviknuti kao na stalno stanje svoje egzistencije.

622 Ibid: $336-337$. 


\subsection{Strah od natprirodnog}

U Delumeauvoj studiji Strah na Zapadu natprirodno kao objekt straha zauzima izraženo mjesto kako u strahovima ruralne populacije, tako u strahovima elita. Folklor je bogat pričama o mrtvacima koji se vraćaju iz grobova, vješticama, vukodlacima i sličnim natprirodnim čudovištima. Delumeau spominje strahove od zlih duhova ljudi koji su umrli nasilnom ili prijevremenom smrću, ponajviše od duhova utopljenika i pobačene i nekrštene djece. ${ }^{623}$ Obrazovane elite osjećaju strepnju pred krajem svijeta i strahuju od Strašnog Suda, Sotone i njegovih demona. Rani novi vijek obiluje književnim, teološkim i filozofskim djelima koja govore o prisutnosti Sotone i njegovih slugu - vještica, čarobnjaka i demona na svijetu. ${ }^{624} \mathrm{U}$ devetnaestom stoljeću su i folklorna čudovišta i eshatološka strepnja i dalje prisutni. Na selu je još uvijek rašireno vjerovanje u nadnaravna bića i magiju ${ }^{625}$, a brojni elementi pučke religioznosti pronose strahove od demona i kraja svijeta i među ruralnu populaciju. Među obrazovanim elitama šire se novi oblici ezoteričnih vjerovanja poput spiritizma i teozofije. Helena Blavatsky već 1870-ih godina predstavlja britanskim, američkim i njemačkim intelektualnim elitama osebujnu mješavinu spiritizma i indijske filozofije a do 1911. godine njezino teozofijskodruštvo u Londonu već ima 16000 članova. ${ }^{626}$ U Njemačkoj, kao i u Austro-Ugarskoj Monarhiji slična vjerovanja širi Rudolf Steiner, koji će svoju antropozofsku školu udaljiti od budističkih uzora i približiti ju katolicizmu, Hegelovoj filozofiji i rasnim teorijama. ${ }^{627}$

Stenjevački štićenici često izražavaju strahove od natprirodnog i vjerovanja vezana za isto su prisutna u njihovim deluzijama. Ranije sam spomenuo slučajeve poput onog lončareve supruge Jele kojoj su „babe napunjavale glavu raznimi prazovjernimi pričami ${ }^{628}$ ". Jelina bolest pojavila se pod direktnim utjecajem strašnih priča koje je navodno čula. Naime, prema liječničkoj svjedodžbi, Jela se oko šestog prosinca 1880 ,probudila kao preplašena” gledajući oko sebe i počela pričati o „strašnih sanjah i čarolijah” i reagirala je bijesno i agresivno kad joj nisu htjeli

623 Delimo, 2003: 129.

624 Ibid, 2003: 337.

625 U ruralnim djelovima Hrvatske posljednji sudski slučaj na kojem se osobu optuživalo za korištenje crne magije datira iz 1996 (slučaj Štefice Balaško iz Kunovec Brega kraj Koprivnice). Slični primjeri vjerojatno se i danas mogu naći diljem svijeta, kako među urbanom tako i među ruralnom populacijom. Čini se da je vjera u okultno, barem što se tiče svakodnevnog folklora, preživjela usprkos modernizaciji društva.

626 Blom, 2008: 211.

627 Ibid: 214.

$628 \mathrm{KPV}, 1881: 319$. 
vjerovati. ${ }^{629}$ Slična vjerovanja u natprirodno spominjala su se i u slučajevima zaposjedanja $\mathrm{i}$ percipiranog gubitka kontrole nad vlastitim tijelom koje sam obradio u prethodnom poglavlju. Kao i štićenice čije sam priče iznio u spomenutom poglavlju, brojni štićenici pripisuju svoju bolest najrazličitijim natprirodnim uplivima. Seljakinja Milka P., stara 21 godinu ponašala se nemirno i mahala zamišljenom zastavom vičući: „Ne dajmo se, mi smo Hrvati, naša je zastava crveno-bijelo-plava a ne zelena. Apcug Mađari. ${ }^{\text {"630 }}$. Nakon što je dovedena u Stenjevec gdje joj je dijagnosticirana „mania” objasnila je liječnicima svoju bolest kroz prizmu folklornih vjerovanja o vješticima i raskrižjima rekavši „da su je coprnice pomotale kad je išla na križanje, tam da je bio jedan veliki vol koji se pretvorio u kravu. ${ }^{9631}$ Vještica se bojala i seljakinja Boja M. iz Gračaca koja nije mogla spavati strahujući „od vještica koje vidi pred sobom. ${ }^{632} \mathrm{Uz}$ vještice, bitno mjestu u imaginariju pučkih čudovišta zauzimaju i duhovi kojih se brojni štićenici boje ili im pripisuje simptome svojih tjelesnih i duševnih oboljenja. Josip L. iz Brestovače krivio je „zlog duha” za niz tegoba koje je osjećao: od zubobolje i impotencije do vlastitih psihičkih teškoća: „Pripovjeda da je u njemu zao duh kojega je u njeg stavio gospodin Isus Krist. Taj mu duh prkosi i radi žena, drži mu žilu i ne da da mu se napne, a pamet mu je već 4 mjeseca okrenuta." ${ }^{633}$ Strah od „zlog duha" ponekad je povezan s osjećajem krivnje zbog grešnog života. Pepa D. iz Varaždina, stara 40 godina, radila je u Zagrebu kao služavka kad su je počele mučiti misli o oženjenom podvorniku u kojeg se zaljubila. Mislila je da njezin ljubavnik podvornik ne želi ostaviti ženu zbog nje jer je „vodila zločest život” pa je pokušala samoubojstvo pijenjem lizola pomiješanog $\mathrm{s}$ terpentinom i petrolejem. ${ }^{634} \mathrm{U}$ Stenjevcu nije mogla spavati i bila je u velikom strahu. Kad ju je liječnik upitao čega se boji, odgovorila je da se osjeća „nesretnom progonjenom od zlog duha jer da je jako griešna". ${ }^{635}$ Bolničarka je također pričala da je Pepa jučer dobila maramu, ali ju je bacila u zahod pričajući kako je u marami „nečastivi duh”. Vjerovanje u „nečiste duhove” nije ograničeno isključivo na štićenike lošijeg socijalnog statusa. Josipa Klemm, supruga tvorničkog nadzornika iz Turopolja također je bila u strahu od duhova koje je halucinirala prilikom suprugove posjete. Pojavu tih duhova također je povezala s grijehom i otvoreno je rekla da ih se boji:,,...pripovieda, da je jučer kod nje bio njezin suprug obučen u žensko odielo a oko njega je

629 Ibid.

$630 \mathrm{KPV}, 1911: 8031$.

631 Ibid.

$632 \mathrm{KPV}, 1914: 8933$.

$633 \mathrm{KPV}, 1911: 8060$.

$634 \mathrm{KPV}, 1911: 8003$.

635 Ibid. 
bilo mnogo grieha: zlih duhova- vidila je to, kad je išla spavati, pa sad ju je velik strah od tih duhova." ${ }^{636}$

Jozefina je primljena u Stenjevec 1905. godine, na preporuku općinskog liječnika Neumanna. U Stenjevcu će ostati sve do svoje smrti od tuberkuloze u veljači 1914. godine. ${ }^{637}$ Sama stenjevačka povijest bolesti Jozefine T. ne obiluje mnogobrojnim detaljima, ali joj je priložena liječnička svjedodžba koju je potpisao općinski liječnik Julijo Neumann kojoj se kao glavni simptom Jozefinine bolesti navodi velika želja za čistoćom i kompuzivno pranje uz deluzije vjerskog i ljubavnog sadržaja. Povijesti bolesti je priloženo i pismo njezinog brata koji prepričava početak njezine bolesti:

„Što se tiče uzroka, mislim ovo: Zaljubila se, drugarice je draškale pa tim i povećale ljubav. Ljubljeni nije odvraćao, bar nije pokazivao ničim i oženio se. Otac je nagle ćudi, višeput nesmiljen prema majci; osim toga čula za nj sestra svašta pripovjedati, što je na nju silno djelovalo i moralo nužno djelovati- i to je jedan veliki uzrok. Nadalje bila je oklevetana od drugarica, rodjakinja još $\mathrm{k}$ tomu, pa se to nje silno dojmilo i posljedica je bila da ih je zamrzila, a jer smo mi govorili da baš nije tako, kako ona misli, zato je izgubila u nas povjerenje sve po redu nije nas trpjela; na koncu nikoga nije trpjela do jedne časne sestre u bolnici pakračkoj. Utješiti se nije dala i bolest je rasla još više i više. Ovi su znaci bili ustrajni. Isprva vidjela je duhove, mrtvace, plašila se, poslije je to prestalo." ${ }^{938}$

Kad psihijatri spominju strah od natprirodnog oni ga ne gledaju isključivo kao simptom neke duševne patologije, iako u jednom dijelu društva nedvojbeno postoji i takva percepcija. U sudskom spisu Jove Ljubojevića, seljaka koji je optužen za umorstvo vlastite supruge navode se izjave brojnih svjedoka koji govore o tome da je Ljubojević išao kod vračara i vjerovao da je začaran. No Žirovčić, u svom mišljenju Ljubojevićeva vjerovanja ne pripisuje duševnoj bolesti već „,seljačkom praznovjerju”. ${ }^{639}$

U navedenim slučajevima strah od natprirodnog nema centralno mjesto u duševnom svijetu navedenih štićenika već se javlja usputno, kao reakcija na specifičnu halucinaciju ili deluziju, ili kao štićenikovo objašnjenje vlastitih tjelesnih ili duševnih tegoba. U nekim slučajevima, vjerovanja u natprirodno i strah od istih će biti neki od središnjih elemenata štićenikovog psihičkog stanja i okolina štićenika će im pristupati mnogo sustavnije nego što je to slučaj kod

$636 \mathrm{KPV}, 1914: 8471$.

$637 \mathrm{KPV}, 1914: 6482$.

638 Ibid.

639 Žirovčić, 1895: 249. 
štićenika gdje se strah javlja samo kao izolirana epizoda ili pojedinačan i kratkotrajan simptom. Vrste prepoznatih oboljenja u kojima strah od natprirodnog često zauzima središnje mjesto je oboljenje koje se u prvim godinama rada Zavoda naziva religioznom manijom ili religijskom paranojom. Dijagnoza će se u kasnijim zapisima javljati sve rjeđe, vjerojatno zbog Žirovčićeve nesklonosti klasifikacijama bolesti koje uzimaju u obzir sadržaj emocija bolesnika. Pri pisanju svoje klasifikacije, Žirovčić se ugledao na Meynerta i klasificirao bolesti prema aspektu uma koji je prepoznao kao poremećen (afekt, mišljenje, etička čuvstva ili cjelokupna duševna konstitucija) i pretpostavljenom uzroku.

Iako je takvom klasifikacijom religijski sadržaj strahova učinjen manje eksplicitnim, strahovi povezani s religijskim koncepcijama grijeha, božje kazne i pakla nastavljaju biti dokumentirani u povijestima bolesti. Jedan od najpoznatijih slučajeva paranoje s religijskim elementima bio je slučaj suca Daniela Paula Schrebera. Slučaj je postao slavan jer je Schreber odlučio objaviti detaljan prikaz vlastite bolesti koji je poslije zainteresirao i Sigmunda Freuda. Freud je na temelju Schreberovog svjedočanstva formirao vlastiti stav o tom dobro dokumentiranom slučaju, povezavši Schreberov strah s njegovim latentnim homoseksualnim željama prema njegovom liječniku doktoru Flechsigu. ${ }^{640}$ Osim toga, Freud gleda na Schreberov sustav kozmoloških deluzija kao na pokušaj samoizlječenja od žudnje koja je kod Schrebera stvarala anksioznost. Schreber se u svojoj deluziji, zamišlja kao „božju ženu“ doktora Flechsiga, čime Schreber nadilazi protivljenje homoseksualnoj pobudi koje je kod njega proizvelo unutarnji sukob. ${ }^{641}$ Stenjevački primijeri strahova vezanih uz religiozna vjerovanja štićenika su jednako brojni kao i oni vezani uz folklorna čudovišta. Nacrt svjedodžbe koju su općinski liječnici koristila za upućivanje bolesnika u Stenjevac predviđao je pitanja o vjerskim navikama osobe: ide li redovito u crkvu, psuje li ili „bogohuli” i ponaša li se „ćudoredno”. ${ }^{642}$ Ponegdje religiozni strahovi bivaju obojeni osebujnim shvaćanjem koncepata preuzetih iz katoličkog nauka. Magda B. seljanka iz Letinca pokraj Brinja primljena je u Stenjevec u stanju velike tjelesne iscrpljenosti od koje je i preminula nakon šest dana 18. travnja 1911. godine. ${ }^{643}$ Za vrijeme boravka u Stenjevcu bolničari bilježe njezine riječi u kojima Magda izražava strah od nečeg što naziva „limba”. Čini se da bolničari ne razumiju na što Magda točno misli, niti su odviše zainteresirani za govor starice na

640 Freud, 2010: 2418.

641 Matijašević.2006:84.

642 KPV, primjer obrasca liječničke svjedodžbe.

$643 \mathrm{KPV}, 1911: 8073$. 
samrti kojoj nisu ni postavili dijagnozu. Magda govori da se „limba” nalazi na zemlji ili u zraku i da je se ona boji i moli joj se. U liječničkom izvješću Magda govori o „limbi” kao o kazni:

„Ona ovu rieč često opetuje. Izgleda kao da joj daje značenje njekakove kazne. Uvijek je u njekom strahu. Hoće da plače i plaštljivim glasom govori: Zabadava je- zabadava plakati sada. Sad je već zavezano... Molim se bogu, ali najviše limbi... ${ }^{644}$

Moguće je da je Magda na samrti govorila liječnicima o svom strahu od Čistilišta, te da je Magda personificirala Čistilište. Naravno, budući da je Magda smatrana duševno bolesnom i da je postojao velik jaz u obrazovanju i statusu između nje i liječnika, oni su na njezine izjave o „limbi” jednostavno gledali kao na besmislicu. U brojnim izjavama štićenika, centralno mjesto njihovih strahova zauzima vrag kao natprirodna prisutnost utjelovljena u stvarnim neprijateljima iz njihove okoline. Prosjakinja Franjica C. iz okolice Delnica, koju su u Stenjevec sproveli redarstvenici je vidjela vraga upravo u njima. Franjica je došla u Stenjevec u velikom strahu i „vidjela vraga u svakom i svakog se plašila, naročito redara u koje se vrag pretvorio i koji ju tjeraju po općinskim zatvorima". ${ }^{645}$ Štićenici često optužuju vragove sa svoje tjelesne tegobe. Posjednik Martin B. tako govori da su tri vraga došla u njega i da mu izazivaju tegobe u udovima i trbuhu. ${ }^{646}$ Ilinka Dj. iz Leskovca tvrdila je da u sebi ima vraga koji joj ne da jesti ${ }^{647}$, Roza M. iz Ogulina je tvrdila da joj vrag ,neda gutati jer joj na grlo navaljuje” i da joj „kuca po svim žilama"648. Na puno slikovitiji način je svoje tjelesne tegobe opisao pjesnik Vladimir Vidrić koji se liječnicima požalio da ga ,čop tunje po trbuhu peha" ${ }^{649}$ (ujeda ga velika tuna koja mu je u trbuhu). Iako se vjerojatno radi o slikovitim opisima tjelesnih tegoba, koja su ponekad bila povezana s pučkim vjerovanjima o natprirodnom uzroku bolesti, liječnici i bolničari ih predano bilježe kao i sve ostale oblike vjerovanja u natprirodno koje bolesnici izražavaju.

U stenjevačkim povijestima bolesti i ranijim liječničkim izvješćima strahovi od natprirodnog zauzimaju daleko značajnije mjesto nego strahovi od siromaštva. Liječnici ih temeljito zapisuju, ponekad tražeći od štićenika da dodatno pojasne svoja vjerovanja. Primjer intervjua sa Spasojem S., nadničarom iz Đakova pokazuje kako liječnici potiču govor o neobičnim i bizarnim vjerovanjima kod štićenika. Spasoje je doveden u Stenjevec 1911. godine i u Stenjevcu je ostao

644 Ibid.

645 KPV, 1911: 7708.

646 KPV, 1880: 57.

647 KPV, 1895: 2327.

$648 \mathrm{KPV}, 1895: 2711$.

649 Župić, 1937: 344. 
samo četrnaest dana prije premještaja u Pakrac. U liječničkom izvješću stoji da ga je brat dao u bolnicu jer „razbija i prijeti polovici sela ubojstvom”650. Općinski liječnik u Đakovu podvrgava Spasoja detaljnom ispitivanju u kojem naročitu ulogu igraju Spasojeva neobična vjerovanja vezana uz crne mačke i pse, i religijske prizore:

„Da li ste čuli ili opažali štogod osobita u toj kući? Jest, jednu noć došla neka velika šarena mačka, krijesile joj se oči, išla oko moje glave dva puta, čupkala me po nogama i tražila mlijeka, zacvilila i nestalo je. Možda ste još nešto čuli ili viđali? Opet došla crna mačka, prevraćala moje cipele, neznam što je ćela i uvijek mi cipele razvrnute, a ja znam kako sam ih ostavio...i opet neki veliki crni pas, neznam što je ćeo, možda kosti tražiti...(to kaže s porugom)Jednoč sam sanjao, ali nisam spavao, a nešto kraj mene prođe, šušne zvizne i sađe nad mene, a ja kažem, da ću u dubine morske, a ono pod mene, a ja kažem da ću u visine nebeske-a tad to krilima mane, pravo sam čuo krila, popiša se i odleti...Šta izvađate iz toga?

Ne odgovara.

Jednoč sam sanjao: Vidim Frušku goru ili kako je zovu, s jedne joj strane ženska u bijelom odijelu, s druge ikona, križ, na vršku zlatna kruna, oko nje andjeli. To govori bolestnik osobito tajanstveno zadovoljnim licem...Jeste još što čuli i vidjevali?

U toj kući ustalo rano ujutro malo dijete, neznam čije i šta je ćelo, došlo do mene, otišlo, išlo se umivati, otišlo napolje, a oni rekli: oće se jačati - a bilo je četiri sata. Vidio sam bijelu ženu-bila je gola, išla prema meni i ja sam bio gol, ona mi kaže: odi na desno, a ja ću na lievo- a ja podjem na lijevo a ona na desno ode. I ljetos se nješto javljalo, došlo u cipelama." ${ }^{651}$

Liječnik u razgovoru sa Spasojem pokazuje interes za njegove riječi u trenutku kad Spasoje počne govoriti o crnim mačkama, životinjama koje su tradicionalno vezivane uz okultizam i čarolije. Iz kasnijih liječnikovih primjedbi daje se iščitati da Spasoje neke od svojih crtica o natprirodnim događajima i snovima ,govori s porugom” i ,sa zadovoljnim izrazom lica” kao da ga zabavlja liječnikov interes za pučka praznovjerja (u Stenjevcu, Spasoje nijednom ne spominje praznovjerne priče o ženama u bijelom i crnim mačkama).

U zapisima iz Stenjevca svako se spominjanje natprirodnog ili straha od vještica, vragova ili sličnih bića gleda u kontekstu patološkog. Pritom se ne razlikuju vjerovanja koja potječu iz folklora, slikoviti opisi koji se utječu religijskom ili magijskom imaginariju i opisi halucinacija i deluzija. Elementi natprirodnog, bilo da se radi o elementima pučke predaje ili kršćanske

$650 \mathrm{KPV}, 1911: 8120$.

651 Ibid. 
religioznosti podjednako su zastupljeni kod štićenika svih zanimanja i svake razine obrazovanja. U slučaju bića koja u predaji imaju ulogu čudovišta vjerovanje u natprirodno je isključivo vezano uz osjećaj straha ili strepnje pred kaznom u zagrobnom životu. Taj strah bio je izvorom patnje za mnoge stenjevačke štićenike, a često je javno iskazivanje tog straha bilo uzrokom njihove hospitalizacije. Spominjanje religioznih navika u obrascu liječničke svjedodžbe kao dokumenta na osnovu kojeg se primalo štićenike u Stenjevec pokazuje da se u okviru psihijatrije formiralo poimanje religioznosti koje se smatralo ,normalnim”. Iako konkretne vjerske navike koje se smatraju „normalnim” izražavanjem vjerskih osjećaja nisu nigdje eksplicirane, strah od natprirodnog nije bio u skladu s koncepcijama religioznog iskustva prevladavajućima u okviru kulture obrazovanog građanstva. Te koncepcije su strahu od božanskog pretpostavljale izgradnju odnosa s Bogom temeljenog na racionalnom poimanju vjere i tradicionalnom građanskom moralu. Manifestacije pučke religioznosti koje su konfesionalnom nauku pristupale na emotivniji i mističniji način, te ju povezivale s različitim magijskim praksama i eklektičnim vjerovanjima dočekivane su s nerazumijevanjem ili bivale otpisivane kao znak praznovjerja, a u nekim slučajevima i patologije.

\subsection{Strah od nasilja}

Povezanost nasilja i duševne bolesti predmet je brojnih rasprava u psihijatriji devetnaestog stoljeća. Od samih početaka psihijatrije vode se rasprave o tome spadaju li nasilni zločini u domenu psihijatrije ili se njima treba baviti represivni i pravosudni aparat. S druge strane, štićenici psihijatrijskih institucija često su bili izloženi nasilju okoline prije dolaska u zavode, nerijetko su bili žrtvama nasilja od strane bolničara ili drugih štićenika i često su izražavala strah od nasilja, bilo da je objekt tog straha bilo nešto izvan same institucije ili su čin institucionalizacije shvaćali kao čin nasilja koji je uvod u daljnje nasilje. Analiza straha od nasilja počivat će na dijakronijskom opisu svih navedenih strahova. Odnos prema strahu i nasilju oblikovan je u podjednakoj mjeri iskustvima i emocijama štićenika kao i iskustvima i emocijama liječnika. Zbog činjenica da su liječnici živjeli u samom krugu psihijatrijske institucije njihov strah od nasilja je mogao utjecati na emotivnu atmosferu koja je vladala u okviru zavoda, čak i ako nije bio ekspliciran.

Ivan Žirovčić u svom članku „O postupku s duševno bolestnimi” naglašava razliku između postupanja s bolesnicima u predmedicinskim društvima i postupanja u modernim psihijatrijskim institucijama. Žirovčić izdvaja dva načina na koje se duševno oboljele tretiralo prije pojave 
moderne psihijatrije od kojih su oba vezana uz strah od duševno oboljele osobe. Prvi je strahopoštovanje pred duševno oboljelim kao pred „mudracem ili prorokom” koje, prema Žirovčiću obilježava tretman bolesnika kod ,nekih primitivnih naroda"652. Nasuprot toma postoji izdvajanje bolesnika iz društva motivirano strahom kojeg Žirovčić smatra praznovjernim i povezuje s vjerovanjem u nadnaravni uzrok duševne bolesti. Povijesni strah od duševno oboljelih Žirovčić dočarava opisom nekadašnjih ludnica koja postaju mjesta na kojima su zatočeni ljudi od kojih društvo strahuje i koje smatra nepoželjnima:

„Ludnice prošlih vremena bile su tamnice, u kojih su umobolnici $\mathrm{u}$ debelih zidinah, iza željeznimi rešetkami, često još okovani i prikovani, u skrajnoj biedi čamili i, prepušteni nemilosrdnosti surovih stražara, jadno pogibali, a nikomu nije bilo na kraj pameti, da bi nesretni umobolnik kraj milosrdnijega i razumnijega postupka možda još mogao ozdraviti ili bar donekle opet dospjeti do čovječanskoga dostojanstva" 653

Naravno, Žirovčić predstavlja psihijatriju kao humanu disciplinu koja je vođena razumnim i znanstvenim poimanjem duševne bolesti kao bolesti organizma. Samim time i suvremeni će zavodi biti opisani kao mjesta humanosti u kojima je strah ustupio mjesto razumu i milosrđu. No, Žirovčić je svjestan toga da je javno poimanje psihijatrijskih institucija i dalje obilježeno strahom:

„Pa ipak lebdi nad timi dvorovi najplemenitijega ljudskoga milosrdja prokletstvo stare surovosti, jer se još i dandanas mnogi ljudi žacaju svoje bolestnike u ludnicu predati, bojeći se zlostavljanja, silovita postupka i potajnih mučila, bez česa si ne mogu pomišljati liečenje umobolnika. Javno mnienje je neobično osjetljivo u pogledu ludnica, pa ako se gdjekad u njih dogodi kojemu bolestniku nesreća, eto krike i vike po svih novinah, eto strke pozvanih $\mathrm{i}$ nepozvanih, da njuškaju, prisluškuju, pretjeravaju, izvraćaju i sumnjiče; a ne pomišljaju, koliko se nesreća odvraća i spriečuje svaki dan u ludnicah. gdje je u mnogobrojnih bolestnih dušah nagomilano toliko užasnih strasti i razvratne napetosti, koja elementarnom silom provaljuje proti vanjštini i vlastitom omraženomu životu, a da se takova nagla i časovita provala bezrazumne uzbudjenosti kadkada niti najpomnijom pozornošću zapriečiti ne da ; ne pomišljaju, koliko je pogibelji, nesreće i štete odklonjeno od ljudskoga družtva, ako se umobolnici za vremena smjeste u ludnicu., ${ }^{654}$

652 Žirovčić, 1897: 320.

653 Ibid: 322.

654 Ibid: $322-333$. 
Iako Žirovčić nastupa s pozicije modernog i znanstvenog poimanja ludila, njegov diskurs još uvijek odaje strah od nekih manifestacija duševne bolesti. Kad govori o unutarnjem svijetu duševno oboljelih, Žirovčić napušta objektivni diskurs i počinje se služiti emotivima. U „dušama” psihički bolesnih su nagomilane „užasne strasti” i ,razvratna napetost,” a njihova je uzbuđenost „bezrazumna” i događa se u provalama. Na početku članka Žirovčić će predstaviti duševnu bolest kao znanstveno spoznatljiv proces kojeg je moguće razumjeti u okvirima somatičke medicine i prirodnih znanosti, da bi čim počne legitimirati nesreće koje se događaju i u modernim institucijama počeo govoriti o štićenicima kao osobama čije strasti mogu izazvati užas i čiji se postupci i motivacija često nalaze onkraj razuma. Uređene psihijatrijske institucije su temelj terapijskog autoriteta na kojeg se Žirovčić poziva, no Žirovčić će ih u istom članku predstaviti i kao sigurnosnu mjeru protiv nasilja duševno oboljelih:’Radi pogibelji, koja od poremećena razuma, čuvstva i volje duševnoga bolestnika prieti,. a za dobro i korist bolestnika samoga najshodnije jest, da se preda u ludnicu, koja je za liečenje i njegovanje umobolnika valjano uredjena..." ${ }^{655}$ Usprkos činjenici da Žirovčić ističe neke duševno oboljele kao opasne za društvo, njegov članak također osuđuje predrasude i stigmatizaciju duševno oboljelih potaknutu strahom:

„Ljudi ne samo da se nekako instinktivno žacaju ludnice, već bolestnika, koji je bio u ludnici, te iz nje, makar zdrav, izašao, žalibože susretaju i motre nekom plahošću, kao da je na njemu ostala neka sramotna ljaga, dočim boravak u bolnici nikoga ne sramoti. Ovakove predsude spadaju, poput mnogih drugih, u slabosti, nepravednosti i nedosliednosti, u ljudske mane, s kojim! se baš mi liečnici obilno imamo boriti, te s koje borbe uviek ne izlazimo pobjednici" 656 Čini se da psihijatri devetnaestog stoljeća ne dovode u vezu strah koji dio javnosti osjeća prema duševno oboljelima i diskurs koji psihijatri ponekad koriste, a koji također povremeno izražava strah i djeluje dehumanizirajuće. Takav stav bit će iskazan i u predavanju koje je Žirovčić u ožujku 1898. godine održao na skupštini zbora liječnika. Predavanje nosi naslov „Ludjačka umorstva, nazvana 'la folie rouge'”. Naslov je zanimljiv jer se u njemu Žirovčić spominje „la folie rouge” „(crveno ludilo)” kao naziv za nasilne zločine duševno oboljelih osoba. Taj termin se inače ne spominje u onodobnoj psihijatrijskoj literaturi i Žirovčićevo predavanje je jedini trag korištenja te fraze na koji sam uspio naći. Nije jasno odakle ga Žirovčić preuzima, on se na početku predavanja poziva na novinske izvještaje o umorstvima, tako da je moguće da se u dijelu 
tiska koristio taj termin. Žirovčić predavanje počinje osporavanjem u javnosti uvriježene percepcije da su djela duševno oboljelih djela bez jasnog motiva, te govori da su čak i „najgrozniji čini” duševno bolesnih motivirani mišljenjem i osjećajima, jedino su kod njih mišljenje i osjećaji nezdravi. ${ }^{657} \mathrm{U}$ nastavku predavanja, Žirovčić će nabrajati koja sve duševna oboljenja mogu pogodovati počinjenju zločina. Pri tom počinje od ,poremećenog” spolnog nagona za koji kao primjer ističe „londonskog Jacka-rasparača"658 čiji su zločini pobuđivali ogroman interes javnosti u devedesetim godinama devetnaestog stoljeća. Ubrzo nakon toga slijedi opis pogubnog utjecaja alkohola u kojem će prevladavati emotivi straha:

„Patholožko pijano stanje i alkoholni delir čine čovjeka groznim strašilom, bjesnećim razornikom, koji nožem i sjekirom, a osobito puškom, navaljuje na tudji život, budi da se baci proti umišljenim, u snatrenju vidjenim i čuvenim napadačem, budi da si naprosto strašna unutarnja živčana napetost probije provalu djelotvornom mišićnom trzavicom."659

Uz alkoholičare, kao predmet straha su predstavljeni i epileptičari- epileptičar tako ,počinja u ludilu strašan pokolj” o epilepsiji se govori kao o „sablasti” a ako je „mišićnu trzavicu epileptičara strašno vidjeti, delir epileptičara je strašan sadržajem". ${ }^{660}$ Osobe koje pate od epilepsije opisane su nizom epiteta koji ih tretira kao emotivno i duševno nestabilne, moralno manjkave i gotovo isključivo opasne za društvo: „...epileptičari odavaju i u svojem karakteru silovitu ćud, ujedljivu razdražljivost, prkositu zakopčanost, tiransku nesnošljivost, naginju na tmasto religiozno snatrenje, te se iztiču okorjelim egoizmom. Tako ustrojene individualnosti imaju sve uvjete, da budu ljudskomu družtvu pogibeljne.”661 Žirovčić kasnije govori da i ostale duševne bolesti, od manije, melankolije i paranoje pa do neurastenije i histerije također mogu biti uzrokom ubojstava. Predavanja vodi prema zaključku kako je za sprečavanje zločina koje počinjavaju duševno oboljeli potrebna bolja i suvremenija psihijatrijska skrb, valjano uređeni zavodi za duševno oboljele i bolji rad upravnih i redarstvenih organa u nadziranju onih duševno bolesnih koji se nalaze izvan zavoda. ${ }^{662}$

Iz ovih članaka može se zaključiti da je psihijatrijski diskurs vezan za strah od duševno oboljelih kao potencijalno nasilnih ljudi dvojak. Psihijatri se s jedne strane percipiraju kao nositelji naprednih i humanih znanstvenih ideja koji trebaju legitimirati svoj položaj unutar medicine i

657 Žirovčić, 1898: 226.

658 Ibid.

659 Ibid: 227.

660 Ibid.

661 Ibid: 228 .

662 Ibid: 232. 
unutar javnih politika. Legitimacija tog položaja ovisi o percepciji ludila kao medicinskog stanja koje ima uzroke u somatskim promjenama. Samim time, oni se suprostavljaju „praznovjernom” strahu od duševno oboljelih i njihovoj stigmatizaciji. S druge strane, način na koji se duševno oboljeli opisuju često obiluju iskazima straha koji su tek na površini skriveni iza objektivnosti i racionalnosti znanstvenog diskursa. Takav naizgled paradoksalan stav je vjerojatno posljedica negativnog kogniziranja straha unutar emotivnog režima građanske klase. Budući da se strah smatra nelegetimnim, njegove se manifestacije nastoji gurnuti u drugi plan ona kada se nastoji tvrdnjama dati znanstveni legitimitet. U slučaju da su psihijatri bili nesvjesni toga da je njihov strah vidljiv u formulacijama kojima su opisivali duševno oboljele, radi se o potiskivanju emocija kako bi se postigao dojam znanstvene objektivnosti. S druge strane, moguće je da je imagem duševno bolesne osobe bio svjesno konstruiran tako da ih se predstavi kao istovremeno osobe koje trebaju medicinsku skrb i osobe opasne za društvo. Takvim naoko kontradiktornim imagemom „luđaka” u kojem se spajaju figura čudovišta i figura žrtve legitimira se psihijatriju kao granu medicine koja štiti društvo od o nereguliranog ponašanja duševno oboljelih.

Za razliku od psihijatara, štićenici Stenjevca nemaju problema s izražavanjem svog stvarnog ili imaginarnog straha od nasilja, a u okviru institucije tim se „snažno” artikuliranim strahovima pridaje daleko veća pažnja nego „slabo” artikuliranim strahovima psihijatara i šire javnosti. Ponekad je strah od nasilja samo usputan i ima karakteristiku instinktivnog, i intenzivnog visceralnog straha kojim se anticipira nešto što će osobi naškoditi ili ju tjelesno ozlijediti. ${ }^{663}$ Primjeri takvog straha su brojni i oni se naročito često susreću kod štićenika kojima su dijagnosticirane takozvane ,afektivne psihoze” - manija i melankolija. Angjelia R. iz Ogulina razboljela se u ljeto 1911. godine (dijagnosticirana joj je „melancholia”) i u Stenjevcu neprestano govori o vlastitim strahovima:

„14. 6. Bolesnica hoda okolo i gleda kao da se koga plaši i kaže da će izgorjeti i da će ju netko ubiti, svaki čas traži jesti, a kad joj se dade, onda neće, već sve razbaciva, navečer se neda nikako u postelju.

5.7. Nemirna, neprestano traži, da bi se objesila ili izgorjela ili da bi ju tko htjeo ubiti. Moli da ju odvedemo tamo, gdje ima vukova, da ju požderu; plačući prosi, da joj ne produljimo života.

663 Ahmed, 2014: 65. 
12.8. Neprestano hallucinira, vidi kako selo gori, plače da su joj djeca izgorjela, posvema smetena hida neprestance okolo, po noći nemirna, mora biti u samici, premještena sa IX b na XI. ${ }^{964}$

Angjelijino stanje straha i smetenosti trajat će sve do njezine smrti od enteritisa u kolovozu 1911. godine. Instinktivni strahovi od nasilja različito identificiraju mogućeg počinitelja nasilja. Manda K. iz Jasenovca užasno se bojala vlastitog oca, a strah je bio potaknut epizodom u kojoj je njezin otac tukao konje:

„Pred osam dana poplašili se konji njezinom ocu, on ih je toga radi nemilosrdno tukao i vikao na njih-ona ga išla miriti, a otac se izdere na nju, da ga pusti na miru. Neka žena koja je bila prisutna, upozorila je bolesnicu, neka se oca rad kani, jer je u istoj zgodi htio njezin otac majci odrezati sjekirom ruku, jer ga išla uzrujanoga miriti. Od toga se bolesnica toliko uplašila i od osam dana stala vikati, plašiti se, da će je ko ubiti, vikala o sjekiri, puškama itd." ${ }^{965}$

Jana L. iz Vidovca smatrala bojala se da će biti izložena izrazito brutalnom nasilju kao kazni za grijehe. Gotovo čitava Janina povijest bolesti se sastoji od njezinih grafičkih opisa vojski i „kanona” i kazni kojima će biti izložena:„,Danas se uzrujala - u velikom strahu plače i viče, da mora pobjeći, jer već cijelu noć pucaju kanoni za njom, da ju ubije, a ovi da joj hoćaju oči iskopati i glavu sjeći, da joj srce izvade i njezino tijelo da na komade sasjeku i onda viče: a joj, joj, kaj bude z mene" ${ }^{966}$

Takvi strahovi su jednostavno artikulirani i kod njih se ne preciziraju motivi zbog kojih bi netko htio nauditi osobi koja se boji. S druge strane, postoje štićenici čiji su strahovi od nasilja često elaborirani i imaju elemente cjelovitih i kompleksnih narativa fokusiranih na opasnost od percipiranih neprijatelja. Objektu straha je tu često prilično jasno definiran, a štićenici mu pripisuju namjeru i motiv, te izražavaju opsesivan strah za vlastitu sigurnost i sigurnost svojih najbližih. U takvim slučajevima strah često opsjeda štićenike i čitav njihov pogled na svijet biva oblikovan odnosom prema prijetnjama i iznalaženjem načina kako ih izbjeći. Sigmund Freud je analizirajući povijest bolesti i terapiju svog slavnog pacijenta „Čovjeka Štakora” osjećaj stalne strepnje pred nasiljem povezao s njegovim potisnutim agresivnim i/ili seksualnim impulsima. Kod „Čovjeka-štakora” često se radilo o agresivnim mislima usmjerenima prema ljudima za koje je vjerovao da stoje na putu između njega i djevojke koja mu se sviđala ${ }^{667} \mathrm{Na}$ kraju, „Čovjek-

$664 \mathrm{KPV}, 1911: 8123$.

$665 \mathrm{KPV}, 1914: 7886$.

$666 \mathrm{KPV}, 1911: 7840$.

667 Freud, 2010: 2147. 
štakor“ je, kako bi zaštitio svoj ego od nasilnih misli, iznašao čitav niz opsesivnih hiperracionalizacija i hiperintelektualizacija koje su ga trebale zaštiti od nasilnih kompulzija. Iako je upitno može li se Freudova analiza specifičnog slučaja primijeniti i na emotivna iskustva stenjevačkih štićenika, seksualne i nasilne fantazije su često bitan dio njihovih strahova i često bivaju više ili manje otvoreno artikulirane u njihovim svjedočanstvima.

Primjer straha od nasilja nalazimo kod stenjevačkog štićenika Mije P.. Mijo P. bio je sin sitne trgovkinje iz Zagreba koji je sa svojom majkom živio na Maksimirskoj cesti. Tijekom 1905. i 1906. godine napisao niz pisama banu Teodoru Pejačeviću potaknut strahom od susjeda koji su živjeli u kući na broju sedamdeset. U svojim zbrkanim pismima, Mijo izražava strah da ga stanovnici te kuće žele tući jer je odbio brak s nekom djevojkom. Od bana je zahtijevao da se svi iz navedene kuće, (uključujući i kućevlasnika i njegovu obitelj) isele jer zbog straha od njih više ne može nikud ići. Uz to, traži da svatko tko mu bude prijetio bude smrtno kažnjen, te da mu ban da garanciju da ga nitko ne može privoljeti na ženidbu s tom djevojkom jer će se on „radije utopiti u Savi nego ženiti." ${ }^{668}$ Gradsko poglavarstvo je na Mijina opetovana pisma reagiralo tako da je odredilo konzilij liječnika koji će ga pregledati. Liječnički konzilij uputio je Miju u Stenjevac. Mijo je u Stenjevcu bio u dva navrata- prvi put od 13. lipnja 1905. do 17. kolovoza 1905. kad je otpušten kao poboljšan, drugi put je doveden od majke 7. veljače 1906., a ostao je u Stenjevcu do svoje smrti od tuberkuloze pet godina kasnije, ponašajući se uglavnom mirno. Miji je postavljena dijanoza ,imbecilitas originario" (urođena slaboumnost) kojoj je kao uzrok postavljena jednostavno „degeneracija”. Ipak kako Miju u pisanju ne odaje ispodprosječno obrazovanje niti teškoće u intelektualnom razvoju, vjerojatno su liječnici postavili navedenu dijagnozu kako bi naznačili da se Mijo nalazi na Maudsleyevom ,borderlandu” između duševno oboljelih i zdravih pojedinaca. Iz iskaza koji je Mijo dao čini se da se Mijo na čudan način osjećao neku vrst obaveze prema nekoj neimenovanoj djevojci iz susjedstva kojoj je pisao i možda udvarao. Nakon što je odlučio da se ne želi oženiti njome, primijetio je da ga „seljaci” motre i žele tući. Ljudi s navedenog kućnog broja su ga više puta zvali da ide sa njima šetati „na ciglanu ili u Maksimir". ${ }^{669}$ Mijo je bio uvjeren da ti pozivi znače da ga oni žele tući jer je bio siguran da ga oni mrze jer ne želi oženiti spomenutu djevojku. Mijo osjeća kao da je po obrazovanju i statusu iznad svojih susjeda- opisuje ih kao ,seljake”, a sve njegove misli vrte se 
oko ženidbe iako nigdje ne navodi je li djevojka kojom je opsjednut uopće u bilo kakvoj vezi s ljudima koji mu navodno žele nauditi. U Mijinim opsesivnim mislima nije teško vidjeti svojevrsnu patološku opsesiju tom djevojkom, iako iz oskudne povijesti bolesti ne možemo točno razabrati prirodu njihovog ranijeg odnosa. U jednom od svojih pisama banu Pejačeviću Mijo odaje i opseg svojih elaboriranih iluzija i svoju percepciju vlastitih susjeda kao ,primitivnih”:

„Na Maksimirskoj cesti u Zagrebu - gdje je naobraženje na vrlo niskom stepenu- tamo mu ljudi ne daju mira, groze mu se, htjeli su ga tući, a možda i ubiti, imali su bičeve i željezne štange za njega u pripravi, što je na svoje oči vidio. Inače je takodje sa svih strana čuo, kako se njegovi neprijatelji dogovaraju, da će ga tući." 670

Jedini uzrok psihičkih poteškoća Mije P. liječnici su vidjeli u „,hereditarnoj degeneraciji”.i čini se da, nakon potvrde da je zbilja psihički bolestan, nisu posvećivali nikakvu pažnju niti njemu niti njegovim elaboriranim strahovima.

Nekoliko godina kasnije prilikom psihijatrijsko-forenzičkog vještačenja makedonskog radnika Stojana Blažova s kraja 1909. i početka 1910. godine, Žirovčić će u svojem stručnom mišljenju povezati hereditet, tjelesnu slabost i predrasude o ,primitivizmu”. Stojan Blažov uhapšen je na Željezničkoj stanici u Zaprešiću nakon što je iz revolvera ustrijelio dvojicu putnika. U iskazu pred sudom izjavio je kako se vraćao kući s rada u Sjedinjenim Državama. Na austrijskoj granici u vlak je ušla grupa ljudi, po govoru Hrvata ili Srba koja se počela došaptavati i pogledavati prema njima. Kad su u Zidanom mostu trebali presjedati u drugi vlak, neznanci su ga slijedili. Pri dolasku u Zagreb postalo je ,njihovo dogovaranje već tako opasno, da je on bio prisiljen njihovoj navali predusresti: stoga je izpalio u svakoga od poginule dvojice po dva hitca, a onda je hotio sebi u čelo, ali je taj hitac zatajio" ${ }^{671}$. Budući da se na sudu činilo da njegov postupak nije imao jasnog motive, Stojan Blažov je predan na vještačenje u Stenjevec. U zavodu se Blažov ponašao mirno. Uglavnom je provodio vrijeme čitajući i družeći se s ,inteligentnijim” štićenicima zavoda. ${ }^{672}$ Pri ispitivanju detaljno je govorio o svom teškom životu, koji je od mladosti bio ispunjen nasiljem i strahom. Odrastao je u mjestu Gorno Vodno nedaleko Skopja i u ranoj mladosti (prilikom ispitivanja bio je star trideset i dvije godine) je izgubio oca i majku zbog bolesti, a mlađeg brata u bizarnoj nesreći s vatrenim oružjem. ${ }^{673}$ Sam se uzdržavao i završio preparandiju no nije mogao naći službu kao učitelj jer se protivio „turskom nasilju”. Prije studija

670 Ibid.

671 Žirovčić, 1911: 33.

672 Ibid: 34.

673 Ibid. 
u preparandiji, imao je kraći živčani slom od kojeg se oporavljao kod kuće. Zbog toga je otišao u Bugarsku gdje je radio kao nadcestar u Ruščuku (danas Ruse u Bugarskoj). Pri povratku u Makedoniju, išao je kraćim putem kroz Srbiju gdje su ga srpski policajci uhapsili kao špijuna i izgladnjivali u zatvoru, te je pušten tek na intervenciju otomanskih vlasti u Makedoniji. Tada je počeo sumnjati da ga njegovi neprijatelji iz Makedonije denunciraju iz političkih razloga i odlučio otići u Ameriku. Mukotrpno je radio kao nadničar, tvornički radnik i građevinski radnik u Virginiji, a tamo se konstantno bojao da mu netko ne ukrade teško zarađen novac. Zaradivši oko 1500 kruna, odlučio se sa dvojicom sunarodnjaka vratiti u Makedoniju. Put je bio iscrpljujuć, vlakovi tijekom cijelog puta pretrpani ljudima, a Blažov se tijekom prekooceanske plovidbe razbolio od neke groznice. Također, čini se da su i Blažov i njegovi makedonski suputnici proveli cijeli put u strahu da ih netko ne okrade: skanjivali su se kupovati hranu i izlaziti iz vlaka na postajama u inozemstvu da netko ne vidi kako imaju novaca i orobi ih, pa su u četiri dana jeli samo dvaput. Također, budući da od Engleske do Zidanog mosta nisu izlazili iz željezničkih vagona, bili su izrazito dezorijentirani, tako da je Blažov od svih mjesta na kojima je vlak stajao zapamtio samo Le Havre u Francuskoj. ${ }^{674}$ Također, među radnicima u Sjedinjenim Državama kružila je priča o ubojstvu hrvatskih povratnika iz Amerike koje se navodno dogodilo negdje u Engleskoj kad su neki prevaranti ,,prodali Hrvatom smrdljiva mesa, koje oni nisu htjeli uzeti odatle proizašle svadje i osvete" ${ }^{675}$

Blažovljev strah se intenzivirao nakon prelaska austrijske granice kad su u njegov kupe ušli ljudi koji su govorili nekim slavenskim jezikom. Velik dio Blaževljevog straha upravo je došao iz činjenice da su to bili prvi suputnici čiji je jezik mogao bar djelomično razumjeti i interpretirati u svjetlu svojih strahova. Jedan od tek pridošlih putnika počeo je tako ispitivati Blažova o tome koliko ima novaca. ${ }^{676}$ Drugi je pak prilikom ručka u vagon-restoranu govorio nešto o nagovaranju nekog da pije pivo, što je Blažov protumačio kao njihovu namjeru da opiju stražara na stanici. ${ }^{677}$ Ubrzo nakon toga, jedan od kasnije ubijenih putnika rekao je da ,popiju pivo sad jer kasnije neće biti raspoloženi, što je Blažov shvatio kao „neće biti raspoloženi nakon što ga ubiju." 678 Blažovljev strah je dosegao vrhunac kad je vlak počeo izlaziti iz Zaprešića i kad su se putnici počeli razgovarati o nekom ,aktu koji moraju obaviti sad jer smo ovdje svi naši”. Jedan od

674 Ibid.

675 Ibid.

676 Ibid: 35 .

677 Ibid: 36.

678 Ibid. 
putnika spomenuo je da u kupeu ima i Bugara na što je njegov sugovornik opsovao majku Bugarima. Nakon toga je jedan od Hrvata ustao i približio se Blaževu, a Blažev je u strahu izvadio revolver i počeo pucati, ustrijelivši dvojcu putnika. Nakon toga je pokušao počiniti samoubojstvo, ali mu je revolver zapeo, pa je pobjegao u pisarnu na željezničkoj stanici i prijavio se vlastima. ${ }^{679}$

Blažev je kasnije shvatio da je njegov strah bio neopravdan i izrazio žaljenje zbog zločina, ${ }^{680}$ no rekao je da je prilikom putovanja pretpostavljao da pravi motiv njegovih ubojica leži u tragičnoj pogibiji njegovog brata. Naime, Blažev je vjerovao da njegov sumještanin koji je slučajno ustrijelio njegovog brata strahuje od moguće krvne osvete pa je unajmio grupu ljudi da ga ubiju na putu. ${ }^{681}$

Životna priča Stojana Blaževa obiluje primjerima nasilja koje mu se događalo- od smrti brata ustrijeljenog u igri puškom, preko političkog nasilja u Makedoniji na prijelazu stoljeća, do brutalnog i opasnog života fizičkog radnika u SAD-u. U svojoj priči Blažev prenosi iskustvo osobe koja se nikad i nigdje nije mogla opustiti i čije su dotadašnja iskustva često uključivala nenadane primjere ekstremnog nasilja, poput njegovog uhićenja na srpsko-bugarskoj granici gdje je prošao ponižavanje, zatočenje, izgladnjivanje i mučenje. ${ }^{62}$ Žirovčić njegovu bolest opisuje kao „progonstveni obman” ili „paranoia persecutoria”. ${ }^{683}$ „Progonstveni obman” Žirovčić definira kao stanje u kojem „kritika razuma iščezava i varave zamjetbe djeluju na bolesnika poput realne istine" i u kojem su navedene varke neprijateljskog sadržaja. Žirovčić, očekivano, gleda na stanje Stojana Blaževa kroz prizmu herediteta i metaboličkih procesa, što je dijagnostički okvir koji često primjenjuje. Pri pregledu Stojana Blaževa Žirovčić nije uočio vidljive „stigme” hereditarne degeneracije. Zbog toga kao dokaz hereditarnog upliva, Žirovčić ističe njegovo ranije oboljenje o kojem ga je izvijestila Blaževljeva tetka. ${ }^{684}$ Osim herediteta Žirovčić ističe da su pojavi bolesti pridonijeli i mnogi vanjski utjecaji koji su uglavnom djelovali na Blaževljev metabolizam: težak rad u Americi, zagušljiv zrak na pretrpanom parobrodu, nedostatak sna od straha i nepovoljnog tjelesnog položaja i izostanak hrane. ${ }^{685}$ Iako Žirovčić navodi stres kao mogući uzrok Blaževljevog

679 Ibid.

680 Ibid: 35 .

681 Ibid: 36.

682 Ibid.

683 Ibid: 37.

684 Ibid: 38.

685 Ibid: 37. 
mentalnog sloma, on je u potpunosti fokusiran na utjecaje stresa na tijelo jer svi navedeni faktori „kvare svježost krvi koja hrani mozdjane” ${ }^{686}$. Pritom pridavanje krvi neodređene kvalitete poput „svježosti” ponovno podsjeća na relikt humoralne medicine. Zanimljivo je da Žirovčić spominje i okolnosti Blažovljevog odrastanja, ali ne kako bi objasnio njegov intenzivan strah, već kako bi objasnio njegovu nasilnu reakciju, potkrijepljenu prilično orijentalističkom slikom samog Blažova. Blažov je „,...rodjen i odgojen usred divlje borbe raznih plemena med sobom i protiv turske sile, vičan oružju, pogibelji, krvoproliću i doma i u Americi, gdje si ljudi ne samo laktom, već i revolverom prokrčuju put..." ${ }^{\text {687 }}$. Prema tome, opasna sredina u kojoj je Blažov odrastao nije imala utjecaj na njegovu psihu koliko na njegove navike - zbog svog porijekla Blažov je posjedovao revolver i bio ga spreman upotrijebiti ga u stanju duševne rastrojenosti izazvane kombinacijom hereditarnih i metaboličkih faktora.

Stenjevački liječnici imaju ambivalentan odnos prema strahu od nasilja i kad je u pitanju nasilje duševnih bolesnika i kad je u pitanju strah samih štićenika od nasilja. Čini se da im je taj strah bitan jedino kao simptom, a i u tom smislu su najbitnije vanjske manifestacije te emocije koje se mogu promatrati medicinski. Među njima, najbitnije im je je li strah od nasilja manifestiran na način koji bi odavao duševno oboljenje, na primjer vrištanjem ili nasilnom reakcijom poput one Blažova. Osim toga, liječnici pokazuju interes za objekt tog straha, ali se čini da sam objekt za njih nema dijagnostičku vrijednost, prvenstveno zato što u njihovoj dijagnostička tradiciji sama kvaliteta emocije nema toliku vrijednost kao njezina prisutnost ili odsutnost i intenzitet i način pokazivanja emocije. Kod straha od nasilja pritom nije bilo bitno je li on bio opravdan ili ne u kontekstu štićenikovog životnog iskustva, iako je kod strahova navedenih u povijestima bolesti veza s pojedinim epizodama iz života štićenika očita.

686 Ibid.

687 Ibid: 38 . 


\subsection{Paranoidne mreže i strah od moći države}

Neki od štićenika demonstriraju strah od suptilnijeg strukturalnog nasilja, a to je nasilje represivnog aparata države. Iako su reakcije psihijatara na te strahove iste kao i reakcije na ostale strahove od nasilja, njihovi emotivni i narativni mehanizmi kojima se štićenici služe su ipak specifični i odražavaju jednu vrstu jedinstvenog pogleda na institucionalnu moć države odozdo, koja dolazi s margina modernizirajućeg društva. Jedan od posljedica procesa modernizacije, prisutan od Ranog novog vijeka naovamo svakako je jačanje državne administrativne moći i širenja njezinog represivnog i nadzirućeg aparata. U devetnaestom stoljeću taj represivni državni upliv biva naročito izražen na polju borbe protiv zločina i poroka koja predstavlja državu kao zaštitnika moralnog poretka. ${ }^{688} \mathrm{Ti}$ aparati nadzora nisu samo simptomi porasta anksioznosti $\mathrm{u}$ društvu nego i sami mogu potaknuti osjećaj anksioznosti i otuđenosti istovremenom impersonalnošću i sveobuhvatnošću vlastitog utjecaja na ljudska tijela i na prostor kojim se ta tijela kreću. Delumeau navodi jedan rani primjer takvog mehanizma nadzora kad, parafrazirajući Montaignea govori o sustavu dvostrukih vrata na ulazu u grad Augsburg u 16. stoljeću:

„Putnici se najprije nađu pred jednim vratima koja prvi stražar, čija se odaja nalazi na sto koraka odatle, otvara sa svoga mesta pomoću gvozdenog lanca, koji zaobilazno i s mnogo zaokreta povlači jedan- također gvozdeni- klin. Pošto se prekorači prag, vrata se najednom ponovno zatvaraju. Posetilac zatim prelazi most iznad gradskog šanca i stiže na malu zaravan, gde pokazuje svoje isprave i daje adresu na kojoj će boraviti u Ausburgu. Stražar onda zvonom obaveštava kolegu koji okreće oprugu smeštenu u prokopu blizu njegovu odaje. Ova opruga otvara najprije jednu pregradu- takođe gvozdenu- zatim pomoću velikog točka, diže pokretni most a da se od svih tih pokreta ne može ništa opaziti: jer oni se obavljaju kroz otvore u zidu i vrata, i sve se najednom ponovno zatvara uz veliku buku. Na drugoj strani pokretnog mosta otvaraju se jedna ogromna vrata od drveta ali okovana s više velikih gvozdenih šina. Stranac stupa u odaju gde se najednom nađe zatvoren sam u mraku. Ali druga vrata, slična prethodnim, propuštaju ga u sledeću odaju u kojoj ovoga puta ima svetla i u sredini koje, obešena na lancum visi jedna gvozdena posuda. U nju on stavlja novac kojim plaća ulaz. Drugi vratar povlači lanac, uzima novac koji je posetilac ostavio i proverava njegov iznos. Ukoliko ovaj ne odgovara utvrđenoj tarifi, vratar će ga ostaviti da dreždi do ujutro. Ali ukoliko je zadovoljan, onda mu na isti način otvara jedna velika vrata slična ostalima, koja se zatvaraju čim se

688 Osterhammel, 2014: 622. 
prekorače i posetilac se nađe u gradu...ispod odaja uređen je veliki podrum za boravak pet stotina naoružanih ljudi, zajedno s njihovim konjima pripravnih na svako iznenađenje. Ako bi zatrebalo, šalju se u rat „,bez znanja običnog sveta u gradu." 689

Delumeau ovaj mehanizam navodi kao dokaz činjenice da su vlasti Ausburga u 16. stoljeću bile u iznimnom strahu, no ono što je još bitnije je da uređaj sam može izazvati anksioznost kod nekog tko se susreće sa njegovim djelovanjem. Impersonalnost mehanizma (posjetitelju je otežana ili čak onemogućena mogućnost komunikacije lice u lice s vratarima, I ne dobiva priliku za dužu komunikaciju s istima), netransparentnost njegovog djelovanja (sam mehanizam pomoću kojeg se vrata otvaraju i zatvaraju je nemoguće opaziti s mjesta s kojeg posjetitelj stoji, i oni koji njime upravljaju su jednako skriveni od pogleda, a umjesto govorom komuniciraju signalima zvona), efekt koji isti ima na osjetila (izmjena osvijetljenih i tamnih prostora, signali zvonom, čekrci i zveket željeznih lanaca) i apsolutnost njegove moći (operator mehanizma može u bilo kojem trenutku ostaviti posjetitelja pred vratima) mogu stvoriti osjećaj bespomoćnosti kod onih koji su izloženi toj demonstraciji moći. Administrativna moć koja upravlja gradom dobiva efekt neljudskosti i neumoljivosti- ona je skrivena iza rigidnog željeza i drva koje otvara i zatvara prostor u skladu s njezinim teško protumačivima signalima, a jedini način da ju se privoli na popuštanje je dokazivanje identiteta i pogađanje točne „tarife”. Može se reći da i sama državna moć posjeduje sve karakteristike modernih tehnologija koje su Hirjak i Fuchs doveli u vezu s deluzijama Tauskovih „strojeva za kontrolu” ${ }^{690}$.

Tehnologije moderne državno-administrativne kontrole imaju skrivene efekte - bilo da se radi o mehanizmu upravljanja gradskim vratima ili mehanizmu birokratskog aparata nepropusnog za nekog neupućnog u birokraciju. One mogu činiti prostorne i vremenske granice propusnima ili nepropusnima pomoću funkcija sigurnosnog ograničavanja prostora i skupljanja podataka o prošlom životu građana. Kroz legalistički i birokratsko-administrativni diskurs mogu stvoriti dojam drugačijih ,virtualnih” realnosti (danas bi takve realnosti, pod utjecajem „Procesa” i „Dvorca” vjerojatno nazvali kafkanesknim). Na kraju, oni reificiraju tijela i populaciju kao objekte nad kojima se vrši nadzor s ciljem ostvarivanja njihove pune produktivnosti, u čemu je i Michael Foucault vidio suštinu biopolitike. ${ }^{691}$

689 Delimo, 2003: 19-20.

690 Fuchs i Hirjak, 2010: 100-101.

691 Foucault, 2003: 242. 
Od vremena prosvijećenog apsolutizma na području Banske Hrvatske se formiraju različiti moderni elementi državne kontrole. Dio stanovništva te mehanizme smatra nasilnima- to naročito vrijedi za područje nekadašnje Vojne Krajine gdje je stavljanje tih prostora pod bansku upravu često bila povezivano $\mathrm{s}$ gubitkom tradicionalnih privilegija. U mnogim slučajevima neprijateljstvo prema elementima državne kontrole rezultira i konspirativnim narativima, poput već spomenutog ,poreza na sunce” ili želje države da uspostavi moć nad brakovima i rađanjem djece. Teorije zavjere stenjevačkih štićenika gotovo su uvijek očito bizarne i patološke. Njihov sadržaj je često osebujan i nestvaran, ali one također svjedoče o osjećaju anksioznosti povezanom $\mathrm{s}$ već navedenim karakteristikama moderne državne moći i njezinim utjecajem na sudbine ljudi. U vremenu afere Dreyfuss i ponovne aktualizacije antisemitskih predrasuda brojne stenjevačke teorije zavjere uključuju Židove kao agente tajnog društva koje vrši nadzor nad štićenicima. Služavka iz Desinića kod Pregrade je tako za svoju hospitalizaciju krivila zavjeru Židova koji su je otpremili u Stenjevec jer „zna mnoge tajne o njima." ${ }^{692}$ Paranoidne misle krajiškog pisara i „stražmeštra” poznatog kao M.M, koji je bio na psihijatrijskom vještačenju u Stenjevcu nakon što se predao sudu tvrdivši da je pokušao ustrijeliti svog oca također se vezuju uz Židove i Slobodne Zidare. Tvrdnje koje je M.M iznio tijekom vještačenja daju persekutornu sliku moderne državne birokracije i percepciju efekata koje je tak aparat imao na neke od pojedinaca na području Vojne Krajine.

Žirovčić u svom detaljnom prikazu slučaja M.M. ne navodi ime grada u kojem su se navedeni događaji odvili, jedino ističući da se radi o području nekadašenje Vojne Krajine. Otac M.M bio je umirovljeni krajiški kapetan, a M.M je pokušao ići njegovim stopama. Pohađao je vojničke zavode iz kojih je ,radi slaba napretka i raznih nepodopština istjeran”. Nakon toga je neko vrijeme bio vojnik i stražmeštar, radio u pisarnama, okušao se u poljoprivredi te dvaput završio na sudu: prvi put zbog pronevjere, drugi put zbog javnog nasilja. U vrijeme prije dolaska $u$ Stenjevec postao je „besposlica i skitalica” koji je dugi niz godina bio u zavadi s vlastitim ocem. Okrivljivao je oca da je ,zatro zadružni imetak” i tražio od njega da mu kupi poljoprivredno zemljište na kojem bi M.M. mogao živjeti i raditi. ${ }^{693}$ Otac mu je više puta posuđivao novac koji bi M. M. brzo potrošio, te je često prijetio da će zapaliti očevu kuću, zbog čega su se i otac i suseljani žalili poglavarstvu. ${ }^{64}$ Jednog jutra M.M. je došao u oružničku vojarnu i prijavio se da je

$692 \mathrm{KPV}, 1911: 3096$.

693 Žirovčić, 1896: 33.

694 Ibid. 
pokušao ubiti oca ispalivši u njega četiri hica iz revolvera. Kao motiv svom činu na sudu je naveo „da je kanio otca ubiti, jer je zatro njihov imetak, jer živi u zajednici s drugimi, koje uzdržava, a njemu neće da kupi posjeda.” ${ }^{695}$ Prilikom ispitivanja, ponašao se „smušeno” i više puta dao oduška svome bijesu vrijeđajući sud, zbog čega je naređeno psihijatrijsko vještačenje. ${ }^{696}$ Prilikom vještačenja, M.M se izdvaja od ostalih štićenika i provodi dane šećući zavodskim perivojem. Ne želi raditi već govori da bi ,jedino na svom vlastitom posjedu poljodjelstvo tjerao, jer to je njegovo pravo zvanje, a da toga nema, kriv je otac, koji je njihov zadružni imetak zatro." ${ }^{967} \mathrm{Ne}$ želi ni čitati knjige iz zavodske knjižnice već tvrdi da želi čitati „nešto uzvišenijega, filozofičnog" ${ }^{9698}$. Njegovo ponašanje odaje distancu prema samoj instituciji: pozdravlja liječnika

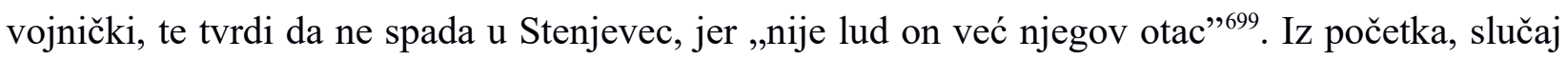
se doima kao obični imovinsko-obiteljski sukob, možda potenciran procesom propadanja zadruga u krajiškim krajevima. Kasnije, u razgovoru s liječnikom pored frustracije ocem M.M. postepeno otkriva progonstvene ideje koje odaju sve veći strah od neke zavjere protiv njega. Na pitanje je li zbilja želio ubiti svog oca, M. M. govori kako je isprva uistinu smatrao oca glavnim krivcem za svoju nesreću, no kasnije ga je počeo držati za agenta državne urote protiv njega:

„Da Vam pravo kažem, jesam zaista bio nakanio otca ubiti, jer sam sudio, da je on kriv svemu. $\mathrm{Nu}$ doduše sad sam druge misli, nije on baš sve kriv, es muss der Hacken anderwärts wo liegen. Ja vidim, da se neki lov tjera na me, to sam reko već kod suda, a mislim, da se je otac sasvim prodao državi ili kralju, ili tako nešto sličnoga." ${ }^{\prime 700}$

Žirovčić detaljno intervjuira M.M. o njegovim paranoidnim mislima i ubrzo postaje jasno da M.M. gradi svoj progonstveni narativ oko tri epizode koje smatra ključnim dokazima zavjere protiv sebe. Prva je njegov odnos s ocem za kojeg kaže da je prodao zadružni imetak i prevario ga za njegov dio te se sad seli iz kuće u kuću ovisno o tome „kako je zgodno za njegove kombinacije” te živi s "prostom selskom flundrom" ${ }^{\text {"701. }}$ M. M. tvrdi da je dokaz zavjere protiv njega i činjenica da njegovo ime nije zapisano u matične knjige, zbog čega navodno nije mogao ostvariti pravo na svoj dio novca od prodaje posjeda. Također sam pokušaj umorstva oca se izjalovio zato što su meci, čini se bili dijelom zavjere- M. M. ih, na svojoj mješavini hrvatskog i

695 Ibid.

696 Ibid.

697 Ibid: 34.

698 Ibid.

699 Ibid.

700 Ibid.

701 Ibid. 
njemačkog naziva ,politische patronen”. ${ }^{702}$ M.M smatra da je njegova namjera da počini umorstvo moralna i taj svoj stav obrazlaže kroz distinkciju „božjeg” i „madjarskog” zakona: „Razlaže, kako se čovjek od životinje razlikuje time, što životinja nemora svojim potomkom ništa ostaviti, dočim čovjek mora. Nije to dovoljno, da samo odgoji djecu, to je 'samo po magjarskom naravogojnom sistemu', kako je to negdje čitao. On da će raditi samo po božjem zakonu, a božji zakon se neprotivi tomu, da on otca ubije"703

Drugi događaj na koji se M.M. stalno poziva je tučnjava u kojoj je nastradao od nekih nepoznatih ljudi. M.M. tom napadu pridaje veliki značaj i zaodjeva ga u svoj jezik zavjere nazivajući ga „Sophienaffaire” i navodeći , da i to spada u kombinacije"704. Naime, u noći 24 svibnja uoči dana Svete Sofije napalo ga je na ulici jedanaest ljudi, te su ga istukli tako da je morao biti prevezen u bolnicu u Zagrebu. Kasnije M. M. govori da je motiv tog napada na njega bio u tome da ga se „napravi besvjesnim” što su njegovi napadači navodno i uspjeli. ${ }^{705}$

Treći element progona u M.-ovom narativu je postojanje čitave mreže državnih službenika koji ga prisluškivaju, uhode i sabotiraju. M. M. govori o nizu zbrkanih događaja koji dokazuju da su se neki „Herrenklubovi” i „Freimauern” urotili protiv njega i ciljano ga progone. M. M. upliće državu, Slobodne Zidare i Židove u fantastične zavjere kojima je cilj upravljanje svijetom, a upitan od Žirovčića da definira tko su „Freimauern” o kojima stalno govori, M.M izjavljuje da se ta kvalifikacija odnosi na svakog obrazovanog državnog službenika. On se od Slobodnih Zidara čak trudio ostvariti materijalnu korist jer je bio uvjeren da ga oni mogu učiniti plemićem, a neki „doktor T.” ga je navodno pozvao da im se pridruži :

„K tomu ja računam u kratko svakoga naobraženoga službenika, baš radi tih stvari, što se proti meni radi. To je ono isto, što se zove Freimaurerorden. Oni si neka svietom vrte koliko hoće, ali meni neka dadu mira. Doktor T. mi je rekao: Wollen Sie nicht beitreten zum Freimauerorden? Ja dobro pazim i razglabam rieči, pa ako se toliko za me zanimaju, bješe im meni pomoći, da budem grof. Pa nebi ja samo za se radio, ja nisam kao židov, premda židovi imaju pravo: Geld regiert die Welt" ${ }^{\text {706 }}$

M.M. prepričava čitav niz događaja koji dokazuju upliv Židova i Slobodnih Zidara u njegov svakodnevni život poput epizode kad su mu oružnici jednom došli s namjerom da mu zaplijene

702 Ibid.

703 Ibid: 36.

704 Ibid: 35 .

705 Ibid.

706 Ibid: 36. 
revolver:,,...jedan od te dvojice da je bio pravi oružnik, a drugi ne, već je samo bio preobučen, 'kao kad Talijan jopca preobuče.' Zapitan, što bi to moglo značiti, da preobučeni ljudi k njemu dolaze, veli, da se svašta dogadja, da se živi ljudi proglase mrtvimi, da si imena promiene"707

Osim toga, M.M. navodi da su ga pratili neki Židovi ,iz Beča i Pešte” koji su se predstavljali kao braća, „,iako nisu bili slični” te da je jednom napisao opširno pismo caru ali se čitav „Postwessen preokrenuo bio kako bi se njegova pošiljka izgubila."708

U pismu koje je namjeravao poslati ocu, M.M. tvrdi kako su i on i otac žrtve te tajanstvene organizacije:,,To tebe u mrežah držeće maurersko družtvo se je u mojoj osobi prevarilo malo neugodno ali neka se tješe sa tobom skupa, jer bi bili bolje uradili, da su ma koju inu sektu producirali, jer ja neću - ne velim nemogu biti ma igdje t. z. varoškim bikom"709

Slične formulacije M.M. ponavlja u svojim pismima Žirovčiću, a Žirovčić ih sve otpisuje kao „nerazumljivu smjesu navoda" ${ }^{\text {„110 }}$. Žirovčić M.-a smatra paranoikom koji pati od „misli samouveličanja” i ,progonstvenih misli"711. No, ono što je znakovito je da Žirovčić, ni u ovoj studiji slučaja ni u svom opisu paranoje kojeg je objavio godinu dana ranije ne povezuje paranoju sa strahom ili tjeskobom. Dapače, čini se da je se, za Žirovčića, suština paranoje sastoji u osjetilnim varkama, a ne u strahu od umišljenih progonitelja:

„Glavni sadržaj i glavno obilježje paranoične bolesti jesu varke ćutila i varke mišljenja, a subjekt, oko kojega se sve te varke kao gusta mreža pletu, jest vlastiti ego bolestnika. Svaki dodir bolestnika sa vanjskim svietom shvaća se krivo i sve se tumači u odnošaju prema vlastitoj osobnosti u dvima pravcima, u pravcu oštećivanja i pravcu uzvisivanja vlastite osobe...Prema tim mislim reagira on budi afektom tuge, budi veselja, a obično se nalazi u trajnom stanju uzrujanosti, razdražljivosti "712

U ovom opisu paranoje možemo naći tragove koncepcije paranoje koju je kasnije iznio argentinski psihoanalitičar Salomon Resnik. Resnik je istakao da osoba koja pati od paranoidnih ideja zapravo konstruira vlastiti „svijet progonstva” tako da projicira osjećaje krivnje, straha i anksioznosti prema van i trudi se funkcionirati po pravilima svijeta oblikovanog projekcijama tih emocija. ${ }^{713}$ Znakovito je da su upravo ti osjećaji posve izostavljeni iz Žirovčićevog opisa

707 Ibid: 35.

708 Ibid.

709 Ibid: 57.

710 Ibid.

711 Ibid: 59.

712 Žirovčić, 1895a: 44.

713 Resnik, 1998: 30. 
paranoje, a zamjenjuju ih tuga, veselje i uzrujanost, odnosno razdražljivosti. Razlog tome je možda upravo u činjenici da su strah i anksioznost projicirani i mogu se iščitati iz paranoikovog opisa stvarnosti, više nego iz njegovog ponašanja. Budući da se govor duševno oboljelih u postojećoj praksi smatrao „besmislenim” nije se posvećivala pažnja samom značenju paranoidnih konstrukcija i tjeskobi koja se često nalazila iza istih. U paranoidnim idejama M.M. bitnu ulogu igraju agenti i službe države: oružnici, poštanski ured, popisi stanovništva i etička opreka između „božjeg” i „mađarskog” zakona. Kroz svoj paranoidni svijet M.M. zapravo konstruira sliku državne vlasti kao agenta koji djeluje protiv njega i koji je kriv za njegovo teško financijsko stanje. Zakon po kojem je M.M. stalno progonjen je upravo „mađarski” a agenti koji ga prisluškuju i prate su iz „Beča i Pešte”. Osim toga, M.M. koristi izraz ,politische” u negativnom smislu kao oznaku za nešto što sudjeluje u zavjeri. Samim time, može se reći da M.M. vidi izvor svoje projicirane anksioznosti u administrativnom sustavu kojem je Vojna Krajina bila podvrgnuta nakon pripojenja Banskoj Hrvatskoj. Administrativni sustav mađarskog dijela Austrougarske monarhije razlikovao se od administrativnog i pravnog sustava Vojne Krajine i bio je primarno birokratiziran, nasuprot militiziranom sustavu koji je tamo prevladavao ranije. ${ }^{714}$ Stav o tome kako mađarski i bečki birokrati žele osiromašiti i eksploatirati stanovništvo Vojne Krajine bio je prisutan nakon ukidanja krajiške administracije, ${ }^{715}$ a kod M.M. nalazimo tragove te mržnje prema državnoj birokraciji i straha od države. Naravno, M-ov strah je svakako patološki, ali se i dalje radi o implicitno kulturnoj i političkoj percepciji države kao „mreže” tajanstvenih društava u kojima se M. kao društveno neprilagođena osoba nesklona disciplini, nije najbolje snalazio i pred kojima je svakako strepio.

Salomon Resnik kao bitne osjećaje kod paranoje uz strah i anksioznost spominje i krivnju. Sudski slučaj zagrebačkog studenta filozofije I. M.-a postavit će krivnju i strah kao emocije kroz koje će se definirati odnos pojedinca i državnog represivnog aparata. I. M. je bio siromašan student koji je živio s bratom i dvjema sestrama u podrumskoj sobici u Zagrebu. ${ }^{716}$ Još kao dijete bio je veoma inteligentan i marljiv, završio je školu s odličnim ocjenama, kao i učiteljsku preparandiju i upisao Filozofski fakultet. Živio je veoma umjereno i provodio dane u čitanju knjiga i novina ${ }^{717}$, no neki od njegovih kolega primijetili su da je ,uobražen” i često zanesen zbog

714 Buczinski, 1994: 79.

715 Pavličević, 1980: 36.

716 Žirovčić, 1909: 291.

717 Žirovčić, 1909: 289. 
čega je bio izložen podsmjehu. ${ }^{718} \mathrm{U}$ zavodu se našao nakon što je 30. kolovoza 1907. priznao redarstveniku da je tjedan dana ranije izrezao komad platna iz portreta bivšeg bana Khuena Hedervaryja koji se nalazio u dvorani zgrade Odjela za bogoštovlje i nastavu Kraljevske i zemaljske vlade. Na čin vandaliziranja slike ga je potakla teška politička situacija u zemlji: činilo mu se da je „čudno, da se vani viče na omraženoga bana, a gore se pred njegovom slikom klanjaju te je smatrao da će mnoge obradovati njegov čin kao osveta za željezničku pragmatiku kojom se u Hrvatskoj „ozakonjuje mađarski jezik”. ${ }^{719}$ Prilikom ispitivanja na sudu, I.M. je često govorio o progonu od strane detektiva, te je predan na vještačenje u Stenjevec. ${ }^{720}$ Prilikom vještačenja u Stenjevcu I.M. navodi kako su detektivi već drugi dan poslije počinjenja njegova čina znali da je on krivac. Na tu misao ga je potaknuo događaj na Zrinjevcu gdje se I.M. odmarao sjedeći na klupi:

„Na Zrinjskom trgu pridje k njemu neki čovjek, pjevkajuć sjedne kraj njega na klupu i upusti se s njim u razgovor. Na to dodje još jedan čovjek sa ženskom izpod ruke, guraju se kao pijani i upuste se takodjer s njim u razgovor. Te ljude drži on za detektive, koji su došli k njemu, da u njom pobude grižnju savjesti. Onaj, koji je prvi k njemu sjeo. hotio je predobiti onu ženu, koja je došla sa svojim mužem, žena htjela i nehtjela, borila se sama sa sobom, savjest ju grizla i jedva se je otela nevjeri. O tom je I. M. razmišljao i došao do zaključka, da ne postoji samo materijalna sila, već da ima i duševna sila, koja moćno upliva na čovjeka, te je i tu ženu sačuvala od nevjere, a njega prisilila, da se sam oda. Takvom silom uplivisanja osobito razpolažu detektivi."’721

U temelju svih paranoidnih primisli koje I.M. prenosi psihijatrima nalazit će se ista ideja: detektivi posjeduju tajnu duševnu silu koja kod ljudi može probuditi grižnju savjest, pa ju je probudila i kod njega. I.M. osjeća strah pred liječnicima i štićenicima zavoda- smatra ih prerušenim detektivima koji glume da su duševno bolesni ili liječnici, te njihove riječi i geste tumači u ključu za svakodnevne stvari (poput oblika medaljona na crtežu govoreći da „nešto znače". ${ }^{722}$ U njegovim paranoidnim mislima opet se javlja moć države jer vjeruje da ga okoliš nekako osobito motri i podpaža, da mu hoće nametnuti svoje političko osvjedočenje; to uplivisanje jest „kameralizam” ${ }^{723}$.

718 Ibid.

719 Ibid.

720 Ibid.

721 Ibid: 290.

722 Ibid: 291.

723 Ibid. 
I kod I.M.-a ko kod M.M.-a vidljiv je izrazit strah od zavjere, a glavni objekti tog straha su akteri države. Dok M. M.-u državni činovnici uspijevaju naškoditi pomoću asimetrije političke moći, detektivi kojih se boji I. M. posjeduju „duševnu silu”. Tu duševnu silu obrazovani I.M. poistovjećuje sa „kameralizmom” - ekonomskom politikom jačanja državne blagajne koja je karakterizirala pruski i austrijski apsolutizam 18. stoljeća. Način na koji I.M. projicira strah od države podsjeća na proces internalizacije savjesti koji je Ann Goldberg opisala u svojoj studiji psihijatrijskog zavoda u Eberbachu. Prema Ann Goldberg modernizacijski procesi su pomoću disciplinirajućih institucija poput škola, zatvora i psihijatrijskih zavoda promijenili naše poimanje osjećaja krivnje. Ono prestaje biti definirano unutar brojnih društvenih odnosa (ili čak odnosa čovjeka s božanskim) i kroz psihološki mehanizam savjesti postaje dijelom integrirane ličnosti pojedinca upravljanog autonomnim razumom. ${ }^{724}$ I.M. projicira svoj osjećaj krivnje (ponovno ga eksternalizirajući) i zbog toga stalno živi u strahu od detektiva koji mu telepatskim silama nastoje utjecati na misli. Zanimljivo je također da kroz svoju definiciju „kameralizma” I.M. stvara svjesnu ili podsvjesnu poveznicu između sustava disciplinskog nadzora i jačanja centralizirane države orijentirane prema ekonomiji, što je jedna od ključnih postavki u Nadzoru i kazni Michela Foucaulta. ${ }^{725}$ Žirovčić ne prepoznaje strah ni kod I.M.-a ni kod M.M.-a. I.M. pokazuje strah puno otvorenije od M.M.-a koji ga skriva iza hvalisanja i agresivnog ponašanja. I.M. ne može spavati, nemiran je, i prema samom Žirovčiću, pokazuje simptome neurastenije. ${ }^{726}$ No za Žirovčićevu dijagnozu paranoje, puno su bitniji iskazi njegovih kolega o tobožnjoj I.-ovoj uobraženosti.

Može se reći da je strah ekstremno hipokogniziran u iskazima štićenika koji ga projiciraju u sliku progonstvenog svijeta- kao emocija uopće nije spomenut, a ključ paranoje traži se u usredotočenosti paranoika na sebe samog. Kompleksne slike državne moći kao prijeteće i nerazumljive tako u psihijatrijskom diskursu neće biti povezivane sa strahovima koji nastaju uslijed nesigurne i burne političke situacije prijelaza stoljeća i sve veće ,politizacije” društva u Banskoj Hrvatskoj. Kao i kod ostalih primjera koje sam naveo u ovom poglavlju strah postaje vidljiv tek u glasu samih štićenika. Sudeći po njihovom glasu, strah i strepnja štićenika često imaju korijene u njihovoj svakodnevici. Strah od siromaštva reakcija je na stalno stanje oskudice kojem su pojedini štićenici bili izloženi. Strah od natprirodnog potječe od duboko ukorjenjenih

724 Goldberg, 1999: 81.

725 Foucault, 1977: 215.

726 Žirovčić, 1909: 290. 
pučkih vjerovanja ili je izraz pojačanog interesa za okultno na prijelazu stoljeća. Strahovi od nasilja i od državne kontrole potaknuti su fizičkim ili strukturalnim nasiljem s kojim su se štićenici suočavali. No, niti sadržaj strahova štićenika, niti njihova svakodnevica nisu u fokusu dijagnostičkog procesa stenjevačkih psihijatara. Strah je medikiliziran i odvojen od životne svakodnevice i kulturne pozadine štićenika koji o njemu govore. No, dok psihijatri nastoje negirati samu emociju straha i tjeskobe u slučajevima straha štićenika od političkih zavjera i progona, govor štićenika ipak ponekad otkriva iskrivljenu, ali vidljivo politiziranu sliku navedenih emocija. Na sličan će se način u narativima štićenika politizirati, a u tumačenjima pojedinih liječnika medikalizirati problemi agresije i nasilja o kojima ću govoriti u sljedećem poglavlju. 


\section{Bijes, nasilje i sukobi}

\subsection{Bijes, nasilje i sukobi u psihijatriji devetnaestog stoljeća}

Na ranim likovnim prikazima duševno oboljele osobe često su prikazane u stanju destruktivnog bijesa. Figure manije i melankolije, prikazane iznad londonskog Bedlama stoljećima su bile tradicionalan način zamišljanja i prikazivanja duševnih bolesti. Uz melankoliju se vezivao osjećaj potištenosti, tuge i ponekad, iskrivljena percepcijaustvarnosti poput one kod Cervantesovog Don Quijotea i Shakespearovog Kralja Leara”. Na spomenutoj Cibberovoj statui iz 1676. godine, Melankolija leži ispružena sa zamišljenim izrazom lica, zadubljena u vlastite misli. Manija je sapeta čvrstim čeličnim lancima, mišići su joj napeti, a dok se pokušava osloboditi na licu joj je izraz gotovo animalnog bijesa. Studija Fione Haslam From Hogarth to Rowlandson: Medicine in Art in Eighteenth-century Britain pokazuje kako su se slike melankolije i manije razvijale na medicinskim ilustracijama i u umjetničkim prikazima ludila kroz osamnaesto stoljeće. Dok su prikazi melankolije često imali romantičan i pomalo tragičan sentiment, manija je u kontekstu sve prisutnijeg racionalističkog poimanja čovjeka kao „bića razuma” služila kao zastrašujući prikaz destruktivnih impulsa nesputanih razumom. Prije nego što su se kompleksniji medicinski pogledi na duševnu bolest proširili među obrazovanim slojevima, „bjesneći manijak” u lancima (uz tragično-donkihotovsku figuru siromaha koji je umislio da je kralj) je najčešći prikaz kojim se kodira duševno oboljenje. ${ }^{727}$ Takav pogled odgovara prosvjetiteljskim percepcijama duševno oboljelog kao osobe koja je izgubila „razum” ili joj su joj racionalne odlike nedostupne. Budući da je razum karakteristika koja u prosvjetiteljskim poimanjima razlikuje čovjeka od životinje, ludilo se dovodi u vezu s ,nižim” instinktivnijim aspektima ljudske prirode. ${ }^{728}$ Nagonsko i ,životinjsko" u čovjeku se često manifestira kao nekontrolirani bijes. Takva percepcija bijesa govori o prevalentno negativnoj hiperkognizaciji bijesa u europskoj kulturi. Bijes je hiperkogniziran iz razloga jer je usko povezan s nasiljem, pa je samim time u emotivnim režimima morao biti podvrgnut raznim oblicima društvene kontrole. Jedan od najranijih primjera književno umjetničke hiperkognizacije bijesa nalazi se u Homerovoj Ilijadi. Već u početnim

727 Haslam, 1996: 167.

728 Ibid. 
stihovima Homer kao temeljnu temu svog epa ne određuje ratničke podvige i prikaze junaštva (na kraju, samo osvajanje Troje nije nikad prikazano u Ilijadi) već upravo bijes ili srdžbu ( $\mu \tilde{\eta} v l \varsigma)$ : „Srdžbu mi, boginjo, pjevaj Ahileja, Peleju sina,Pogubnu, kojano zada Ahejcima tisuću jada,",29 Svađa Ahileja i Agammemnona rezultira pogibijom za ahejsku vojsku upravo zato što Ahilej, potaknut Ateninim savjetom odabire određen način pokazivanja vlastite srdžbe. Ahilej odlučuje susprezati svoje emocije upravo kad mu boginja vojne strategije Atena kaže da će pokazavši bijes odbijanjem ratovanja, a ne direktnim fizičkim sukobom dobiti daleko veću satisfakciju za svoj povrijeđeni osjećaj časti. Primjer „Ilijade” pokazuje da je kognizacije bijesa vezana uz osudu direktnih iskazivanja te emocije i uz što učinkovitiju kontrolu gnjevnih impulsa prisutna još od Starog Vijeka.

Norbert Elias je kroz svoju studiju „Civilizacijskog procesa” detaljno prikazao modele postepenog podvrgavanja nasilnog ponašanja društvenoj kontroli. Upravo Eliasovi primjeri dobro ocrtavaju povezanost između emotiva kao čina iskazivanja emocije u određenom socijalnom kontekstu i unutarnjeg kogniziranja same emocije. Formalni i neformalni oblici kontrole agresivnog ponašanja, vezali su bijes uz nasilje te ga učinili emocijom koju je društveno neprihvatljivo pokazivati. Pojavom racionalističke koncepcije ljudskog uma, bijes je sveden na instinktivnu emociju čije otvoreno iskazivanje služi kao dokaz slabljenja racionalnih mehanizama.

Pitanje bijesa i agresije predstavljalo je neodgovoren problem za psihologe, psihijatre i psihoanalitičare. Jedan od najranih prijepora u psihoanalizi je upravo mjesto agresivnosti unutar psihodinamičkih koncepcija ličnosti. Freud, za kojeg su dugo vremena bili ključni seksualni nagon i nagon za samoodržanjem, na početku nije pridavao važnost agresivnim implusima niti emociji bijesa, za razliku od svog suvremenika Alfreda Adlera koji je agresiju smatrao biološkim nagonom i postulirao ,agresivni poriv” unutar svoje teorije o kompleksu inferiornosti. ${ }^{730}$ Kasnije će Freud početi shvaćati agresiju kao jednu od manifestacija „thanatosa” ili nagona smrti. Za razumijevanje kasnih Freudovih pogleda na agresiju, bitno je njegovo djelo Nelagoda u kulturi iz 1930. godine.U Nelagodi u kulturi Freud će zaključiti da je postojanje destruktivnih agresivnih nagona koji bi rezultirali nasiljem da nisu inhibirani, pretpostavka za postojanje društvenih inhibicija i samim time, za postojanje uređenih društava. Za Freuda, ljudi nisu dobrohotna bića, 
sposobna braniti se od opasnosti već su obdareni agresivnošću kao jednim od svojih urođenih nagona. Ta sklonost agresiji je stalna prijetnja za ljudsko društvo, a društvo, kako bi izbjeglo dezintegraciji mora postaviti restrikcije protiv seksualnih sloboda i agresivnog ponašanja. Kao jednu od ključnih restrikcija, Freud vidi zapovjed o „ljubljenju bližnjega svoga ka samog sebe”. Freud tvrdi da taj naputak, ne bi imao razloga postojati da ljudi po svojoj prirodi nisu podložni agresivnom nagonu. ${ }^{731}$ Kao mladi psihoanalitičar s izraženim interesom za forenzičku psihijatriju, Jacques Lacan se bavio uzrocima nasilja. Lacan se u svom članku „Motivi paranoičnog zločina: zločin sestara Papin” bavi zločinom sestara Christine i Lee Papin koje su 1933. u Le Mansu na osobito brutalan način ubile svoju gazdaricu i njezinu kćer. U analizi zločina Lacan ističe vezu između agresivnog nagona i paranoidne psihoze pri čemu agresivni nagon služi kao baza paranoidnog delirija i koji se u činu umorstva manifestira putem kompromisa $\mathrm{s}$ integriranim društvenim zahtjevima koji maskiraju istinski motiv zločina. ${ }^{732}$

Jedan od najtemeljitijih analiza agresije i agresivnosti dao je Erich Fromm, psihoanalitičar i filozof koji je bio jedan od predstavnika „Frankfurtske škole”. U Anatomiji ljudske destruktivnosti Fromm je podijelio agresiju na benignu i malignu. Oblici agresije koje je Fromm odredio kao benigne nastali su kao posljedica evolucijskog razvoja ljudske vrste, a javljaju se kao odgovor na prijetnju jedinki. Često se javlja i kod ljudi i kod životinja i nikad nije spontana i eskalirajuća, već obrambena i reaktivna, a za cilj ima otklanjanje prijetnje. ${ }^{733}$ Benignu agresiju, Fromm je dalje podijelio na pseudoagresiju (agresivni postupci koji mogu naškoditi nekome, ali im to nije primarna svrha) i obrambenu agresiju koja nastaje kao reakcija na stvarnu ili umišljenju opasnost. Malignu agresiju za Fromma predstavljaju postupci koji su svojstveni samo čovjeku i ne javljaju se u životinjskom svijetu. Ona je uvijek destruktivna i jedan je od mogućih odgovora na specifične psihičke potrebe ukorjenjene u ljudskom bivanju i nastaje uslijed različitih oblika interakcije društvenih okolnosti s tim potrebama. ${ }^{734}$ Fromm je malignu agresiju vidio kao manifestaciju dva različita oblika destruktivnosti: prvu je nazvao spontanom destruktivnošću koju dalje dijeli na osvetničku i ekstatičku. Druga je destruktivnost ona koja proizlazi iz specifične strukture ličnosti. Za Fromma postoje dvije vrste destruktivnosti koje mogu biti utkane u strukturu ličnosti: sadizam i nekrofilija. Sadizam za Fromma znači seksualnu ili aseksualnu želju

731 Freud, 2010: 4504-4505.

732 Fazerkaš, 2016: 95.

733 Fromm, 1974: 187.

734 Ibid: 218. 
za nanošenjem boli drugima, a nekrofilija užitak u smrti i uništavanju. Razvoj ranih psihoanalitičkih pogleda na bijes i agresiju odaje jednu važnu karakteristiku promatranja agresivnih i „destruktivnih” emocija: one često nisu ni opisivane ili doživljavane kao emocije već ih se konceptualiziralo kao „nagone”, ,instinkte” ili ,porive”. Time se naglašavala njihova iracionalna, primalna, „niža” priroda što govori o njihovoj negativnoj percepciji unutar emotivnih režima. No, s razvojom psihoanalitičkih teorija pogled na bijes i agresiju postaje daleko kompleksniji i u njega se nastoje uključiti kako sukobi unutar pojedinca tako i šire društvene dimenzije koje mogu povoljno djelovati na razvoj agresije, tako da će postfrojdovska psihoanaliza obilovati analizama agresivnosti i narcisističkog bijesa.

U godinama kad se moderna europska psihijatrija tek počela formirati veliku je pažnju privukla bolest Georgea III, ,ludog kralja” Velike Britanije i protopsihijatrijski tretman kojem je bolesnog kralja podvrgao njegov liječnik Francis Willis. Novija istraživanja bolesti Kralja Georgea III navode da je bolovao od porfirije, nasljedne bolesti metabolizma koja između ostalog uzrokuje promjene raspoloženja i psihozu ${ }^{735}$. Kraljevi ispadi nekontroliranog bijesa i Willisova sposobnost ublažavanja istih, izvršili su velik utjecaj na terapeutske metode ,moral treatmenta” i na poimanje ludila u devetnaestoljetnoj psihijatriji. Willis je smirivao kraljeve ispade bijesa kombinacijom tehnike ,fiksiranja” (navodno je Willisov pogled bio toliko čvrst da je prilikom jednog sastanka natjerao vođu opozicije Edmunda Bourkea da obori oči pred njim) $)^{736}$ i nametanjem neupitnog liječničkog autoriteta. Primjer tog tretmana je učvrstio percepciju liječnikovog autoriteta kao važnog elementa unutar ,,moral treatmenta”. Willisove terapeutske metode bile su toliko utjecajne da ih Phillipe Pinel navodi kao uzor postupanja prema duševnim bolesnicima ustvrdivši da je Willisova metoda izolacije kralja Georgea i njegovo nametanje vlastitog autoriteta, dodatno potpomognuto dvojicom „snažnih pomoćnika” dovela do ,sigurnog i trajnog izlječenja. ${ }^{737} \mathrm{U}$ istom dijelu, Pinel stvara vezu između bijesa i manije koje će se psihijatri držati kroz cijelo devetnaesto stoljeće. Pinel piše: „Onaj koji je poistovjetio ljutnju s bijesom ili prolaznim ludilom (ira furor brevis est) je izrekao tvrdnju čiju smo istinitost više ili manje skloni potvrditi proporcionalno s opsegom našeg znanja o ludilu. Paroksizmi ludila su uglavnom tek pobješnjele emocije koje traju duže od svog uobičajenog trajanja..." ${ }^{738} \mathrm{Za}$ Pinela su sama kvaliteta, valencija,

735 Macalpine i Hunter, 1966: 69.

736 De Young, 2015: 245.

737 Pinel, 1806: 188 u engleskom prijevodu s početka devetnaestog stoljeća nije bilo moguće otvoreno istaknuti da se radi o još vladajućem engleskom monarhu.

738 Ibid:19. 
osjećaj ili cilj emocija nebitni u razlici između prihvatljivog izražavanja emocija i luđačkog paroksizma: paroksizam manijaka je određen time što traje duže nego što je uobičajeno bez slabljenja intenziteta. Kao primjer emocije koju je već i poslovično teško odvojiti od ludila, Pinel ističe upravo bijes.

No, u kasnijoj psihijatriji oštro poistovjećivanje ludila s bijesom nestaje. Za Žirovčića tako bijes kao konkretna emocija nije bitan simptom duševnog oboljenja već on u svojim pojavama govori o veselom i turobnom raspoloženju, razdražljivosti i osjećaju straha ${ }^{739}$, dok maniju poistovjećuje s veselim raspoloženjem. ${ }^{740}$ Takva distinkcija neće biti izražena u kliničkoj praksi: brojni štićenici kojima će se dijagnosticirati „mania” pokazivat će znakove bijesa i agresivnog ponašanja, a ono će biti prisutno i kod većine drugih duševnih oboljenja. Tako su prvi simptomi bolesti književnika Ante Kovačića, koji je 1883. umro u Stenjevcu s dijagnozom „manije” bili obilježeni upravo velikom agitacijom i bijesnim ponašanjem. Prema povijesti bolesti ona je počela „nespavanjem, vikanjem, skakanjem, uništavanjem stvari... Bio je tako bijesan da su ga vezana u zavod doveli." ${ }^{741} \mathrm{O}$ agresivnom i za društvo opasnom ponašanju brojnih štićenika, Žirovčić je pisao u svom članku „Ludjačka umorstva nazvana la folie rouge” iz 1898. godine. U tom članku, kako je istaknuto u prošlom poglavlju, Žirovčić govori o sklonosti duševnih bolesnika prema počinjenju nasilja i pritom osobito ističe epileptičare, alkoholičare i ,hereditarno opterećene pojedince" ${ }^{\text {742 }}$. Čini se da se, sa somatizacijom etiologije duševnih bolesti u psihijatriji, važnost bijesa kao emocije smanjuje. No ono što ostaje je percepcija duševno bolesnih osoba kao pojedinaca sklonih agresiji. On je vidljiva i u Žirovčićevim člancima, i u povijestima bolesti i u pojedinim teorijama „kriminalne antropologije” poput one koje je razvio talijanski kriminolog Cesare Lombroso. Lombrosove teorije tražile su uzrok kriminalnog ponašanja pojedinaca $u$ psihijatrijskim teorijama degeneracije ${ }^{743}$, te su imale velik utjecaj na njemačku forenzičku psihijatriju i posljedično, na poimanje kriminalnog i agresivnog ponašanja kod stenjevačkih liječnika.

739 Žirovčić, 1896b: 252.

740 Žirovčić, 1895a: 4.

741 Župić, 1937: 345.

742 Žirovčić, 1898: 228-229.

743 Jones, 2016: 116. 
Ono što je karakteristika bijesa i agresije je činjenica da se javljaju u konfliktnim situacijama, te da služi kao emotivni način razrješenja određenog sukoba. Somatiziranje agresije kakvo je predložio Lombroso, izmjestilo je bijes i agresiju iz konteksta sukoba u kojima se oni javljaju. Stvarnost sukoba u nekoj društvenoj sredini, bilo da se radi o obitelji, široj zajednici ili čitavom društvu postaje nevidljiva u psihijatrijskim čitanjima zločina i agresije. Način na koji se sukob percipira, bit će usmjeren na osobu za koju je ustanovljeno da je akter agresije pri čemu se njezin bijes čita isključivo kao simptom uz sve ostale dijagnostičke faktore koje psihijatrijski pogled smatra bitnima za identificiranje duševno oboljelog ili hereditarno degeneriranog pojedinca: tjelesne „stigmate”, obiteljska povijest ludila ili devijantnog ponašanja i slično. Medikalizacijom bijesa i agresivnog ponašanja i biologizacijom zločina čine se nevidljivima brojni partikularni događaji koji su doveli do svake nekontrolirane provale bijesa ili nasilnog akta. Ipak, stenjevačke povijesti bolesti sukreirali su i sami štićenici kroz svoj neposredan ili posredovan govor. U tom govoru, možemo naći različite narative fizičkog, psihičkog i emotivnog nasilja koje se događalo u obiteljima, malim zajednicama i u širem društvu. Dok se psihijatri bave obuzdavanjem destruktivnih emocija štićenika i dok traže neurološki izvor njihovih tegoba, štićenici često govore o brojnim sukobima, mikroagresijama i frustracijama koje su obilježavale njihov svakodnevni život. U iduća četiri dijela, pisat ću o sukobima unutar obitelji, devijantnom ponašanju adolescenata, sukobima unutar ruralnih zajednica i o političkom nasilju te ću, na temelju povijesti bolesti i forenzičkih vještačenja nastojati ustanoviti na koji je način psihijatrijski diskurs progovarao o tim sukobima, suočen s govorom štićenika. U navedenim primjerima psihijatri će morati napustiti isključivo medicinski pogled na bijes i agresiju i preuzeti ulogu medijatora u konfliktnim situacijama, konstantno nastojeći razlučiti „devijantno” i ,patološko” iskazivanje bijesa $\mathrm{i}$ agresije od uobičajenih oblika nasilja manifestiranih u konfliktnim situacijama

\subsection{Sukobi unutar obitelji}

Usponom građanske klase u osamnaestom i devetnaestom stoljeću, pojavljuje se nova koncepcija obitelji. Unutar emotivnog režima građanstva, javni prostor kao sfera kojom dominiraju muškarci, sve više postaje prostorom racionalnog djelovanja. S druge strane, obitelj se doživljava kao afektivna i emotivna zajednica. Shorter navodi da je shvaćanje obitelji kao prvenstveno emotivne zajednice u suprotnosti s ranijim shvaćanjem obitelji kao zajednice utemeljene na 
odnosima vlasništva i rodoslovlja. ${ }^{74}$ Obitelj kao mjesto emotivne sigurnosti povezuje se $\mathrm{s}$ percepcijom oca i supruga kao „patera familiasa“ čija je moć unutar zidova obiteljskog doma neupitna. Marija Jambrišak je 1921. godine opisala obitelj kao emotivnu zajednicu koja prvenstveno služi za zadovoljavanje emotivnih potreba muškarca:

„U onom času kad je muž prekoračio kućni prag- u drugom je svijetu. U svojoj porodici neka strese sa sebe prašinu vanjsku, neka ostavi pred kućom dnevne brige..." Obiteljski život ono njega savija ,bedem koji odbija navalu vanjskih misli i briga i dnevnih napora, on sjedi u njemu i podaje se cijelom dušom novim radostima drugog porodičnog svijeta." ${ }^{675}$

Jambrešak također implicira da unutar te zajednice većinu emotivnog rada treba obavljati žena izjavivši da je „muž glava, a žena srce kuće ${ }^{\text {‘746. }}$. Jasno je da u okviru građanskog emotivnog režima, obiteljski dom mora služiti kao protuteža muškarčevim zahtjevnim zadaćama u javnom životu. $^{747}$ Od supruge se zahtijevalo da podredi svoj društveni život emotivnim potrebama supruga. Građanski slojevi i plemstvo sve su češće uređivali svoje obiteljske odnose tako da da odgovaraju ideji obitelji kao takvog emotivnog utočišta.

Zanimljivo je da je Edward Shorter, kao jedan od uzroka porasta broja štićenika u zavodima devetnaestog stoljeća, naveo upravo takvu promjenu u poimanju obitelji. Naime, ako se obitelj počela poimati kao sentimentalna $\mathrm{i}$ emotivna zajednica, prisutnost osoba $\mathrm{s}$ duševnim poteškoćama bila je disruptivna za ,mir porodičnog svijeta”. Dok se ranije za takve osobe nastojalo skrbiti u krugu obitelji, one su sad percipirane kao osobe koje narušavaju emotivnu ravnotežu, te ih se zbog tog narušavanja nastojalo smjestiti u zavode, čak i u slučajevima kad za to nije bilo stvarne potrebe. ${ }^{748}$ Tako je interniranje u zavodu postalo jedan od načina za rješavanje potencijalno konfliktnih situacija u krugu obiteljskog doma. U trenutku kad se obitelj odluči na institucionalizaciju jednog od svojih članova, psihijatrijski diskurs postaje jedan od diskursa unutar kojeg se postavljaju emotivni sukobi, a liječnici, kroz komunikaciju sa štićenikom i njegovom obitelji, jedni od posrednika i arbitara sukoba. To se često događa u trenucima kad su se pojedinci u krugu obitelji počeli ponašati toliko nasilno da je njihovo interniranje bilo jedinim

744 Shorter, 1997: 50.

745 Iveljić, 2009: 339-340.

746 Ibid: 340.

747 Ibid.

748 Shorter, 1997: 50. 
načinom da obitelj ostane sigurna. Po povratku u Ozalj iz Zagreba, akvarelistica Slava Raškaj je plašila čitavu svoju obitelj svojim nasilnim ispadima bijesa za vrijeme kojih je uništavala pokućstvo i nekoliko puta na jeziku gluhih saopćila majci da ju želi ubiti. Čini se da je i sam boravak u krugu obitelji poticao agresivno ponašanje Slave Raškaj, budući da je u zavodu njezino ponašanje opisano kao mirno. Već po dolasku u zavod samo je tiho, na njemačkom odgovarala liječnicima da se osjeća dobro. ${ }^{749}$

S druge strane, ideja obitelji kao emotivne zajednice ukorijenjena u građanskim slojevima prijelaza stoljeća, još se uvijek ponegdje prožima s drugom koncepcijom obitelji koja prvenstveno zamišlja obiteljski dom kao kućanstvo. U sudskim zapisnicima koje je analizirala Eliza Earle Ferguson, a koji se tiču pariških obitelji radničke klase s prijelaza stoljeća, najčešća riječ koja se koristi za domaćinsku zajednicu nije „familie” (obitelj) već „ménage” (kućanstvo). ${ }^{750}$ Kućanstvo, uz emotivni i simbolički, podrazumijeva i ekonomski aspekt te zajednice jer obuhvaća i zajednički dom i predmete koji se u istom nalaze. Može se reći da krajem stoljeća, aspekti obitelji kao „kućanstva” supostoje s aspektima obitelji kao središta emotivnog života. To znači da u životu većine obitelji, privatna sfera emocija i javna sfera sudjelovanja na tržištu rada i zarađivanja nisu bile strogo odvojene. I uistinu, i u slučajevima koje je istražila Eliza Ferguson i u brojnim stenjevačkim povijestima bolesti, (a nasuprot relativno oštroj razdjelnici koju favorizira Shorter) u sukobima unutar obitelji često se isprepliću emotivno i ekonomsko, a ponekad ih postaje teško jasno razdvojiti. U obrazloženjima u kojima se traži smještanje štićenika u zavod, ekonomski aspekt postaje daleko važniji od emotivnog, što se vidi po činjenici da se smještanje u zavod često opravdava činjenicom da obitelj nema financijskih sredstava ili vremena da skrbi za disruptivnog člana obitelji. Tako su ostarjelog ratara Imbru K. njegovi ukućani predali liječničkoj skrbi, ne jer je narušavao emotivni sklad obitelji, već jer im je, zbog prirode poljodjelskog rada bilo teško „čuvati”. Sin je Imbru preuzeo nakon 28 dana boravka u zavodu i odveo ga kući, vjerojatno zbog toga što je završetkom žetve prestalo vrijeme intenzivnih radova. ${ }^{751}$ Iako je Imbra bio star, nemoćan i psihički nestabilan, čini se da je njegovo interniranje u zavodu bilo potaknuto

749 KPV, 1906: 5364 Činjenica da u razgovoru s liječnicima (koji možda ne znaju znakovni jezik gluhih) Slava Raškaj uspijeva artikulirano vokalizirati nekoliko riječi dovodi u pitanje uobičajene prikaze te slikarice kao gluhonijeme.

750 Ferguson, 2010: 56.

$751 \mathrm{KPV}, 1911: 8135$. 
specifičnim ekonomskim potrebama kućanstva, a da je vraćen kući jer ga se ipak doživljavalo dijelom emotivne zajednice.

Ispreplitanje ekonomskog i emotivnog, uz posredovanje različitih medicinskih diskursa kako bi se razriješio obiteljski sukob vidimo na kompleksnom slučaju Darinke Dj., supruge liječnika iz Sarajeva koja je bila u zavodu od 1903. do svoje smrti od tuberkuloze 1914. Darinka je dovedena u Stenjevec iz Vakufske bolnice u Sarajevu. U Vakufsku je bolnicu, Darinka dospjela iz zavoda u Grazu, gdje su se pojavili prvi simptomi njezine bolesti. Bolest joj je prvo dijagnosticirana kao „amentia” a zatim kao „dementia secundaria”. Njezino duševno stanje prilikom prijema u bolnicu u Sarajevu bilo je izuzetno teško. Unos u povijesti bolesti iz Vakuf-Spitala u Sarajevu iz 30. listopada 1902. govori da je njezino pamćenje bilo "...sasvim iščeznulo, djelimice falsificirano uslijed tlapnja i smetenosti." ${ }^{, 52}$ Upravo činjenica da se Darinka, čini se nije mogla sjetiti posljednih dana svog boravka izvan bolnice je bila razlog kasnijeg višegodišnjih optuživanja između Darinkine obitelji i njezinog supruga liječnika. Darinkina obitelj je optužila njezinog supruga, Damjana, da je uzrokovao njezinu psihičku bolest zlostavljanjem, dok je Damjan oštrim riječima predstavio Darinkinu obitelj kao hereditarno opterećenu i sklonu seksualnim nastranostima. Damjan Dj. je bio perspektivan student medicine u Grazu, no kako sam priznaje u pismu Ivanu Žirovčiću, imao je financijskih poteškoća. ${ }^{753}$ U studijima ga je na početku uzdržavao brat. Zaruke s Darinkom iz imućne obitelji Ć. donijele su mu znatnu financijsku korist- dobio je 2500 forinti po sklapanju braka, a obećano mu je još toliko nakon što završi studij medicine. Damjan je tvrdio da je prvih 2500 forinti uložio u zemaljsku banku u Sarajevu na Darinkino ime. ${ }^{754}$ Bračni par se, nakon vjenčanja 1900. godine, uputio u Graz, gdje je Damjan završavao studije i gdje se Darinka razboljela. Povijest bolesti iz Vakuf-Spitala ističe da je Darinka, usprkos hereditetu s očeve i majčine strane (,otac podat piću, majka je nakon poroda bolovala od „akutne duševne bolesti”) bila zdrava do udaje za Damjana Dj.. ${ }^{755}$ Prvi znakovi koji su upućivale da nešto nije u redu bila su Darinkina pisma koja je slala braći iz Graza. U njima je, navodno tvrdila da je ,je vrlo nesretna i ucviljena, da je muž zapušćuje, da joj se grozi kako će je pustiti, da se nje u javnosti stidi, jer da nije lijepa, da novac troši, da ona plače dan i noć itd." ${ }^{756}$. Sarajevski liječnici

$752 \mathrm{KPV}, 1914: 5731$.

753 Ibid.

754 Ibid.

755 Ibid.

756 Ibid. 
istakli su da se Darinka jako bojala supruga, te je molila braću „da joj mužu ne kažu, kako se je tužila na njega, jer bi je on ubio" ${ }^{757}$. Na kraju je svom bratu, upravitelju manastira Obrena Vasilju Ć. poslala telegram u kojem govori kako je doznala da joj suprug ima izvanbračno dijete u Grazu i „kako ju kani pustiti”. ${ }^{758}$ Istovremeno s Darinkinim telegramima, telegrame Darinkinoj obitelji šalje i Damjan. U njima Damjan opisuje stanje svoje žene koristeći medicinske termine: tvrdi da Darinka „oboljela na histeriji” i da ima „Heimweh” (nedostaje joj dom). ${ }^{759}$ Brat je došao po nju i odveo ju u Cilj, gdje joj se „uzrujanost njezina tako pogoršala, da su telegrafirali po muža u Graz, da je odvede natrag." Provela je nekoliko tjedana u Grazu, nakon čega je premještena u Sarajevo. Damjanovo opsivanje Darinkinog stanja kao „Heimwecha” osobito je indikativno ako se uzme u obzir da su tih godina psihijatri heidelberške škole poput Karla Wilmannsa, povezivali osjećaj nostalgije za domom kod žena i djevojaka s degeneracijom i sklonošću kriminalu. ${ }^{760}$

Tijekom boravka u Sarajevu, liječnici ističu da su dominantne emocije kod Darinke ,žalost i strah" a zapisan Darinkin govor odaje dezorijentiranost i zbunjenost, no znakovito je da Darinka često spominje novac i optužuje nekog neodređenog da joj je „pomiješao um”:

"Zašto vi ne jedete?

Nema tko platiti, ovo nije plaćeno. Pomeli mi moj mozak, pa ništa neznam, što radim.

Tko Vam je pomeo mozak?

Vi svi...

26.9. Dajte me molim Vas pustite da idem služiti, nemam samo nego $2 \mathrm{Kr}$.

27.9. Govor mi se prevrće u mozgu kao da sam poludila...

30.10. Što se ovo od mene radi- gdje su mi novci ko će ovo za mene platiti" ${ }^{\text {"761 }}$

Nakon gotovo godine dana boravka u sarajevskoj bolnici, Darinka je 25. svibnja 1903. dovedena u Stenjevec. U stenjevačkom zavodu njezino je stanje izuzetno teško i čini se da je izgubila svaki dodir sa stvarnošću. Prema povijesti bolesti „vlada se nemirno i bezobrazno, pjeva vesele poskočice, pleše i smije se bez razloga." ${ }^{972}$ Tijekom godina stanje joj je nepromijenjeno, jedino se može pratiti njezino fizičko propadanje. Zapis s kraja 1907. tako govori:,„Izgubila skoro sve zube

757 Ibid.

758 Ibid.

759 Ibid.

760 Spector, 2016: 53.

$761 \mathrm{KPV}, 1914: 5731$.

762 Ibid. 
često veoma uzrujana, silovita, erotična, tako da je morala često biti osamljena. Po noći često veoma nemirna. Nečista, neuredna. Sasvim glupa i tupa."763

U tom stanju, stenjevački liječnici nisu mogli dati jasno mišljenje o uzrocima njezine bolesti, niti o tome igraju li neobične obiteljske prilike i nesretan brak ikakvu ulogu u njima. No, Damjanova uloga u Darinkinoj bolesti nije prestala zanimati njezinu obitelj, koja se obratila vlastima. Kancelarija Dobro-bosanska poslala je 1907. godine zahtjev za Žirovčićevim stručnim mišljenjem o bolesti Darinke Dj. Zahtjev je sadržavao četiri pitanja:

„1. Može li se dokazati da je Darinka Dj. rodj. Ć., sa amencijom nasljedno obterećena?

2.Što je mogao biti razlog da je bolest u nje odmah prvijeh nedjelja poslie stupanja u brak izbila?

3. Da li se ista žali na muža?

4.Može li se, i kada, bolest njene na bolje, i u kojoj mjeri okrenuti, da bi za bračni život sposobna bila?"764

Žirovčićev odgovor na upit Dobro-bosanske kancelarije je bio neuobičajen za hrvatsku psihijatriju prijelaza stoljeća. Kod prvog pitanja Žirovčić nije posegnuo za uvriježenim pretpostavkama o hereditarnoj etiologiji duševnih bolesti već je bio neodređen. U svom šturom odgovoru, Žirovčić daje do znanja da ne može utvrditi hereditet kao uzrok Darinkine bolesti:

„Mnogostručno iskustvo uči da duševne bolesti ne prelaze na potomstvo baš u istoj formi bolesti kakva je bila u roditelja nego da se u potomstvu pojavljuju najrazličitiji oblici duševnog ili živčanog oboljenja, manjkavosti i tromosti duševnog i tjelesnog razvitka, a da i ne moraju hereditarno obterećeni potpmci duševno oboljeti Tako nalazimo u obitelji Ć. u oca alkoholizam, u matere akutnu porodjajnu psihozu; a od njihovog potomstva samo je kći duševno obolila u dvadesetoj godini života, dočim od braće jedan brat ima poteškoću govora, a drugi je obtužen radi nećudoredna čina, što kod obojice još ne znači duševnu bolest. Ne može se dakle dokazati, da je Darinka sa amencijom nasljedno obterećena, nego se može uztvrditi, da je ona od oca alkoholičara i prolazno umobolne matere nasliedila sklonost na duševno oboljenje. Oboljenje je moglo i sasvim izostati ili pod uplivom osobitih životni prilik buknuti.",765

Jedna od takvih životnih prilika za Žirovčića je i ulazak u brak jer

763 Ibid.

764 Ibid.

765 Ibid. 
,"Sam brak i bračne dužnosti ne mogu biti dostatnim motivom za navalu duševne bolesti, ali nesretan brak, otrovan bezobzirnim vriedjanjem i ponižavanjem mlade supruge po njezinom suprugu, kojega je ona uza sve to ljubila, te je moralo njezinu duševnost duboko potresti i to je bio povod da je duševna bolest kod nje tako silno izbila." ${ }^{766}$

Iako će kasnije Žirovčić reći da se Darinka tijekom boravka u zavodu „nije žalila na muža” te da ,je izgubila moć bistra sjećanja i sve nježnije sveze što ju čuvstveno spajahu sa svietom u njezinoj su duševnosti raskinute. Odlomci rastrganih uspomena, koji bi se u njezinom neobuzdanom snatrenju i pojavljivali nebi imali nikakve vriednosti, da se na njih gleda kao na njezino mišljenje iz doba mladobračnog života." ${ }^{, 767}$ istaknut će i da Darinka nije i vjerojatno neće biti sposobna za bračni život radi „opasnosti za svoje potomstvo”, ${ }^{768}$ ali će kao uzrok njezine bolesti navesti ,affectus (nesretan brak”769.

U svom mišljenju, Žirovčić govori o Darinki znatno manje dehumanizirajućim rječnikom nego što ga koristi kad govori o nekim drugim stenjevačkim štićenicima. Kad govori o „raskidanju nježnijih veza" Žirovčić na trenutak čak djeluje sentimentalno i u njegovom se govoru može naslutiti suosjećanje. Usprkos svom kliničkom somatizmu, čini se da je Žirovčić kroz iskustvo interakcije s Darinkom, u njoj prepoznao žrtvu nasilja u braku, te na pomalo nekarakterističan način, odredio traumu zlostavljanja kao uzrok njezine bolesti. Glas o takvom Žirovčićevom mišljenju se proširio u krugu tada još uvijek malene medicinske zajednice, i preko prijatelja koji nije imenovan, došao do Damjana Dj. koji je reagirao ljutitim pismom Žirovčiću. Pismo je zanimljivo jer Damjan, da bi se obranio od optužbi za zlostavljanje koje „Darinkina porodica trubi po cijeloj Bosni i Hercegovini" ${ }^{\prime 770}$ poseže za medicinskim diskursom. U uvodnom dijelu objašnjava optužbe protiv sebe da je Darinku u Grazu ,zaključao, nije joj dao ništa jesti, a on otišao i lumpovao po cio dan i noć. ${ }^{711} \mathrm{U}$ nastavku, Damjan se upušta u akademsku raspravu i objašnjava Žirovčiću etiološke postavke koje iznosi Emil Kräpelin. Tako Damjan citira da po Kräpelinu „, kod 60-70\% pa čak i do 90\% duševnih bolesnika dispozicija ima glavnu ulogu"772 te

766 Ibid.

767 Ibid.

768 Ibid.

769 Ibid.

770 Ibid.

771 Ibid.

772 Ibid. 
da je „trauma vrlo rijedak etiološki momenat u duševnim bolestima” i da „strah, gladovanje, brige, itd. mogu užasno biti jake, pa ipak da ne proizvedu duševnu bolest u zdravom mozgu"773.

Zanimljivo je da Damjan navodi medicinsku poziciju kojoj se Žirovčić inače priklanjao u nekim slučajevima spomenutim u prethodnom poglavlju. Također, u čitavom pismu Damjan nigdje eksplicitno ne negira optužbe o izgladnjivanju, već se brani činjenicom da one ne bi izazvale duševnu bolesti da Darinka nije imala hereditarne dispozicije. Nakon takve obrane, Damjan drugi dio svog pisma u medicinskoj tradiciji naslovljuje" anamneza". U tom dijelu Damjan navodi gomilu anegdotskih dokaza o alkoholizmu, kriminalu i seksualnim nastranostima Darinkine obitelji. Nijedan član obitelji nije pošteđen Damjan „dijagnoza” koje ih predstavljaju kao duševno poremećene ili „degenerirane”. Darinkin djed i otac su bili „potatori”, a poziva se i na predrasude o Bosancima kao alkoholičarima kad kaže da je poznato „Kakvu je ulogu igrala a i danas igra po Bosni kod srednjeg i nižeg staleža: šljivovica a kod bogatijeg: mastika." ${ }^{774}$ Ujaci i tetke su također ubojice, alkoholičari ili priglupi, majka joj je pijanica, a brat joj je „,pederast” koji „,ne poznaje nikakvog roda osim matere i sestre. On je svaki svoj rod kojitovao - sve što mu je došlo pod ruku" ${ }^{\text {"75 }}$. Također navodi da sva Darinkina braća mucaju i govori kako je Darinka uvijek bila „dosta ograničena" ${ }^{976}$. Na kraju svog pisma o odnosima svoje supruge i njene braće govori gotovo pornografski, a priznaje da je Darinku oženio zbog svoje financijske koristi i činjenice da tada

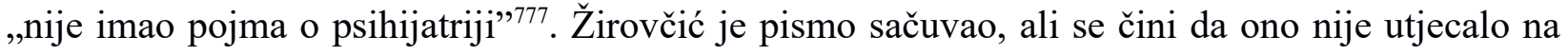
njegovo ranije izrečeno mišljenje o Darinkinoj bolesti.

Slučaj Darinke Dj. pokazuje način na koji su psihijatri ponekad bili prisiljeni posredovati u slučajevima zlostavljanja u braku, te kako je Žirovčić, potaknut konkretnim kliničkim iskustvom i empatijom prema žrtvi, bio u stanju izaći iz okvira uvriježenih prevladavajućih psihijatrijskih teorija. Žirovčićevo svrstavanje na stranu Darinke kao žrtve, suprotno tada aktualnim spoznajama i optužba koju je u svom mišljenju iznio protiv kolege liječnika, govore kako su interakcije između štićenika i psihijatara ponekad mogle probuditi i suosjećanje i osnažiti psihijatre za ostvarivanje uvida u stanje štićenika koji su bili ispred svog vremena. Darinkin slučaj pokazuje

773 Ibid.

774 Ibid.

775 Ibid.

776 Ibid.

777 Ibid. 
dva suprotstavljena pogleda na duševnu bolest. Ono što je osobito zanimljivo je da Žirovčić zastupa gledište koje u psihijatriji onog vremena nije bilo često: da je trauma nasilja u obitelji uzrokovala teško Darinkino mentalno stanje. Pritom se Žirovčić ne poziva na medicinske autoritete već isključivo na vlastito promatranje pacijentice. Damjan $\mathrm{Dj}$. koji doduše nije psihijatar, zastupa stav koji je bio daleko učestaliji u psihijatriji devetnaestog stoljeća, negira mogućnost da nasilje u braku uopće može biti uzrokom duševnog oboljenja. U svojoj redukciji uzroka Darinkinog oboljenja na hereditet, Damjan se oslanja na medicinske autoritete onog vremena. Činjenica da upravo Žirovčić odstupa od somaticističkog redukcionizma kako bi naglasio mogućnost da se Darinka razboljela zbog toga jer je bila zlostavljanja u braku, pokazuje da su stenjevački psihijatri često u praksi prepoznavali traumatične posljedice sukoba u obitelji i nasilja u braku.

U nekim sukobima s kojima su se liječnici u Stenjevcu susretali, ekonomsko, afektivno i seksualno se isprepliću na nevjerojatne načine tvoreći rašomonsku sliku obiteljskih i bračnih odnosa u vremenu modernizacije. Takav je slučaj Jakoba K., trgovca židovskog porijekla iz Virovitice koji je prebačen u Stenjevec 1895. nakon što se liječio prvo kod Richarda von KrafftEbinga, zatim u privatnoj klinici doktora Wilhelma Svetlina u Beču i u budimpeštanskom zavodu za umobolne. Zavodski liječnici trebali su procjeniti je li Jakobova supruga imala aferu s njegovim šogorom i poslodavcem Josipom Takačem ili su optužbe za nevjeru bile Jakobova deluzija. Jakob je svoj sukob za suprugom i Josipom Takačem detaljno opisao u razgovoru sa Žirovčićem i u kasnijem pismu upućenom Žirovčiću, koje je poslao tridesetog travnja, nakon nešto više od mjesec dana boravka u Stenjevcu. Prema Jakobu, nevolje u njegovom braku počele su kad ga je Takač nagovorio da dođe u Banja Luku i uloži novac u njegovu kožarsku tvornicu. Prema Jakovljevom mišljenju tada su Takač i njegov partner počeli manipulirati njegovom ženom i ,izprepletali oko njega mreže, da ga na taj način dovabe u Banja Luku, da mogu tjerati svoje bezsramne orgije" ${ }^{978}$. Tijekom razgovora, Jakob optužuje ženu za flert i seksualnu nevjeru i izražava izrazito neprijateljstvo prema njoj. Vidio je nju i Takača kako se „srdačno pozdravljaju, diraju nogama ispod stola, sluškinje su ih ogovarale, a na posljetku mu je supruga navodno sama priznala aferu.”Osim toga, Jakov je vidio dokaz nevjere u supruginom uljepšavanju. ${ }^{779}$ „Bijesan i

$778 \mathrm{KPV}, 1895: 2640$.

779 Ibid. 
ljubomoran, Jakob je počeo „svoju ženu i T.-a psovati, a napokon je i samu ženu otjerao njezinoj majci." ${ }^{.780}$

Iako je Jakov bio neprijateljski raspoložen prema svojoj supruzi i Takaču, čini se da je Takač uspio postići znatan utjecaj nad Jakovom. Takač je tako smirio Jakova i uvjerio ga da potraže hipnotizera kako bi hipnotizirali Jakovljevu suprugu, kako bi ona pod hipnozom izjavila da nije prevarila svog supruga. U tu svrhu, Jakov i Josip Takač su 1894. godine posjetili Stenjevec, no prema Jakovljevoj izjavi liječnik je odbio hipnotizirati njegovu suprugu. Nakon toga, Takač je ustvrdio da je Jakov „uzrujanih živaca” i odveo ga Krafft-Ebingu u Beč. Krafft-Ebing je Jakovu dijagnosticirao „Einfensuchtswahn” (ljubomorno ludilo). Krafft-Ebing ga je uputio na liječenje u Svetlinov zavod. Jakov je tvrdio da je prije prijema u zavod Takaču predao na čuvanje svotu od 6000 forinti koju mu ovaj do danas nije vratio. ${ }^{781}$ Čini se da je Jakov istovremeno sumnjičio ženu za aferu i s druge strane polagao veliko povjerenje u njezinog navodnog ljubavnika Takača. Dopustio mu je da ga ovaj vodi po zavodima i da mu ostavi popriličnu svotu novca bez priznanice jer „neće me valjda prevariti”. ${ }^{782}$ Jakovljev iskaz odaje čudnu dinamiku međusobnih odnosa unutar građanske obitelji te se na trenutak ne može jasno razlučiti pati li Jakov od umišljaja ili je Takač zapravo umješni manipulator koji mu je razorio obitelj i financijski ga upropastio. Žirovčić je Jakovu dijagnosticirao „neurastheniju” te ga nakon nešto više od tri mjeseca boravka u zavodu otpustio kao poboljšanog. U zavodu Jakov govori da se radi o zavjeri njegove supruge, njezinog brata psihijatra kojeg ne spominje imenom i Takača „s ciljem da ga smjeste u ludnicu i da mu supruga bude u boljem položaja pri brakorazvodnoj parnici." Žirovčić ne komentira takve optužbe, no njegova nevoljkost da na duže vrijeme zadrži Jakova u zavodu odaje da možda nije vjerovao da je Jakov ozbiljno bolestan.

Zanimljivost Jakovljevog slučaja je u mjestu koje psihijatrijski diskurs i diskurs o seksualnosti zauzima u ovom obiteljskom sukobu. Takač, optužen za zavođenje Jakovljeve žene predlaže hipnozu kao pouzdan način za utvrđivanje istine o bračnoj nevjeri, a Jakov prihvaća tu metodu bez previše sumnje. Kod Krafft-Ebinga, Jakovljeva ljubomora je patologizirana u osobitu vrstu poremećaja, kojem je emocija u samom imenu i koji dotad nije bio jasno opisan u psihijatrijskoj 
praksi. I samo ime Krafft-Ebingove dijagnoze, nije tipično za austrijsku i njemačku psihijatrijsku tradiciju. U Stenjevcu, Jakov se služi psihijatrijskim diskursom kako bi dokazao da nije poremećen. Jakov svoj razgovor s liječnicima počinje negirajući obiteljsku anamnezu koju im je prenio brat njegove žene psihijatar koji je opisao njegovog oca kao alkoholičara, i izjavio da mu se bratić ubio a sestra bila gluhonijema:

„Detaljno opisuje svog oca koji "nije bio potator” tvrdi da brat njegove žene laže o tome. Govori o bratiću koji se ubio u Beču, te opravdava njegov čin ("čini mi se da je imao sifilis i bojao se od revolvera pa smo se čudili da se ubio") i sestri koja je umrla kao gluhonijema",784 Jakov je, dakle upućen o narativ o hereditetu kao uzroku duševne bolesti i trudi se opovrgnuti ga. I Jakov i Takač se zapravo upuštaju u vlastito, laičko tumačenje Jakovljeva stanja putem aproprijacije diskursa psihijatrijske struke, a nekonzistentne i neuobičajene dijagnoze i oklijevanje psihijatara da jasno zauzmu stav o sukobu, upućuje na činjenicu da ni psihijatri nisu mogli rasplesti mrežu optužbi koju su Jakov, njegova supruga i njezin brat ispleli jedni oko drugih. Osim psihijatrijskog diskursa, Jakov otvoreno progovara o vlastitom poimanju seksualnosti i njegove riječi pružaju rijedak uvid u stavove građanstva o seksualnosti. Jakov spominje kako je otvoreno govorio sa suprugom o seksu i kako mu je ona spomenula da se upustila u čin analnog seksa s Takačem: „Žena mu je, jednom, posle svršenog coitusa... ...počela pričati kako je Josip Takač š njom na zahodu po dva puta i to per buzora puteno obćio i kako njoj to ništa škodilo nije..." 785

S jedne strane, Jakovljevo ponašanje granični s patološkom ljubomorom, no s druge ne zna je li njegovo ponašanje posljedica kombinacije neobičnog odnosa sa šogorom Takačem i suprugom koja se vjerojatno nije ponašala u skladu s Jakovljevim patrijarhalnim nazorima. Znakovito je da Žirovčić, nigdje nije opisao Jakova kao nekog tko umišlja supruginu aferu. I nakon boravka u Stenjevcu, Jakov je ustrajao u tvrdnji da ga je supruga prevarila, a istog je mišljenja bila i Jakovljeva strana obitelji. Slučaj Jakova K. govori da su se građani na laički način služili psihijatrijskim diskursom pri objašnjavanju sukoba unutar obitelji. Sve strane u iznijetom obiteljskom sukobu ga objašnjavaju medicinskim pojmovima i pozivaju se na psihijatrijski skup znanja o psihi, seksualnosti i emocijama. Psihijatrima je dana uloga posrednika koji trebaju objasniti i razrješiti sukob i utvrditi istinu o mogućoj nevjeri Jakovljeve supruge. Od psihijatrije 
se traži znanstvena i objektivna procjena i validacija emocija oko kojih nastaje sukob: ona treba razdvojiti opravdanu ljubomoru od patološke, stvarnu seksualnu transgresiju od umišljene, zamišljenu nepravdu od stvarnog iznevjeravanja povjerenja. Može se reći da pojedine građanske obitelji vide psihijatriju kao validaciju emotivnog režima.

Sukobi unutar obitelji u nekim su stenjevačkim zapisima završavali tragično. Manda M., nadničarka iz Aljmaša, boravila je u Stenjevcu u pet navrata između 1885. i 1914. godine, kad je umrla od „bronchopneumonie" Mande, stenjevačkih ravnatelja i Mandinih ukućana koji su od nje živjeli u strahu. Spirala nasilja u ovom Aljmaškom kućanstvu doživjela je vrhunac 1888. godine kad je probola svog supruga Marijana nožem. ${ }^{787}$ Mandin život je od djetinjstva bio težak: liječničko izvješće s kraja 1888. godine, upućuje da joj je otac bio „potator” a da je ona rođena kao nedonošče u 7 mjesecu trudnoće, te da je patila od „hydrocephalus”. „Hydrocephalus” ili „,vodena glava” je medicinsko stanje koje je moglo upućivati na neki oblik neurološkog oštećenja. Manda je prvi put u Stenjevcu boravila od 29.9. 1885. do 23. 5. 1886. uz jedan kratkotrajan pokušaj bijega nakon kojeg je vraćena u Stenjevec. U zavod ju je doveo njezin suprug Marijan s kojim je imala i dijete. On je općinskom liječniku kako već deset godina živi u strahu od nje:

„Po pričanju Marijana Mariančevića jeste isti opazio još prije 10 godina da njegova žena Manda nije duševno posve zdrava, a to je zaključio stoga što je u to doba začela mnogo govoriti, u govoru skakati od jedne stvari čak na desetu, pritom je postala svadljivom, nije dala niti mužu niti komšiluku mira, svakoga uzimala u pretres, osobno ga grdila najgadnijim riečima, te s te svoje mane postala je upravo strašilo cieloga sokaka, a zatim bi posao svoj zanemarila, a povremeno i nasilnom postajala tako da joj je muž morao mlogu noć van kuće probaviti od straha." ${ }^{788}$

Dok liječničko izvješće, pozivajući se na suprugov iskaz od Mande pravi svojevrsni objekt straha od nasilja, „strašilo cijelog sokaka” Manda u stenjevačkom zavodu daje vlastito objašnjenje svog ponašanja: „Ne taji ni sama da joj u glavi nekoliko dužicah manjka, nu dodaje da se više čini ludom nego jest, jer se u društvu takvom ne može pametno vladati."

$786 \mathrm{KPV}, 1914: 6573$.

787 Ibid.

788 Ibid.

789 Ibid. 
Manda dakle govori da se „više čini ludom nego jest” jer joj njezina okolina onemogućuje pametno vladanje. U svom prvom iskazu, Manda ne navodi čime ju njezina okolina potiče da se ponaša na način svojstven duševno bolesnoj osobi. U samom zavodu izrazito je nemirna i dolazi u sukob sa zavodskim osobljem:

„U bolnici bijaše obično nasilna i nesnosljiva. Neima toga što bi joj godilo, ili joj u volju učinilo. Psuje bolničarke groznimi psovkami i pogrdami, baca jelo na tlo, svojom pogani maže sobu, viče pri tom što ju grlo nosi s čega promukne, ili opet nariče kao nad mrtvacem, drugi put pak časak boga moli, a svrši psovkama na boga, treći put opet skače i igra."

Povijest bolesti uz opis ponašanja koje je više-manje opće mjesto u kartonima nemirnih štićenika, naglašeno spominje Mandino nezadovoljstvo, time zapravo implicirajući da je njezino ekstremno ponašanje oblik bunta protiv nečega, a o buntovnosti govori i činjenica da je jednom pobjegla iz zavoda. Njezina prvotna dijagnoza glasila je „Periodična mahnitost uz benavost” ${ }^{790}$ iz čega se vidi da su ju liječnici smatrali duševno zaostalom osobom sklonom napadajima bijesa.

Manda je u Stenjevcu drugi put završila nakon što je 14. prosinca 1888. ubila muža nožem tijekom svađe. Liječničko izvješće govori da je Marijana „...u svadji nožem u lievu stranu leđa duboko probola, tako da mu je slezenu ozliedila uslied čega je silni izliev krvi u trbušnu šupljinu nastupio tako da je za kratko vrieme umro"791. Dijagnoza je ovog puta glasila „periodična mahnitost" a u stenjevačkoj se povijesti bolesti po prvi put spominje „slabljenje etičkih i estetičkih čuvstava" što je u devetnaestom stoljeću bio jedan od ključnih elemenata psihijatrijskog narativa o degeneraciji:

„Opaža se neko pomanjkanje ili umanjenje estetičnoga i etičnoga čuvstva- pripovjeda ko sasvim bezazlen događaj s mužem, te lahke duše- tako rekuć smijuć se- opetuje kako je muža ubola, te joj ga nije žao. U tom pokazuje i slaboumnost jer slabije kombinira i sudi, djetinjasta je i jogunasta." ${ }^{792}$

Osim liječnikovog mišljenja, povijest bolesti iz 1889. donosi i Mandin glas spominjući kako ona često ponavlja frazu „Manda luda, ne imade suda"793 i donoseći njezino opravdanje za umorstvo supruga:,,Veli da muža ne bi bila niti ubila da ju nije dražio riečim "luda Manda" pače i tukao kad

790 Ibid.

791 Ibid.

792 Ibid.

793 Ibid. 
bi se napio. Ići će svojoj kući, gdje je čeka njezino diete koje sada pazi neki Kovač, koji stanuje u kući i uživa zemljište njezino." 794

Štićenici koji su počinili zločin u neuračunljivom stanju su najčešće mogli računati na doživotni boravak u Stenjevcu: pritisak javnosti da se „opasni luđaci” barem na ovaj način liše slobode, bio je prevelik da bi psihijatri riskirali ugled vlastite profesije puštajući potencijalno opasne štićenike na slobodu. Zato je jako neobično da je Manda, nakon godine dana boravka u Stenjevcu 1.svibnja 1890. otpuštena kao poboljšana. Povijest bolesti često govori o Mandi kao o „djetinjastoj i slaboumnoj" te im se usprkos svojem zločinu, Manda ne čini opasnom.

Tri godine kasnije, 9. svibnja 1893. Mandu će ponovno prebaciti u Stenjevec iz beogradske bolnice. U beogradskoj je bolnici završila nakon što je, u posjetu rođacima oboljela od neke očne bolesti. Tamo je ubrzo postala nasilna i fizički napadala bolesnice i bolničarke. Izvješće iz beogradske bolnice navodi kao njezinu dijagnozu „Manie reigne chez une dégénérée” 795 (hereditarnu maniju zbog degeneracije) uzrokovanu alkoholnim pićima. Povijest bolesti ne donosi detalje incidenta koji je doveo do Mandine hospitalizacije, no čini se da se i ovaj put radilo o nekom sukobu u krugu njezine obitelji, jer je ta okolnost istaknuta i u stenjevačkoj povijesti bolesti i u liječničkom izvješću iz Beograda. Ni u jednom od dva medicinska kartona nema spomena bilo kakve očne bolesti. Manda je pobjegla iz Stenjevca 23. prosinca 1893. godine. Ubrzo je uhvaćena i 15. siječnja 1894. vraćena u Stenjevec. Njezino ponašanje ponovno varira između djetinjastog i izrazito nasilnog. Često traži burmut i cigare od liječnika i bolničarki, ali zabilježen je i incident prilikom kojeg je ,držalo od drvene žlice turila jednoj bolesnici u vaginu i ozledila ju, tako da je ova krvarila" ${ }^{\text {"996 }}$. Doduše, iako zapis iz povijesti bolesti tumači taj čin kao nasilan, nije isključeno da se možda radilo o seksualnom činu koji je slučajno završio ozljedom. Ponovno je pobjegla trećeg kolovoza 1895. godine. Ponovno je dovedena u Stenjevec 23. veljače 1906. godine. Nakon što je provela gotovo deset godina u bijegu, Manda se vratila kako bi od pastorke (kćeri pokojnog supruga iz ranijeg braka) tražila pravo na kuću. Uz Mandinu povijest bolesti priloženo je i pastorkino pismo koje upozorava na Mandinu umješnost u bježanju iz zavoda izražava realan strah pred njom:

794 Ibid.

795 Ibid.

796 Ibid. 
"Dana 23 ovoga otpravljena jest odavde luđakinja Manda Marijančević na liečenje k slavnom naslovu. Ista bijaše prije 10 godina sa istom bolesti na liečenju u pomenutom zavodu iz koga je umakla posakrivce. Toga radi dolazim oniže potpisata slavnu upravu zamoliti da na itu paziti dade da ne umakne, a u slučaju da bi ista iz zavoda umakla molim da mene slavna uprava odmah o tome obavijesti: radi tog da mogu oko moje kuće postaviti dati stražu i pažnju jer ona u svome ludilu bi mogla kuću da zapali ili inu nedaću da napravi." ${ }^{\$ 97}$

S druge strane, čini se da je Mandino blago djetinjasto ponašanje također nestalo. Ona se ponaša nasilno, te otvoreno prijeti pastorki ubojstvom. Ipak, liječnik koji je napisao uputnicu za prijem u Stenjevec nastoji prikazati sukob Mande i njezine pastorke donekle objektivno:

„Bolesnica je momentarno mirna, vrlo živahno gestikulira i razgovara, smije se, mnogo pripovjeda, psuje svoju pastorku i njenog priležnika koji da ju žele baciti iz kuće van (nešto je uistinu na stvari, jer se ona sa pastorkom ne slaže, svojata kuću za se, a pastorka tvrdi da joj pripada samo 4. dio). Muž je bio padavičar i pijanac, često ju tukao po glavi. Kad je htio prodati zemlju, došlo je do raspre i tom prilikom do ubojstva. Čin je ispočetka tajila.”Od tri nedjelje je sasma nemirna, grozi se da će zaklati pastorku, zapaliti kuću etc. Konflikt je u kući navodno nastao jer je zadnje vrieme pastorka uzela k sebi svog ljubavnika. Navodno rado pije, slabo spava, čista je, jede dobro."${ }^{, 798}$

Mandina dijagnoza će sad u skladu s novom, "meynertovskom" klasifikacijom, koju je uveo Ivo Žirovčić, glasiti „Mania hysterica”, a povijest bolesti više neće sadržavati bilo kakve reference na Mandinu djetinjastu i duševno zaostalu prirodu, umjesto toga ju prikazujući kao potencijalno opasnu ženu sklonu nasilnim ispadima i alkoholu. Manda će u Stenjevcu dočekati smrt od „bronchopneumonie” 13.4. 1914.

Slučaj Mande M. je ilustrativan jer pokazuje na koje su načine psihijatrijske institucije posredovale prilikom sukoba unutar obitelji. S jedne strane, prilikom ranog Mandinog boravka u Stenjevcu, psihijatri i bolničari iskazuju ambivalentne stavove između percipiranja Mande kao nasilne duševno oboljele osobe i duševno zaostale žrtve suprugovog zlostavljanja. Nakon opetovanog Mandinog nasilničkog ponašanja i brojnih bjegova, njihova se percepcija Mande mijenja. Nema više govora o ,periodičkim” napadajima ludila- Mandi je dijagnosticirana histerična manija, bolest svrstana u konstitutivne i degenerativne neuroze. Ta je dijagnoza nosila i 
daleko značajnije moralističke implikacije od jednostavne urođene slaboumnosti. Ostaje nejasno je li Manda na početku glumila bezopasnu osobu kako bi izbjegla kaznu za umorstvo i lakše pobjegla ili su liječnici počeli čitati njezino djetinjasto ponašanje kao oblik „histeričnog” ponašanja, a ne kao simptom urođenih mentalnih poteškoća.

Sukobi u obitelji stavljali su stenjevačke psihijatre u prilično nezavidan položaj. Priče o muževima i ženama koji predstavljaju svoje supružnike kao psihički bolesne kako bi došli do financijske koristi ili olakšali ljubavnu aferu kružile su u tisku i popularnim romanima poput „Nevine u ludnici” tijekom čitavog devetnaestog stoljeća Uz to, dugotrajne posljedice emocionalnog zlostavljanja i ,gaslighting” nisu bili prepoznati unutar devetnaestoljetne psihijatrije. Psihijatri su morali stjecati uvide u privatni život štićenika, uzimati u obzir kompleksnost njihovih obiteljskih odnosa i često se hvatati u koštac s oblicima nasilja koji nisu bili objašnjivi unutar tadašnjih somaticističkih paradigmi. U nekima od slučajeva, poput onog Darinke Djokić, psihijatri ipak priznaju posljedice tih oblika nasilja na duševno zdravlje. U drugim slučajevima, poput onog Jakova K., često pridaju veliku pažnju glasu štićenika kako bi bili sigurni da oni sami ne postaju sredstvo manipulacije u obiteljskom sukobu. Napokon, u nekim slučajevima poput Mandinog, psihijatri su svjedočili psihičkom i fizičkom nasilju unutar obitelji koje je trajalo desetljećima i znanje o kojem je često informiralo njihove dijagnoze. Može se reći da je susret psihijatrije s obiteljskim odnosima uvelike redefinirao i psihijatriju i poimanje obitelji, te doveo do često nejasnih ispreplitanja intimne sfere obiteljskog $\mathrm{i}$ javne sfere zdravstvenog.

\subsection{Dječaci s revolverima: nasilničko ponašanje adolescenata}

Uz promjenu poimanja obitelji, psihijatri i liječnici na prijelazu stoljeća počinju u povećanoj mjeri obraćati pozornost na djecu i adolescente zasebnu dobnu skupinu koja ima vlastite potrebe, ali i čije je ponašanje također potrebno regulirati i o njemu skrbiti. Adolescencija je u Europi i Sjedinjenim Državama prepoznata kao zasebno životno razdoblje tek u drugoj polovini devetnaestog stoljeća, a u Austro-Ugarskoj Monarhiji, Allgemeines Buergerlich Gestzbuch nije tretirao osobe starije od četrnaest godina i mlađe od 24 godine kao punoljetne ${ }^{799}$. Prije prepoznavanja adolescencije, kojem je ponajviše doprinio američki psiholog Stuart Hall, pojam je

799 Iveljić, 2007: 318. 
često bio obuhvaćen elastičnim definicijama djetinjstva koje su isto nekad protezale i do tridesete godine života. ${ }^{800}$

Mnogi povjesničari adolescencije usko vezuju adolescenciju s procesima urbanizacije i modernizacije. John i Virginia Demos, tako postuliraju da su ruralne obitelji bile karakterizirane unutarnjom kohezijom između dobnih skupina: i djeca i odrasli dijelili su sličnu vrst poslova, imali slične oblike razonode, kretali se unutar istog kruga ljudi i imali slična očekivanja u pogledu budućnosti. ${ }^{801} \mathrm{U}$ modernim gradovima, djeca nisu imala ekonomsku ulogu unutar obitelji kakvu su imala na selu. Ako su radila, kao u slučaju dječjeg tvorničkog rada, njihov posao bio je drugačiji od onog njihovih roditelja, Također, na poslu, ulici i u školama, kretali su se u društvu svojih vršnjaka. Ti faktori doveli su do određenog „diskontinuiteta među generacijama” koji je učinio adolescenciju kao razdoblje fizičkog i psihičkog razvoja uočljivom. ${ }^{802}$ Povjesničar adolescencije Jon Savage, također dovodi prepoznavanje adolescencije koje se događa $u$ devetnaestom stoljeća u vezu s modernizacijskim procesima. Savage naglašava ulogu političkih i ekonomskih promjena s kraja osamnaestog stoljeća na poimanje mladosti u Zapadnom svijetu. Prema Savageu adolescencija je konstruirana iz niza društvenih procesa koji su nepovratno promijenili svakodnevicu mladih i njihovo mjesto u društvu. Industrijska revolucija je potaknula preseljene stanovništva sa sela u gradove, stvorivši urbano društvo temeljeno na materijalizmu, konzumerizmu i masovnoj proizvodnji, te zauvijek mijenjajući tradicionalne strukture rada, susjedstva i obiteljskog života. Ti procesi odvijali su se kroz čitavo dugo devetnaesto stoljeće i događali su se istovremeno s prodorom sve većeg broja egalitarnih političkih ideja i povećanjem pismenosti. ${ }^{803}$

Svijet adolescenata, naročito onih koji su dolazili iz ekonomski depriviranih društvenih slojeva bio je ispunjen nasiljem. Tjelesno kažnjavanje djece bilo je široko rasprostranjeno i smatrano je prihvatljivim oblikom discipliniranja, te se događalo u mnogim domovima $\mathrm{i}$ školama. Život $\mathrm{u}$ siromaštvu, često je navodio mlade na koketiranje s raznim oblicima kriminalnog i devijantnog ponašanja. Mnogo izraženiji doticaj sa čitavim spektrom političkih ideja, povezan s rubnim položajem mladih, ograničenjima koje je nametalo tradicionalno društvo i egzistencijalnom nesigurnošću poticao je adolescente prema buntovnom ponašanju i često prema političkom ekstremizmu. Problem adolescentske delinkvencije i sve vidljivijeg nasilja među mladima brzo je

800 Shuttleworth, $2010: 20$.

801 Demos i Demos, 1969: 636.

802 Ibid: 637.

803 Savage, 2007:4-5. 
privukao pažnju široke javnosti. Psihijatri su, kao stručnjaci za različite oblike devijantnog ponašanja također sudjelovali u pokušajima da se novi društveni problem adolescentskog nasilja objasni kroz medicinski diskurs.

Prepoznavanje adolescencije i društvenih problema vezanih uz istu u medicinskim i pravnim krugovima rezultiralo je različitim teorijama o uzrocima devijantnog ponašanja adolescenata. Ekstremni primjeri adolescentskih zločina poput onog Jesseja Pomeroya, petnaestogodišnjaka iz Bostona koji je otimao, mučio i ubijao djecu iz susjedstva i Anne Marie-Boeglin, sedamnaestogodišnjakinje iz Stettina koja je otrovala svog oca i dvojicu braće plijenili su pažnju tiska željnog senzacije, ali i psihijatara koji su odlučili sudjelovati u nastojanjima da se delinkvenciju objasni i disciplinira.

Za psihijatre, devijantno ponašanje adolescenata bilo je društveni i medicinski problem. Taj je problem sagledavan u skladu s moralističkim pogledima devetnaestoljetnih liječnika na duševnu bolest, kao i s biološkom paradigmom engleske i njemačke psihijatrije koja je povezala pojam „borderlandsa” s načelom herediteta kao primarne etiologije . Također, slučajevi adolescentskog nasilja bili su u skladu s eugeničkim postavkama psihijatara poput Nordaua koji su govorili o postupnoj degeneraciji populacije. Nordau je u svojoj knjizi Degeneracija moralističkim diskursom eksplicitno istaknuo utjecaju nove generacije književnika poput Baudelairea, Nietzschea i Wildea kao pisce koji slave individualnost, opisujući Wildea kao „patološku aberaciju rasnog instinkta" ${ }^{904}$ Devijantno ponašanje mladih bilo je u okviru tih narativa uglavnom izolirano od društvenih okolnosti, te je u njemu često tražen dokaz hereditarnog slabljenja mladih generacija. Ipak, ponegdje se naglašavala uloga siromaštva i utjecaj pogubne literature na mlade. U slučaju Jesseja Pomeroya, mnogo je pažnje posvećeno njegovoj strasti prema šund romanima koji su šezdesetih i sedamdesetih godina 19. stoljeća kao široko dostupan način razonode doživjeli izrazitu popularnost među mladima, naročito onima iz urbanih radničkih slojeva. ${ }^{805}$ No jednaka pažnja posvećena je i veličini i obliku Pomeroyjeve lubanje i činjenice da mu je jedno oko bilo deformirano što su novinari koji su pratili slučaj smatrali sigurnom stigmom hereditarne degeneracije koja je obilježila Pomeroya kao rođenog zločinca. ${ }^{806}$

804 Ibid: 29.

805 Schecter, 2000: 91.

806 Ibid: 86-87. 
Psihijatrijski narativi o nasilnom ponašanju adolescenata bili su dijelom medicinskog diskursa o duševnim oboljenjima djece i mladih koji se u psihijatriji počeo razvijati od sredine devetnaestog stoljeća. U prvoj polovici devetnaestog stoljeća, psihijatri se nisu mogli usuglasiti mogu li djeca, budući da još nisu razvila „racionalnost odraslih” uopće patiti od ludila. ${ }^{807}$ Iako Haslam, Esquirol i Morel spominju primjere djece i adolescenata koji pate od psihičkih poteškoća navedeni slučajevi su često bili anegdotalni i psihijatri se njima nisu bavili na sustavan način niti ih promatrali odvojeno od duševno oboljelih odraslih. Pogledi na dob i ludilo često su bili nesistematični i kontradiktorni: Esquirol tako navodi da se u djetinjstvu može pojaviti jedino mentalna zaostalost, a da je pubertet, kao „razdoblje menstruacije i naglog rasta” životna dob kad se prvi put javljaju simptomi duševnih bolesti. ${ }^{808}$ Ipak Equirol u nastavku svoje studije donosi slučajeve sedmogodišnjih djevojčica oboljelih od „umorstvene manije” prikazavši ih u poglavlju o monomanijama ${ }^{809}$. Esquirol i ostali psihijatri prve polovine devetnaestog stoljeća uglavnog naglašavaju utjecaj lošeg odgoja na razvoj psihičkih poremećaja kod djece.

Prvi stručni članak koji se bavi ludilom u djetinjstvu i adolescenciji bio je tekst Jamesa Crichtona Brownea „Psychical Diseases of Early Life” (Duševne bolesti u ranoj životnoj dobi”). Browne će se kasnije proslaviti kao jedan od vodećih britanskih neuropsihijatara i dati ime Browneovom znaku, dijagnostičkom znaku za rano prepoznavanje progresivne paralize. Članak je rezultat predavanja koje je devetnaestogodišnji student medicine Browne održao pred edinburškim Kraljevskim medicinskim društvom. Objavljen je u The British Journal of Psychiatry 1860. godine. Browne je, uz Maudsleya bio jedan od studenata mlade generacije britanskih psihijatara koja se počela okretati dalje od terapeutskih postavki „moral treatmenta” i okretati se Darwinovim teorijama i somatizmu. Browne radi oštar otklon od dosadašnjih psihijatara koji su se bavili duševnim bolestima u ranoj dobi. Prvi se njima bavi kao zasebnom problematikom i odmiče se od odgoja kao glavnog faktora u razvoju duševnih oboljenja, naglašavajući umjesto toga biološke pretpostavke ludila. Rad Crichtona Brownea zanimljiva je mješavina vjerovanja preuzetih od antičkih autora ili iz narodne medicine, prevladavajućih pretpostavki „moral treatmenta" i novih teorija o degeneraciji inspiriranih psihijatrima poput Morela. Zaokret prema pomalo ekstremnom somaticizmu vidljiv je već od prvih stranica predavanja Crichtona Brownea. Ono počinje karakterizacijom čovjeka kao skupa hereditarnih utjecaja koji se realiziraju od

807 Shuttleworth,2010: 20.

808 Esquirol, 1845: 34.

809 Ibid: 372. 
trenutka sjedinjenja spermatozoida i jajašca. Spolne stanice, smatra Crichton prenose potomstvu stečene sklonosti i slabosti predaka prema određenim bolestima, no one ne prenose samo potencijal za razvoj djeteta $\mathrm{u}$ određenom smjeru već i ,najsitnije i osobite posebnosti i neobičnosti, kako tjelesne tako i mentalne koje karakteriziraju roditelje. ${ }^{810} \mathrm{U}$ skladu sa svojim biološkim i hereditarnim determinizmom, Browne će tako zaključiti da je ludilo prisutno već in utero od samog trenutka začeća embrija. Osim hereditarnih utjecaja Browne naglašava sklonost roditelja ovisnostima i seksualnim porocima kao faktor koji može utjecati na razvoj duševnih oboljenja kod djece, navodeći neumjerenost u hrani, alkoholizam, masturbaciju i razvratan život te duševna uzbuđenja. ${ }^{811}$ No uz te štetne uplive, Browne govori o djelovanju snažnih emocionalnih utisaka na majku tijekom trudnoće vjerovanje direktno preuzeto antičke i pučke medicine. Između ostalog, Browne navodi vjerovanje da žena koja je vidjela epileptičara tijekom napadaja može roditi dijete koje će i samo patiti od epilepsije, te da blage i produhovljene crte lica koji imaju žene u katoličkim zemljama imaju uzrok u satima koje njihove trudne majke provedu u molitvi pred slikama Bogorodice." ${ }^{812}$ Stavljanje takvih vjerovanja uz bok primjerima koji govore o štetnom utjecaju alkohola na razvoj embrija svjedoče o sudjelovanju brojnih epistemičkih lanaca znanja u formiranju psihijatrijskog diskursa. Za razliku od Esquirola, Browne prepoznaje kod djece svaku duševnu bolest koju je moguće pronaći kod odraslih.

Browneov suvremenik Henry Maudsley bio je nešto oprezniji u svojem shvaćanju duševnih oboljenja djece, iako je dijelio Browneov ekstremni somaticizam. Maudsley je drugo poglavlje svoje knjige The Physiology and Pathology of mind (Fiziologija i patologija uma) čije je prvo izdanje objavljeno 1867. godine posvetio ,ludilu u ranoj životnoj dobi”. U tom poglavlju Maudsley opisuje mnogobrojne vrste psihičkih i neuroloških poremećaja ranog i kasnog djetinjstva, počevši od konvulzivnih poremećaja kod novorođenčadi ${ }^{813}$ i noćnih strahova. ${ }^{814}$ Posebnu pažnju Maudsley posvećuje određenim poremećajima vezanim uz nasilne porive kod djece. Budući da smatra dječji mozak nedovoljno formiranim za razvoj kompleksnih psihičkih poremećaja, Maudsley ističe da su neki od najčešćih poremećaja „monomanije ili djelomična idejna ludila". Monomanije nastaju djelovanjem neke sumanute misli usađene u djetetov um na centar za kretanje djeteta tjerajući ga na počinjenje nasilnih čina. Tim nasilnim porivima dijete se

810 Browne, 1860: 285.

811 Ibid: 290.

812 Ibid: 294.

813 Maudsley, 1867: 262.

814 Ibid: 266. 
ne može oduprijeti, a oni ga mogu natjerati na počinjenje ubojstava, krađa, paleža i samoubojstava. ${ }^{815}$ Od naročitog su interesa za Maudsleya duševni poremećaji kod djece nazvani afektivnim ludilima. Afektivna ludila direktno su povezana s devijantnim ponašanjem $\mathrm{u}$ djetinjstvu i kasnije u adolescenciji, a Maudsley ih dijeli na dvije skupine: poremećaji nekog temeljnog instinkta i ,sistemska moralna perverzija koju laici često smatraju običnom zloćom" 816 Prvu skupinu je nazvao instinktivnom podvrstom afektivnog ludila, a drugu pravim moralnim ludilom („,moral insanity proper”). ${ }^{817} \mathrm{U}$ te dvije skupine Maudsley je svrstao niz devijantnih ponašanja kod djece i adolescenata: od poriva da se fizički naudi ili čak ubiju vlastiti roditelji do seksualiziranih ponašanja djece. „Moral insanity proper” za Maudsleya podrazumijeva preuranjenu sklonost izraženoj zloći koja je od malena prepoznata kao neprirodna. ${ }^{818} \mathrm{I}$ jedan i drugi poremećaj Maudsley smatra posljedicom hereditarnog tereta koji su „degenerirani” roditelji prenijeli djeci. ${ }^{819}$ Maudsley također opisuje takvu djecu na izrazito dehumanizirajući način govoreći o njima kao o morbidnim podvrstama ljudi koji nemaju niti instinkte životinja niti razum i svjesne aspiracije čovjeka. ${ }^{820}$

Maudsley, kao ni ostali njegovi suvremenici ne spominje adolescenciju kao zasebno razdoblje. Njegove ideje o dječjem mozgu kao nedovoljno razvijenom te, uglavnom upravljanom porivima kojima se ne može učinkovito oduprijeti utjecat će na percepciju mladih štićenika u psihijatrijskim zavodima. Maudsleyeva eksplicitno postavljena veza iza moralnog ludila i ostalih hereditarnih stigmi obilježit će velik dio psihijatrijskog narativa o adolescentima koji su počinili zločine. Na kraju, iako Maudsley spominje moguć utjecaj odgoja na dječju psihu, navodeći primjer djeteta koje je tijekom noćnih strahova haluciniralo vraga jer su mu ,punili glavu budalastim i opasnim idejama o vragu i paklu"821 njegovo gledište na razvoj duševnih bolesti u mladoj dobi je naglašeno somaticističko i primarno prikazano kroz vokabular živčanih impulsa, nervnih stanica i nesvjesnih pokreta kojima je nemoguće odoljeti. Utjecaj te vrste somatizma očitovao se u načinu na koji su psihijatri pisali o svojim mladim štićenicima. Psihijatrijski diskurs

815 Ibid: 273.

816 Ibid: 281.

817 Ibid.

818 Ibid: 288 .

819 Ibid.

820 Ibid: 291.

821 Ibid: 270 . 
o mladim štićenicima će često pojašnjavati njihove postupke kroz očište poriva, previđajući mogućnost samostalnog izbora.

Velik prilog bavljenju duševnim problemima u adolescentskoj dobi dala su dvojica njemačkih psihijatara Karl Kahlbaum i njegov asistent i učenik Ewald Hecker. Kahlbaum je početkom sedamdesetih godina 19. stoljeća bio na poziciji ravnatelja psihijatrijskog zavoda u Goerlitzu u Gornjoj Lužici, gdje je Hecker služio kao kućni liječnik ${ }^{822}$. Njihov glavni doprinos bio je u opisivanju specifične duševne bolesti koja je primarno pogađala adolescente, a koju je Hecker u članku iz 1871. godine nazvao hebefrenijom (hebephrenia, prema Hebi, starogrčkoj božici mladosti). Hebefrenija je za Heckera bolest koja se javlja na samom kraju puberteta. Hecker ju dovodi u vezu s procesima formiranja identiteta pojedinca u pubertetu. Hecker slikovitim rječnikom opisuje tjelesne i duševne transformacije koje dijete prolazi u pubertetu:

„,..čitav niz mračnih imaginacija budi u duši mladog muškarca ili žene...Novo stvaralačko ,ja” želi aktivno prodrijeti u staro, ali ne nalazi dovoljno mjesta u postojećim oblicima. Tijelo i duša se rastežu i šire u nezgrapnim pokušajima da se prilagode novim osjećajima i idejama... To je doba kad se najnaglašenije suprotnosti dotiču i pojavljuju jedne kraj drugih u neuravnoteženoj maniri. Entuzijastična ozbiljnost i sklonost ekstravagantnim idejama i zrelim razgovorima miješa se sa specifičnom duhovitošću i sklonošću prizemnim i frivolnim šalama. Zajedno s nježnim osjetima i osjećajima javlja se grubost i surovost...Tek krajem tog razdoblja,oko osamnaeste i devetnaeste godine događa se skupljanje i sjedinjavanje i počinje se formirati određeni oblik, još uvijek neodređen i krhak." ${ }^{823}$

Heckler osvještava postojanje i važnost adolescencije kao prijelaznog razdoblja u kojem se formira ličnost odrasle osobe. Upravo graničnost i nedefiniranost tih godina čini adolescente osobito sklonima hebefreniji specifičnom obliku duševnog oboljenja, koji se među ostalim manifestira i konfliktnošću i nekontroliranim ispadima bijesa i nasilja. Hebefrenija pogađa mlade ljude baš u trenutku kad se njihova „,nova ličnost” počinje konsolidirati, djelujući destruktivno na istu i razarajući njenu još uvijek krhku strukturu ${ }^{824}$. Slike uništenja i kaosa kojima Hecker opisuje pubertet $\mathrm{i}$ hebefreniju zrcale se u destruktivnom ponašanju svojih pacijenata čije je slučajeve donio u nastavku članka: jedan od njih je pokazivao znakove agitacije, udarajući djecu i

822 Noll, 2011: 59

823 Hecker, 2009: 97.

824 Ibid. 
životinje ${ }^{825}$, drugi je bio „ljut na sve oko sebe, psovao, vikao i bjesnio bez razloga, te je jednom čak fizički napao svog oca ${ }^{826}$. Također, Hecker na temelju pisama pacijenata pokazuje nekoherentnost ponašanja koja karakterizira hebefreničare. Hebefreniju Hecker promatra paraleleno s progresivnom paralizom jer u njima vidi dva oblika jasno prepoznatljive, neizlječive duševne bolesti u kojima je postepno slabljenje duševnih i intelektualnih sposobnosti bolesnika prisutno od samog početka. ${ }^{827}$. Obje bolesti počinju naglim promjenama afektivnih stanja i slijede progresiju od manije, preko melankolije do zatupljivanja i konačnog propadanja svih psihičkih funkcija. Ono što ih razlikuje je činjenica da se hebefrenija javlja u adolescenciji dok je progresivna paraliza bolest zrelije životne dobi, i činjenica da hebefreniju prema Heckeru karakterizira djetinjasto i nezrelo ponašanje i „,površnost osjećaja” ${ }^{228}$

$\mathrm{Na}$ Heckerov klinički opis hebefrenie kao specifičnog oblika progresivne bolesti adolescenata, nadovezat će se Emil Kräpelin, utjecajni njemački psihijatar. Kräpelin je u svom udžbeniku kliničke psihijatrije prepoznao hebefreniju kao jedan od tipova njegove dementiae praecox, uz katatonični i paranoidni tip. Kräpelin je samu dementia praecox smatrao bolešću mlađe životne dobi tvrdeći da bolesnici mlađi od dvadeset i pet godina čine više od šezdeset posto pacijenata, dok je među oboljelima od hebefreničnog tipa dementiae praecox udio bolesnika mlađih od dvadeset i pet godina gotovo tri četvrtine ${ }^{829}$ Kräpelin povezuje dementia praecox u širem smislu s „autointoksikacijom” tijela tijekom puberteta ${ }^{830}$ time zapravo pretpostavivši njezine metaboličke uzroke, a među simptomima hebefreničnog tipa te bolesti su uz halucinacije i deluzije i afektivne promjene i devijantno ponašanje. Osobe koje boluju od hebefrenije tako između ostalog „gube svoju uobičajenu energiju, povlače se u sebe, postaju stidljive i osamljuju se, ili su pak razdražljive, svojeglave i nepažljive, ne mare za sve svoje obaveze, često odlaze u krevet gdje ostaju tjednima, ne mare ni za kakav posao. Često lutaju, osobito noću ili se upuštaju u promiskuitetne seksualne odnose." ${ }^{" 831} \mathrm{~S}$ druge strane, njihova bolest može rezultirati i agresivnim ponašanjem od kojeg Kräpelin spominje paljenje kuća i razbijanjem prozora. ${ }^{832}$ Ukratko Kräpelinova slika hebefrenije pokriva mnoštvo emotivnih stanja i ponašanja, od seksualnog

825 Ibid: 236.

826 Ibid: 238.

827 Ibid: 93.

828 . Ibid: 98 .

829 Kräpelin, 1902: 153,

830 Ibid.

831 Ibid: 162.

832 Ibid: 167. 
promiskuiteta do izrazite pobožnosti, od nedostatka energije do izrazite aktivnosti i kompulzivne potrebe za kretanjem koja hebefreničara tjera na skitnju, od depresivnih stanja do nezrelog duhovitog ponašanja i agresivnosti. Kao i kod Heckera, tijek bolesti je degenerativan i šanse oporavka su male.

Stenjevački psihijatri često liječe adolescente, ali rijetko raspravljaju o životnom razdoblju adolescencije kao životnoj dobi od posebnog interesa. Žirovčićeva klasifikacija, oslanjajući se na Meynerta, a ne na Kräpelina ne spominje dementia praecox. Na stranicama Liječničkog vjesnika, bolest se spominje u popisu inventara nabave za knjižnicu Zbora liječnika iz 1903. godine kad se spominje naručivanje knjige marburškog psihijatra Maximiliana Jahrmaerkera Zur frage der Dementia praecox. ${ }^{833}$ Žirovčić nudi svoj pogled na hebefreniju i dementia praecox u dvjema psihijatrijskim vještačenjima iz 1906. i 1908. godine. U prvom vještačenju Žirovčić prikazuje slučaj 30-godišnjaka koji je ubio svog rođaka. Zaključivši da okrivljenik boluje od hebefrenije, Žirovčić prikazuje hebefreniju kao prijetvornu bolest koju je teško dijagnosticirati na početku njezinog razvoja jer su njezini znakovi suviše suptilni i često ih se smatra izrazima „,...zloće, pokvarenosti jer se očituju činima odpornosti, često i škodljivosti" ${ }^{934}$. Žirovčić kao još jedan od simptoma hebefrenije navodi sklonost neuobičajenim raspoloženjima i naoko bezrazložnim ponašanjima:,,S jedne je strane neka potpuna pasivnost i neki nepojmljivi negativizam, posvemašnja nehajnost za sve, što se naokolo sbiva, mlitava bezvoljnost, tupost ćudi, nepomičnost, mrtva šutnja; s druge opet strane iznenadna provala sasvim nesmislenih, bezrazložnih, protuslovnih čina." ${ }^{\$ 15}$

Pri opisu hebefrenije, Žirovčić ne govori o halucinacijama i deluzijama kao što to čini Kräpelin, niti nagovještava potencijalne uzroke. Navodi da je „mladenačka psychoza” poznata pod raznim imenima: „hebephrenia, dementia primaria - simplex- praecox i imbecilitas, glavna karakteristika je „u polaganom otupljenju intelektualnih i estetičnih svojstvi sve do raznih stepena duševne propasti. ${ }^{836} \mathrm{U}$ drugom slučaju iz veljače 1908. godine, Žirovčić opisuje hebefreniju na sličan način, kao bolest koja se razvija u mladosti ili čak još u djetinjstvu te njezin naziv prevodi kao „mladenačku neumnost”. Simptomi su opet različita neuobičajena ponašanja i emotivna stanja: „nepromišljenost i neposrednost, sklonost na izvanjski neosnovana zloraspoloženja ćudi i na lude,

833 Schwarz, 1903. 76.

834 Žirovčić, 1906: 163.

835 Ibid.

836 Ibid: 163-164. 
blesave čine. ${ }^{837}$ Ponovno, Žirovčić ističe da ova bolest najčešće završava potpunim propadanjem duševnih funkcija. Istaknutim naglašavanjem emotivnih promjena i devijantnog ponašanja kao simptoma hebefrenije, psihijatri su otvorili put medikalizaciji adolescencije. Sukobi između adolescenata i roditeljskog ili učiteljskog autoriteta, kao i poneka emotivna stanja poput „povlačenja u sebe” ili nagla i učestale promjene raspoloženja, mogla su biti čitana kao prvi znaci uznapredovale duševne bolesti. Neposredno prije Prvog svjetskog rata, kad se pojam adolescencije već počeo koristiti u psihološkoj literaturi u Sjedinjenim Državama, psihijatri u Austro-Ugarskoj monarhiji počinju pokazivati izrazito zanimanje za problem adolescentske i dječje delikvencije. Taj se trend odražava i u medicinskim publikacijama u hrvatskom dijelu Monarhije, gdje Liječnički vjesnik u svibnju 1913. godine donosi prijevod članka češkog neuropsihijatra i proponenta eugenike, Ladislava Raškovca „Potreba skrbi za mladež duševno pogrješnu i ugroženu". Raškovčev članak pisan je iz perspektive neuropsihijatra koji je studirao kod Charcota u Parizu i koji je pomno pratio trendove europske psihijatrije i želio ih proširiti među liječnicima u Austro-Ugarskoj i odaje sve veću zabrinutost zbog mnogobrojnih socijalnih problema vezanih uz mlade, naročito mlade u urbanim sredinama. Potpisan je prezimenom prevoditelja, doktora Machaceka. Među mladima su, prema Raškovcu, naročito rašireni problemi „zločinstva, prostitucije i samoubojstva” a uzrok tih problema Raškovec vidi u raširenosti mnogobrojnih karakternih nedostataka među mladima: „Bolesna zavist, tvrdoglavost, lijenost, ravnodušnost i rasipnost što priječe odgoj i ustrojenje vlastite eksistencije”. ${ }^{838}$ No, sami karakterni nedostaci ne proizlaze primarno iz odgoja, niti su posljedica socijalnih i ekonomskih kriza u kojima se društvo nalazi. Čini se da je Raškovčev članak prvenstveno bio zamišljen kao apel društvenim institucijama da počnu promatrati problem maloljetničkih zločina i samoubojstava iz medicinske i eugeničke perspektive. Nakon što je naveo pojave koje laici često smatraju uzrokom delinkvencije među mladima, poput petparačkih romana i moralne krize društva, Raškovec odlučuje medikalizirati problem ukazujući na opasnost degeneracije. Klicu degeneracije nose i na prvi pogled duševno zdravi ljudi:

„Na oko lagana bolesna živčana i duševna stanja gmaze po tijelu društva kao plazeći čir, te učine više štete i kvara nego patentirane i svim jasne i dobro poznate duševne bolesti. Nije tu potrebno na široko raspredati, da su mi na misli defekti nepregledne čete nervoznih od

837 Žirovčić, 1908: 45.

838 Machacek, 1913: 251. 
rodjenja, na fobije, opsesije, inhibicije naginjujući, bića slabe volje, bolesnog emotiviteta, spolnih pretjeranaca, ćudoredno i čuvstveno izopačenih i anestetičkih, degeneriranih.." ${ }^{\$ 39}$

Kao način spriječavanja sve raširenije degeneracije i delinkvencije mladih koja proizlazi iz iste, Raškovec predlaže obrazovanje školskih liječnika u neurologiji i psihijatriji kako bi mogli na vrijeme prepoznati pojedinci koji su „duševno i živčano bolesna i degenerirani” i kako bi im se na vrijeme mogla pružiti psihijatrijska skrb, ${ }^{840}$ zatim izgradnju zavoda za duševno oboljelo djecu, obrazovanjem ljudi koja se svodi na podizanje „ćudoredne razine ljudstva koja utišava strast za nasladama" i borbu protiv alkoholizma i sifilisa." ${ }^{841}$ Raškovec svoju borbu protiv devijantnog ponašanja mladih zasniva na istoj mješavini konzervativnih moralističkih ideja i biološkog determinizma uvriježenog u psihijatriji. To ispreplitanje najočitije je u njegovom objašnjenju uzroka degeneracije iz „nesređene i nesavladive čežnje za pustim nasladama” i ,iz pomanjkanja pravog poznanja i odgoja". ${ }^{842}$

Pojam adolescencije nije primjenjivan u stručnoj psihijatrijskoj literaturi, no promjene ponašanja i emotivnih stanja u pubertetu su percipirane od strane psihijatara. Emotivna stanja koja nisu bila u skladu s dominantnim emotivnim režimom i devijantno ponašanje mladih postepeno su vezivani uz hebefreniju, specifičnu duševnu bolest koja je opisivana kao bolest koja se manifestira brojnim i raznolikim simptomima. Također, narativ o degeneraciji bio je naročito primjenjiv na adolescente- oni su bili najmlađi naraštaj i osobe promatrane $u$ razdoblju tjelesnog $\mathrm{i}$ duševnog razvoja i njihove psihičke tegobe gledane su kao posljedica moralnog posrnuća društva i biološkog slabljenja rase.

U skladu s takvim stavovima, nije iznenađujuće da je velik broj štićenika mlađih od dvadeset pet godina došao u Stenjevec nakon sukoba s roditeljima ili zakonom i da su psihijatri posvetili mnogo pažnje potencijalnim znakovima degeneracije na njihovim tijelima i neobičnim emotivnim stanjima koja se mogla upućivati na hebephreniu ili dementia praecox. U jednom od najranijih detaljnije opisanih slučajeva hebefrenije, bolest je u povijesti bolesti nazvana „mania hebephrenica" a štićenica je bila osamnaestogodišnja kći posebnice iz Bjelovara. Njezina majka

839 Ibid: 252.

840 Ibid: 254.

841 Ibid: $256-257$.

842 Ibid: 256. 
dovela ju je kotarskom liječniku i opisala njezino stanje kao uzrokovano prekomjernim čitanjem i zaljubljenošću:

„Čitala je dan i noć... ...knjige najraznorodnijega sadržaja. Istim veseljem kojim je čitala kakovu znanstvenu medicinsku ili prirodoslovnu knjigu zadubila bi se i u kakav god njemački "Schund roman". Od tri tjedna počela je pisati pjesme jer se je po navodu majke zaljubila te ju ovo potonje tako uzrujalo, da je počela nesuvisno govoriti, sablazljivo se ponašati i vikati bez razloga na svoju okolinu." 843

Liječničko izvješće također ističe da ju majka ne smatra duševno bolesnom već samo zaljubljenom. Štićenica je ubrzo otpuštena kući kao neizlječena. ${ }^{844}$

Drugačiji tip neobičnog i konfliktnog ponašanja doveo je u Stenjevec Srećka O., bivšeg realca iz Tršća. Srećko O. doveden je u Stenjevec tri puta između 1906. i 1911. godine, svaki put primljen s dijagnozom amentia hebephrenica, otpušten kao poboljšan. Umjesto neposrednog nasilnog ponašanja, Srećka je u konflikt s roditeljima dovela njegova pasivnost, introvertiranost i zanemarivanje obrazovanja kakvo su za njega predvidjeli njegovi roditelji. Najviše detalja o pojavi njegove bolesti doznajemo iz pisma njegova brata u kojem se navodi da se Srećko stalno Žali:

„(da) već nije 14 dana jeo ništa, da je slab, propao, da ga progonimo, netrpimo da mu ne damo ništa jesti. Potajno naručuje liekove, ocu majci otima iz ruku novac, a ako mu se što ma i u najljepšoj formi predbaci, odmah se razdraži tako žestoko, da se prieti vješanjem, strieljanjem i.t.d. Zatvara se u svojoj sobi, bavi se bezsmislicama, stenografirajući,, matematikom i sličnim." 845

U zavodu Srećko se uglavnom ponaša apatično i odbija hranu. Na pitanje zašto je u zavodu odgovara da mu se „brat grozio da će ga tući pa ga je stoga poslušao i dao se ovamo dovesti” 846 Nasuprot poimanju hebefrenije kao neizlječive bolesti koja rezultira postupnim gubljenjem duševnih funkcija, o čemu pišu i europski i stenjevački psihijatri velik broj mladih ljudi kojima je ista dijagnosticirana, otpuštan je iz zavoda brzo, nakon nekoliko mjeseci.

Anton P., gimnazijalac iz Požege, primljen je u Stenjevec nakon što su se njegovi roditelji žalili liječniku da je sklon lutanju i da pati od halucinacija. No u povijesti bolesti se halucinacije na spominju. Sam Anton ih negira u razgovoru s liječnikom, te daje nejasnu izjavu ,samo ranije

843 KPV, 1904: bez broja.

844 Ibid.

845 KPV, 1911: 7948.

846 Ibid. 
imao je ružne, vidio zmije, osobe malene, sitne koje se samo poskliznu. ${ }^{" 847}$ No bijesna pisma koja je Anton slao roditeljima ukazuju na činjenicu da je između njih postojao neki sukob. U dvjema pismima priloženima povijesti bolesti Antonov ton djeluje konfuzno i ogorčeno. Anton opetovano zahtjeva da mu roditelji kažu što žele i očekuju od njega:

„U ostalom, ja hoću da znam točno i potpuno što hoćete, a onda dalje što bilo od mene, meni je svejedno, prije ili poslije smrti se ne bojim, a to vam je dosta. Zato dođite, što prije, jer što kasnije, bit će ljući sud među nama. Hoću da znam zašto živim i zašto vi sada živite. Koliko je vama do života, ne znam ali meni vrlo malo, te bi bilo čudo da bi se preokrenulo, jer mi je sve dodijalo. Ovdje sam malo ozdravio, nisam gledao baš to oko vas, što me je najviše mučilo, pa vas molim da me sada odavde izbavite." ${ }^{948}$

Iako Anton nigdje ne eksplicira detalje svog sukoba s roditeljima, iz tona pisma se može zaključiti da ih krivi za svoje teško duševno stanje i da se, u neku ruku istovremeno osjeća napušteno od njih i nemoćnim ispuniti očekivanja koja su postavili pred njega. Anton je, kad je bio primljen u Stenjevac imao dvadeset i dvije godine, i zakonski je još uvijek bio u skrbi svojih roditelja, bez zanimanja i vlastitih sredstava za život, a sama obiteljska situacija mu je nedvojbeno izazivala emotivnu patnju, na što upućuju njegove izjave da mu je dosta života. Iako mu je dijagnosticirana hebefrenije koju se smatralo neizlječivom, Anton je otpušten kao zdrav nakon tri mjeseca boravka u zavodu.

Marica A. osamnaestogodišnja sluškinja iz Vaganca upućena je u Stenjevec iz bolnice Sestara Milosrdnica u Zagrebu gdje se na veneričnom odjelu liječila od upale maternice i konjuktivitisa. Za vrijeme liječenja počela se ponašati konfliktno, bila je „neposlušna, svađala se s drugim bolesnicama i tražila muško društvo, pače posjećivala muškaračke sobe" ${ }^{\text {"49. }}$. Liječnik iz bolnice Sestara Milosrdnica u svjedodžbi daje zanimljivo objašnjenje svoje odluke da uputi Maricu u Stenjevec. Odlučio se za taj korak nakon što nespecificirane „disciplinarne kazne” nisu djelovale. Marica je prvo premještena na psihijatrijski odjel, gdje je postala još uzrujanija, nakon čega je upućena u zavod. ${ }^{850}$ Takvo postupanje implicira da su neki liječnici gledali na psihijatrijski zavod kao na instituciju koja može poslužiti „discipliniranju” devijantnih pojedinaca koji nastavljaju prkositi autoritetu usprkos kaznama. U Stenjevcu se Marica ponašala primjerno, te nije dolazila u sukob s drugim štićenicama niti s liječnicima. Povijest bolest navodi kako se

$847 \mathrm{KPV}, 1911: 7989$.

848 Ibid.

$849 \mathrm{KPV}, 1911: 7701$.

850 Ibid. 
„sasvim razbistrila, smirila, postala uljudna, prijazna, pozdravlja liječnike sa: klanjam se, daje im ruke, umiljava im se, traži pudera, ponaša se prema njima erotično, ali pristojno." ${ }^{851}$ Prilikom razgovora s liječnikom Marica je na pitanje zna li čitati ili pisati „spremno i razumno” odgovorila da ne zna ,jer je nitko nije za mlada učio, a sad je već kasno - ljubiti je ali već mlada naučila." 852 Marica je puštena kući kao zdrava nakon godinu dana boravka u zavodu, a iz zapisa se da zaključiti da su liječnici zaključili da je ozdravila jer se ponašala staloženo i jer je bila marljiva prilikom rada u kuhinji koji joj je dodijeljen u svrhu terapije.

Romantične emocije i seksualnost mladih djevojaka se često nalaze u žarištu medicinskog pogleda stenjevačkih liječnika koji u povijestima bolesti naročito bilježe govor o seksualnim i romantičnim iskustvima i primjere ponašanja koja interpretiraju kao „erotična”. Ako je agresivno ponašanje štićenice navedeno kao povod njezinu smještanju u Stenjevec, stvara se asocijativna veza između tek probuđene ženske seksualnosti i agresije. Kao jedan od osnovnih simptoma hebefrenije i dementia praecox kod muškaraca prepoznavana je njihova pasivnost i povlačenje $u$ sebe, što govori o činjenici da je diskurs o tim bolestima unutar hrvatske psihijatrije bio izrazito orođen: patološkom se smatralo aktivno pokazivanje seksualnosti kod djevojaka i introvertiranost kod dječaka. Stenjevački liječnici čini se, nisu shvaćali hebefreniju i dementia praecox kao neizlječive, već su, čini se imali stav da je moguće zavodskim liječenjem disciplinirati „devijantne” emocije mladih štićenika i uklopiti ih u postojeći emotivni režim. Takav stav rezultirao je otpuštanjem tih štićenika kao ,poboljšanih” ili „ozdravljenih” u trenutku kad je njihovo ponašanje u zavodu počelo odavati „zdrav” stav prema emocijama.

S obzirom na sve češću karakterizaciju mladenačkog nasilja kao društvenog problema kojim se psihijatri trebaju ozbiljnije pozabaviti posebno su zanimljivi slučajevi adolescenata koji su došli u sukob sa zakonom. Takvi slučajevi davali su priliku Žirovčiću, kao najistaknutijem forenzičkom psihijatru u Banskoj Hrvatskoj da izrazi svoje stavove o problemu adolescentskog nasilja. Jedan od ekstremnijih slučajeva, „zločinačke mladeži” kojima se Žirovčić morao baviti bio je onaj Rudolfa Stanića, šesnaestogodišnjeg pisarskog vježbenika iz Osijeka koji je bio optužen da je u Sesvetama ubio kočijaš koji ga je povezao. Rudolf Stanić služio je kod odvjetnika Reina u Osijeku. Otac mu je bio siromašni bilježnik koji je služio kod gospodarskog društva u Osijeku nakon što je bio suspendiran iz općinske službe. Svojom mjesečnom plaćom od devedeset kruna, 
uzdržavao je petoro djece i svoju suprugu. Rudolfova majka prošla je kroz deset porođaja (samo petoro djece je preživjelo) u trenutku kad se protiv Rudolfa vodio sudski proces bila je ponovno trudna. Liječnički vještaci koji su ju pregledali ustanovili su da ,je tjelesno slaba i u sedmom mjesecu trudna, da liječnicima na pozdrav ne odzdravlja, tuži se na veliku slabost, jedva na nogama stoji, ne može jesti ni spavati, da je već 4 godine veoma uzrujana i često ne zna što govori." ${ }^{\gg 53}$ Rudolfov otac opisuje svog sina kao dobro odgojenog dječaka koji doduše „nije imao volje za nauku" kad je pohađao realku u Osijeku, te je ponavljao prvi i drugi razred. Nakon toga otac ga je dao u službu trgovcu u Glini, gdje ga je njegov poslodavac hvalio u pismima, a zatim kao pisara odvjetniku doktoru Reinu. Otac je također naveo da Rudolf nije pokazivao nikakve znakove duševnog oboljenja, te da ga je tukao kad bi izostajao iz škole, a bio je fizički kažnjavan i u školi prije nego što je odustao od iste ${ }^{854}$ Odvjetnik Rein navodi da je Rudolf marljivo radio i dobro se ponašao jedino „nije pazio na vanjsko lice napisanog”. Rudolfovi postupci od prvog lipnja 1906. morali su iznenaditi sve koji su poznavali mladića. Rudolf je tad preuzeo od Reina svotu od 310 forinti kako bi ju predao na poštu, no Rudolf je ukrao novac i pobjegao iz Osijeka, k Brodu na Savi. Svom ocu je napisao zbrkano pismo u kojem se opravdava kako je novac izgubio, i u strahu od kazne pokušao pobjeći pišući:,,bježao sam do iza dolnjeg grada, gdje sam skočio u Dravu, plivati nijesam znao i ugušio sam se ${ }^{955}$ U Brodu se Rudolf očito obskbio za dulji bijeg od kuće: kupio je odjeću, duhan, sat s lancem, batinu i revolver. ${ }^{856}$ Nakon toga otišao je u Glinu, a zatim u Zagreb gdje je živio u hotelu, rasipavao novce i udvarao se djevojkama po gostionicama ${ }^{857}$ Petog lipnja Rudolf je sjeo u fijaker i naredio kočijašu da vozi prema Sesvetama, gdje ga je ustrijelio iz revolvera. Ranivši kočijaša odvezao je fijaker i konje do Sv. Ivana Zeline gdje je tvrdio da su njega i kočijaša napali razbojnici i da im je jedva umakao. Uhapšen je sutradan, a pri saslušanju je isprva tvrdio da je htio počiniti samoubojstvo, a kočijaš mu je pri tom smetao pa ga je ubio, da bi na kraju rekao da je ubio kočijaša da ukrade fijaker i konje i proda ih. Na glavnoj raspravi 20. rujna njegov branitelj je predložio psihijatrijsko vještačenje, čemu je sud udovoljio $^{858}$.

853 Žirovčić, 1907a: 93.

854 Ibid: 94.

855 Ibid: 93 .

856 Ibid.

857 Ibid.

858 Ibid. 
Po dolasku u Stenjevec, Rudolf je podvrgnut uobičajenom pregledu, a Žirovčić je pomno zabilježio pojedine fizičke stigme koje bi mogle upućivati na degeneraciju u skladu s uputama Maudsleyja i Lombrosa:

„Lubanja strebasta, široka, objam 57 ctm. Čelo nizko, uzko, koso. Ušesa nejednaka, desno nešto veće. Zjenice veoma široke, okrugle, jednake,reagiraju spremno na svjetlo i akomodaciju. Nos ovelik, debeo, tubast. Zubi zdravi - sluznica ždrijela malko zažarena. Ustroji disanja i krvokruženja u redu. Desno mudo manje od lijevoga, sasvim drobno, kao omanji orah, kao da je poslije bludobolne upale atrofiralo." ${ }^{959}$

U zavodu se Rudolf ponekad ponaša mirno, a ponekad podrugljivo, očito nastojeći isprovocirati liječnike i bolničare. Kako vrijeme odmiče, postaje sve razdražljiviji pa jednom prilikom govori „da mu dodijalo, da ima nož, zaklao bi kojega liječnika. Njemu nije stalo za ljudski život, ako sada dobije i deset godina, pa kad bude izašao, bit će mu tek 27 godina, i onda će svjet čuti, što će on sve raditi. ${ }^{\circ 600}$

Pri razgovoru naglašava da su ga često fizički kažnjavali u „realci” a na pitanje od odlasku u krčme se „grohotom smije i kaže da je išao. Na pitanje o tome kakve je knjige čitao govori da je čitao „Svašta, romane, dozvoljene i zabranjene, najradje povijest.” S velikim užitkom govori o nekom zabranjenom romanu kojeg je čitao:

„Naslova se ne sjeća, a da su zabranjeni, to je na koricama bilo debelo pisano, za to je išao tu knjigu kupiti. Bila je to njemačka knjiga s nekakvim židovskim, jako smiješnim naslovom.

Bilo je tu pisano proti vjeri i popovima, da Isus nije nikada eksistirao, to da su samo izmislili.

Od onda je zamrzio popove, nije išo u crkvu i nije se Bogu molio." ${ }^{961}$

Povremeno se čini očitim kako šesnaestogodišnji Rudolf čak i pretjerano naglašava svoju sklonost nasilju, nekonvencionalnim vjerovanjima i hrabrost u opasnim situacijama, kao kad kaže bolničaru da je onu večer kad je ubio fijakerista: ,,... u Zagrebu došao u jedan bordel, tamo da su ga napali neki soldati s bajunetama, on je pucao iz revolvera, nastala galama, on pobjego i na Jelačićevu trgu skočio u fijaker - pa je kočijaša u srditosti ubio!"862 Upravo su Rudolfova hvalisanja, njegov fizički izgled i njegovo vlastito naglašavanje nedostatka empatije prema ljudima (koje je Žirovčić uzeo za dokaz njegove „moralne nezdravosti”) bili kriteriji koji su stenjevačkim psihijatrima omogućili da Rudolfa svrstaju u Lombrosov tip „,rođenog zločinca”.

859 Ibid: 94.

860 Ibid.

861 Ibid: $94-95$.

862 Ibid: 95. 
Rudolfova službena dijagnoza bila je „moral insanity” koji Žirovičić pojašnjava analogijom između etičkog osjećaja i sluha za glazbu i poistovjećuje s određenim stupnjem degeneracije:

„kao što ima ljudi, koji neshvaćaju harmonije zvukova, te ne mogu pojmiti ljepote ne samo kakvog umjetnog glasbotvora, već niti najjednostavnije pjesme, tako može biti ljudi bez obdarenosti za altruističo ćućenje i moralno pojimanje. Redovito potiču moralno nezdravi ljudi od predaka, koji su bili duševno ili živčano bolestni, ili pijanice, ili su inače imali u svojem biću nešto stranoga , neobičnoga; oni se svojom duševnošću , a često i obličjem odstranjuju od poprečnoga tipa čovjeka- stoga se nazivaju ,degeneriranima “ iliti „, izrodjenima “683

Za Žirovčića su Rudolfova navodna hladnokrvnost, odsustvo suosjećanja prema kočijašu i sklonost laganju, te njegova nepromišljenost, svojstvena moralno nezdravim ljudima dokaz da Rudolf spada u „manje vrijedne ličnosti”864. Žirovčić se osvrće i na izjave Rudolfovog oca i drugih ljudi koji su poznavali Rudolfa koji govore o njemu kao o djetetu koje se nije isticalo svojom zloćom. Žirovčić misli da ti ljudi ublažuju Rudolfovu zločinačku prirodu, ali i pretpostavlja da je pojava devijantnog ponašanja povezana s njegovim ulaskom u pubertet: „Moguće ipak, da je sve to u njemu spremljeno i pritajeno bilo, pa je tek u šestnaestoj godini izbilo, jer je spolna dozrelost u moralnih idiota obično doba, u kojem se njihov defekt začne pojavljati nemoralnim činima". ${ }^{865}$ Žirovčić se također odmiče od strogo somaticističkog pogleda i dopušta mogućnost da su uz „degeneriran i moralno manjkav ustroj” i teške obiteljske okolnosti mogle nagnati Rudolfa na počinjenje nasilnog zločina. No pod teške okolnosti Rudolfova odrastanja, Žirovčić ne ubraja ni siromaštvo ni tjelesno kažnjavanje kojem je bio redovito izložen i u školi i kod kuće, a koje sam Rudolf često spominje. Umjesto toga, Žirovčić stavlja naglasak na duševnu bolest njegove majke i njezinu nesposobnost da na adekvatan način vodi kućanstvo:

„Moguće je dakle, da Rudolfa Stanića nije samo loše možgjansko ustrojstvo dovelo do zločina, nego i loš odgoj. Ktomu bilo je prilike u obiteljskim odnošajima maloga činovnika, slabo plaćenoga, koji mijenja mjesta, koji je suspendiran radineke nepravilnosti, gdje kućanstvom rukovodi i s obitelju upravlja slabašna umobolna žena, koja radja već jedanaesto dijete, mada joj svaki porodjaj sve više zdravlje ruši, a u svijet stavlja kržljavo pokoljenje-što je doduše u

863 Ibid: 96.

864 Ibid: 98.

865 Ibid: 97. 
dogmatičnom smislu snošljivo s moralom, ali po prirodnom shvaćanju jamačno nevaljano i nemoralno" $" 866$

Žirovčić se ne osvrće na teške socijalne i ekonomske prilike, na činjenicu da je Rudolf morao raditi odgovoran posao kako bi pomogao prehraniti obitelj niti na sveprisutno tjelesno kažnjavanje koje je od malena izlagalo mlade nasilju, već promatra okolnosti Rudolfova odrastanja iz direktno patrijarhalne perspektive, ističući ulogu majke kao osnove obiteljskog doma i njezin angažman kao preduvjet zdravog duševnog razvoja djece. Osim toga, Žirovčićeva poruka o rađanju potencijalno „kržljavog” potomstva upućuje na činjenicu da on vidi rješenje problema maloljetničkog nasilja u eugeničkim i moralističkim kategorijama.

Rudolfovo vještačenje može se usporediti sa slučajem drugog „dječaka s revolverom” osamnaestogodišnjeg Gjure Molnara. Gjuro Molnar je boravio u Stenjevcu od 15. studenog 1908. do 12. siječnja 1909. ${ }^{867}$ Molnar je, kao i Rudolf odrastao u teškim uvjetima, bez majke, uz oca alkoholičara koji je propio njihov posjed i otišao služiti kao vincilir u Cabunu. Uz to ga je njegov brat često tukao. ${ }^{868}$ Pobjegavši od kuće, Gjuro je počeo preživljavati od krađe, a u Stenjevec je doveden nakon što je ranio Antuna Matičevića iz revolvera. Sam događaj je bio bizaran: nakon što je ustrijelio Matičevića u ruku, Gjuro je odbio novac kojeg mu je ovaj ponudio te mu ispričao svoju životnu priču rekavši mu da se ne slaže s ocem te je zbog toga pobjegao u šumu i odlučio ubiti nekoga, pa sebe. ${ }^{869}$

Žirovčić je i Molnara svrstao među degenerirane „osobe manje vrijednosti” opisavši ga kao mladića čija ,pojava odaje već vanjštinom čovjeka nerazvijena, umno ograničena, izobličena, degenerirana." ${ }^{870}$ Molnaru Žirovčić nije dijagnosticirao moral insanity nego je samo zaključio da je Molnar „manje razvijen, imbecil nižeg stepena." ${ }^{871}$ I iako Žirovčić spominje teške okolnosti okrivljenikovog života, ipak ih ne dovodi u vezu sa psihičkim stanjem Gjure Molnara prije počinjenja čina, već se fokusira na njegovu „moralnu tupost”. Dok se Rudolf hvalio svojim nedostatkom kajanja, Molnar govori da mu je žao što je pucao na Matičevića i opravdava se pijanstvom. ${ }^{872}$ No Žirovčić se ne osvrće posebno na tu njegovu izjavu, pretpostavljajući da je

866 Ibid.

867 Žirovčić, 1910: 250.

868 Ibid.

869 Ibid: 249.

870 Ibid: 251.

871 Ibid: 254.

872 Ibid: 251. 
Molnar na svom stupnju duševnog razvoja nesposoban razviti osjećaj krivnje. ${ }^{873} \mathrm{I}$ u slučaju Rudolfa i Gjure Molnara Žirovčić ne pripisuje zločin niti jednoj duševnoj bolesti, otpisujući eksplicitno hebefreniju u navedenim primjerima. Umjesto toga, Žirovčić na osnovu njihove vanjštine, neprilagođenog ponašanja i samih njihovih pojedinačnih nasilnih djela, promatra dvojicu maloljetnih delikvenata kao „degenerirane” pojedince. Oni na temelju vlastitog porijekla i intelektualnog ustroja imaju sklonost nasilju i zločinačkom životu - Rudolf jer ne može pojmiti moralne nazore, Gjuro jer ne posjeduje mentalni kapacitet da uistinu suosjeća s drugima, niti je sposoban kontrolirati vlastite porive. Žirovčić prepoznaje da je njihovo teško odrastanje, ispunjeno bijedom i nasiljem moglo doprinijeti konkretnom razvoju situacije koji ih je doveo na krivu stranu zakona, ali mu odriče ulogu u formiranju njihove ličnosti.

Ako uzmemo prilike odrastanja mladih, siromašnih ljudi u gradovima prijelaza stoljeća, fenomen ovakvog nasilničkog ponašanja postaje puno razumljiviji. Na kraju, Rudolfov i Gjurin zločin su motivirani imovinskom dobiti, loše isplanirani i izvedeni od strane mladića koji su odrastali u uvjetima siromaštva i bili fizički zlostavljani. Za mnoge od mladića koji su se našli u Stenjevcu, odrastanje je bilo iskustvo obilježeno nesigurnošću i brutalnošću, a adolescencija je, kao najava odrastanja značila nove izazove. Nasilje je ponekad bilo izraz želje da se pobjegne iz siromaštva, a ponekad kao u slučaju agresivnog napada na sve društvene tabue u izljevima hvalisavog bijesa kojima u zavodu pribjegava Rudolf Stanić želja da dobiju osjećaj moći nad zajednicom gradeći sliku sebe kao opasnih i beskrupuloznih, bijesnih mladih ljudi na sličan način na koji su to činile adolescentske bande $u$ većim gradovima poput pariških „Apaša” ${ }^{874}$ Psihijatri na nasilje mladih gledaju iz moralističke i biološke perspektive, promatrajući sve veću učestalost delinkvencije kao krajnju posljedicu degeneracije. Najmlađa generacija tako dobiva ulogu žrtve „grijeha otaca” i primjeri njezina problematičnog ponašanja postaju upozorenje za čitavo društvo koje se nastoji usmjeriti kako prema aktivnijim mjerama socijalne medicine, tako i prema eugenici.

Problem prisutan unutar obiteljskog doma su i oni neprilagođeni i buntovni adolescenti čije emocije nisu u skladu s emotivnim režimom građanstva. U Stenjevcu je hebefrenija imala upravo ulogu objašnjavanja neobičnih emotivnih stanja pojedinih adolescentskih pacijenata. No iz primjera štićenika kojima je dijagnosticirana hebefrenija, vidimo da je njezina klinička slika bila

873 Ibid: 253.

874 Savage,2007: 46. 
mnogo drugačijom od opisa danog u stručnim medicinskim tekstovima: češće od degenerativne bolesti koja završava potpunim duševnim propadanjem, vidimo sukobe između emotivnih režima roditelja i adolescenata te nemogućnost njihove međusobne komunikacije. Hebefreničari često bivaju vraćeni u okrilje obitelji kao zdravi, tek ponekad demonstrirajući u okružju zavoda konfliktno ponašanje na koje su se žalili ljudi iz njihove okoline. Mnoge od psihijatrijskih dijagnoza vezanih uz ponašanje adolescenata proizlaze iz činjenice da se adolescencija kao zasebno razdoblje obilježeno i vlastitim poimanjem sebstva tek počela razvijati i biti prepoznata. Fenomen adolescencije je uz razvojno-psihološku imao i snažnu društvenu i kulturnu komponentu, koja je izmicala onodobnim znanstvenicima a naročito psihijatrima sklonima percipirati svijet iz medicinsko-biološke i ponekad moralističke perspektive.

\subsection{Epileptičari i gorući štagljevi: sukobi unutar ruralnih zajednica}

Za ruralne zajednice, prisustvo osobe s duševnim poteškoćama bilo je izvor stalnog straha. Čak i u doba moderniteta, svakodnevica seoskog života bila je obilježena ustaljenim ciklusima poljoprivrednih radova i godišnjih svetkovina. Veličina zajednice i način života unutar nje rezultirali su mrežom međuljudskih odnosa gdje su ljudi dobro poznavali jedni druge. Obiteljska povijest, životne prilike zdravlje i financijsko stanje nisu se mogli tajiti i definirali su međusobnu komunikaciju suseljana. Kanadski sociolog Erving Goffman opisao je društvenu ulogu tih osoba kao trajno obilježenu stigmom mentalne bolesti. Za Goffmana, mentalne poteškoće spadaju u kategoriju stigme karakternih mana zajedno sa kriminalnom prošlošću, ovisnošću, alkoholizmom, homoseksualnošću, nezaposlenošću, suicidalnim ponašanjem i radikalnim političkim stavovima. $^{875}$

Kao i sve ostale stigme, stigme karakternih mana rezultiraju time da pojedinac koji bi inače bio prihvaćen u socijalnoj interakciji, privlači pažnju nekom svojom karakteristikom koja odvraća ljude koji s njime komuniciraju od njega i zasjenjuje sva ostala svojstva koje pojedinac posjeduje ${ }^{876}$. Bitno obilježje Goffmanova gledanja na stigmu je upravo činjenica da je kvaliteta percipiranih osobina sekundarna u odnosu na sam okvir društvene interakcije - odnos i definicije „normalnog” $\mathrm{i}$ „devijantnog” upravo se formiraju kroz proces socijalnih interakcija. ${ }^{877} \mathrm{U}$ tom smislu su socijalni kontakti unutar malih zajednica u kojima se većina interakcija odvija licem u lice bili veoma bitni za formiranje koncepata devijacije.

875 Goffman, 1963: 4.

876 Ibid: 5 .

877 Ibid: 138. 
Širenjem utjecaja medicine, sve je veći opseg devijantnih ponašanja bio medikaliziran, a liječnici i osobito psihijatri našli su se u poziciji medijatora kojima su se zajednice uklanjale kad bi unutar njih izbio sukob. Osobe koje se ne ponašaju u skladu s uobičajenim obrascima ponašanja nosile su stalnu stigmu, a ako bi u bilo kojem trenutku ušle u direktan sukob sa zajednicom, zajednica bi se počela zalagati za njihovo uklanjanje iz društva - naročito ako te osobe nisu mogle računati na podršku vlastitih obitelji. Budući da su na selu ljudi živjeli jedni blizu drugih, međusobno pomagali jedni drugima pri radovima i često bili povezani ženidbenim ili ekonomskim vezama, seoska zajednica posjedovala je učinkovit mehanizam kolektivnog nadzora i discipliniranja. „Devijantne” pojedince bilo je izrazito lako prepoznati, društveno ih izolirati i kolektivnim apeliranjem na medicinski, policijski ili administrativni autoritet osigurati njihovo uklanjanje iz zajednice.

U ruralnim zajednicama sukobi su često rezultirali počinjenjem imovinske štete. Imovina, u obliku gospodarskih zgrada ili poljoprirednih dobara bi bila zapaljena ili na neki drugi način uništena. Svjedočanstva seljana predstavnicima vlasti ili liječnicima obiluju spominjanjem imovinske štete koju je devijantni pojedinac nanio ili bi mogao nanijeti svojim susjedima i suseljanima. Sprječavanje imovinske štete najčešće se ističe kao razlog zbog kojeg se tražilo institucionaliziranje nasilnih pojedinaca. Strah od imovinske štete i sklonost da se istu nanosi u konfliktnim situacijama Regina Schulte je objasnila činjenicom da je napad na imovinu pojedinca u ruralnim zajednicama predstavljao mnogo više od uništavanja materijalnih objekata. Identitet ratara ili stočara bio je usko vezan uz njegovu sposobnost da preživljava i stječe imovinsku korist pomoću zemlje i stoke i poljoprivrednih oruđa koje mu omogućavaju bavljenje istom. Samim time, može se reći da je udar na seljakovu imovinu predstavljao napad na jedan od ključnih elemenata njegovog identiteta. Nadalje, dramatičan čin paleža ili sličnog uništavanja imovine bio je izrazito javan i obilježavao je napadača i žrtvu pred cijelom zajednicom, čineći sukob vidljivim. ${ }^{878}$ Upravo zbog toga, prisutnost osobe koja je spremna počiniti palež ili sličan destruktivan čin bila je pogubna za koheziju i identitet zajednice i predstavljala je snažan argument za traženje pomoći psihijatara.

878 Schulte, 1994: 26. 
Primjeri štićenika koji su počinili imovinsku štetu ili ju prijetili počiniti bili su disproporcionalno brojni u povijestima bolesti od samog osnutka institucije. Slučaj Augustina M., ratara iz Krasice i jednog od prvih štićenika zavoda, slučaj pokazuje da se u slučajevima sukoba u manjim zajednicama, nije odmah posezalo za smještanjem osobe u zavod.

Prema svjedočanstvima seljaka, Augustin se četrnaest godina ponašao čudno i nasilno no oni su se obratili vlastima tek kad im je njegovo destruktivno ponašanje nanijelo veliku materijalnu štetu: prema izvještaju poglavarstva Augustin je postao „osobito rječit i brbljav te pokušavao sve korisno utamaniti i uništiti" ${ }^{\prime 79}$. Augustin je prvo smješten u pritvor, no budući da je od tamo uspio uništiti zid i pobjeći, poslalo ga se u stenjevački zavod. Takav razvoj pokazuje da su sukobi na selu mogli su trajati godinama prije nego što se zatražila intervencija izvanjskih autoriteta. Također, čini se da je ključnu su ključnu ulogu u smještanju Augustina u Stenjevec imale vlasti riječke podžupanije. Liječnička svjedodžba je izrazito štura i sadrži samo sažet opis Augustinovog fizičkog stanja i ranije preboljelih bolesti uz kratku napomenu da je kod njega „opažena (je) monomania, da sve što mu pod ruku dođe hoće zatrti i uništiti.” Načelnikov dopis sadrži opis pritužbi suseljana i sve korake koje je podžupanijsko poglavarstvo poduzelo, sa posebnim osvrtom na imovinsko stanje njegove obitelji. Takav razvoj situacije govori da se, $u$ trenutku kad je sukob eskalirao, prvo tražilo od obitelji da se pobrine za nasilnog pojedinca, a onda su se poduzeli pravni koraci, da bi se naposljetku pokušalo problem riješiti pomoću internacije u psihijatrijski zavod. Suseljani su ga odlučili predati poglavarstvu nakon što je razbijao prozore i pčelinjake te zapalio pastirske kolibe u šumi. Poglavarstvo ga je držalu u pritvoru, no on je u pritvoru uspio provaliti zid. ${ }^{800}$ Dopis načelnika riječke podžupanije poglavarstva priložen povijesti bolesti donosi svjedočanstva suseljana od Augustinovom agresivnom ponašanju i ističe da njegova obitelj u "slaboj kući uz siromaštvo i nejaku djecu ne može najmiti potrebnog čovjeka za čuvanje" ${ }^{881}$. Augustin u Stenjevcu tvrdi da je „krsnik” (ime za iscjelitelja u Primorju) rođen u „kapici” (vjerojatno pučki izraz za amnionsku membranu koja u rijetkim slučajevima može prekriti lice i glavu novorođenčeta) nekoliko puta iskazuje svoju nevinost i tvrdi da su optužbe protiv njega „,djelo zlih ljudi koji su me optužili krivo.”882

879 KPV, 1880-1881: 48.

880 Ibid.

881 Ibid.

882 Ibid. 
Zanimljiva je i kompleksna dijagnoza koja je Augustinu izrečena u zavodu: „Mania destructionis in vero similiter epileptico" $" 883$ - uništavalačka manija zapravo nalik epilepsiji. Činjenica da su stenjevački liječnici usporedili Augustinovo oboljenje s epilepsijom, iako ni liječničko izvješće ni povijest bolesti ne spominju epileptične napadaje upućuje na osobit oblik stigme koja je pripisivana epileptičarima, a koja ih je dovodila u vezu s nasiljem i paležom. Također, povezanost epilepsije s određenim oblicima kriminalnog ponašanja bilo je prisutno i u tadašnjoj forenzičkoj psihijatriji. Cesare Lombroso, čiji su rani radovi svakako bili poznati stenjevačkim liječnicima, tvrdio je da „svi urođeni zločinci pate od prikrivenog vida epilepsije koja se klinički ne manifestira epileptičkim napadajima već pervazivnim poremećajem ličnosti. ${ }^{884}$

U četvrtom izdanju svoje opširne studije zločinačkog ponašanja L'uomo delinquente (Zločinac) objavljenoj 1889. godine, Lombroso postulira nekoliko razina povezanosti između epilepsije i zločinačkog ponašanja. Prva razina su fiziološke sličnosti između „rođenih zločinaca” i epileptičara. Lombroso $\mathrm{u}$ iste uvrštava asimetriju lubanje, nedostatak osjetljivosti na dodir i ljevorukost, osobine, prema Lombrosu, natprosječno česte kod zločinaca i epileptičara. ${ }^{885}$. Lombroso naglašava prikriven karakter epileptičara. Karakteristika „zločinca-epileptičara” koju Lombroso konstantno naglašava je njegova sklonost ekstremnim emocijama i prikriven karakter njegove bolesti. Epileptičar tako „u trenutku kad dođe u sukob sa zakonom pokazuje lucidnost zbog koje se često doima kao da lažira svoju epilepsiju, a to stanje može trajati satima, danima ili tjednima". ${ }^{886}$ Ono na čemu Lombroso u najvećoj mjeri temelji vezu između epilepsije i zločina navodna je sklonost epileptičara bezrazložnom nasilju. To je naročito vidljivo u njegovoj definiciji „skrivene epilepsije”. Prema Lombrosu, glavna karakteristika skrivene epilepsije su „nagle, nepredvidive provale nasilnog ponašanja. Ti „psihološki ekvivalenti fizičkog epileptičkog napadaja su obilježeni nepredvidivošću i razornim bijesom koji pretvaraju uobičajeno ponašanje epileptičara u kratkotrajnu karikaturu zločinačkog ponašanja." ${ }^{887}$

Definiranjem „skrivene epilepsije” kao egzaktnog psihijatrijskog fenomena, epilepsija time prestaje biti isključivo bolest koja je zbog svojih dramatičnih i intenzivnih simptoma bila lako prepoznatljiva i laicima. Ona postaje zajedničkom dijagnozom za mnoštvo teško objašnjivih nasilničkih ponašanja. Budući da se primarni uzroci epilepsije traže u hereditetu, ona postaje još

883 Ibid.

884 Fatović-Ferenčić i Kuhar, 2017: 461.

885 Lombroso, 2006: 248-250.

886 Ibid: $250-251$.

887 Ibid: 257. 
jedno stanje koje se prepoznaje kao posljedica degeneracije, granična pojava koja se može dugo skrivati kod naoko zdravih pojedinaca samo da bi se iznenada manifestirala provalom destruktivnog bijesa.

Lombrosova „epilepsija urođenih zločinaca” i oboljenja koja su se manifestirala epileptoformnim napadima bila su isprepletena u medicinskim i laičkim narativima. Stenjevački kućni liječnik Dragutin Forenbacher u svom je članku o „moral insanity” proširio Lombrosovu teoriju i doveo svaki tip epilepsije u vezu s nekim oblikom „moralne degeneracije” ustvrdivši sljedeće: „Već u mladosti padavičavca, pa ma se još i nepokazali pravi znakovi padavice pokazuje se pokvarena ćud, kašnje biva toga i više" ${ }^{988}$. Dakle, uz činjenicu da se kriminalce koji su počinjali paleže i bili skloni sukobima smatralo epileptičarima također su i osobe koje su patile od epileptičkih napada bile su često smatrane opasnima. Stav hrvatskih psihijatara o epilepsiji dijelili su i mnogi laici, a osobe koje su patile od epilepsije bile su često percipirane kao opasne za zajednicu koja je tražila njihovo zatvaranje u zavode. U liječničkim izvještajima bolesnika s epileptičkim napadima, gotovo se kao pravilo spominje opasnost od paleža. Dora K. četrdesetogodišnja seljakinja iz Novigrada koja je redovito imala epileptične napadaje bila je u Stenjevcu od 1890. godine do 1895. kad je umrla od „nepoznatih uzroka” za vrijeme jednog napadaja. Njezina liječnička svjedodžba traži njezino zatvaranje u zavod je je "opasna za društvo čovječje naginjući na podmetanje vatre" 889 iako se nigdje u njezinoj dokumentaciji ne spominje da je podmetnula požar ili se na bilo koji način ponašala nasilno. U liječničkom izvješću Gjoke A., seljaka iz Ostrova, liječnik dovodi u usku vezu njegovu epilepsiju, sklonost alkoholu i konfliktno ponašanje. Izvješću su pridodana izjava anonimnog suseljana koji svjedoči o Gjokinom nasilničkom ponašanju:

„Bolesnik je nađen na ulici, sav usplahiren, izbuljenih očiju, iz usta mu curi pjena, govori bez smisla, držeći u obje ruke po jedan oveći kamen. Svi ljudi žene i djeca bježe od njega. Na pitanje podpisanoga, kojeg on od bolesti oca i brata poznaje; koga traži odgovara: ،'Neprijatelje, koga on može odma umlatiti.' Zatim je prešao preko ulice i ušao u jednu kuću, gde je pre nekoliko meseci bila birtija V. M.-a, koji mu je u odbrani glavu razbio, te je tamo sve prozore i kuhinjske sudove razlupao, ukućani se svi odavno razbjegli; posle toga je jurišao na

888 Forenbacher, 1893: 50-51.

889 KPV, 1895: 1737. 
crkvu, gde se je služilo večernje, zatim je otišao u birtiju, gde je počeo piti, preteći se birtašici da će je ubiti ako mu neda piće." 890

I u Gjokinom slučaju svjedoci spominju raniji sukob pri kojem je Gjoka čak i pretrpio ozljedu glave, što upućuje na činjenicu da je Gjoka duže vrijeme bio izvor problema za Ostrovljane. Budući da je Gjoka opisan kao epileptičar liječnik se mora osvrnuti na vezu te pretpostavljenu vezu te bolesti s podmetanjem požara zaključivši svoje izvješće jednostavnom primjedbom „Dali je palikuća ne može se doznati."

U slučaju Petra S., seljaka iz Starog Čiča priroda bolesti problematičnog pojedinca postala je predmetom prijepora između predstavnika zadruge kojoj je Petar pripadao i stenjevačkih liječnika. Petar je u Stenjevcu bio u pet navrata između 1890. i 1911. kada je umro od tuberkuloze. Svaki njegov boravak trajao je nekoliko mjeseci i postavljan mu je niz dijagnoza od „acutne hallucinatorne bezumnosti” preko „manie periodice”, „epilepsie” i „psychose” periodice do ,amentie periodice catatonice”. Nakon svakog boravka bio je otpušten s napomenom „poboljšan” ili „,izlječen”. U Stenjevačkoj povijesti bolesti je redovito opisan kao „smeten” i primijećeno je da često govori o religiji ${ }^{892}$ No, činjenica da Petra otpuštaju iz bolnice izaziva negodovanje drugih članova njegove zadruge koji redovito pišu pisma upraviteljima Stenjevca, tražeći da se Petra tamo stalno zadrži. U pismima, zadrugari opetovano opisuju Petra kao opasnog i opetovano ističu strah od požara kao primarni razlog zbog kojeg bi Petra trebalo zatvoriti:

„Mi smo svi celo selo jedan drugoga blizu sa zgradami a svoje staine slamom pokrivamo, drugo, nas im a u zadrugi Sobolski osim Petra 13 dušah ili osoba mi po običaju svi u jednu sobe stanujemu i spavamo, što bog da čuvaj da on dođe van što bi mogel štete počiniti u jedne noći kada društvo po zaspava on je pogibeljan i radi ubojstva i radi požarne propasti, molim lipo meni kao molitelju bilo bi mi jako drago da moj Petar dodje kući zdrav i bistra uma...ali ako bi on obstrelan na pogibel, bolje da bude tamo gdje je kao što su i drugi koji su pogibeljni." ${ }^{893}$

890 KPV, 1911: 8086.

891 Ibid.

892 KPV, 1911: 4356.

893 Ibid. 
Pismo zadrugara iz 1892, također spominje Petrovu pokojnu „ludu majku”894 i ističe element herediteta, kojeg liječnici u njegovom slučaju ne spominju.

Gjuro K. dvadesetšestogodišnji seljak iz Kozarevca patio je čitav život od epileptičnih napadaja. Poslan je u Stenjevec 1903. godine, a obaveznoj i šturoj liječničkoj svjedožbi priložena su pisma župnika i njegovog oca. Njegov otac piše da ga je dvaput uhvatio kako pokušava potpaliti štagalj, a župnik navodi kako je prijetio da će potpaliti i kuću. Gjuro negira sve ove navode, a iako nije pokazivao znakove agresivnog ponašanja niti opsesije vatrom, ipak je zadržan u Stenjevcu punih osam godina, sve do $1911 .^{895}$

Slučajevi navedenih štićenika pokazuju da je uklanjanje problematičnog člana zajednice u psihijatrijski zavod često bila aktivnost oko koje su se angažirale osobe koje su smatrane autoritetima u zajednici poput župnika i predstavnika zadruge. Također, liječnici nisu uvijek bili pretjerano skloni medikalizirati sukobe unutar zajednice, često u povijestima bolesti dajući glas štićenicima i zapisujući njihovo poricanje optužbi. S druge strane, sukobi između zajednice i stigmatiziranih pojedinaca često su bili dugotrajni, a poticaj za obraćanje vlastima najčešće je bila nenadana eskalacija nasilja i trenutak u kojem pojedinci iz ekonomskih ili nekih drugih razloga više nisu mogli računati na potporu svojih obitelji. Eskalaciji nasilja ipak je često prethodio dugotrajan period u kojem bi stigmatizirani pojedinac svakodnevno trpio zlostavljanje i izolaciju od strane svojih sumještana. Samim time, njihovo je nasilje često bilo tek dramatična reakcija na situaciju koja se činila nepodnošljivom.

Takav razvoj možemo pratiti u oba slučaja paleža koje je Dragutin Forenbacher opisao u članku naslovljenom „Dva slučaja paleža, kao prilog k psychiatricko-sudbenoj praksi”. Članak je izišao u dva broja Liječničkog vjesnika iz 1888. godine. Foenbacher u članku opisuje forenzička vještačenja dvojice muškaraca iz Bjelovarske županije, gdje se po Forenbacheru ,palež osobito često počinja." 896 Počinitelji paleža o kojima Forenbacher piše su muškarac koji je patio od epilepsije i drugi koji je opisan kao osoba s poteškoćama u intelektualnom razvoju. Glavni motiv njihovih zločina bila je osveta za zlostavljanje koje su pretrpjeli od strane suseljana. Prvi počinitelj bio je S.G. dvadesetogodišnji seljak iz Severina. Prema Forenbacherovoj kliničkoj slici S.B. nije polazio školu, pa nije znao ni čitati ni pisati, već četiri godine patio je od epileptičnih

894 Ibid.

895 KPV, 1911: 5598.

896 Forenbacher, 1888: 85. 
napadaja koji su ga spopadali jednom mjesečno. Pored toga opisivan je kao miroljubiv i pošten čovjek. ${ }^{897}$ S. B. je, prema rezultatima istrage zapalio kuću svog kuma, nakon što ga je ovaj iz nepoznatih razloga nekoliko puta udario po ramenu. Forenbacher u svojoj sažetoj analizi izbjegava zločin paleža i emociju bijesa kojom je S. B. reagirao nakon ničim izazvanog napada dovesti u direktnu vezu s S. B. - ovom epilepsijom. S.B.-ov odvjetnik bazirao je obranu pred sudom na činjenici da je njegov branjenik patio od napadaja. Forenbacher jednostavno ističe da je palež „bio motiviran srčbom i osvetom, a izveden je u psycholožkom načelu”. ${ }^{998}$ Emociju „srdžbe” Forenbacher spominje na nekoliko mjesta u tekstu ističući da je ovakvo njezino iskazivanje i osveta putem paleža sasvim očekivana za ruralnu sredinu u kojoj je S. B. živio: „U toj srčbi, a u namisli na osvetu, obtuženik namah ju i izvede; - izvede na način, koji je u onoga diela našega naroda i najobičniji, naime paležem". ${ }^{899}$

Drugi slučaj, čiji je prikaz nažalost nedovršen u Liječničkom vjesniku tiče se S.J. -a, koji nije patio od padavice, ali je prikazan kao odgojno zapušten čovjek s poteškoćama u razvoju. Prema Forenbacherovoj anamnezi, majka se nije brinula za njega, udavši se ponovno nakon očeve smrti te nije naučio govoriti ni hodati do pete godine. Općinsko poglavarstvo opisalo ga je kao „razuzdana i nećudoredna čovjeka” ${ }^{900}$. Forenbacher u svom vještačenju naglašava da je S. J. često trpio porugu i nepravedan tretman od strane suseljana: opisivali su ga kao „budalu nesposobnu za ikakav rad osim čobanstva" lijenog i nesposobnog čovjeka sklonog ispadima bijesa kojeg su seoska djeca zadirkivala rugalicom „brusnica i šogor”. ${ }^{901}$ S.J. je uhapšen nakon što je zapalio štagalj svog bivšeg gazde J.M.-a nakon što mu je ovaj odbio dati plaću, a u požaru je poginulo i dvoje J. M.- ove malodobne djece koja su spavala u štaglju. Budući da je cilj vještačenja bilo prosuditi je li S.J. u trenutku kad je počinio čin paleža (i potencijalno, umorstva) bio smanjeno ubrojiv, Forenbacher mnogo vremena posvećuje postupcima J. M.-a i ostalih seljaka koji su mogli nagnati okrivljenika na čin osvete. S. J.-a su nagovarali da u ponoć nosi križ na groblje kako bi dokazao kako se ne boji sablasti ${ }^{902}$, J.M. ga je naveo da umjesto njega preuzme krivnju za štetu počinjenu u šumi i odleži u zatvoru, često ga zapošljavali da im obavlja razne poslove nalazeći izlike da mu ne plate, tvrdeći da su svinje koje je čuvao počinile štetu. ${ }^{903} \mathrm{Sam} \mathrm{S}$.

897 Ibid.

898 Ibid: 87.

899 Ibid.

900 Ibid: 148.

901 Ibid.

902 Ibid.

903 Ibid: 149-150. 
J. Je istakao da ga je štagalj zapalio iz osvete jer mu J.M. nije platio za mjesec dana rada, te ga nastavio zadirkivati. ${ }^{904}$ Iako su okrivljenici pokazivali znakove duševnog oboljenja, Forenbacher u navedenim slučajevima prepoznaje sukobe koji su se događali u seoskim zajednicama kao motiv zločina i ističe učestalost paleža u sličnim sukobima.

Najdetaljnije opisan slučaj paleža u forenzičkoj praksi stenjevačkih liječnika onaj je Save Dragosavljevića, pedesetsedmogodišnjaka iz Dugog Sela. Sava Dragosavljević doveden je u zavod 24. listopada 1902. godine iz pritvora Kraljevskog sudbenog stola u Zagrebu gdje je bio pod optužbom da je 18. lipnja iste godine zapalio kuću Milke Dragosavljević i Vuje Dragosavljevića, te pokušao zapaliti kuću Nikole Dragosavljevića ${ }^{905}$ Prema izjavama očevidaca Sava je Milkinu kuću zapalio potpalivši slamnati krov šibicom dok je Nikolinu kuću pokušao zapaliti na osobito bizaran način: ušao je u kuću i bacao rukama žeravicu na krov dok ga domaćica Petra Dragosavljević i njezina kćer Milica nisu otjerale. ${ }^{906}$ Seljani su ga pronašli mokrog u jednoj šikari, prema svjedočenju jednog od seljaka: „s pjenom u ustima, držeći mokre žigice u ruci od kojih su se glavice pušile; on je bulaznio i svakojake gluposti govorio" ${ }^{907}$ Seljaci su grubo postupali s dezorijentiranim Savom: vukli su ga pod ruku, tjerali da hoda preko brvna i prijetili mu da će ga baciti u vatru ${ }^{908}$ a zatim su ga svezali i ostavili pred zgarištem jedne od kuća cijelu noć tako da mu je „kiša u usta padala”909 da bi ga tek ujutro predali oružnicima. Sava je, prema izjavi suda već ranije dolazio u sukob i sa zakonom i sa seljanima. Prvi put je osuđen na osam dana zatvora 1890. godine zbog sprečavanja pljenidbe. Prema Savinoj izjavi danoj liječniku, pokušali su greškom plijeniti svinju njegove žene zbog štete u šumi koju je počinio Savin pokojni brat. Drugi put se 1896. posvađao sa susjedom i potukao se sa njim te bio osuđen na tri dana zatvora. Suseljani su ga također sumnjičili da je prije nekoliko godina zapalio kuću Stevana Radosavljevića ${ }^{10}$. Također, općinska svjedodžba opisivala je Savu kao „zlobnog i opakog čovjeka silovitog vladanja." ${ }^{\prime 11}$

904 Ibid: 150 .

905 Žirovčić, 1908: 231.

906 Ibid.

907 Ibid.

908 Ibid.

909 Ibid: 233.

910 Ibid: 232.

911 Ibid: 231. 
Kao što je bio slučaj i s ostalim štićenicima poslanima u Stenjevec nakon nekog nasilnog čina i kod Save je prisutna duga povijest sukoba sa zajednicom u kojoj je živio. Poput većine ostalih, Sava se u Zavodu ponaša mirno i ne pokazuje sklonost nasilnom ponašanju ni ispadima bijesa. Prema Žirovčićevom kazivanju mirno govori svoju verziju događaja: cijeli dan je okapao zemlju, išao je obići svoju kćer Jelicu koja je bila sa stokom na paši. Čuo je povike o vatri, potrčao prema selu i putem pao u lokvu vode. Srela su ga trojica suseljana, prijetili mu da će ga baciti u vatru i zavezali ga. Negira da je ikad bio duševno bolestan, a naročito se čudi izjavi da je bacao žeravicu golim rukama na kriv, izjavivši: „ta ne bi ni najbedastiji ovdje toga učinio, a gdje bi ja koji nisam bedast." ${ }^{912}$ Također, tijekom ispitivanja ističe se da niti jedan svjedok nije prisegao da je sa sigurnošću vidio Savu kako pali kući, osim Petre Dragosavljević. ${ }^{913}$ Ivan Žirovčić je dobio dojam da je Sava Dragosavljević miran i zdrav čovjek bez simptoma bilo kakvih duševnih bolesti i epilepsije. Budući da nikad nije bježao od natruha senzacionalizma kad je pisao o slučajevima iz svoje forenzičko-psihijatrijske prakse, naslovio je svoj članak „Zagonetan palež”. Usprkos povijesti sukoba između Save i suseljana i sudske presude u kojoj je stajalo da je Sava sposoban za čine nasilja, Žirovčić se ipak odlučuje njegov čin objasniti epileptičnim napadajem - čini se jedinim u Savinom životu. Pritom Žirovčić daje opis epilepsije koji se uvelike oslanjao na Lombrosove poglede.

Žirovčić velik značaj za dijagnozu epilepsije pridaje hereditarnim stigmama poput asimetrije lubanje („Lubanja napadno malena, opseg 540, širina 153, duljina $183 \mathrm{~mm}$, nepravilna, čelo nisko, tjeme verugasto, zatiljnica izbočena) ${ }^{914}$ pritom uopće ne spominjući osjetljivost na dodir, niti ruku koju Dragosavljević preferira. Također, Žirovčić potvrđuje da Dragosavljević nije imao niti jedan epileptični napadaj za vrijeme boravka u zavodu, iako je čitava dva mjeseca bio „dan i noć pod paskom bolničarskog osoblja." ${ }^{915}$ Prepoznavanje uobičajenih hereditarnih stigmi bilo tjelesnih (asimetričnost lubanje) ili psiholoških (neuobičajeno miran ili „silovit” karakter,) i nedostatak jasnog motiva kod Žirovčića će imati daleko veći značaj za prepoznavanje epilepsije od prisutnosti epileptičnih napada u ranijoj anamnezi Uz pasku bolničara, liječnici su, ozbiljno shvaćali psihijatrijska vještačenja i prema Žirovčićevoj izjavi posjećivali su Dragosavljevića dvaput dnevno pomno bilježeći i prateći njegovo ponašanje i duševno stanje. Opisali su ga kao

912 Ibid: 232.

913 Ibid: 233.

914 Ibid: $231-232$.

915 Ibid: 233. 
razumnog, mirnog, strpljivog i bistrog čovjeka. ${ }^{916}$ Takav opis je bio prilično daleko od osobe kakvom je Dragosavljević prikazan u općinskoj svjedodžbi- silovit i nasilan čovjek već dvaput pritvaran zbog buntovnog ponašanja i tučnjava. No, Žirovčić sljedeći Lombrosa, zaključuje da Dragosavljevićev miran i staložen karakter prikriva oblik epilepsije koji se manifestira neobjašnjivim ispadima nasilja. Za Žirovčića, inače sklonog demistifikaciji duševnih bolesti, „bitnost epileptične bolesti još je neotkrita tajna" ${ }^{917}$. Žirovčić epilepsiju dijeli na najčešći tip u kojem bolesnici „padaju i doskora se tresu u grčevitoj trzavici mišićja” zatim „epileptičnu absentiu” koja se manifestira samo kratkotrajnim gubitkom svijesti, „epileptični somnambulizam” u kojem ljudi „dospiju u stanje trajne duševne omračenosti”, ali su i dalje sposobni obavljati kompleksne radnje, hodati i govoriti, te „epileptični delir”" ${ }^{918}$, stanje kojim će Žirovčić tumačiti Dragosavljevićeve postupke.

Žirovčić daje slikovit opis ,epileptičnog delira” i objašnjava povezanost istog s nasiljem: ,...tu probijaju u duševnosti patnika strašne tlapnje, halucinacije i iluzije na koje on odvraća otporom i groznim činima; tu se dakle na mjesto običnih epileptičkih grčeva pojavlja silna trzavica u obliku sporedjenih kompliciranih čina, a kako je sadržaj epileptičnih tlapnji obično zastrašujući, to ide reakcija snatrećeg epileptika ponajviše u smjeru uništavanja, ubijanja, mrcvarenja, paljenja, osobito paljenja! Epileptici imadu često priviđenja crvene boje, a buduć oni tako često ubijaju i pale, to se misli da u njih između crvenih halucinacija, predstava crvene krvi, crvene vatre i konačnih silovitih čina opstoji neki asocijativni uzročni savez"919

Za Žirovčićevo shvaćanje epilepsije je ključno da se manifestira nekim oblikom „trzavice”- bilo grčenjem mišića tijekom epileptičnog napada ili grčevitim nasilnim djelima, koje Žirovčić, zanimljivo, dovodi u vezu s halucinacijama „crvene boje” stvarajući asocijativnu vezu između poriva za podmetanjem požara i iskustava osoba koje pate od epilepsije. Žirovčić također postulira da se taj specifičan oblik epilepsije može manifestirati samo jedanput u životu ,jer takvih slučajeva ima zabilježeno u kazuistici kriminalne psihopatologije" 920 Žirovčićeva dijagnoza rezultirala je prekidom sudskog procesa protiv Save Dragosavljevića koji je proveo još pet godina života u zavodu, prije nego što je kao zdrav otpušten kući. Za vrijeme svog boravka,

916 Ibid.

917 Ibid: 234.

918 Ibid: 233-234.

919 Žirovčić, 1908: 234.

920 Ibid: 235. 
ponašao se mirno i razumno, pišući kući da bi se raspitao o svojoj obitelji i nastojeći brinuti o svom gospodarstvu iz zavoda. ${ }^{921}$

Sukobi u ruralnim zajednicama ponekad su rezultirali i umorstvom ili pokušajem umorstva. Slučaj Tome Mihalića iz Kajgane kod Garešnice, koji je 29. studenog 1909. predan u Stenjevac na motrenje nakon što je pokušao iz revolvera ubiti svog suseljana Filipa Rietkovića daje tragičnu sliku dugotrajnog sukoba u zajednici koja je rezultirala jednim umorstvom i jednim pokušajem ubojstva.

Tomo Mihalić, bio je rodom iz Klokočevca, a doselio je u Kajganu 1904. godine kad je otkupio posjed ženine braće, nekih Malekovića iz Kajgane. Kao pridošlica od početka se nije snašao u Kajgani i bio je umiješan u brojne sudske rasprave: 1905. godine je udario i ozlijedio Petra Malekovića jer je potonji „zatjerao race u njegovu travu”"922. Dvije godine kasnije pretukao je Evu Gojak šakama jer ga je „potvorila da je ukrao luka,” zbog čega je također osuđen na dva dana zatvora, a 1908. osuđen je na tri dana jer je „ćušnuo Maru Aržek koja je htjela otjerati svoju svinju „koju je on pritvorio jer ju je našao pod svojoj jabukom u kvaru" ${ }^{23}$. Osim toga opisao je stanovnike Kajgane kao „nesnosljive i svadljive ljude" ${ }^{24}$ koji su mu bili zavidni na njegovom bogatstvu. Očito je Mihalić radi ženidbene veze uspio povoljno kupiti dobro zemljište koje su mnogi Kajgančani vjerojatno htjeli za sebe. Nasilje je eskaliralo nakon što je bio svjedok u sudskom procesu protiv grupe ljudi koji su ubili jednog duševno bolesnog čovjeka, motivirani strahom od njega. U spisu nam je dostupna jedino Mihalićeva verzija događaja. Mihalić navodi da se Miško Gjurović, „slabouman čovjek” vratio iz Lepoglave gdje je služio zatvorsku kaznu radi umorstva. Seljaci su ga optuživali da krade i bili u strahu od njega. Na kraju su ga dvanaestorica seljaka namamili u jednu kuću gdje su ga „zlostavljali” dok nije podlegao ozljedama ${ }^{925}$ Mihalić se pojavio kao svjedok na suđenju toj dvanaestorici čime je navukao na sebe bijes suseljana. Trojica seljaka umiješana u incident navodno su sačekala Mihalića kad se vraćao iz krčme te su ga isprebijali dok nije izgubio svijest. Sutradan ih je prijavio sucu u Garešnici. No njegova tužba je odbačena jer svjedoci koje je imenovao nisu pristupili prvom ročištu, a s drugog je bio odsutan sam Mihalić. ${ }^{226}$ Filip Rietković, na kojeg je Mihalić ispalio tri hitca iz revolvera, 921 Ibid.

922 Žirovčić, 1912: 151.

923 Ibid.

924 Ibid.

925 Ibid: 153.

926 Ibid: 152. 
bio je jedan od trojice seljaka koji su sudjelovali u napadu na Miška Gjurovića i koji su bili oslobođeni krivnje. Mihalić se branio da nije htio ustrijeliti Rietkovića već samo izazvati sudski postupak „da njihova stara raspra opet dođe na sud” jer se osjećao oštećenim time što Rietković i druga dvojica napadača nisu bili osuđeni prvi put. ${ }^{927}$ Mihalić je naime bio uvjeren da su mu u tučnjavi nanesene ozbiljne i potencijalno smrtonosne ozlijede, iako su liječnici tvrdili da je potpuno zdrav. ${ }^{928}$ Osjećao je veliki revolt zbog nespremnosti svjedoka da se pojave na suđenju i zbog sudske odluke da odbaci njegovu tužbu, te se ustrajno žalio liječnicima i bolničarima na nepravdu koja mu je nanesena.$^{929}$

Nakon što je bio optužen za pokušaj ubojstva, Mihalić je postao još više razočaran u pravosudni sustav, bijesan što su njegove pritužbe ignorirane i što ga se navođenjem prethodnih presuda izrečenih protiv njega nastojalo opisati kao konfliktnu i nasilnu osobu. Svoj bijes je izrazio tijekom razgovora s liječnikom u Stenjevcu i Žirovčić je pomno zabilježio njegove emocije:

„Pri tom dolazi u afekt zacrveni se u licu, govori glasno i uzvišenim tonom, ljuti se, zašto ga nisu odmah poslali ovamo, kako je branitelj predložio, vriedjalo ga je, kad mu je sudac čitao njegove prijašnje kazne, a to su bile sitnice, zatvor je bio pretvoren u globu, i on ju je platio, pa o tom nije trebalo više govoriti. ${ }^{"} 330$ Upravo je njegovo ustrajanje u tvrdnjama da je ozbiljno ozlijeđen i da će uskoro umrijeti bilo razlogom zbog kojeg je Mihalić upućen na forenzičko vještačenje u Stenjevec. Žirovčić je zaključio da Mihalić pati od bolesti koju je nazvao paranoia hypochondrica - vrsta paranoje koju karakteriziraju patološke misli o vlastitom oboljenju ${ }^{931}$. Njegovu želju da nastavi tražiti zadovoljštinu pred sudom, čak i pod cijenu toga da bude optužen za pokušaj umorstva, Žirovčić je objasnio drugim paranoidnim poremećajem natruhe kojega su se počele javljati kod Mihalića - paranoiom querulans - „pravdaškom ludošću” ${ }^{932}$ vrstom poremećaja karakteriziranom stalnom željom oboljelog da se upušta u parnice i obraća se sudovima.

Za razliku od Forenbacherovih ranijih vještačenja, vidimo da Žirovčić u Dragosavljevićevom i Mihalićevom slučaju ignorira specifičnu pozadinu sukoba između optuženika i ljudi iz njihove životne sredine svodeći razloge njihovih dijela isključivo na njihovu biološki determiniranu

927 Ibid: 154.

928 Ibid: 157.

929 Ibid: 155.

930 Ibid.

931 Ibid: 157.

932 Ibid: 158. 
duševnu bolest. U Dragosavljevićevom slučaju bolest je zagonetni oblik epilepsije, „delir” koji se kod njega manifestirao samo jednom, nestao jednako naglo kao što se i pojavio i natjerao ga na čin paleža. Kod Mihalića, radilo se u uznapredovaloj paranoji koji ga je navodila da traži sudsku zadovoljštinu. Iako oba slučaja daju poprilično detaljnu povijest sukoba između optuženika i drugih ljudi iz njihove sredine (Mihalićev slučaj čak govori o ranijem ekstremnom nasilju grupe stanovnika Kajgane prema duševno oboljeloj osobi) Žirovčić ne spominje osvetu ili bijes niti se osvrće na moguće motive počinjenih djela gledajući nasilje i bijes primarno kroz prizmu somaticističke psihijatrije.

U slučajevima sukoba u ruralnim sredinama, psihijatrijski je diskurs često bio preuziman $\mathrm{i}$ korišten od laika članova zajednice, nositelja administrativne vlasti i crkvenog autoriteta. S druge strane, psihijatri su ga koristili kako bi legitimirali svoju poziciju medicinskih radnika i na naoko objektivan te znanstveno utemeljen način pokušali objasniti brojne slučajeve nasilja.

Uključivanje psihijatrije u sukobe između neprilagođenih pojedinaca i zajednice često je dovodilo do prodora psihijatrijskih ideja, poput onih o hereditetu i povezanosti između epilepsije i nasilničkog ponašanja u zajednice i nudilo prihvatljiv okvir za promatranje i klasificiranje oblika ponašanja koje se smatralo devijantnima. Psihijatri su ponekad, ponajviše inspirirani idejama Cesarea Lombrosa o povezanošću epilepsije i neobjašnjivih nasilnih zločina. No u nekim slučajevima, stenjevački su liječnici, komunicirajući s kotarskim i općinskim liječnicima, lokalnim vlastima i autoritetima poput poglavara zadruge, župnika i sudova, uistinu ulazili u međuljudske odnose unutar zajednica, nastojeći razlučiti medicinske uzroke devijantnog ponašanje od društvenih devijacija koje bi rezultirale nasiljem. Naravno ti su odnosi često tumačeni na izrazito moralistički način, u skladu s uvriježenim pogledom na selo kao prostor $\mathrm{u}$ kojem vladaju alkoholizam i ,primitivne strasti”, bez naročitog osvrta na društveni kontekst bijesa i agresije. Također, u skladu s poimanjem psihijatrije kao grane medicine čija je svrha liječenje ljudi, psihijatri nisu bili skloni smještanju devijantnih štićenika u zavode, tim više što su isti često bili nemirni i nasilni, te je u lošim uvjetima u kojima je Zavod za umobolne u Stenjevcu djelovao za njih bilo teško skrbiti. 
Komunikacija između šire javnosti i zavodskih liječnika stavila je i dodatan pritisak na same liječnike. Istovremeno, liječnici su se našli u situaciji da odgovaraju na potrebe širih zajednica koje su od njih zahtijevale zatvaranje devijantnih i nasilnih pojedinaca iza zidova psihijatrijskih zavoda. To je značilo da zavodi nisu više mogli biti isključivo prostorom skrbi za duševno oboljele, kakvima su zamišljeni u danima „moral treatmenta” već su u sve većoj mjeri služili institucionaliziranju devijantnih pojedinaca. Slično se dogodilo u sudskim slučajevima, kad je prosudba od strane psihijatra značila smještanje optuženog u zatvor ili zavod. Psihijatrija se, kroz proces medicinskog reguliranja slučajeva nasilja, polako preobražavala u instituciju društvenog nadzora. Uz pomoć vlastitog epistemičkog autoriteta psihijatri su, arbitrirajući i opisujući nasilje pojedinca prema drugim pojedincima i zajednice prema pojedincu, konstruirali ruralnu zajednicu konflikta i stigmatiziranog epileptičnog ili paranoičnog pojedinca. Psihijatrijski diskurs postepeno je zamjenjivao raznolike i polifone glasove bijesa i osvete unificirajućim narativima somaticističke psihijatrije i kriminalne antropologije. Ti narativi postat će naročito važni kad devijantni pojedinci postanu nositeljima devijantnih političkih ideja i kad njihov bijes postane usmjeren na postojeći politički poredak. Uloga psihijatrije kao institucije društvenog nadzora doći će u prvi plan kad psihijatri dobiju ulogu u sukobima koji su imali politički karakter.

\subsection{Anarhisti i atentatori: politički sukobi u psihijatriji 19. stoljeća}

Do kraja devetnaestog stoljeća mnoge nove i radikalne političke ideje prodrle su do šire javnosti. Neki od uzroka njihova širenja su u sve većoj prometnoj povezanosti, urbanizaciji i porastu pismenosti i raširenosti političkog tiska usprkos prisustvu cenzure u većini europskih zemalja. Politika prestaje biti „regnum arcana” i ne odvija se više u dvorovima i ministarskim kabinetima kako je to bio slučaj ranije, već se polako preljeva u javnost. I dok su javne manifestacije političke moći poput trijumfa i krunidbi već tisućljećima služile za njezinu legitimaciju u dugom devetnaestom stoljeću sve vidljivijima postaju i javne manifestacije političkog otpora: agitacija, pamfleti, štrajkovi, demonstracije pa sve do jedne od najdramatičnijih: političkog atentata. Modernizacija utječe na formiranje brojnih novih ideja o političkom uređenju društva, no ona također mijenja emotivne režime i poglede na identitet. Pojedinac koji se formira u okviru modernizirajućih društava također prolazi transformaciju i u svojim se idejama, emocijama, obrascima ponašanja i svakodnevnom životu često nalazi između ,tradicionalnog čovjeka” i individualca modernog doba. U svojoj studiji političkog i religijskog ekstremizma u Ujedinjenom Kraljevstvu viktorijanskog doba, engleski povjesničar književnosti Clive Bloom nazvao je 
devetnaesto stoljeće stoljećem u kojem su ,nerealizirano sebstvo i nerealizirana država, oboje s naizgled beskrajnim potencijalom, $\mathrm{u}$ jednakoj mjeri postojali unutar glava ljudi i u vanjskom svijetu i kad su revolucionari smatrali da utjelovljuju budućnost ili ju donose svjedočeći Evanđelje politike koju su prigrlili."

U takvim okolnostima izljevi političkog bijesa i političkog nasilja postali su sve učestaliji. Revolucionari spremni na nasilje, često su legitimizirali svoje akte iznoseći nove političke ideje, nepoznate velikom dijelu javnosti. Nakon što bi bili optuženi za nasilne zločine, često su dolazili pod povećalo psihijatrije, koja je već u svojim počecima nastojala proširiti svoj autoritet i na tumačenje i potencijalno liječenje zločinačkog ponašanja. Jedno od najranijih suđenja atentatorima, bilo je suđenje Jamesu Hadfieldu, članu milenarističke sekte, koji je 1800. godine pucao na kralja Georgea III. Na njemu još nisu svjedočili psihijatri, ali su dvoje kirurga i liječnik za kojeg je sud utvrdio da je „stručan u pogledu ludila” utvrdili da je Hardfield pucao na kralja u stanju pomućenog uma, što je dovelo do oslobađajuće presude. ${ }^{934}$ Psihijatri su imali presudnu ulogu 1840. i 1843. godine prilikom suđenja Edwardu Oxfordu, osamnaestogodišnjaku koji je pokušao ubiti kraljicu Viktoriju i Danielu M'Naghtenu koji je ustrijelio Edwarda Drummonda, premijerovog tajnika. Na Oxfordovom suđenju sudjelovao je John Connolly, jedan od vodećih autoriteta na polju „moral treatmenta” u Velikoj Britaniji sredinom stoljeća, dok su vještaci na M'Naghtenovom bili ugledni liječnici iz psihijatrijskih zavoda u Londonu i Glasgowu Edward Thomas Monro i William Hutchinson. ${ }^{935}$ Obojica okrivljenika oslobođena su optužbi zbog vlastite neubrojivosti u trenutku počinjenja kaznenog djela. Ovi slučajevi, doveli su do ispreplitanja političkog, pravnog i medicinskog polja, a činjenica da su atentatori čija su djela prijetila državnom poretku izbjegli smrtnu kaznu intervencijom psihijatara legitimirali su ulogu psihijatrijskih vještaka u sudskim procesima i naveli pravnike da pokušaju formulirati što je moguće jasniju definiciju pravne ubrojivosti.

Štićenici koji su na neki način došli u sukob s vlastima i izražavali bijes prema institucijama moći bili su prisutni u Stenjevcu od otvaranja institucije. Jedna od najranijih povijesti bolesti je ona učiteljice pletenja Klementine B. preuzete iz Bolnice milosrdne braće koja je 1876. javno prijetila

933 Bloom,2013: 3.

934 Jones, 2016: 64.

935 Ibid: 73 . 
pred zgradom gradsko-delegiranog kotarskog suda u Zagrebu. Sačuvano je i njezino liječničko izvješće iz gradske bolnice u kojem je opisan Klementinin čin:

„Proljećem i lietom o.g. vidjevala se obično pred večer i to u Ilici, na Jelačićevom i Zrinskom trgu visoka žena, blieda i suha,živahna i nestalna pogleda vazda jednako vrlo neukusno i previše nakićeno i ureseno odjevena, vazda sama, lagano hodajući, svakoga koga sretne začuđeno gledajući,katkada se smješeć, kadkada namrgodiv lice, u jednoj ruci suncobran u drugoj rubac i lepeza, kod muzike vazda glavom kimajući po taktu glazbe: to bijaše Klementina B., učiteljica koja jedva umije svoje ime potpisati- nu kojoj to ne bijaše predmet poduke-ona nauča plesti čarape... Dan kad je privedoše ovamo u zavod šetala se vrlo brzo po Markovom trgu pred delegovanim sudom mašući u ruki s velikim kuhinjskim nožem grozeći se š njim naprama raznim kućama najčešće naprama navedenom sudu." ${ }^{936}$

Liječnik koji je sastavio izvješće o Klementininom ponašanju u njezinom slučaju radi stilski otklon od uobičajenog načina pisanja liječničkih izvješća i prepričava njezin napad na delegirani sud na romantiziran i pomalo podrugljiv način. Može se reći da liječnik, u određenoj mjeri, čak literarizira događaj o kojem piše, ubacujući u njega izrazito subjektivne detalje poput „Živahna i nestalna pogleda" ili izraza njezinog lica te ubacivši ime pacijentice tek u sredinu odlomka kao da mu je cilj graditi neki oblik dramske napetosti unutar forme medicinskog dokumenta. Klementina progovara o svom postupku na samom kraju izvješća. Nažalost, njezin je iskaz dosta štur a govor posredovan:,...bila je vrlo nemirna, uzrujana, da s nožem nije nikog raniti ni ubiti htjela, već da je htjela samo predstojniku delegovanog suda, kaj misli da ona hrabra nije, pokazati htjela da je ona vrlo hrabra nu da mu nije ništa učiniti htjela." ${ }^{" 937}$

Točan razlog Klementininog nezadovoljstva predstojnikom suda nije zanimao liječnike. U Stenjevcu Klementini je originalna dijagnoza „hysteria” prepravljena u „Vesaniu”. Otpuštena je 1880. godine. Taj slučaj jedan je od rijetkih slučajeva gdje se politički sukob navodi kao jedan od povoda institucionalizacije, a sudeći po povijestima bolesti politika se ne javlja često u govoru štićenika (izuzetak su štićenici s teškim deluzijama koji tvrde da su političke figure). Jedan od najintrigantnijih slučajeva intervencije psihijatrije u političke procese počet će 1897. prvim dolaskom Miloša Krpana u Stenjevec. Miloš Krpan bio je pučki učitelj u selu Dubovik kraj Slavonskog Broda, a rođen je 1862. u mjestu Lipe kraj Gospića kao dijete siromašnih roditelja sa

$936 \mathrm{KPV}, 1879-1880: 162$.

937 Ibid. 
sela. ${ }^{938}$ Usprkos skromnom porijeklu i formalnom obrazovanju koje se sastojalo samo od učiteljske preparandije u Petrinje, Krpan je kao autodidakt stekao široko obrazovanje iz povijesti i filozofije, a u mladosti je uspio proputovati Palestinu, Egipad, SAD, Kanadu, Njemačku, Francusku, Belgiju i Englesku formiravši se kao čovjek širokih političkih pogleda koji je imao poznanstva diljem Europe. Njegovi politički nazori bili su poprilično kompleksni: hvalio je Antu Starčevića, nazivajući ga „sjajnim meteorom"939 deklarirao se kao anarhist i socijalist, bio izrazito anti-klerikalno nastrojen te je bio načelnik općine Podvinje na listi Komunističke partije Jugoslavije 1920. godine. U Stenjevac je prvi put dospio nakon što je seoski starješina Đuro Ostojić prijavio gradskom poglavarstvu u Brodu na Savi da „Miloš Krpan, socijalist na bunu diže seljake i čudne skupove s njima održava" ${ }^{940}$. Prilikom istrage, na školskom tavanu pronađeni su Krpanovi subverzivni spisi. Krpan je uhićen i optužen ,radi zločina pokušanog zavođenja na veleizdaju, uvrede članova C. i Kr. kuće ometanja javnog mira i ometanja vjerozakona."941 Optužnica je temeljenja na zaplijenjenim spisima koje je Krpan namjeravao objediniti u knjigu pod naslovom „Liepa naša Domovina” koju bi ilegalno distribuirao među lokalnim obrazovanim ljudima. Među inkriminiranim ulomcima iz Krpanove nikad objavljene knjige je izjava kako je dužnost „svih ljudi srca i razuma da se late na obranu svoje zasužnjene braće noža, puške, bodeža, dinamita da ruše tirane, crkve i prestolja" ${ }^{942}$ te uvrede izrečene na račun carice Marije Terezije koja je „dielila spajiluke svojim razkalašenim priležnicima ali mantijaši i zavedena prostačina i danas vapi za vladom majke carice jer je ona popovske Werkstatte zidala." 943 U optužnim spisima Krpan se nekoliko puta naziva socijalistom i anarhistom, predstavljajući program anarhizma kao internacionalan i vođen čovjekoljubljem: „Anarhizam ne poznaje vjere, narodnosti, zemlje, za njega je mjerodavna oplemenjena savjest, zajednička mater zemaljska kruglja i njezina djeca ravnopravno i radino čovječanstvo..."944

Sudski vještaci su na zahtjev Krpanovog odvjetnika Josipa Franka pregledali Krpana i iako su prilikom istrage prosudili da je „Miloš Krpan svojih djela svjestan, da je ubrojiv i za svoje riječi i djela odgovoran, no da se u njega razvila neka vrst megalomanije, koja je često preteča ozbiljne

938 Pejić, 2016: 143.

939 Ibid: 142.

$940 \mathrm{KPV}, 1899: 3745$.

941 Ibid.

942 Ibid.

943 Ibid.

944 Ibid. 
duševne bolesti. ${ }^{945}$ No, na samoj sudskoj raspravi vještak dr. Isidor Schliek je promijenio svoj iskaz i donio mišljenje prema kojem Miloš Krpan nije ubrojiv. ${ }^{946}$ Krpan je na temelju tog mišljenja oslobođen optužbe. Ubrzo nakon oslobađajuće presude Krpan je postao jedan od rijetkih štićenika koji su sami zatražili smještanje u Stenjevec navodeći kao razlog da je „iz razlaganja sudbenog vještaka dra Schlieka pri sudbenoj raspravi, te iz obrazloženja osude razabrao da su se u njegovom životu pojavili znakovi koji se mogu tumačiti kao početak duševne bolesti, ali koji se mogu, po izjavi dr. Schlichta „mirnim životom i dobrom njegom izliečiti” pridodavši da „osjeća neku nervoznost." ${ }^{\text {} 947}$

Krpan u Stenjevcu iznenađuje liječnike svojim uglađenim ponašanjem i naobrazbom, kakvu čini se nisu očekivali od pučkog učitelja. Ipak, zapažaju na njemu određenu aroganciju i sklonost buntovnom razmišljanju. U statusu praesens, Krpan je opisan na sljedeći način: ,...miran, čist i dobro orientiran...govori mnogo kad ga se nagovori, ali sasvim logično i vrlo rječito...Akoprem je vrlo učtiv naspram liječnikom to se može opaziti da se drži bez dvojbe ako ne pametnijim to ipak isto tako pametnim i učenim kao što su oni. Ako što pripovieda to radi uvjek u nekom poučavajućem i odrešitom tonu, koji izključuje svaki protuslov te pokazuje kako je duboko i nepokolebivo uvjeren u istinitost svega što kaže." ${ }^{\text {"94 }}$

U zavodu su Krpana zamolili da napiše svoj životopis što je on, sa zadovoljstvom učinio. Životopis je bio naslovljen „Kaplja u moru ili iz života jednog nazovi-luđaka, napisao Krpan, Motto: empiričkom filozofijom za vječnim idealima." ${ }^{949} \mathrm{U}$ tom spisu, Krpan zaogrće svoju životnu priču u pomalo mesijansku auru kakvu je kod predvodnika novih političkih pokreta devetnaestog stoljeća opazio i Bloom. Navodi da je kao dječak jednom na paši čitao djela Vase Pelagića kad su ga srela dva „učenjaka evropskog glasa” koje je fascinirao svojom duhovitošću tako da su rekli da će „ovaj dječak jednom biti slavan muž” ${ }^{950} \mathrm{U}$ mladosti se zainteresirao za čitanje filozofskih djela, te je živio „kao pustinjak kloneći se svieta i njegovih bučnih bachanalia, jer je vidio da je sviet odviše sebičan i zloban" ${ }^{951}$. Odlučio je posvetiti život zalaganju za

945 Ibid. 946 Ibid.

947 Ibid.

948 Ibid.

949 Ibid.

950 Ibid.

951 Ibid. 
siromašne i od tog je trenutka njegov život bio nalik ,ladji na uzburkanom moru” i uvijek su ga proganjali „izprazni, sebični, okrutni, glupi, ljudi današnjeg društva, koji misle da će pomoću tamnice i ludnice održati svoje nakaradne odnošaje." ${ }^{952}$

Liječnici su, na temelju spisa priloženih optužnici i autobiografije zaključili da Krpan boluje od „paranoie originarie”. Nalaz iz zavoda pojašnjava Krpanovu dijagnozu:

„Ne ćemo ustvrditi da je on ludjak kakvoga si obično lajci (sic) predstavljaju već mislimo pod imenom paranoika čovjeka koji već od djetinjstva gaji na jednoj strani misli progonjenja a na drugoj misli precjenjivanja svoje osobe. Duševni abnormalitet takvog čovjeka netreba biti napadan njegovoj okolici, dapače taj čovjek može biti radi svojih ideja i nazora smatran vrlo učenim i ženialnim čovjekuljobom i borcem za poboljšanje ljudskih prilika." ${ }^{953}$

Za stenjevačke vještake spoznavanje društvene stvarnosti putem observacije i knjiga te kasnija borba za poboljšanje uvjeta života ljudi i usvajanje novih i revolucionarnih ideja bila je očekivana posljedica razvoja Krpanove paranoje:

„Ovakvi ljudi osjećaju se još od svoje mladosti pozvanima da postanu nešto velikoga. Najprije promatraju narav, odnošaje ljudske, uče i čitaju vrlo mnogo, postaju nezadovoljni sa postojećima odnošajima svojima i drugih ljudi, te hoće da svojim izvanrednim požrtvovnim radom i plamtećim govorom poboljšaju stanje ljudsko u smislu svojih novih ideja." ${ }^{954}$

U daljnjem tekstu medikaliziran je svaki element političkog i međuljudskog djelovanja Miloša Krpana: učtiv i pomalo nadmen govor i ponašanje postaju znakom da se Krpan drži boljim od većine drugih ljudi, njegovo pozivanje na kontakte s inozemnim učenjacima je ismijano kao pretjerivanje, a prepoznavanja svećenika i državnih službenika kao neprijatelja svojih ideja kao znak progonstvenih ideja. ${ }^{955}$ „Paranoia originaria” okarakterizirana je kao oblik neizlječivog i kroničnog ludila, koji se još nije manifestirao do kraja i koji će Krpana prije ili kasnije dovesti u sukob sa zakonom ili ćega dovesti do konačnog ludila. Pažnja je posvećena i opasnosti koja može doći od daljnjeg širenja Krpanovih ideja. U mnijenju je istaknuto kako u Krpanu postoji „neodoljiv nagon da svoje socijalističke ideje i svoje osebujne filozofične i znanstvene nazore u govoru i pismu raširuje" ${ }^{956}$. Taj nagon liječnici su smatrali opasni zbog njegovog zvanja kao

952 Ibid.

953 Ibid.

954 Ibid.

955 Ibid.

956 Ibid. 
pučkog učitelja, te su bili zabrinuti da bi Krpan mogao djeci koju podučava „u srdca usaditi sjeme mržnje prema postojećem zakonom i društvenim odnošajem. Kratko rečeno, mislimo da bi uzgajao moderne pesimiste." 957

Krpan je nakon nešto više od mjesec dana boravka u zavodu pušten kući na revers, na zahtjev Terezije Krpan, njegove supruge. Liječnici su se očito bojali da će dalje dolaziti u sukob s vlastima i Terezija Krpan je morala potpisati očitovanje u kojem stoji da će „osobito paziti da on nikakvih spisa na sudove i novine nešalje". ${ }^{958}$ To je jedan od rijetkih slučajeve u kojima se liječničkom preporukom nastojalo ograničiti javno djelovanje otpuštenog štićenika. Usprkos reversu, Krpan će u Stenjevcu završiti još jedanput 1898. godine, nakon što je optužen zbog uvrede vjerozakona jer je svom zamjeniku na mjestu pučkog učitelja u Duboviku u svađi opsovao Uskrs. ${ }^{959}$ Vještačko mišljenje uglavnom ponavlja prijašnje zaključke o Krpanovoj duševnoj bolesti samo što se ovaj put njegovo stanje dodatno medikalizira time mu se pretpostavljeni uzrok nalazi u činjenici da Krpan ,potječe iz hereditarno obterećene porodice” te da je „već u mladosti imao za svoje doba abnormalne nagone da, naime, marljivim čitanjem i velikim znanjem nadkrili svoje drugove". ${ }^{960}$ Neuobičajeni stavovi Miloša Krpana, zbog kojih je opetovano dolazio u sukob s okolinom somatizirani su kao posljedica herediteta, a njegova želja da se obrazovanjem izdigne iz svoje siromašne sredine i omogući si bolji život je tumačeno kao početni simptom paranoičnog poremećaja. Krpan je ponovno otpušten na revers u travnju 1899. godine. Nakon otpusta, umirovljen je kao učitelj i sudeći po njegovoj kasnijoj biografiji (između ostalog, osnovao je međunarodnu anarhističku komunu u okolici Dubovika i nakon Prvog Svjetskog Rata se pridružio Komunističkoj partiji Jugoslavije) $)^{961}$ nastavio je s političkim radom, uspješno izbjegavši kazneni progon i novu hospitalizaciju.

U oba navrata u kojima se Krpan našao u Stenjevcu, liječnici su ključnima za dijagnozu smatrali dva aspekta njegove ličnosti: njegovu percipiranu intelektualnu nadmoć nad okolinom i osjećaj da je progonjen od strane vlasti. No Krpanovi stavovi i ponašanje bili su u mnogočemu tipični za svijet političkih revolucionara 19. stoljeća karakteriziran milenarizmom i slijepim vjerovanjem u ostvarenje političke utopije kroz zalaganje grupe „osvještenih” pojedinaca. Čak su i njegovo

957 Ibid.

958 Ibid.

959 Ibid.

960 Ibid.

961 Pejić, 2016: 150. 
„uzvisujuće” ponašanje i „podučavajući” način govora tipični za osobu neuobičajeno širokog obrazovanja u odnosu na svoju sredinu i koja je na sebe preuzela ulogu agitatora i širitelja naprednih ideja u siromašnoj ruralnoj sredini.

Godine na prijelazu devetnaestog u dvadeseto stoljeće, značile su i radikalizaciju političke situacije u Banskoj Hrvatskoj. Formiranje Hrvatsko-srpske koalicije i njezin otpor uvođenju mađarskog jezika na željeznicama rezultirali su političkim previranjima, čestim smjenjivanjima i ostavkama banova. Sukob između bana Pavla Raucha i Hrvatskog Sabora rezultirao je raspuštanjem Sabora. Otpor brojnih zastupnika i političkih stranaka budimpeštanskoj i bečkoj vladi doveo je do suspenzije ustava 1912. Pored postojećih napetosti, krajem devetnaestog stoljeća prošireno je izborno pravo, čime dnevna politika postaje sve važnijim pitanjem interesa za šire slojeve. Samim time, politička pitanja su sve prisutnija u javnom govoru.

Zaoštravanjem političke situacije i politizacijom javne sfere iskazi štićenika u zavodu postaju sve politiziraniji. Ivan B., kočijaš iz Ličkog Osika, primljen u Stenjevac 1909. godine sa dijagnozom „paranoie” patio je od progonstvenih ideja vezanih uz svoj glas na izborima za Sabor. Ivan je mislio da ga progone jer je glasao za dr. Banjačevića i ,jako vikao i klicao Banjačeviću i Hrvatskoj" ${ }^{962}$. Po dolasku u Zemun da ga progone „seljaci, gospoda, popovi i Mađari” koji su ga zbog njegovih uvjerenja htjeli zatvoriti, a njegov strah od uhićenja je pojačavalo to što su djeca na ulici vikala „ključ” i „mislio je da se to tiče njega." ${ }^{663}$ Neki štićenici koji su bili u Stenjevcu duže vremena počinju iskazivati strahove ili misli progonstva vezane uz političku situaciju, dok su iste prije toga imale drugačiji karakter. Kosta S., magistar farmacije iz Stare Pazove bio je šest puta institucionaliziran u Stenjevcu između 1901. i 1910. u više navrata bježeći iz zavoda, sve dok 1911. nakon posljednjeg bijega nije nestao iz bolničkih spisa. U početku, Kostine se sumanute misli uglavnom tiču odnosa unutar obitelji. U pismu poslanom liječnicima prilikom Kostinog dolaska u zavod, njegov brat kaže kako Kosta ima „fiksu ideju da ja oću njega da prevarim", ${ }^{964}$ a sam Kosta piše duga pisma u kojima objašnjava kako ima pravo na svoj dio očeve imovine koji mu njegov brat želi na prevaru oduzeti pa ga je zato smjestio u zavod. ${ }^{965}$ Sedmog prosinca 1901. Kosta daje liječnicima detaljan opis svog progonstvenog svijeta u kojem glavnu

$962 \mathrm{KPV}, 1911: 7551$.

963 Ibid.

964 KPV, 1911: 8021.

965 Ibid. 
ulogu uistinu ima njegova obitelj koja ga navodno progoni i uskraćuje mu nasljedstvo, smještajući ga zdravog u „ludnice"966. Nakon zaoštravanja odnosa između Austro-Ugarske i Srbije nakon Svibanjskog prevrata i rasta međuetničkih napetosti nakon prosvjeda zbog članka „Srbi i Hrvati” u „Srbobranu” 1903. godine, Kostini strahovi sve više postaju vezani uz političke sukobe. Sredinom 1904. će tako optužiti ravnatelja Žirovčića da ga progoni jer je on (Kosta) Srbin, a tri godine kasnije opet se žalio ga da u zavodu proganjaju zbog njegove narodnosti i tražio kaznu za liječnike, Hrvate koji s njim loše postupaju. ${ }^{967}$ Osim toga, Kosta se pokušao i politički angažirati pisanjem pisama koja je adresirao vođama svim političkih stranaka i ministarstvu obrane. U pismu ministarstvu obrane, Kosta „savjetuje kruni da trži s Racima jer će pomoću njihovom najlakše Madjare otjerati u Mongolsku”, ${ }^{968}$

U tim politički burnim godinama početka dvadesetog stoljeća, Ivan Žirovčić je, kao već etablirani forenzički psihijatar često pozivan da pruži stručno mišljenje u procesima protiv pojedinaca koji su počinili zločine političkog karaktera. Jedan od takvih slučajeva, onaj studenta I. M. koji je oštetio portret bana Karola Khuena Hedérváryja donio sam u prethodnom poglavlju. Daleko su ozbiljniji bili slučajevi nasilnih politički motiviranih zločina, kakav je bio onaj Josipa Vugrina, bolničara iz Bolnice milosrdne braće koji je 1. prosinca 1905. godine hicima iz revolvera ranio brdovečkog župnika Matiju Penića. Vugrin tijekom slučaja iznosi tri različita motiva zločina. dmah nakon pokušaja ubojstva Vugrin je govorio seljanima da je pucao je na župnika jer ga je župnik „opsovao fakinom” dok je nakon uhićenja počeo pričati ,da je župnika htjeo naumice ustrijeliti i tako iz Brdovca maknuti, jer je župnik „Obzoraš“ i s narodom zlo postupa, a on, Josip Vugrin, je župniku politički protivnik, čita i drži si „Hrvatsko Pravo“, koje je toga župnika grdilo, i to je Vugrina tako podjarilo, da je odlučio osvetiti se župniku, pa je u tu svrhu pod izlikom kućne diobe uzeo dopust i oboružan revolverom, pošao u Brdovec. Odvjetnik Josip Frank zatražio je psihijatrijsko vještačenje i usprkos žučnim prosvjedima, Vugrin je doveden u Stenjevec. U zavodu se Vugrin ponaša mirno, no u pismima Franku i dalje inzistira da nije bolestan. Tada iznosi i treći motiv svog zločina

„Kaže, da nije to baš bilo povodom njegovog atentata, već da je župnik u selu omražen,jer je za poslijednje bune narod huckao, narod je životom nastradao, a župnik se je narodu iznevjerio, 
on je nemilosrdan, siromacima se ruga, u crkvi narod psuje, težake plaća s 3 seksera i još im kod plaćanja prezirno novac pod noge baca. On kaže, da se danas u Brdovcu nebi ni jedan župljan našao, koji ne bi rekao : šteta, da Vugrin nije župnika do mrtva ubio... To ga je potaknulo, da se on za druge žrtvuje." ${ }^{.99}$

Vugrin i dalje ostaje pri tvrdnji da su motivi zločina bili političke prirode, jedino ga sad ne povezuje sa stranačkom situacijom već se predstavlja kao zaštitnik siromašnih seljaka u njihovom navodnom sukobu za župnikom.

Uvidom u anamnezu koju je u Stenjevac dostavio Josip Frank, dobiva se slika Josipa Vugrina kao ekscentričnog čovjeka sklonog laganju i nasilnim ispadima: prilikom služenja vojske pokušao je bajunetom probosti stražmeštra koji ga je kaznio zbog kartanja, drugi bolničari su ga u bolnici Milosrdne braće zvali „nori” ili „smušeni”, a sukobljavao se i s liječnicima i tukao bolesnike. ${ }^{970}$ Često se pravio važan pretjerujući u korištenju stručnih izraza koje je uz to i krivo izgovarao te je mnogo pio. ${ }^{911} \mathrm{Na}$ osnovi činjenice da se, osim stalnog laganja, kod Vugrina ne pojavljuju znakovi duševne bolesti, Žirovčić će zaključiti da Vugrin nije duševno bolestan „nego da ima u njega nezdravih svojstava i duševnih nedostataka, što čini njegovu duševnu ličnost manje vrijednom i

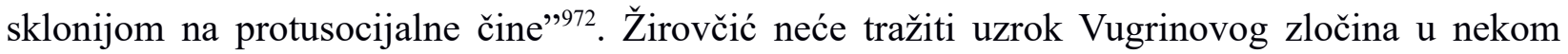
određenom duševnom poremećaju pa čak niti u Vugrinovom pijanstvu, već će ga zaključak o mogućim motivima napada temeljiti na svojem poimanju nižih slojeva. Kao što sam već spomenuo $\mathrm{u}$ jednom od prethodnih poglavlja, mnogi liječnici obrazovani u inozemstvu, uključujući i Žirovčića, promatrali su siromašne seljake kao „primitivne” osobe koje su duševno, tjelesno i moralno manje vrijedne od osoba građanskih slojeva. Za Žirovčića će stoga biti prirodno da širenje političkih ideja među širokim masama može reagirati samo eksplozijom nasilja i u podužem odlomku predstavlja Vugrinov atentat na župnika kao dokaz primitivizma ruralnog stanovništva i nesposobnosti istog za razumijevanje i bavljenje politikom.

„Pita se ponajprije, može li mu se zaista vjerovati, da je on nakanio usmrtiti župnika iz mržnje kao političkog protivnika. Vjerodostojnost toga razloga ne da se poreći, ako se uvaži, kako žestoko se razplamćuju strančarske strasti, te bijesna buka bezobzirne i za kulturu sramotne lično-strančarske borbe iz sabornica i novinstva odjekuje čak u seljačkim kolibama, gdje

969 Žirovčić, 1907: 29.

970 Ibid: 30.

971 Ibid: 31.

972 Ibid: 33. 
doduše ne može pobuditi razumijevanje, ali može uzbuditi surove nagone neuka puka." ${ }^{973} \mathrm{Uz}$ Vugrinovo primitivno porijeklo, Žirovčić smatra i da je kraj (okolica Zaprešića) iz koje Vugrin potječe također formirala njegov karakter učinivši ga nasilnom i moralno manjkavom osobom. Pritom se poziva na povijest prijašnjih zločina u tom kraju. Navodna krvava povijest tog kraja i njegova zaostalost i primitivizam nisu mogli u Vugrina „odgojiti osobitu plemenštinu, niti zatomiti divlju okrutnost čovjeka- životinje. ${ }^{974 \text { " }}$

Za razliku od Krpana kojeg je duševna bolest nagnala na usvajanje radikalnih ideja, kod Vugrina se čak ni ne može govoriti o političkom radikalizmu, već jednostavno o niskim strastima koji proizlaze iz lošeg porijekla i odrastanja u sredini koju Žirovčić smatra osobito primitivnom. Za Vugrina, politička borba može biti jedino shvaćena kao nagonsko nasilje. Rođen na selu, bio je predodređen za život primitivizma, a selidbom u grad zarazio se političkim idejama i postao svojevrsna himera- čovjek životinja. Prema tome, čini se da Žirovčić misli da neobrazovano ruralno stanovništvo, sklono nasilju i zlodjelima, od političke borbe može usvojiti jedino nasilne emocije osvetničkog bijesa i okrutnosti.

Najpoznatiji slučaj političkog nasilja u kojem je Žirovčić sudjelovao (i koji će gotovo zapečatiti njegovu karijeru forenzičkog vještaka) bio je slučaj Luke Jukića, člana napredne omladine koji je 8. lipnja 1912. pokušao ubiti bana i kraljevskog povjerenika Slavka Cuvaja. Atentat je bio neuspješan- Jukić je promašio Cuvaja i smrtno ranio njegovog savjetnika Ivu Hervoića. Javnost je bila zaprepaštena Jukićevim činom i ubrzo su se pojavile teorije o njegovoj neuračunljivosti u trenutku počinjenja zločina. Izvještaj o atentatu koji je sljedećeg dana izišao u Jutarnjem listu indirektno dovodi u vezu sam čin atentata s atipičnim mentalnim stanjem: „Sasvim ljudski osjećaj javlja se pri tom: osjećaj da je samo fanatična zasljepljenost mogla u duši atentatora proizvesti psihološku dispoziciju pod kojom je počinio svoje zločinstvo." 975

Vještaci Ivan Žirovčić, tadašnji ravnatelj zavoda za umobolne u Stenjevcu i Artur Lang, primarni liječnik istog zavoda mogli su pregledati Jukića i Neidharta u njihovim ćelijama tijekom suđenja i promatrati njihovo ponašanje za vrijeme sudskih rasprava. S obzirom na ugled koji je Žirovčić već tada uživao, njegovo svjedočenje je moglo osloboditi Jukića smrtne kazne. Pozivanje na

973 Ibid: 32.

974 Ibid.

975 Jutarnji List, 1912., br. 84: 1. 
Jukićevu neuračunljivost bila je osnova njegove obrane, a u prilog toj tezi išli su Jukićevi emotivni ispadi bijesa u sudnici, kao i činjenica da je 1910. godine bio otpušten iz vojske zbog duševne bolesti navedene pod kompliciranim nazivom: „Reizbare Schwaeche des Nervensystem als ausdruck einer psychopatischen Veranlagung gekennzeichnet durch andauerende Verstimmung durch Verworrenheit zustaenden zunehmende Abmagerung. Degenerationszeichen: Pupillendifferenz, angewachsene Ohrlaeppchen"(Razdražljiva slabost živčanog sustava kao izraz psihopatske predispozicije, koja se manifestira uznemirenošću i zbunjenošću i gubitkom težine. Znakovi degeneracije: različite zjenice, velike ušne školjke). ${ }^{976}$ Osim toga, Jukić je imao obiteljsku povijest duševnih bolesti i bolesti živčanog sustava i s očeve i s majčine strane, a i sestra mu je bila štićenica stenjevačkog zavoda. U izvješću vojnog liječnika je također stajalo da je bolest bila posljedica herediteta i da nije nastupila tijekom vojne službe. ${ }^{977}$

Žirovčić i Lang su iznijeli rezultate svog vještačenja pred sudom. Žirovčić je prvi iznio svoje mišljenje, već na početku odredivši Luku Jukića kao „teško hereditarno obterećenog čovjeka”. ${ }^{978}$ No, prije iznošenja mišljenja o Jukićevom duševnom zdravlju, Žirovčić govori o povezanosti političkih zločina i duševne bolesti, govori da je percepcija atentatora kao duševno bolesnog uvriježena u javnosti te priznaje da se i njemu samom isprva činilo da bi počinitelj mogao biti „kakav lud čovjek” te spominje tri vrsta duševne bolesti koje su mu pale na um: „umobolnik” koji odjednom „,bez svakog razmišljanja prasne nekim silovitim činom” hebefreni kojima „poput djece padne kakva god opasna ludorija u glavu” i ,paranoici koji žive pod dojmom kakve utuvljene obmane koja ih goni na silovite čine" 979 Žirovčićevi dotadašnji članci bili su objavljeni u stručnom časopisu i bili namijenjeni liječnicima koji su imali osnovna znanja o duševnoj bolesti. Govoreći pred sudom u svjedočenju koje je preko tiska bilo preneseno široj javnosti, Žirovčić iznosi sažetu definiciju duševno bolesnog pojedinca:

„Umobolan čovjek goji u svojoj duši svoj posebni umišljeni svijet, koji s vanjskim realnim svijetom nije u skladu, a bolesnik ipak dojmove svojega sobstvenoga mišljenja stavlja $u$ vanjski svijet kao realnu činjenicu, te dolazi tom bludnjom s realnim svijetom $\mathrm{u}$ opreku i $\mathrm{u}$ sukob. On proteže ne sebe ono što ga se nimalo ne tiče, utvara si neprijateljstva i progonstva te na ti reagira otporom: ili sebe preuveličava ludom obmanom, umišljajući sebi osobitu kakvu

976 Jutarnji list, 1912., br. 134: 3.

977 Ibid.

978 Ibid.

979 Ibid. 
važnost, uvijek je vlastiti njegov ja ono središte s kojega proizlazi i na koje se vraća sve njegovo mišljenje... "980

Ova definicija ludila iznosi podsjeća na definiciju paranoje koju je sam Žirovčić opisao 1895. godine i na način na koji je opisana Krpanova duševna bolest petnaest godina ranije. Žirovčić je isključio iz definicije „umobolje”, sve bolesti temeljene na patološkim raspoloženjima, epilepsiju i hebefreniju koje je prije uključivao i naglasio trenutak nesklada sa stvarnošću i usmjerenost duševno oboljelog na sebe samoga. Nakon toga, Žirovčić je zaključio svoje vještačenje mišljenjem u korist optužbe, izjavivši da Jukićev čin nije proizišao iz njegovog sukoba s realnim svijetom. Umjesto toga Jukić je ,gojio plemenite težnje” poput kulturnog i političkog sjedinjenja svog naroda i samostalnosti i slobode domovine, a na sam čin atentata natjerala ga je „njegova divlja ćud uzbuđena „burnim vremenima”. ${ }^{981}$ Raniju dijagnozu duševne bolesti koju su postavili vojni liječnici Žirovčić dovodi u pitanje, definirajući je kao slabost živčanog sustava koja može rezultirati duševnim oboljenjem, a ne kao samu duševnu bolest.

Vladimir Prebeg odlučio se na agresivno unakrsno ispitivanje Ive Žirovčića, prvo dovevši u pitanje njegovu nepristranost i upitavši ga je li vladin činovnik na što je Žirovčić odgovorio da jest, ali da je u svojoj znanosti nepristran i da svoje mišljenje daje u najboljoj savjesti. ${ }^{922}$ No, u nastavku ispitivanja, Žirovčić počinje djelovati nesigurno. Tako ga Prebeg navodi da prizna kako nije podrobno pregledao optuženog: nije provjerio boluje li Jukić od sifilisa, onanira li, te je ustvrdio da stigme degeneracije, za koje je priznao da su uočljive na Jukići nisu presudne za dokazivanje duševne bolesti. ${ }^{983}$ Time je Žirovčić naizgled napravio odmak od somaticističkog determinizma i moralističkog poimanja duševne bolesti i opetovano isticao da je Jukićev čin bio promišljena reakcija na političku situaciju u zemlji. Žirovčić također nije mogao na zadovoljavajući način objasniti Jukićevo ponašanje i poneke bizarne tvrdnje poput one da mu raste nova kost ispod jezika a na Prebegove upite je odgovarao uglavnom kratkim rečenicama. ${ }^{984}$ Nakon Žirovčića, svjedočio je Lang. Čini se da je on ipak detaljnije pregledao okrivljenika, provjerio mu fizičko stanje i reflekse i utvrdio osjetljivost kože na dodir i bol. ${ }^{985}$ Lang je potvrdio Žirovčićev sud o Jukićevoj stanju i zaključio da je Luka Jukić „exogeno i endogeno nervozan 980 Ibid.

981 Ibid.

982 Jutarnji list, 1912., br. 134: 4.

983 Ibid.

984 Ibid.

985 Jutarnji list, 1912., br. 134: 5. 
čovjek nu da ne spada u ni jednu meni u psihijatriji poznatih duševnih bolesti”. ${ }^{986}$ Ostatak njegovog svjedočenja bio je više manje istovjetan Žirovčićevom. Obrana neuračunljivošću nije urodila plodom i Luka Jukić je osuđen na smrtnu kaznu koja je kasnije preinačena u doživotni zatvor. Iz zatvora je izišao nakon uspostavljanja Kraljevine SHS. Zbog svog svjedočenja, Žirovčić je bio žestoko kritiziran od strane Liječničkog zbora koji se ogradio od njegovog vještačenja. ${ }^{987}$ Članovi Liječničkog zbora ubrzo su bili kažnjeni od strane Slavka Cuvaja, a Žirovčić je dao odgovor u Narodnim novinama u kojem je istaknuo svoje razočaranje zbog osude udruženja u čijem je časopisu proteklih devetnaest godina objavljivao psihijatrijska vještačenja. ${ }^{988}$

Uloga koju je Žirovčić igrao u smrtnoj presudi Jukiću s kojim je veliki dio pro-jugoslavenski orijentiranih članova Liječničkog Zbora vjerojatno simpatizirao i kasnije kazne izrečene pojedinim liječnicima zauvijek su narušile Žirovčićeve odnose s kolegama. Nakon sukoba s Liječničkim Zborom, Žirovčić će u Liječničkom vjesniku objaviti samo još jedno vještačenje godinu dana prije svog prijevremenog umirovljenja. Žirovčićevo vještačenje Luke Jukića bilo je u suprotnosti s brojnim njegovim dotadašnjim zaključcima, a njegov nastup je odavao dojam nesigurnosti što je navelo brojne suvremenike i povjesničare poput Josipa Horvata i Stjepana Sirovice da zaključe da je Žirovčić učinio ustupak vlastima. ${ }^{989}$ Ipak, ako se Žirovčićevo iskaz usporedi s njegovom analizom atentata koji je počinio Josip Vugrin, primjećuje se da je Žirovčić smatrao da je burna politička situacija u državi kadra navesti ljude niskog porijekla i upitnog obrazovanja na nasilje bez da pojedini nasilni postupci imaju svoje uzroke u nekoj određenoj duševnoj bolesti. Žirovčić je nedvojbeno osjećao veliki pritisak, budući da ga je ban Khuen Héderváry već jednom smijenio s mjesta ravnatelja Stenjevca, zbog daleko banalnijeg sukoba $\mathrm{s}$ vlastima. Kao dugogodišnji i predani ravnatelj, posvetio je čitavu svoju karijeru napredovanju zavoda i imao je motivaciju ponuditi sudu mišljenje koje neće kompromitirati njegov položaj. Na kraju, njegova nesigurnost je mogla potjecati od činjenice da nije dobio priliku pregledati Luku Jukića u samom zavodu kako je to obično činio i da je njegovo vrijeme s osumnjičenikom bilo ograničeno.

986 Jutarnji list, 1912., br. 134: 6.

987 Thaller, 1933: 470.

988 Fatović-Ferenčić i Kuhar, 2019:15-16.

989 Ibid: 17. 
Slučaj atentata na kraljevskog namjesnika Cuvaja dokaz je recepcije psihijatrijskih ideja u javnosti krajem devetnaestog stoljeća. Branitelji, pisci novinskih članaka, okrivljenici i liječnici daju vlastita tumačenja odnosa između duševne bolesti, političkog radikalizma i nasilnih postupaka. Može se reći da se političko i medicinsko isprepliću od početka do kraja Jukićevog slučaja: onodobni intelektualci poput Antona Gustava Matoša i kasniji povjesničari poput Josipa Horvata se ne mogu osvrnuti na atentat bez da se upuste u dijalog s psihijatrijom, ili pribjegnu davanju medicinskog mišljenja o Jukićevom stanju. S druge strane, način na koji je Žirovčić kao najugledniji psihijatar u Banskoj Hrvatkoj tog vremena bio izložen profesionalnim i političkim napadima govori kako su slučajevi „političkih bolesnika” mogli imati dalekosežne posljedice na karijeru liječnika. Psihijatri su morali balansirati između ugleda vlastite discipline kao grane medicine koja donosi objektivan i znanstveni sud o društveno važnim pitanjima i političkih pritisaka kojima su se izlagali davanjem mišljenja u slučajevima poput Jukićevog. Na posljetku, Žirovčić je nakon svog svjedočenja bio izložen napadima upravo zbog sumnje da nije djelovao kao medicinski stručnjak već kao državni službenik, dok se Jukićev slučaj nastavljao opisivati psihijatrijskim diskursom korištenim od strane laika.

Slučajevi nasilja, bilo da se radilo o obiteljskom nasilju, adolescentskom nasilju, konfliktima u ruralnim zajednicama ili političkim sukobima uvijek su dovodili psihijatre u težak položaj. S jedne strane, psihijatri koji su pokazivali interes za forenzičku psihijatriju imali su jasnu namjeru da legitimiraju novu medicinsku granu iznoseći svoj vlastiti medicinski sud o nasilju i zločinu, najčešće utemeljene u biološkom determinizmu Lombrosove kriminalne antropologije. No uz tu je tendenciju uvijek postojala svijest o tome da nasilje često ima kompleksne uzroke koji nisu svodivi isključivo na biologiju. Također, čak i onda kad bi psihijatri nedvojbeno opisali konfliktne štićenike kao „rođene zločince” ili „duševno manje vrijedne ličnosti” kao što je to bio slučaj s Rudolfom Stanićem i Josipom Vugrinom, često su oklijevali proglasiti ih duševno bolesnima, odabirući umjesto toga granične pojmove „primitivizma” ili „moral insanityja”. Njihov pristup se često razlikovao od slučaja do slučaja, pa je tako Miloš Krpan proglašen neuračunljivim zbog same nepokolebljive uvjerenosti u vlastite političke ideja, dok je Luka Jukić proglašen zdravim upravo zbog toga što je počinio zločin motiviran jasnom političkom idejom. Psihijatrijski tretman slučajeva nasilja, naročito kad je isto imalo političku dimenziju probudilo je interes javnosti za psihijatriju i politiziralo ju na mnogo eksplicitniji način nego što je to bio 
slučaj s drugim problemima kojima se psihijatrija bavila, jer je za razliku od emocija ili seksualnosti, nasilje gotovo uvijek smatrano problemom od javnog interesa. 


\section{Zaključak}

Ideja o osnivanju Kraljevskog i zemaljskog zavoda za umobolne u Stenjevcu rodila se u trenutku kad je nedostatak institucije za duševno oboljele u tadašnjoj Banskoj Hrvatskoj prepoznat kao ozbiljan društveni problem. „Ludnički odjeli” koji su postojali u ostalim zemaljskim bolnicama nisu više bili adekvatni za zbrinjavanje sve većeg broja duševno bolesnih, a uostalom, funkcionirali su više kao ustanove palijativne skrbi. Još sredinom stoljeća, postojalo je čvrsto uvjerenje da izgradnja specijaliziranih zavoda koje vode specijalizirani zavodski psihijatr. iRješavanje tog problema motiviralo je liječnike i saborske zastupnike no put od prvih diskusija do izgradnje takve institucije bio je izrazito dugotrajan. Na kraju, zavod je otvorio svoja vrata 1879. godine, u doba kad je zavodska psihijatrija u Europi već bila preplavljena duhom terapeutskog pesimizma- zavodi su bili zapušteni i prenapučeni i nije se činilo izvjesnim da će se liječnici koji su njima upravljali pronaći način učinkovitog tretmana za duševne bolesti. Sam zavod, od svojih se početaka morao boriti s logističkim i ekonomskim problemima- zemljište je bilo neadekvatno i močvarno, što je pogodovalo širenju epidemija, broj štićenika je rastao, i već od prvih godina premašivao kapacitete zavoda, planovi o samoodrživosti zavoda su bili osuđeni na propast jer je većina štićenika bila nesposobna za rad zbog teškog tjelesnog i psihičkog stanja, a osoblje nije imalo iskustva u upravljanju poljoprivrednim zemljištem. U drugom desetljeću postojanja zavoda, te su probleme pratile i poteškoće s nadležnošću i vlasništvom nad zavodskim zemljištem i sukobi ravnatelja sa zemaljskim vlastima. Iz tih razloga terapeutski pesimizam je bio jedan od elemenata koji su formirali intelektualnu klimu u kojoj su Rohaček, Forenbacher, Žirovčić i ostali djelovali.

Imenovanje kaznioničkog liječnika Jana Rohačeka prvim ravnateljem zavoda u Stenjevcu od početka je usmjerilo hrvatske psihijatre prema forenzičkoj psihijatriji. Uz tada suvremene i naoko revolucionarne teorije Ceserea Lombrosoa i Richarda von Kraffta Ebinga, usmjerenost forenzičkoj psihijatriji čvrsto je povezala percepciju duševne bolesti sa društveno devijantnim ponašanjem i seksualnim praksama koje su još ranije bile opisane kao nemoralne. Kako se bližio kraj devetnaestog stoljeća, ideje o „degeneraciji”, popularizirane od strane europskih psihijatara i konzervativnih filozofa koji su usvojili ideologiju „znanstvenog rasizma” proširile su se i među 
hrvatskim liječnicima, a kroz književnost i pisanje brojnih socijalnih reformatora prodrle su i u širu javnost. Obrazovanje liječnika na austrijskim, češkim i njemačkim sveučilištima upoznalo ih je s tada aktualnim somaticizmom i biološkim determinizmom. Susret sa štićenicima od kojih je većina bila siromašna i ruralnog porijekla, doveo je do povezivanja ideja o „degeneraciji“ $\mathrm{s}$ predrasudama o ruralnom stanovništvu kao primitivnom i manje inteligentnom. Intelektualni horizont hrvatske psihijatrije prijelaza stoljeća bio je oblikovan terapeutskim pesimizmom prožetim s ostacima paradigme moral treatmenta. Naslijeđe moral treatmenta je osobito vidljivo u preživljanju velikog broja terapijskih metoda, poput radne terapije, važnosti ispravne prehrane, izolacije i liječnikovog neupitnog autoriteta. No dominantna obilježja psihijatrijskog diskursa u Hrvatskoj i dalje su biološki determinizam i somaticistička etiologija duševne bolesti, teorije o degeneraciji i tendencija $\mathrm{k}$ diskurzivnoj i praktičnoj medikalizaciji brojnih ponašanja smatranih društveno i/ili moralno devijantnima. Svakodnevna praksa hrvatske psihijatrije, značila je s druge strane, stalnu borbu liječnika za preživljavanje štićenika koji su bili držani u teškim životnim uvjetima, prenapučenost, epidemije, nedostatak stručnog osoblja, konstantnu komunikaciju sa štićenicima i više ili manje pomno bilježenje njihovog govora. U tim bilješkama, koje su činile osnovni dio svake povijesti bolesti vidi se sukob koji je obilježio hrvatsku psihijatriju. Radi se o sukobu između teorijski formulirane »normalnosti« utemeljene u emotivnom režimu i patrijarhalnom moralu građanskih slojeva i traumatične svakodnevice marginaliziranih štićenika, sukob između modernističkog utopijskog sna moderne medicine i nemogućnosti komunikacije između intelektualnih elita i marginaliziranih pojedinaca. Narativi bolesnika, skupljeni iz pisama i zapisanih izjava susreću diskurs liječnika koji se trude zadržati epistemičku hegemoniju i legitimirati svoju društvenu ulogu medicinske discipline koja može objasniti i disciplinirati svijet devijantnih praksi i atipičnih emotivnih stanja. Dolazi do otpora- štićenici se trude izraziti svoju perspektivu i objasniti svoje okruženje i svoj unutarnji svijet vlastitim riječima. Pravo na govor, na iskazivanje istine i definiranje vlastite ličnosti postaje predmet stalne borbe. Neki od štićenika uživaju u nadmudrivanju liječnika, pokazujući im otvoreno da ne mogu prosuditi njihovu poziciju. Neki usvajaju psihijatrijski diskurs, objašnjavaju svoje simptome na naoko stručan način. Štićenici, bilo da su umrli u zavodu, pobjegli iz njega ili su ih liječnici odlučili pustiti, često ulažu izuzetan trud u pričanje vlastitih priča, iskazuju emocije riječima i postupcima, šalju pisma ili nude svoju verziju stvarnosti liječnicima na razmatranje, poneki među njima, kao Miloš Krpan pišu vlastite biografije u kojima iznose poglede na svijet zbog kojih su zatočeni. 
S druge strane, brojne društvene institucije počinju komunicirati sa zavodom i uključuju ga u brojne mreže društvenih odnosa. Pravosudni organi, obitelji štićenika i predstavnici lokalnih administrativnih vlasti percipiraju zavod kao odgovor na probleme s kojima se susreću, bilo da se radilo o nasilju, moralnoj krizi ili društvenim anksioznostima. Odvjetnici i suci traže psihijatrijsko vještačenje klijenata. Tisak piše o pojedinim štićenicima kao nepravedno zatvorenima i proširuje u javnosti sliku psihijatrijskih zavoda kao stravičnih simbola društvene nepravde. Liječnici, često djelujući na intervenciju obitelji ili lokalne vlasti, šalju u zavod osobe čije je ponašanje godinama predstavljalo problem za njihovu okolinu. Sami psihijatri nastoje etablirati društvenu poziciju psihijatrije kao discipline koja će pronaći znanstveni odgovor na probleme društva i pomoći brojnim ljudima kojima duševne poteškoće uništavaju živote. No, njihova znanost je ukorjenjena u svjetonazoru građanske klase i njezinom konzervativnom pogledu seksualnost, emocije i politiku. Ona pati od napetosti između deklarativnog slavljenja moderninteta i anksioznosti pred svijetom koji se ubrzano mijenja. Psihijatri smatraju da je racionalni muškarac europske više srednje klase ideal duševnog zdravlja i gledaju na štićenike i štićenice kroz tu, uvelike ideologiziranu sliku. No, kao dio rubne i mlade grane medicine, provodeći vlastiti život izolirani u zavodima u siromašnoj zemlji u kojoj je zemaljska vlast zanemarivala zdravstvenu i socijalnu politiku, vodeći bitku s nedostatkom stručnog osoblja, epidemijama kolere, tuberkuloze i tifusa, liječnici i sami predstavljaju grupu koja se često nalazi u sukobu sa širim društvom.

Povijest Kraljevskog i zemaljskog zavoda za umobolne u Stenjevcu može biti opisana kroz kompleksnu mrežu odnosa između tih triju aktera. Prvi vrh trokuta čine pojedini štićenici, njihove emocija, traumatična iskustava i životne priča. Drugi vrh su liječnici, koji kroz prizmu psihijatrijskih znanja i vlastitih moralnih nazora interpretiraju ponašanje štićenika i obilježavajući pojedina ponašanja kao ,poremećena” normaliziraju pojedine norme ponašanja i načine iskazivanja emocija. Treći kut trokuta čini javnost, predstavljena u glasovima članova obitelji, pravosudnih organa, književnika, kotarskih liječnika i predstavnika političke vlasti. Niz pojedinačnih slučajeva opisanih u ranijim poglavljima pruža nam uvid u mjesto koje su rod, seksualnost, strah, anksioznost, politika i nasilje zauzimali u tom trokutu i koje su se episteme međusobno susretale u diskurzivnoj mreži odnosa. 
Pitanja roda i seksualnosti, kako je Foucault pokazao u svojoj „Povijesti seksualnosti”, u građanskoj kulturi devetnaestog stoljeća postaju važna u smislu njihovog medicinskog i znanstvenog proučavanja. Kao što smo vidjeli na primjeru studije Richarda von Krafft-Ebinga znanstveno proučavanje seksualnosti i roda išlo je ruku pod ruku s normativiziranjem postojećih patrijarhalnih i moralističkih pogleda na rodne uloge i ljudsku seksualnost. Psihijatrijska praksa u zavodu obiluje primjerima specifično patrijarhalnih i konzervativnih pogleda na rod i seksualnost. Ženska tijela su erotizirana kako prilikom pregleda po dolasku u zavod, tako i kroz interpretaciju njihovih emocija i ponašanja kao „erotičnih” što je epitet kojim liječnici gotovo nikad ne opisuju muškarce. Etiologija psiholoških simptoma pacijentica bila je percipirana kroz klinički pogled koji je stavljao naglasak na njihov reproduktivni sustav i percipiranu mentalnu „ranjivost”. Tijela štićenica i dalje su bila gledana kroz predmedicinko očište koje je u središte stavljalo reproduktivni sustav i mapiralo njihova tijela kao fluidna, karakterizirana permanentnom nestalnošću osjeta, emocija i motiva. Javno istupanje žena, interes za politiku i čitanje, te učestalo suprostavljanje muškim autoritetima smatrani su simptomima duševnih poremećaja (ponajviše histerije), a čitanje knjiga se ponekad smatralo uzrokom duševne bolesti. Što se psihijatrijskih dijagnoza tiče, liječnici su i dalje smatrali žene osjećajnijima i podložnijima tjelesnim utjecajima na psihu. Iz tog razloga, češće im se pripisivalo takozvane ,afektivne psihoze” dovođene u vezu s intenzivnim emotivnim stanjima poput „manije” i „melankolije”, a rjeđe poremećaje povezane s pogrešnom primjenom logičkih i „racionalnih” kognitivnih postupaka poput paranoje. Kod uzroka bolesti kod žena, često se ignoriraju specifičnosti njihovog svakodnevnog života i ishodište problema se somatizira i smješta u reproduktivni sustav što dovodi do navođenja, menstruacije i dismenoreje kao uzroka bolesti. Prema tome, može se reći da povijesti bolesti govore u prilog tezi o histerizaciji ženskih tijela, koju je postavio Michel Foucault, a koji su prepoznali brojni povjesničari i povjesničarke devetanestoljetne medicine.

Same štićenice, kroz svoje iskaze i simptome, često govore o teškim životnim situacijama koje su obilježavale svakodnevicu brojnih žena i djevojaka u devetnaestom stoljeću. Ana Schier će tako direktno govoriti o teškoćama kojima su izložene žene koje pokušavaju ostvariti neko pravo preko suda, a koje pritom nemaju podršku muškaraca. Brojne štićenice su udovice ili napuštene od muževa i odbačene od obitelji i djeluju u ruralnim patrijarhalnim društvima, te se često zbog 
strukturalne opresije kojima su bile izložene ne mogu izboriti za svoj glas. Brojne svjedoče i o seksualnom, emotivnom i fizičkom zlostavljanju od strane svojih muževa, obitelji, pa i drugih muških osoba na poziciji društvene moći poput bolničara ili liječnika. U većini analiziranih slučajeva, psihijatri nisu uzimali ta svjedočanstva ozbiljno, a govor štićenica je uvijek bio bilježen isključivo kao demonstracija njihovih simptoma i nije bio uziman u obzir kao dijagnostički ili terapeutski relevantan.

Hrvatski liječnici su bili rano i dobro upoznati sa Charcotovom definicijom i kliničkim opisom histerije i neki od njih, poput Nike Selaka su ekstenzivno pisali o histeriji kod svojih pacijentica i pacijenata. Iako su stenjevački liječnici bili upoznati sa Charcotovim radom, njihov klinički tretman histerije bio je mnogo drugačiji i opet je od histerije učinio ,protejsku bolest” fluidnih simptoma. Također, histerija je, u skladu s njezinim opisom koji daju njemački klinički psihijatri poput Kräpelina, bila više odlikom duševnog i tjelesnog ustroja samih žena, stanje koje je zapravo inherentno ženama i koje se samo u određenim okolnostima manifestira u obliku „histerične psihoze” ili „histeričnog ludila” (histerrisches Irrensein). Prema tome, narativ histerije bio je stalno prisutan u percepciji štićenica, čak im nije postavljena specifična dijagnoza histerije. Kad je histerija dijagnosticirana, u većini slučajeva koje sam imao priliku analizirati povezivana je s transgresijom emotivnih režima i kršenjem normi ponašanja vezanih za rodne uloge. Unutar emotivnog režima građanstva, žene su ohrabrivane i odgajane da pokazuju „nježne” i „pasivne” emocije dugog trajanja i niskog intenziteta poput majčinske ljubavi, a njihova temeljna uloga sastojala se u afektivnoj brizi za privatnu sferu. Pokazivanje intenzivnih emocija poput izrazite seksualne strasti i bijesa ili njihovo djelovanje u javnoj sferi na način koji otvoreno prkosi muškim autoritetima bio je smatran transgresijom, koja je bila dovoljnom za dijagnozu histerije. Možemo dakle reći da se histerija u praksi hrvatske psihijatrije rjeđe doživljava kao precizno definiran i opisan skup psiholoških i neuroloških simptoma kao kod Charcota, a više kao trajno emotivno i fizičko stanje žena koje mora biti strogo regulirano odgojem i koje žene čini nesposobnima za javno, političko i intelektualno djelovanje (,osobe niže duševne vrijednosti” po Žirovčiću). To stanje ponekad može dovesti do brojnih manifestacija duševne bolesti. U prilog činjenici da je histerija kod stenjevačkih psihijatara bila strogo povezana uz konzervativno poimanje rodnih uloga u građanskom društvu govori i odsutnost „histeričnih” muškaraca u praksi zavoda, iako su ih opisali i Charcot i neki hrvatski liječnici. 
Osim svjedočanstava o zlostavljanju, štićenice ponekad spominju deluzije vezane uz zaposjedanje ili strojeve kontrole. U tim slučajevima žene gube kontrolu nad vlastitim tijelom, pa čak i tjelesni integritet. Među tim slučajevima osobito su važni oni kod kojih je osoba koja vrši kontrolu muškarac na poziciji moći. Takvi slučajevi govore o depersonalizaciji i gubitku identiteta do kojeg dolazi u situacijama izrazite nejednakosti moći između štićenica i muškaraca. Njihovom analizom i uzimanjem glasa štićenica i njihovih emocija u obzir mogu se povući jasne paralele o zrcaljenju stvarne administrativne i financijske moći koju su spomenuti muškarci imali nad navedenim ženama u njihovim fantazijama o magijskoj i tehnološkoj kontroli.

Kompleksnost problematike roda i seksualnosti u hrvatskoj psihijatriji devetnaestog stoljeća nazire se u tretmanu jedne tipično „muške” bolesti - „dementiae paralytice” ili progresivne paralize, degenerativne bolesti živčanog sustava koja se razvija u tercijarnom stadiju sifilisa. Ta tada neizlječiva bolest već je od sredine devetnaestog stoljeća dovođena u vezu sa sifilisom, a muškarci oboljeli od nje činili su velik udio populacije europskih zavoda za duševno oboljele. No, velik dio europskih i hrvatskih psihijatara osporavao je vezu između zaraze sifilisom i progresivne paralize. Među stenjevačkim psihijatrima, izuzetak je bio kratkotrajni ravnatelj Ivan (Jan) Šimsa koji je pomoću obdukcija pacijenata oboljelih od progresivne paralize utvrdio postojanje veze između sifilisa i kasnijih patoloških promjena na mozgu koje dovode do pojave te degenerativne bolesti. Drugi psihijatri poput Forenbachera i Žirovčića, tražili su uzroke progresivne paralize u nemoralnom životu, alkoholizmu i iscrpljenosti. Sifilis je ponekad prepoznat kao uzrok progresivne paralize kod nižih društvenih slojeva, zajedno sa alkoholizmom i nemoralnim životom, dok se kod oboljelih muškaraca iz građanskog sloja bolest pripisivala iscrpljenošću uslijed napornog rada. Takvi pogledi na progresivnu paralizu odražavali su uvjerenje brojnih onodobnih liječnika o seljacima i siromašnim radnicima kao nemoralnima, raskalašenima i sklonima alkoholu i građanstvu kao klasi koja žrtvuje svoje zdravlje naporno radeći i stječući.

Moralističko poimanje seksualnosti kod psihijatara manifestira se i u psihijatrijskim definicijama seksualnih patologija. Začetnikom psihijatrijskog proučavanja seksualnosti smatra se Richard von Krafft-Ebing, čiji je rad ostavio značajan trag na poimanje seksualnosti kod stenjevačkih 
liječnika. Gotovo svi bitniji autori koji su radili u stenjevačkom zavodu se često pozivaju na Krafft-Ebingovu „Psychopatiu sexualis”. U tom djelu Krafft-Ebing, bez da je za svoje tvrdnje pružio ikakve uvjerljive dokaze biologizira postojeće rodne uloge i seksualne norme, dajući im medicinski autoritet. Seksualne prakse poput homoseksualnosti i masturbacije koje su prije bile smatrane grijehom i moralnim prijestup sad su dobile značaj patologije i medicinske devijacije. Pod utjecajem vijesti o senzacionalnim zločinima poput londonskih ubojstava Jacka Trbosjeka, naročita se pažnja posvećuje vezama između devijantne seksualnosti i ostalih oblika društveno devijantnog ponašanja poput krađa i nasilja. Seksualnost štićenika u stenjevačkom zavodu bila je pomno bilježena, praćena, regulirana i nadzirana, a navodno devijantne seksualne prakse smatrane su dokazom duševne bolesti ili hereditarne manjkavosti štićenika. Iz ponekih pisama štićenika vidljivo je da i poneki bolje obrazovani štićenici sami usvajaju medikalizirani diskurs o seksualnosti.

Osim nadzora koji se događa unutar Stenjevca, pokušaji discipliniranja ljudskih tijela i moralističko-medicinskog ograničavanja seksualnosti bit će prisutni u liječničkim pokušajima da utječu na bračne i seksualne navike šire populacije povezujući navodni „primitivizam” hrvatskih seljaka sa njihovom lijenošću i intelektualnom zaostalošću, a njihove seksualne prakse poput ranih brakova smatrane su uzrocima moralne i društvene degeneracije. Prema tome, može se reći da su tendencija da se patrijarhalno poimanje rodnih uloga, tradicionalni pogledi na ljudsku seksualnost legitimiziraju kroz psihijatriju i medicinu bila je prisutna u hrvatskoj psihijatriji od samih njezinih početaka. Ona je išla ruku pod ruku s percepcijom građanske klase kao intelektualno, moralno, tjelesno i duševno nadmoćne ruralnoj populaciji iz čijih je redova dolazila većina štićenika, a sve je to nedvojbeno utjecalo na način kako su se navedene ideje, ogrnute aurom znanstvene objektivnosti, širile i još čvršće ukorjenjivale u društvu Banske Hrvatske.

Uz rod i seksualnost, brojne povijesti bolesti tematiziraju strah. Isti se doduše, mnogo manje javlja u stručnim člancima stenjevačkih psihijatara, no emocije straha i anksioznosti su opisane kao simptomi određenih duševnih bolesti ili uzroci istih. Poimanje straha kao uzroka duševnog oboljenja preuzeto je još iz zapisa Phillipea Pinela. Teorije o degeneraciji i radikalno somaticističko shvaćanje etiologije duševnih bolesti koje prevladava od sredine devetnaestog stoljeća gurnule su strah i anksioznost u drugi plan, te se isti u medicinskoj literaturi spominje 
isključivo kao simptomi duševne bolesti. No, iako je eksplicitno spominjanje straha i anksioznosti u medicinskoj literaturi rijetkost, to ipak ne znači da opisi degeneracije kao postepenog i neizbježnog propadanja zapadne civilizacije uslijed nasljednog fizičkog, duševnog i moralnog slabljenja populacije ne odišu tim emocijama. U djelima poput $O$ Degeneraciji Maxa Nordaua vidi se kako je strepnja koja je na prijelazu stoljeća obuzimala obrazovane elite bila u velikoj mjeri prisutna i u psihijatriji. Dio psihijatrijskog pogleda na društvo bio je obilježen strahom od posljedica sve većeg širenja hereditarnih karakteristika koje su liječnici smatrali patološkima. To je značilo sve veći broj ljudi koji su se nalazili u prostoru ocrtanom kao „borderlands” granično područje između ludila i ideala duševnog zdravlja, a takva je perspektiva u atmosferi sve raširenijeg terapeutskog pesimizma rezultirala mračnom slikom budućeg društva. Uz to, anksioznost, strepnja i strah sve su više činili dio svakodnevne emotivne kulture društvenih elita, bilo da se radilo o pitanjima diplomacije, ekonomije, posljedica tehnološkog razvoja ili politike. Uz somaticizam, njihova sveopća prisutnost u javnom diskursu, učinila ih je relativno nevidljivim u kliničkim opisima duševnih oboljenja. Tek Freudovim odbacivanjem somaticističke etiologije, teorija o degeneraciji i prepoznavanjem „,neurotičnih” elemenata u temeljima građanskog društva i europske kulture u cjelini, strah i anksioznost postaju eksplicitno prepoznati kao emocije bitne za prepoznavanje uzroka određenih duševnih poteškoća.

U Stenjevcu štićenici demonstriraju strah od neimaštine, natprirodnog, nasilja i moći države. Strah od siromaštva i strepnja pred gladovanjem često se javljaju kod štićenika i štićenica koji pripadaju najsiromašnijim društvenim grupama. Naročito se svojom brojnošću ističu siromašni seljaci koji su često živjeli na rubu oskudice, a prvi ravnatelj Zavoda Ivan Rohaček čak je naveo siromaštvo i slabokrvnost uslijed neadekvatne prehrane kao vjerojatan uzrok bolesti većine štićenika. Štićenici koji u iskazuju strah od siromaštva i strepnju za vlastito preživljavanje najčešće imaju dijagnoze melankolije i manije.

Te dijagnoze su u pravilu prevladavale kod siromašnog ruralnog stanovništva. Definicija tih bolesti kao ,afektivnih psihoza” uklapala se u dominantni emotivni režim građanske klase koji je smatrao siromašnije slojeve sklonijima emotivnim uplivima, a same emocije držao inferiornima razumu. Osim seljaka, u prvim godinama postojanja stenjevačkog zavoda siromaštvo je čest motiv u povijestima bolesti štićenika identificiranih kao „bosanski bjegunci”- izbjeglice iz ruralnih krajeva Bosne i Hercegovine koji su pobjegli u Bansku Hrvatsku pred valovima nasilja 
nakon austrougarske okupacije 1878. godine. U kasnijim godinama, veza između straha za vlastitu egzistenciju u uvjetima teške neimaštine i duševne bolesti se gubi iz povijesti bolesti i uzroci bolesti se sve više traže u fiziologiji štićenika i štićenica. Ta tendencija je vidljiva na primjeru dvaju žena koje su ubile svoju djecu i tvrdile da su učinile taj zločin strahujući od gladi. U oba slučaja, psihijatri koji su trebali dati svoje stručno mišljenje o sposobnosti rasuđivanja tih žena nalaze motivaciju za taj zločin izvan materijalnih okolnosti okrivljenica. U oba slučaja okrivljenice su govorile o teškoj neimaštini kao motivu umorstva, no psihijatri su odlučili ignorirati takvo objašnjenje. Ni neimaština kod Žirovčića nije promatrana kao stanje koje može izazvati traumatičnu strepnju, već isključivo kao stanje u kojem neadekvatna prehrana uzrokuje fiziološke promjene i slabi živčani sustav.

Premda psihijatri nisu uzimali strah od siromaštva $\mathrm{u}$ obzir, česta prisutnost istog u govoru štićenika nam približava povezanost emotivnog svijeta štićenika sa njihovom teškom borbom za materijalnu sigurnost. Isto vrijedi i za brojne primjere straha od natprirodnog koji se javlja $\mathrm{u}$ povijestima bolesti štićenika. Strah od natprirodnog uglavnom se manifestira kao strah od bića iz pučke predaje: sablasti, „muri”, vila, „coprnjica”. Ponekad, kao u slučaju seljakinje Magde, religiozni koncepti poput Čistilišta su personificirani i o njima se govori kao o bićima. Strah od vraga, kojeg se krivi za životne poteškoće, utjelovljuje u neprijateljima i kome se pripisuje uzrokovanje bolova i tjelesnih poteškoća je također učestalo. Štićenici često govore o svojim strahovima od natprirodnog i njihovi strahovi govore o širokoj rasprostranjenosti vjerovanja $u$ magiju, fantastična stvorenja i bogatoj pučkoj religioznosti. Sami liječnici pokazuju izražen interes za te strahove, potičući štićenike da govore o svojim vjerovanjima. U nekim slučajevima, liječnici ne shvaćaju vjerovanja u fantastična bića i natprirodne pojave znakom duševne bolesti, već ih jednostavno pripisuju praznovjerju i nedostatku obrazovanja. Ipak, religijske navike štićenika jedna su od rubrika istaknutih u Liječničkoj svjedodžbi. interes liječnika za religiozne navika štićenika odaje posebnu dimenziju odnosa između religiozih vjerovanja i psihijatrije. Psihijatri su smatrali vjerski život štićenika važnim pokazataljem njihovog mentalnog zdravlja. Definicija „normalnog” religioznog ponašanja nije nigdje eksplicirana, no vjerovanja istaknuta kao neuobičajena u liječničkim svjedodžbama i povijestima bolesti pokazuju da je ideja religioznosti koju su psihijatri i drugi liječnici percipirali kao „,normalnu” imala svoj izvor u građanskom poimanju religioznosti kao racionalnog razumijevanja vjere i tradicionalnom moralu, 
dok su rituali i vjerovanja prožeti mnogo emotivnijim i sinkretičnim doživljajem božanskog kakav je karakterizirao pučku religioznost u konteksu promatranja u psihijatrijskom zavodu mogli puno lakše biti shvaćeni kao znak patologije.

Strah od nasilja česta je tema u stručnoj psihijatrijskoj literaturi devetnaestoj stoljeća. Strah od nasilja u izvorima ima dva lica: s jedne strane možemo pratiti emotive vezane uz strah psihijatara i javnosti od nasilja duševno oboljelih, dok s druge strane možemo pratiti govor samih duševno oboljelih koji izražavaju strah od stvarnog ili zamišljenog nasilja. Psihijatri su često pisali o strahu od duševno oboljelih koji je još uvijek bio prisutan u javnosti i o percepciji duševno oboljelih kao nasilnih. Deklarativno, opovrgavali su taj strah nalazeći njegove izvore u predmedicinskom praznovjernom stavu prema duševnim oboljenjima. Ipak neki od stručnih radova implicitno koriste taj strah i predstavljaju psihijatriju kao instituciju koja štiti društvo od nasilnog ponašanja štićenika. Također, usprkos konstantnom ekspliciranju stava o ljudskoj psihi kao podrućju koje se može spoznati na objektivan i znanstven način, porivi i emocije duševno oboljelih se često opisuju makabričnim slikama čija upotreba odaje strah ili strepnju. Psihijatrija prijelaza stoljeća je obilježena ambivalentim stavom prema samim duševno oboljelima: s jedne strane, liječnici poimaju duševno oboljenje kao bolest i nastoje se izboriti za human tretman duševno oboljelih i za suzbijanje stigme. No, sami evociraju strah o ludila prisutan u javnosti kako bi naglasili društvenu važnost psihijatrije, a njihovi slikoviti opisi duševnih stanja odaju određen strah i nerazumijevanje duševnih oboljenja, ponekad dehumanizirajući duševno oboljele. Sami štićenici često iskazuju strah od nasilja, bilo kao jednostavnu visceralnu reakciju kojom se anticipira moguća opasnost po njih, bilo kao elaboriran strah od jasno definiranih osoba koje rade protiv njih i žele im nauditi. Bez obzira na samu prirodu straha, psihijatri ne obraćaju mnogo pažnje na sam objekt straha koliko na njegovu prisutnost ili odsutnost (prisutnost straha se uvijek gleda kao mogući znak duševne patologije) i na način pokazivanja emocije straha. Također, za psihijatre nije previše bitno je li strah bio opravdan prijašnjim životnim iskustvima štićenika.

Posebna vrsta straha od nasilja koja se javlja kod određenog broja štićenika je strah od strukturalnog nasilja državnog aparata. Štićenici koji ističu takav strah odaju kognitivni fenomen koji je Solomon Resnik nazvao „konstrukcijom progonstvenog svijeta”. Progonstveni svijet štićenika obilježen je izrazito „politiziranom” slikom stvarnosti u kojoj se događaji iz njihove 
svakodnevice tumače kroz prizmu malicioznog djelovanja državne administracije, tajnih društava i agenata državne represije. Sami psihijatri u tim slučajevima ne pokazuju previše interesa za strah koji štićenici manje i više eksplicitno pokazuju, a iako im često dijagnosticiraju paranoju, sam strah nije dio kliničkog opisa paranoje koji je Žirovčić dao u svojoj „Razdjelbi duševnih bolesti” iz 1895. godine. Iako mu psihijatri nisu pridavali osobito značenje, strah štićenika od državnog aparata i sa njime povezanog nadzora svjedoči o anksioznosti koju su mnogi osjećali pred povećanjem moći državnih institucija i većom prisutnošću birokratskih i represivnih elemenata tradicionalnog nadzora u svakodnevnom životu ljudi.

Najintenzivnija prisutnost psihijatrijskog diskursa u javnosti povezana je s agresijom, konfliktima i slučajevima nasilja. Kad se radilo o nasilnim zločinima, psihijatri su bili u intenzivnom kontaktu s pravosudnim institucijama i objavljivanjem svojih vještačenja nastojali etablirati psihijatriju kao društvenu institucija koja može objasniti fenomen društvene devijacije kroz prizmu medicine. Osim s pravosuđem, psihijatri su u svojoj svakodnevnoj praksi susretali sa članovima obitelji štićenika, članovima zajednice u kojoj su štićenici živjeli i predstavnicima administrativnih vlasti, te drugim liječnicima. Njihova društvena uloga dovodila je do činjenice da su u mnogobrojnim sukobima bili percipirani kao institucionalni autoritet od kojeg se očekuje medicinsko rješenje konflikta. Rješenje koje se od psihijatara najčešće zahtjevalo bilo je uklanjanje problematičnog pojedinca iz zajednice. U slučajevima obiteljskih sukoba i sukoba u ruralnim zajednicama psihijatri često iskazuju ambivalentne stavove. Tako stenjevački psihijatri često ne prihvaćaju sud članova obitelji i zajednice o tome da problematični pojedinci nužno predstavljaju opasnost i iziskuju hospitalizaciju. U slučajevima nekih duševno oboljelih štićenika, psihijatri poput Žirovčića su spremni napraviti odmak od somaticizma i prepostati zlostavljanje u obitelji kao uzrok duševnog oboljenja. Sukobi unutar obitelji predstavljaju i jedinstven slučaj ulaska psihijatrije kao javne institucije u obitelj koja se u građanskom društvu smatrala privatnom sferom.

Svaki put kad se nasilje i konflikti pojave u psihijatrijskim zapisima, svjedočimo interakciji psihijatrije sa društvom u cjelini, a psihijatri su u tim slučajevima prisiljeni zauzeti ulogu institucije društvene kontrole devijacije. Tu kontrolu psihijatri artikuliraju kroz medicinski diskurs. Nekad je epistemički okvir spoznavanja duševne devijacije zaogrnut u narative novih 
duševnih bolesti, poput hebefrenije koja se koristi za objašnjavanje burnih emocija i buntovnih postupaka adolescenata ili širokog shvaćanja pojma epilepsije kojom se objašnjavaju slučajevi paleža u ruralnim zajednicama. Drugi put radi se o konstrukciji granične kategorije „osoba niže duševne vrijednosti” bilo da se radilo o „osobama hereditarno oslabljene nervne konstitucije”, „moralnim idiotima” ili Lombrosovim „rođenim zločincima”. U bilo kojem od navedenih slučajeva, psihijatrija nudi spremno objašnjenje društveno devijantnog ponašanja u medicini. U prvim godinama postojanja stenjevačkog zavoda, neki liječnici poput Forenbachera nastoje objasniti pojedine nasilne čine kulturnim i društvenim praksama, no kako vrijeme odmiče, agresivnost i nasilje se sve češće objašnjavaju biološkim uzrocima. Čak i u slučajevima kad psihijatri ne prepoznaju jasnu duševnu patologiju kod osobe koja je počinila neki čin nasilja, na počinitelje se primjenjuje diskurs degeneracije kojim se objašnjava njihova sklonost nasilnom ponašanju.

Psihijatrijski diskurs na prijelazu stoljeća u početku razdoblja kojim se ovaj rad bavi nema hegemoniju u objašnjavanju psihe čovjeka. Bio je samo jedan od mnogih diskursa kojima su se objašnjavali kognitivni procesi poput emocija ili seksualne privlačnosti. Na kraju krajeva, budući da je za razvoj psihijatrijskog znanja bila potrebna heterotopija psihijatrijski zavoda, u prvim desetljećima posTojanja Zavoda za umobolne u Stenjevcu, psihijatrijski diskurs je i sam u stadiju formiranja- dijagnoze, uzroci bolesti, etiologija i terapijske metode su u eksperimentalnoj fazi.

Možemo identificirati dvije kategorije dokumenata kojima psihijatri oblikuju vlastiti diskurs. U prvu kategoriju spadaju interni dokumenti namijenjeni samim psihijatrima poput povijesti bolesti i stručne literature. Njihov glavni cilj je pronalaženje medicinskog objašnjenja za određene oblike devijantnog ponašanja koji su se ono vrijeme opisivali pojmom ludila. Objašnjenje je značilo klasifikaciju, pronalaženje uzroka, detaljan opis simptoma i tek u rijetkim slučajevima moguće metode liječenja. Putem proizvodnje i diseminacije internih diskursa o duševnim bolestima stvarao se set kliničkih znanja o ljudskom mozgu, kognitivnim procesima i ponašanjima. Ta znanja bila su isključivo medicinska znanja, koja su postepeno reducirala emocije i ponašanje na njihove biološke uzroke. Takva redukcija ne znači da su emocije i ponašanja bili jednostavno opisani kao patološki ili normalni. Psihijatri su već od sredine stoljeća baratali pojmovima „borderlandsa” i degeneracije te su predviđali čitav niz kategorija ljudi koji su bili smješteni između duševnog zdravlja i patologije, a prema njihovoj slici modernog društva, 
u tu je kategoriju spadala većina ljudi. Hoće li neki ljudi podleći duševnoj bolesti ili ne, nije ovisilo isključivo o hereditetu već i o njihovim životnim uvjetima. Tako su psihijatri predviđali alkoholizam, masturbaciju, pretjerano upuštanje u spolne odnose, venerične bolesti, iscrpljenosti, zapušten odgoj, određene emocije i siromaštvo kao moguće uzroke duševnih bolesti. Takav pogled nužno je dalo psihijatrijskom diskursu moralističku komponentu, dok joj je zagovaranje somaticističke etiologije i biološkog determinizma dalo eugeničku komponentu. Psihijatri pritom zagovaraju moralne nazore i način života obrazovane građanske klase.

Interni diskurs psihijatrije nastaje u bliskoj interakciji sa štićenicima. Odnos psihijatara i štićenika je ambivalentan. S jedne strane obilježen je ekstremnom asimetrijom moći: psihijatri su ugledni i obrazovani članovi društvene elite, štićenici već prije dolaska u zavod nose stigmu duševne bolesti i uz to je u Stenjevcu većina njih bila teškog imovinskog stanja, neobrazovana i pripadala je ruralnoj populaciji. Nad štićenicima se provodi epistemičko nasilje: njihova svjedočanstva i glas iako često sustavno i temeljito zapisana nemaju nikakvu težinu u dijagnostičkom procesu i terapiji. Psihijatri imaju potpunu moć što se tiče objašnjavanja simptoma štićenika, njihove klasifikacije unutar dijagnostičkog sustava i internog „,arhitektonskog” sustava odjela u zavodu, načinom na koji se sa njima postupa unutar samog zavoda i njihovim eventualnim otpuštanjem iz zavoda. S druge strane, njihovom govoru i ponašanju u kliničkom kontekstu posvećena je izrazita pažnja- njihove riječi su zapisane, pisma koja šalju i primaju su sačuvana, a sa njima se opetovano razgovaralo i tražilo se pojašnjenje njihovih emotivnih stanja i postupaka. Razlog istovremenom ignoriranju i bilježenju glasova štićenika bio je upravo u činjenici da je zapisivanje govora duševno oboljelih osoba bilo čin stvaranje kataloga simptoma što je bio ključan korak u formiranju prvih dijagnostičkih priručnika na temelju kojih us psihijatri klasificirali i razvrstavali duševno oboljele. S druge strane, podvrgavanje svakog čina duševno oboljele osobe kliničkom zoru pretvorilo je svaki čin koji je bio u suprotnosti s građanskim moralom ili emotivnim režimom u potencijalni simptom duševne bolesti, što je imalo presudnu ulogu u trenucima kad su psihijatri progovarali o društvenim problemima poput adolescentskog ili političkog nasilja.

Vanjski psihijatrijski diskurs bio je diskurs kojim je psihijatrija komunicirala s ostatkom medicinske zajednice, društvenih institucija i šire javnosti, uključujući i štićenike i njihove porodice. Taj diskurs služio je prvenstveno etabliranju psihijatrije kao društveno važne discipline 
i medicinske grane koja doprinosi zdravlju društva u cjelini. No, budući da psihijatrija nije mogla ponuditi učinkovitu terapeutsku metoda koja bi dovela do liječenja ili prevencije duševnih bolesti, postepeno se sve više pretvarala u instituciju društvenog nadzora. Psihijatrijski zavod prestao je biti mjestom liječenja i postao mjestom zatočenja i izolacije društveno devijantnih pojedinaca. Sami psihijatri su se borili protiv takve percepcije psihijatrijskih zavoda i stigme koju je ista značila i za njih i za njihove štićenike, no njihov entuzijazam brzo je ugašen u atmosferi terapeutskog pesimizma i teških uvjeta rada u prenapučenim zavodima u kojima nije bilo dovoljno osoblja, hrane, odjeće ni medicinskih potrepština. Sami štićenici u zavodima su bili protiv svoje volje, a tamo su u najboljem slučaju mogli dobiti samo palijativnu skrb. Dapače, budući da su u zavodu epidemije bile veoma učestale, moguće je da je institucionalizacija zapravo smanjila njihove šanse preživljavanja. Bijegovi iz zavoda su česti, primjeri štićenika koji svojevoljno dolaze u zavod rijetki (mnogi od istih biraju zavod suočeni s alternativom zatvora), a komunikacija štićenika i psihijatara obilježena epistemičkim i institucionalnim nasiljem i dehumanizacijom s jedne strane i primjerima otpora $s$ druge strane. Najvidljivija posljedica kontakta psihijatrije sa širom javnošću vidi se u postepenom širenju medicinskih pogleda na ljudsku psihu u književnosti, tisku, kriminologiji, sociologiji i antropologiji. Medicinske ideje o emocijama, društvenoj devijaciji i ljudskom umu do kraja Prvog svjetskog rata biti će potpuno ukorjenjene u hrvatskom građanskom društvu, usprkos postojanju alternativnih pogleda na iste. Govor štićenika i štićenica koji sami počinju progovarati o svojim emocijama i duševnom stanju medicinskim diskursom samo je jedna od posljedica tog širenja.

Početkom dvadesetog stoljeća psihijatrija počinje sve više biti percipirana kao jedina disciplina koja uživa znanstveni autoritet u pogledu dijagnosticiranja, traženja uzroka duševnih bolesti i njihovog tretiranja. Doba terapeutskog pesimizma, tko će prestati ubrzo nakon Prvog svjetskog rata, kad će iznalaženje novih terapeutskih metoda poput terapije groznicom koju je tijekom ratnih godina razvio bečki psihijatar Julius Wagner-Jauregg. Terapija inokulacijom malarijom inducirala je dugotrajne remisije kod oboljelih od progresivne paralize te produžila životni vijek i poboljšala kvalitetu života oboljelih od te teške i neizlječive bolesti. Wagner-Jauregg će zbog tog svog otkrića postati prvi psihijatar dobitnik Nobelove nagrade za medicinu, a njegovo otkriće će početi doba eksperimentiranja s raznolikim terapijama u zavodskoj medicini. Sami zavodi se pretvaraju u prave istraživačke klinike u kojima se vrše laboratorijski testovi i gdje se aktivno 
iskušavaju brojne terapije, od hormonalnih terapija, terapija induciranom komom do elektrokonvulzivne terapije i psihokirurgije koje se javljaju u osvit Drugog svjetskog rata. Novi optimizam liječnika, psihijatrijski termini i načini govora o ljudskom umu postaju sve prisutniji u javnosti. Govor o psihopatologiji izišao je iz psihijatrijskih klinika i ušao u svakodnevni govor ljudi, a likovi psihijatara i duševno oboljelih počinju se sve češće pojavljivati u književnosti i filmu. Joanna Bourke primijetila je kako je od 1930-ih godina, govor o strahu u memoarima nekadašnjih vojnika prestao biti tumačen kao izraz pukog instinkta za samoodržanjem i postao prožet psihijatrijskim i psihoanalitičkim diskursom. ${ }^{990}$ Psihijatrija će tako prestati biti marginalnom disciplinom koja se bavi ljudima odbačenima od društva i postat će disciplinom čije će ideje sve više oblikovati javni diskurs prodirući u ostale institucije društva i pojavljujući se u ostalim znanstvenim disciplinama.

U dvadesetom stoljeću, ta će recepcija psihijatrijskih ideja imati dvije veoma izražene dimenzije koje će većinu vremena biti suprotstavljene. Jedna se sastojala u transformaciji diskursa o degeneraciji u eugeniku i znanstveni rasizam koji će u razdoblju između dva svjetska rata postati dominantnom idejom u brojnim europskim društvima, a u nekim politikama ostavit će trag sve do danas. Eugenika i znanstveni rasizam, kao trendovi naročito prihvaćeni u njemačkoj psihijatriji (i u jednoj mjeru u psihijatriji Sjedinjenih Američkih Država) ostat će mrlja na povijesti psihijatrije, jer će u konačnici dovesti do teške dehumanizacije duševno oboljelih. Najtragičnija posljedica te dehumanizacije bio je organizirani projekt ubijanja duševno oboljelih u nacističkoj Njemačkoj, zloglasna akcija T4 koja upravo zbog sveprisutnosti eugenike u psihijatrijskim krugovima nije naišla na značajan otpor psihijatara. Tijekom akcije T4 ubijeno je oko 300000 duševno oboljelih koji su proglašeni ,životima nevrijednim življenja.” Utjecaj znanstvenog rasizma bio je očit i u drugoj velikoj psihijatrijskoj tragediji dvadesetog stoljeća, tragediji psihijatrijske kolonije $\mathrm{u}$ Barbaceni u brazilskoj pokrajini Minas Gerais gdje je zbog zlostavljanja i zanemarivanja od 1903. do 1980. godine umrlo više od 60000 štićenika od kojih je većina bila Afro-Brazilskog porijekla. Utjecaji eugeničkog i rasističkog nasljeđa na psihijatriju izazivaju kontroverze i danas, kao što je vidljivo na primjeru nedavnih kontroverzi oko dijagnoze Aspergerova sindroma. Prvi klinički opisi kasnih 1930-ih godina odražavali su percepciju mentalnog zdravlja ukorijenjenu u

990 Bourke, 2003. 120-121. 
nacističkog poimanju „,normalnosti”, a Hans Asperger po kojem je sindrom dobio ime, bio je strastven podržavatelj nacističkih mjera i programa eutanazije duševno oboljelih ${ }^{991}$.

No, odnos psihijatrije i društva nije rezultirao isključivo shvaćanjem psihijatrije kao biopolitičkog sredstva duševne kontrole čija je uloga uklanjanje „društvenih patologija” pod svaku cijenu. Već u vremenu između dva rata psihijatrija se pomalo počinje fokusirati na kulturne i interpersonalne aspekte duševnih bolesti. Kao reakcija na dehumanizirajući pokret eugenike, sve veći broj psihijatara počinje uviđati važnost zalaganja za destigmatizaciju i dostojanstven tretman duševnih bolesnika, kako unutar duševnih bolnica, tako i u širem društvu. Nakon Drugog svjetskog rata, užasni uvjeti u brojnim psihijatrijskim klinikama dospjevaju u medije i počinju rezultirati pozivima na sveobuhvatnu reformu psihijatrije. Neki liječnici, poput Thomasa Szassa i Ronalda D. Lainga odabrali su radikalan smjer propitivanja samog koncepta duševne bolesti kao medicinske činjenice. Njihovi radovi su i danas važan doprinos kritičkom promatranju psihijatrije, no najopipljiviji rezultat postigao je samozatajni talijanski psihijatar Franco Basaglia. Basaglia je tijekom šezdesetih godina dvadesetog stoljeća radio kao psihijatar u Gorici i Trstu, gdje je počeo implementirati svoj projekt postupne deinstitucionalizacije i reforme psihijatrijskih klinika: prestao je s praksom vezivanja pacijenata i ukinuo sobe za izolaciju. Kroz svoju udrugu „Demokratska psihijatrija” izborio se za takozvani „Zakon 180”. Donesen 1978. godine, zakon je stavio izvan zakona prisilnu hospitalizacijue u psihijatrijskim bolnicama, zabranio izgradnju novih psihijatrijskih bolnica i potaknuo osnivanje odjela za liječenje duševnih bolesnika u općim bolnicama na kojima se oboljeli mogu liječiti uz pristanak. Time je talijanska psihijatrija prestala biti povezana za institucije bazirane na izolaciji duševno oboljelih i stvorila je uvjete za tretiranje takvih bolesnika u općim bolnicama i komunalnim centrima mentalnog zdravlja. Posljedice zakona bile su dalekosežne- trideset godina nakon psihijatrijske reforme Italija je imala manje psihijatrijskih kreveta od ostalih europskih zemalja, manje populacije je uzimalo psihofarmakološke lijekove a broj od 18 hospitalizacija na 100000 stanovnika, zabilježen 2004. godine među najnižima je u Europi. ${ }^{992}$ Italija je postala primjer zemlje koja već desetljećima provodi uspješan model mentalnog zdravlja baziran na pristupu duševno oboljelima koji smanjuje njihovu patnju, istovremenu štiteći njihovu slobodu izbora i dostojanstvo.

991 Kontroverze u vezi s nacističkim nasljeđem Aspergerova sindroma detaljno je istražila Edith Sheffer u knjizi Asperger's Children: The Origins of Autism in Nazi Vienna objavljenoj 2018. godine.

992 Amaddeo, Barbui i Tansella, 2012: 315 
Kraj terapeutskog pesimizma koji je nova generacija psihijatara donijela nije nužno značio kraj poimanja psihijatrije kao sredstva društvene kontrole, ali je pružio realnu alternativu. Psihijatrija se njime oslobodila iz mračnih zidova „muzeja ludila” i postala mjestom ne samo diskursa o društvenoj degeneraciji i patologiji, već uistinu diskursa o duševnom zdravlju. No, veća društvena uloga psihijatrije rezultirala je i nekim izazovima sa kojima se i psihijatrija i društvo tek trebaju suočiti. Kako je psihijatrija postajala priznata znanost tako se širila njezina moć da objasni različita psihička i emotivna stanja unutar vlastitih medicinskih okvira. Medicinski diskurs kojim se počelo govoriti o emocijama, često može dovesti do zanemarivanja njihovih interpersonalnih, društvenih, kulturnih, pa i političkih aspekata.Dva ključna događaja iz sredine dvadesetog stoljeća pomogli su psihijatriji da nametne novo medicinsko poimanje psihe. Prvi od tih događaja bila je standardizacija psihijatrijskih dijagnoza kroz Međunarodnu Klasifikaciju Bolesti (ICD) koju je 1949. donijela Svjetska Zdravstvena Organizacija i Dijagnostički $i$ Statistički Priručnik Mentalnih Poremećaja (DSM) čije je prvo izdanje tiskano 1952. godine. Standardizacija i klasifikacija psihijatrijskih dijagnoza omogućila je njihovu primjenu na velik broj različitih ponašanja i simptoma. Uz to, u kasnijim izdanjima ovih priručnika, broj dijagnoza neprestano raste: prvi DSM razlikovao je 106 dijagnoza, a trenutno je na snazi peta verzija koja ih prepoznaje preko 400. Ostaje li otvoreno pitanje odražava li povećanje broja dijagnoza rafiniraniji dijagnostički i klasifikacijski aparat suvremene psihijatrije ili se radi o sve većoj medikalizaciji ljudskih ponašanja i emotivnih i duševnih stanja. Druga velika povijesna promjena bilo je otkriće djelotvornih psihofarmaka poput klorpromazina sintetiziranog 1950. godine i brojnih antipsihotika i sredstava koja inhibiraju i utječu na raspoloženje. Uspon psihofarmakologije od sredine stoljeća do danas, pružio je psihijatriji novi način terapije koji je bio lako provodiv i koji je nedvojbeno pomogao daljnjoj legitimaciji psihijatrije kao medicinske discipline jer je nalikovao terapeutskim pristupima ostalih medicinskih grana. ${ }^{993}$ Uspon psihofarmaka dao je vjetar u jedra novoj somaticističkoj paradigmi, koja ovaj put nije bila bazirana na degeneraciji i eugeničkim temeljima, već na diskursu o neurotransmiterima i neuravnoteženoj kemiji mozga. Ono čime će se svako društveno-humanističko istraživanje psihijatrije morati pozabaviti su veliki profiti koje psihofarmakološko liječenje duševnih bolesti donosi globalnoj farmaceutskoj industriji. Kao što je istaknuo Andrew Scull, antipsihotici i

993 Scull, 2015: 382. 
antidepresivi se, otkad su se našli na tržištu, nalaze među najprofitabilnijim farmaceutskim pripravcima. ${ }^{994}$ To nije zbog toga što predstavljaju neku vrst „psihijatrijskog penicilina” ${ }^{\text {"995 }}$ njihovo djelovanje više je palijativno nego kurativno i tretman psihifarmacima rijetko rezultira potpunim izliječenjem. Upravo je njihova nepotpuna učinkovitost ono što ih čini profitabilnima jer ih duševno oboljeli moraju uzimati dugi niz godina kako bi olakšali simptome vlastitih oboljenja. Jedan od najvažnijih zaključaka ovog istraživanja je da su psihijatriji devetnaestog stoljeća (uključujući i liječnike Kraljevskog i zemaljskog zavoda za umobolne u Stenjevcu kojima se ovaj rad bavi) često bili rastrgani između humane želja da ublaže patnju, uloge agenata koji kontroliraju društvenu devijaciju koja im je bila pripisivana i nemogućnosti da uspostave komunikaciju s vlastitim pacijentima radi vlastitih predrasuda, te emotivnog režima i morala $u$ koji je oblikovao njihov pogled na psihu. Ta rastrganost rezultirala je u sustavu mentalnog zdravlja koji je djelovao izrazito represivno, a najčešće se pokazao neuspješnim u onome što je smatrao svojom zadaćom: pomaganju osobama sa duševnim tegobama. Ono što će se nametati kao pitanje onima koji proučavaju i koji će proučavati psihijatriju naših dana je utjecaj globalnog farmaceutskog tržišta na kurativnu ulogu psihijatrije. U kojoj je mjeri znanstvena psihijatrija danas sposobna djelovati kurativno, a u kojoj mjeri doprinosi medikalizaciji interpersonalnih i društvenih problema koji bi se možda mogli bolje riješiti intervencijama koje uključuju promjenu cjelokupnih društvenih stavova o mentalnom zdravlju?

Ova disertacija prati povijest stenjevačkog zavoda do 1918. godine, godine obilježene brojnim povijesnim diskontinuitetima od kraja Prvog svjetskog rata i uspostave novog političkog i društvenog poretka u Europi, do kraja Austro-ugarske monarhije u sklopu čijeg sustava mentalnog zdravlja je zavod dotad djelovao. Prestanak terapeutskog pesimizma odrazio se i u hrvatskoj psihijatriji. Mjesto njezinog razvoja koje više neće biti samo zavodi za umobolne već će, kao dio širokog pokreta socijalne medicine u obje jugoslavenske države borba duševno zdravlje populacije biti vođena u čitavoj javnosti. Autoritet psihijatrije kao znanstvene i medicinske grane, potvrđuje se i u Hrvatskoj, osobito nakon što je 1921. studentima Medicinskog fakulteta Sveučilišta u Zagrebu omogućena specijalizacija iz neuropsihijatrije. Time se uistinu počinju razvijati specifična psihijatrijska misao u Hrvatskoj koja usprkos osnutku drugih klinika postaje usko vezana uz stenjevački zavod kao središnju instituciju. Sam zavod ubrzo mijenja ima

994 Scull, 2015: 402.

995 Ibid: 401. 
u „Bolnica za duševne bolesti Stenjevec”, i ta promjena također odražava novu percepciju institucije, kao mjesta čija je uloga eksplicitnije terapijska nego što je to bila dotad. Pritom će u konkretnom jugoslavenskom slučaju, glasovi koji su se zalagali za somaticizam i eugeniku postajati sve tiši. Fokus koji su zagovornici socijalne medicine stavljali na prosvjećivanje ruralne populacije nije mogao dugo supostojati sa starim pogledima na stanovništvo sela kao na primitivno i nepovratno degenerirano. Hrvatska psihijatrija će, kroz kontakt s javnošću i postepenu politizaciju, s vremenom sve više poprimati socijalni karakter. Naravno, tome su uvelike doprinijela medicinska otkrića poput Salvarsana i inzulinske terapije, kao i obrazovanje čitave nove generacije psihijatara poput Rudolfa Hercega, Stanislava Župića i Dezidera Julijusa koji su bili spremni eksperimentirati i zbog činjenice da su imali intenzivniji dodir s a većim spektrom medicinskih znanja i terapeutskih perspektiva. Upravo cee Dezider Julijus, nekoliko mjeseci prije vlastite tragične smrti (počinio je samoubojstvo 1953. godine nakon što je na sastanku lokalne partijske organizacije optužen za teško kršenje zakona u vođenju bolnice) donijeti iz Švicarske prve uzorke klorpromazina čime je započeo psihofarmakološku fazu u hrvatskoj psihijatriji. Način na koji su se suvremeni trendovi u intelektualnoj povijesti psihijatrije uklopili u nove kulturne i političke kontekste hrvatskog društva u dvadesetom stoljeću, trebat će proučavati u skladu s napetošću između psihijatrije kao medicinske discipline i psihijatrije kao sredstva društvene kontrole devijantnih ponašanja i emocija koje je obilježilo čitavu njezinu povijest. 


\section{Bibliografija}

\section{Izvori:}

\section{Arhivsko gradivo:}

Arhiv Klinike za Psihijatriju Vrapče, povijesti bolesti.

Budapest Főváros Levéltára.1906. Civil law cases: (VII.2.c - 1906 - V.0530: 1- 7).

\section{Tisak:}

Jutarnji list. Godište:1912.

Liječnički vjesnik. Godišta:1875.-1952.

\section{$\underline{\text { Stručni članci i medicinske knjige toga vremena: }}$}

Beard, George. 1869. „Neurasthenia or nervous exhaustion.” The Boston Medical and Surgical Journal, br. 13, str. 217-221.

Blankini, Anthony. 1906. „19 slučajeva railway spine.” Liječnički vjesnik, br. 31. str. 79-96.

Braid, James. 1853. Neurohypnology or The Rationale of Nervous Sleep Considered in Relation with Animal Magnetism. J.Churchill, London.

Browne, J. Crichton. 1860. „Psychical Diseases of Early Life”. Journal of Mental Science, br. 33, str. 284-320.

Esquirol, Jean-Étienne Dominique. 1845. Mental Maladies: Treatise on Insanity. Lea and Blanchard, Philadelphia.

Forenbacher, Dragutin. 1886. „Slučaj hypnotizma u hystero-epileptične žene”. Liječnički vjesnik, br.10, str. 158- 160 .

Forenbacher, Dragutin. 1888. „Dva slučaja paleža, kao prilog k psychiatricko-sudbenoj praksi”. Liječnički vjesnik, br. 6, str. 84-87. 
Forenbacher, Dragutin. 1892. „O progresivnoj paralizi”. Liječnički vjesnik,.br. 1, str.1-7.

Guči, Ante. 1880. „Kako se može preranoj ženitbi u Posavini na put stati”. Liječnički vjesnik,. br. 1, str. $1-9$ i br. 2 , str. 17-23.

Guislan, Joseph. 1826. Traité sur l'Aliénation Mentale Et sur les Hospices des Aliénés. J. Van Der Hayt et fils, Amsterdam.

Gundrum, Fran. 1910. „Dr. Ivo Žirovčić: Zdravstveno izvješće kr. zemalj. zavoda za umobolne u Stenjevcu za godinu 1908.“ Liječnički vjesnik, br. 3., str. 151-154.

Haslam, John. 1810. Illustrations of madness: exhibiting a singular case of insanity and a no less remarkable difference in medical opinion ... with a description of the tortures experienced [by the patient, James Tilly Matthews, in hallucinations]. G. Hayden for Rivingtons, etc., London.

Heckler, Eward. 2009. „Hebephrenia: A Contribution to Clinical Psychiatry.” History of Psychiatry, vol. 20, br. 1-2., str. 87-106, str. 233-248.

„Iz povijesti bolnice Vrapče: Izgradnja i razvoj bolnice”. 2014. Brošura Klinike za Psihijatriju Vrapče.

Kräpelin, Emil. 1902. Clinical Psychiatry: A Textbook for Students and Physicians Abstracted and Adapted from the Sixth German Edition of Kräpelin's Lehrbuch der Psychiatrie. The Macmillan Company, New York.

Kräpelin, Emil. 1992. „Psychiatrische Randbemerkungen zur Zeitgeschichte”. History of Psychiatry, br. 10, str, 256-269.

Krafft-Ebing, Richard von. 2011. Psychopatia sexualis: The Classic Study of Deviant Sex. Arcade Publishing, New York.

Kuljženko, Aleksej. 1931. „Medicinska statistika državnog zavoda za duševno bolesne u Stenjevcu za godinu 1930.” Liječnički vjesnik, br. 8, str. 673.-708.

Lockheart-Robertson, Charles. 1861. „On the Sedative Action of the Cold Wet Sheet in the reatment of Recent Mania, with cases: A contribution to the curative treatment of Mental Disease." Journal of Mental Science, br. 38, str. 265-277.

Lombroso, Cesare. 2006. Criminal man. Duke University Press, Durham \& London.

Lopašić, Radoslav. 1925. „Ivan Žirovčić (1855.-1925)”. Liječnički vjesnik, br. 9, str. 230-232.

Machacek, Franjo. 1913. „Iz slavenske medicinske literature. Prof. dr. Lad. Haškovec: Boj s detskou zločinnosti, prostituci a sebevraždou.” Liječnički Vjesnik, br.6. str.251-257. 
Maudsley, Henry. 1867. The Physiology and Pathology of the Mind. D. Appleton and Company, New York.

Maudsley, Henry. 1870. Body and Mind. Macmillan, London.

Maudsley, Henry. 1874. Responsibility in Mental Disease. Kegan Paul, London.

Morel, Benedict Augustin. 1857. Traité des dégénérescences physiques, intellectuelles et morales." Baillière, Pariz.

Morel, Benedict Augustin. 1860. Traité des maladies mentales. Masson, Pariz.

Nordau, Max. 2016. Degeneration. Popular edition, London.

Pinel, Phillipe. 1806. A Treatise on Insanity: In which are Contained the Principles of a New and More Practical Nosology of Maniacal Disorders Than Has Yet Been Offered to the Public. W. Todd, Sheffield.

Reil, Johann Christian. 1803. Rhapsodieen über die Anwendung der psychischen Curmethode auf Geisteszerrüttungen. Halle.

Rohaček, Ivan. 1885. „Liečničko izvješće kr. Zem. Zavoda za umobolne u Stenjevcu”. Liječnički vjesnik, br.4, str. 49-63.

Rohaček, Ivan. 1889. „Kr. zemaljski zavod za umobolne u Stenjevcu godine 1887. i 1888”. Liječnički vjesnik, br. 10, str. 147-149.

Schwarz, Dragutin. 1903. „Knjižnica”. Liječnički vjesnik, br.2, str. 76.

Selak, Niko. 1887. „Kraniotomija u hypnosi”. Liječnički vjesnik, br.8. str. 114-117.

Selak, Niko. 1888. „Hemianaesthesia uslijed psyhičnog uzdrmanja padom u zdenac”. Liječnički vjesnik, br. 11, str. 167-170 .

Selak, Niko. 1891. „Hypnotizam ili Braidizam”. Liječnički vjesnik,. br.1 str. 9-12.

Stojanović, Gjuro. 1888. „Kupalište Neuhaus u južnoj Štajerskoj”. Liječnički vjesnik, br.9, str. 137-142.

Šimsa, Ivan. 1898. „Syphilis cerebri”. Liječnički vjesnik, br. 1, str. 1-7.

Thaller, Lujo. 1933. „Teodor Wickerhauser”. Liječnički vjesnik, br. 10, str. 466-471.

Van Deusen, Edwin Holmes.1869. „Observations on a form of nervous prostation (neurasthenia) culminating in insanity". Journal of Insanity, br. 4, str. 445-461. 
Wynter, Andrew. 1877. The Borderlands of Insanity and other papers. The Strand, London.

Žirovčić, Ivan. 1895. „Casus Ljuboević . Kriminalno - psyholožka crtica”. Liječnički vjesnik, br. 12 , str. $234-251$.

Žirovčić, Ivan. 1895a.“O nazivlju i razdielbi duševnih bolesti”. Liječnički vjesnik, br. 4, str. 66-69.

Žirovčić Ivan. 1896. „Crtica iz kriminalne psychologije”. Liječnički vjesnik, br.2-3, str. 33-60.

Žirovčić, Ivan. 1896a. „Moralna izkvarenost i duševna bolest”. Liječnički vjesnik, br. 9, str. 201-206.

Žirovčić, Ivan. 1896b. „O nekojih temeljnih pojavih duševnoga bolovanja”. Liječnički vjesnik, br.11-12, str. 249-292.

Žirovčić, Ivan. 1897. „O postupku s duševno bolestnimi”. Liječnički vjesnik, br. 10, str. 318324 i br. 11, str. 353-360.

Žirovčić, Ivan. 1898. „Ludjačka umorstva nazvana "la folie rouge”. Liječnički vjesnik,. br. 7, str. 225-232.

Žirovčić, Ivan. 1904. „II. Sudbeni slučaj, u kojem je mlada seljačka žena osumnjičena, da je zadušila brata svoga supruga”. Liječnički vjesnik, br.10, str. 309-316.

Žirovčić, Ivan. 1905. „III. Slučaj bluda učitelja sa školskim djevojčicama”. Liječnički vjesnik, br.4, str. 120-128.

Žirovčić, Ivan. 1905a. „Hysterična žena pred sudom radi klevetanja“. Liječnički vjesnik, br. 7 , str.271-280.

Žirovčić, Ivan. 1906. „VI. Slaboumnik palikuća”. Liječnički vjesnik, br.6, str. 219-223.

Žirovčić, Ivan. 1906a. .„Ubojstvo u pomućenom duševnom stanju”. Liječnički vjesnik, br.5, str. 161-164.

Žirovčić, Ivan. 1907. „X. Zvekast napadač”. Liječnički vjesnik, br.2, str. 27-33.

Žirovčić, Ivan. 1907a. „Dječak ubojica”. Liječnički vjesnik, br. 4. str. 93-98.

Žirovčić, Ivan. 1908. „Zagonetan palež.”. Liječnički vjesnik, br.8, str. 231-235.

Žirovčić, Ivan. 1910. „Benav dječak igra se razbojnika”. Liječnički vjesnik, br. 7, str. 249-254.

Žirovčić, Ivan. 1911. „Zločin u progonstvenom obmanu”. Liječnički vjesnik, br. 2, str. 33-38. 
Žirovčić, Ivan. 1912. „Napadač iz obmana”. Liječnički vjesnik, br.4, str. 152-158.

Žirovčić, Ivan. 1918. „Potopila rodjenu djecu od gladi”. Liječnički vjesnik, br. 11, str. 333338.

Župić, Stanislav. 1937 „O bolesti Harambašića, Vidrića i Kovačića”. Liječnički vjesnik, br. 8, str. 341-346.

\section{Književna djela:}

Gjalski, Ksaver Šandor. 1964. Đurđica Agićeva. Branko Đonović, Beograd.

Homer. 2003. Ilijada. Nakladni Zavod Matice Hrvatske, Zagreb.

Jorgovanić, Rikard. 2002. „Stella Raiva”. U Rikard Jorgovanić: Izabrana djela, ur. Miroslav Šicel. Matica Hrvatska, Zagreb.

Kovačić, Ante. 2015. $U$ registraturi. elektire.škole.hr. Preuzeto s: http:/gimnazija-sb.com/portal/wp-content/uploads/2015/02/kovacica_uregistraturi.pdf, 13. rujna 2018 .

Leskovar, Janko. 1993. Sabrana djela I. Boris Krizmanič, Pregrada.

Matoš, Antun Gustav. 1990. Vidici i Putovi. Naši ljudi i krajevi .Tiskara Rijeka, Rijeka.

Shelley, Mary. 1994. Frankenstein or, The modern Prometheus: the 1918 text. Oxford University Press, New York.

Vukelić, Vilma. 2003. Tragovi prošlosti. Zagreb: Nakladni zavod Matice Hrvatske.

\section{Literatura:}

Ahmed, Sara. 2014. Cultural Politics of Emotion. Edinburgh University Press, Edinburgh.

Ammadeo, Francesco, Corrado Barbui i Michele Tansella. 2012. „State of psychiatry in Italy 35 years after psychiatric reform. A critical appraisal of national and local data." International Review of Psychiatry, br.4, str. 314-320.

Antić, Ana. 2017. Therapeutic Fascism. Experiencing the violence of Nazi New Order in Yugoslavia. Oxford University Press, Oxford.

Arbex, Daniela. 2013. Holocausto brasileiro: vida, genocidio e 60 mil mortes no maior hospicio do Brasil. Geração Editorial, Sao Paulo. 
Beddies, Thomas Müller. 2006. „The Destruction of 'Life Unworthy of Living' in National Socialist Germany". International Journal of Mental Health, vol. 35, br.3, str 94-104.

Blom, Philipp. 2008. The Vertigo Years: Europe 1900-1914. Basic Books, New York.

Bloom, Clive. 2013. Victoria's Madmen: Revolution and Alienation. Palgrave Macmillan, Basinstoke.

Bogousslavsky, Julien i Francois Boller. 2005. Neurological Disorders in Famous Artists. Karger, Basel.

Borossa, Julia. 2003. Histerija, Ideje u psihoanalizi. Jesenski i Turk, Zagreb.

Bourdieu, Pierre. 1996. Distinction: a social critique of the judgement of taste. Harvard University Press, Cambridge.

Bourke, Joanna. 2005. Fear: A Cultural History. Kindle Edition.

Bourke, Joanna. 2003. „Fear and Anxiety: Writing about Emotion in Modern History”. History Workshop Journal, br. 55, str. 111-133.

Buczynski, Alexander. 1994. „Organizacija policije i pravosuđa u Vojnoj krajini”. Povijesni prilozi br. 13., str. 77-109.

Butterfield, Herbert. 1965. The Whig Interpretation of History. Norton and Company, New York.

Campbell, Brad. 2007. „The making of 'American': race and nation in neurasthenic discourse." History of Psychiatry, br.2., str 157-178.

Čeč, Filip, Vani D'Alessio i Heike Karge. 2017. "Crime and Madness on the Opposite Shores of the Adriatic: Moral Insanity in Italian and Croatian Psychiatric Discourses". Acta Medica Historica Adriatica, br. 2, str. 219-252.

Davidoff, Leonore. 1998. „Adam spoke first and named the orders of the World': Masculine and Feminine Domains in History and Sociology". U Gender and History in Western Europe,. ur. Robert Shoemker i Mary Wincester, str. 85-104. Arnold, London, New York, Sydney, Auckland.

Davidoff, Leonore. 2003. „Gender and the Great Divide:Public and Private in British Gender History." Journal of Women's History. br. 1, str. 11-27.

De Young, Mary. 2015. Encyclopedia of asylum therapeutics, 1750-1950s. McFarland \& Company, Jefferson, North Carolina. 
Delimo, Žan. 2003. Strah na Zapadu (od XIV do XVIII veka). Izdavačka knjižarnica Zorana Stojadinovića, Sremski Karlovci.

Demos, John i Virginia Demos. 1969. „Adolescence in historical perspective”. Journal of Marriage and Family, vol. 31, broj 4, str. 632-638,

Dennen, Johann. . 2005. „Theories of Aggression: Psychoanalytic theories of aggression“. Default journal, preuzeto s https://core.ac.uk/download/pdf/148195139.pdf, 15. studenog 2019. godine,

Draaisma, Douwe. 2009. Disturbances of the Mind. Cambridge University Press, Cambridge.

Drača, Vinko. 2017. „'Stenjevačka Ofelija' Ana Schier: rod i duševna bolest u Hrvatskoj na prijelazu stoljeća“. U Kamen na cesti: granice, opresija i imperativ solidarnosti, ur. Lada Čale Feldman, Lidija Dujić, Maša Grdešić, Renata Jambrešić Kirin, Anita Dremel, Nataša Medved. Centar za Ženske Studije, Zagreb.

Dujić, Emanuela. 2012. „Povijest kliničkog laboratorija u psihijatrijskoj bolnici Vrapče”. U Ludnica i lučbarnica. Razvoj laboratorija u psihijatrijskoj bolnici, ur. Stella Fatović-Ferenčić i Marko Pećina, HAZU, Zagreb.

Elias, Norbert. 2000. The Civilizing Process: Sociogenetic and Psychogenetic Investigations. Blackwell Publishing, Oxford.

Evans, Dylan. 1996. An Introductory Dictionary of Lacanian Psychoanalysis. Verso, London.

Farge Arlette i Jacques Revel. 1999. The vanishing children of Paris: rumor and politics before the French Revolution. Harvard University Press, Cambridge.

Fatović-Ferenčić, Stela i Marin Kuhar. „'A Tortured Nation Gave Birth to a Lunatic': The Construction of Insanity in the 1912 Terrorist Act in Croatia." Social History of Medicine, članak hkz043. https://doi.org/10.1093/shm/hkz043 (objavljeno 19.7. 2019.,).

Fatović-Ferenčić, Stela i Marin Kuhar. 2017. „They accused me of strangling her: epilepsy and violence debate in Croatia at the end of the nineteenth and the beginning of the twentieth centuries". History of Psychiatry, vol. 28, br. 4, str. 460-472.

Fazerkaš, Ana. 2016. „Diskurzivne tvorbe zločina: Papin-Lacan-Genet”. Književna smotra: Časopis za svjetsku književnost, vol.48, br. 179 (1), str. 81-98.

Ferguson, Eliza Earle. 2010. Gender and Justice, Violence, Intimacy and Community in fin de siecle Paris. The Johnson University Press, Baltimore

Foucault, Micheal. 1977. Discipline and Punish: The Birth of the Prison. Vintage Books, New York. 
Foucault, Michel. 1989. The Birth of the Clinic: An archeology of medical perception. Routledge, London.

Foucault, Michel. 1998. The History of Sexuality: Volume one. The Will to Knowledge. Penguin Books, New York.

Foucault, Michel. 2002. Madness and civilization: a history of insanity in the age of reason. Routledge, London i New York.

Foucault, Michel. 2003. Society Must Be Defended Lectures at the Collège de France 19751976. Palgrave Macmillan, New York.

Foucault, Michel. 2006. Psychiatric Power: Lectures at the College de France 1973-1974. Palgrave Macmillan, New York.

Freud, Sigmund. 2000. „Opća znanost o neurozama”. U Uvod u psihoanalizu,. Stari Grad, Zagreb.

Freud, Sigmund. 2010. „Civilization and its Discontents.” U Freud-Complete Works, ur. Ivan Smith. Str. 4462-4532. E-pub edition, preuzeto $\mathrm{s}$ https://www.valas.fr/IMG/pdf/Freud_Complete_Works.pdf 9. rujna, 2018.

Freud, Sigmund. 2010. „Notes Upon A Case of Obsessional Neurosis”. U Freud-Complete Works, ur. IvanSmith, str. 2125-2194. E-pub edition, preuzeto s https://www.valas.fr/IMG/pdf/Freud_Complete_Works.pdf .9. rujna, 2018.

Freud, Sigmund. 2010. „Psycho-Analytic Notes on an Autobiographical Account of a Case of Paranoia". U Freud-Complete Works, ur. Ivan Smith, U Freud-Complete Works, ur. Ivan Smith, str. 2385-2448. E-pub edition, preuzeto s https://www.valas.fr/IMG/pdf/Freud_Complete_Works.pdf. 9. rujna, 2018.

Fromm, Erich. 1973. The Anatomy of Human Destructivness. Holt, Rheinhart and Winston, New York, Chicago i San Francisco.

Fuchs, Thomas i Dusan Hirjak. 2009. „Delusions of Technical Alien Control: A Phenomenological Description of Three Cases". Psychopathology, br.2, str. 96-103.

Fugier, Anne-Martin i Michelle Perrot,. 1990. „The Actors ”. U A History of Private Life IV: From the Fires of Revolution to the Great War, ur. Michelle Perrot, The Belknap Press of Harvard University Press, Cambridge Massachusetts, London, England, str. 95-261.

Gerrard, Donald L. 1997. „Chiarugi and Pinel Considered: Soul's brain/person's mind”. Journal of the History of the Behavioral Sciences, vol. 33, br. 4, str 381-403.

Gilman, Sander L., Helen King, Roy Porter, G. S. Rousseau, i Elaine Showalter. 1993. Hysteria Beyond Freud. University of California Press, Berkley. 
Glesinger, Lavoslav. 2012. „Povijest psihijatrije u Hrvatskoj- pretisak doktorske disertacije”. U Ludnica i lučbarnica. Razvoj laboratorija u psihijatrijskoj bolnici, ur. Stella FatovićFerenčić i Marko Pećina, HAZU, Zagreb, str. 18-88.

Goffman, Ervin. 1963. Stigma: notes on the management of spoiled identity. Prentice Hall, Inc. Englewood Cliffs.

Goldberg, Ann. 1999. Sex, Religion, and the Making of Modern Madness: The Eberbach Asylum and Germany Society, 1815-1849. Oxford University Press, New York.

Goldberg, Ann. 2002. „The Mellage Trial and the Politics of Insane Asylums in Wilhelmine Germany". The Journal of Modern History, br. 74, str. 1-32.

Goodman, Gilman. 1970. The Biological Basis of Therapeutics. Macmillan, London.

Greenfeld, Liah. 2013. Mind Modernity Madness: The Impact of Culture on Human Experience. Harvard University Press, Cambridge and London.

Haslam, Fiona. 1996. From Hogarth to Rowlandson: Medicine in Art in Eighteenth-century Britain. Liverpool University Press, Liverpool.

Harris, Ruth. 1997. „Possession on the Borders: The 'Mal de Morzine' in Nineteenth-Century France." The Journal of Modern History, br.3, str. 451-478.

Hayden, Deborah. 2003. Pox: Genius, Madness and the Mysteries of Syphilis. Basic Books, New York.

Herceg, Rudolf. 1933. „Zavod za umobolne 'Stenjevec' od 1879. do 1933.“ U Stenjevecdržavna bolnica za duševne bolesti 1879.-1933.Spomenica povodom pet decenija rada, str. 630. Društvo za socijalnu pomoć duševnim bolesnicima u Stenjevcu, Zagreb,

Horwitz, Allan i Jerome Wakefield. 2012. All We Have to Fear: Psychiatry's Transformation of Natural Anxieties into Mental Disorders. Oxford University Press, New York.

Iveljić, Iskra. 2007. Očevi i sinovi : privredna elita Zagreba u drugoj polovici 19. stoljeća. Leykam International, Zagreb.

Jones, David W. 2016. Disordered Personalities and Crime: An analysis of the history of the moral insanity. Routledge, London i New York.

Jukić, Vlado. 2015. Izgradnja, dogradnje $i$ adaptacije zgrada $i$ drugih infrastrukturnih objekata bolnice 'Vrapče' od 1877. do 2014. godine - iz povijesti Bolnice Vrapče. Medicinska naklada Zagreb, Zagreb.

Kaplan, Morris B. 2005. Sodom on the Themes. Sex, Love and Scandal in Wilde Times. Cornell University, Ithaca. 
Kibria, Ayisha A. i Neil H. Metcalfe. 2016. „A biography of William Tuke (1732-1822): Founder of the modern mental asylum.”Journal of Medical Biography, br. 3, str. 384-388.

Laqueur, Thomas Walter. 2003. Making Sex: Body and Gender from Greeks to Freud. Harvard University Press, Cambridge, Massatchusetts i London, Engleska.

Lerner, Paul i Mark Micale. 2001. Traumatic Pasts: History, Psychiatry, and Trauma in the Modern Age, 1870-1930. Cambridge University Press, Cambridge.

Lifton, Robert Jay. 1986. The Nazi Doctors: Medical Killing and the Psychology of Genocide. Basic Books, New York.

Lunbeck, Elisabeth. 1994. The Psychiatric Persuasion: Knowledge, Gender and Power in Modern America. Princeton University Press, Princeton.

Macalpine, Ida i Richard Hunter. 1966. „'The Insanity ' of King George III: a Classic Case of Porphyria". British Journal of Medicine, br.1, str. 65-71.

Matijašević, Željka. 2006. Strukturiranje nesvjesnog: Freud i Lacan. Biblioteka Sintagma, Zagreb.

Meyer, Manuella. 2017. Reasoning against Madness Psychiatry and the State in Rio de Janeiro, 1830-1944. University of Rochester Press, Rochester.

Micale, Mark i Porter, Roy. 1994. Discovering the History of Psychiatry. Oxford University Press, Oxford i New York.

Milošević, Dragan. 2016. Vlastelinstva i seljački posjedi u Slavoniji od 1699.-1848.- 1945. godine- povijesna, ekonomska $i$ društvena analiza, preuzeto $\mathrm{s}$ https://www.zupavalpovo.com/dokumenti/kronologija/Vlastelinstva_1699-1945.pdf, 7. rujna 2018. godine.

Neumann, Roderick. 1975. „Masturbation, Madness, and the Modern Concepts of Childhood and Adolescence". Journal of Social History, br.3, str. 1-27.

Noll, Richard. 2011. American Madness: The Rise and Fall of Dementia Praecox. Harvard University Press, Cambridge Massatchussets, London, England.

Osterhammel, Jürgen. 2009. The Transformation of the World: A Global History of the Nineteenth Century. Princeton University Press, Princeton.

Pavličević, Dragutin. 1980. Narodni pokret 1883. u Hrvatskoj. Sveučilišna zaklada, Zagreb.

Pejić, Luka. 2016. Historija klasičnog anarhizma u Hrvatskoj. Fragmenti Subverzije. DAF, Zagreb. 
Petrungaro, Stefano. 2011. Kamenje i puške: društveni protest na hrvatskom selu krajem XIX. stoljeća. Srednja Europa, Zagreb.

Pietrzak-Franger, Monika. 2017. Syphilis in Victorian Literature and Culture: Medicine Knowledge and the Spectacle of Victorian Invisibility. Palgrave MacMillan, London.

Plamper, Jan. 2012. The History of emotions: An Introduction. Oxford UniversityPress, Oxford.

Pocs, Eva. 2018. „Small Gods, Small Demons: Remnants of an Archaic Fairy Cult in Central and South-Eastern Europe “. U Fairies, Demons and Natural Spirits: 'Small Gods' at the Margins of Christendom, ur. Michael Gostling, str. 255-277. Palgrave MacMillan, London.

Porter, Roy. 2003. Flesh in the Age of Reason. Penguin Books, London.

Porter, Roy. 2002. Madness: A Brief History. Oxford University Press, Oxford.

Rachman, Stanley. 2004. Anxiety. Psychology Press, New York.

Reddy, William. 2002. The Navigation of Feeling: A Framework for the History of Emotions. Cambridge University Press, Cambridge.

Resnik, Solomon. 1998. „Being in a persecutory world: the construction of a world model and its distortions". U Even paranoids have enemies - new perspectives on paranoia and persecution. ur. Joseph H. Berke, Stella Pierides, Andrea Sabbadini i Stanley Schneider, str. 16-36. Routledge, London.

Savage, Joe. 2007. Teenage: The Creation of Youth 1875-1945. Chatto \& Windus, London.

Schecter, Harold. 2000. Fiend: The Shocking True Story of America's Youngest Serial Killer. Pocket Books, New York.

Schulte, Regina. 1994. The Village in Court: Arson, infanticide, and poaching in the court records of Upper Bavaria, 1848-1910. Press Syndicate of the University of Cambridge, Cambridge.

Scull, Andrew. 2014. Cultural Sociology of Mental Illness: An A-to-Z Guide. University of California, San Diego.

Scull, Andrew. 2009. Hysteria: the Biography. Oxford University Press, Oxford.

Scull, Andrew. 2015. Madness in Civilization: Cultural History of Insanity from the Bible to Freud, from the Madhouse to Modern Medicine. Princeton University Press, Princeton.

Shorter, Edward. 1997. A history of psychiatry: from the era of the asylum to the age of Prozac. John Wiley and Sons New York. 
Showalter, Elaine. 2001. The female malady: women, madness, and English culture, 18301980. Virago Press. London.

Shuttleworth, Sally. 2010. The Mind of a child.Child development in literature, science, and medicine 1840-1900. Oxford University Press, Oxford.

Spector, Scott. 2016. Violent Sensations: Sex, Crime, and Utopia in Vienna and Berlin, 18601914. University of Chicago Press, Chicago.

Spongberg, Mary. 1997. Feminizing Venereal Disease: The Body of the Prostitute in Nineteenth-Century Medical Discourse. New York University Publishing, New York.

Sugden, Philip. 2006. The Complete History of Jack The Ripper. Constable and Robinson ltd., London.

Tackett, Timothy. 2015. The Coming of the Terror in the French Revolution. Harvard University Press, Cambridge.

Tattersall, Mason. 2014. „Thermal Degeneration: Thermodynamics and the Heat-Death of the Universe in Victorian Science, Philosophy, and Culture." U Decadence, Degeneration, and the End-studies in European fin de siecle, ur. Marja Härmänmaa i Christopher Nissen, str. 1735. St. Martin's Press, New York.

Tausk, Viktor. 1992. „On the Origin of the 'Influencing Machine' in Schizophrenia”. The Journal of Psychotherapy Practice and Research, br. 2 , str. 184-206.

Verwey, Gerlof. 1985. Psychiatry in an Anthropological and Biomedical Context: Philosophical Presuppositions and Implications of German Psychiatry,1820-1870. D. Reidel Publishing Company, Dodrecht,Boston, Lancaster.

Wagner, Karel. 2011. Psychiatrie a fenomén zvaný Poltergeis.

https://karelwagner.blog.idnes.cz/blog.aspx?c=229735, 23. travnja 2018.

Yanni, Carla. 2007. The Architecture of Madness: Insane Asylums in the United States. Minnesota University Press, Minneapolis. 


\section{Životopis}

Vinko Drača rođen je 1989. godine u Zagrebu Završio je preddiplomski studij novinarstva na Fakultetu političkih znanosti i diplomski studij povijesti na Filozofskom fakultetu u Zagrebu. Upisao je doktorski studij na studiju Moderne i suvremene hrvatske povijesti u europskom i svjetskom kontekstu na Filozofskom fakultetu u Zagrebu gdje je primarno istraživao povijest duševnih bolesti. Sudjelovao je na brojnim međunarodnim znanstvenim skupovima u Zagrebu (,Zagorkini dani 2016.“ i „Zagorkini dani 2017.“. Desničini susreti 2017. i 2018. godine), Beogradu („Migrations in Visual Culture“, „Creating Memories in Early Modern and Modern Art and Literature“) i Ljubljani (,Selfologija“ „Simbozij“). Teme iz povijesti psihijatrije predstavio je na kongresu „RI-seminario” u Rijeci, međunarodnoj radionici „Managing Maladjustment in the Modern World. Perspectives from Southeastern Europe" te na ljetnoj konferenciji ASEEES-a u Zagrebu 2019. Sudjelovao je na ljetnoj školi GHI u Dubrovniku, „Cultural trauma and Crisis of Democracy" u srpnju 2019. godine.Bio je organizatorom međunarodne doktorandske konferencije „Revolutions and Upheavals in History“ i član organizacijskog odbora ISHA-ine konferencije „(Re)making Europe“. Radove jeobjavljivao u časopisima „Historijski zbornik“ i „Radovi zavoda za hrvatsku povijest Filozofskog Fakulteta u Zagrebu“ te u zbornicima navedenih skupova. 